\title{
PERFIL DO LEITOR COLONIAL
}

\author{
por \\ JORGE DE SOUZA ARAUJO
}

Tese de Doutorado em Literatura Brasileira, apresentada à Coordenação dos Cursos de PósGraduação da Faculdade de Letras da Universidade Federal do Rio de Janeiro. orientador: Professor Doutor Gilberto Mendonça Teles.

Faculdade de Letras/UFRJ

19 semestre de 1988 
DEFESA DE TESE

ARAUJo, Jorge de Souza. Perfil do leitor colonial. Tese de Doutorado em Literatura Brasileirá, apresentada à Coordenação dos Cursos de Pōs-Graduação da Faculdade de Letras da UFRJ. Rio de Janeiro, 1988. 732 fls.

BANCA EXAMINADORA

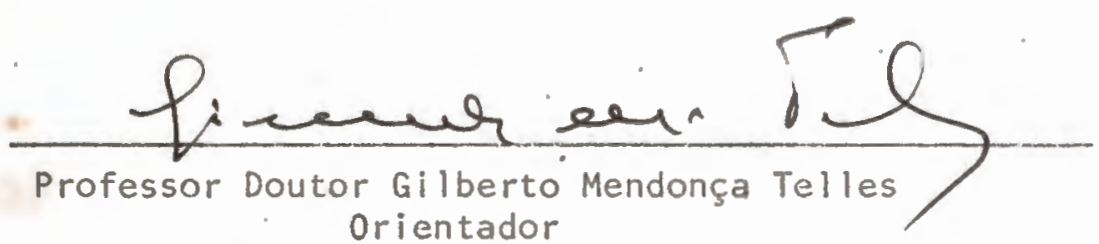

Professor Doutor Gilberto
Orientador

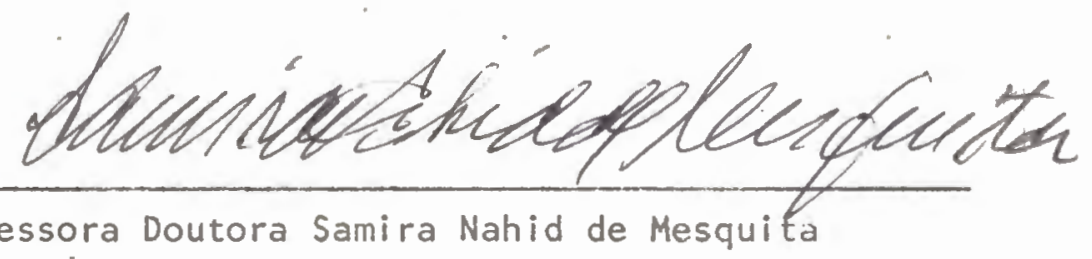

Professora Doutora Samira Nahid de Mesquila

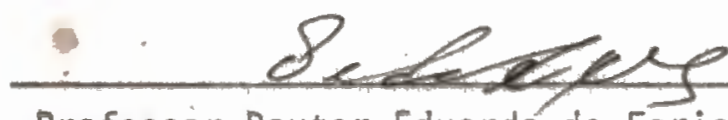

Professor Doutor Eduardo de Faria Coutinho

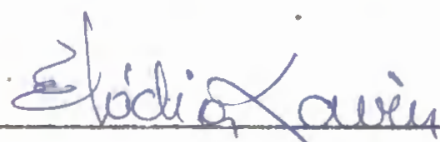

Professora Doutora Helena Parente Cunha

Maris Canearinhi datar Professor Doutor Mário Camarinha da Silva

Defendida a Tese

Conceito:

Em / /1988 
A Solange Lisboa, anti-musa na obsessão deste trabalho

A Ana Lūcia d'Angelo e Sônia Regina Nunes, pela afetuosa colaboração

A Izi, Ciça, Maroto e Alcina, meus amigos

E a Vitōria Pamplona, parceira de levantes e de tédios

Agradecimentos especiais a

Afrānio dos Santos Coutinho Gilberto Mendonça Teles

Sarviço de Documentação da FEEMA

Dora Hees de Negreiros

Iara Verocai

Tarcício Ferreira, da UFMG

Funcionārios de arquivos e bibliotecas brasileiros

e a Esther Caldas Bertholeti, sem cujo decisivo apoio este trabalho dificilmente seria concluĩdo. 


\section{SINOPSE}

Estudo das tendēncias e características de leitura no Brasil Colōnia e da natureza intertextual da produção literāria brasileira no período. 


\section{SUMARIIO}

1. INTRODUÇAO

2. ESTILOS E TENDENCIAS DO BRASIL LEITOR
$2.7-\underset{\sim \sim}{\text { No }} \underset{\sim}{\operatorname{se}} \underset{\sim}{\operatorname{cu}} \underset{\sim}{\operatorname{uto}} \underset{\sim}{X V I}$

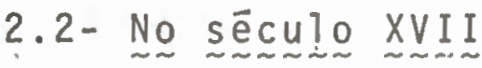
2.3- $\underset{\sim}{\text { No }} \underset{\sim}{\text { século }} \underset{\sim}{X V I I I I} \underset{\sim}{\operatorname{II}}$
2.4 - № $\underset{\sim}{\text { sejculo }} \underset{\sim}{\operatorname{XIX}}$

3. PERFIL DO LEITOR COLONIAL
3.1 - Lejitores paidres, mëdicos, bacharëis
3.2 - Doutrinas e devoções

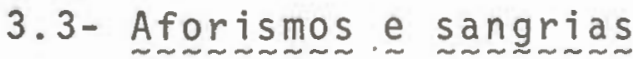
3.4 - Vade-mecum e ordenações
$3.5-\underset{\sim}{\text { clāsssicos, moralistas e gramáticos }}$

4. UMA LEITURA REVOLUCIONARIA

5. OS LIVROS DAS ORDENS E

OS LIVROS QUE O MARQUES QUIS VER

6. UM PUBLICISTA, UM POLITICO-MILITAR, UM DIPLOMATA, UM BISPO; UM PROFESSOR E UM COMERCIANTE DO SECULO XIX

7. CONCLUSAO

8. BIBLIOGRAFIA

9. NOTAS 
Timeo hominem unius libri (Arreceio-me do homem dum só livro) SANTO TOMAS DE AQUINO *

* Apud Goudin, A. Philosophia thomistica. Coloniae, 1732, p. 167 


\section{INTRODUÇÃO}

O perfil de leituras brasileiras dos séculos XVI ao XIX vem sendo objeto de nosso estudo hä algum tempo, mais precisamente hã sete anos. Desde 1980, vimos procedendo a uma verdadeira peregrinação por todos os notórios centros de irradiação e guarda cultural do país, recolhendo dados sobre o assunto em bibliotecas e arquivos, inclusive alguns em Portugal. Um número extraordinärio de títulos e dados bibliogrä́ficos foram reunidos para uma "Memória Bibliogräfica Brasileira", que conterá organização catalográfica e dicionarizada de obras - desde os incunäbulos do século XV aos. livros com data de publicação limite em 1825 - trabatho em que estamos envolvidos para posterior apresentação . Número igualmente expressivo observa-se quanto a títulos, autores e matérias extraỉdos de fontes documentais primárias, vale dizer, dos inventários de bens, em livros, atē à data limite de 1850 , que fornece a melhor base de orientação aqui seguida.

A definição precisa deste estudo, ou seu objetivo mais determinado, seria ampliar o horizonte dos dados recolhidos em pesquisa de campo para o desenvolvimento de una amostragem crítica e descritiva de livros e leituras no Brasil Colônia e sua provável influência na produção intelectual brasileira do período. Seu interesse enquanto pesquisa, cremos, serā o de resgatar a memória cultural brasjileira da quadra colonial mediante a anälise de uma eventual so- 
ciologia da leitura em nosso país, ou seja, o mapeamento cultural e literärio brasileiro do Quinhentos ao Oitocentos. Como produto final, servirá de instrumento à observação crïtica acerca do papel e das relações conectivas da Cultura e da Literatura no período colonial.

Não evitaremos aqui uma estética ou uma teoria da recepção de leituras, mas sem formal obediência á qualquer rigor ou sistema teórico, descreveremos analiticamente a recepção passiva do leitor brasileiro enquanto eventual possuidor de uma biblioteca na Colônia e, num segundoe decisivo caso, a de um leitor-produtor, ou próprio de uma recepção ativa, ou retroprojetiva, no exercício de rever a literatura brasileira a partir das suas relações intertextuais.

Não faremos também uma história da leitura no Brasil, mas uma amostragem pontuada de observações sobre experiências de leitura no Brasil Colônia, o que se depreende do mapeamento e 1 istagem de livros nas fontes documentais objeto de nossa investigação, com máxima relevância para os livros e autores pertencentes à āreà dé. Letras. Valerā o trabalho, talvez, como diacronia e retrospectiva de alguns brasileiros leitores é suas nem sempre claras relações com grandes ou pequenos 1ivros. Em princípio, trata-se de revelar umleitor quase anônimo, de formação burguesa, a maior parte de origem rural ou de um universo urbano ainda muito incipiente. Scguimos as pegadas desse leitor, acompanhando suas tendências de leitura justamente pela descrição e estatística de seus livros como peças inventariadas em documento para fins de partilha. 
Neste passo, percorremos algumas das propostas de estudos desenvolvidos quanto às raízes cultural e.literária no Brasil, com lembrança especial aos trabalhos de Rubens Borba de Moraes, Serafim Leite, S.J., Fernando de Azevedo, Carlos Rizzini, Laurence Hallewell, Wilson Martins e outros, que assinalam, enquanto historiadores da cultura brasileira, a trajetöria do livro como elemento transformador da mentalidade nativa. Nossa perspectiva aqui serā, todavia, um tanto paralela, diversa, talvez, quanto aos métodos de análise. E oporțuno reafirmar que a conceituação deste trabalho não será a de uma história da cultura, mas a abordagem e o esboço de uma Sociologia da leitura a partirdo apontamento descritivo e analitico da circulação de liviros e suas possiveis influências na produção literária do período colonial. Seră, portanto, um esforço de convalidar a nossamemöria pe1a organização e qualificação de acervos bibliográficos ou de inventärios dos livros que, de alguma forma, relativizaram a formação do homen brasileiro da Colônia.

Com isso, talvez, estaremos ocupando o espaço de uma Sociologia da Literatura defendida pela historiadora Maria Beatriz Nizza da Silva, em artigo no Suplemento literário de "O Estado de São Paulo", de 30 de maio de 1971, que toma a compreensão sociológica do livro enquánto bem de consuno e não. apenas em seu modo de produção, distribuição ou interesse intelectual. No capítulo dos inventários, porém, até porque não nos preocupa fazer. História mas ensaio sobre a evolução da Literatura brasileira e a circulação de livros e leituras, ressaltamos um ou outro autor e alguma obra sig- 
nificativa para essa evolução dentre os livros como bens de consumo no Brasil Colônia. E trabalho, portanto, cansativo, no esforço garimpeiro de investigação e demonstração, sem grande encanto teōrico. Não hâ, portanto, grande desvelo de natureza estilistica ou estêtica na amostragem, apenas um levantamento demonstrativo e um esforço de interpretação do comportamento do leitor brasileiro na fase colonial.

Assim, este trabalho pode tambēm ser percebido naquiIo que a mesma Nizza da Silva qualifica como necessidade de reposição e reorientação dos estudos literários, uma vez que, segundo ela, "para estudar as relações entre literatura e sociedade è preciso examinar não só o que essa sociedade produz, mas tambèm o que ela consome" (Cultura e Sociedade no Rio de Janeiro, (1808-1821), (1978), p. 171). Destarte, compreendemos nosso exercício de uma Sociologia da Literatura no Brasil, não apenas debruçando-nos no grau de interrelações entre o que se leu e o que se produziu; mas igualmente procurando reconhecer e identificar as.opções de consumo da Literatura no Brasil Colônia, não só registrando a freqüencia dos autores ditos clässicos e mais importantes. mas antes revelando a própria proeminência de leituras, mesmo aquela que não se resenhe como "Importante" ou "Clássica".

As dificuldades da pesquisa, seus conceitos e resultados são questões a serem respondidas na forma de una exposição cirçunstanciada, vảlida em outra ocasião, embora algumas dessas questões possam desvendar-se no curso deste trabalho. A metodologia seguida pertence a critériosde inves- 
tigação historiogräfica, uma vez que levantamos fontes documentais primärias para o mapeamento de autores e obras pertinentes ao assunto. De igual modo, foi feita a pesquisa em bibliotecas, inclusive algumas particulares, e ern conventos, mosteiros, arquivos e institutos históricos, comofichamento bibliográfico e organização catalogrăfica de obras existentes ainda hoje no pais, para servir de fonte subsidiāria ao conhecimento do perfil de leituras.

Tarefa de amostragem e resultado de pesquisa, esta descrição do Brasil leitor a partir da investigação em inventārios de bens ou em bibliotecas coloniais não tem a apoiā-la um suporte teórico específic.o. E nem seria lastimável a ausência, uma vez que o caráter incidental deste trabalho serâ mesmo o de anotar o resgate da informação cultural pela amostragem e descrição de dados pesquisados. Não se fará, contudo, una simples enumeração de títulos, autores ou idéias correntes, tampouco indicações para o conhecimento pacífico de nosso passado.

Descrevendo e interpretando o perfil de leituras brasileiras, do início do ciclo colonizadox à constituição do Império, sem düvida estamos ampliando o conhecimento da irradiação cultural oriunda de leituras numa sociedade incipiente como a brasileira, revendo-se aqui sua tipologia sociomoral e suas características literárias. O Brasil Colônia era inculto, provinciano, limitado e bacharelesco, scmifeudal e na bitola anacrônica do assentimento colonizador português, absolutamente herdeiro da tradição católico-medic val. Assim, a sociedade brasileira conteráos clementos tí- 
p̈icos do colonizador e sua tradição leitora salientará os aspectos que vão desde o paisagismo histórico e tratadista à História natural, ao ditirambo e panegírico de uma ciência 1 iteräria nascente.

No capitulo 2, que estuda característicasde leituras a partir de notícias gerais da circulação de livros no Brasil, tomamos a perspectiva histórica mais ou menos reiterativa. Acompanhamos a visão sócio-cultural do Brasil Colônia a par'Eir de análises feitas predominantemente por Rubens Borba de Moraes em Livros e Bibliotecas no Brasil Colônia, seguidas das contribuições hisțóricas verificadas em Fernando de Aze-

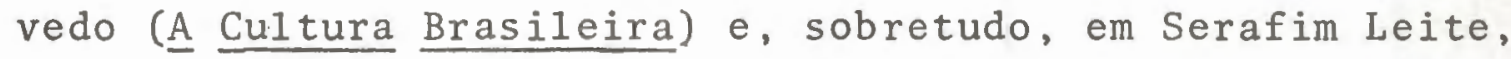
S.J. (História da Companhia de Jesus no Brasil). Completam - estudo a visão de aspectos da formação social brasileira, notícias da instrução pública, instituição de colégios jesuitas, franciscanos e beneditinos, além da premissa de fundação. de bib.liotecas e coisas das humanidades em nosso país, como o ensino não-técnico, a docência teocêntrica, o tímido interesse colonizador impresso numa culturatravestida. Ademais, diacronicamente, observamos o saber Iivresco, as relações do B'rasil com a Universidade de Coimbra, as cartas e informes jesuíticos sobre a Colônia, o embargo cultural da Metrópole, os livros proibidos, a ausência da imprensa e expulsão dos jesuitas, o espírito censório português, a Inquisição, Pombal e a reforma pedagógica, a legislação e a adini= nistração coloniais. Tudo isso forma ụ conjunto ideológico aqui tomạdo em forma subliminar, talvez até semgrande aprofundamento, para o reconhecimerto e identificação de um público leitor no Brasil. 
No. capítulo 3, que dá título ao trabalho, tratamos da evolução da leitura dirigida no Brasil, descrevendo os 1ivros encontrados nos inventários de bens, desde os mais antigos do sëculo XVII, aos inscritos na data limite de 1850, avaliando a predominância de um leitor especializado em obras de seu interesse imediato, leitura obediente a oficio ou profissão. Também acontece haver um leitor brasileiro sentimentalmente preso a obras devocionais, da mistica católica, como é fácil supor em virtude da forte presença religiosa no processo colonizador. O capitulo traça uma noticia concreta do perfil e da sociologia de leituras especificas com base em inventários de livros dispostos como bens nos documentos manuscritos. Buscamos as fontes em todos os Estados da Federação, sendo principais os arquivos, museus, bibliotecas, institutos históricos, ana'is e sociedades de pesquisa situados no Rio de Janeiro, em São Paulo, Minas Gerais, Bahia e Rio Grande do Sul. A análise dos dados seguem os passos da amostragem descritiva dos livros oriundos dessas bibliotecas, registrando-se prevalência de obras nos ramos das Letras, da Religião, da Medicina e do Direito.

Por isso o desenvolvimento do capitulo investe na abordagem de assuntos que vão desde o ofício ou especialidade do consumidor de livros no Brasil Colonia (3.1 - Leitores padres, mëdicos, bacharéis), suas preferências por obras de conteúdo moral e religioso, na tradição obediente de uma leitura não-crítica, mistificada e padrão, formulada pela docência jesuitica (3.2 - Doutrinas e devocões), ou incidindo diretamente em obras próprias de uma ciência prática, co- 
mo a Medicina, a Cirurgia, a Farmäcia (3.3- Aforismose sangrias), ou de una ciência especializada, aquela típica da natureza jurídica ou legislativa (3.4.- Vade-mecum e ordenações). Para o estudo de estilo e tendências de leitura na área de Letras, pelo óbvio sentido desta tese, tomamos a constituição de títulos e autores próprios doesppirito humanista, analisando as caracteristicas convencionais de um leitor letrado (3.5 - Clässicos, moralistas e gramáticos).

No capítulo 4, procuramos relacionar a constituição de bibliotecas pertencentes a lideres.e personalidades brasileiras envolvidas em projetos revolucionários com a influência direta da leitura de obras de espirito reformista. A reflexão provocada pelo corpo de idéias nos livros combina-se com a ação libertāria de agentes-leitores. Os exemplos típicos seriam os inconfidentes mineiros de 1799, os conspiradores baianos de 1798, os 1ivres-pensadores da Sociedade literäria do Rio de Janeiro em 1794.

O capítulo 5 analisa a natural tendência de leituras dos religiosos no Brasil, nomeadamente as ordens dos jesuítas, franciscanos, carmelitas e beneditinos. Destes ültimos, destacamos um catálogo preparado por Fr. Gaspar da Madre de Deus, que chegou a Abade do Mosteiro de São Bento no Rio e que, obediente aos ditames pombalinos, remeteu a Portugal uma lista sumāria dos livros que compunham a biblioteca dos monges cariocas.

A curiosidade da constituição bibliogräfica dos estilos de leitura no século XIX é apresentada no capitulo 6, onde estudamos as livrarias oitocentistas mediante os inventá- 
rios de um publicista famoso da ëpoca, Evaristo Ferreira da Veiga; um político e militar de sensivel presença na cena política de São Paulo, o brigadeiro Luis Antônio de Souza e Queiroz; um lente da Faculdade de Direito de São Paulo, ninguẻm menos que o avô'e homônimo do poeta, Luís Nicolau Fagundes Varela; um diplomata baiano, deputado àscortes constitucionais em Portugal, 1820, José Lino Coutinho; um bispo, D. Fr. José da Santíssima Trindade, de Mariana; e um comerciante de Rio Grande (RS); Francisco Xavier Ferreira e sua mulher, Ana Joaquina Ferreira. Estes representam a tipologia do leitor brasileiro dos princípios do século XIX.

De forma diacrônica, vamos observar a evolução de estilos e tendências do Brasil leitor, do século XVI ao XIX. No século XVI, por exemplo, o Brasil seria leitor de Horácio, Quintiliano, Marcial, Sêneca, Virgílio. E da Bỉblia e dos doutores da Igreja. Em que pese haver pouco recurso conhecido ou disponível para o acesso a essas conclusões, ensaiamos uma tentativa de apontamento do leitor brasireiro quinhentista.

o Brasil leitor, concretamente, com base em documen tos factuais, excetuando os raríssimos casos dos colégios jesuítas, começa, na verdade, no século XVII. Os inventärios seiscentistas nos socorrem a respeito e informam a circulação de 1 ivros e autores num quadro histórico em que não vamos encontrar grandes resguardos de memória cultural. 0 que se lia no Brasil do Seiscentos è o que descobrimos no capítulo aqui correspondente. O século XVII brasileiro não nos antecipa, do ponto do vista da Literatura, autores como Lo- 
pe de Vèga, Graciān, Quevedo ou Göngora. Nem Molière, Racine ou Pascal. Nem Dante ou Petrarca. Registra, contudo, Cervantes e um tímido Calderón. Dos portugueses, Camões, Sá de Miranda e Rodrigues Lobo jā serão populares no sẻculo XVIII. Bernardim Ribeiro, Gil Vicente, os dramaturgos e poetas satíricos da tradição peninsular, ou os patéticos e místicos do mundo ibérico não aparecem nunca. Lope de Vega tem presença tambëm no século XVIII.

Os dados principais para essas interpretações foram colhidos nos inventärios e servem como testemunho da influência. literária no espírito e na formaçã̃o do brasileiro co1onizado. Os livros existentes em suas bibliotecas, anotados e mapeados por assunto ou especialidade, registram um gosto de leitura e uma tendência politico-cultural, com destaque para os de interesse em nossa concentração - Letras e Linguística. Seră, então, possivel reconhecer a igualização ou diferenciação do leitor, identificá-1o socialmente , surpreendê-10, pela descrição de seus livros, em sua importância crítica e histórica e no desenvolvimento sócio-cultu ral do brasileiro na fase colonial.

Nas Conclusões, reafirmamos as tendências de leitura no periodo estudado, encerrando a fixação definitivado perfil do leitor colonial brasileiro.

No tocante à Bibliografia, buscamos uma prätica dálcitura distintiva e anotada de trechos importantes da llistória geral e da Cultura. Histöria social e politica do Brasil, Historiografia literäria e Sociologia da Literatura,alëm de textos oriundos da produção 1iterắria brasileira es- 
tudada, para melhor descrição e identificação das carạcte risticas presuntivas de um leitor brasileiro atento à circularidade bibliogräfica. Apoiamo-nos numa bibliografia cspecializada, com fins informativos, uma vez que este traba1ho, realizado em campo virgem de investigação, projetado numa linha de pesquisa pouco explorada na ciência literária, tinha devaler-se, como, de fato, se valeu, dos dados oferecidos em seu próprio devir, e em seu próprio valor.

Restam, por fim, alguns esclarecimentos. A maior parte das transcrições dos 1ivṛos inventariados obedecem ao critério historiográfico de registro tal como aparecem nos documentos. Ou seja, procuramos ser o mais possível fiéis ao espirito das fontes de que nos servimos. Algumas dessas transcrições podem causar a1gum embaraço ao entendimento, mas reproduzem a massa de informação de todo pertinente ao objetivo aqui expresso. No tocante às Notas, as finais traduzem a referência bibliográfica das fontes onde indicam algum elemento informativo indispensável. Jầ as referências a documentos de época e sua localização vão anotadas, entre parênteses, no próprio corpo do texto. E desejo nosso facilitar a compreensão de todo o esforço desta tese. E nossa alegria, maior, será a troca de experiências, permanentemente válida em qualquer tarefa intelectual. 


\section{ESTILOS E TENDENCIAS DO BRASIL LEITOR}

Quem 1ia o que na sociedade colonial brasileira?

A pergunta pode trair uma indisputada sensação de conforto se a tomarmos para ser respondida apenas na tábua rasa do enunciado reiterativo, do já dito, e insuficientemente dito. Para respondê-la mais amplamente, nomeando e descrevendo livros e leitores de segura circulação e permanência no ambiente colonial, tivemos de ir mais fundo na busca de noticias sobre a relação homem-livros no Brasil, sobre häbitos e comportamentos de leitura, sobre tendências ideológicas e obras populares, e, até, sobre uma certa estatística sintomática de modelos culturais e criticos no sistema social da Colônia.

O resultado a que chegamos, em que pese as dificuldades próprias de toda pesquisa de campo, é que o brasileiro, se não lia tudo ou bem, ao menos lia. E lia razoavelmente vário: e muito. A fonte primeira e mais direta para esta nossa observação fomos buscá-la, e adiante a demonstraremos, na fórmula inquestionảvel dos documentos de época: os inventários de bens.

Antes, contudo, de perseguirmos a trilha segura oferecida pela análise dos inventários de bens, objeto nuclear de nossa pesquisa, consideremos aqui algumas caracteristicas, genéricas, de um leitor brasileiro desde o século XVI ao XIX, levando em conta a natureza transparente das informações his- 
toriogräficas a respeito. Para tanto, no caso do colonizadox, desde o sëculo de Quinhentos, è indispensảvel levar em consideração o estāgio político e social da Colônia, durante anos em lastimävel inërcia administrativa. Recorrendo ao óbvio, somenté a partir de 1549 , com a chegada do primeiro Governador Geral, (uma vez fracassada a experiência das Capitanias Hereditārias), é que se podem perceber alguns vestígios (incipientes) de civilização portuguesa chegando aos trópicos, conquanto nem sempre se possam, traduzir esses traços civilizatórios em termos de livros e bibliotecas.

Pode dizer-se, á propósito e com segurança, que a experiência colonizadora dos portugueses em muito diferiu da espanhola. no resto da América Latina: Conforme demonstra muito bem Irving Leonard em seu Los 1ibros del conquistador ${ }^{1}$. Os espanhöis trouxeram livros em suas aventuras de anexação de territórios no Novo Continente, predominantemente livros de cavalaria, e com isso influíram, de maneira decisiva, ra formação de um modelo de cultura literāria que, não será errôneo supor, deve ter intensificado imaginações e fornecido elementos configuradores para a apreensão sensível das vārias realidades da América Latina, caso que enseja pressentir influência atê mesmo - numa antecipação do imaginário coletivo - na produção da mais moderna literatura hispanoamericana.

o caso português, pois, é mosmo singular. Além do atraso, em quase meio sêculo de assunção administrativa, provoca outrosatrasos em nosso possível desenvolvimento cultural. No Brasil, o colonialismo portugués praticou um caso típico de dirigismo por ausêncià. Em outras palavras, Portugal in- 
fluiu aqui pela negação da cultura em livros, uma vez que, com exceção do século XIX, a partir da mudança da Corte para - Brasil, nunca houve real decisão política de tráfego de livros, mesmo os de cavalaria, para cá. Certo que o século XVIII, com o modelo da ilustração pombalina, desenvolveu e intensificou aqui uma certa pedagogia de época, com os previsíveis desdobramentos quanto aos interesses do colono no cannpo de uma bibliografia específica. Mas é o século XVIII que tambëm proíbe a Antonio Isidoro da Fonsẹca de aqui instalar-se com sua editora e sua experiência de impressor.

No exercício de prospecção do assunto, em sua base secundāria de informação histórica, deparamo-nos com um caminho que aponta, além das naturais dificuldades provenientes do embargo português ao surgimento e evolução de uma inteligência brasileira, as dificuldades oriundas da ausência de documentos definitivos sobre o acesso e sobre as caracteristicas de leitura em nosso país. As duas carências serão suficientes para retardar e obscurecer nosso auto-conhecimento enquanto povo e nação, expresso. aqui na forma da transmissão da cultura literária, ou seja, da leitura ou circularidade da vénda de livros. Daí a vala comum das reiterações sobre os séculos XVI e XVII. Nada há de novo sob o sol da historiografia, brasileira ou não, a respeito.

. o elevado grau de repressão e uma atrasada visão colonizadora portuguesa tornam-se, sem dúvida, responsáveis pelo soterramento de possiveis avanços intelectuais do colono. Desde cedo desprovido de cscolas de orientação humanista c, mais ainda, inteiramente distanciado de um universo favorá- 
vel à livre circulação de idéias, o homem brasileiro começa a exercitar-se enquanto leitor mais de um século decorrido do início do processo colonizador, não vaiendo atribuir tal atraso a quaisquer determinismos eugênicos que nos inferiorizem enquanto povo. Estas, inegaveimente, podem ser tomadas como das principais causas de o nosso desenvolvimento cultural ter sido duramente retardado.

Para equilibrar a carência, nos séculos seguintes, o homem médio brasileiro, filho de familiạs abastadas, buscou na formação acadêmica ou profissional em Coimbra, seu devir ètnogrảfico. Eal formação, a despeito de um extrato jesuítico conservador e pseủdo-humanista, teve relativa importância e contribuiu para o alargamento do nosso conceito antropológico. Os que aqui permaneceram conformaram-se aos estudos de feição letrada e mecânica, educação inchada da vọação latinizante dos colëgios religiosos, num ensino adaptado e conservador dos postulados casuisticos da Idade Média. Afora isso, pouco se tem de notícia convincente a respeito do acesso colonial à cultura e aos livros europeus.

A questão do acesso passa também, por critérios econômicos, desde o século XVI na raiz dos eternos entraves ao nosso desenvolvimento. Só os abastados, entāo como até hoje, tinham possibilidade de ascensão cultural. Os inventärios que pesquisamos são, na verdade, documentos que atestam o poder econômico, retrato do modelo de propriedade dos homens brasileiros no período colonial. Podemos, afinal, concluir que o livro também foi símbolo de riquéza e hierarquia social, objetio a que raríssimos não-ricos puderam ter acesso. 


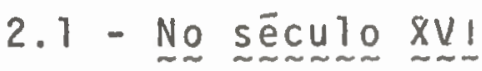

Sem pretender atrair maior controvérsia e independente de outras consideraçōes de ordem política, ou ideológica, devemos destacar como importante a contribuição da Companhia de Jesus na instrução pública brasileira. O carāter docente dos jesuitas, se esquecermos a bitola estreita de sua base católica contra-reformista e a força impregnante de uma educação ritualista à roda do automatismo, indiretamente ampliou e trouxe as primeiras leituras para o Brasil. Mesmo leituras obrigatōrias e para servir de cópias aos modelos clässicos ou eclesiásticos, aos poucos vieram alicerçar a formação social e literária da Colônia.

Se o quadro introdutório da cultura na segunda metade do século XVI ainda é muito precário e insuficiente, antes a presença portuguesa era inexistente. Atē 1549, o que se verifica da colonização è um imenso vazio cultural, coincidente, aliās, com o próprio vazio político e administrativo de um ịmpério luso essencialmente preocupado com seu destino no Oriente. Se,da primeira metade de Quinhentos, não nos chega nenhuma proposta concreta de colonizaçāo, claro que serā um tanto inverossimil o preenchimento de qualquer assentamento cultural entre os primeiros colonos brasileiros. Somente a partir da segunda metade do século XVI, portanto, com a chegada de Tomé de Souza à Bahia,é que se notará uma certa animação político-administrativa na Colōnia. Começa então um efetivo processo colonizador, o que inclui e justifica a presença intensiva e extensiva dos, jesuítas em nosso processo educativo e cultural. 
A Igreja, representada pelos padres da Companhia de Jesus, realiza aqui um gueto, da cultura, particularmente no que toca ao papel moralizador e pedagógico. Sobrevêm aos jesuitas, os beneditinos, os franciscanos, os carmelitas, formando, por mais de dois séculos, uma, significativa parce1a de ativismo religioso-cultural na Colônia. Certamente, a esse tempo e até fins do século. XVI, sobretudo os jesuítas, teriam trazido livros de sua devoçāo. A esse respeito, Rubens Borba de Moraes acredita ter havido circulação de Iivros não apenas nas mãos dos religiosos, como tambëm "em mãos de alguns particulares" ${ }^{2}$. Não hä como comprovar a afirmativa, pois inexistem documentos e, muito menos, noticias sobre titulos ou matêrias desses livros. As cartas jesuiticas nada esclarecem sobre existência ou tipologia de obras. Menos esclarecedora, ainda, è a quase nula correspondência oficial de então.

Se não aparece informação direta sobre títulos, pode- se presumir que os livros que circulavam entre os religiosos seriam mesmo os de devoção, aqueles necessärios à tarefa evangelizadora. Em carta datada de "Baía 15 de abril de 1549", Nóbrega renova ao Superior da Companhia em Lisboa, o padre Simão Rodrigues, pedido de livros, num parágrafo que é un primor de peditório:

Antonio Pirez pede a V.R. alguma ferramenta de carpinteiro, porque elle hé nosso official de tudo; Vicente Rodriguez, porque hë hermitão pede muitas sementes; ho Pe. Navarro e eu, os 1 ivros que jä là pedi, porque nos fazem muita min- 
goa para duvidas que cà há, que todas se preguntão a mym. 3

Eram livros que o mesmo Nóbrega depois declararia ter recebido em carta datada de "Porto Seguro, 6 de janeiro de $1550 "$, confirmando terem chegado duas caixas contendo livros e ornamentos. 4 Que livros seriam? Não hä registro, embora devessem ser aqueles de matéria religiosa para fins de doutrina e catequese.

Carta do P. Cipriano Suárez ao P. Inäcio de Loyola, dirigida a Roma e datada de "Lisboa, 25 de abril de 1553", fala da missão evangelizadora no Brasil e menciona a prestimosa ajuda do rei D. João III de Portugal que "não só provê os Nossos de viātico, mas também dinheiro muito liberalmente para que aos Nossos se enviem biblioteca, e outras coisas que faltam naquelas regiōes" 5 . Se não nos chegam notícias quanto a títulos, chegam quanto a matérias. Carta de Nốbrega dirigida ao P. Luís Gonçalves da Cāmara, em Lisboa, datada de "São Vicente, 15 de junho de 1553", informa que os meninos Indios aprendem a ler e escrever e outros mamelucos mais häbeis aprendem gramātica com un rapaz que é gramático e veio de Coimbra ${ }^{6}$. 0 mesmo diz aos padres e irmãos de Coimbra o P. Brās Lourenço, em carta datada de "Baía, 30 de julho de 1553", indicando que o padre Antonio Blásquez se dedica ao ensino dos meninos indios em ler, escrever e a alguns ensina gramātica ${ }^{7}$.

o processo de educação püblica integrada aos postulados jesuiticos vem a ser um mote frequente nas observações e 
debates dos padres. Faz parte da ideologia contra-reformista e dos objetivos expansionistas da Compania de Jesus. Em carta dirigida ao P. Inácio de Loyola em Roma e datada de "Lisboa, 14 de fevereiro de 1554", O P. Diego Mirón assinala a necessidade da pedagogia e menciona tipos de ensino a serem aplicados:

Éstä bien con que se haga un collegio de escuelas püblicas en la India y en el Brasil como tenemos aqui y en Evora, donde se remediasse la ignorantia de aquelas partes en los clérigos con la lición de casos de conscientia, y en los demäs con las liciones de grammática y latin. 8

Os estudos, porẻm, sè desenvolviam com lentidão e dificuldade, justamente por faltarem livros que melhor instruíssem sobre as matêrias de doutrina e gramática. Carta do P. Luís da Grã ao P. Diego Mirón, dirigida a Lisboa e datada de "Baía, 27 de dezembro de 1554", anuncia a extensão do ensino de casos morais para instrução religiosa dos nativos e de rudimentos de latim, pelo padre Blázquez, lamentando não haver livros de latim. E reforça o pedido:

Si V.R. pudiera aver alguna limosna para libros de latín, que sirvan para el principio con otros para los mäs aprovechados poderseä hazer algün fructo. 9

Como se observa, pouco havia em matêria de livros nos primördios da colonização portuguesa. Os sucessivos pedidos reiteravam o começado por Nóbrega em 1549. Os padres regis- 
travam seus esforços como copistas das obras disponiveis, reconheciam a aquiescência e habilidade dos nativos em aprender, desenvolviam estudos para compreender a língua dos índios e adaptavam os casos morais ao tupi parid uma mais fácil compreensão. Por fim, identificavam suas pröprias dificuldades docentes, uma vez que o ensino, face à pouca circulação de livros, se processava de forma rudimentar, fastidiosa. e quase inütil. Pode-se, deduzir que haveria, entre os padres, os livros de uso individual, pois seria mesmo inpensável que os soldados da Companhia de Jesus viessem para uma tarefa evangelizadora, num agudo momento de ação missionária, sem seus extensivos amuletos ideológicos de Teologia, Ascese ou Didātica hagiogräfica. Todavia, a não ser que adiante surjam novas e esclarecedoras provas documentais, é praticamente insustentävel afirmar quais os títulos que teriam circulado é, em consequência, determinar um perfil de leituras à época. E assim voltamos a um mesmo ponto de interrogarão. Afinal, que livros teriam circulado no Brasil de Quinhentos?

Talvez as ordenações do Reino, no plano civil e administrativo, por seu caräter legislador, e obras devocionais e teológicas dos religiosos da Companhia. Dificil prever, por exemplo, se; atë ao fim do sẹculo XVI, teriam sido lidos os autores populares em Portugal desde o século anterior, como Zurara, Castanheda, Jerônimo Osório, ou o Fernão Lopes com seu carāter distintivo de valorização da nacionalidade lusa através da crônica dos feitos gloriosos dos portugueses em sua aventura renascentista de descoberta e anexação de novos mundos. Nenhuma notícia temos a respeito de obras conhe- 
cidas è circulares na Metrópole. Para nós, por exemplo, é inteiramente desconhecido o ciclo dos descobrimentos. Não sabemos do livro de Antonio Galvão sobre as Antilhas e Indias. Nem do de Gabriel Rebelo sobre as ilhas Molucas - Nem de Pedro Teixeira sobre a Pérsia, ou o de Pedro Fernandes Queirós sobre as ilhas do Pacífico. Desconhecemos o Congo e regiões vizinhas presentes na relação de Duarte Barbosa. Também nos é inteiramente desconhecido o Tratado em que se contam muito por extenso cousas da China, com suas particularidades, e assim do Reino de Ormuz, do Fr. Gaspar da Cruz,publicado em 1570. Nem o Itinerärio de Antonio Tenreiro,o livro de Galeote Pereira sobre a China ou o de Tomé Lopes, Navegação às Indias Orientais.

A segunda metade do século XVI assiste, em Portugal, a um tímido apogeu da voga renascentista. Desta, porém, nada se passa ao Brasil. Como observamos, não nos chegam as experiências de livros de cavalaria e de moral que marcaram a colonização espanhola na América. Nem sequer a tradição do teatro quinhentista nas naus da India parece ter sido expandida na rota brasileira. Também aqui não chegaram os Autos do Leal Conselheiro, ou o Livro de ensinança de bem cavalgar, conhecidos em Portugal antes mesmo do espirito humanista. Tambēm aqui desconhecemos as traduções que D. Duarte mandou fazer e igualmente as histórias por ele encomendadas. O Brasil do século XVI, com extensão até ao século XIX, não conheceu Gil. Vicente, ou os dramaturgos populares do cordel português. Esse contiecimento talvez tenha se manifestadoindiretamente, como é o caso do teatro dẹ Anchieta e Antonio Josć. 
Nosso Quinhentismo ẻ, sem düvida, anacrônico. Nada se emite ainda da circulação de clássicos conhecidos no Portugal renascentista, como o Sêneca de De beneficiis, o Cícero de De officiis, o Aristöteles da Politica, ou Avicena, ou os doutores da Igreja como o Santo Agostinho das Confissões. Nem os grandes autores da Patrística, da Mística, da Apologētica. Nada do Livro de Buen Amor, popular em Portugal,do Arcipreste de Hita, ou do Livro del conde Lucanor, de D.João Manue1. Nada. também das trovas dos reis Dinis e Afonso. Nada do Cancioneiro geral de Garcia de Resende - que reúne a poesia portuguesa galante e cortesã, a poesia ora do alheamento, ora da impregnação existencial e a poesia satírica e amorosa - publicado em 1516. Não se tem aqui referência sobre a circulação da Crônica de D. João II, do mesmo Garcia de Resende.

No mesmo passo, resulta impossível prever motivos e influências do 1 irismo comovido de Roiz Castelo Branco, ou de Francisco Lopes. Nada dos renascentistas como Bernardim Ribeiro (Menina e moça è de 1554), o que afasta do Brasil, pelo menos no século XVI, a formal influência de Sanazzaro. A ausência também alcança Cristóvão Falcão e Damião de Góis, este talvez pelas implicações renascentistas da corrente erasmiana $e$, mais provavelmente, por imposição das perseguições rẹigiosas deflagradas a partir das maledicências do Pe. Simão Rodrigues, Superior Provincial da Companhia de Jesus em Portugal. O Brasil de Quinhentos permanece na sombra. Não conhece a erudição religiosa e poética de Samuel Usque ou lleitor Pinto (que vai apareccr entre nós já 
no sëculo XVII), nem o romântico avant la lettre que è Ama-. dor Arrais, ou Tomé de Jesüs. Que dizer, em nosso século XVI, da poesia ascética de Agostinho da Cruz? Nada. O Brasil de Quinhentos parece que não 1ia. No entanto, a imprensa tipográfica já se havia introduzido em Portugal desde o século XV, alcançando, no século XVI, uma florescente indústria desenvolvida sobretudo por iniciativa de artífices e empresārios judeus - esforço, aliảs, pulverizado pelo Estado, com os seqüestros de praxe.

Hā, para o nosso atraso bibliogrāfico, razões muito plausiveis do ponto de vista do colonizador. Em princìpio, o século XVI brasileiro só tem, para Portugal, um interesse especulativo. A extração de riquezas ainda era incipiente, não se descobrira potencialidade da terra quanto a ouro ou prata, ferro, trigo, ou gado e só as especiarias da primeira ocupação e o pau-brasil das capitanias hereditärias forneciam matérias-primas à Metropole. Assim, aos olhos de Portugal, o Brasil. não passava de colônia de rito expansionista, a servir de pasto a uma crescente população de miserâveis cidadãos e degredados portugueses excluidos do banquete metropolitano. O Brasil Quinhentista é habitado, além dos nativos, por vorazes asilados da decadente sociedade lisboeta, aristocrātica ou burguesa. São eles os condenados à povoação brasileira. A literatura de propaganda da terra serviu para atrair os excedentes famintos c desocupados de uma extenuada e gasta sociedade metropolitana. O Brasil, então mostrado como ambiente paradisíaco, de clima excepcional, de fartás riquezas naturais, de muita água 
e muita. terra por ocupar, atraiu-os, forçados pela tangência politica central. O fascínio da propaganda trouxe uma população ainda não numerosa e aqui injetou um incipiente processo colonizador não-civilizatōrio, atendendo a uma tática reinol de expatriamento de velhos problemas, sem assunção de navoṣ.

A. prātica desse comportamento colonizador sō poderia refletir-se numa mentalidade de apropriação e ganāncia, de par com uma natural negligência pelas coisas da cultura num país habitado por um povo considerado como selvagem e bestial. Portugal assim se orientou. Assumindo a planta asiātica, o escravo africano, a terra americana, julgava assentar seu prestigio imperialista. O ciclo extrativo do século era exclusivamente o do pau-brasil. O interesse mercantilista português se mostrava, pois, pouco concorrido num mercado capitalista ávido por outras e mais brilhan tes riquezas. Isso sō se alterarā intensamente,com o ciclo da cana-de-açūcar,jā na fronteira dos sēculos XVI-XVII. O Portugal comerciante fortalecerá sua presença, mesmo, no século da mineração, interesse que jā vinha pontuando desde a frequência do.ciclo do gado vacum desde o sēculo XVII, frequência que se estende até o sēculo XIX.

A negligência portuguesa pelo Brasil revela-se, no entanto, discriminatória e diferenciada da atitude colonizadora na Africa e na Asia. Ali o colonizador mostra-se complacente, permitindo, inclusive, a implantação da imprensa e estimulando um fluxo permanente de contatos e informações. O Brasil da atividade rudimentar. c população incipi- 
ente não diferiria muito do ambiente das colônias africanas e asiāticas. A razão da discrepância, entretanto, estā no imediato interesse colonizador e no grau de resistência adversária ao processo de colonização no Oriente. $\mathbb{A}$ frica e Asia eram continentes vistos como de uma importância capital em função do conjunto de riquezas pressentidas e, portanto, como símbolo da avultada glória na campanha expansionista. A India e o Marrocos tinham, para a Corte portuguesa, um interesse especialíssimo. A América, não. Esta trazia consigo apenas a mística do paraíso, a visão de um ambiente intocado, desconhecido, para o futuro, habitado por selvagens broncos e nus, selvagens ingênuos e mansos da versão européia presumida e cantada por Montaigne e Ronsard.

Talvez não seja por acidente que a carta de Caminha sō veio a ter divulgação dois séculos após escrita e enviada.: Gandavo apelava, numa clara ideologia propagandística, para a necessidade da colonização, mas Portugal só tinha olhos para a Africa e a Ásia. A formidāvel épica cámoneana melhor se manifesta narrando a dureza da aventura colonizadora em terras e mares do Oriente. A América portuguesa, em Os Lusiadas, entra apenas como reforço cumulativo das glórias portuguesas. O concīlio dos Deuses só é convocado e o velho do Restelo só se manifesta em função das glórias e desditas dos portugueses no ultramarino africano e asiātico. F D.Sebastião, o mais caro mito português de uma experiência sonhadora do Quinto Impērio, somente se realiza a partir da aventura contra os mouros. Na mesma li- 
nha, só África e Asia dão suporte à fantāstica imaginação de Fernão Mendes Pinto em suas Peregrinações. Ou seja, a aventura portuguesa no Brasil é tida como sem maiores problemas, sem resistência ou importância imediata e nem mesmo a tentativa da França Antārtica é seu empecilho. 0 Brasil só virā a tornar-se dor de cabeça para os portugueses um século depois, com as invasões holandesas e com os quilombolas.

No geral, difere da portuguesa a proposta colonizadora hispânica em solo americano. Pode-se especular sobre a forte cultura das civilizaçōes inca e asteca, civilizações pré-colombianas que impunham respeito aos conquistadores. Mas a tarefa da conquista, com a crueldade típica de quem anula o inimigo e o submete à humilhação do destroçamento político e social, poderia servir também como elemento de desagregação no plano cultural. E’ foi o que aconteceu, de fato. Os espanhóis substituíram a cultura inca e asteca e forneceram elementos integradores da sua prōpria,dacultura do conquistador. Por isșo trouxeram livros e forçaram um modelo de civilização. Claro, atuaram politicamente no sentido de imantar sua cultura, sufocar a encontrada, impor uma universalização ideológica e uma prātica de conquista. De qualquer forma, porēm, no interesse especifico da circulação de livros, os espanhóis praticaram diverso dos portúgueses, ao menos trazendo obras de moral e romances de cavalaria, favorecendo a implantação de uma imprensa, promovendo as artes e a literatura - é não apenas no limite estrito do dogmatismo teológico. 
0 espaço de 60 anos, de 1580 a 1640 , em que se exercita a dominação espanhoḷ, extensiva ao Brasil, não muda - panorama cultural da Colônia. Talvez pela esquiva disposição do poder hispânico, talvez pelos interesses de Castela orientados de forma diversa da que se deu no resto da América, de sua direta iniciativa colonizadora. De qualquer modo, a atitude portuguesa para sua colônia brasileira, alêm de meramente extrativa, não vislumbrou interesse na expansão de um processo civilizatório duradouro e consequente, quanto à cultura literāria. Nada fez Portugal nesse particular, deixando aos jesuítas tóda a tarefa educativa e cultural. E não se diga que por temer algo que pusesse em risco a integridade de seu impērio. Não bastassem.outras razões, somente três séculos decorridos da descoberta e anexação do Brasil ao Reino luso, e ainda por obediência a específicos interesses da sobrevivência aristocrätica, aqui, è que viemos a conhecer a imprensa e acompanhar a evolução das idéias correntes no mundo civilizado.

o Brasil das capitanias hereditārias tinha sido feudal. A experiência dos governos gerais avançou um tanto na direção de uma proposta de unidade territorial e princípio colonizador efetivo. Nada, contudo, transparece quanto ao processo civilizatório e cultural. As escolas permanecem da exclusiva iniciativa jesuitica, para fins da catequese. As dificuldades avultam no campo da cultura. Os nativos passam de prē-históricos a indivíduos cooptados a un equívoco sistema social. E, pior, os colonizadores permanecem degredados ou funcionários ocupados com a burocracia 
do processo expansionista. Ou seja, quem não é nativo, ou jesuita, ou governo, é o inculto povo preocupado com as ambiçōes únicas da atividade de exploração e acumulação. Daí a Literatura nascer sob o signo da recusa, como expressão social e histórica alienada e tardia. Não serā, por conseguinte, valorizada.

A Amērica portuguesa dos ṕrimeiros sēculos não trata da formação ou desenvolvimento de qualquer processo educa.tivo que tome a Literatura como instrumento de transmissão cultural. As manifestaçōes e respostas da Literatura não podem portanto, evoluir e o processo literārio brasileiro nem chega a inventar-se. Mesmo a Literatura de celebração, de conhecimento e propaganda da terra - caso de Gandavo e Gabriel Soares - não alcançam a répresentatividade e a repercussão que seriam de esperar ou merecer. Inexistiam fundamentos estēticos e sōcio-cultúrais, como se desconheciam. formas literärias prōprias. Por conseguinte, temas e recursos expressionais da Literatura européia passaram ao largo da mentalidade colonial brasileira.

A cultura jesuítica ou sua transmissão, sō se fez objeto de um conhecimento comprometido com a ideologia reacionäria e conservadora da Contra-Reforma. A leitura aí inscrita só se manifesta enquanto mecanismo retörico para uso da imediata ação missionāria. Nesse quadro, como será possível entender e afirmar a circularidade cultural do livro no Brasil de Quinhentos?

Uma primeira resposta è que o Brasil, do sēculo XVI ao XVIII, é a pätria cultural dos jesuítas, de cuja educa- 
ção emergem os vagidos de uma nesga de cultura literāria, ainda que segregada no absolutismo teocêntrico. 0 Brasìl Quinhentista, serā, pois, o que Rubens Borba de Morais chama de a Idade Média brasileira ${ }^{10}$. Se, na Metrópole,não havia ainda um sentido massivo de tipografias, se a mentalidade portuguesa, no particular de uma cultura extensiva, era a mais atrasada da Europa e tinha um rol considerävel de livros proibidos, fica evidente que não se poderia prever maior desenvoltura cultural e literärïa no Brasil. E isto apesar de Portugal jä conhecer a imprensa desde 1487 , data do primeiro impresso português, feito em Faro, no Algarve, uma edição do Pentateuco hebraico. Em 1489, o invento chega a Lisboa e em 1495 registra-se a primeira impressão em linguagem da Vita Christi em 4 volumes (versão: o livro da vida de Cristo). Jă em 1551, por ação de D.Henrique, editam-se listas contendo livros proibidos à circulação, inclusive a leitura da Bíblia em vernáculo. Quer dizer, os livros vão se sucedendo em impressão. A Doutrina cristã de S.Francisco Xavier ë de 1557, o Tratado... contra os erros scismaticos dos abexins, de Gonçalo Rodrigues, é de 1561. O Compêndio espiritual da vida cristã, de Gaspar de Leão,é de 1561; 0 Colóquio dos simples, e drogas e coisas medicinais da India, de Garcia da Orta é de 1563.11. Ou seja, livros havia editados pela Metrópole, o que não havia era sua circulação livre no processo colonizador entre nós. Em parte, o interdito corria por conta da determinação contra-reformista em conter o. livre acesso de idéjas nas nações cristãs sob a custōdia da Inquisição e da 
Companhia de Jesus.

Tomé de Souza e 1549 são signos, portanto, da sistematização administrativa de Portugal no Brasil, como os jesuítas no plano da disseminação de práticas educativas que conduzem à idéia da circulação de livros. A segunda metade do século XVI è a instituição missionāria dos jesuítas no Brasil constituem, assim, o surgimento de nossa formaçãocultural, o movimento possível de idéias e de livros, a vontade contingente da cultura. Afinal, foram os padres da Companhia que nos trouxeram o alfabeto, o latim, a gramätica e a literatura de fundo místico e ascético.

O contato com as obras de Anchieta e Nóbrega, Gabriel Soares de Souza e Ambrósio Brandão, Bento Teixeira e Fernão Cardim, Fr. Vicente de Salvador e outros torna evidente o espírito de época no Brasil, uma vez que, obras de historiadores, poetas, ideólogos, revelam häbitos de leituras, ou de uma muito provāvel influência advinda de circulação de livros. Mas, que livros seriam? A inexistência de documentos, mais uma vez, compromete afirmações definitivas. Levando-se em conta, no entanto, as condições do país, a força que se imprime na riqueza extrativa da terra - do paubrasil ao açûcar - observado, embora, o carāter autoritário do ensino jesuítico, é possível presumir os tipos e as características dessas leituras e desses livros. Só indiretajnente, só com a leitura atualizada dos autores de época serā possível identificar alguns traços de um perfil do leitor entre fins de Quinhentos e ecmeços de Sciscentos. 
Até 1757, com Pombal, os jesuitas mantiveram o dominio exclusivo do ensino e da cultura. A Inquisição e os objetivos missionārios da Companhia de Jesus representaram bases de sustentação nesse domínio, que se estendeu aos aspectos do gosto literário e da programação editorial. Aqui, no conjunto de dificuldades de outra ordem, os livros sempre foram insuficientes. Os próprios padres reconheciam , como vimos, desde 1549 aos fins do século XVI, pelo menos, a ingente necessidade de mais livros para a formação de almas nativas ou de mais missionārios, para, com isso, ampliar o espaço da catequese. Livros de doutrina, casos de consciência, obras devocionärias, claro. Os colēgios jesuĩtas se ampliam na Bahia, no.Rio de Janeiro, no Maranhão, em São Vicente, no Espĩrito Santo e, evidentemente, requerem mais e mais volumes de livros para extensão da fé e do conhecimento retórico.

Cardim fala da livraria que observou no Colēgio da Bahia, ao lado de uma boa capela e dos trinta cubículos de moradia dos padres, em 1583. Não descreve a feição de 1ivros ou matérias que compunham as estantes dessa livraria, mas faz 'referência a características do ensino ali ministrado, compreendendo "uma lição de Theologia, outra de casos, um curso d'artes, duas classes de humanidades, escola de ler e escrever", o que torna previsível una certa tipologia de livros para atendimento aos $\operatorname{cursos}^{12}$. 0 mesmo Cardị relata uma dezena de representações teatrais, devotas, de indios e seminaristas, en todas as provincias por onde passou. Uma dessas representaçōes era "um breve diã- 
Iogo e devoto sobre cada palavra da Ave Maria, e esta obra dizem compoz o padre Alvaro Lobo e até ao Brasil chegaram suas obras ¿e caridades"13 Não sabemos onde incluí-1a no concerto pequeno da obra do jesuita Alvaro Lobo, cronista e historiador portuguēs (1551-1608), autor provävel de uma Cronica do Cardeal D. Henrique.

Alēm dos jesuitas, tambēm os beneditinos, os franciscanos e os carmelitas tiveram aqui suas bibliotecas algo fornidas. No entanto, por esse tempo de Quinhentos, pouco hā de informe preciso a respeito de títulos e autores e sobre a constituição dessas bibliotecas, menos ainda do que contamos a propōsito da informação histōrica dos jesuítas. Da presença cultural das outras ordens religiosas, no exíguo repertório disponível, destacam-se os beneditinos e franciscanos, especialmente nos meadós dos sēculos XVII e XVIII. Dos primeiros, temos até um catảlogo organizado pe1o historiador Fr. Gaspar da Madre de Deus para a biblioteca do Mosteiro de São Bento do Rio de Janeiro e enviado a Pombal, que, em lugar próprio,vai comentado e descrito. Saliente-se, contudo, (o catālogo è de 1763), que nada exis te sobre a constituição da biblioteca dos beneditinos no Brasil com data anterior a esse catảlogo - o que nos dá um conhecimento exato do perfil de leituras beneditinas apenas ua segunda metade do século XVIII. Dos franciscanos, hä menos ainda de informaçōes relativamente a livros ou leituras no século XVI, e mesmo atē XVIII. Nada, aliás, das outras ordens, nos chega próximo da enorme contribuição de Serafim Leite, SJ, com sua IIistória da Companhia de Jesus no Brasil. 
Basilio Rower, OFM, in päginas da história franciscana no Brasil, apresenta uma pälida notícia a respeito dos costumes franciscanos quanto a livros ou bibliotecas, isso jā referente aos sēculos XVIII e XIX. Nada sobre a presença franciscana em Quinhentos e Seiscentos. Falando sobre a biblioteca do convento de S. Bernardino, em Angra dos Reis, Rower atesta que a dita livraria, em 1808, contava "exatamente 240 volumes, assim especificados: Sagrada.Escritura e expositores, Sermōes, Teologia moral, Histōria sacra e profana, Ascéticos é.Miscelâneos" ${ }^{14}$. O historiador considera o número de livros um forte indício da presença cultural e pedagógica dos franciscanos e encarece como boa a livraria, dois sēculos e meio decorridos da instalação da província franciscana no Brasil.

Os jesuĩtas sāo, de fato, e até sua expulsão, os educadores de mais significativa presença e influência no espirito cultural brasileiro. Eram práticos em incipientes ensaios botânicos, curiosos na apreensão de aspectos histõricos e geogrāficos, retōricos no estudo do latin clāssico, colonialistas no estímulo linguístico de troca em gramäticas portuguesa e tupi. Teriam, em suas estantes, pequenas obras de orientação religiosa e catequētica. Alēm da Bahia, outras bibliotecas, jesuiticas foram-se formando e notabilizando, como as do Maranhão, Parä, Rio de Janeiro, São paulo e Espirito Santo. Em dois sēculos de ocupação pedagógica colonial, sua ação exerceu poderosa influência no comportamento do leitor brasileiro, significativa presença quando sabcmos que sua biblioteca, ao tempo da debandada 
em 1757, era da ordem de $15 \mathrm{mil}$ volumes.

Obra dos jesuítas, o Brasil leitor do século XVI é, portanto, o do esforço desesperado, conquanto equívoco,feudal e absolutista, do envolvimento intelectual dependente, ora da catequese, ora do colonialismo cultural exercido via um ensino mecanizado, não-humanista, mimētico de modelos clāssicos para uso retórico da ação evangelizadora. De qualquer maneira, excetuando-se as circunstâncias de um meio cultural introvertido e envergonhado, espaçadamente no século XVII e um tanto mais massivo no século XVIII, os livros que circularam no Brasil vieram trazidos pelos jesuítas e è com eles, superlativamente, que se dả um fenômeno de transferēncia de bases culturais europēias, por força, claro, das expectativas do colonizador.

Nossos primeiros leitores foram, em consequência, eur ropeus viciados em mecanismos de leitura comprometida. Fo ra deles e avançando pelos séculos seguintes, os filhos de colonos e os nativos cooptados, em suas leituras de colégi- religioso, foram escalando a trilha livresca de cartilhas, livros de devoção, práticas dos sermonārios e catecismos teológicos, muitas vezes utilizando volumes copiados de um original batido, caso dos clāssicos, de leitura obrigatōria para fins docentes do ensino do latim em sua acepção retórica. Clāssicos, aliäs, expurgados, desde o Ratio. Studiorum, de trechos considerados, inconvenientes pela Inquisição ou pelo moralismo doutrinārio da catequese e do redil teocēntrico.' Dai, resulta, entretanto, un perfilde leituras ainda pouco claro. 
Virgílio, Cícero, Horäcio, Ovídio e Sêneca seriam,então, pais (embora adulterados de sua versāo original) de nossa aventura literäria. Teriam chegado em fins do sécu10 XVI e seguramente no Seiscentos. e Setecentos decididamente incorporados em nossa tradição leitora, uma vez integrados ās estruturas curriculares obrigatórias do ensino jesuítico e, em seguida, do experimento pombalino. Talvez até fosse possivel acrescentar a essa lista um ou outro clässi.co grego por intermediaçäo direta do latim e da leitura dos doutores da Igreja. Não surpreende que brasileiros de Quinhentos a Seiscentos tivessem tido em mãos Aristóteles e Platão, e presumivelmente Epicuro - este, atë, por uma necessidade paranóica da recusa. Aristōteles, relido por Thomas de Aquino, e Platão, por Santo Agostinho seriam expoentes, numa escala indireta, da tentativa de uma coersãoalternativa de leitura, adaptados, claro, aos objetivos da Doutrina. Não hā informação segura sobre a leitura deles nos fins do Quinhentismo, mas constavam em volumes expurgados dos seminārios jesuíticos do século XVII. Vieira, por exemplo, manifesta particular agrado na citação de Homero, Platão, Aristōteles, Quintiliano, Sêneca, Cícero, Virgílio Horācio, Ovídio e, mesmo, Epicuro, para efeito do confronto doutrinārio.

Mas, nem Aristóțeles nem Platão podiam ser lidos no original. Só as versōes latinas, com os expurgos, é que seriam aceitas. Sem embargo da violência do mutilamento textual, é oportuna a referência indireta dessas leituras. Mesmo que, para o docente, esses autores entrassem justa- 
mente como clässicos de que se aproveitariam exemplos e regras para o bem escrever, para o estrito cultivo da retórica, claro estä que foram os bons autores que acompanharam os brasileiros numa formação incipiente. Eles, os clāssicos, servem de balizamento para um enviesado perfil das leituras brasileiras à ēpoca.

Aristōteles, aliās, aparece como um dos autores recomendados aos estudantes de Filosofia nos colégios jesuítas. 'Devia ser lido na versāo convenientemente.interpretada, na vertente do uso que dele fez o Doutor Angëlico e nunca na interpretação "tendenciosa" de autores "infames ao Cristianismo". Junto com o Estagirita, entre os gregos, sempreos antigos como Demōstenes, Platão, Tucídides, Homero, Hesiodo e Pindaro, todos naturalmente expurgados. Entre os 1atinos, para o Curso Superior de Gramātica, deviam constar as Cartas de Cícero aos parentes, à Atico e ao irmão Quinto. Para o segundo semestre, os livros de Cícero, da Amizade e da Velhice. Os poetas compareciam tambëm. Horäcio com suas epístolas, e Ovìdio no primeiro semestre. No segundo, Catulo; Tibulo, Propércio e as Éclogas de Virgílio ou, ainda do mesmo Virgilio, os livros mais fäceis.

Como, para compreender o quadro da cultura no Brasil dos dois primeiros sēculos, é sobretudo indispensävel compreender o papel e a trajetória dos padres jesuítas, igualmente se torna obrigatória a recorrência à llistória da Companhia de Jesus no Brasil, de Serafim Leite, SJ, obra que esclarece a maior parte dos pontos obscuros da presença e pedagogia dos jesuítas entre nös. 0 tomo II, 1ivro V, cap. 
I $\leqslant 3$ da História...., por exemplo, refere carta dos jesuitas a propósito do reiterado pedido de livros. Nela, com oportunidade, cita-se o P.Irmão Pero Correia que, em 1553, pedira livros em linguagem para as tarefas da catequese. Entre os livros citados, constavam Confissões de um pecador, Doutrina cristã (que presumimos tenha sido, na verdade, o Catecismo ou doutrina cristã, obra do orador sacro D. Fr. Bartolomeu dos Martires, 1514-1590, uma vez que o Doutrina cristã, de S.Francisco Xavier é de 1561 e o do padre jesuita Marcos Jorge, morto em 1571, consta como publicado somente em 1579, em Goa), mais uma Exposição do primeiro salmo de Davi, uma Suma de doutrina cristã e o Catecismo cristão para instruir os meninos.

Havia, ainda,em 1553, a necessidade de virem livros escritos em português para facilitar o acesso dos estudantes e a atividade missionária. Isto porque o que mais se precisava era de livros em linguagem, $j \vec{a}$ que, conforme acentua Serafim Leite, "livros latinos, de natureza ascētica ou doutrinal, houve-os suficientes, desde o começò, exceto nalguma casa mais pobre, como a do Espirito Santo, onda Brăs Lourenço não possuĩa, em 1554, senão a Vita Christi" 15. Saliente se que escasseavam mais os livros de texto para as escolas e que, em virtude da carência de livros para atender à demanda dos alunos, sempre em bom nūmero, os padres se viam na circunstância, de copiar os mais necessārios às funções, tarefa de que não escapou e, antes, foi prolifico, o padre Anchieta.

Assim, livros não havia muitọs e meșmo os aqui intro- 
duzidos eram livros da imediata destinação missionāria. Livros de doutrina, de devoção mística e ascētica, ou os clāssicos expurgados de trechos em que a seleção censória evitou o acesso irrestrito, pondo fim à impertinēncia dos objetivos da catequese. Isso era uma prätica desde os fins do século XVI que avançou nos sēculos seguintes, o que valida a certeza de que nossa cultura nasce já censurada, e uma censura que, desde 1549, quando os jesuĩtas aqui se instalaram, trazia uma ideologia classificatōria quanto à leitura, de acordo com os objetivos expressos pelo Ratio Studiorum, pela Companhia de Jesus e sua obediência ao espírito da Contra-Reforma.

Sem referir-se especificamente a títulos, nem a autcres, os livros estariam submetidos ao crivo censörio dos jesuítas, em estrito serviço aos rigores inacianos aplicados em todas as suas instituiçōes.' Somente os permitidos pelo. Index inquisitoriai, "acomodados" aos sentidos "santos" da disciplina teológica, estes foram os livros que primeiro circularam entrè nōs. Em outras palavras, além das naturais dificuldades da vinda de livros, havia a questão impeditiva da entrada aqui de muitos deles. Trēs pontos, sob essa restrição censōria, eram invioláveis, contra os quais não se podiam indispor idëias e, consequentcmente livros: Monarquia, Moral e Religião. Com atenção a tudo - que pudesse pôr em risco a segurança de um Estado Catölj.co e contra-reformista foram proibidos alguns e obstada a livre circulação de outros livros. A relação Estado-Igreja responde pela solidificação de uma frente comum para con- 
ter o avanço de ideologias conträrias ou que contivessempotenciais düvidas e ameaças sobre a intima e duradoura conformação de Estados autoritārios.

Tal situação - a que envolve livros proibidos - não escapa a Rubens Borba de Moraes, que analisa a tipologia de obras interditas jā em 1769, com a Real Mesa Censōria criada por Pombal. Assim, em dois sēculos, saltamos de um rigor autoritärio de extrato inquisitorial, com seu Index e seus modelos de estudos, para um mecanismo de interdição da inteligência via o regalismo pombalino. Mutatis mutandis, a cultura não se exercia livremente tambēm no século da Ilustração e, muito menos, a inteligência estava longe de mostrar-se independente de mordaças ${ }^{16}$.

A possibilidade da dominação absoluta, porém, registram-se algumas subversōes ideológicas. Muitos desses Iivros defesos entraram no Brasil e forneceram elementos de reflexão e desenvolvimento da inteligência nativa. A amostragem com os inventārios por nös pesquisados demonstra isto adiante, com o aparecimento de inúmeros títulos que estariam na mira dos interditos jesuitico e secular. A lembrança mais notōria vem a propósito do inconfidente cônogo Luis Vieira da Silva, de Mariana, estudado por Eduardo Frieiro em seu 0 diabo na livraria do cônego.

Desde o sēculo XVI, a leitura sob a ötica da pedagogia jesuitica era de natureza passiva, de forma a renovar - anacrọnismo de uma Idade Média reacionária. Em 210 anos de autoritarismo dogmātico, claro que o substrato cultural e conservador perinanecóu indelével e suitil na sociedadebra- 
sileira "culta" e "elitizada" conforme a ideologia de uma fé robustecida, de uma intima revitalização da ascese e dogma cristãos. Os objetivos mais evidentes seriam os da permanência do poder, mascarados pelo biombo dos ideais de redenção e ganho celestial post-mortem.

A base da leitura jesuitica assenta-se na reprodução de sentidos marcados pela ideologia da Contra-Reforma. Vale a pena aqui transcrever um modelo da pedagogia inaciana em fins do século XVI, quando se prescrevia a continuidade do diploma clerical e dogmätico dos estudos:

Isto era em 1596 mas jā estava em vigor, desde o tempo de Santo Inācio, a legislação geral da Companhia no que toca a livros obscenos e heréticos, aqueles totalmente proibidos, os segundos admitidos com as devidas cautelas. Os livros poèticos tambëm não estavam nas boas graças da pedagogia da época. (grifo nosso). Distinguiam-se, porém, os livros escritos em latim e os escritos "em romance". Com os ültimos havia maior rigor, pelos devaneios que suscitavam em cabeģas juvenis, e porque eram obstäculo ao cultivo sério do latim, a língua culta de então. Sendo informado o Pe. Geral, de que se introduzira no Brasil o costume de celebrar as festas com sonetos. e coplas espirituais. 
mostrou-se contrārio, e proibiu tal uso, não por ele, em si, mas pela leitura de livros profanos, a que esse häbito daria ocasião. Igual proibição atingia certos clássicps latinos. A Congregação Provincial da Bahia (1583) propôs "que se desse alguma emenda aos livros de humanidades de Plauto, Terêncio, Horäcio, Marcial e Ovidio". Com efeito, receberam-se no Brasil estes autores, como se usavam, já expurgados e adaptados ao ensino da juventude, no Colégio Romano ${ }^{17}$.

Ora, isso demonstra o exponte autoritärio dos padres em seu carāter docente. Livros permitıdos seriam os escritos em latim, mas apenas os que funcionassem como elementos de divulgação utilitāria do idioma enquanto meta de um aprendizado mecânico, não se abrindo ao uso da līngua como expressão da cultura renascentista. Os escritos "em romance" seriam objeto da determinação de vigilância, a fim de evitar "devaneios que suscitavam em cabeças juvenis, e porque eram obstáculo ao cultivo sērio do latim, a língua culta de então". Ou seja, proibiam-se as obras que pudessem conduzir à abstração, ou à evasão poētica tida em mā conta pelas autoridades espanholas ciosas na repressão (tantas vezes des-moralizada) contra novelas de cavalaria, romances de invulgar popularidade no Quinhentismo hispanamericano.os "livros obscenos e herēticos", só os eram na concepção medicvalista da Inquisição e da Contra-Reforma. A proibição de represen- 
tações cêniças. alcançando mesmo aquelas com propōsitos santos, apenas por circularem em linguagem,. e não em 1 atimpassa um atestado de rematada ignorância - para evitar o prolongamento de leitura de livros profanos "a que esse hābito daria ocasião" - i.gnorância combinada com hipocrisia do tipo "não por ele, em si".

Não serā à toa que, alēm dos latinos expurgados - e assim as comēdias de Plauto, Terêncil, as sentenças de Marcial, o erotismo de Horäcio e ovídio se teriam desvirilizados em sua graça e conteūdo - os ūnicos autores admitidos no curioso panteão seriam os doutores da Igreja, sobre quem seria impossĩvel, senão ridícula, a tarja proibitória. Os jesuítas dispunham dessá forma seus próprios modelos de purgação de costumes e exalçamentó da moral, arruinando em parte a graciosa visão latina de mudança social, de uma ética à base do castigat ridendo mores. Para nosso desalento, aqui tambêm não temos indicação de obras, senão de autores. Sim, sabemos que o sēculo XVI brasileiro lia Horācio e Ovídio, mas o que de Horäcio e Ovídio? As Metamorfoses? a Arte poética? A Arte de amar? Provavelmente, os trechos das infinitas seletas que nos chegaram até o sécu10 XIX . .

- rigor censōrio constrangia, até o que hipoteticamente se poderia entender como a própria auto-referênciareligiosa. A proibição da leitura da Bíblia em vernāculo,decidida desde o fim do Concílio de Trento, atravës do seu complemento inelutável, o Index 1ibrorum prohibitorum, publicado por pio IV em 1564, na verdade obcdecia à proposta 
católica de permanência do poder e manutenção da ignorância - conträria às Bíblias nacionais de Lutero e de Calvino sob o argumento tosco de que era para evitar a confusão dos leitores sobre trechos confusos dos livros sagrados. A Bíblia - oráculo do poder evangelizador - nāo se poderia vulgarizar na língua literäria nacional, nem frequentar estantes letradas que pusessem em jogo a autoridade dos padres. Estes, sim, deveriam ter acesso ao formidåvel veículo de transformação espiritual. Os Livros Sagrados nunca deveriam chegar ao saber comum.

Além da Bíblia, o que se podia ler de texto sagrado? Os doutores da Igreja e os manuais de Teologia dogmätica,os livrinhos de ascese e de elevação moral. Mas, que doutores? Provavelmente, por suposto de uma reconhecida prevalência, Tomás de Aquino, Soto, Navarro, Silvestre e Acürsio. Agostinho e Bernardo, Crisóstomo e outros viriam um século depois, como se demonstra nos sermões de Vieira.

Literatura profana, então, impossíve1. Nada que cheirasse à Renascença, nada de civilização antropocêntrica,por perigosa, amoral, sujeita a equírocos luteranos e calvinistas. A atitude cultural jesuíta,fora do rigor dognätico, era de inanidade intelectua1. Por isso era, tambēm, como nos confirma Wilson Martins, uma cultura intelectual "fundamentalmente medievalista e representava uma tentativa de prolongação do passado mais do que um esforço de integraçãosimpática ṇo presente e de antecipação favorảvel ao futuro"18.

Essa tendência ao retrocesso, essa vocação pelo récorrente passado, tinha, porém, sua razão de ser sob a ötica je- 
suítica. Era a política e a função ideológica e sectāria que propugnava barrar a fúria do convencimento calvinista no mundo, um mundo ameaçado pela "barbärie" da Reforma, pe1a "inversão" dos valores sagrados da Religião. Para o Brasil, era preciso "salvar essa gente" indígena e boçal, selvagem e predadora dos santos ideais de virgens e mártires do medievo português contra-refơrmista. Por essa toada,tudo o que não pertencesse ao dogmatismo tridentino sobraria por irrelevante e, mais que isso, perigoso como antitese da grande tarefa redentora da humanidade. Não esqueçamos que a Companhia de Jesus era a reinvenção das Cruzadas, fiTha dileta do Concílio de Trento e,sob,inspiração deste ūitimo, espalhou-se pelo mundo, com máxima prevalência num território bárbaro e inculto como o Brasil de Quinhentos.

Não chega a causar espanto, todavia, a proibição de livros, e em especial dos livros poēticos. Estes conteriam o equivalente da fantástica disposição do ideal de beleza e harmonia humanas. Até se poderiam admitir os escritos em latim, recolhidos ao porão das citações de exemplos estéreis, mesmo porque o latim era a língua literāria, língua dos clássicos, que ensinava e convertia ao uso culto. Livios em linguagem, porém, seriam perniciosos ao bom desenvolvimento de uma retórica santa e implicariam no desvio de uma atenção ritmada no projeto missionārio. Tal foi feito tambēm pela civilização hispânica no México e no Pcru. E em vão, pois os livros circulavam como peça de contrabando, sob as vistas complacentes de autoridades e mcmbros da corte, estes também francos consumidores das nove- 
las de cavalaria ${ }^{19}$.

Os livros, enquanto objeto da cultura e da prática social, eram admitidos como símbolos de uma ascensão intelectual nem sempre consentida dentro do rigor axiomático dos jesuitas. Ler para apreender e compreender, segundo os cânones inacianos e os padres-professores, não o mundo à volta, mas o mundo como o imaginava e coagia a inteligência jesuítica. Nenhum espaço para a fantasia, para o imaginārio, para a abstração, ou para a comoção estética ou - experimento crítico. Livrós,só os que renovassem a sacralidade da instituição católica medievalizante e sua permanência irreversivel. A ịdeologia jesuitica era, portanto, a da Contra-Reforma, a do Concílio de Trento, a do Index librorum prohibitorum, a do Ratio et institutio studiorum Societas Jesu. Tudo, pois, a serviço de conteūdos medievalizantes, teocêntricos, conservadores de uma prätica polîtica que obstasse a expansão da Reforma. Sua cultura, consequentemente, avaliza uma determinação histōrica marcadamente contrária aos ideais renascentistas.

Por definição, a intelectualidade jesuítica sō podia ser mesmo autoritāria, na exata consonância com a reação peninsular. Todo o empenho docente, vale dizer, toda a circularidade cultural na forma de livros, realizou-se no sentido de desbastar perigos que a paranóia contra-reformista vaticinasse como herético, fosse judeu ou protestante. Donde resulta um claro sentimento de ameaça e expatriamento da iconoclastia profana, da poesia.ou do cientificismo renascentista. $\Lambda$ ciência inaciana, aqui, como em portugal 
ou em Roma, foi a ciência do dogma, ou seja, a anti-dialētica. E o ensino e a leitura dela provenientes serão tributārios da técnica de aliciamento intelectual de fundo molalizador e teocrätico. Por isso, o empenho dos jesuítas em compreender o Brasil, em compreender a língua e os costumes dos indios, em pregar para os nativos na língua e na. forma em que pudessem apreender o sịnificado da pregação. Recusando a Renascença, reafirmar-se-ia a notação medievalizante da cultura. E, consequentemente, mais fäcil se faria a missão apostólica a sustentar a moral e o dogma cató$1 \mathrm{icos}$.

Indiretamente, porēm, e por acidente escapo ao desejo imediato da catequesè, o fenômeno de curiosidade na apreensão da língua e dos costumes indígenas termina por fundar uma etnolinguística brasileira. A Arte da gramātica, de Anchieta, a Arte da língua brasilica, de Luis Figueira, mais compêndios, narrativas e dicionārios etnogrä́ficos, com base no tupi, alimentam o esforço inteleçtual que pontua o nascimento da cultura brasileira. o aparecimento dessa tendência contribui, ainda que pela curiosidade dọ "acidental", ou do "involuntārio" da conquista, para a formação de um leitor especialíssimo, aquele que se impregna não apenas das matérias contidas nos livros, mas tambēm do que pode advir da experiência prātica. O esforço de compreensão do tupi alcança os fins missionärios, se tomarmos como pertịnente a informação de Serafim Leite, SJ., que dá como primeira "referência concreta a vocabulärio" tupi a obra Doutrina cristã, do jesuíta Marcos Jorge, de que se pediu, 
em 1585, licença a Roma para publicá-la em portuguēs e que foi objeto de tradução para a linguagem indígena feita pelo padre Leonardo do Vale ${ }^{20}$.

Razão final serā concordar que a instrução jesuítica - e os livros que circularam na esteira do ensino - foi instrumento da catequese e a esta serviu, mais que à cultura brasileira tout court. Aqui não se desenvolveu a instruçāo pela instrução, nem o ensino como propósito e modelo de mudança intelectual, ou de elevação social da Colônia, mas o ensino contemplado pela dominação catequētica. o que não deve necessariamente encaminhar ao sectarismo idiota de considerar nula essa instrução ou nulos seus efeitos.Embora abstruso e comprometido, o modelo docente dos jesuítas implantou, de fato, até independentemente da vontade sutil ou manifesta de seus praticantes, uma corrente cultural que, escapando da camisa-de-força teocêntrica, alargou o conceito de prática intelectual no Brasil. E aqui vai nos interessar como elemento de irradiação da cultura literária em nosso país. 


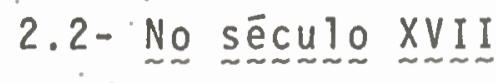

Do ponto de vista da cultura 1iterâria, excetuando-se talvez os dados oriundos da informação dos inventários a que recorremos, o século XVII no Brasil aparece um tanto descolorido, quase desconhecido pelos historia. dores. Este desconhecimento se acentua quando tomamos a questão relacionada com a circulação de livros ou for mação de bibliotecas. Restam-nos informes da ação pedagōgica dos jesuítas, mas pouco hâ de substantivo nesses informes que nos oriente sobre os possiveis livros 1idos pelos brasileiros seiscentistas. Por isso, avultam trabalhos como os de Taunay e Alcântara Machado, que se debruçaram sobre inventārios publicados pelo Arquivo do Estado de São Paulo entre fins dos anos vinte e meados dos trinta, deles extraindo as melhores notícias sobre módelos de leituras à época. No campo estrito da historiografia crítica, oportuno tambēm é o estudo de Gilberto Mendonça Teles no livro Camões e a poesia brasileira. Em respeito e sequëncia a essas trajetórias, descreveremos aqui tais modelos de leitor, sobretudo o seguido desde São Paulo por brasileiros do Seiscentos.

o sēculo XVII brasileiro é representado por três tipos de experiências administrativas e civilizações distintas, a saber: a portuguesa stricto sensu, a espanhola-portuguesa e aquela dos' Países Baixos localizada cm Pernambuco. Isto sem falar na força política e tellporal da Igreja Católica, verdadeiro poder paralelo que 
se reservava a instância de fornecer os principiós sócio-culturais prevalentes no Brasil Colônia. No entanto, pouco conhecemos ou nada nos chegou, dessas administra ções, no particular de uma cultura extensiva e socializada, menos ainda com respeito a livros.

Do ângulo português, a sonegação cultural, em parte, pode ser debitada aos embargos, por decretos sucessivos e cada vez mais repressores, dos indices de livros proi- bidos, intimidando e interdittando a cultura, refreando a entrada, mesmo em Portugal, de obras científicas, sobretudo as estrangeiras ou nacionais inspiradas na ciência alienigena. 0 Index romano publicado em Portugal em 1624, por exemp1o, denuncia'esse grau de supressão e estrangula qualquer signo de divulgação de obras científicas ou literärias. Razão terā, nesse sentido, Antonio Josē Saraiva, que acentua a grave crise trazida ao espírito cultural da ëpoca: "o século XVII português oferece-nos o espetáculo de uma cultura frustrada, vazia de experiência e de.intelecto, em que as palavras chamam as palavras; uma espécie de delírio manso, calmo, convicto, incorrigível e fixo"' 21 .

A experiência luso-espanhola também em nada parece ter alterado a situação de entrave à circulação de livros no Brasil. E o mesmo se poderia dizer do esforço civilizatório aqui tentado pela Holanda - guardadas, embora,as proporções que respeitem, inclusive.e em particular, o embaraço.representado pclo idioma. No traço específico da influência cultural holandesa que poderia ter sido a- 
qui desenvolvida, não se registra, no Brasil do sëculo XVII, a circulação de obras como a de um Johannes de Laet, por exempio, ou a de um Hugo Grotius, populares no sēculo e na expansão cultural dos Países Baixos. Todavia, data de 1642, numa edição de Paris, a principal obra de Grotius, sua Dissertatio de origine gentium americanarum. Antes disso, em Amsterdam, Laet publicara sua Histöria ou narrativa anual dos atos da Companhia Privilegiada das Indias Ocidentais (em holandês, Histoire ofte Jaerlifck verhael van de Verichtingen der Geoctroyerde Westindische Compagnie), livro indispensável para a compreensão da presença holandesa no Brasil e em toda a América, assimilando um significativo espectro de tempo, entre 1621 e 1636, dessa presença.

Laet e Grotius, aliās, envolveram-se posteriormente numa acirrada polêmica, com publicações sucessivas de suas teses e debates, alguns dos quais destacando as relações do imperialismo holandês com o universo americano. Nada disso se passou até nós. l'al fato se pode atribuir tanto à barreira do idioma, quanto à conjuntura histórica in-terna do Brasil, em especial à guerra luso-espanhola contra o dominio holandês. De qualquer sorte, pouco ou nada resultou, enfim, para nosso conhecimento, a circulação dessas e de outras obras populares no período seiscentista, seja no eixo da Penīnsula Ibērica, ou no dos Países Baixos.

Há notícia a propôsito de una procupaçāo do Brasil Holandês com vistas à educação do negro brasileiro. Joa- 
quim Ribeiro faz menção a um Regulamento Holandês de 1634, oriundo de um Conselho eclesiästico calvinista que propugnava pela educação religiosa e cristã dos negros pernambucanos. Tal regulamento, conforme Ribeiro, determinava "levar aos negros o conhecimento da palavra de Deus e da verdadeira.religião crista â2 $^{22}$. Esta escola parece ter funcionado em.1645, mas poucos frutos conhecemos de sua ação ou repercussão, sobretudo no campo das leituras. A política cultural'holandesa, com Nas'sau à frente, pode ter mesmo incentivado uma reunião de intelectuais holandeses no Brasil, más pouco se sabe desse movimento no tocante a circulação de livros ou formação de bibliotecas. Josë Antonio Gonsalves de Melo referencia uma proposta holandesa para a educaçāo de índios, em 1638. Essa educação se daria no Brasil e na Holanda, integrando örfãos holandeses no aprendizado, aqui, do português. e do tupi, ao passo que os meninos indios aprenderiam, aqui e na Holanda, o alfabeto e, posteriormente, o catecismo huguenote ${ }^{23}$. Infelizmente, não há notícia sobre resultados, métodos ou continuidade dessa proposta, como não hä tambēm notĩcia a respeito de livros que seriam utilizados no processo educativó.

o século XVII brasileiro formaliza, assim, um pacto de desconhecimento que $j a ̄$ se pronuncia desde o século anterior. Pode dizer-se que é, afinal, no século XVII que o país começa a organizar-se enquanto colōnia de mais franca presença portuguesa. Podé dizer-se tambērn, ao inverso, que de 1580 a 1640 , Portugal está atrelado à polí- 
tica de uma esquiva unificação da península, sob o tacão da Espanha. De qualquer forma, porëm, muita coisa da cultura não nos passa no pröprio sẻculo em que vivia a Colônia. Nāo se conhecia; por exemplo, Barléus, o Gaspar Barlēus da História dos feitos recentemente praticados durante oito anos no Brasil, obra situada e produzida num momento histórico riquíssimo da história colonial brasileira e de sensiveis repercussões para o conhecimento do horizonte brasileiro sob o domínio holandês.

A chamada "Idade de Ouro" da ocupação holandesa em Pernambuco nos é inteiramente desconhecida no próprio século em que os acontecimentos se deram. Barlēus jà publicara uma obra sobre Pernambuco em 1630, a partir de dados que the foram fornecidos. O curioso è que o autor nunca esteve fisicamente na Colônia.. Seu nome completo era Gaspar van Baerle (1584-1648). Era teōlogo e estudioso, natural da Antuérpia e morto em Amsterdam. Foi vice-regente do Colëgio Estatal de Leiden em 1612 e professor de Lógica em 1618. A primeira publicação de sua Histōria dos feitos foi em 1647, em. latim e dá uma panorâmica do Brasil Colônia quanto aos costumes, à administração de Nassau e à representação de fatos histōricos fundamentais para a compreensão do Brasil Holandês. Mas não a conhecemos, senão muito raramente no século XVIII e, tambēm pouco, no sēculo XIX.

O mesmo desconhecimento do século XVII, que aprofunda - desconhecimento de si mesmo pelo Brasil,observa-se quanto a situações, atē mais próximas. Por exemplo, a publi- 
cação original da Prosopopéia de Bento Teixeira è de 1601. A Crônica da Companhia de Jesus no Estado do Brasil, de Simão de Vasconcelos, SJ., é de 1663. A Vida do padre Anchieta do mesmo Simão de Vasconcelos,SJ., ē de 1672. Vieira, cujos sermões foram editados entre 1679 e 1690 sō veio.a ser conhecido aqui no século XVIII. Tambēm desconhecido entre nōs foi a publicaçāo da primeira parte do Valeroso Lucideno, que é de 1648. Tampouco se conheceu o Castrioto lusitano, de 1679, obra do monge Rafael de Jesus. Nem Francișco Barreto, herói de Guararapes, autor de uma Relação diāria, de 1654 e redigida por Antonio Bacelar. Ou a década primeira de A Nova Lusitania, 1675, de Francisco de Brito Freire. Nent tampouco as Memórias diārias de Duarte de Albuquerque Coelho, publicado em Madrid, em espanhol, ano de 1654. Nenhum desses livros circulou no Brasil Colônia no sēculo de suas pubḷicaçōes.

$\mathrm{E}$ isso não chega a espantar, porquanto ê quase da praxe brasileira, sob a forte influência reinol, tal desconhecimento. Desconhecimento, aliās, que provoca situações embaraçosas e desconcertantes, para não dizer, situações de extravagante anacronismo, como o notório saber de obras que sō muito depois ganharam publicação. Começa com a carta de Caminha, só conhecida, em termos de publicação,neste século XX. O livro de Gabriel Soares de Souza, escrito provavelmente em fins de 1587 , sō três séculos depois mercceria publicação. Da mesma forma as cartas de Ambrösio Brandão, ou os Diālogos dis Grande- 
zas do Brasil, obra cscrita no século XVI.I. As Cartas chilenas, de TAG, são de $1788 / 89$ mas sô foram publicadas em 1845. A História do Brasil, de Fr. Vicente de Salvador é de 1627 mas só a conhecemos em primeira edição de 1889. Isso sem falar na poesia de Gregório de Matos, entre 1660 e 1692, que só teve a graça da primeira publicação em 1904.

- Mas ainda hã os brasileiros que mereceram publicação em Portugal e cuja obra passa despercebida aqui, na mesma época de sua publicação é o caso de primeira obra da literatura médica brasileira, o Tratado único das bexigas e Sarampo, de Simão Pinheiro Morão (1618-1685), publicado em Lisboa (1683) com o pseudônimo de Romão Mosia Reinhipo. 0 Tratado ünico da constituição pestilencial de Pernambuco. sobre a epidemia de febre amarela na América do Sul em novembro e dezembro de 1685, è de Lisboa, 1694, de autoria atribuída a João Ferreira da Rosa. Alguns destes livros, no entanto, serão conhecidos jā no século XVIII. Hã outros casos de notícias históricas relacionadas com obras literārias que escapam à formulaçāo concreta da circulação, em livro, no Brasil.

No ensaio histōrico o Rio de Janeiro no século 17. Vivaldo Coaracy registra ter havido a encenação de uma comēdia por estudantes cariocas em homenagem a D.João IV, aclamado rei de Portugal. O registro, lamcntavelmente, vem desacompanhado de maiores elementos informativos alcm da dața (1641). Afirma Coaracy que "o povo do Rio de Janeiro não desconhecia os espetáculos teatrais", adiante 
acrescentando, porëm, que esses eram raros, e os que ocorriam, seguindo a trạdição do teatro jesuítico do sēcu10 XVI, eram de corte religioso, conforme o modelo dominante da pedagogia católica. Claro, nenhuma referência transparece quanto a títulos ou autores dessas comédias ${ }^{24}$.

Falando sobre a educação maranhense em A revolta dé Bequimão, Milson Coütinho fixà umodelo característico das aulas de leitura e contas nos colégios dos jesuítas naquele Estado nordestino. Conclui o autor,aliäs reiterando a noticia brasileira de um quadro de incultura generalizada, que, no Maranhão, tambēm pouquíssimo se exercitava um pensamento político de educação e cultura, pois "o mais era (...) o rolar indiferente nos dias e noites, num quadro-negro onde se pode pintar o Maranhão, num estágio primitivo, primaríssịmo, de que só conseguimos sair cerca de dois séculos depois"25.

A ausência de outros documentos representativos que estabeleça respoṣtas conclusivas sobre as tendências de leitura no sëculo XVII, obriga-nos frequentemente a cair na malha da reiteração especulativa. Devia haver livros entre os bens coloniais do Seiscentos brasileiro, como os devia haver entre os primeiros habitantes civilizados do Brasil em Quinhentos. Mas, que livros seriam esses? Nenhum historiador de nossa cultura arrisca traduzir com segurança - por absoluta carência de documentos a respeito - um sentido orgânico da leitura brasileira no sêculo XVII. E assin, com efeito c jụstiça, nenhum o faz. Extra os compromissos da investigação direta cm in- 
ventärios, como a que fizemos, e na base da especulação, pois, serā possível supor a circulação de livros no Brasil do século XVII. E muito provável que livros tenham circulado no Seminārio de Belēm, em Cachoeira, no recôncavo baiano, sob a orientação do jesuita Alexandre de Gusmão (1625-1724), conquanto os documentos de que dispomos não façam qualquer menção a esse respeito. As duas cartas, de 1692 e 1693, transcritas por Braz do Amaral na obra de Vilhena e relativas ao Seminário, não tocam no assunto ${ }^{26}$. Tampouco trata do assunto a Carta Régiade 1693. consentindo na conservação do Seminārio em Cachoeira, documento que se encontra na Seção Histórica do Arquivo do Estado da Bahia, em Salvador ${ }^{27}$.

0 padre Alexandre de Gusmão (não confundi-1o com o homônimo, irmão de Bartolomeu Lourenço de Gusmão e político e diplomata influente em Portugal Setecentista) teve intensa participação na história brasileira do sẽculo XVII. No Brasil desde 1644, aqui entrou para a Companhia de Jesus em 1646, foi professor de humanidades e criou, em Cachoeira, o seu cêlebre Seminärio de Belëm, onde foi mestre do famoso. "padre voador" Bartolomeu de Gusmão. 0 colégio no Recōncavo baiano atendia a brancos e mamelucos e. teve sua ação pedagógica ampliada até meados do sēculo XVIII. E da autoria do padre, aliās, a curiosa Histōria do Predestinado Peregrino e seu irmão Precito, livro de espiritualidade morali à Fénèlón, bastante popular no Brasil Setecentista e cuja primeira edição data de 1682 , em Lisboa, tendo merecido una segunda, edição $\log \mathrm{cm} 1685, \mathrm{~cm}$ 
Evora e certamente outras no século XVIII.

Em linhas gerais. - com exceção das noticias, jâ um tanto reiterativas sobre os colëgios jesuitas, no. v. $V$ da Histöria da Companhia de Jesus no Brasil, de Serafim Leite SJ., - se não temos informações mais concretas e precisas de fontes documentais ou histōricas, sobre mecanismos de educação e, mais especificamente, sobre livros e leituras circulares no Brasil Seiscentista, alguns informes tōpicos nos podem ésclarecer quanto às tendências e características de um incipiente leitor à época, quando nada por sua feição de leitor via, citação.

Assim, o livro do Fr. Manoel Calado, $\underline{0}$ valeroso $\underline{\mathrm{Lu}}$ cideno e triunfo da liberdade, que é de 1647, referindo-se a acontecimentos entre 1634 a 1637, alëm de pregar abertamerite uma guerra santa contra os holandeses após o enterro de "livros e papéis manuscritos", traz alguns trechos e citaçōes diretas de autores e obras. Jā no pörtico da obra, um poema do autor em homenagem-dedicatória a D. Teodósio, inscreve passagens tiradas a Erasmo, Plutarco, Ovídio, Homero, Virgílio e Herödoto, o que, obviamente, insinua a leitura desses autores. Outros poemas que abrem o livro, após o "Ṕrólogo ao leitor!" e desta vez louvando o prōprio frade autor, contēm expressas citações dos nomes de Tūlio, Tấcito, Homero e Lívio, como no soneto do padre Manocl Adrião, que, em outro poema, em dëcimas, tambēm faz refcrên cia explicita a Marcial. De Pedro de Noronha, cm louvor a Calado e à obra, um "Soneto"' inclui.rcferência a Tácito.Dc Antonio Pinhciro de Mariz, sobrinho do frade cremita autor 
do Valeroso Lucideno, um soneto em espanhol cita Camões,Petrarca, Garcilaso, Ovídio, Tansilo e Tácito. Por fim, no intróito da obra, com a rubrica "Aclamação", em oitava rima e décimas nos moldes camoneanos, o próprio Calado faz referência direta a Homero, justo para simbolizar a energia com que os pernambucanos, seus representados e heróis, em odisséica bravura, recuperariam para Portugal (e para a religiāo catōlica, vale dizer, para o espírito da contra-Reforma) o solo brasileiro ${ }^{28}$.

Já um manuscrito de assuntos brasileiros, pertencente à Biblioteca da Universidade de Coimbra, (códice 388, fls. 274 a 288), traz exercício gratulatório com o comprido título de "Breve Compêndio do que vai obrando neste governo de Pernambuco o senhor Antônio Luís Gonçalves da Câmara Coutinho, Comendador das Cómendas de São Miguel de Bobadela, Santiago de Bonfë, São Salvador de Majorca, Almoṭacérmor do Reino e Governador das Capitanias de Pernambuco e suas anexas", documento relacionado por Francisco Morais no Catálogo dos Manuscritos da Biblioteca Geral da Universidade de Coimbra relativos ao Brasil (Coimbra,1941, p.11).' o "Breve Compêndio... "foi escrito por um tal Gregório Varela de Barreto Pereira, cidadão de Pernambuco, e entóa loas ao mesmo Câmara Coutinho duramente espezinhado na Bahia por Gregório de Matos, que o chamou de "nariz de embono" e que viria a ser o principal mövel das desgraças do poetá em sua terra. Logo no primeiro capitulo do seu escorço gratulatório, Varela demonstra-se leitor de $\Lambda$ ristóteles e chega até a exercitar uma certa tcoria do discurso retörico: 
(...) e como a incapacidade do meu trabalho è tosca e grosseira, pois não continuei os estudos, que são os meios que fazem os sujeitos politicos para a narração de suas obras, por esta razão seră esta mais grosseira que politica; mas direi com Aristóteles que o orador mais se há- de esmerar em contar a histöria com correnteza, que não no concerto das. palavras politicas e delicadas dos gramáticos, que só se deve advertir na sustância da histōria e não nos acidentes, que são as palavras esquisitas, que às vezes sucede tirarem o gosto da obra, e, animado desta autoridade, me resolvo a continuar o prometido 29 .

Em Pernambuco, como vimos, presumir-se-iam então leitores de Homero a Ovídio, Erasmo , Plutarco e Heródoto, Tảcito e Virgílio, Garciliaso a Petrarća e Camões.E mais Aristōteles da retórica : não-escolästica, o que demanda, no mínimo, uma parcela de nossa curiosidade. Homero, por óbvia diligênçia à mitologia épica e à apropriação de um historicịsmo heróico, comparece no louvor a Calado e'seu Valeroso Ludideno, traduzindo uma reificação ör fica da epopéia luso-brasileira em defesa do solo pernambucano. Garcilaso, pelo signo humanizante e impressivo de beleza e melodia no "Triunfo da Liberdade". Ovídio, Petrarca e Camões, pelos sentires harmônicos, humanistas e neo-platônicos associados às circunstâncias da resistência luso-católịica à dominação holandesa e protestante. Por isso, a obra de Calado ganha a reśsonância poêtica que al- 
guns lhe atribuem.

Aristóteles, formalmente citado no panegírico de Barreto Pereira a Câmara Coutinho, seria o filósofo mentor do espírito retórico, passando ao panegirista e sua oraçãogratúlatória um àtestado de categoria politica e retórica,com a autoridade do clāssico e do pedagogo.

No plano documental, repetimos, não dispomos no Brasil e talvez nem mesmo em Portugal, na Espanha.. e na Holanda, de outras referências que consagrem o estabelecimento seguro de um perfil de leituras na sociedade brasileira do periodo seiscentista. O percurso è difícil sem que o apóie uma. sólida base de investigação, como a que aqui nos orienta. E assim escolhemos, para referendar a pesquisa, os inventārios de bens oriundos de arquivos, institutos históricos, fōruns, tribunais de justiça e cartórios dos principais centros culturais no país, vale dizer, das capitais dos Estados e cidades históricas de reconhecida tradição na guarda de caracteristicas documentais marcantes.

Para um esforço de interpretação nesse sentido,identificar um perfil de leituras mediante a anālise de inventārios revelou-se assim a única fonte possível. Os pouquíssimos estudos e bibliografia a respeito da circulação dé livros no Brasil são, como vimos, insuficientes. A notícia desses inventärios teve ilustres predecessores, de forma localizada em São Paulo e através do estudo em documentos publicados pelo Arquịvo Püblico do tistado de São Paulo nos anos 20 e 30 . Aqui destacamos Alcântara Machado, em Vida e morte do bandeirante, aproveitando a picada a- 
berta por Taunay (quem primeiro se debruçou sobre inventārios seiscentistas) e aprofundando um estudo dos modelos sociais e administrativos da Colônia, vistos a partir do universo cultural paulista.

Da relação desses inventärios seiscentistas publicados pelo Arquivo Püblico de São Paulo e que foram objeto de anälise por Taunay e Alcântára Machado, somente dezesseis deles apresentam livros entre os bens descritos pelos - inventariantes. Um outro documento publicado, incluindo livros, é de 1710 e será descrito em outro lugar deste trabalho, quando estudarmos as caracteristicas do leitor brasileiro do Setecentos. Alcântara Machado descreve a composição da sociedade e da cultura do bandeirante paulista a partir de mostra sócio-cultural extraída dos documentos. Fala da pouca circulação de livros à época,manifestanido um compreensível azedume para com seus coestaduanos. Justamente em virtude da ausência de maior nümero de obras 1iterárias entre os bens das livrarias. Faz o exato registro. do aparecimento.das Novelas de Cervantes e observa a curiosa transcrição de estâncias camoneanas nas costas do papel de um inventário de 1616 pertencente a um certo Pero de Araujo 30 - documento que, ironicamente, não indica qualquer livro entre os bens do inventariado. Mas. no verso da última folha do inventário, aparece a transcrição do Canto Quinto, de Os Lusíadas, das estâncias II, VII, XI e XV. Erà escrivão de órfãos Antonio Teles. (Alcântara Machado registra como "escrivão do arraial Francisco Rodrigues de Gucra") e nada mais óbvio que se tratasse de um Intimo e apaixonado leitor de Camões. Transcrevimos as 
estâncias assinaladas:

- Entrava neste tempo o Eterno lume No animal Nemeio truculento;

E o Mundo, que com tempo se consome, $\mathrm{Na}$ sexta idade andava, enfermo e lento.

Nela vê, como tinha por costume, Cursos do Sol quatorze vezes cento, Com mais noventa e sete, em que corria, Quando no mar a armada se estendia.

\section{VII}

- Passámos os limites, aonde chega O Sol, que para o Norte os carros guia; onde jazem os povos a quem nega 0 filho de Climene a cor do dia. Aqui gentes estranhas lava e rega Do negro Sanagä a corrente fria; Onde o Cabo Arsjnārio o nome perde Chamando-se dos nossos Cabo Verde.

\section{XI}

- As Dórcadas passamos, povoadas Das. Irmãs que outro tempo ali viviam, Que, de vista total sendo privadas, Todas três dum só olho se serviam. Tu só, tu, cujas tranças encrespadas Neptuno lä nás äguas acendiam, Tornada $j a ́$ de todas a mais feia, De bívoras encheste a ardente areia.

\section{XV •}

- Assim passando aquelas regiões Por onde duas vezes passa Apolo, 
Dous invernos fazendo a dous verões, Enquanto corre d'um ao outro Pólo; Por calmas, por tormentas e oppressões, Que sempre faz no mar o irado Eolo; Vimos as Ursas, a pesar de Juno, Ganharam-se nas águas de Neptuno. 31

o que teria a ver o documento com o poema ou vice-versa? Nada, aparentemente. O escrivão não era livreiro-avaliador, não hã no corpo do inventārio qualquer referência a um único volume. O inventariado Pero de Araujo parece inteiramente desambicioso quanto à cultura ou a livros. Quem sabe não seria o escrivão um tímido poeta, mimético leitor do "prïncipe dos poetas hespanhōes": Ou a. transcrição seria um mero recurso para espantar o ócio de um entediado funcionário?... A sugestão do poema, e justamente das estâncias II, VII, XI e XV do Canto Quinto de Os Lusiadas, tudo fica por conta de uma curiosa circunstância no comecinho do século XVII brasileiro. A propósito dessa circunstância curiosa, Giberto Mendonça Teles assinala o fato de o.inventário ter sido levado a efeito no sertão paulista, com os rigores adversos típicos das Entradas, transcrevendo as mesmas impressões de Alcântara Machado, para quem as adversidades ali sofridas teriam se inspirado nas passagens camoneanas" "por calmas, por tormentas e opressões, e transposto o limite aonde chega o Sol" 32 .

No inventārio. mais antigo dos publicados pelo Arquivo Püblico de São Paulo (Noticias e Testamentos. São Pau10. Arquivo do Estado, 1920) - fonte de recorrências tan- 
to para Taunay quanto para Alcântara Machado - com data de 1612 (o testamento é de 1603), vêm descṛito os bens de Martim Rodrigues. Dentre esses bens, constam quatro livros, três deles pertencentẹs às coisas da religiāo (을etảbulo da vida de Christo, Instrucção de confessores, Mistérios da paixão) e uma Chronica do grão capitão, que talvez escape à especificidade religiosa e que Alcântara Machado acredita tratar-se do livro de Fernando Perez del Pulgar sobre - Gonçalo de Córdova ${ }^{33}$. Dos quatro livros, configuram-se a circulaçäo de um popular manual para confessores, jā em 1603, ou 1612, e a mesma Instrucão de confessores que, com - título possivelmente alterado para Conduta de confessores, no século XVIII, é. dos livros mais circulares no Brasil atē meados do século XIX,1ivro lido não apenas por religiosos, mas igualmente por fiēis naturalmente identificados com as circunstâncias em que se devia desenvolver o sacramento da confissão auricular.

Os inventārios de Manuel Vandala (1627) e Manuel Pinto Suniga (1627) reforçam o estilo do leitor seiscentista predominantemente ligado a livros de doutrina religiosa. o de Vandala registra uma única obra, o Libro de la Divina... 0 de Suniga, uma Aplicação da Bulla da Cruzada. Quanto ao primeiro, Alcântara Machadc manifesta o secreto desejo de que se trate da Divina Comédia, supondo assim um feliz preenchimento das reticências no documento. Parece-nos pouco provāvel tenha sido Dante um autor que caprichosamente circulasse em São Paulo, a essa ëpoca. Em nossas investigações de fonte primāria, a presença do autor da Divina Comédia só serā notada, de forma clarạ e incontestável, ' em 
documentos do século XIX. O Libro de 1 a Divina, com grafia espanhola, talvez assente melhor como obra de cunho religioso, a exemp1o do Libro de 1a Verdad, de Pedro de Medina, ou o Libro de 1a Oración y meditación, do Fr. Luis de Granada, autor tambëm de um popularissimo Guia de pecadores. Em todo caso, fica consignado o curioso da probabilidade.

Matheus Leme (1633) destoa um tanto da tendência dominante de livros religiosos. 0 inventārio de seus 1ivros reflete um certo ecletismo do leitor, aparecendo um Livro dos segredos da natureza (na partilha, com a viúva), um Tratado prático de Arithmêtica (ficou com o filho) e un Repertório (na partilha, com um amigo do falecido). Ou seja, alëm dá leitura corrente, uma obra pertencente à ārea das Ciências Matemáticas e outro à de Legislação portuguesa. Se tomarmos, ainda, o "Livro dos Segredos da Natureza" como atinente à Botânica, a inclusāo de uma obra em Ciệncias Naturais, aqui, em pleno século XVII, estamos diante de algo extraordinärio, face ā voga de obras nos ramos das Ciências humanas e especialmente da Religião. O Repertōrio é obra de leitura obrigatōria para bacharel,mi litar ou funcionärio e, portanto, não surpreende pela presença. Surpresa mesmo serā o volume de Aritmética, das Ciências Matemăticas, ārea que será mais frequente nos inventärios brasileiros do século XVIII.

0 livro "Horas de resar escrito em linguagem" aparece nos inventärios de Antönio de Almeida (1636) e de Scbastião Paes de Barros (1688). Manual de fundo místico. 
espécie de catecismo com oraçōes e práticas espirituais para todo c ano, contendo exercícios da moral evangélica para serem seguidos pelo fiel, é dos mais populàres no Brasil e antecipa outros de igual característica e invulgar circulação entre nós nos séculos subsequentes, como Horas marianas, Horas portuguesas, Horas seräficas, Horas 1usitanas, Horas latinas, Horas da Semana Santa etc.

No inventārio de Catharina de Siqueira (1638), entre um "Confissionàrio" e dois livros sem identificação, vamos encontrar "Villegas, P. 2", seguido de "Fernäo Mendes Pinto", "Heitor Pinto P. 1" e as "Novelas de Cervantes". Permanece o caráter religioso e místico, na base do manual da preparação teológica para as relações do fiel com seu patrono espiritual, mas $j a \overrightarrow{~ s e ~ n o t a ~ u m a ~ n a t u r e z a ~ m a i s ~ a b r a n-~}$ gente de um novo interesse da leitura, aĩ incluindo-se a história fantásiosa do autor das Perégrinações de Fernão Mendes Pinto. As Novelas exemplares, de Miguel de Cervanțes Saavedra, aqui presentes, serão a primeira anotação de obra ficcional entre os documentos pesquisados. Embora não seja frequente (como, de resto, a literatura hispânica não o è), Cervantes irá aparecer em outros documentos, com o D. Quixote, popularísimo nos séculos XVII e XVIII em Portugal e, nos séculos XVIII e XIX, no Brasil. Interessante tambëm notar os livros do Fr. Heitor Pinto, místico do século XVI, monge de S. Jerônimo, rebelde e asceta, com nascimento provável na Ilha de Covilhã (1528?) e morte no exilio (1584?).

Autor com bom trânsito nas bibliotecas brasilciras 
dos séculos XVII e XVIII, catedrático das Escrituras na Universidade de Coimbra, Heitor Pinto escreveu a Imagem da vida cristä, ordenada em diálogos, cuja parte I teve sua primeira edição em 1563. Guardando reminiscências platonizantes, esta obra foi editada umas vinte vezes só no sēcu10 XVI. Deve tratar-se, pois, de sua obra mais conhecida a referência "Heitor Pinto P. I" que aparece no inventārio de Catharina de Siqueira. A Imagem da vida cristã é obra de narrativa e conteüdo moral, organizada conforme uma linha confessional e auto-reflexiva, na vertente provävel de Santo Agostinho, este idealista do Cristianismo de fundo utópico,investido na tentativa de catolicizar a filosofia platônica e facilitar a assunção de exemplos por parte de leitores e fiéis.

0 mesmo Fr. Heitor Pinto vai aparecer no inventārio de Manuel Preto (1638), com a deścriçāo de "Livro velho de Heitor Pinto", ao lado de um outro "Livro velho", sem identificação de autoria. E muito provãvel que Manuel Preto também fosse leitor da'. Imagem da vida cristã, por não haver registro explícito da circulação, entre nós, de outras obras mais conhecidas do monge asceta, como In Isaiam prophetam comentaria, 1561; In Ezechielem prophetam commentaria. Salamanca, 1568, de confirmada notoriedade na América espanhola ainda no século XVI; ou In Danielem. Nahum et Jeremias prophetas commentaria; Coimbra, 1579. Salvo reconhecimento posterior, não cremos possível a circulação dessas ựtimas obras entre nós. Seguranente, a Imagem da vida cristã è o livro de Fr. Hcitor Pinto mais divulgadole provavelmente 1ido) no Brasil. Vamos enconträ-1o, mesino 
sem a indicação do seu autor - prätica, aliās, desgraçadamente constante no modelo dispersivo da descrição dos 1ivros nos documentos.

No inventărio de Ignez Camacho (1623) se referenciam os bens do marido, 'como era praxe da época, extensiva,pelo menos, até ao sëculo XIX. Nele, vamos encontrar uma "Ordenação de Sua Magestade", ou, as Ordenaçōes do Reino, exemplar, como vimos, de invulgar manuseio por parte de funcionärios, bacharëis, militares e outros inventariados. Joäo da Costa (1639) traz, em seu inventário, uma lista pequena de livros que atestam o retrato mais frequente doleitor brasileiro no período colonial: "Livro da vida christã", "Livro de Säo Josë" e "Livro de concertos", este ū1timo destacado como obra provavelmente indicativa do interesse do leitor por música. Jā o "Livro da vida christä" deve mesmo tratar-se da obra vista do Fr. Heitor Pinto.

Uma leitura apressada ou generosamente favorāvel à Metrópole poderia enxergar um natural advento da imprensa no Brasil ao identificar, no item "Ferramenta" do inventärio de Pedro Fernandes (1653), "um torno de emprensar 1ivros"34. Impossivel seguir por essa trilha. Tratava-se mesmo de máquina de encadernação, ou prensa, mas de livros dos assentos de contas do inventariado. Pedro Fernandes, aliās, tinha como ünica obra um "Livro de sernões", sem outra identificação. Como o registro vem em português, ju1gamos tratar-se de sermonário em linguagem, escrito por pregador corrente, do sēculo XVI ao XVII. O documento è de. 1653. Assim, pode ser autor desse "Livro de scrmões" tan- 
to um D. Antonio Pinheiro, bispo de Miranda e de Leiria, mestre de D. João e âulico do imperialismo português, com seu "Sermão na trasładaçäo de D. Manuel, em Belém", publicado em 1551, quanto um Fr. Baltasar Limpo, cuja obra, Doze fugas de David e seu inimigo Sau1, data de 1642.

Não se pode excluir a possibilidade de que o "Vilhegas", que aparece no inventārio de Catharina de Siqueira (1638) seja o mesmo que aparece no inventārio de Isabel Cunha Lobo (1641), aqui descrito unicamente, enquanto livro, como "Fralsantonio de Vilhegas". Para Alcântara Machado, em Vida e morte do bandeirante, cit., página 94, poderia ser Esteban Manuel de Villegas, ou Quevedo y Villegas, autor de uma Histöria y vida de gran Tocaño llamado Buscon, romance burlesco de 1626. Para nós, no entanto, esta obra de "Villegas" deve tratar-se de disciplina ascética ou doutrināria, como as outras próprias da ciência religiosa.

Permanecemos na descrição de títulos de Doutrina. No inventärio de Sebastião Preto (1640), confirma-se tal predominância entre as 1eituras brasileiras do Seiscentos.São "Livro de Salve Rainha", "Livro da conquista de Jerusalën" e "Livro de São João". Assim também no documento de Clemente Alvares (1641), onde encontramos, alëm de quatro liobras sem qualquer possibilidade de identificação, o Contemptis mundi e um Confessionārio. Este ū1timo, jā vimos aparecer ma frequencia de outros leitores, como no inventärio de Catharina de Siqueira (1638). Já o Contemptis mundi , provavelmente um exemplar de origem espanhola, muito popular no sêcculo XVI da civilização hispanamericana, è obrH 
por excelência de extrato medieval, com seu pathos de orientação espiritual e ascētica e recorrência a exemplos tomados ao Novo Testamento, mimético da vida de Cristo, na explícita convocação do leitor para as excelências da salvação eterna e redenção humana. O título com que veio depois a consagrar-se na literatura mística è De Imitatione Christi, cuja autoria jă foi atribuída a Santo Antônio,mas que estudos modernos resgatam o nome de Thomas de Kempis, cônego regular de Santo Agostinho, como seu verdadeiro autor.

o último documento destacado entre os publicados em Inventārios e Testamentos (São Paulo, Arquivo do Estado, 1939) data de 1710 e estä, portanto, num perfil de leituras pröprias do século XVIII. Nele, adiante descrite,anotamos iguais características de leitura dos brasileiros seiscentistas, leitura que näo se altera muito e demonstra umà esmagadora preferência para as matērias religiosas. 


\section{$2.3-\underset{\sim}{\text { No }} \underset{\sim}{\text { se }} \underset{\sim}{\operatorname{cu}} \underset{\sim}{u} \underset{\sim}{0} \underset{\sim}{X V I I I} \underset{\sim}{I I}$}

Tendências e comportamentos de leitura no Brasil do século XVIII distinguem-se dos do século XVII, em quantidade e qualidade de títulos e de assuntos. E não apenas porque o país avança em sua destinação de colônia historicamente imprescindivel a um Portugal decadente, mas igualmente porque denuncia uma maior e mais franca presença de outros modelos culturais e. literários passados ou não diretamente pelos colonizadores. Mais: por um conjunto de fatores históricos de fácil percepção, um deles - de maior relevância a transferência do eixo político da Colônia, da Bahia ou Pernambuco para Minas Gerais, centro de descobertas de ouro e diamantes. Sob o ângulo da cultura, portanto, a Colônia aumenta o número de seus filhos estudando em Coimbra, altera-se o ensino, as técnicas se ampliam e se renovam com os estudos na universidade coimbrã. 0 mundo inteiro se escora no modelo iluminista, ou da Ilustração européia capitaneada pe1a França - terra de enciclopedistas e revolucionários. Por fịm e emblematicamente, o fenômeno Pombal e o ambiente polêmico da reforma dos estudos vieram dar a senha decisiva para alterar o modus vivendi português e, por via de consequência, o nosso.

Não existe entre nós, ainda, o leitor que se evidencie intclectualmente, debatendo sua cultura com os demais numa sociedade de signo crescente, avaliando ou questionando scu 
devir social,estimulado pelas värias camadas da leitura de obras representativas. Os documentos de que dispomos indicam um leitor apenas refletido a partir das áreas diretamente oriundas de um interesse específico de ampliação de status acadêmico ou profissional. Os livros permanecem na predominância de obras de devoção, mas jă vão aparecendo, em número considerävel, os clässicos latinos, as gramäticas e dicionärios, Ciências naturais e Filosofia. Hä pouca coisa de 1iteratura portuguesa ainda (Camões quase exclusivamente e mais exclusivamente $\underline{\text { Os }}$ Lusiadas) e de brasileira (os moralistas do século e os poetas mineiros). Cervantes e Calderón pontuam na literatura hispânica. Nada de 1iteratura inglesa ou alemā. E muitos livros franceses, de Filosofia e Literatura. Muita pregação moralista e um incipiente traço do pietismo protestante. Apesar do reducionismo autoritärio e maniqueísta da dominação católico-estatal, as obras dos enciclopedistas franceses, o Raynal da Histoire philosophique, os relatos de viagem, obras de Direito natural, as vocações de curiosidade pelas notícias do mundo civilizado começam a se impor.

Percorremos primeiro as informaçōes gerais do prōprio século, colhidas em documentos de fonte primária ou secundária, que ilustram nossa compreensão do papel da cultura 1iteräria no Brasil colônia. Começamos pelo contributo ao cntendimento da fase de mudanças provocadas no século. Alguns documentos reforçam no pesquisador situações novas de compreensão do Brasil quanto às determinações reinóis no campo da politica e da administração dos negócios que envolvem. a educação e a cultura. Algumas dessas determinações surprecn- 
dem, mesmo aquelas anteriores a Pombal. E todas elas, no estrito espaço de interpretação da circularidade cultural numa quadra de tempo certamente critica para os nossos destinos, formam e deformam. o universo de leituras brasileiras porque envolvidas com a instrução, o desenvolvimento artístico, a censura ou a permissividade com livros etc.

Carta régia de 28 de março de 1709 , por exemplo, dirigida ao governador da Bahia, dispõe "Sobre não admitir nesta capitania religioso algum que venha do reino sem expressa oṛdem de Sua Magestade":35 Uma carta seguinte, de 22 de junho do mesmo ano, recomenda "cautela na execução da ordem que proíbe entrada de religiosos neste Estado sem 1icença de Sua Magestade". 36 Nas relações Igreja-Estado, embora estas se exercessem sob pressão direta dos jesuítas, - Estado transigia e, em alguns pontos, mostrava-se permeável a rever posições. A entrada de religiosos, com fins da educação e catequese, na Bahia e demais províncias, de qualquer forma se dava desde o século XVI e aqui as outras ordens religiosas igualmente exercitaram uma missão associada à catequese e à transmissão do Evangelho, base do evolucionismo imperialista ibérico. Essas cartas de início do século agilizam uma movimentada teia de situações culturais novas no Brasil, com desdobramentos e consequências claros para a formação de leitores.

A circulação de livros, ou a necessidade impositiva do ler ou, ainda, a facilidade do acesso a uma produção escrita, pode-se inferir da carta régia de 31 de março de. 1722, dirigida ao vice-rei da Bahia, rometendo momória im- 
pressa com instruções sobre notícias necessārias à composição de uma "História Portuguesa" incumbida à Academia Real da Corte, em Lisboa. A carta recomenda também a leitura da dita memória e solicita as colaborações do Arcebispado e dos demais poderes locais para facilitar a edição da obra. 37

Sobre questões relacionadas com a. presença educadora de religiosos na Bahia - o que indiretamente nos interessa pela investigação da possibilidade de circulação de lïvros hā, na Seção Histórica do Arquivo do Estado da Bahia, Ordem Régia de Lisboa, de 24 de setembro de 1752 , falando a respeito do alvará pelo qual foi dada licença ao missionärio Gabriel de Malagriáa, da Companhia de Jesus, para edificar Seminärios na Amërica e sobre o lançamento da primeira pedra do seminärio novo da Bahia. 38

Ainda no tocante à Instrução Püblica no interior do Estado da Bahia, hã a registrar uma "Lista de alunos da aula de Gramatica. latina da vila de Camamu, em 1765", o que evidencia a permanência. dọ latim nos estudos menores. 39 No testamento de Josefa. Maria, em 1752, consta ter a testadora um filho estudando no Seminärio de Belēm, aquele mesmo situado no distrito de Cachoeira; criado por Alexandre de Gusmão nos fins do século 17 e até então sobrevivente.

Preocupação com a leitura e a edição vai encontrar ressonäncia no próprio Pombal. 0 volume 17 dos Anaes do Arquivo do Estado da Bahia, na seção "Cartas e Portarias", registra una carta do Marquês e Conde de Oeyras, datada de 
11 de abril de 1761, em que recomenda o Tenente-Coronel Dr. Josē Mirales, na Vedoria do Estado do Brasil," para ver livros da Repartição pois o cidadão se acha escrevendo a Historia militar do mesmo Estado". 40 Mirales era baiano e, como tantos outros, autor de um soneto apologético dirigido a Pombal. Ganhava aqui as graças do todo poderoso ministro para vasculhar, com aquiescência e colaboração dos patrícios, os nossos parcos arquivos em busca de dados que - auxiliassem na composição de sua famosa obra, a História Militar do Brasil, dedicadá a D. José I e incumbida ao autor, segundo parece, pela Academia dos Renascidos. A obra vem cheia de citações clássicas, farta documentação e numerosos fatos, abrangendo a faixa de tempo desde a fundação da Bahia (1549) ao ano limite de 1762, data certamente de conclusão do trabalho.

$A^{\circ}$ Instrução Püblica, no interior da reforma pombalina, é assunto que se afigura como contribuição ao conhecimento de um perfil de leituras no século XVIII. Em Recife, na Divisão de Pesquisa Histórica da UFPE, encontramos o $\vec{u}-$ nico inventärio de livros, do século XVIII, com que Pernambuco comparece em nossa amostragem. E o inventário do bispo D. Thomas da Encarnação Costa Lima, de 5 de maio de 1784 , comentado em outro lugar deste estudo. O mesmo D. Thomas, segundo Pereira da Costa, mourejava em Olinda na metade do século e era autor de uma Historia ecclesiastica lusitana. Regalista militante, o bispo fora pregador em uma oração pela boa saüde de Pombal em 1776 e teve papel relevante na desenvoltura das reformas pombalinas na instrução pública 
de Pernąmbuco ${ }^{41}$. Sobre algumas características dessa instrução, aliās, Pereira da Costá conclui que

Funcionavam então na colônia varias escolas particulares no Recife e 0 linda, geralmente dirigidas por padres seculares, nas quais se ensinava o portugês, latim, retórica e filosofia; aulas püblicas de grego e matemāticas, e à falta de bibliotecas püblicas, tínhamos as das casas religiosas, riquíssimas, pelo avultado nūmero de obras, de todo gênero que possuíam, sem contar as suas preciosas coleções de manuscritos, as quais eram franqueadas a pessoas estra-. nhas, mediante licença.

Por ai ficamos sabedores das guardas pombalinas dos oratorianos em Olinda, com predominância, em 1755, para estudos que levavam em conta a oratória sagrada, estudos históricos e torneios poéticos de cultores de conferências e festejos reunindo 1 iteratos. Nada, contudo, transparece quanto a titulos ou autores.

o capítulo da reforma e expulsão dos jesuĩtas, dos reinos de Portugal, conquanto não ofereça matizes precisos dos seus efeitos, certamente trouxe dissabores. No Espirito Santo, por exemplo, registra-se prejuízo considerävel para a instrução. A biblioteca do colégio praticamente desapareceu. "Anos mais tarde - informa José Teixeira de Oliveira - o Tribunal da Real Mesa Censória exigiu os livros, cabendo ao ouvidor da comarca a tarefa de deitar bando e recebê-Ios, em restituição, das mãos dos que se acusaram. Em 1794, incendiou-se o remanescente."43 o ensino pủblico que 
se seguiu ao dos jesuitas ficou sendo mantido pelo subsídio Literário desde 1772. No Espírito Santo, como no resto do país, a população manteve os mestres nas escolas, por força" de um imposto coletado pelas câmaras. 0 ensino teve a circunstância da obrigatoriedade. A recusa, era mandado - faltoso para as milícias. No fim do Setecentismo, em toda a capitania do Espirito Santo, havia dois únicos professores, um de gramātica e outro para ler e escrever. Nada, porẻm, ainda aqui se informa quanto a livros ou autores que formavam as bibliotecas ou orientavam o gosto e a prätica educativa.

Sobre a instrução pública em Mato Grosso, evidencia- se uma tendência singular para o ensino técnico, de um incipiente caráter mais ilustrado ou cientificista, com a criação das cadeiras de Arithmetica, Geometria e Trigonometria, alēm da manutenção dos cursos de Grego e Latim, com o pagamento dos mestres decorrendo do Subsĩdio Literário. Carlos Moura destaca o papel educador do padre José Manue1 de Siqueira (1750-1825), natural de Cuiabá que, voltando de Lisboa, onde cursara História Natural e Filosofia Racional e Moral; foi ser professor régio de Filosofia Racional e Moral em Cuiabá. 0 ensino de Engenharia foi ainda implementado no século XVIII e o de Artes Militares, no século XIX. Aqui também, todavia, nada transparece quanto a $1 \mathrm{i}-$ vros ou autores estudados. 44

o século XVIII estende e acompanha o signo da cducação em todo o país: Na Amazônia, às referências vão para 
os estudos de Teologia: e Filosofia, em Belém e São Luiz. No Maranhão, aliảs, é que se concentravam os estudos filosóficos e teológicos, no Colégio dos Jesuítas, com lembrança significativa para os estudos de letras. Carta do Padre Geral Miguel Angelo Tamburini ao Superior da Missão do Maranhão e datada. de Roma, 21 de fevereiro de 1711, salienta a importância desses estudos:

E. porque sabemos que o Colëgio Maranhense ë bom para os estudos de letras, os Nossos dediquem-se ali ao cultivo das letras. Se, todavia, cursos Teolögico e Filosóficos forem realizados simultarieamente, então ensine-se Teologia no Colegio Paraense, pois no primeiro não existirá lugar para todos os membros. Se o curso for $\bar{u}-$ nico, seja de Teologia, seja de Filosofia, ensine-se no Colégio Maranhense. 45

Garcilenil do Lago Silva, em Educação na Amazônia Co1oniàl, lembra os esforços dispensados pelo vigẻsimo Governador e Capitão-General do Estado do Grão Pará, Maranhão e Rio Negro, Manoel Bernardo de Mello e Castro, que assumiu o poder em 2 de março de 1759. Nas provincias, era grave a falta de escolas. O governador impôs entāo o restabelecimento dos estudos de Doutrina cristã, estudos de 1etras, escrever, contar, solfa e Gramätica, pelos religiosos de Nossa. Senhora das Mercês, exigindo paralelamente que os pais levassem os filhos às escolas, inclusive com o encaminhamento de livros pelo método moderno de escrever, 1er, contar e Gramātica. 46 
A mesma atitude, agora com relação ao ensino da língua portuguesa, impôs o governador que sucedeu a Mánoè Bernardo do de Mello e Castro, Fernando da Costa de Ataíde Teive em 14 de setembro de 1763. Tambëm aqui não se presta anotação no particular de títulos de livros ou autores. Mas hã expressa referência ao regime dos estudos, de seis horas de aulas diārias - três pela manhã e três pela tarde,com citação de alguns dos livros didäticos de adoção obrígatōria pelos professores: o Catecismo de Montpe1ier, obras sobre História de Portugal e o Mercurio Britânico. Este ültimo título deve ser especialmente observado como o melhor catecismo político, produzido pelos portugueses, tido como capaz de destruir pela raiz o "sistema de libertinagem" pregado pelos franceses. Previsível, contudo, a carência desses livros num sistema social e politico fechado e numa administração onde faltava tudo, convocava-se a inteligência - no sentido da utilização de títulos sucedâneos, pois,

... na falta dos referidos compêndios poderiam ser utilizados outros que satisfizessem os mesmos fins. Desses livros seriam extraídos textos, criteriosamente selecionados pelos professores, com o duplo objetivo de incutir no espírito dos alunos mäximas saudäveis e de ensinä-los (sic) a escrever corretamente. 47

Infelizmente, não se tem notícia a propósito dos livros que eventualmente sucederam os faltantes...

Da instrução em Minas, ou, antes, das dificuldades que a cercavam, carta do governador Lourenço de Almeida, su- 
cessor do Conde de Assumar na adminīstração da provincia, ao rei de Portugal, datada de "Vila Rica, 28 de setembro de 1721", com o curioso título de "Sobre casarem.os homens destas Minas e Mestres nas Vilas para ensinarem os rapazes", antecipa alguns dos maiores problemas da educação no Brasil. Lamenta-se o governador que

.. em todas estas Minas não há mulheres que hajam de casar, e quando hä alguma que viesse en companhia de seus pais (que'säo'raras), são tantos os casamentos que lhe saem, que se vê o pai da noiva em grande embaraço sobre a escolha que hä de fazer de genro.

A carta menciona o esforço local para conseguir subvienção que financie os estudos, 1ógica de difícil execução; uma vez que os muitos rapazes faltos de estudos. "receio muito que estes tomem pouca doutrina por serem todos filhos - de negros, que não é possível que lhe aproveite as 1 ições, conforme a experiência que há em todo este Brasil". O governador encerra sua carta ao rei um tanto constrangidamente pela dificuldade assinalada, salientando, entretanto, sua fiel observância às determinações reais e observando que "sempre se há de obedecer a Vossa Magestade como è justo e somos obrigados." 48

A observação vinha a propósito das recomendações do rei D. João V, que determinara a seu governador, em Carta Régia de 22 de março de 1721, o estabelecimento em Minas, em cada vila, de um "Mestre que ensine a.ler, e escrever, contar, que ensine Latim, e os paes mandem seus filhos a 
estas esçollas"- A preocupação do rei era louvável, uma vez que, nas vilas mineiras, segundo asseverava o governador, "hä muitos rapazes, os quaes se crião sem doutrina alguma, que como são ilegitimos se discuidão os paes delles, nem as mays são capazes de 1he darem doutrina."49

o salto para o Subsídio Literärio pombalino fez surgir, na provincia mineira, alguns dos estudos recomendados pelo Reino, como a criação, em Vila Rica, de uma cadeira de Latim, uma de Filosofia e duas de Instrução primeira, em 1774. Mas è somente em 1799, já cóm ò príncipe regente D. João VI, que Vila Rica vem a conhecer, por criação formal de uma escola, as cadeiras de Aritmética, Geometria e Trigonometria. A carta régia de 19 de agosto de 1799 recomenda à administração local não esquecer de instalar e assegurar os estudos do Grego e do Latim. O mesmo D. João VI determina, em carta régia de 3 de setembro de 1799 , criar á figura do inspetor ou fiscal do ensino em Minas, alguêm com prātica pedagógica, conhecido e conhècedor das matérias de elevação intelectual e literária, que

... va fazer a rigorosa visita das Escolas, examinando a assiduidade, e deligenciando Professores, e Mestres no cumprimento de tão essenciaes deveres, do Methodo que seguem nas Licções, e explicaçōes dos Autores, da Escolha dos Livros por onde ensinam. 50

o deserto de informações quanto a títulos e autores desses livros perpetua, entretanto, um grave desconhecimento para o estilo e características do leitor colonial minciro. 
O século XVIII português é marcado a ferro pela singular presença, - inquieta, polêmica e de rica biografia do Marquês de Pombal. Com este Conde de Oeyras, valeu-se a civilização portuguesa para operar as mudanças necessārias ao Reino, sobretudo no campo politico da educação e, clarọ, da circulação ou não de livros e idéias e das reformas produzidas na seara pedagógica da Universidade de Coimbra, até então feudo exclusivo dos jesuĩtas. Expulsos estes, com Pombal nasce um movimento de ilustração não-1ibertāria, envergonhada, mas de significativa irradiação, expressa superlativamente no Verdadeiro método de estudar, de Verney com seus desdobramentos e consequências.

No Brasil, o detalhe dessas mudanças é de extraordināría vitalidade e amostra decisiva quanto à avaliação de livros e idéias circulantes, de livros lidos ou tidos em importância, das tendências de leitura dos brasileiros. Claro está, na órbita das bruscas cirurgias oriundas da Metrópole, sob o comando poderoso daquele estadista que mudou a fisionomia de um Portugal modorrento e que se fortaleceu a partir de uma ação decidida no terremoto de Lisboa que vitimou dez mil ou mais pessoas. A ilustração no Brasil corre por conta das ações dos filósofos do plantão pombalino, aqui sobretudo expresso pelos oratorianos em Pernambuco e pelas reformas na educação, regras que atingem a toda a Colônia.

Como o século. XVIỊI portugủês è, pendularmente, o da segunda metade, com Pombal e todo o.conjunto de reformas 
responsáveis pela circulação polêmica de idéias, ou seu interdito, chegamos, enfim, à consequente repercussão da ação regalista de D. José I no Brasil. As circunstâncias históricas que fazem surgir o fenômeno Pombal não nos interessam analisar aqui. Mas as açōes e reaçōes provocadas pelo ministro e marquës no campo estrito da educação e da cultura vale acentuar, da circulação de livros - isto, sim, nos interessa.

Carta do. Desembargador Thomaz Roby de. Barroṣ Barreto, dando conta da natureza da reforma dos estudos na provincia da Bahia, reflete bem o espírito das mudanças e das atitudes contrārias ao expansionismo jesuítico no campo da educação. Diz o missivista, em certo trecho, quesseguirä em tempo e hora a magnanimidade da decisāo real quanto à melhoria do ensino da mocidade na Bahia, a partir do "Alvarä e Instrucçoens de 28 de julho de $1759^{\prime \prime}$, com vistas à completa reforma, ąbolição, cassação e proibição dos antigos métodos do ensino de Gramática Latina, Grego, Hebraico e Retórica. Na execuçāo do projeto reinol e em obediência ao alvarā e instruçōes, o desembargador salienta a fiscalização exercida sobre os 1 ivros condutores do método e ensino condenados. Informa que as Artes (de Gramätica Latina) do padre Antonio Pereira e a do Antonio Félix Mendes não chegavam a 400 exemplares "e que o primeiro tomo da Selecta não excedia o número de 200 e os Diccionarios muito poucos", por isso mesmo limitava a ação reformadora apenas à cidade da Bahia e à villa de Cachoeira, permitindo que, nos outros lugarcs da província, permanecesse o antigo método "enquanto não che- 
gavão os livros necessärios para o seu total estabelecimento" 51 Na mesma carta, o vigilante desembargador cuida de cercear a livre circulação daquela que seria, apesar disso, a mais concorrida obra de estudos linguísticos no século XVIII brasileiro: a Prosodia de Bento Pereira. Tal repressão revela, no entanto, o cuidado do funcionärio em condicionar. a proibição do livro à chegada dos novos Dicionarios pelo novo sistema: Pede, portanto, urgência no envio das obras que substituam a aborrecida Prosodia, o. que demonstra a circulaçāo da obra do Pe. Bento Pereira, enquanto não chegavam os livros adotados pelo regalismo pombalino.

Outra carta do mesmo Desembargador para o Diretor geral dos Estudos, D. Thomaz de Miranda e datada de "Bahia, 29 de março de $1860^{\prime \prime}$, refere sequestro e inventärio dos bens dos jesuitas, mencionando ter-1he sido apresentados por Joaquim Ignacio da Cruz, Procurador do Thesoureiro da Directoria, 3 caixões de livros, um para ser remetido para Pernambuco e o outro para o Rio de Janeiro, alinhando ainda terem chegado 200 Selectas (naturalmente as expurgadas) e 100 "Instruç̧oens". No parágrafo seguinte, nomeia as Artes do padre Antonio Pereira e de Antonio Fëlix Mendes que "vieram remetidas a estas hum livireiro e aquellas aos Padres da Congregação do Oratōrio". O padre Antonio Pereira de Figueiredo era oratoriano, mestre de Gramātica, Retórica e Música e homem do século pombalino. Artes, Cartapäcios e outras obras têm aí registro necessārio em tirar de circulação, justo para fazer frear o expansionismo do antigo método, já devidamente condenado por Verney no VM e adotado por Pombal. Mas o Desembargador adverte ser 
... indispensavelmente necessario, que V. Exa. faça remetter com brevidade os 2 tomos da Selecta, como tambēm a.Minerva de Sanches, as oraçoens selectas de Cicero, Quintiliano, Tito Livio e - Dicionario latino e portuguez, porque na verdade se necessitão muito.

Em outro lugar, já em 1762 , o funcionário enfatiza a recomendação de D. Jósē I quanto aos livros que deviam circular e ser estudados, o que implicava a proibição dos demais, que se deviam evitar. 52 o destaque vai para Minerva, de Francisco Sanches (1523-1601), reconhecido filósofo e gramático, autenticado por Verney. no VM especialmente quanto ao estudo da sintaxe. O título completo é Minerva de causis 1inguae latinae(1. ed. 1587) na esteira do igualmente considerado Julio Cesar Escalígero (1484-1558) e seu De causis 1inguae latinae (1. ed. 1540) .

Continuavam, portanto, as aulas de Gramātica Latina, Retoórica, inclusive no jả dito Seminārio de Belém, sobrevivente desde o século anterior com Alexandre de Gusmão, na vila de Cachoeira, recôncavo baiano. A fim de sacramentar a extinção do antigo sistema, uma Pastoral do Cabido da Bahia comenta a ação do novo mētodo implantado pelo Alvará de 28 de julho de 1759, restaurador da ordem nova dos estudos, ante o fogoso avanço intelectual dos estudos de Latim e Gramātica por parte dos jesuitas. O alvará, nesse entendimento, vem reprimir uma metodologia considerada perniciosa ao espirito secular, notadamente ao condenar e proibir, em todos os domínios do Reino, "o uzo e ensino da Grammatica latina pela 
Arte do Padre Manoel Alvares, e seus explicadores Antonio Franco, João Nunes e José Soares e o extenso e inutil Madureira e todos os seus cartapacios.".53 Assim se consagrava - modelo intervencionista de cunho pombalino para afugentar - "com que os jesuitas instruião o seu pernicioso e terrivel methodo". Os Iivros que Verney descompusera e a Corte proibia eram, pois, objeto de censura e interdição estendidas a todos os domínios do Reino. A Gramātica latina do padre Manoel Alvares S.J. (1526-1583) foi um dos livros de mais ampila circulação no Brasil à épocia. Em nossa investigação nos inventārios, verificamos inúmeras referências à "Grammatica latina" embora nem sempre com indicação de autoria. Era, as mais das vezes, a obra do excomungado linguista, apesar de - rigoroso interdito pombalino intentar suprimi-la a partir da Reforma dos Estudos, em 1759. Gramático e autor de uma Arte poética e de De institutione grammatica libri tres, este publicado em Lisboa, 1572, o padre Alvares tinha público cativo em função do domínio jesuítico. Sua gramātica latina era famosa, tendo alcançado cerca de 300 edições entre os séculos XVI e XVIII. Atacada por Verney-mentor intelectual do anti-jesuitismo pombalino - a gramática do padre $A 1$ vares caiu num curioșo e perverso Index, razāo da preocupação geral em condená-1á, interditā-la e provocar a prisão de seus possuidores nos reinos de Portugal. Para o regalismo, proibir a Gramatica latina dos jesuitas validaria a experiência de sua definitiva expulsāo dos escaninhos pedagógicos. Portanto, a providência, na verdade, radica razões de natureza polítića, de sorte a intertidar em tudo o espaço aos 
jesuitas e pulverizar sua influência no Reino.

o que Verney diz a propósito da Gramática latina do padre Alvares?

No Verdadeiro método de estudar, Verney desenvolve um extenso juízo crítico ao método corrente na Universidade de Coimbra relacionado com a Gramātica latina do padre Manoel Alvares S. J., sumariando aquilo que considera danoso ao entendimento da mocidade portuguesa. Assenta sua crítica, primeiramente, por ser a Gramātica latina do padre Alvares toda ela escrita em latim e, como tal, exigir praticamente uma sērie de outras obras que serviriam para explicá-la. A propōsito das obras e dos explicadores, Verney ironiza, na "Introdução ao estudo da Gramātica latina" que "quando entrei neste Reino, e vi a quantidade de Cartapácios e Artes que eram necessárias para estudar somente a Gramática, fiquei pasmado" 54 .

. Uma obra que não facilite o estudo direto de questões do idioma, na opinião de Verney, só traz confusões e seus inúmeros experimentos explicadores só prejudicam a boa educação. Ele próprio autor de uma Gramática latina, Verney justifica suas impressões inclusive avocando insuspeitos testemunhos dos próprios jesuítas, que teriam achado confusa e difusa a obra do padre Manuel Alvares, mas se resignavam a adotá-la em virtude da política oficial da Companhia, que radicava a adoção e a obrigatoriedade do uso.

Não só o padre Alvares, como seus explicadores são estigmatizados por Verney no Verdadeiro método. Por isso, au- 
tores como Antonio Franco (do Prontuário de sintaxe), Madureira (Arte explicada), João Nunes Freire (Cartapácios de gēneros e pretéritos) e outros passariam tambẻm pelo expurgo pombalino e mereceriam o rigoroso interdito. Hā ainda notícia de um Cartapácio de sillabas e figuras, sob o mesmo teor de explicaçāo da Arte do pe. Alvares, impressa em 1738 , Lisboa, composto, segundo Rubem Borba de Moraes, 55 por um brasileiro, natural do Rio de Janeiro, Inãcio Leão de Sã, e dado. à luz por Mathias Rodrigues Portella, estudante nos "pāteos da Companhia de Jesus na cidade da Paraiba do Norte do Brasil." O detalhamento de algumas destas obras encontra-se no capītulo "Clāssicos, moralistas e gramāticos" deste nosso estudo.

Thomaz Roby de Barros Barreto, em 1760, já Chanceler da Relação da Bahia, em carta a E1-Rei D. Josē, descreve fatos relacionados com sequestro, inventārio, vendas e administração dos bens dos jesuítas, particularmente quanto "á avaliação das suas livrarias". Não menciona títulos ou autores, mas considera muito rica a biblioteca, avaliada, por baixo, em quase $5 \mathrm{mil}$ e 500 réis. Confirma o interesse e alto valor da livraria, já que "della querem algumas Religioens comprar alguns jogos dos melhores livros", o que não ocorre em vista de algumas recusas de comprar alguma parte truncada de obras - o que era considerado, por incompleto, inútil. Barros Barreto confirma a existência de 1ivros nos Seminārios de Belém e dạ Conceição e encerra sua carta informando ao rei a intenção de alcançar dinheiro com o produto da venda dos bens dos jesuitas, e em especial afirma 
ficar "na inteligencia de vender todos os livros, que respeitão á Caza do Noviciado e aos Seminarios de Belem e da Senhora da Conceição e tambem os que pertencem à Caza dos Exercícios, quando possäo vender-se" 56 .

A expulsão dos jesuítas, em termos da eliminação de sua base cultural e de suas livrarias, alcançou todos os domínios de Portugàl. Já vimos o que aconteceu no Espírito Santo e na Bahia. O mesmo aconteceu no Maranhão e nas outras provincias onde a Companhia de Jesus tinha franca presença. Borba de Moraes especula que, em todo o Brasil, muitos desses livros devem ter. sido vendidos a preço vil, condenados a embrulhar unglentos, em virtude da sanha intervencionista do Estado pombalino. 57 Uma curiosidade ocorreu na Amazônia, onde os livros dos jesuítas se perderam ou tiveram destino inusitado. Garcilenil do Lago Silva diz que "entre os bens sequestrados aos. jesuítas, incluĩam-se as bibliotecas do Co'1égio de Santó Alexandre è da vila da Vigia, cujos livros deveriam ser vendidos em Belêm."58 Em virtude da dificuldade de venda por um preço justo e pela incapacidade financeira da população predominantemente pobre do Pará, e a cidade não ter biblioteca que pudesse aquinhoar-se com as "luzes que de tão util beneficio se costumão receber", o Governador Manuel Bernardo de Mello e Castro propôs à Metrōpole organizar uma biblioteca estadual no Pará, remetendo livros duplicados a Lisboa com o fim de venda. Segundo carta a Thomé Joaquim da Costa Real, datada de Parä, 8 de agosto de 1760 (ABAPP, 8, 1913. p. 253-254), Me11o e Castro propunha ainda contratar uma "pessoa de letras" para bibliotecärio, 
com ordenado oriundo dos próprios bens sequestrados dos jesuítas. 59 Não se tem notícia de que as idéias do governador prosperaram, ou nāo.

Em que pese, porém, todos os equívocos, exageros e desvios certamente ocorridos com o fenômeno Pombal (1760), a expulsao dos jesuitas e a mudança completa no sistema educácional vêm a ser marcos expressivos da civilização portu guesa e em suas colônias, uma vez que ratificam a assunção, pelo Estado, da responsabilidade social com o modelo educa tivo. Dos jesuítas nos vieram os automatismos da aprendizagem comprometida com o rigor do apostolado. A Ratio Studiorum de 1586, reformulada em 1599, ordenou a metodologia e o didatismo onde a máxima era ministrar lições do lex e do escrever, lições comprometidas com as tarefas da prātica expansionista da Companhia de Jesus: Assim, os modelos didáticos seriam aqueles típicos da ideologia catequista, da memória mimetizada, da verborréia, da disciplina monástica e dos exercícios espirituais. 0 século de Pombal veio alterar tudo isso. O eixo da educação a serviço se desloca então da Igreja para o Estado. Muda tambēm o eixo censōrio. Não serão interditas apenas as obras contra a moral ou a religião. Estas proibições permanecerão, acrescidas de outras, especialmente contra obras estrangeịras ou traduzidas, próprias dos enciclopedistas, ou dos filósofos cujas idéias pudessem por em risco o patrimonialismo pombalino. A Real Mesa Censória substituiu assim a Inquisiçao.

Com efeito, o. retrato de Pombal enquanto homem públi- 
co, leitor, ou estadista, poderia revelar o espírito e o comportamento político e administrativo do regalismo de $\mathrm{D}$. José I. E, aliās, curioso o perfil de Pombal enquanto leitor. Em Londres, 1743, antes portanto de tornar-se ministro plenipotenciário num momento agudo da crise lusa, a biblioteca de Pombal seria típica de um homem de gosto mas uma biblioteca comum. Dicionârios, Gramāticas, livros de Teologia, Jurisprudëncia, Literatura e Epistolografia dão o tom das matérias e ciências do futuro Conde de Oeyras. Sua livraria é similar das muitas que encontramos no Brasil desse tempo. Lá estão o Vocabolario portuguez e latino de Bluteau; (que Verney acha maçudo e insubsistente); As $\underline{\text { Me- }}$ mórias e documentos da Academia Real de Historia Portugesa de 1721 a 1734 ,de responsabilidade do espezinhado Conde de Ericeira, D. Luiz de Menezes; a Gramatica franceza ou a Arte para aprender o francez por meio da Lingua portuguesa, cbra conceituada na interpretação verneyana, cuja primeira edição é de 1710 e 2. ed. em Lisboa, 1737; oo livro do Abade de Vallemont, traduzido por Pedro de Sousa de Castelo Branco, Elementos de Historia ou o que he necessario saberse da Chronologia (Lisboa, 1734); o Methode pour étudier 1'histoire avec un Catalogue des principaux historiens (Paris, 1735); mais os livros de interesse genérico como as relações de viagem, a Histōria greco-romana, os C1ássicos, a Geometria, as Navegaçōes. 60

Conhece-se o homem.por seus livros? Se assim for, pombà não teria nada de calculista, ou maquiavêlico. Também não se revelaria dono de uma excepcional cultura, erudição, 
ou suposta intelectualidade. Seu aprendizado em politica seria um tanto cândido ou comedido, a julgar pór sua estante. Assim, leitor dos Testamentos politicos de Colbert (ediçāo de Haia, 1689); e do também marquês de Louvois (edição de Colônia, 1696). Claro, era também leitor do Cardeal de Richilieu (Amsterdam, 1719). Leitor ainda da atividade mentora de monarcas, como atesta o livro L'Institution d'une Prince (edição Leide, 1739). E o mais? Pombal seria um utópico? Pois 1á. estava Thomas Morus e sua Utopia na estante do Marquês. Moralista, sim, e catổlico. Tạmbēm tinha a versão da Moral de Tácito. Mais? Os livros de consulta obrigatória, regulamentos, ordenações militares, tratados de comércio, coleções de leis...

Um dos principais teóricos da reforma pombalina nos estudos e na cosmovisão lusitana de Setecentos, Antonio Ribeiro dos Santos (1745-1818), o poeta árcade Elpino Duriense,autor de $\underline{A}$ verdade da religião cristã (Coimbra, Real Imp. da Universidade, 1787), este, sim, seria um polemista, um argumentador, um tratadista do Direito Natural, contra os arrivismos de Voltaire e Rousseau, contra o espírito prático da Ilustração francesa - inscrita, aliās, em Portugal apenas por citaçāo ou intenção, mas sem a equivalência real de idéias e profundidade. Ao contrário, o Neo-Classicismo português antipatiza a Ilustraçāo justamente por seus pressupostos franceses e revolucionários. 0 itinerário intelectual de Ribeiro dos Santos foi o de uma Ilustração contida, italianizada e católica, tornada secular por antinomia ao doutrinarismo jesuítico, rito de passagen a um outro tipo 
de dominação - o pombalismo. 0 modelo intelectual de Ribeiro dos Santos è o prevalente no Direito Natural portuguès do Setecentos, o de Genuense com seus Elementos de Metafysica, i.e., a predominância de um sistema moral e existencial absolutamente reto e regular, traindo teorias presentes no século XVIII, com máxima lembrança para Isaac Newton, ou Locke, ou Descartes.

Outros inspiradores da reforma pombalina, pedagogos ou executores, como Verney, D. Luis da Cunha, Antonio Nunes Ribeiro Sanches, Manuel do Cenäculo Vilas Boas, João Pereira Ramos de Azevedo Coutinho, Padre Francisco José Freire (o Cândido Lusitano, tradutor da Arte poética de Horäcio), o poeta Nicolau Tolentino de Almeida, o gramātico Pedro José da Fonseca, Sacheti Barbosa, o oratoriano Antonio Pereira de Figueiredo, quase todos vieram a ser autores populares, com livros de circulaçäo garantida ẹtre os leitores do sēculo XVIII no Brasil. A tese principal desses assessores, do ponto de vista político e moral, foi da dessacralização do ciclo jesuítico na eduçação, substituindo-o por um iluminismo frouxo, de base cátólico-regalista e monarcófila, sem a iconoclastia secularizada dos franceses. A abertura para outros estudos que não os eminentemente teocēntricos șe dā em função de interesses políticos imediatos ou emergentes de uma sociedade recēm-saída da catāstrofe de um terremoto. Estudos sobre o comërcio ilustram bem essa necessidade de afirmação de um nacionalismo culto, aberto para o mundo prätico de soerguimento do Estado. 61 
Dois dos livros bäsicos da reforma pombalina - o Verdadeiro metodo de estudar para ser util à Republica e à Igreja: proporcionado ao estilo e necessidade de Portugal exposto em varias cartas escritas pelo R.P.+++ Barbadinho da Congregação da Italia ao R.R.P. +++ Doutor da Universidade de Coimbra e o Novo metodo de Gramatica latina, da Congregaçäo do Oratorio - são, pelos motivos acima, muito populares no Brasil da segunda metade do Setecentos.

A notação do próprio colonizador, porém, não é o que poderíamos consignar como modelo avançado de cultura. Portugal do século XVII e XVIII, em que pese algumas contribuições no plano da literatura, sobretudo, è de uma cultura isolada, vexada, tímida em face dos avanços mais significativos observados na França, e mesmo na Itália ou Espanha. Não medra em Portugal uma filosofia que interprete esses dois séculos ou suas variantes. Galileu, Bacon, Descartes, Kant săo elementos de uma cultura muito distanciada de Portugal. E não se culpe exclusivamente o modelo pedagógico jesuítico por essa exclusão. O Estado tem superlativa parcela de omissão na fatura desse extrato recusante da cultura ou do conhecimento.

Sem dúvida, o modelo jesuítico estigmatizou o pensamento escolástico de forma circular, inteñsiva e extensivamente. A repressão mental moldou comportanentos de forma a determinar os temas e leituras permitidas. Daí, resulta, possivel e passivamente, assuntos e matérias que não demandem iminentes riscos para a reiteração autoritária da Igreja. Os livros são o resultado da predominância de temas a- 
colhidos pelo poder escolástico - e isso desde o século XVI. Assim, os livros mais lidos seräo mesmo os seráficos, os agiológicos, os edificantes de uma moral conservadora e retrógrada. Por isso, tambèm, os portugueses se distanciam do confronto com outras nacionalidades e, em especial, na relação de conquistas operadas no campo da Filosofia. O Brasil, sabemos todos, sofre o influxo negativo das ojerizas particulares dos colonizadores. Por isso não temos, no Brasil, um Setecentismo autenticado pela leitura de autores como Bacon ou Kant, Descartes ou Locke. Claro que não se pode aqui, no espaço de um trabalho desta natureza e sob o risco de desvio de curso, destacar autores e matérias extra aqueles conteúdos nas fontes de que nos servimos. Dessa sorte, debruçamo-nos muito mais sobre o perfil do que liam (e nem sempre do que deixaram de ler) os brasileiros.

Mas não passa em julgado a consideração um tanto óbvia a propósito das ausências de leitura brasileira no Setecentos. Embora a tipologia do leitor por nós encontrado seja, até, surpreendente quanto à variedade de interesses culturais, é pacífico reconhecer que não existe entre nós o leitor típico de um Rousseau, por exemplo. Pouquíssimos leram Rousseau no Brasil Colonial. E certamente a esses poucos nāo parece familiar uma obra como Emile, básica na pedagogia da época, obra atenta, inclusive, para a própria questão da leitura, para a abordagem e métodos de apreensão literārias indicadas às crianças. Assim, o. Brásil Setecentista perdcu - melhor Rousseau, aquele das Confissōes, leitor āvido estimulado por seu pai e idenficando-se com Bossuet, Molière, 
La Bruyère, Ovidio e Plutarco - autores que estimularam o escritor e espicaçaram sua identidade filosófica e literária. Tambëm perdeu o Brasil Stecentista o Rousseau de La Nouvelle Heloise. Alguns raríssimos leitores tiveram em mãos esșa obra que é incomparável na pedagogia do ler e cujas personagens sāo, ils mêmes, leitores. E significativo lembrar aqui Rousseau, por ser ele um raro exemplo de autorleitor de livros, fundador de uma ensaística filosófica sobre a atitude leitora, o incontido e compulsivo escritor que deixa abertas as veias de uma influência apreensivel das leituras que fez. A lembrança de Rousseau, aliās, traz outra muito importante. A de Nicolas-Antoine Viard e seu Les vrais principes de 1 a lecture, 1ivro que divulgou e influenciou sucessivas gerações de franceses desde que alcançou a expressiva marca de 24 edições de 1763 a 1830 , e que è um verdadeịro tratado da formação do leitor, indicação de bibiiotecas, de seletas para orientar o gosto etc.

A experiência pombalina é, mais ou menos, o resultado da reação nacionalista contra propōsitos revolucionários. Nesse quadro, concretamente, era impossível admitir a circulação de idéias ou livros que invertessem o öbvio sentido regalista. O flanco preferencial nessa batalha por idéias paradoxalmente modernas e conservadoras estava escolhido: - espírito jesuítico. Mas nem Pombal ou seus propósitos consegucmeliminar o atraso português no campo da Ilustração. Apenas deslocam-no de fundo e forma. Ao invés de uma gramática latina, escrita em Latim por um jesuita, o padre Manuel Alvares - desde o sēculo XVI manual obrigatörio nos colëgios 
inacianos - o Novo método da Gramática latina, escrito em linguagem, do consentido oratoriano Antonio Pereira de Figueiredo.

A obra de Figueiredo, autor bastante popular entre nós, é um fermento de conciliação, de adaptação aos objetivos seculares e.reinóis. Aristóteles e o tomismo estudados pelos jesuítas passam por uma reavaliação. O espírito iluminista da Congregação do Oratório - que se passa ao Brasil e, especialmente, a Recife e 0linda - seră o da adequação híbrida de movimentos racionalistas com o espírito tradicional de um Estado católico. O Verdadeiro método de estudar, a despeito de ser tido como a bíblia dos estudos pelo rei D. José I e por seu feitor, Pombal, saiu muitas vezes como peça clandestina e como tal amplamente consumida. 0 próprio Verney se viu banido de um Reino que imaginava possível mudar. Rousseau, Voltaire, Hobbes, Diderot, Mandeville, - Spinoza saíram indexados ra Real Mesa Censória. Um Breve do Núncio dos oratorianos em Pernambuco proibia o empréstimo de livros, sobretudo da Bíblia, justamente para não proliferarem idéias conflitantes com o espírito reinol. Destarte, mesmo com a propalada intenção de garantir ao homem sua maioridade, inclusive intelectual, não se pôde observar, na prática política dos iluministas portugueses, uma vontade nacional de impor uma definitiva derrota ao obscurantismo. Não se registrou avanço substantivo no curso das idéias, cerrada a porta da educação e da cultura. Não foi à toa que o próprio Verney e o Padre Teodoro de Almeida viram e experimentaram o despotismo pouco esclarecido cm scu país e por decisão (ou despeito) dos antigos amigos regalistas. 
Ou seja, os próprios corifeus do novo sistema sentiram - peso da politica regalista que perdeu seus rumos originais. $\mathrm{Na}$ verdade, Pombal tendia a ser uma espécie de fascista avant la lettre, com seu desbragado e suspeito nacionalismo catolicizante,e com sua ferreñha oposição a filósofos "pervertidos" a.lienígenas, portadores do virus de idéias revolucionárias. Antonio Pereira de Figueiredo, ao contrārio de Teodoro de Almeida e Verney, inteiramente alinhado com o pombalismo e buscando conciliar um oratorianismo eclesiástico com os ideais de um Estado acima dos cidadãos;, dá o tom da imposição autoritária da súmula pombalina no Brasil. No pólo oposto, após a queda do regalismo, a’ proscrição da Sociedade Literāria do Rio de Janeiro pelo. Conde de Resende evidencia um grau de sufocamento intelectual a leitores e livros que trouxessem qualquer resquício de condimento à Pombal, vitimado este e aquele à vaga da "viradeira". Os novos potentados crucificavam idéias dos seguidores da antiga ordem, este, por sua vez, vingadora do ideário jesuítico. Censura e repressão são; portanto, circulares.

o arremedo de Ilustração portuguesa não era, pois, avançado ou progressista, mas centralizador. Ribeiro Sanches, por exemp1o, mentor das melhores idéias para 1ibertar da asf̣ixia a ćultura jesuíta, era também contrário ao progresso das colọnias, vistas por ele, aliás, como povoamentos secundários, sem expressão cultural e como tal assim mesmo deveriam permanecer. O oratoriano Azeredo Coutinho, famoso criador do Seminário de 0linda, era um perseguidor implacävel das idêias rousseaunianas e demonstrava um formidável azedume para com a' Ars amandi de Ovídio. 
Hã que reconhecer, contudo, no estrito sentido das reformas, algumas de suas boas qualidades. 0 verdadeiro método de estudar, por exemplo, tem o mérito de introduzir,em Portugal, a filosofia racionalista e lógica de Locke, o John Locke, inglês, autor de An Essay Concerning Human Understanding (Ensaio sobre o entendimento humano), cuja primeira edição data de 1690 e que não era conhecido em Portụgal - e muito menos no Brasil. Aqui só vimos a conhecer Locke a partir de meados do século XIX. Verney, por conseguinte, é quem faz chegar ao conhecimento do acanhado mundo 1usitano um filósofo maldito e avesso ao dogma. Em outras palavras, com Verney, lemos Locke, como Sarmento introduziu Bacon nos estudos portugueses. E possivel então ver em Verney um anunciador, um São João Batista do enunciado filosófico de Locke em Portugal. Não hã como esquecer que Locke teria indiretamente entrado em Portugal na forma adaptada do seu Some Thoughts on Education a partir da obra de Martinho de Mendonça de Pina e Proença (1693-1743), Apontamentos sobre a educação de um menino nobre (1734). Mas se Pina e Proença adapta o pensamento lockiano em seu estudo, Verney aplica o método indutivo de Locke. Não pratica apenas uma transcrição, mas usa e divulga o método na prâtica pedagógica. Convém, a propósito, lembrar também que o Ensaio sobre o entendimento humano, no original ou tradução, teve proibida sua circulação por ato de Pombal, através da Real Mesa Censória em 16/6/1768, sendo censores o Padre Antonio Pereira de Figueiredo, Frei Francisco de $S$. Bento e Frei Inācio de S. Cactano, com voto pela liberação do texto dado por Fr. Francisco. 0 argumento da proibição, na pena definitiva de 
Antonio Pereira, è que Locke pretenderia "reduzir a onipotencia divina e os seus mistérios e prodígios à limitada esfera do entendimento humano", a que se ajunta que o fi1ósofo "ensina e pretende mostrar que no coração do homem não existe lei alguma escrita nele por Deus". 62

Verney ê, sem dūvida, um reformador conhecido amplamente no. Brasil Setecentista, não só por seu Verdadeiro método de estudar, como tambēm pelo Apparatus ad Philosophiam e o De Re Logica ad usum Lusitannorum adolescentium, libre quinque, ambos de 1751. De Re Logica teve 2. ed. em 1757. Tambëm conhecido seu De Re Methapysica ad usum adolescentium, de 1753 e sua Gramātica latina, de 1758, aparece como provável opção de leitores adeptos do espírito de reformas públicas na instrução.

Entretanto, o livro mais curioso e polêmico de Verney é mesmo o Verdadeiro metodo de estudar, igualmente o mais indicado nos inventârios e provavelmente um dos mais conhecidos e lidos no Brasil do Setecentos. E do que trata essa bíblia da reforma pombalina? Publicado pela primeira vez, em Valença, por Antonio Balle, 1747, refiete a natureza indutiva com que amplia a questão educativa da Universidade de Cojmbra,discutindo modelos e qualidades do ensino, operando um animus de mudança. ${ }^{63}$ A obra é de natureza episto- lográfica, em que o barbadinho missivista traduz ao seu destinatário,"doutor" da universidade coimbrã, um método experimental que esqueça a triadição e "expulse" os barbarismos da pedagogia jesuitica. Organizado por cartas, 16 ao todo, 
poderia também ser compreendido como um modelo adventício da Estética en Portugal, já que é um veŕdadeiro ensaio sobre o "bom gosto" verneyano. E não seria de todo absurdo supor que o embate coimbrão do bom senso versus bom gosto, inscrito no Realismo do século XIX,tivesse em Verney um inspirador .

A primeira carta do livro trata da precariedade do ensino do Latim em Portugal. Propõe substituir o método de ensino do ịdioma adotado por uma gramátịca do Latim, escrita em linguagem. A segunda carta cuida da atualização estrutural do ensino do Latim. A terceira, da utilização de outros recursos como a Geografia, a Cronologia e a História para uma correta interpretação do dito Latim e evitar o. escandaloso equívoco do ensino. A quarta carta prevê a extensão do ensino de línguas orientais. A quinta trata do bom uso da Retórica, expurgada dos vícios jesuiticos. A sexta, da valorização de figuras de linguagem e de estilo extensivas à prosa. A sêtima, de igual valorização em poesia. A oitava, da reavaliação da filosofia sob o influxo lockiano e sua adaptação à vertente moderna, com o remodelamento das disciplinas afetas à ciência filosófica. A nona, da reforma da Metafísica e crïtica à prática metafísica do ensino tradicional. A décima, da apreensão da natureza conjugada a uma nova visão do conhecimento da Física. A décima-primeira, da autonomia da Etica. A décima-segunda, da revalidação do ensino da Medicina e de outros programas de educação superior. A décima-terceira, da Jurisprudência romana. A décima-quarta, da Teologia: A décima-quinta, do 
Direito Canônico. E, finalmente, a décima-sexta carta trata dos estudos de Gramätica e Teologia, de questões práticas do ensino em geral, da educação extensiva e didática e da instrução das mulheres. E um curioso passeio sobre a Lógica, nas pegadas de Locke, discutindo questões ambiciosas de natureza específica da pedagogia e do generalismo cultural da época. E nos interessa aqui, não só por ser um dos mais lidos livros do século XVIII no Brasil, como também por representar um dínamo de mudanças. E dele uma aparente obviedade, na Carta VI, admoestando o panegirista Conde de Ericeira. E uma pérola de lógica cartesiana,que incitaria a curiosidade e satisfaria o senso leitor dos brasileiros do Setecentos: "Não basta ter os livros, ē necessärio entendê-1os."64

Sem dúvida, é Verney a personagem mais polêmica e rica no complexo universo das reformas aplicadas à pedagogia portuguesa do Setecentos. Seu Verdadeiro método de estudar tem a lógica de combate sistemático ao atraso desolador observado na prātiça educativa dos jesuítas, vale dizer, do Colégio das Artes e da Universidade de Coimbra. Verberando contra todos os aspectos que representavam esse atraso, Verney demonstra um extraordinārio senso de análise crítica co comparar os tímidos avanços da educação portuguesa com o conjunto da experiência européia, em particular das culturas francesa e italiana, que conhecia bem. Desenvolve seu raciocínio e suas observações, as mais das vezes, com oportunidade e autonomia, tendo em vista a necessária e ampla reforma por que devem passar os estudos lin- 
guísticos, literários, filosofícos, jurídicos, teológicos e canônicos em seu país.

Em defesa da simplicidade, da clareza, do espírito prático e não-contemplativo, a linha do pensamento verneyano é. reformista strictu senso, assente num ecletismo mitigadoda Ontologia tradicional e refletindo livremente sobre. a cultura portuguesa, com base no racionalismo natural junto à observação e ao juízo de cunho científico. Com tato e habilidade para não parecer de todo conträrio à escolástica, evitando fustigar os tomistas mediante um anti-aristotelismo que dissimula, Verney não comunga da tradição metafísica bebida em Aristóteles, mas tambēm não entra no deliciado aparte teórico do.ser e das razões do ser. Prefere um neo-platonismo inspirado em Santo Agostinho, dai o fragmentário das opiniões em Teologia, e a opção empírica do pensar filosófico aproximado das Ciências Exatas: Em Filosofia, Verney pratica uma sistematização não-sistêmica, ou convencional, associando o pensamento filosófico à ciência aplicada, tomando a eduçação como foco de análise.

0 Verdadeiro método de estudar tem antecedentes representativos no plano da cultura francesa. E o caso de Charles Rollin (1661-1741), com seu Traité des études e de Bernard Lamy, com seu La Retorique ou l'art de parler. Alguns passos de Verney estão na diretiva de influência desses autores. E muito mais na de Gícero, de cuja companhia - autor do VM parece nunca querer desprender-se. Curioso é que Verneý não cita Locke (autor que conheceria de tra- 
duções francesas, ou talvez a edição londrina, 1768, desconhecendo-se, no século XVIII, tradução portuguesa do fílósofo inglês): Em nenhum momento de sua obra, provavelmente para não ativar o preconceito português contra o pensador que põe em dúvida a noção criștã dasidéias inatas, Verney o cita.

Sob a forma epistolográfica, o VM tenta uma espécie de "epistemologia do senso comum". Hã,por todo o texto,uma busca sensivel da linearidade e da clareza racionalistas, buscando-se a noção da Beleza associada ao simples e natural. O Belo é visto como resultado e sensação do racional, do pensar bem, da harmonia entre a sensibilidade e a razão. Sem imaginação e sem fantasia, a beleza residiria no racionalismo, na harmonização dos sentidos e dos elementos. Mas a reforma proposta por Verney não será apenas de natureza escolar. E muito mais ampla e complexa, compreendendo as Leis, a Medicina, a Economia, a sociedade portuguesas. A ứltima carta do VM é, tacitamente, a de uma reprogramação sócio-cultural, proposta para o Reino de Portugal, compreendendo desde o ensino primário gratuito à assistência médica.

Se Pina e Proença apresenta-se cronologicamente anterior a Verney, na apreensão e "1eitura", do método indutivo de Locke, se Azevedo Fortes, em sua Lógica racional geométrica e analítica (1744), antecipa alguma preocupação de introduzir um sentido de reforma ao ensino da Lógica em Portugai, acompanhando-se de Descartes, em especial, e de Aristóteles; Platão e Santo Agostịnho, entre os antigos; Galileu, Pedro Gassendo, Newton, Port-Royal (da Lógica, ou Arte 
de pensar), Malebranche, Arnaud e Pascal, entre os modernos, tudo isso passa a ter importância quando se subordina - espírito de renovação ao equilíbrio da exposição intelectual. Pode dizer-se que Pina e Proença e Azevedo Fortes tentaram fazer, intelectualmente, o esforço de desautorar a prática educativa vigente. No entanto, tentaram sugesti-. vamente, com suas obras. Verney, talvez, tenha feito um pouco mais, uma vez que soube acirrar as contradições apontadas por Azevedo Fortes e intuídas por. Pina e Proença. O verdađeiro método de estudar toma a si a tarefa de anular as barreiras oficiais, de desmitificar o sistema fechado do ensino jesuitico. Servindo-se de elementos conclusivos que puseram a nu as flagrantes contracepções do modelo pedagógico em. curso, Verney abre as portas para a reforma que se processará no regime Pombal, aliando ao talento da análise intelectual percuciente o talento retórico de espírito inquieto e inquietante, polêmico e, algumas vezes, arrivista. A certeira capacidade de indignar-se contra o anacronismo do sistema de idéias imposto ao ensino oficial e a notação pragmática fizeram de Luiz Antonio Verney um iniciado amante do experimentalismo e da observação.

Contudo, tem ainda outros méritos o verdadeiro método de estudar. Popularíssimo, foi o livro que se deu por inteiro à atitude intelectual e provocadora de democratizar o debatè da reforma dos estudos, dirigindo-se a um püblico de decisão, embora sem juízo formado,e a um leitor anônimo, buscando espicaçar sua reflexão. Fiel ao geral sentimento de mudanças, trazendo à tona questões; que, acaso omitidas, 
passariam em julgado na consideração púb1ica, a obra de Verney veio alterar a visão do ensino e da cultura em Portugal, mesmo sem formular objetivamente um sistema inteiriço de filosofia pedagógica, não se opondo formalmente ao cartesianismo, à Escolástica ou a qualquer outro sistema filosófico em voga. Opunha-se ao caráter da docência nas escolas do Reino.

Por aborrecer o espirito seiscentista e barroco, Verney, não raras vezes, escarnece desse estilo, em particular contrapondo-se a Graciān. Toma o D. Quixote, por exemplo, para satirizar títulos preciosistas ou obras circulares no sèculo, como o Atalaia da vita contra as hostilidades da morte, do médico João Curvo Genedo, publicado em 1729 ou o Alivio de tristes, consolação de queixosos, do Padre Mateus Ribeiro,publicado entre 1672 e 1674,com vârias reedições. Discutindo pontos que considera obscuros e danosos ao entendimento dos estudantes e dos métodos de estudar, Verney apresenta em cada carta uma breve bibliografia daqueles autores que mereceriam estudo ou indicação da maneira em que deveriam ser estudados. Neste sentido, o VM vale também como um manual seletivo de leituras e de obras cujas leituras deveriam ser evitadas. E notável o conhecimento de Verney (algumas vezes, na forma indireta, i.e., com indicação bebida em outros autores) quanto a obras e autores nos mais diversos campos do conhecimento, em particular no estudo da Retórica e dos autores latinos. Hã citações abundantes de Fedro, Plauto, Terêncio, comọ autores de fácil assimilação, pelos estudantes, no estudo do Latim e trechos, di- 
reta ou indiretamente, tirados sobretudo das Orações, de Cícero, da Eneida, de Virgilio, etc. Em outros termos, com o Verdadeiro método, o leitor terá também um extenso catảlogo assistemático de livros de leitura obrigatória para integrar-se ao mundo da cultura tipicamente neo-clássica. Por isso - VM é curioso para este nosso estudo, tanto mais que é um dos livros mais frequentes nas bibliotecas setecentistas brasileiras.

Um dos traços singulares que reponta do VM é que, para Verney, não é necessário ler muito, mas bem. Diz ele, criticando os mestres, que os "autores não se devem ler correndo, como muitos fazem; mas devem-se ler e reler atentissimamente" 65 e, mais adiante, "antes querem 1 er muito, entendendo pouco, do que saber bem a lingua com um só livro"66, aludindo a que, com isso, os alunos pouco ou nada aprendiam, pois "quem não reflete como deve no que lêe, tanto importa que leia Cícero, como os actos de Maria Parda". 67

A maior demonstração de avanço no VM foi tomada como sintoma de anti-jesuitismo. Verney recomendava o aprendizado das linguas nacionais e isso incomodou significativamente o oficialismo na educação,pois os jesuitas tinham no Latim uma espécie de pátria linguística comum e obrigatória. Verney, porém, não foi de espírito anti-jesuitico, foi, antes, autônomo. Colocou-se contra tudo o que representasse atraso, mesmo quando este atraso dissesse respeito à sua própria Congregação. Daí os contratempos com Antonio Pereira de Figueiredo (1725-1737), Francisco Josë Freire (1719-1773) e outros como o franciscano Manocl do Cenäculo Vilas-Boas (1724$1814)$. 
Verney é, por exemplo, bem mais ilustrado do que o oratoriano Azeredo Coutinho, pois recomenda o Ovídio da Arte de amar, a quem "quiser ler amores", conträrio senso do bispo de 0linda que execra como infame a obra. Ao lado de 0vídio, são outros bons poetas líricos considerados por Verney, Ca'tulo, Tibulo e Propércio. Na sátira, recomenda Horácio "que è mestre". Alēm de Juvenal e Pérsio, Marcial, autor de "Mil coisas repulsivas, tem algumas boas". Agradam- The os Epigramas de Catulo. Lucrécio e Manílio são, além de poetas, filósofos. E, arrematando o juízo crítico, diz que "nisso se compreende o melhor da Antiguidade". 68

Autoritário, por vezes inquisitorial e presunçoso, Verney procura se destacar aludindo a si mesmo na figura de "Um amigo nosso." etc. ${ }^{69}$ Muitíssimo bem informado do que se publica em Portugal, manifesta-se sobre um estilo, que defende como o mais apropriado aos estudantes, concluindo, sem qualquer modéstia: "o melhor é 으 que aponto" lico, investe sobre o uso do "pai-velho", apelido dado ao Ordo verborum, e sobretudo sobre seu autor "que põe a tradução de Virgílio, ou o que quer que é, palavra por palavra, merecia ser açoitado pelas ruas públicas, e também os Mestres que se servem dele, e o livro queimado em praça pública", sob a alegação de que "não há coisa mais prejudicial para. a Mocidade que semelhantes livros". 71

Mas onde melhor mesmo se apresenta o VM é na orientação crítica de edições e de autores. Desde autores consagrados dentre os antigos a uns poucơs de sua contemporanei- 
dade, Verney demonstra-se cioso leitor e criterioso selecionador da bibliografia indispensāvel a uma boa formação neoclássica. Depois de recomendar indiretamente Cervantes (VM, V. II, p. 88) e talvez Quevedo (VM, II, p. 84), volta-se ao Dicionario de grego ou o Lexicon graecum-latinum, de João Scapula, (gramático alemão do século XVI), publicado em 1759 (VM, I, p. 261): Critica Sêneca, "primeiro que começou a perverter o bom gosto da Latinidade com tão enfadonhas sentenças" (VM,II, p. 115). Concorda "que o melhor Poeta e mais claro é. Aristófanes; mas è bastantemente obsceno" (VM,. I, p. 257). Ainda dentre os gregos, destaca de,forma gradativa, as leituras dos Estratagemas de Polieno, dos Diälogos de Luciano, dos Caracteres ethici de Teofrasto (chamado de "elegantíssimo"), e mais Xenofante e Heródoto ("delicadeza e graça da línga ātica"), Tucídides e os oradores Isócrates e Demóstenes e o filósof̣o Platão ("o mais eloquente e culto da Antiguidade" (VM, I, p. 255). Recomenda ainda as Fábulas de Esopo, A vida dos homens ilustres, de Plutarco, Homero, (reconhecendo ser útil e proveitoso, antes de ler Homero, ler seus comentadores), e Hesiodo, os dois últimos considerados os mais fáceis dentre os poetas heróicos. Dos bucólicos, Verney consagra Mosco, Bion e Teócrito (indicando, para auxílio aos estudantes, o. Dicionario de Screvelium). Finalmente, dentre os trágicos, Verney considera Eurïpides e Sófocles. Para a amada Retórica, os preferidos de Verney são Aristóteles, Cicero, Quintiliano e Longino (VM, II, p. 176) .

Ou seja, toda a civilização clásíca praticamentc apa- 
rece no juizo crítico de Verney, que ainda os expurga daquilo considerado exagero ou descabimento, o que radica um certo sentido de independência do selecionador. Em verdade, o que se evidencia superlativamente no VM è a quantidade e qualidade dos autores que Verney denota ter lido, e que tinha em alta conta, sobretudo Cícero, Quintiliano e S. Agostinho. E como indica algumas vezes o lugar de onde tira as mâximas e recursos retóricos, o VM autoriza, defende e consagra o conhecimento desses autores pelo leitor anônimo. Suteônio, Salústio, Cornélio, Catão-o velho são alguns nomeados. Dentre os da civilização portuguesa, Camões e Vieira, Os poetas Dante e Petraca e outros são igualmente referidos para oferecer ao estudioso níveis de argumentação profana/sagrada do discurso e para "ensinar" um verdadeiro método de estudos.

Duas obras se destacaram imediata e inerentemente contrārias ao Verdadeiro método. Uma delas è a Reflexoens apologéticas a a obra intitulada Verdadeiro método de estudar derigida a persuadir hum novo metodo para em Portugal se ensinarem, e aprenderem as sciencias, e refutar 을 queste Reino se pratica; expendidas para desagravo dos Portuguezes em huma Carta, que em resposta de outra escreveo da Ci-

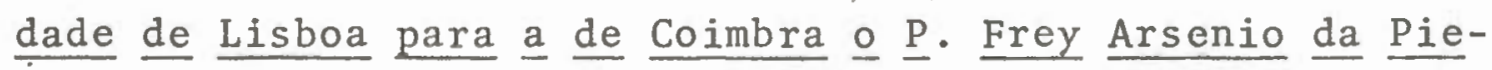
dade. (criptônimo do jesuíta José de Araujo). Valensa, 1718. E a outra obra, bem mais completa e contundente é a Conversação familiar do padre Severino Modesto, de violenta reação intelectual ao espírito do reformismo pombalino e que dá o tom da corrente adversa à de Verney. Obra que compre- 
ende aspectos da Filosofia e da Moral e propriamente encara as questões de natureza educacional sob o enfoque metodoló gico conträrio ao do Barbadinho, busca fixar, de maneira direta e expressiva de comunicação, um novo modelo pedagógico. A Conversação familiar è também um dos livros mais frequentes nas bibliotecas setecentistas brasileiras. Seu título completo è quilométrico: Conversação familiar e exame crítico em que se mostra reprovado o Methodo de estudar que com 으 título de Verdadeiro, additamento de ūtil á Republica, e $\underline{\text { à }}$ Igreja, e proporcionado ao estylo, é necessidade de Portuga1, expoz em dezesseis Cartas 으. ‥ ․ Frei... Barbadinho da Congregação da Italia: E tambem frivola a Resposta do mesmo Reverendo às solidas Reflexoens do P. Frey Arsenio da Piedade, Religioso Capucho. Autor o P. Severino do S. Modesto, Presbytero, Comunica-o a seus amigos Rozendo Eleutherio de Noronha, particular amigo do Author, Valensa, 1750. O gosto pela polêmica é um dos signos da intelectualidade do século. Mas Verney, ao menos aqui, parece levar a pảlma, seguindo a lógica lockiana com base na sensação e na reflexão, fórmulas reunidas pelo Barbadinho numa equação única: o aparato dos sentidos e o privilégio à indução como métodos. o Verdadeiro método de estudar é obra sinuosa de busca do racionalismo aplicado.

- Por curiosidade oportuna, observemos as caracteristicas de Verney enquanto leitor. Sua biblioteca em Roma, no ano de 1771, registra alguns dos 1ivros que atestam um perfil do leitor setecentista denunciado em suas preocupaçõcs 
com o ideário de mudanças na eștrutura pedagógica portuguesa. O documento é, na verdade, uma nota de "Venda de livros da Biblioteca de Verney. Libri che restarono dal Sig. re Emilio Polidori, in Roma nel Giuylio di 1771. Appartenenti all'Ill.mo Sig.re Cavalier Verney"

Scapula = Lexicon Grego Latinum. fol.; Buxtorfio = Lexicon Hebraicum 8:; Pereira = Novo metodo da Gramatica Latina inPortoghese. 1756.

II:; Lima = Gramatica Francese, e Portoghese 4\%; - Gramatica Grega, di Portogallo Lisbonna. 1760 Mag.s; - Almeida = Fisica Portoghese Tomi 3. n 12:; - Mappa de Portugal. Tomi 3. in 4\%; - Carvalho = Chorographia Portugueza Tomi. 3. in fol.; - Vida de D. Joam de Castro. fol.; Memorias dos Grandes de Portugal. $8 \%$; - Deduçaln chrnologica, e Analítica. Tomi 2 in fol. carta ondata - Provas de Deduçam. Tomo 2. Carta ondata; - Deduçam detta Tomi 2. alla Francese; - Collecçam dos Breves Pontificios. Tomo 2, alla Francese; - Deduzione detta in ltaliano. Parte la. vol. 2 Prove della P. te 2a. e 2: vol. 2. Sono 4 tomi in 12: (mancó un tomo della p. te $2 a$. fui trovato nel 74 dal Signor $0-$ nofrio), e riposta (de outra letra); - Cartas do vieira. Tomo un solo; - Cudivoth = Systema Intellectuale Tomi 2 fol.; Gravina = De Origine Juris. Tomi 2 in 4 ?

A' nota vem assinada por J. Emidio Polidori "mano propria": Outros livros parecem integrar o documento, ou "In-

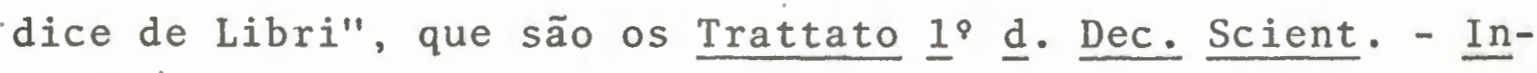
tellectiones et notitiae Manuscriptac; - Cursus Philosophici Manuscriptus Tom. 1 n ${ }^{\circ}$; - Riflessioni di due scritture Manoscritte; - Animast. ${ }^{72}$ 
Dessa forma, observa-se uma biblioteca com titulos comuns a alguns tantos que encontramos no Brasil Setecentista. Alguns títulos, no entanto, ressaltam a natureza do reformador, do intelectual e pedagogo responsável pela emulação de um importante movimento filosófico em Portugal, um pensador, inscrito entre os grandes ideólogos do século XVIII português. Assim, aparecem ainda na biblioteca a Grammatica franceza ou Arte para apprender 0 francez, por meyo da lingua portuguezal, regulada pelas notas e reflexõens da Academia de França, obra da autoria de D. Luis Caetano de Lima, cuja primeira edição é de 1710 , a 2a. edição de 1733, nas oficinas da Congregação do Oratório e a terceira é de 1756. Também a Deducção chronologica e analítica, obra de propaganda anti-jesuítica e o Novo método de Gramática latina (do oratoriano Antonio Pereira de Figueiredo e do também oratoriano Manoel Monteiro), texto básico do regalismo pombalino. Verney demonstra ainda seu interesse pelo Hebraico, pelo Grego, pela física e pela Filosofia, interesse que coincide com suas idéias, no VM, mais ou menos como alguns dos nossos leitores do Setecentos. Com a diferença óbvia de tratar-se, como se tratou, de um leitor especial, aquele responsävel por um conjunto de mudanças que se estenderam ao próprio caráter das leituras no século XVIII.

No Brasil Setecentista, porém - mais frequente que Verney nas estantes de nossos compenetrados leitores - o autor mais popular entre os reformadores pombalinos é o oratoriano Padre Teodoro de.Almeida (1722-18.04) - que supera os portugueses e ombreia com os franceses nas preferências do 1ei- 
tọr brasileiro. A Recreação filosofica ou Dialogo sobre a Filosofia Natural, para instrução de pessoas curiosas que não frequentaram as aulas (Lisboa, 1751-1799) em 10 volumes, espécie de escorço enciclopédico, foi livro de cabeceira de muitos dos leitores brasileiros, fato observado em nossa investigação como constante referência na maior parte dos inventários. O objetivo claro do padre, ou do livro, e antes o objetivo do próprio Verney, parece ter sido alcançado no Brasil: livros publicados em linguagem para um justo conhecimento de todos. Parece também que o oratoriano Almeida era um democrata, a julgar por seus pronunciamentos favoráveis a uma maior. largueza da cultura intelectual, pugnando por uma espécie de socialização do saber. E isso foi extraordinário para banir o excesso de livros publicados em Latim, para aliviar o peso da cultura livresca assentada tão. somente, na obrigatoriedade do Latim como idioma intelectual e típico da sabedoria escolástica.

Outro oratoriano consagrado no Brasil, menos pelo que escreveu e mais por sua ação pedagógica ou seu perfil de leitor, è o bispo fundador do Seminảrio de Olinda, Azeredo Cou-. tinho. Sua biblioteca evidencia o sempre presente Verney com o De Re Logica e.o livro de Heinecio, Fundamenta Stili, entre outros autores e sobretudo os clássicos. Verney,aliás, estava bem representado: a biblioteca do bispo de Pernambuco espelha o homem de gosto segundo o modelo dos reformadores pombalinos, com disciplina obrigatória em Filosofia e Educação. Nele aparecem o indispensẩel italiano Antonio Genovese (1713-1769), o Genuense, autor do igualmente conheci- 
do nas livrarias setecentistas brasileiras As instituições da Lógica; ou o tambëm frequente Compendium Philosophiae (1721), do oratoriano Padre Tomé Vicente Tosca, obra que exprime uma desesperada tentativa de conciliar a Filosofia com a Ciência, a compreensão desta por aquela. No "Estatuto do Seminário Episcopal de Nossa Senhora da Graça", Azeredo Coutinho deixa transparecer a sua própria orientação de leitura como aquela consagrada na reforma pombalina. Para o ensino da Poesia, dever-se-ia ministrar aulas conforme a Arte poêtica de Horäcio, traduzida por Cândido Lusitano, passando, è claro, pelo uso e indução, nas composições dos alunos, seguindo-se modelos clássicos e os de Camōes, este, aliâs, admirado pelo bispo de 01 inda, mas com o seguinte reparo: "ver as belezas dos nossos poetas, especialmente de Camões, que apesar dos seus defeitos, ñão deixou de ser um excelente poeta". 73

$\mathrm{Na}$ pauta de livros recomendados para leitura pelos estudantes brasileiros segundo a reforma pombalina, è interessanta e curiosa a "Memória para o novo método", coligida e transcrita por Banha de Andrade como um dos apêndices documentais no imprescindivel A reforma pombalina dos estudos secundários no Brasil. Tão interessante é o documento que não resistimos ao imperativo de transcrevê-lo aqui, com o que, sem dưvida, se atesta o grau de tolerância e interdito observado pela Real Mesa Censória a que se impunha obediência. Em outras palavras, pela análise do documento, é possível compor um perfil do leitor setecentista, estudante ou 
especializado,e cuja formação estava condicionada ao determinismo regalista. Vê-se, pelo documento, que há um contro1e estreito e vigilante, particularmente quanto aos livros "defesos". Todos os que estejam fora do quadro abaixo, serão os indexados, aos quais consequentemente não se "aconselhava" a leitura:

"Memória dos livros aconselhāveis e permitidos
para o Novo Método"

Rhetorica de Aristoteles com os.commentarios de Schradevo impressa em Helmstad, 1674.

Demetrio Falareu da edição do Pe. Victorio feita em Florença, 1562.

Dionizio Halicarnas toda a obra impressa em Paris, 1547 por Roberto Estevão.

As obras de Hermogenes da edição Laurencia feita em Genebra, 1614 .

Longino tract. do Sublime da edição de Folio, e da traducção de Boileau com as notas de Dacier.

Todas as obras de Cicero da edição de Gronovio em Leiden, 1692.

Quintiliano da celebre edição de Burmane.

As obras Rhetoricas de Vosio que depois de Aristoteles hé o melhor conceito de Buchnero. Também hë utilissimo o tractado deste Buchner de commutanda Ratione dicendi.

A Rhetorica de Fr. Luiz de Granada, junta com a do Bispo Agostinho Valerio, e a do Pe. Stella em 4: impressa em Verona 1732.

Demostenes da ultima edição, com versão latina.

Tito Livio, Salustio, Cornelio Nepos, e todos os Escriptores Latinos de Proza e Verso principalmente das edições que se acharam de Cellario. 
- Methodo de Estudar as bellas lettras do Rolin, e as suas Historias Antiga e Romana.

A Historia da Fabula de Banier para inteligência dos antigos.

Alguma Historia da Igreja abreviada, como a do Racine para noticia dos Padres de quem serão os exemplos para a Predica.

Dos Padres Gregos bastarão as Homilias de S. João Chrisostomo.

Dos Latinos os Sermoens de S. Agostinho que andão separados, e o tratado de Doctrina Christiana.

Dos Autores Portuguezes, são precizos os melhores para com elles se fazer paralelo com os antigos, como Sua Magestade ordena principalmente são necessarios todos os Escriptos do grande Fr. Luiz de Souza, Camõens, Antonio Ferreira, Diogo Bernardes, etc. As bras de Duarte Ribeiro de Macedo.

Os Diccionarios Gregos de Escapula e de Escrevelio, os latinos de Fabro, e Facciolati.

A Logica critica do Verney, ou do Genovezi.

Alēm de muitas obras Rethoricas, de que deve servir-se o Professor.

"Memoria"

He necessario fazer imprimir aqui a Minerva de Francisco Sanches e as Instituições de Quintiliano. Destes livros ha poucos.e se vendem carissimos.

Deve tambem imprimir-se a Ortografia do Verney, e o Fundamenta stili cultioris do Heinecio, que todos são raros, e recomendados como necessarios 'nas Instruções. 
As oracões Seletas de Cicero para o uzo dos que frequentão a Rethorica, deve imprimir-se.

Tambem os primeiros Livros de Tito Livio.

De tudo he necessario saber o numero que se ha de imprimir, e aonde. 74

Pela memória dós livros permitidos e "aconselhāveis", nota-se uma característica política determinante na condução do gosto do leitor adaptado à política do Estado. Na verdade, pratica-se aqui um retorno aos expurgos que os jesuitas fizeram dos clássicos latinos, deles excluindo o que thes parecia inconveniente do ponto de vista da pedagogia da época. Mudaram-se os tempos, mudaram-se as vontades, mas a censura tinha sua permanência assegurada e, neste passo, desviada para a ideologia do regalismo. Logo, o. Aristōteles permitido somente o da Retórica na edição de Helmstad, em 1674; - Cícero recomendado era o da edição de Gronovio, em Leiden, 1692 e assim por diante. Somente autores e edições indicados, orientados por um gosto único e sem contestação. Autores permitidos segundo.o cânone da reforma e divulgação dos seus corifeus.

Assim se fundamentam as bases da pedagogia dos oratorianos, em especial a proferida por Verney e seus êmulos. Basta conferir autores e obras aqui recomendadas para se consagrar em importância o modelo de ensino defendido pelos religiosos do Hospital das Necessidades. Não esquecer que, em particular, os padres da Congregação do Oratório representavam uma cabeça de ponte da política pombalina de destruir a Companhia de Jesus nos domínios de Portugal. 
Neste sentido, o ensino dos oratorianos seria de mo1de a substituir a presença docente dos jesuítas, implantando uma filosofia de educação que em nada lembrasse a passagem e experiência anteriores. Interesșa-nos verificar que as tendências e estilos de leitura igualmente irão se alterar.. Permanecerá o Aristóteles da versão recomendada pelos escolâsticos, o Aristóteles caro ao tomismo militante, que Verney, no VM,sabiamente trata muito por alto, não enunciando maior ressalva ao monumento mais caro à filosofia dos peripatéticos. Alguns autores recomendados também não passaram pelo crivo verneyano, como o "Demetrio Falareu da edição do padre Victorio feita em Florença, 1562" ou o "Dionizio Halicarnas com toda a sua obra impressa em Paris, 1547, por Roberto Estevão" ou, ainda, "As obras de Hermógenes da edição Laurencia feita em Genebra, 1614". Outros autores e obras fazem parte das cogitações de Verney e dos demais representantes da Congregação do Oratório. Tal, por exemplo, è o caso do Tratado do sublime, de Dionísio Longino, com que se acentua o quadro de preferências dos seguidores de São Fe1ipe Neri. O Longino recomendado era o da edição francesa, feita por Boileau, com as notas de Dacier.

A obra retórica De Institutione, de Quintiliano, as obras de Vossio, os clássicos latinos Tito Lívio, Salústio, Cornélio Nepos "e todos os escritores latinos de prosa e verso principalmente das ediçōes que se acharam de Cellario" assentam na contrafação ao universo de escolha dos jesuitas e ratificam algumas das orientações seguidas por Verney no VM. Aliās, um dos modelos de inspiração que Verney utiliza 
no VM aqui estä presente: o Methodo de estudar as bellas letras, do padre Rolin, autor igualmente festejado da História antiga e da História romana. Para o conhecimento da literatura antiga, a lista oratoriana recomenda a Histōria da fábula, de Banier. 0 mais que aparece na relação radica o interesse Estado-Igreja enquanto sócio na reforma dos estudos. Não serão esquecidos os ensinamentos e dogmas cristãos, buscando derivar no estudante obras de doutrinação como a História da Igreja abreviada, de Racine: Dos Santos Doutores Gregos, "bastarão as homilias de S.João Crisóstomo", considerado o mais perfeito estilista dentre os padres não-latinos, maior até que os celebrados S. Gregório Nazianzeno e S. Basílio Magno. Com referência ainda aos doutores santos que fizeram à glória do século IV d.C., os oratorianos consagram S. Agostinho como o indispensável entre os latinos, estudando-se os seus sermões e o Tratado da doutrina cristã. Verney amplia no VM a necessidade, para fortalecimento ou sustentatação da cultura dos pregadores, o estudo tanto da prática retórica cristã; como a dos pagãos (devidamente expurgados de alguns acidentes, claro). Dentre os latinos, por exemplo, Verney faz expressa referência a $S$. Am brósio e, especialmente, a S. Jerônimo, desconsiderados no entanto na recomendação de leituras em escolas superiores da reforma pombalina.

Considerando a necessidade do estudo do vernáculo, os oratorianos inspiraram a reforma no estudo dos autores portugueses, exprimindo a necessidade de selecionar "os melhores para com elles se fazer paralelo com os antigos como Sua 
Magestade ordena". E que autores portugueses os padres da Congregação de S. Felipe Neri recomendam? Começando pelo "grande Fr. Luiz de Souza", a recomendação privilegia bem poucos: Camões, Antonio Ferreira, Diogo Bernardes, Duarte Ribeiro de Macedo. Em que sentido essas recomendações infḷuíram no gosto e na seleção feita pelos leitores setecentistas no Brasil é um tanto impreciso fazer-se. Mas dessa relação, somente Camões, Duarte Ribeiro de Macedo e Diogo Bernardes frequentaram as estantes brasileiras desde o sécủlo XVIII, lembrando que Diogo-Bernardes pouquíssimo aparece e apenas com sua obra $\underline{0} \underline{\text { Lima. }}$. Fora dessa seleção, todavia, autores e obras.ganharam as graças do leitor brasileiro de Setecentos: o campeoníssimo jesuíta Antonio Vieira e o tambêm concorrido oratoriano Manoei. Bernardes.

A memória dos livros que se deviam ler nas escolas da reforma pombalina organiza aqueles autores que reforçam a ideologia pedagógica dos oratorianos. A Logica de Verney ou Genovesi, os Dicionarios de Escapula, de Escrevelio, para estudo do grego e os de Fabro e Facciolati, para o latim. o próprio Verney, aliâs, faz expressa recomendação desses autores no VM. Para a nossa compreensão da reforma imprimida no espírito filosófico do setecentos português, è sintomática a recomendação da Minerva, de Francisco Sanches (15511623) um pensador independente da escolástica portuguesa. Sanches desenvolvera no Quod nihil scitur (ou Que nada sei) (1581), uma reação a Aristōtelis, uma contrafação ao absolutismo das considerações peripatếticas. De Sánches, a 1 ista recomenda a Minerva, seu de causis 1inguae 1atinae. 
comentarius (reimpressão em Lisboa,1760, reproduzindo edição de Salamanca (1587). Alērn da Minerva, recomendam-se as Instituições de Quintiliano, com a ressalva feita pelos organizadóres da Memória: "Destes livros ha poucos e se vendem carissimos". Tal hipótese se realiza no concreto da vida brasileira colonial, como deduzimos das dificuldades observadas pelo Desembargador Thomaz Roby de Barros Barreto, na Bahia, em 1759, pedindo 1he mandassem da Corte mais Minervas de Sanches, de que se ressentia a administração colonial para o cumprimento dos bons ofícios do rei e da reforma dos estudos.

Por último, confirma-se que os autores tidos em conta pelos oratorianos na Memoria dos livros aconselháveis e permitidos parao Novo Mundo seriam os mesmos defendidos por Luis Antonio Verney no seu VM. Além da Ortografia do próprio Verney, a "Memoria" recomenda o Heinecio do Fundamenta stili cultioris, sendo ambos "recomendados como necessarios nas Instruções". Completam o quadro, aqueles autores consagrados pela ideologia reformista orientada pela pedagogia do VM: o Cícero das Orações seletas e os "primeiros livros de Tito Lívio", uma vez que se toma o espírito da Retórica como aquele que, por sua maior importância, sacraliza-se no objeto da persuasāo. Daí o vulto que a Retórica assume nesses estudos e,por. conseguinte, a maior consideração atribuída aos que melhor escreveram no latim clássico, autores que seriam. tomados como espelho do bem escrever, argumentar e pensar.

Assim, pelos livros defendidos como necessários à per- 
manência de um estudo anti-jesuítico e modernizador, verifi= ca-șe a instilação de um modelo de gosto e métodos de ensino, estudo e leitura. Não há nessa lista nenhuma obra constante de outras eventuais preferências das escolas da Companhia de Jesus. Tal ausência se cristaliza por força da ação política e reformadora portadora do consōrcio Pombal-Congregação do Oratório.

Sobre o ensino dos oratorianos, aliās, a partir da sistematização doṣ estudos em Lisboa, haveria uma circunstância comum estendida a todas as escolas da Congregação: o ensino igualitārio quanto a métodos e orientações de leitura que, claro, passaria à experiência do Seminário de Olinda, em fins do século XVIII,e meados do XIX. Aí é que se destaca o papel do teólogo Francisco Pedroso, sob cujo magistério se desenvolveriam, num sistema orgânico, as disciplinas seguidas nos coḷégios sob reforma.

Nas escolas de primeiras letras, por exemplo, seguir-se-ia o seguinte organograma de obras e autores metodologicamente recomendados:

1) Folhas de escrever (1a., 2a. e 3a. cartas, antes de 1748 .

2) Catecismo (4a. carta), só em português, na 1 . ed, texto português e latino, na edição de Lisboa, 1748 , com o título de Exercicios da língua latina e portuguesa. Na Oficina de Miguel Rodrigues.

3) Instrução de principiantes (5a. carta). Texto de leitura, de temas geográficos e histöricos, como complemento da carta anterior. Lisboa, na Oficina de Miguel Rodrigues, 1750 . 
4) Directörio de contar (as quatro operaçōes). Não se imprimiu, ao menos de princípio.

5) Tabuada para a Numeração (a multiplicação e operação dos nụmeros complexos, moedas, pesos e medidas). ("Imprima-se e volte", 9 de junho de 1777). Pode ser a satisfação ampliada do nümero anterior.

6) Diălogo da esfera celeste e terrestre. Lis-. boa, 1751 .

7) Diálogo da Histöria sagrada. Lisboa, 1751.

8) Diālogo da Histöria romana. Lisboa, 1751.

9) Diálogo da História grega. Lisboa, 1751.

10) Diálogo dos Concilios gerais da lgreja. Lisboa, 1751 .

11) Diälogo dos principes da Europa. Lisboa, 1751.75

A descrição desses livros fornece elementos indicativos da formação de leitores à luz das tendências polêmicas que a reforma dos estudos proporcionou em Portugal, com consequêncịas óbvias no Brasil . Notamos por lembrança antitética ao predomínio dos estudos jesuíticos, especialmente no campo da'Gramätica latina, que a Arte do P. Monteiro foi editada pela primeira vez em 1746. A lnstrução de principiantes é dà autoria de Antonio Pereira de Figueiredo. 0 Novo método de se aprenderem as primeiras letras saiu em 1750, em Lisboa, tenḍo alcançado a 2. ed. em 1780 e a 3 . ed. em 1793. Não se țem notícia do seu autor, mas pode-se supor a inclusão do P. Diogo Verney como um dos que compuseram a obra. Os oratorianos, parece, seguiram um caminho de facilitação de modelos de ensino e leitura, optando pelo experimentalismo, talvez, oriundo da inspiração de Luiz Antonịo Verney. A Coleção de palavras familiares, assim portuguesas como latinas teve una 
2. ed. em 1757 è outras, a última em 1821.76 Já os Exercícios da língua latina e portuguesa, de autoria mista, são atribuỉdos a Estácio de Almeida, Manuel Monteiro e Antonio Pereira de Figueiredo.

0 volume de História romana teve sua 1. ed. em 1751, e edições sucessivas em 1788, 1794 e 1807, sempre pela Régia Oficina Tipográfica. O da História grega, também teve uma 1. ed. em 1751, merecendo reedições em $1792,1807,1813$ e 1829. O Diălogo da esfera celeste e terrestre é de 1751 e alcançou novas edições em 1788, 1794 e 1807. O Diálogo sobre os Concilios gerais da Igreja, de 1751 , teve reedições em 1793, 1807, 1813 e 1830. Sobre a autoria de cada um dos diālogos, especula-se que o Diảlogo da História sagrada seria do Padre João Chevalier, assim como os dos Concílios, da Histôria grega e dos Príncipes, bem como um Epitome da História de Portugal em forma de diálogo. Para uso das escolas da Congregação do Oratório etc. o Dialogo da esfera... tambēm pertenceria ao pe. Chevalier, ou ao Pe. Estäcio de Almeida.

Ainda para as primeiras letras, hä menção a um livro que teria circulado na Congregação do Oratório, o Tratado de Aritmetica e Algebra, em 의 qual, com muita.clareza, se explica tudo o que pertence a esta Arte e se descrevem as regras principaes da Geometria e as proporçoens que as distinguem. Lisboa, José Lopes Ferreira, Impressor da Rainha Nossa Senhora, 1713 in $4^{\circ}$. 
Aqui, como nos demais estágios, verifica-se a obrigatoriedade da utilização de obras cujos autores pertençam à Ordem, ou the sejam fiêis. Assim, desloca-se a órbita de influência cultural e editorial, dos jesuítas para os oratorianos, confirmados estes, aliás, desde o reinado de D. João $V$ a substituir a autoridade da Companhia de Jesus na formação educacional do Reino.

Para a Escola secundária ou dos estudos avançados, o programa de disciplinas e leitura dos oratorianos vinha distribuído por trēs seçōes, a saber: o Latim, a Poética e Retórica e a História e Geografia. Para o estudo do Latim, as obras recomendadas eram:

1) Novo método para se aprender a Gramática Latina, pelo P. Manuel Monteiro. Lisboa, Francisco da Silva, 1746-1751.

2) Exercicios da língua latina e portuguesa (2:

fasciculo): Constão de saudaçoens e dialogos. Lisboa, Miguel Rodrigues, 1751. (3: fasiculo): Acerca de diversas cousas, pelo P. Antonio Pereira. Lisboa, Miguel Rodrigues, 1751.

3) Novo método da Gramática latina, pelo P. Antonio Pereira. Lisboa, Miguel Rodrigues, $1752-1753$.

4) Colecção de palavras familiares, assim portuguesas como latinas, pelo P. Antonio Pereira. Lisboa, Miguel Rodrigues, 1755.

5) Novo método de Gramătica latina, reduzido a compêndio, pelo P. Antonio Pereira. Lisboa, Francisco Luís Ameno, 1759.

6) Ortografia da lingua latina, pelo P. Antonio Alvares. Lisboa, Miguel Rodrigues, 1759. 
7) Diālogos sobre os autores da língua latina, pelo P. Antonio Pereira. Lisboa, Oficina Silviana, 1760.

8) Breve dicionário de iatinidade pura e impura, com a significação de ambas. Lisboa, Francisco Luís Ameno, 1760.

Para o estudo de Poética e Retórica, era obras recomendadas:

i) Arte poética ou regras da verdadeira poesia em geral, por Francisço José Freire. Lisboa, Francisco Luís Ameno, 1748.

2) Arte de Horäcio, tradução de Francisco José Freire. Lisboa, 1758.

3) Elementós da invenção e locução retörica ou Princípios da Eloquência, pelo P. Antonio Pereira de Figueiredo. Lisboa, Francisco Luís Ameno, 1759.

4) Māximas sobre a Arte Oratöria, extraidas das doutrinas dos antigos mestres, por Cândido Lusitano. Lisboa, Francisco Luís Ameno, 1759.

5) Dicionärio poètico para uso dos que principiam a exercitar-se na poesia portugesa, por Franciscio José Freire. Lisboa, Francisco Luis Ameno, 1765.

Finalmente, para o estudo de História e Geografia, eram obras recomendadas:

1) Métódo breve e fácil para estudar a Histöria portuguesa, por Francisco José Freire. Lisboa, Francisco Luís Ameno; 1748.

2) Exercicios da lingua latina e portuguesa. Parte 2a. da "Histōria eclesiástica. Pa- 
ra uso das Escolas do Oratörio na Casa de Nossa Senhora das Necessidades". Ms. de que resta fragmento.

3) Priricipios da Histöria eclesiástica, escritos em forma de diálogo; tomo l:, Contém os Princípios de Cronologia; tomo 2:, os de Geografia, pelo P. Antonio Pereira de Figueiredo. Lisboa, Miguel Rodrigues, 1765 .

4) Compêndio das épocas e sucessos mais ilustres da Histöria geral, pelo P. Antonio Pereira de Figueiredo. Lisboa, Rếgía of. Tipogräfica, 1782 .

o regulamento oratoriano estabelecia, ainda, para o Ensino secundārio e superior, as ciências físico-matemáticas e filosófico-teológicas, tendo como disciplinas: 1) Lógica e Ontologia; 2) Filosofia experimental; e 3) Filosofia moral e Teologia. 77

Em 1772, a Diretoria Geral dos Estudos teria elaborado em mapa nomeando as escolas que a Congregação tinha mBrasil, sendo 2 no Rio de Janeiro, 4 na Bahia e 4 em Pernambuco e outras em Mariana, São Paulo, Vila Rica, Sabarā, S. João del Rey, Pará e Maranhão. Eram escolas de ler, escrever e contar. Banha, de Andrade registra cartas de religiosos no Brasil. De Recife,o P. Francisco de Sales dirige-se ao P. José da Veiga, em Lisboa, com data de 16 de dezembro de 1790 , encomendando Resumos da gramática latina e pedindo suspensão do envio das Artes Grandes e Novos métodos, por não corresponderem ao consumo 1ocal. Do Rio, Antonio Jacinto Machado, em 8/8/1790 verificava que as Artes e os Novos métodos eram muito caras e pedia suspensão tambëm do envio. ${ }^{78}$ 
Para o segundo grau ou escola dos estudos avançados, anotamos que o Novo método para Gramatica latina do padre Manuel Monteiro é o "primeiro livro didático para o $2^{\circ}$ grau do método a instalar na Casa de Noșsa Senhora das Necessidades."79 O autor pertencia à Academia Real da História Portuguesa, desde 1738 e escrevera e publicara a História de Carlos XII, rei da Suécia, (Lisboa Occidental, Oficina da Congregação, 1739), na verdade uma tradução sob pseudônimo da cbra de Voltaire, obra, aliās, bastante corrente no Brasil Setecentista. O livro de Manuel Monteiro, aparecido no mesmo ano do Verdadeiro método de Verney, logo presumia a substituição daquele execrado De Institutione Grammatica 1ibri tres (1.ed. Lisboa, 1572), do jesuita Manuel Alvares. Algumas obras foram escritas em desagravo do padre Alvares e e contrapondo opiniões ao autox do Novo método... Uma dessas obras, bastante popular no século XVIII brasileiro, é o Antidoto gramatical $^{80}$ (Valensia, Antoṇio Balle, 1750), por Silvestre Silvério Silveira Silva, pseudônimo de Manoel José de Paiva (1706- ). Também popular e conträrio ao volume de Manoel Monteiro é o Anti-Prologo critico e apologético, no qual, à luz das mais claras razões se mostrão des-

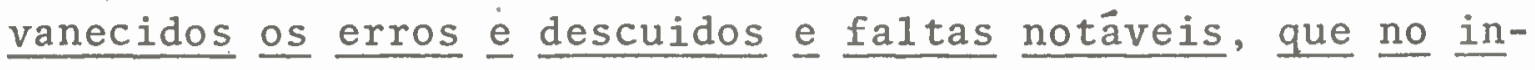
signe padre Manoel Alvares presumirão descubrir os RR. AA. do Novo Methodo da Grammatica latina (...) Por Manoel Mendes Moniz (...) Guarda dos Estudós püblicos desta Corte no Rea1 Collegio de Santo Antão etc. Lisboa, Off. MMC, Imp. do S: Ofício, 1753. Na verdade,essa resposta se dirige a duas obras com o mesmo título de Gramática 1atina, o Novo Mc- 
todo de Monteiro e Antonio Pereira. Deste último, o Novo método tem a 1.ed. 1754; 3.ed., 1756; 4.ed. 1760; 5.ed. 1765; 6.ed. 1777; 7.ed. 1775. A ü1tima edição parece ser a de 1814 pela Impressão Régia. Défendendo-se das acusações, Antonio Pereira de Figueiredo ou Antonio Pereira, o oratoriano mais fiel ao regalismo pombalino e reformador, proiifico autor de Manuais e membro vigilante da Real Mesa Censória escreveu um folheto chamado Defensa do Novo methodo da Gramatica latina contra o anti-Prologo critico (Lisboa, M. Rod., 1754), sob o pseudônimo de Francisco Sanches. Os jesuítas contra-atacaram atravēs da Defensa apologetica e jocoseria da famosa e nunca assás louvada Arte latina do grande padre Me1. Alvares por Francisco Urbano do Amaral (Lisboa, 1753). Depois, José Caetano, mestre de Gramâtica publicou o Juizo grammatical ou primeira audiência feita na casinha da Almotaçaria, (Lisboa, 1754). Do mesmo autor, sairam a Segunda audiência gramatical e Carta de hum velho hon-

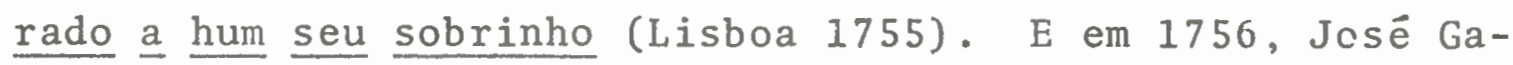
go publicou Discursos gramaticaes, sobrando algumas farpas para Verney.

0 Novo método de Gramatica latina reduzida a compêndio, de Antonio Pereira de Figueiredo, saiu em 1. ed. em Lisboa, Miguel Rodrigues, 1758. Teve novas edições. Em 1759, a 2.ed. Lisboa, Francisco Luís Ameno. A 3.ed. saiu em 1760; a 4., 1780; a 5., 1788; a 6., 1795; a 7., 1800; a 9., 1802; a 10., 1811: Obras bastante populares e divulgadíssimas sob auspícios da reforma pombalina, tanto o Novo mëtodo, quanto o Novo método reduzido a compêndio, tiveram 
franca . presença no Brasil. Segundo Banha de Andrade, uma e outra de Antonio Pereira "usavam-se no Recife e demais cidades brasileiras, sobretudo no Rio de Janeiro."81

0 Breve Dicionario de latinidade, pura e impura, com a significação portugesa de ambas, impresso em Lisboa (Francisco Luís Ameno, 1760) é também da autoria do Padre Antonio Pereira,com o.título latino de Parvum Lexicon purae et impurae latinitatis, cum notis et interpretatione, acrescido com outro livro, de 99 páginas, chamado Diálogo sobre os autores da lingua latina, com o juízo critico das suas obras, idades, estylos e impressões. Para o uso das escolas da Congregação do Oratório, (Lisboa, Of. Silviana, 1760). Este ưltimo livrinho ê uma espêcie de micro história da literatura clássica, 0 prolífico oratoriano foi autor ainda de Figuras de sintaxe latina, editado em Lisboa, Miguel Manescal da Costa, 1761, que alcançou uma 2.ed. em 1781 e uma 3.ed. em 1813. Foi o mais atuante autor de obras da propaganda pombalina. Sua Tentativa teológica è de Lisboa, 1768, lugar e ano também do Apendix e ilustração da Tentativa teológica.

$\mathrm{Na}$ parte de História geral e eclesiástica, Francisco Josê Freire, oratoriano, tradutor de Horäcio com o pseudônimo de Cândido Lusitano, pontuava amplamente em Poética e Retórica, aparece com um Metodo breve e fácil para estudar a História portuguesa, formado um humas taboas cronológicas e históricas dos reis, rainhas e príncipes de portuga1 (Lisboa, Francisco Luis Ameno, 1748): Freire tambëm traduziu a Vida do venerảve1 Padre Bartolomeu de Quental, obra elo- 
gíaca sobre o fundador da Congregação do Oratório escrita em latim pelo Padre José Catalano (Lisboa, 1741).

o campo da Retórica e Poética exercitado por oratorianos é de domínio quase exclusivo de Franciso José Freire (festejado autor, no Brasil, do best-seller colonial o secretário português). Dos cinco títulos recomendados para o estudo retórico e poético, quatro pertencem ao Cândido Lusitano. Sua Arte poética ou regras da verdadeira poesia (1748), a tradução da Arte poética de Horácio (1758), as Maximas sobre a Arte Oratória, extraídas das doutrinas dos

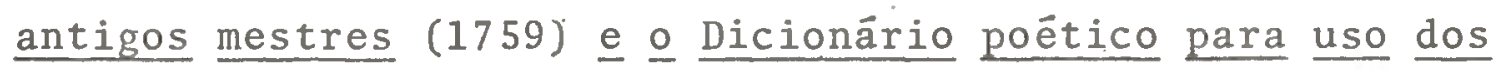
que principiam a exercitar-se na poesia portuguesa (1765). Sobra para o vigilante e prolífico Antonio Pereira de Figueiredo apenas os Elementos da invenção e locução retórica ou Princípios da Eloquência (1759).

Dessas relações de livros "aconselhāveis", passamos aos "desaconselhados", os publicamente censurados, os interditos por um sistema político e social que escolhia outras formas de obscurantismo para manifestar-se. E não se pense que a prática da censura se exercia apenas na fórmula da recomendação ou do regulamento. o capitulo da censura secularizada por Pombal ganha outros contornos quando analiśamos a determinação regalista de obrigar pessoas e instituições, nos domínios do Reino, em especial aquelas ligadas, às tarefas educativas, a enviar à Real Mesa Censória todo um catálogo dos livros que possuíssem. Edital neste sentido foi baixado em 10 de julho de 1769 e, no Brasil, segundo 
nossa investigação, pelo menos uma instituição mandou a Lisboa o catálogo de sua livraria: o Mosteiro de São Bento do Rio de Janeiro, numa rica sistematização catalográfica, embora incompleta de dados, feita por título de matéria, coleções e autores. Os livros da biblioteca do Mosteiro tiveram a devotada organização de ninguém menos que o abade $D$. Gaspar da Madre de Deus (1715-1800), num catálogo que descrevemos e comentamos no capitulo "Os livros das Ordens e os livros que o Marquês quis ver".

A relação de matérias proibidas ou de livros impedidos de circular obedecia ao aspecto legal de defesa do Estado. Os sentidos dessa defesa, no entanto, são puramente subjetivos ou pertencem a una objetividade facciosa, distante do universo mental da Ilustração européia. Destinavam-se a proteger o próprio Estado, a Religião, a Moral e a Reforma pombalina.Vale a pena a transcrição aqui dos interditos para melhor compreendermos o espírito censório do tempo de Pombal. Eram, portanto, proibidos:

1) os livros de autores ateus,

2) os de autores protestantes que combatessem o poder espiritual do Papa e dos bispos ou atacassem os artigos da Fé Católica,

3) os que negassem a obediência ao Papa,

4) os livros de feitiçaria, quiromancia, magia e astrologia,

5) os que, apoiados num falso fervor religioso, levassem à superstição ou fanatismo,

6) os livros obscenos,

7) os infamatórios, 
8) os que contivessem "sugestões de que se siga perturbação do estado político e civil e desprezando os justos e prudentes dictames dos direitos divinos, natural e das gentes, ou permitem ao Soberano tudo contra o bem-comum do vassalo, ou vão na outra extremidade fomentar a abominável seita dos sacrílegos monarcomacos... que tudo concedem ao Povo contra as Sagradas e inviolaveis pessoas dos Principes",

9) os livros que utilizam (sic) os textos das Sagradas Escrituras em sentido diferente do usado pela Igreja,

10) os autores que misturassem (sic) artigos de fé com os de mera disciplina,

il) os que impugnassem (sic) os Direitos, Leis, Costumes, Privilégios etc. da Coroa e dos Vassalos,

12) as obras "dos pervertidos filósofos destes ültimos tempos"...

13) os livros publicados na Holanda e na Suíça atribuidos a advogados do Parlamento da França e que tratam da separação entre o "Sacerdöcio e o Império",

14) todas as obras de autores jesuitas baseadas na "autoridade extrínsica da razão particular",

15) os livros "compostos para Onsino das Escolas Menores que forem contrarios ao sistema estabelecido por lei anterior" 82

Tudo isso vem contido no Alvará de 4 de julho de 1771 , com vistas ao controle da inteligência no campo da Religião, da Política, da Educação e da Cultura. Não há citação explícita a títulos ou autores. E nem seria preciso: o en- 
dereço dos excluidos era bem conhecido. Jesuitas, protestantes, filósofos ateus. Tudo era pretexto para proibir o que não estivesse assente com o regalismo, com a interpretação da soberania do Estado acima da vontade e da defesa dos cidadãos. A "Ilustração" portuguesa freava assim o entusiasmo pelo livre arbítrio, pela livre circulação de idéias e conhecimentos proporcionados sobretudo pelo encilopedismo francês, pelo caräter revolucionärio desse enciclopedismo. Por isso, d'Alembert, Buffon, Diderot, Condillac, Mably, Montesquieu, Rousseau, Raynal e Voltaire formavam um elenco de autores tidos em perversão da sacralidade ilustrada do pombalismo militante. Mas toda censura, é claro, apresenta rachaduras em seus edifícios moralistas. Assim, no Brasil Setecentista, muitos dos autores "proibidos" chegaram a ter regular circulação. 0 caso de Marmontel e seus Contos morais é sintomático de que o interdito tinha gosto de descoberta e subversão. Ou o caso de Jéremy Bentham, autor de franca popularidade no Brasil da primeira voga do constitucionalismo do Oitocentos.

Outra forma de cerceamento - a impossibilidade de aqui se desenvolverem as tipografias - amplia o fosso de um sistema político e cultural rarefeito e contraditório. A proibição que atingiu Antonio Isidro da Fonseca no Rio de Jaṇeiro, em 1747, dispensa maiores considerações e atrasou, por mais meio século, a implantação de um canal de desenvolvimento educacional e literário que promovesse também um maior avanço intelectual e libertário. A expulsão do cândido Isidoro do Brasil e o grau inibidor de fundação de uma 
imprensa na Colônia não ficam restritos apenas ao Rio de Janeiro. o caráter censório da medida alcançou também à Bahia, conforme registram duas cartas do Rei de Portugal dirigidas ao Vice-Rei do Brasil, datada de Lisboa, 16 de junho de 1747, "ordenando mandar preso para o Reino todos os donos de letras e oficiais de imprensa que houver nos limites do seu Governo". A resposta do Vice-Rei ao monarca, datando de Bahia, 16 de outubro do mesmo ano, declara não haver na Bahia, nem nos limites do seu Governo, oficiais de imprensa que imprimam obras ou papëis avulsos e quando tiver notícias que haja algum mandarà sequesträ-1o e remetê-10 para o Reino. ${ }^{83}$

Neste quadro, pouco havia de estimulante à boa formação de leitores no Brasil de Setecentos. E por esta razão surpreende o número e a diversidade de boas bibliotecas brasileiras no século, as principais, ricas e curiosas situadas em Minas, São Paulo, Rio de Janeiro e Bahia. Para tanto, em muito contribuíram os religiosos, donos de monumentais livrarias e, até, leitores desapaixonados de algumas das obras incluîdas no Index do século. Um dos títulos mais curiosos e frequentes entre as peças das livrarias setecentistas, máxime nas livrarias dos padres, é o "Catecismo de Montpelier", ou Catecismo da Diocese de Montpelier, traduzido para fins de circulação das luzes da doutrina e para esparzir os bens da espiritualidade. A edição que conhecemos no Brasil deve ser a segunda, a do.Porto, 1769 e que, depois de a obra ser condenada como jansenista jạ em 31 de janeiro de 1721 . teve novamente aprovada sua divulgação por ato de Pombal a 
partir de 1765, Foi adotado livremente no Brasil, aceito pe10 prelado do Parä, Fr. João de S. Josë que, por isto, foi apontado como jansenista na visão ortodoxa de Serafim Leite. 84

Passa por ortodoxa também a visão pouquíssimo esclarecida revelada no "Estatuto que se hã de observar os mestres das escolas dos meninos" em São Paulo. O parägrafo 7 desse documento prevê a proibição do ensino de ler e escrever senão pelas lições ordenadas por um mestre de Lisboa, Manuel de Andrade Figueiredo, autor de uma Nova escola para aprender $\underline{\text { a ler, }}$ escrever e contar, escrita em 1718 e publicada provavelmente em 1720, em Lisboa, na Oficina de Bernardo da Costa de Carvalho. o referido parágrafo estabelece "que todos os Mestres sejāo obrigados a ensinar pelo livro do Andrade, e seguir em tudo aquellas regras que no princípio do dito livro se prescrevem, para a boa direção das Escollas". 85

$\mathrm{Na}$ base dessa coerção, o ensino de Doutrina se processava inelutavelmente pelo Compendio da Doutrina Christã, 1ivro bastante popular no Brasil Setecentista, ou de uma Carti1ha do Padre Mestre Ignacio. Outros livros impostos à leitura e ao uso dos mestres, para coonestar os alunos nos bons exemplos morais e na composição futura da maioridade civil: Educação de hum menino nobre, de Martinho de Mendonça de Pina e Proença Homem - livro agora explicável em sua frequente aparição nas livrarias brasileiras; as obrigações civis de Cicero; a Gramática latina de Verney. E vão se sucedendo as leituras obrigatórias. Aquele que é dos maiores best- 
sellers do periodo no Brasil, a Rudimenta Grammaticae Phi1osophicae, do alemão Gaspar Schopp (1676-1649); as Orationes selectae M. Tullii Ciceronis na edição de Lisboa, Francisco Luiz Ameno, 1760; Quintiliano e sua De Institutione Oratoriarum Iibri duodecim, (ad usum Scholarum accomodati, recisis quae minus necessaria visa sunt et brevibus notis a Car. Rollin ilustrati, Lisboa, 1760, ou a edição de Miguel Rodrigues, 1759 e 1760); os Manifestos de Tito Livio, e sua Historiarum ab urbe condita, talvez edição de Coimbra, 1640; e, por fim, livro tambëm de frequente presença em nossos inventários, o Dicionario latino e português, ou Parvum lexicon latinum, lusitana interpretatione adjuta, ad usum lusitanorum adolescentium, de 1762 , composto por Pedro José da Fonseca. Tudo, claro, com os beneplácj.tos dos inspetores do quarteirão pombalino.

A fúria repressora dos livros assumia então ares de Inquisição secular e estatal, transformando em fogueira tudo o que lembrasse o antigo regime de estudos. Esta a razão invocada pela Metrópole para ordenar ao desembargador João de Sousa de Menezes Lobo, Chanceler da Relação de Goa, que queimasse todos os livros de Gramätica latina pelo antigo mëtodo, com o fim evidente de impedir a circulação e consequente uso de tão "perniciosa" obra..

E, no mínimo, curioso o zelo com que El-Rei D. Josë I deu vez e voz a Pombal, à Congregação do Oratório e a Real Mesa Censória na santa cruzada contra a Gramätica latina do Padre Manuel Alvares,SJ. El-Rei proibiu não apenas a ciṛculação da obra do indigitado padre, como também as de scus 
comentadores Antonio Franco, João Nunes Freire, José Soares "e em especial Madureira mais extenso e mais inútil; e de todos, e cada hum dos Cartapacios, de que até-agora se usou - ensino de Grammatica". 0 zelo real era tanto que ameaçava prender todo aquele que sonegasse a lei, "prezo para ser castigado ao meu Real arbitrio". Não obstante, Madureira é dos mais populares autores em circulação no Brasil Setecentista, com sua Orthografia para o duque de Lafoens...

O fundamental, especificamente no caso do ensino de Gramática latina, era substituir o curso das explicações do latim para o português. Com vistas ao uso latino de autores como Terêncio, Plauto e outros, recomendava-se A Collecção dos diálogos, de Luis Vives; a Collecção das palavras familiares portuguesas, e latinas, de Antonio Pereira, da Congregação do Oratório; e mais: recorrer aos Exercicios da lingua latina, e portuguesa acerca de diversas cousas, ordenados pela Congregação do Oratório. Isso tudo se depreende da "Instrução para os professores de Gramätica latina". 87

Os livros permitidos pela Real Mesa Censória pombalina lembram aqui, e não por coincidência, alguns dos mais lidos no periodo do Setecentos brasileiro. Assim a Sellecta 1atini Sermonis, de Pierre Chompré (1698-1760), autor tam- bẻm de um divulgadíssimo Dicionario da fäbula, traduzido e publicado por Pedro Josē da Fonseca em 1785. Dentre os proibidos - apontados na toada de estarem eivados de incorreções da linguagem latina - alguns tambêm pontificam nas livrarias 
setecentistas brasileiras. Por exemplo, o Breviario e' Concilio, incrivelmente populares no Brasil à época. Não se permitia expor os alunos ao "perigo" da imperfeição do idioma e assim, embora não se tenha notícia da destruição dos livros defesos, persistia a necessária vigilância contra a Selecta antiga, ou Virgílio, Horário e Ovídio em edições não recomendadas. Também pela permissão regalista è que se pode explicar a enorme popularidade de obras como o septem Linguarum Calepinus hoc est Lexicon Latinum. Variarum linguarum interpretatione adjecta in usum Seminarii Patavini. Editio octava retractior. Patavini, Typis Seminarii, MDCCVIII. 2 v., do célegre Ambrosio Calepino (1435-1511), obra reformada pelo não menos célebre Jacopo Facciolati (1682-1759). Abade e professor do Seminârio e da Universidade de Pádua desde 1723, Facciolati foi convidado por Pombal, mas não aceitou dirigir o Colëgio dos Nobres. A edição do Calepino original è de 1502, mas a que tradicionalmente circula pela maior parte das livrarias brasileiras setecentistas è mesmo a que Facciolati deu novo modelo, em colaboração com Egídio Forcellini, cuja edição de Pádua data de 1710 e dai sucessivamente. Os escrivães, nos inventārios, chegam mesmo a indicar o livro "Calepino de Facciolati", tal a associação da obra e seu autor com o seu reformador.

E muito oportuno ler a "Instrução referente ao ensino de grego" baixada pela reforma de Pombal. Pelo documento, ficamos sabendo da proibição de ler os clássigos gregos cm versão latina. Aos alunos que jä soubessem ler, aplicar-se-ia o Epitome do Methodo, de Port-Royal, traduzido em por- 
tuguês conforme regras claras, breves e sölidas justamente como matéria sucedânea e preparatória para o estudo do grego, evitando-se a leitura dos clássicos helênicos em versões latinas "corrompidas" pelos jesuitas. O desenvolvimento dos estudos e leituras corresponderia a uma sequência, tomando-se o Evangelho de Lucas, trechos seletos de Heródoto e Xenofonte, dos Caracteres de Teofrasto e dos Dialogos de Luciano, via "Colleç̧ão de Patuza" organizada para a Academia Real de Nápoles. Para uso dos alunos, o Dicionario Manual de Screvelio, mais os de Escapula; o Thesouro de Carlos Estêvão, os livros de Ubbo Emio e João Meursio para as notícias da Antiguidade grega. Por fim, Demóstenes e Tucídides. Depois, para os alunos bem adiantados, lições de Homero, onde se encontraria tudo relacionado com o estilo "polido e agradåvel". Paradoxalmente, um poeta dá sensibilidade profana como Homero servia aos objetivos docentes e moralizantes de um Estado católico, pois, rezava a Instrução para os estudos de grego, era altamente produtivo ler Homero, por ser "o melhor modelo de hum grande Poéta, util ainda para a oratória, para a facil intelligencia dos Escritores Sagrados, pela grande analogia, que com elles tem na simplicidade do esti10". 88 o parägrafo IX da mesma "Instrução" estabelece ainda a leitura sistemática dos clássicos latinos (Cícero, Virgílio, Tito Lívio), mas com a obrigatoriedade da tradução de trechos latinos para o português.

$\mathrm{Na}$ "Instrução, parạ os professores de Rethorica", aconselhava-se o uso das liçõcs de Aristóteles, Cícero e Lungino. Entre os modernos, Vossio, Rolin e Fr. Luis de Granada. 
O $\S$ VI do documento trata das virtudes da Elocução, cujo modelo a ser seguido confirmará as lições de Heinecio, no Fundamenta styli cultioris, especialmente nas edições de Leipzig, Genebra ou Veneza. Os exemplos da Poesia deveriam ser extraídos das obras de Homero, Virgílio e Horácio.

Em tudo, um modelo para a constituição das bibliotecas setecentistas no Brasil. As recomendações, deliberações e interditos, em grande parte, moldaram o perfil do leitor colonial. Livros como o Dicionärio de Scapula constavam da biblioteca de Verney, como vimos. Todos, certamente, pontuariam nas livrarias dos outros reformadores pombalinos, como espelho provável de uma personalidade "coletiva" imprimida pela ideologia dominante. Claro, também, que por aí se explica a frequência com que muitos dos autores e livros reiterados pela prätica leitora dos arautos do pombalismo encontravam-se nas bibliotecas setecentistas da Colônia.

Num certo sentido, as ações e reações da reforma pombalina tiveram ressonância. na vida intelectual e na atitude leitora brasileira, com influência no gosto ou no aborrecimento de livros e idéias. E possível observar um determinismo de leituras, ou localizar tendências e caracteristicas dos leitores coloniais conforme sua cooptação, oposição ou neutralidade às imposiçōes do regalismo e das mudanças operadas. nos estudos. Em que pese todo o esforço desse reformismo, porëm, o Brasil leitor não é um rigoroso observante do gosto ou determinação prevalentes. Terä sido no restrito e notório ambiente das escolas, entre Mestres de ler e scus discípulos numa situação colonial a reboque da Metrópolc. 
Nas livrarias particulares, nos livros que anotamos e descrevemos dos inventariados de Setecentos, o que se observa, alêm das reiteradas influências jesuiticas nos livros de Doutrina e Ascese, è uma preferência por livros proibidos, muitos deles em francês, muitas gramäticas e dicionários de explicação da Arte francesa, latina e italiana. E, com destaque, aparecem os "repulsivos" Madureira, com sua Orthografia e Bento Pereira, com sua Prosodia. Concretamente, o século XVIII português, operou mudanças, sim, no comportamento do leitor brasileiro, não no que o regalismo pretendia mas no que efetivamente provocou. O leitor do Setecentos lê mais que seus antecessores do sëculo XVII. E amplia o universo das leituras, variando o gosto e as matérias do que $1 \hat{e}$.

Chegamos, enfim, a outras indispensãveis observações históricas a propósito das leituras no Brasil Colônia. Antes, durante ou depois da marcada influência da era Pombal, os brasileiros aqui desenvolveram suas leituras basicamente nos colégios, de ensinọ tradicional, ou nas livrarias que formavam. Provavelmente a mais notâvel e a primeira das livrarias na colônia foi mesmo a dos jesuitas, que começou com a chegada dos primeiros missionários em 1549, cresceu com Noobrega, Anchieta, Luís de Grã, Vieira e outros e foi firmando um nome nos dois séculos e pouco da presença dos inacianos no Brasil. A livraria dos jesuítas foi de enorme importância, em quantidade, variedade e interesse intelectual, particularmente com os livros da Bahia e do Rio de Janeiro. No Rio, já em 1601, a livraria se enriquecera com o 
acervo deixado pelo Visitador Eclesiástico Bartolomeu Simões Pereira, grande parte de obras versando sobre Direito Canônico. A livraria baiana tambëm era muito rica, chegando perto dos 15 mil volumes quando da expulsão dos jesuítas. Outro tanto, em nümero e qualidade, certamente se supõe perdido nas estantes de outros colégios desbaratados em 1757 no Maranhão, Pará, Espírito Santo, e São Paulo.

Os jesuítas eram fortes nos estudos latinos, de História e Geografia, de Filosofia e Teologia. Entre seus autores conhecidos, figuravam Pedro de Almedia (In Suetonium), Francisco de Mendonça (Viridarium sacrae et profanae eruditionis), o Calepino 'reformado por Faciolatti (Septem linguarum), o Gradus ad parnasum, o Thesaurus linguae latinae traços iniludíveis da significativa tendência para os estudos clássicos de Latim e Linguística geral. o Colégio do Rio de Janeiro tinha 110 títulos só em Gramātica e o da Bahia, volumes de Matemática e outras ciências, conforme se verificou à época da expulsão. Destacaram-se os inacianos também nas Ciências naturais e na Filosofia moral. Em suas estantes, os Elementos de Matemática de Boscovich, obras de Clavio, Kircher, Newton e, até, Descartes. O Colégio do Rio de Janeiro tinha 34 tomos de Lógica, a obra de Platão (Plato opera), alêm das inevitáveis considerações da Teologia dogmática, da Ascese, da Mística, da Hagiografia. Consagravam-se a Vida do padre Anchieta e a Chronica da Companhia de Jesus no Brasil, do pe. Simão de Vasconcelos; a I- magem da virtude e a Synopsis annalium do padre Antonio Franca, o detestado comentador do padre Alvares já citado; a 
Gloriosa coroa, de Bartolomeu Guerreiro; e Juan Luis Vives, Busembaum; e Mapas do mundo: Novo Atlas; Exame de bombeiros; Memoires pour servir à 1'histoire des sciences et des Beaux Arts. A Brasilia Pontificia, do padre Simão Marques, destacava-se entre os bens confiscados em 1757, no Rio. Havia dela 17 exemplares somente no colégio carioca e não passa como irrelevante o fato de ser. o Brasilia Pontificia, junto com a Constituição do Arcebispado da Bahia, dois bestsellers setecentistas no Brasil. Completam o quadro da riqueza bibliográfica dos jesuítas a variedade de títulos em História e Geografia, como a Monarquia ilustrada, o Orinoco ilustrado e Marañon y Amazonas. Mais a Biblioteca Lusitana de Barbosa Machado, vinte exemplares da Bỉblia (uma delas em grego), Voyage du monde de Descartes, do padre Gabriel Daniel, a Poliantea de Curvo Semedo, o Itinerário de Andrade, a Coleção da Academia Real, Os Lusiadas, as Novelas de Cervantes, ao lado de Vieira, Bernardes, São João da Cruz, Santa.Tereza de Jesus. Enfim, uma formidável coleção de livros que servem de amostragem das tendências de leituras dos inacianos e de que foi feito um "Auto de Inventário e avaliação" do colégio do Rio de Janeiro, publicado na Revista do Instituto Histórico e Geogrä́fico Brasileiro. ${ }^{89}$

Sim, os jesuitas seguiam lendo seus livros, condicionados ou não ao que se passava na Metrópole. o fenômeno Pombal, com determinações, equívocos e contradições, se assenhoreava de uma combalida monarcofilia portuguesa. As mudanças despontávam. A "Sentença de sequestro dos bens dos jesuítas 1767/1798", relativa à Bahia, fala da biblioteca 
dos padres, embora não relacione 1ivros. 0 volume 17 dos Anaes do Arquivo do Estado da Bahia, sobre o sequestro, também não cita livros, mas, trechos da carta do Marquês de Lavradio ao rei de Portugal, de 25 de março de 1760 , relata que o representante do rei distribuiu "as collecçōes impressas, em que manifestamente se mostrão os horrorozos factos, que a todos forão publicos das façanhosas culpas dos jesuítas", livro do pombalismo.

Dos franciscanos, carmelitas e dominicanos, e outras ordens menores, hā pouco de informação conclusiva sobre as tendências de leituras do século XVIII. Sobre os beneditinos e franciscanos, junto com os jesuítas, vão apontadas no curso deste trabalho algumas caracteristicas das livrarias em capitulo pertinente. Nada sabemos dos dominicanos. Dos carmelitas, encontramos uma breve memöria de inventário de livros ém Santos, recolhida no Carmo de Belo Horizonte. Mas os jesuítas, sem dúvida, predominam. Dos franciscanos, è interessante observar seu regime de estudos, como aquele registrado no Convento dọ Bom Jesus, em Sapucaia (RJ), exemplo provảvel do mëtodo seguido em outros conventos, regime e estudos indispensáveis aos bons proveitos da disciplina monástica e aprendizado teológico:

4 hs da manhã - levantar, estudar

5 hs da manhã - horas menores do ofício divino Missa no altar da. Conceição, "para os colegiais se afeiçoarem a esta devoção e a tomarem por Patrona de seus estudos"

7 hs - classes. Estudo por uma hora 


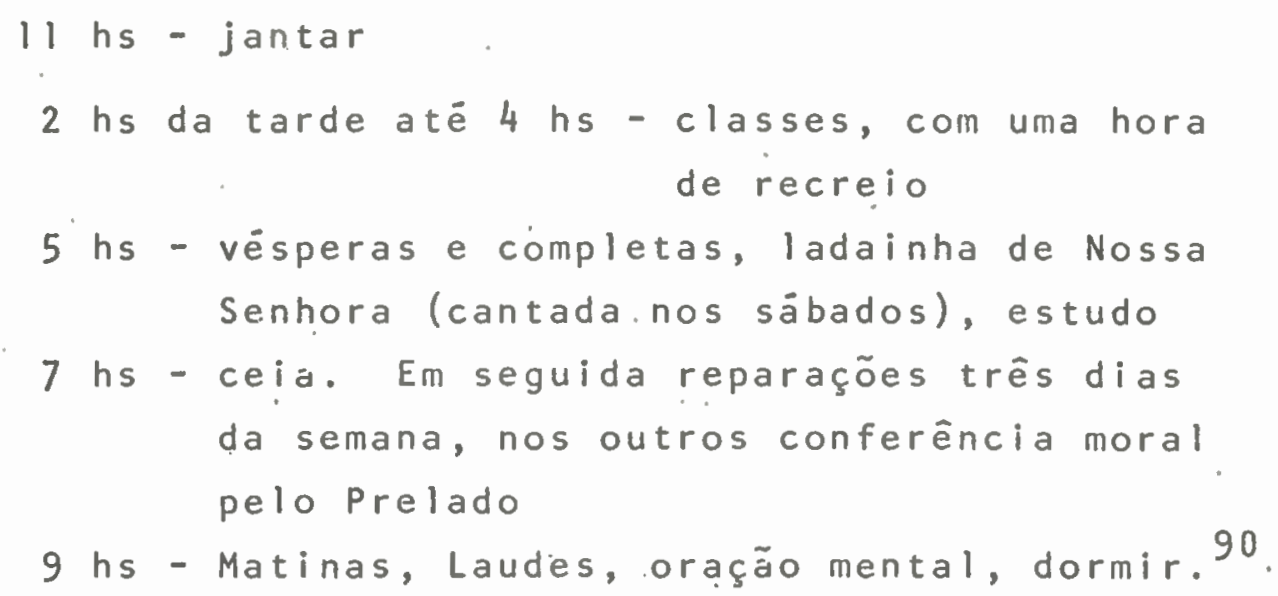

Assin se desenvolviam os estudos entre os franciscanos, numa rígida disciplina que só se alterava, em 1 hora, nas três primeiras etapas da manhā, no inverno mais rigoroso ainda...

Os religiosos no Brasil tambëm tiveram uma influência sensivel e determinada no campo das Artes, mais precisamente no campo do Teatro. Não esquecemos, inclusive, que o nosso sêculo XVI pode ser tomado como o sëculo das experiências cẽnicas dos jesuítas e índios, começando por Anchieta. Hã uma dezena de referências de uma dramaturgia do sagrado e do maravilhoso cristão testemunhado por Cardim \& Gandavo, por exemplo, na prätica ritualística de padres e silvícolas na segunda metade do Quinhentos. O século XVII certamente teve seu influxo dramático e algumas peças devem ter circulado para leitura e encenação, embora nada se tenha concretamente de notícia a respeito.

No sêculo XVIII, data de antes da era pombalina algumas representações (o que implica leitura de textos) de autos sacramentais. Em 1734, um folhcto de Simão Ferreira Ma- 
chado, Triunfo eucaristico, publicado em Lisboa, descreve a pompa litúrgica e as encenaçōes dramáticas por ocasiãoda trasladação do Santíssimo Sacramento da Igreja do Rosärio, em Vila Rica, para novo templo, fato ocorrido em 24 de maio de 1733. No evoluir da descrição, o folheto menciona que um Tablado de Comédias levou à cena E1 secreto a vozes, E1 principe prodigioso e EI amo criado. Era governador da capitania $0^{\circ}$ conde de Galveias, o mesmo ostentador e rico herdeiro de grande biblioteca no Palácio de Campo Pequeno, em Portugal. As duas primeiras comédias pertencem a Calderōn, - que explica talvez o aparecimento deste comediógrafo espanhol num inventário de Vila Rica. Afonso Ávila acredita terem sido feitas as representações no original castelhano, em vista da tradição do uso do espanhol como língua 1iterāria. 91

A tradição cênica, do teatro de ciricunstância, parece ter feito carreira em Minas, tal como vem descrito no Aureo Trono Episcopa1, colocado nas minas de ouro, ou Notícia bre-

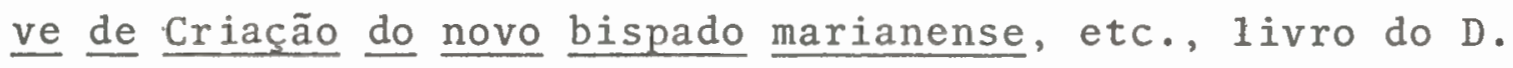
Fr. Manoel da Crus (Lisboa, Migue1 Menescal da Costa, 1749), que destaca as cerimônias eclesiásticas com representações püblicas de teatro. 0 "drama para se recitar em músi$c^{\prime \prime}$, O Parnaso obsequioso, panegírico em louvor do Conde de Valadares, jovem governador da província mineira, escrito por Ciāudio Manoel da Costa, foi encenado a 5 de dezembro de 1768 em Vila Rica. Avila acredita que antes, no período de 1753 a 1771, no Teatrinho de Chica da. Silva, no arraial do Tijuco, deve ter havido algumas encenaçōes, scgundo a impressão de Joaquim Felício dos Santos, com destaque para a re- 
presentação das obras de Antonio José, Encantos de Medéia e Anfitrião ou Júpiter e Alcmena. ${ }^{92}$

O teatro em Mato Grosso ê de uma tradição singular, conforme demonstra Carlos Moura. 93 Já em 1729, nos festejos pelo traslado da imagem do Bom Jesus, de Camapuã para Cuiabá, segundo o cronista José Barbosa de Sā, houve encenação de duas comédias. Moura conclui pela representação, em Cuiabá, em 14 de agosto de 1790, de $\underline{\text { Saloio }}$ cidadão, peça de resgate moliéresco de $\underline{0}$ Burguês fidalgo, numa linha que lembra o tambëm molieresco $\underline{0}$ Fidalgo aprendiz, de Francisco Manuel de Melo, dentro da escola vicentina. Em Cuiabá, no centro-oeste do Brasil, meados da exploração colonizadora, foram representadas, a partir da última década do século, óperas e comédias como Emira em Suza e Fugir à tí-

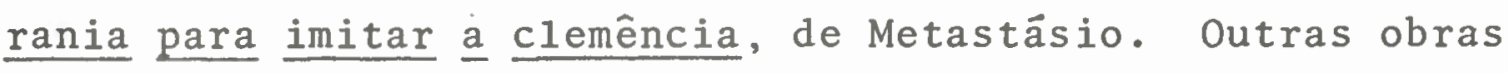
corriam a velha Cuiabá e província de Mato Grosso: Ezio em Roma; Temerlão na Pérsia; Aspasia na Syria, Eurene perseguida e triunfante; Saloio cidadầo; Zenöbia no Oriente; Tragédia de D. Ignez de Castro; Amor e Obrigação; o Conde Alarcos; Zaira; o tutor namorado ou as indústrias das mu1heres; Tragédia de Focas; e Esganarelo ou o Casamento por força, esta ültima uma comédia imitando Molière. Na intro-

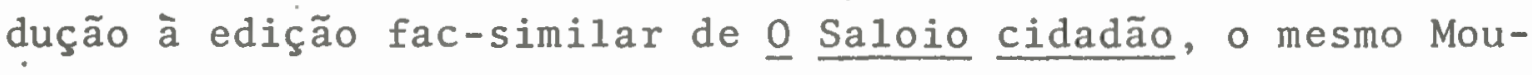
ra acrescenta outros títulos de obras que teriam sido representadas em Mato Grosso: As preciosas ridículas, de Molière, Guerra do Alecrim e da Mangerona, de Antonio José, $\underline{0}$ velho namorado, Amor e perseguição c, finalmente, Ósmia. Infelizmente, a notícia do historiador não documenta a maioria dessas peças com a indicação de seus autores. ${ }^{94}$ 
Alguns desses títulos, todavia, parecem inscrever-se na tradição cômico-dramática ou mesmo trágica do teatro português. Sobre Osmia, por exemplo, duas atribuições 1 he podem ser feitas. Há, com efeito, uma tragédia com este nome, composta pela poeta e dramaturga Teresa de Mello Breyner (1735-1790), e' que ganhou um prêmio da Academia das Ciências em 1788. E. há também Osmia, a lusitana -, de Manuel de Figueiredo (17251801) encenada e provavelmente publicada em 1773 , sobre o conflito entre o amor e o patriotismo.

No Rio de Janeiro, acredita-se na encenação de óperas de Metastásio na Casa da Opera dirigida pelo padre Ventura desde a primeira metade do século XVIII. Aliảs, Metastásio e Antonio José forain autores consagrados tambëm no Rio, a dar crêdito às informações históricas disponíveis. Foram representadas $\underline{0}$ labirinto de Creta. As variedades de Proteu, As guerras do Alecrim e da Mangerona, A vida de D. Quixote, $\underline{0}$ precipicio de Faetonte e Os encantos de Medéia, todas do Judeu. Parece, portanto, ter havido no Rio Setecentista também um traço expoente da tradição cênica (e leitora de dramas e comédias) do Brasil Colônia.

Diz' Afrânio Peixoto que "a Bahia nunca foi rica de teatros"195 o prolífico baiano registra, porém, ter havido em 1733, no salão da Câmara Municipal da Cidade algumas representações e onde "se chegou a representar Gil Vicente". A informação vem desacompanhada de prova documental, mas fica - registro válido como possibilidade que não chega a absurdo. Como não seria absurdo também a assertiva do historiador quanto à existência, na livraria destruída dos jesuítas 
em seu Colégio da Bahia, de um exemplar da Biblia polyglota, remanescente que se teria passado à Biblioteca Püblica no século XIX.96

Das livrarias particulares, antes de chegarmos ao objeto nuclear da descrição dos inventários que pesquisamos, hã que fazer menção ao rastilho, via citação, daqueles autores estabelecidos numa intertextualidade com obras brasileiras. Alberto Lamego, estudando a Academia Brasilica dos Renascidos, registra as obras citadas pèlo acadêmico José de Oliveira Bessa, cônego da Sé, Primaz e Arquiepiscopal, emsuas alocuções. Obras e autores revelam o perfil de um leitor atento à história e à moral religiosa, com especial interesse em assuntos brasileiros. Entram na citação de D. Bessa as obras atribuídas a Bento Teixeira, Cristóvão de Gouveia, Fr. Vicente de Slvador, Fr. Bartolomeu Pinto, Bernardo Vieira Ravasco, mais as memórias impressas de Gandavo, Fr. Rafael de Jesus, Fr. Manoel Calado, Duarte de Albuquerque Coelho, Fr. João Josē de S. Tereza, Gaspar Barlêus e Andrê Thevet. Completam a citação autores e obras assim nomeados:

Pedro de Mariz - Diälngos de Väria História

Simão de Vasconcelos - Crônica da Companhia de Jesus do Estado do Brasil

Sebastião da Rocha Pita - Histöria da América Portuquesa

Jorge Cardoso - Agiológio luzitano

Diogo Barbosa Machado - Biblioteca luzitana

Pe. Fr. Agostinho de Santa Maria - Santuário Mariano 
Francisco de Brito Freire - Nova Lusitānia

D. Sebastião Monteiro da Vide - Constituições Sinodais do Arcebispado da Baía

Hugo Grotius - De Origine Gentium Americanarum Spondanus - Anais

Baltazar Teles - Crônica da Companhia de Jesus em Portugal etc.

Padre Antonio Franco - Imagem da virtude 97

O mesmo procedimento, de citação de obras e autores que teriam servido como influência ou memória de exemplos para composição de seu próprio, trabalho, segue o beneditino Fr. Gaspar da Madre de Deus, nas Memórias para a História da Capitania de $\underline{\text { S. Vicente }}$ (1797). Com efeito, no final do livro, o nosso monge apõe um "Catālogo das obras e documentós, que foram consultados na confecção das Memorias para a Historia da Capitania de S. Vicente". E um registro de honestidade inteleçtual e de modelar informação sobre as perspectivas deleitura no século XVIII. No caso particular de Madre de Deus, os livros, então, mais "clássicos" para sua atitude enquanto historiador eram, citados nominalmente:

Charlevoix - Histöria de Portugal

D. Antonio Caetano de Souza - Histöria genealógica da Casa Real

Fr. Francisco de Santa Maria - Ano histörico

Fr. Rafael de Jesus - Castrioto lusitano

Geläsio - Suplemento da Histöria cronológica

Gandavo - Histöria da Provincia de Santa Cruz, a que chamamos Brasil

Jaboatão - Crônica da Província de Santo António do Brasil 
L. S. Pimentel - Arte de navegar

Padre Manuel da Fonseca - Vida do Padre Belchior de Pontes

Pedro Taques de Almeida Paes Leme - Nobiliarquia paulistana histōrica e genealögica

Pimentel - Roteiro do Brasil

Pitta - História da América. Portuguesa

Sampaio - Nobiliarquia portuguesa

Santa Maria - Santuārio mariano

Șimão de Vasconcelos - Crônica da Companhia de Jesus

- Noticias antecedentes das cousas do Brasil

- Vida do Padre Anchieta

Vaissette - História geogräfica, eclesiástica e Vallemont - Geografia 98.

Não escapa do interesse e curiosidade tal modelo de eficiência e zelo memorial, inclusive registrando documentos consultados nos arquivos de Guiana, S. Vicente, São Pau1o, Santos e Rio de Janeiro, do monge que veio a ser abade do Mosteiro de São Bento no Rio. Alêm da ordem alfabética, inventärio demonstra uma atençāo do autor para com suas fontes. Como leitor, porẻm, Gaspar da Madre de Jesus não é asceta rigoroso, interessando-se por outras matérias a exemplo de Geografia e Navegação. Leitor especial que tinha consigo livros que escapam ao teocentrismo, conforme o documento de esppólio de seus bens (lamentavelmente sem data) transcrito no"Livro de Espólios dos monges", existente no Arquivo do Mosteiro carioca, inventärio observado no triênio do Provincial Abade Fr. Vicente Joseph de Santa Catarina, empossado em 11 de outubro de 1801. Do espólio de Madre de 
Deus, constavam poucos 1ivros: "Hum caderno da Ordem", "David penitente", "Tratado da oração mental", "Marcos Antonio 2 t.", "3 t. da Biblia (comprados por Fr. Joze de Santa Engräcia)"e "Chronicas de S. Francisco (idem)".

E.as livrarias vão se sucedendo. Taunay lembra a riqueza de obras em genealogia presentes na casa de Pedro Taques, citando a Genealogia dos grandes de Portugal, obra que - pröprio Taques, em correspondência a C1äudio Manoel da Costa, diz ter trazido de Portugal.99 Rubens Borba de Moraes traz informação segura que the foi passada por um descendente do ouvidor Lourenço de Almeida Prado (1732-1796), cujo inventärio, na comarca'de·Itu, em fins do século XVIII, acusaria

\footnotetext{
"Hum livro metodo de falar com Deus/Hum dito combate Espiritual/ Hum dito dissionario latino/ Hum dito quinto curso aumentado/ Seleta primeiral Hum dito quinto curso velhol Hum ditto xamado o Indice Universal/ Hum ditto o Crioulo triste". 100
}

Lá então tinha o ouvidor ituano os seus volumes espirituais, uma seleta latina, dicionārio e os livros de Quinto Cúrcio. Não seria pouca coisa. Borba de Moraes ainda informa que, datada de 2 de dezembro de 1783 , carta do contratador João Rodrigues de Macedo ao dr. Ricardo Barbosa da Cunha daria conta de que o primeiro comprara livros de um tal $\mathrm{dr}$. Albergaria, em Minas. 101

João Felício dos Santos historia que o Contrato Social, de Rousseau; o Espírito das Leis, de Montesquieu e o Te1êma- 
co (Aventuras de Telêmaco), de Fénelon teriam aportado no arraial do Tijuco já em fins do século XVIII. A informação pode ser procedente, embora não disponha de documentos conclusivos. 102 Teriam sido ricas também as bibliotecas de Sabarā. Borba de Moraes destaca a do padre sabarense José Correia da Silva, possuidor da Enciclopédie française. 103 Em nossa investigação por bibliotecas brasileiras, na composição, paralela a esta tese, de uma "Memória Bibliográfica Brasileira (1500-1825)", de fato encontramos uma biblioteca razoavelmente rica, sobretudo ein livros franceses, e com o ex-libris do padre Correia da Silva e que hoje compõe o acervo raro da Biblioteca Pública de Sabará. A Enciclopêdie française ainda lá se encontra, truncada e incompleta, alẻm de um bom número de obras de fins do século XVIII e princípios do XIX.

Havia, portanto, no Brasil um significativo e crescente interesse por livros e leituras. Em 1775, Antonio Máximo'de Brito pedia em Lisboa à Real Mesa Censória licença para trazer livros para o Rio de Janeiro. Avaliando o pleito, a censura pombalina quis ver que livros eram. Lá estavam A arte de furtar, L'Homme conduit par 1a raison e uma obra do naturalista francês Barrère. ${ }^{104}$ Em 1795, o Conde de Rezende acusava o fato de os brasileiros procurarem os navios que aportavam no Rio de Janeiro para "obter notícias e gazetas estrangeiras e que até haviam estabelecido uma sociedade". 105

A respeito dessa circulação de idéias e interesse por formar bibliotecas, è significativo também identificar, no sē- 
culo XVIII, a prätica do comércio de livros. Este modelo e mostra de consumo da cultura bibliográfica, que se acentua e estende a todo o país jâ no sẻculo XIX, teria alguns elementos de ampliação no Setecentos brasileiro, embora, certamente, de uma maneira bastante tímida e pouco massiva.

A essa possibilidade de um comércio incipiente de li-. vros no século XVIII, encontramos recurso na cidade da Bahia, pelos começos do século. Ali um requerimento neste sentido traz o teor seguinte: "João Martins de Andrade, mercador de livros, morador na cidade da Bahia, soldado da companhia de Sebastião da Rocha Pita, pede isenção do serviço e das fachinas, pelo facto de não ter quem tome conta de sua logea e pélos grandes riscos e prejuisos". Mandado o requerimento ao Vice-Rey Vasco Fernandes Cesar de Menezes e, a infor. mar, ao coronel Rocha Pita, este o faz favoravelmente, com o despacho final: "Como pede e se nesta cidade houvesse Torre do Tombo ou Archivo em que se depositassem as memorias mais preciozas, hé certo que com tão bôa informação o elegera para... della". A data è de "Bahia, junho 22 de 1722" e embaixo vem a rubrica do autor do parecer. 106

Paréce-nos fato notável a existência de um "mercador de livros" na Bahia, jâ na segunda década do século XVIII. Se havia alguém anunciando que vendia livros, preocupado com"quem tome conta de sua logea e pelos grandes riscos e prejuisos", justificando seu pedido de dispensa da milicia e do serviço ativo como soldado da companhia de Sebastião da Rocha Pita em virtude de sua atividade econômica e comercial, claro que não se trataria de um "mercador de livros" scm 
mercado. Tanto mais que evidenciava sua preocupação com a loja de livros, com o estabelecimento que ninguém podeiria tomar conta em seu lugar, e por isso pedia dispensa para evitar mais riscos e prejuízos. Será então possível deduzir a pertinência de um comërcio ainda simples de livros entre os brasileiros de Setecentos. A informação é precāria, uma vez que, por ela, não dispomos de um melhor entendimento da natureza e qualificação deste comércio nem das obras porventura consumidas no Brasil. Entretanto, é a fonte mais antiga sobre o assunto e será aqui validada sobretudo porque insinua expressamente a questão do acesso, da aquisição e, antes, da instalação de um mercado de livros entre nós. o próprio Rocha Pita, (ao que tudo indica, o mesmo autor da História da América Portuguesa), ao justificar a concessão e a importância do pleito, reconhece a atividade e excelência, de seu comandado, tanto que afirma que o elegeria para provimento de uma vaga de bibliotecário-arquivista, caso houvesse na Bahia à época, uma "Torre do Tombo ou Archivo".

Em Vila Rica, por volta de 1750, o advogado, capitão e livreiro Manuel Ribeiro dos Santos, adninistrador dos contratos dos Dízimos da Capitania de Minas Gerais entre 1741 e 17.50, era uma espēcie de mascate da cultura bibliogräfica. Seu comércio era franco e funcionava como passaporte literärio entre o Brasil Colônia e a Europa. A importação incluía obras como o "Ipitome de las historias portuguesas" de Manuel de Faria e Souza, os "Comentos de Camōes" (que nada mais eram que Os Lusíadas, podendo tratar-se da obra em 2 tomos, anotada por Faria e Souza e impressa em Madrid, em 1639) e mais os "Sermões do Bispo. de Patava, Fr. José de 
Jesus Maria, chamado o Beatinho (...) 5 tomos de 4"n'. Pedidos havia das inevitáveis Constituiçōes do Arcebispado da Bahia, best-seller setecentista do bispo D. Sebastião Monteiro da Vide. E mais o Erario mineral, livro de medicina de Luis Gomes Ferreira, numa edição de Lisboa, 1733, em 2 tomos. Também vinham para Vila Rica os livros de Direito, a Arte latina do espezinhado Pe. Manuel Alvares, os cartapácios de sílabas e de sintaxe de um João Nunes Freire ( 1654) encontradiços nos inventārios de Minas e São Paulo, e outros comentadores do Padre Alvares, obras igualmente encontradiças nos inventārios de Minas e São Paulo. Dos clássicos, os costumeiros Virgilio, Horácio, Ovídio e Cornểio. Dos portugueses, Camöes e Bernardes. Dos 1usobrasileiros, os Sermões de Vieira e peças de Antonio José, como o "Alecrim e a Mangerona", na companhia dos muitos populares "Missaes da Antuérpia". O livreiro Manuel Ribeiro dos Santos, que tạbém era leitor, buscava as obras completas de autores de sua preferência. Feijó, por exemp1o, de quem pedia o Teatro critico y universal e as Cartas eruditas y curiosas, alëm da celebrada "Apollogia" (obra do próprio Feijó, feita em defesa de suas cartas). Havia, portanto, um mercado crescente de livros em Minas e nisso dão provas os títulos, como veremos, dos inventärios que investigamos, onde se confirma, em quantidade e qualidade, que as bibliotecas setecentistas davam segurança aos esforços dispendidos pelo livreiro de Vila Rica. Ribeiro dos Santos encomendava até jornais e revistas de êpoca a fim de atender à curiosidade dos mineiros por notícias da Europa. Em vista disso, o livreiro pedia "ọs mercurios deste ano de setecen- 
tos e 52 e todos os que se forem imprimindo de 753 até segunda ordem". 107 Não era o"Mercurio Britânico,"revista de natureza política contra o espírito enciclopedista dos franceses. Era outro título, como veremos.

o comércio de Manuel Ribeiro dos Santos deve ter sido dos mais concorridos e rentáveis, a julgar pelo documento que se encontra no Arquivo Püblico Mineiro, pesquisado por Silvio Gabriel Diniz. ${ }^{108}$ A f1. 15 do documento,acha-se apropriadamente una"Receyta dos Livros q. : me ha de fazer merce comprar o S.r Jeronimo Roiz Ayraó auzente o S.r Manoel da Cunha Neves com capas de pasta das milhores tt.os nas costas douradoz, e todas das compoziçoens mais modernas q.' ouver." O pröprio livreiro estabeleceu um modelo primário de organização catalogräfica em sua "receyta", distribuindo os pedidos por classificações setoriais como "Direito Latinos", "Histöricos Portuguezes", "Latinos" e os chamados 1ivros "Para Caża" (que tanto podem indicar obras para uso próprio, como livros para constarem do acervo, em estoque disposto à venda na casa do livreiro). Há algumas outras receitas desses livros, com datas diferentes.

A primeira, de 6 de outubro de 1747, indica, pela ordem, obras consagradas do Direito português. Lả comparecem conhecidos autores na área de Legislação e comentärios da Jurisprudência. Assim:

2 Tomos prim.ra e 2a. P.te Phebo Adicionado

1 tom. Antonio da Gama decizoens

1 tom. Gregorio Miz. Caminha tratado dos Libellos 
1 tom. Manoel Alz'. Solanno do valle cugitaçoens juridicas e furences $q^{\prime}$. tem no fim o regim.to

3 tom. Manoel Glz'. da S.a a ordenaçaó

2 tom. Antonio vanguerve Cabral tendo os abcdarios todos no principio milhor praticas Judiciarias

2 tom. Manoel Lopes Ferreira Pratica judicial digo criminal devertindo $q^{\prime}$. saó dos $q^{\prime}$. tem os 4 tom. juntos cada hum $q^{\prime}$. pesso

1 tom. Sennador Joaó Pinto Ribr. o relaçoens

1 tom. Antonio de Paiva Ponna dos orfaōs

I tom. Diogo Guerreyro Camacho de Alboim escolla moral palestras

Percebe-se que o livreiro não apenas entendia de variedade dos títulos, como ainda demonstrava estar perfeitamente afeito ao seu ofício, discriminando bem a que obras e edições estava se referindo, a fim de evitar reclamações como aquelas dispostas em suas cartas. As reclamações, como:a que aparece na carta de Antonio Ribeiro. Alvares em 25/8/1753, exam expressas com gosto e espirito, advertindo que 1 he chegaram, por exemp1o: "douz Vanguerves do tempo das a'dagaz, 1 Lemos a Instituta velho e caro, 1 Moura de Incantacions pe103 Quevedo que não tem era e quando a minha lista dizia em bom portuguez que hera da ultima Empresa, e que tinha hum $A B C$-dario no princípio de p.ans e outro no fim de toda a obra". Noutro lugar, o livreiro rèclama que lhe mandaram um "Justo Emperio lucitanorum, empresso a mais de $1000 \mathrm{a} . \mathrm{s}$ e todo roto". A relação de livros tambëm evidencia o modelo preferencial dos compradores de Vila Rica servidos por Manuel Ribeiro dos Santos. Ai se encontram os au- 
tores típicos do Direito portugues como Phebo, Caminha, Solano, Vanguerve, Diogo Guerreyro Camacho de Aboym e outros, nomes que pontuam nas bibliotecas setecentistas no Brasil, o que, sem dūvida, torna corrente e divulga o modelo de literatura jurídica orientando o leitor brasileiro da época.

Já os títulos em História, ou, como vem expresso na "Receyta", os "Históricos Portuguezes", apresentam alguma diferenciação daqueles frequentes nas livrarias que percorremos em outras fontes, embora o que a"Receita"chama de "Históricos" inclui tambëm. "3 tom. obras de Luis de camoens comentadas (.) folhas", alguma coisa de prosa doutrinal e atẻ obras no campo da Linguística. Completam o quadro:

2 Tomos Bento Gomes Coelho militares la. e 2a. p.te

2 tom. 1a. e 2a. p.te de Supico

18 toin. de P: e Antonio vr.a, 14 Sermoens, 2 Cartas, 1 do futro, 1 vozes Saudozas, e mais alguns se ouver

6 tom. de mercurios da guerra, $q^{\prime}$. por ora laboraó ou menos naó havendo tantoz

4 Livrinhos em branco, q.to mais piquenos milhor p.a andarem na algibr.a

l tom. patuá q'. tem ein mesmo verço Lingoa Latina, Franceza, Ingleza, e outras, q.tas mais milhor

1 tom. obras de Francisco Roiz Rego primavera, e Inverno

l tom. Giografia Portugueza, q'. dä noticia das terras do R. no

Sem dúvida, um pedido eclético, destacando-se o jornal de Antonio de Souza de Macedo, "Mercurio Portuguez, com as 
Novas da Guerra entre Portugal e Castela", também conhecido como "Mercúrios Portugueses, ou Relaçōes dos Sucessos Militares entre Portugal e Castela"... entre 1663 e 1666 publicadossem indicação de autoria, e muito provavelmente em edição do próprio século XVIII, já que, como vimos, o livreiro de Vila Rica não gostava de livros velhos, mas sempre "da ultima Emprensa". Macedo, como sabemos, é um dos autores provâveis da Arte de furtar (obra pủblicada em 1652, há tempos atribuida a Vieira) e tambẻm de Eva e Ave ou Maria triunfante, alêm de outras compósições.

Com o título mais aceito - "Mercurio Português com as novas da guerra entre Portugal e Castela" - o Jornal foi publicado pela primeira vez em 1663, em Lisboa, saindo com periodicidade mensal, e completando um total de 50 números, até o mês de dezembro de 1666 .

A indicação pouco precisa de ".2 tom. 1a. e.2a.p.te de Supico" trata-se certamente da Coleção política de vários apotegmas, de Pedro José Supico de Morais, obra publicada em primeira edição, parte primeira, em Lisboa, 1718 , tendo a segunda parte cunhado o tỉtulo de Coleção moral de vários apotegmas, Lisboa, 1719. As sucessivas edições (1720, 1732, 1733 e 1761) dão o tom da popularịdade desta obra, aliás, pouco tida em conta pelo pedagogo Verney, que no Verdadeiro método de estudo, toma Supico como modelo de prosa a evitar nas escolas em virtude da abundância de citações despropositadas. Como a "Receita"de Manoel Ribeiro de Santos é de 1747, as edições pretendidas deviam ser as de 1732, 1733. A obra recolhe testemunhos, ditos espirituosos, contos de 
sentido moral, enfim, traços da moralidade portuguesa, envolvendo personalidades do século, outros aproveitando a tradição popular, o que documenta a paisagẹn social politica e moral do século XVIII português. Supico teve vida atribulada, acusado de ter traído o reino de D. João V, favorecendo o irmão deste, D. Francisco. Por isso teve sua obra e trabalho duramente atingidos pelo esquecimento. Vejam-se dois exemplos do espirito de sua Coleção de Apotegmas, envolvendo escritores portugueses.

\section{Jorge de Montemor}

Achava-se no Terreiro do Paço conversando com Luis de Camões, Jorge de Montemor, célebre poeta daqueles tempos. Estava em uma janela do quarto das Damas, D. Francisca de Aragão, dama mui formosa da Rainha D. Catarina. Chegou-se um pobre a eles a pedir-lhe(s) esmola e Jorge de Montemor, apontando para a dita Senhora, Ihe respondeu:

Si hermano pedis por Diós,
A aquel Serafin pedid, $Y$ pedid para los dos,
La libertad para mi,
La limosna para vós.

D. Francisco Manuel de Melo

Havia no Mosteiro de Salvador uma freira mui celebrada nesta Corte por discreta e por tal era buscada de toda a fidalguia: Reparava ela que, cortejando-a todo o homem entendido, só D. Francisco Manuel a não tratasse. Achando-se acaso D. Francisco em umá Profissão no dito Convento, encontrou-se em uma grade com ele a tal Religiosa, encobrindo o seu nome e lhe disse: 
- Admiro-me muito, Senhor D. Francisco Manuel, que sendo Vossa Mercê um Fidalgo tão entendido, não tenha vindo ainda a este Convento buscar a Madre N.... de quem dizem que é a mais discreta freira que hoje hä na Corte.

Respondeu D. Francisco: - Senhora, a todas Vossas Mercês estimo qeralmente e tambēm tenho assentado comigo que o entendimento da mais discreta.mulher chega a saber acomodar com acerto um baú de roupa.

Dissimulou a tal Senhora mas empenhou o resto apurando toda a sua discreção no discurso daquela tarde. Na despedida, supondo a D. Francisco mui pago de a ter ouvido, se descobriu dizendo-lhe o seu nome e continuou: - Agora, Senhor D. Francisco, quero saber se na opinião de Vossa Mercê poderei também arrumar com acerto um baú de roupa.

Respondeu D. Francisco: - Minha Senhora, pelo que tenho ouvido, poderā Vossa Mercê arrumar dois baūs. 109

Dos livros "Latinos" pedidos por Manuel Ribeiro dos Santos, constam na "Receita" apenas "3 Seletas, 1 tom. escritura Sagrada de m.a folha com estampas sem concordata "e" 1 tom. as obras de Seneca A poezia e comento havendoo". Aqui também se evidencia o gosto literärio brasileiro da ëpoca, especialmente em Minas. As Seletas são obras de leitura obrigatória, assim como a não menos obrigatōria Bíblia, "com estampas e sem concordata". Curioso é o pedido de obras de Sêneca, incluindo-se a poesia e os comentärios sobre o autor latino.

Reside uma certa confusão no atribuir-se a Francisco 
Roiz Rego, a autoria de "l tomo obras de... primavera e Inverno". Desconhece-se o nome dele comoautor, devendo tratar-se de correspondente de Ribeiro dos Santos, em Lisboa, uma vez que carta do livreiro de Minas, de 4 de julho de 1750 , é dirigida a Luis Salgado dos Santos, na ausência do Sr. Miguel Roiz Batalha, e na de ambos o sr. Francisco Roiz Rego. De qualquer forma, a carta pede providenciar uma remessa de livros, indicando que "...ha huns regim.tos Militarez, ou chamadoz novas ordenanças, Leyz Reaiz q'. tem no fim hum abcdario tamanho como o corpo naó passando de 1280 rs. mandeme hum sendo novo.". Esta receita vem contida no documento do Arquivo Público Mineiro. A página 75, consta carta a Jerônimo Roiz Airão, ausente'o Sr. Antonio Ribeiro Neves, pedindo livros em branco para assentos, enfatizando que os ditos livros tenham o tamanho de uma Prosódia, ai entendendo-se medidas de comprimento e largura. Ou seja, atē para pedido de livros em branco, a referência a livro publicado é a que mais seguramente conhecia e fazia circular, em sua carta, o.1ivreiro de Minas.

A pägina 171 verso do documento, Manoel Ribeiro dos Santos fez. constar uma nova "Receita dos L.os q'. mando vir de Lx.a esta Frota de 1750 a Jeronimo Roiz Airaó - o seguinte":

5 tom. de Sermoins Espanhois em 4: intitulados nada comvox vendemse nas Logeas dos Castelhanos $q^{\prime}$. vendem. 1 .os

1 tom. de Sermoins Portuguezes, autor o Dr. Luiz Glz'Pinhr. o vendemse na portaria do comvento de S. Moniça 
2 tom. em quarto de Sermoins ltaliannos auctor - P.e Ing. Caris da Companhia de Jesus

2 tom. em quarto de Sermoins Italiannos auctor - P.e Fonti da Companhia de Jezus

Por aí se destacamo interesse e a continuidade do comércio de livros na Vila Rica do século XVIII. Na mesma "Receita", com a îndicação de livros "Para Casa", o livreiro Manue1 Ribeiro dos Santos pede

2 tom. de Medicina Irario Mineral autor Luiz Gomes Ferr.a $q^{\prime}$. morou nesta $v . a$ e curou o Nevez

2 cx.as de Guerra, como as trez, q'. me mandou, naó tendo vindo na prezente Frota, q'. inda naó vi cartas.de v.m., nem receita, nem o Nevez

l jogo de ordenaçoinz novas, naó tendo vindo na prez.te Frota

2 tom. repertorio ou Index das mesmas ordenaçoins novas, q'. me dizem se estava acabando de Compôr

2 Constituiçoens de Lx.a

3 Comentos de Cornelio, com o Latim convertido em Portuguêz

4 Artes Latinnas do P.e M.el Alz'

8 tom. q'. saó 2 Jogos de Artes explicadas de Madr. a naö tendo vindo na F'rota

1 3: tom. de Comentos de Himnos, auttor o P. e M. Fr. Josë de Assup.m q'. o primr.o e 2 : cäo tenho

2 Cartapacios de Silaba

2 Jogos 2'. saó 4 tom. Devertim.to de estudiozos

1 Jogo 4 tom. Devertimento Erudito

1 Giografia Portugueza como a q'. mandou

2 Jogos 4 tom. Larragas de moral la. e 2a. p.te

2 tom. Porque de todas as Couzas

2 tom. Queixas do Amor diviño 
2 regimentos de Botica

4 milletarez com abecedario no fim como os $q^{\prime}$. memandou

o interessante è a forma com que o livreiro, algumas vezes, registra o seu.pedido, acrescentando elementos informativos ou curiosos como o que declara a respeito de Luiz Gomes Ferreira, autor do Erário mineral, livro dos mais populares no Brasil no século XVIII e cujo autor, como o próprio livreiro informa, "morou nesta vila e curou o Neves", ou seja, alguẻm que, de uma forma ou de outra, ele conheceu e soube ter exercido a clínica médica em Vila Rica, tendo sido pessoa de suas relações. o liv́reiro mostra-se espirituoso, pedindo 2 caixas de guerra, que não 1 he chegaram, nem "inda vi cartas de v.m., nem receita, nem o Nevez". Ribeiro dos Santos está ao par de tudo o que saía ou estava para sair dos prelos portugueses, uma vez que pede tomos do Repertörio ou Index das 1eis, segundo 1 he informaram "se estava acabando de Compôr" em Lisboa. E especifico, explícito e direto no pedido de certas obras. Como no dos "3 comentos de Cornelio, com o Latim convertido em Portuguez", atento que estava a um provävel interesse direto demonstrado por seus clientes, leitores potenciais da Vila Rica Setecentista.

Ainda não havia chegadó a temporada pombalina e o 1ivreiro de Minas pedia as Artes latinas do jesuita Manuel Ảlvares e as Artes explicadas de Madureira, assim como os Cartapácios de sillaba, obra provável de João Nunes Freire, autor de outros cartapácios como o de sintaxe grande, o de gê- 
neros e pretérios com suas regras, todas obras publicadas no século XVII, ou o Cartapácio de sílabas e figuras de Inácio Leão da Silva, publicado em 1738. Ribeiro dos Santos chega ao primor da especificação, pedindo apenas o volume $3^{\circ}$ do 1 ivro Comentos dos Himnos, uma vez que o primeiro e o segundo ele jấ os tinha: "o prim.ro e o $2^{\circ}$ cà o tenho". Lá está também o Divertimento erudito, do Fr. João Pacheco (16771747), obra publicada entre 1734 e 1738. A obra é na verdade, aquilo que, na tradição literária protuguesa, se chama Centão, espécie de reunião de vérsos de vârios autores formando um sentido orgânico, quase original. Na mesma ordem é o Divertimento de estudiozos. Hä ainda livros contendo curiosas manifestações doutrinärias, na prosa corrente desde o século XVII, como é o caso de porque de todas as Couzas; e Queixas do Amor Divino, obras de explícito sentido moral e dogmático.

A pägina 215 do documento manustrito do APM aparece uma "Receita" pela primeira vez nomeando valores, quantias cobrāveis e atribuíveis dos livros pedidos para comprar a Jerônimo Airão, na ausência de Manoel Carvalho Silva e, na ausência destes, dirigida a João Roiz Moreira e, por último, a Manuel Roiz Pontes. Os livros são os seguintes:

I Tom. L.o de Medicina Irario Mineral, autor Luiz Gomes Fer.a q'. morou nestas Minnas e curou por Sirurgia nellas

1 Tom. L.o de Medicina Madeira llustrada

10 ou 12 gazetas das q'. dicerem os Ministros q'. saem ileitos em todo: R.no e L.os q.e saem 
impressos, e alúas couzas mais notaveis do R.no as mais modernas

2 Caixas de Guerra, com as $3 q^{\prime}$. me mandou....... Algūns autoz, e Panafraz das Guerras da India 1 Auto chamado Seera

2 Jogos das novas ordenaçoēns q'. Sahiraó agora novamente impressos

I Livrinho intitullado Despertador Cotidianno p. a. ter bons dias, Larga vida e Saude, vendese no Livreiro do Adro de 5 . Domingos

Algúas couzas das asima d.as já pedi a v.m. por outra via q'. cazo estejaó compradas naó se repitaó agora segunda vez

I Arte de Lingoa Franceza

I Ora de recreyo, emortais

2 vanguerve tratado pratico juridico de sacrilegio, epilogo juridico, e tudo o maiz q'. este compuzece, menos a pratica judicial, q'. ca a tenho

1 Para todos do monte Albano

1 cardozo impraxe addcionado

2 Castijaó Alfabetico juridico com todas as letras do A.B.C., impressos em 738

A obra do Dr. Diogo Guerreiro camacho de Alboim tudo $q^{\prime}$. elle compoz

2 Estevăo Daviz Index de direito arumado pellas Letras do A.B.C., como prozodia impressos em 742

A obra e tudo q'. compóz Joaó Pinto Rib.ro, menos as relaçoins, $q^{\prime}$. că tenho

A obra de Agostinho Barbosa tudo q'. compóz, em $q^{\prime}$. Forem Thezoiros dos lugarez commúns Axiomas adicionados por Tabor, impressos en 1737

2 Tom. Artes Legaez

22 Tom. toda a obra do Peg. 14 ord., 7 Forencez, 5 demayoratu, 1 de Competencias, 1 tratado 
vario, I Alegaçoens, e mais algum se o compuzece

3 Solanno, Index, ou Sucos ao d.o Peg., e mais algüns $q^{\prime}$. este tenha camposto, menos as $\mathrm{Cu}-$ gitaçoens juridicaz, e forences $q^{\prime}$. cä tenho

l M.el Barboza remiçoens a ord. e mais alguns secos cumpuzece

3. Moraes de execuçoens

1 Porq'. de todas as Couzas

1 Prozodia de Bento Per.a

1 Jogos com oito tom. Artez, Artes explicadas de Madur.a

2 Jogos 6 Tom. comentos de Seleta com o Latim vertido logo em Portuguez

2 Jogos 6 Tom. comentoz de Virgilio d.os

1 Comento de Horacio d.o

2 Comentoz de Cornelio d.os

1 Instituta comentada, a mais moderna, taōbem em P.ortuguez q'. tenho not.a a ha

2 Seletas

4 Artes Latinas em pasta

2 Jogos 4 Tom. devertimento de estudiozos

1 Queixas do amor Divino

A obra de Luis de Camoéz comentada, a melhor

As florestas do P. e M.el Bernardes

2 Jogos de Davis. Perceguidos

1 Jogo escolla do Curial

1 tom. O Secret.ro Portuguez

2 Antonio de Souza Machado desizoens, e Thome Valasco, Legaçoens

1 tom. Repertorio ou Index a ordenaçaó addicionado impreçaó mais moderna

Completam a "receita" acima, as observações, cada vez mais pertinentes ao bom ofício de livreiro, de Manoel Ribeiro dos Santos, cuidando para que nāo se perdessem oportunidades 
de realizar um bom negócio com as mercadorias que mandava vir de Lisboa.

Todos estes Livros seraó com as melhores capas $\dot{q}^{\prime}$. ouver tt.. os dourados nas Costaz, e os mais modernos $q$ !. ouver, e addicionadoz, custando os preços porq'. sempre se costumaraö vender o mais barato geralm.te e cazo haja algūns $q^{\prime}$. estejaó fora do Seu comum presso por haver poucos, e hir acabando a imprença em tal cazo naó venhaó, e havendo os por morte de algum Letrado, ou Livreiro, ou vindoz de fora, ou na feira baratos, ainda $q^{\prime}$. Seajó uzados estando Saós podem vir sendo os jogos direitoz com presso q'. tudo deixo de sua eleiçaó.

E.importante destacar a preocupação do livreiro com $\therefore$ : detalhes e aspectos decisivos de cada obra. Para alguns, acentua ele que jā dispōe do tomo tal ou qual. Em outros pontos, destaca a necessidade de ter em estoque alguma coisa mais moderna recém saída dos prélos do Reino, exemplo do pedido de "10 ou 12 Gazetas das q': dicerem os Ministros q'. saem ileitos em todo o R.no e L.os q.e saem impresos, e algúas couzas maís notaveis do R. no as mais modernas." Ou seja, o livreiro cuida de ter seu estoque atualizado com as noticias mais recentes da modernidade portuguesa, vale dizer, deixar à disposição de seus clientes, os fatos da contemporaneidade portuguesa do Setecentos. Outras vezes, o zeloso Manuel Ribeiro dos Santos dă a indicação precisa de onde seu procurador em Lisboa deve encontrar algumas obras que procura." Como em "1 Livrinho intitulado Despertador 
Cotidiano pıa ter bons dias, Larga vida e Saude, vendese no Livreiro do Adro de S. Domingos". Adverte o procurador para que não compre obras duplicatas, pedindo conferência em outros pedidos anteriores e, "caso estejaó compradas naó se repitaó agora segunda vez". Noutras oportunidades, indica expressamente a edição que quer, como em "2 Castijaó Alfabetico juridico com todas as letras do A.B.C., impressos em 738". Ou, demonstrando que tem estado atualizado com as notícias vindas d'além mar: "1 Instituta comentada, a mais móderna, taóbem em Portuguez $q^{\prime}$ : tenho not.a a ha". E faz questāo de adquirir as obras mais qualificadas: "A obra de Luiz de Camoéz comentada, a melhor". A indicação "1 Para todos do monte Albano" parece sugerir a obra de Montalvan Para todos.

Aqui percebemos um Manue1 Ribeiro dos Santos no exercício pleno de seu ofício de mercador de livros, formando um quadro o mais eclëtico possível de leitores nas Minas Gerais do século XVII. O livreiro pede, por exemplo, um "Auto chamado Seera", as costumeiras obras da apologética ou doutrina católica como a Éscola de curial de värias 1ições, dedicada à Virgem Nossa Senhora do Desterro, do padre Dr. Fradique Espínola, editado em Lisboa, 1698, em 4 volumes e com reedições no século XVIII. As igualmente costumeiras obras do Direito português, as consagradas prozodia de Bento Pereira e as Artes explicadas do P: João de Morais Madureira Feijó. E pede ainda o livro Hora de recreio, nas férias de maiores estudos e opressão de maiores cuidados, obra de curiosa doutrinação moral, sob a fơrma pedagógica, como i- 
nümeras outras correntes no século, e cuja publicação se deu em duas partes, 1742 e 1743, de autoria do padre João Baptista de Castro. No fruir e fluir do moralismo setecentista, Hora de recreio ombreia com outras de igual espirito moralista como as Reflexões sobre a vaidade dos homens (1752), de Matias Aires, Governo do mundo em seco (1748 3.ed. 1751) de Manuel Josê de Paiva (pseudônimo: Silvestre Silvério da Silveira e Silva,e $\underline{0}$ Feliz independente do mundo e da fortuna (2.ed. 1779,13 vj; do padre Teodoro de Almeida. o moralismo tem largo curso na literatúra doutrinária portuguesa, como ilustram as obras de Bernardes, Alexandre de Gusmão, Camacho de Aboim, Pe. Manuel Consciencia entre outros.

Não pāram aí os pedidos de livros de Manoel Ribeiro dós Santos. A página 317 do documento do Arquivo Püblico Mineiro recorta uma "Receyta de livros pedidos ao mesmo Jerônimo Roiz Ayrão, na ausência de Pedro da Costa Guimarães e Baniel Roiz Braga", com data de 27 de agosto de 1752. Os livros pedidos são:

4 Tomos, 2 jogos Saber impressos novam.te comprou v.m.ce cada jogo a 2.860 rs.

2 Tom. hum jogo Davis Index de Direyto Civel comprou v.m.ce 5.50 .0

I Tom. de quarto Nuno Freyre da S.a a intitula comprou por 480

1 Tom. se já se imprimio do A para diante repertorio novo das ordenaçoins agora impreças - pr.o tomo imprimiose em 749

Os mercurios deste anno de cetecentos 52 todos os que se forem imprimindo de 753 athe 2 a. ordem (.) 
As leis alvaras e cartas que se foram imprimindo em folhas de papel albuças de l4.de M.ço do prezente anino de 52 emd. e que athe ali tenho cá com declaraçaó que se quando partir a frota chegarem athe Cem folhas de papel se imprimiraö e vira dourada a imprença nas costas com tt.o de leis do Rn.om e dahi para cima o mesmo, e naó chegando a cem folhas de papel viraó soltas

I Tom. 2a. p.te de Feyjo abreviado deg.to

1 Missal de Antuerpia, que naó seja dos mais caros

9 Tom. I Jogo Guerreyro, comprou v.m.ce por $12 \$ 800$

2 Tom. ou a obra de Alvaro Balasco

I Tom. ou a obra de Antonio da Gama decizoins

1 Tom. em 4: Antonio Vasques Chaves

1 Tom. promptuario juridico Bento Per.a

2 Tom. de papel branco emquadernado em bezerro com tt.o nas costas cartas sem brochas e só como os de letra dourado de meya $f$.

2 D.os da mesma forma de q.to sem brochas

1 Tom. Guergorio Miz. Cam.a

2. Tom. Manual pratico Alex. e Caetano Gomes

Como se vê, a predominância é da literatura jurídica, espelhando-se no modelo de leitura à época. o livreiro é sempre cioso da precisão com que as obras devem estar acordes com o gosto do püblico, seus clientes. Faz sempre questão de que as obras sejam das mais modernas, recém-saidas das ültimas impressões. Não satisfeito com as recomendações que exprime diretamente na relação, ou "receita" desses 1ivros, adverte seu procurador para a qualidade, beleza e economia dos mesmos, questionando a oscilação de preços e asseverando a premência de só adquirir os que the interessam. Por isso prevịne seu representante 
Devertindo que todos estez L.os haó de ser das imprensas as mais modernas, e ultimas a que ninhum seja impresso senaó de 729 emd. e com th. os dourados nas costas. Os mais dourados e milhores todos novos, e ninhum uzado e pelo estado da terra porque se custumaó sempre geralmente vender, e estando alguns mais caros por falta das imprenças naó venha.

Logo, os pedidos de livros para a botica de Manuel Ribeiro dos Santos obedecem a um rigoroso critério de atualização e novidade. Para um pedido de 1752, o livreiro só admite receber livros com um espaço de tempo de pouco mais de 30 anos. Ou seja, só àdmite receber obras impressas de 1720 em diante. E pelas renitentes observações nesse sentido, parece que ele era, as majs das vezes, atendido em suas perorações. 0 exigente Ribeiro dos Santos estava tambëm atento aos valores enviados aos representantes lisboetas pedindo que cada um fiscalizasse o outro, evitando mandar duplicatas e sugerindo prestações de contas. Em algumas circunstâncias, o livreiro antecipa até os valores das obras, por conta de informações que 1 he chegam de quanto as coisas valèm na Metrópole.

Carta dirigida a Jerônimo Rọiz Airão; de $1^{8}$ de setembro de 1752, encomenda o Regimento nautico, "a imprensa maiz moderna e ultima imprensa que houver bem enquadernado com titulo dourado nas costas". Pede tambëm un outro livro que costuma aparecer com frequência nos inventärios setecentistas, obra da estante obrigatória na ārea das ciências da saúde. Trata-se da "Farmacopéia de Boticario Fubalece" (1eia- 
I Epanaforas da India 4 em 1 tom. $q^{\prime}$. se pedirä a Franc.o Gomes da cruz q'. Ihe emprestey aqui aliaz compre

2 Prados Escholasticos

2 Larragas 1a. I 2a. p.te de Moral empresa de 1735

2. Vieyra abreviado Sommados 4 de Sermoens de 1736

1 Constituiçaó da Bahia 1720

I Gama decioens (sic) de 17352000 rs addicionado

I Bento Pereira Promptuario juros de 1690

I Manuel Barboza remiśsoens a ord. 1730

1 Manoel Mendez de castro addicionado q'tenha no fim depois do Abcdario 32 Arestos cada hum com a sua Ley em.Portuguez no R. no e o Abcd.ro da pr.a e 2a. p.te juntos no fim imprensa a mais moderna e se achar

3 Silvestré Gomes de Moraes as execuçoens 1722 1 1742

1 Axioma juriae 1718

2 Alex.e Caetano Gomes 1748 a...8 858 rs

2 Taboins (sic) de Agost.o Barbosa ambos a 2860 rs

4 Manoel Alz'Solanno 1 cogitae 3 suco e Abcedario de Peg. impresa de 1739

2 Vanguexe (sic) pratica e Epilego juridico, a pratica ha de ter 6 pitez em hum tom. com hum Abecdario no principio das petiçoens e outro no fim junto de todas as $6 \mathrm{p}$.ez 1742

Aqui o livreiro parece mais incisivo na aquisição de obras sō as mais novas, as de ưltima impressão, salientando expressamente que, não as encontrando, não as comprem. Ra1ha, rabugentemente seus correspondentes, quanto aos preços dos livros, que os sabe todos, não admitindo que o roubem e, antes adiantando o preço que conhece de cada obra pedida. Nesta relação, aparecem algumas novịdades curiosas, como o pedido de 4 tomos do poeta barroco Francisco de Quevedo c, 
-se Tubalense), igualmente "da ultima imprensa". E encerra sua "receita" com o pedido da obra de Antonio Mendes Arouca em 3 tomos, exigindo a impressa em 1747 (portanto, a mais recente editada, cinco anos apenas decorridos deste seu presente pedido), além de 1 tomo da obra de Direito de Antonio Vasques de Chaves, antecipando não aceitar outra senão a editada depois de 1706 - o que implica a completa identificação do livreiro com a ordem de publicação das obras. Finalmente, Manuel Ribeiro dos Santos pede um livro de Antonio Córdeiro, da Companhia de Jesus; açentuando ser esta obra a impressa em 1718 ou outra mais moderna.

Já à página 381 v́erso, o livreiro pede, em "Receita de tudo o $q^{\prime}$. agora. se pede ainda o mesmo q'. vay na carta por mais facilidade demais doq'. se tem pedido", alëm de livros, escravos, uma "mollequa" da nação mina, de 15 anos e duas crioulas, de qualquer nação, para cozinheira e costureira. No que se refere a livros, pede:

A obra de M.el. de Faria e Souza a Saber Ipitome delas historia portuguezas devidido em quatro partes adornado com retratos dos Reys de Portugal do Conde D. Henrique athe Fellipiz o Vigessimo Rey de Portugal; e Comentos de Camoens;

E'o mais q'. Compós Emprensa q'. achar mais moderna; e senaó achar, sinaó o Ipitome esse mesmo traga

1 Livro Maximas de Luiz 14 de França Creticadas por hú M.e Frade.

6 Tomos Escolla de Córial cada hû com duaz p.ez empresa de 1696

4 D. Francisco de Quevedo 
singularmente, as Maximas de Luiz XIV de França. A predominância continua sendo de obras de Direito, e não será difícil imaginar o porque, face à organização do Estado português no Brasil, e em Minas Gerais, com a abundância aqui de 'magistrados, desembargadores e bacharéis. 0 próprio livreiro tinha formação específica em Direito. Além de Direito, todavia, comparecem nessa amostragem obras de História portuguesa, como o Epitome da História de Portugal de Manuel de Faria e Souza (1590-1649). O curioso é que o 1ivreiro dá todas as descrições da obra, antecipando que ela vem ilustrada com retratos dos reis de Portugal, desde o Conde D. Henrique até Felipe de Espanha. Aparecem igualmente as Epanafóras da India, obra apologética da conquista portuguesa na Asia. A literatura doutrinária e de moral cristã aparece, com a Constituições primeiras do Arcebispado da Bahia, do bispo Sebastião Monteiro da Vide, o padre Larraga, do Prontuário đe Teologia mora1, que Ribeiro dos Santos indica preferir a adição de 1735; o padre Vieira dos Sermões, numa edição de 1736 .

$\mathrm{Na}$ mais extensa "Receita de Livros", que aparece à página 398 verso e página 399 do documento citado do Arquivo. Público Mineiro, Ribeiro dos Santos pede

4 tom. 2 Jogos Saber q'. comprou o Ayrão cada dous tom. q'. hum jogo

2 Castijaó Alfabetico juridico com preço d.o

2 Davis index de direito Civil com preço d.o

1 Nuno Freire da S.a em 4: a instituta

8 tom. 2 Jogos de M.el Aiz'Solanno 2 de Pegas. 
6 exccujetaçōes forences, Comproou o d.o Ayraó hum jogo dos Sucos por $4 \$ 150$ e os 4 cujitaçöes por $1 \$ 600$

2 tom. vanguerve Pratica judicial, obra nova com Index das petiçoens no principio e outro no fim, junto de todas as 6 p.tes

2 Jogos 6 țom. de Comt.os de Seleta

3 Jogos Comentos de Concilio

3 Jogos 1 Comentos de Innoz (sic)

3 Cartapacios da Sintaxe

3 de generos e Preteritos dos P.es

3 d.os de rudim.ta

6 Artes Latinnas do.P.e M.el Alz'

8 tom. 2 Jogos Artes explicadas de Madr.a

1 Emblemas de Alcrato (sic) construhidos os Ipigramás em Portuguez literalm.te como os mais com.tos $q^{\prime}$. pesso asima

2 Jogos 18 tom. de Davis

2 Jogos 12 tom. de escola do curial

2 Jogos 10 tom. de Florestas do P.e Bernardes

6 tom de Comentos de Horat.

1 ou 2 tom. de Repertorios das novas ordenaçoens - que for de $H$ para diente q. o tom. até ahi me mandou já o Auráó

I jogo de mais inteiro do d.o Repertorio das novas ord. 'se ja estiver acabada todas as Letras do $A \dot{b} c$

4 ovidios, comentados q'. tenháo os 5 L.os dos tristes e toda a obra

4 Comentoz dos tristes, e havendo de Arte Amandes e outros venhaó outros 4 jogos os tomos q'. ouver de opra (sic) hum de cada couża, naó vindo huä opra (sic) duas vezes as mais modernas $\mathrm{c}^{\prime}$. ouver como vindo a opera de Alecrin e mangereno em hum tomo, naó vir deste Na frota mandarä v.m. todas as gazetas e seus suplementos do anno do pr.o de Janr.o emtè a 
sahida da Frota, e taöbem todas as Leys, ou couza q'. se publicque e se imprima como a Pragmatica, e naó se (.) disto como a am.o Ayraó

2 Prozodias de Bento Per.o

2 tom. Panaforas (sic) da India

2 Selletas

2 'Jogos 4 tom. de Supicoz (sic)

2 virgilios

2 Jogos toda a obra de vieyra 46 tom.

2 Jogos 6 tom. com.tos de virgilio

a obra de feijö manher critica, e tudo mais q'. he da d.a obra, ad.e vai d.o

I Jogo 4 tom. obra de D. Franc.o de quevedo

1 Jogos 4 tom. de. Larragas de moral

Pa 0 Rd.o Franc.co da Costa

Sermoens Espanhoes entitullados nada comvox, vendemce nos Castilhanos q'tem logeas de L.os os sermoens do Dr. Luiz Glz' Pinh.ro, per alcunha o toucinho, vendemce na Portaria do Most.ro de S. Monica

os Sermoens do Bispo de Patara Fr. Jose de Jesus Maria, chamado o Biatinho, vemdemce no Corvento de S. Dm.os saó 5 tom. de 4: quando se naö achem na Portaria do d.o Comvento se se fizer a deligencia algum religiozo do mesmo comvento os ha de vender; ou dizer onde os ha Tiatro critico de Feyjó - toda a obra escrita por elle 1 Antetiatro de Manher a mesma obra 1 Sarmento 2 tom. resposta a mariher = Concordata Salazar a mesma obra = Apologia feita pello mesmo feijō em defença da sua obra = os exorcismos = tom. 2 Impressos em coimbra sobre a mathematica, resposta taōbem a d.a obra = tom. de Cartas do mesmo feijo = e todas as mais obras $q^{\prime}$. tiverem sahido do d.o. Feijó ou contra elle 
2 Missaes de Antuerpia

2 tom. Constituiçoens da Bahia

27 tom. de folio ............54:000

187 dos de $1 / 4 \ldots \ldots \ldots \ldots . \ldots . . . .93: 000$

$147: 000$

Esta receita de 1 ivros com as recomendações de praxe quanto a preços e qualificações das mercadorias segue em carta ao "Sr. Antonil Rib.ro Neves auz.te o sr. Daniel Roiz Bra, e na de ambos o sr. M.el Roiz Pontes"., com data de 6 de maio de 1751. Entre outros pedidos de material a ser adquirido em Lisboa, Ribeiro dos Santos faz questão de receber os ditos livros, salientando que o procurador busque os mais baratos, que se vendem em feiras, não esquecendo de adquirir os mais modernos, da ültima impressão, e os compre barato, mesmo usados, desde que inteiros. Expressa a orientação de que
"Pella fantezia (sic) pareceme emportaraó os d.os L.os $300 \$ r s$. vaó quatrocentos o resto fi- carà p.a hir correndo com as demandas sempre me venha a receyta inteyra que pesso, e se p.a ella, e gastos faltar dr.o o tome v.m. a juro ou a risco, e. passe Letra sobre mim".

Assim se demonstra o superior interesse de Manuel Ribeiro dos Santos em adquirir as obras inteiras e novas, certamente para as revender em Vila Rica. Alguns titulos repetem pedidos anteriores, outros parecem indicar pleito de algum cliente com desejo de adquirir cọisa nova. Aparece o pedido da obra de Antonio. Josē; a ópera Guerra do Alecrim 
e Mangerona, os clássicos despontam, como os pedidos de Ovídio, Virgílio, Horácio, sobretudo Ovídio, de quem se pede a obra completa, e mesmo a pouco frequente Arte de amar. Também se pedem as obras de João Nunes Freire, os célebres Cartapacios de sintaxe, Cartapácios de generos, Cartapácios de pretéritos, e mais o Rudimenta. Pela primeira vez, vê-se aqui o Emblemata de Alciati, com construções epigramáticas em português, incluindo comentários. Alciati é autor que aparece também na Bahia em documento adiante comentado. Permanecem como autores portugueses preferidos Camões e Bernardes, aiêm do luso-brasileiro Vieira. Destacam-se, pela preferência, a costumeira Prozodia de Bento Pereira e a Gramática latina do padre Manoel Alvares SJ. A relação repete pedidos de obras de Quevedo e dos autores de doutrina e moral cristãs, como Larraga e os sermonaristas de curso frequente no Brasil Setecentista. O curioso é o interesse demonstradopelo lịvreiro de Vila Rica em adquirir toda a obra de Benito Feijó, o discutido e polêmico autor do Teatro crítico universa1. O livreiro não apenas pretendia toda a obra de Feijó, como também aquela dos autores que polemizaram com o religioso, demonstrado-se o interesse pelo debate em torno de ịdéias da filosofia de fundo místico e escolástico.

E a seleção de obras para exposição e venda do livreiro Manuel Ribeiro dos Santos permanece com a Receita constante das päginas 402 e 403 do documento pertencente ao Arquivo Público Mineiro. A carta dirigida a Antonio Ribciro Neves, de 24 de junho de 1751 , reafirma as mesmas recomendações de conseguir livros das.mais novas impressões, com 
as melhores ilustrações, capas douradas, edições adicionadas e pelos melhores preços. Neste ponto, o livreiro de Minas arremata o interesse em títulos novos, sobretudo de obras de Direito acrescentando pretender "de cada autor q'. procuro toda a obra que elle compor e paresseme, q'. naó hä mais autor portuguez que escrevesse de 740 p.a deante novo de Dir.to e havendoo venha taóbem", demonstrando um apurado senso de oportunidade e conhecimento em matéria de edições em Portugal. 0 documento se completa com o pedido de "Os mercurios $q$ '. se tiverem emprimido de pr.o de Jan.ro de 750 em diente e ate findar o prez.țe de 751 remeta o resto".

São os seguintes os livros constantes da "Receita" de 24 de junho de 1751:

1 Jogo 2 tt.o Giografia portugueza

obra tudo o que compos M.el de F.a e Sz.a com os com.tos a Camoins

1 Jogo 3 tt. com.tos de Ingnez (sic)

2 Grados gramaticos p.a Estud.oz

2 tt. Biblia e Concordata infolio Letra grd.e como huas q'. me mandou o Ayraó empreçás em 731 e ambas custaraó ...6\$400

2 Concilio e Com.to vertido Latim em Portuguez de 1739

As leys impreças as mais modernas e milhores que se acharem de q'. trata a ord. do L.o 3: t t.o 64 tudo bom os Sagrados Canones todos os de q'. trata a d.a ord.

1 Jogo de 3 ord. nova's impreças em 747

1 Jogo de Reportorios das mesmas imprenças 749.

2 tt. de Reportorios infolio impreços em 743 'q'. tem todas as letras do Abc 
2 tt. la.e 2a.p.e de regm.tos da faz.da R.l ou

Siztemas impreços. em 724

2 Jogos 18 tt. de Guerreyro 1733

2 tt. I Jogo de Alvaro vallasco emprenço 1731

2 tt. Antonio da Gama desizoins empreço em 735

1 tt. em quarto Ant.o vasq.s de chaves impreço - mais moderno

2.tt. Bento Per.a prontuario in juris de 690

1 Jogo 7 tt. de Pegas Forences de 729

2 tt. M.el B.ar em as remiçoins a ord. de 730

2 tt. m;el Mendes de Castro com Abc daz duaz p. tes junto no fim, e 32 leys do Rn.o em portugues taóbem no fim em cada t $t$. o mais moderno

2 L.oz de folio em branco com capa e tt.os dourados como os $q^{\prime}$. vierem de letra redonda o t t.o dira pecullo juriz

2 d.o na mesma forma com os mesmo tt.os dourados em $g \cdot e$

2 Jogos 4 tt. Gabriel Per.a de Castro

2 tt. Jeorge de cabelo (sic) 1734

2 tt. Gregorio Miz Camenha de Libelle (sic) 731

1 t t. Joaó Miz da Costa nos estillos da caza da Suplicaçaó

1 tt. Luis Sanches de Mello de indicis

I t t. Matheus Homem Leitaó

$1 \mathrm{t} t$. Michael Reynoso

2 Jogos 6 tt. S.e Gomes de Morais as exc.ez de 742

1 tt. Simaó de olivr.a da Costa de 718

2 t t. Simaö vas B.ar axiomas de 717

1 tt. Thome vás allegaçoins de 731

1 Jogo 2 tt. de Tabores a B.ar

3 tt. Alex.e Caetano Gomes 748

2 tt. Ag.o de Barros Ferr.a a Instituta e Leys e o mais q'. tiver composto 1746

1 Jogo 2 tt. Castijaö

1 Jogo $2, t$. Davis

2 tt. Ferr.a pratica criminal com as 4 p.tes em cada t .1741 
I tt. obras de Joaó P.to Rib.ro de 729

1 Jogo 2 tt. Bento Gomes coelho Milicia pratica

2 tt. d.a Jogo de Jozé de Alm.da

1 Jogo Espada e Toga

1 tt. Nunio (sic) Fr.e da S.a a instituta de 1740

2 Jogos 8 tt. dos Sulannos cogitaçoins e sucos a Peg. 1739

1 Jogo $4 \mathrm{tt}$. (.) a ord. 1741 e o mais se algum tiver escrito p.a diente a d.a ord.

A obra e tudo q'. tiver composto o Dezembargador do Passo Ignacio da Costa Quintēlla

4 tt. 2 Jogos de Vanguerve praticas epiligos juridicos com os Abc juntos nofim, e outros de petiçoins no principio isto se entende as duas raticas $q^{\prime}$. os dous epillogos o q'. se achar mais moderno 742

obra e o q'. tiver composto Ant.o Cord.ro

Aqui não se verificam muitas novidades dos outros pedidos feitos por Ribeiro dos Santos. São matérias sobre as quais ele mais se debruça ou mais requisita, obras do Direito português. No entanto, distinguem-se alguns autores e títulos, colno o Desembargador Ignacio da Costa Quinte1la, ou o jurisconsulto português João Pinto Ribeiro ( -1649) his.toriador de prestígio no século XVII e mesmo no XVIII, autor de uma singularíssima preferência das 1etras às armas, publicada em 1645. A João Pinto Ribeiro tambëm se atribuiu a autoria da Arte de furtar, já que este antes toma a Historia portuguesa como um dos modelos de espírito libertário da ẻpoca e é o escritor doutrinário dos Tratados da usurpação, reterição e restauração de Portugal, que aparece em suas $\underline{0}-$ bras varias, publicadas entre 1729/1730, contra a malquista 
ligação política de Portugal à Espanha. Entre a predominância de obras do Direito português, registram-se uma obra de Geografia, os comentários de Manuel de Faria e Souza com os títulos de Camões, o Grados gramaticos para os estudiosos, 'e alguma matéria religiosa.

Finalmente, são, ao todo, dez relações e um igual número de cartas dirigidas, principalmente a Jeronimo Roiz Ayrão, Antonio Ribeiro Neves, Manoel da Cunha Neves, Manuel Roiz Pontes, Manuel Carvalho Silva, João Roiz Moreira, Miguel Roiz Batalha, Francisco Roiz Rego. Quando não relaciona diretamente os livros que quer, Ribeiro dos Santos manda em carta algumas queixas e reclamações a respeito do estado dos livros ou de sua qualidade, sobretudo quanto à data de impressão.

Assim vem transcrita a última carta disponível, dirigida a Domingos Ribeiro Neves, com data de 12 de abril de 1753, mais uma vez pedindo o envio de obras com data atualizada, a maioria de Direito. São pedidas 3 ordenações impressas em 1747 e outras que completèm a coleção de repertórios de que dispõe o comprador. Pede-se ainda um jogo de obras, as mais novas, em 9 tomos, de Diogo Camacho Guerreiro de Aboim. Mais um volume de Chorro $($ Sic $=$ Xorro) ou Arte portuguesa e 3 tomos de Alexandre Caetano Gomes, edição de 1748; 2 jogos em 4 tomos da obra de Tabores a Barbosa; 2 tomos in $4^{\circ}$ da Instituta com comentārio do latim vertido em português, de Nuno Freire da Silva, impressa em 1740; 1 jogo de 2 tomos da obra de Davis com abecedário de juris; Os "mercurio" de 1752 
e 1753 e mais as gazetas de 1752 e as leis todas de 20 de setembro de 1752 em diante até a data de recebimento da carta pelo procurador.

Esta última carta traz ainda uma queixa do livreiro de Vila Rica a Domingos Ribeiro Neves. E a de ter recebido um livro com as leis novas de Portugal, excluido o regimento da Relação do Rio de Janeiro. Ribeiro dos Santos adverte que nem recebeu a dita relação em suplemento, como atesta ter circulado em avúlso por Vila Rica. E enfatiza, por fim, que as gazetas 1he cheguem na forma impressa e não em avulso como as que recebeu do mesmo Domingos Ribeiro Neves em 1752 .

Já nos fins de Setecentos, São Paulo dá o tom das características de leitura de feitio prätico. Carta de 12 de julho de. 1797, assinada pelo Secretārio de Estado D. Rodrigo de Souza Coutinho ao Gal. Antonio Manuel de Mello, indica remessa de livros que trata de curar e preservar a peste. ${ }^{110}$ Carta de 21 de agosto de 1798, do mesmo Secretário, remete impressos sobre a cultura do cânhamo. Na de 7 de fevereiro de 1799, manda livros para

... povos habitantes dessa capitania afim que por meio da sua lição adquirão aquellas luzes e noçoens, que lhes são necessarias para o adiantamento da cultura de suas propriedades territoriais, fazendo uso dos conhecimentos, que mais analogos forem ao terreno. 110

E que livros eram? Justamente 
Fazendeiro do Brazil em dois volumes 20 exs.

Memoria sobre a cultura do loureiro

cinamomo por Fr. Jozé Mariano da

Conceição Vellozo

20 exs.

Pipireira negra, pelo mesmo

50 exs.

Memoria sobre o methodo economico de

transportar para Portugal a aguar-

dente

40 exs.

Memoria sobre a caneleira

50 exs.

Memoria sobre a plantação dos algo-

doens, por Jozé de Sá

10 exs.

Extracto sobre o methodo de se pre-

parar a potássia

100 exs.

Extrato do methodo de se fazer ni-

trato de potassa, ou salitre

Chaptal

50 exs.

Instrucção sobre a combustão dos vegetaes - João Felipe da Fonseca

25 exs. 111

Junto com outra carta, de $1^{8}$ de abril de 1799 , D. Rodrigo de Sousa Coutinho envia ao mesmo Gal. Antonio Manuel de Mello, mais livros e livros, com indicação de preços, na primeira demonstração conhecida de coação de leituras e formação de gosto dirigido, via merchandising da Tipografia do Arco do Cego e dos interesses do Estado:

Alcalis fixos. V. I Potassa

Ditos i luminadas

Sciencia das sombras

Folnetos do cravo Girife

Ditos da cultura das Urumbebas

E mais outros 1ivros, em carta de 6 de maio de 1799: 


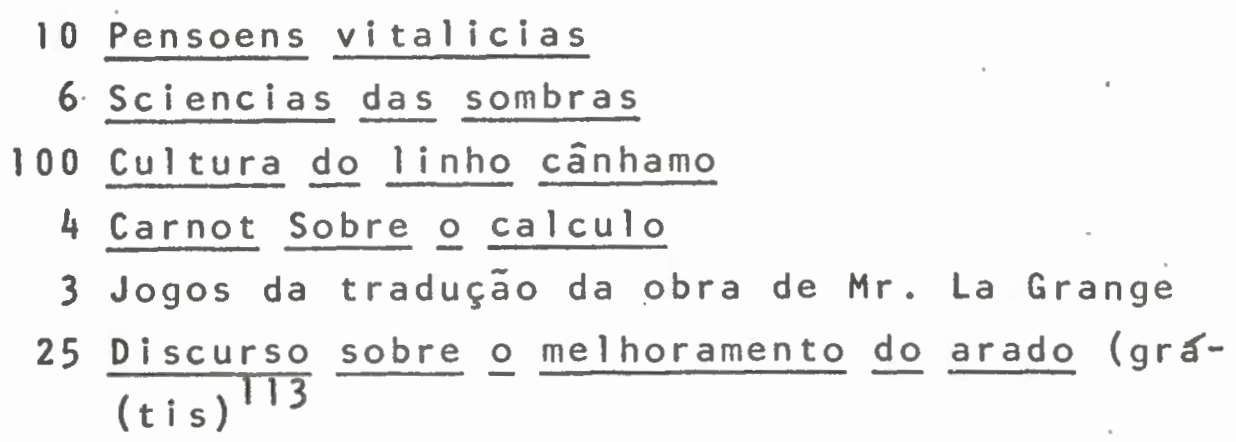

Tai.s preocupações de uma cultura das ciências präticas, extensiva a uma população necessitada de luzes revelam o interesse do Estado em "forçar" determinações de juízo nãobeletrista, assente talvez com a natureza do estágio agrário da Colônia. A isso responde o Gal. Antonio Manuel de Castro e Mendonça a D. Rodrigo de Sousa Coutinho, de forma favorāve1, em 21 de novembro de 1797, primeiramente, comunicando ter feito distribuição de livros traduzidos "Sobre o modo de curar, e preservar o mal da peste". 114 Em 20 de novembro de 1797, antecipa distribuição "dos exemplares q. contem a discripção, e dezenho das arvores da Quina inviados com o oficio de 23 de abril do corrente, e ja tenho destribuido alguns por aquelas pessoas, que mostrão ter conhecimento de Botanica". 115 Carta de 20 de abril de 1798 dispõe sobre cumprimento de determinação superior, 1iberando o professor de Gramatica latina da cidade, "que Sua Mag. 1 he permitia poder ensinar pela Gramatica que.julgasse mais util, e facio ao progresso dos seus discipulos", 116 o que evidencia a abolição dos métodos da reforma pombalina, democratiza o ensino do Latim, e pulveriza o elemento nuclear das mudanças verneyanas... 
Em.carta de 13 de abril de 1799, o mesmo Gal. Antonio Manuel de Castro e Mendonça dá conta do recebimento de uma obra sobre Arquitetura Naval, assegurando que "della procurarei tirar a maior instrucção, reputando-me feliz, se por esta parte das Mathematicas, tão protegidas de V. Exa. poder fazer algum serviço ao Estado". 117 De 10 de janeiro de 1800 , declarando ter recebido "o volume dos exemplares da obra sobre os alambiques para a destilação das agoas ardentes, - qual logo fiz entregar a João Manso Pereira". ${ }^{118}$ Em 16 do mesmo janeiro, comunica o recebimento de folheto sobre a cultura dos cânhamos, "a qual S.A.R: tão encarecidamente manda animar em Curitiba, e Paranaguä"119, o que significa estender o merchandising literärio a provincias próximas da órbita de São Paulo. Em 4 de janeiro de 1820, confirma o recebimento da obra "Curso de estudos para 'o uzo do commercio"120, o que possibilita concluir o esforço estatal pela leitura de temas e matérias prāticas; ampliando o universo de livros além da natureza renitente e pertinaz de assuntos exclusivamente religiosos. Em fevereiro do mesmo ano, Castro e Mendonça considera sobre os poucos discípulos em Retórica e Filosofia, mas acentua a vocação de muitos, na capitania, pela carreira eclesiástica.

De São Paulo, ainda, jã no princípio do sëculo XVIII, é a "Memória do convento do Carmo do Mogy, para se remeter às Academias Reaes, que fazem em Lisboa, 1723". o convento, fundado desde 1629 , tem seu interesse aqui despertado pe10 "Cathalogo dos livros do convento"; registrando as obras seguintes: 


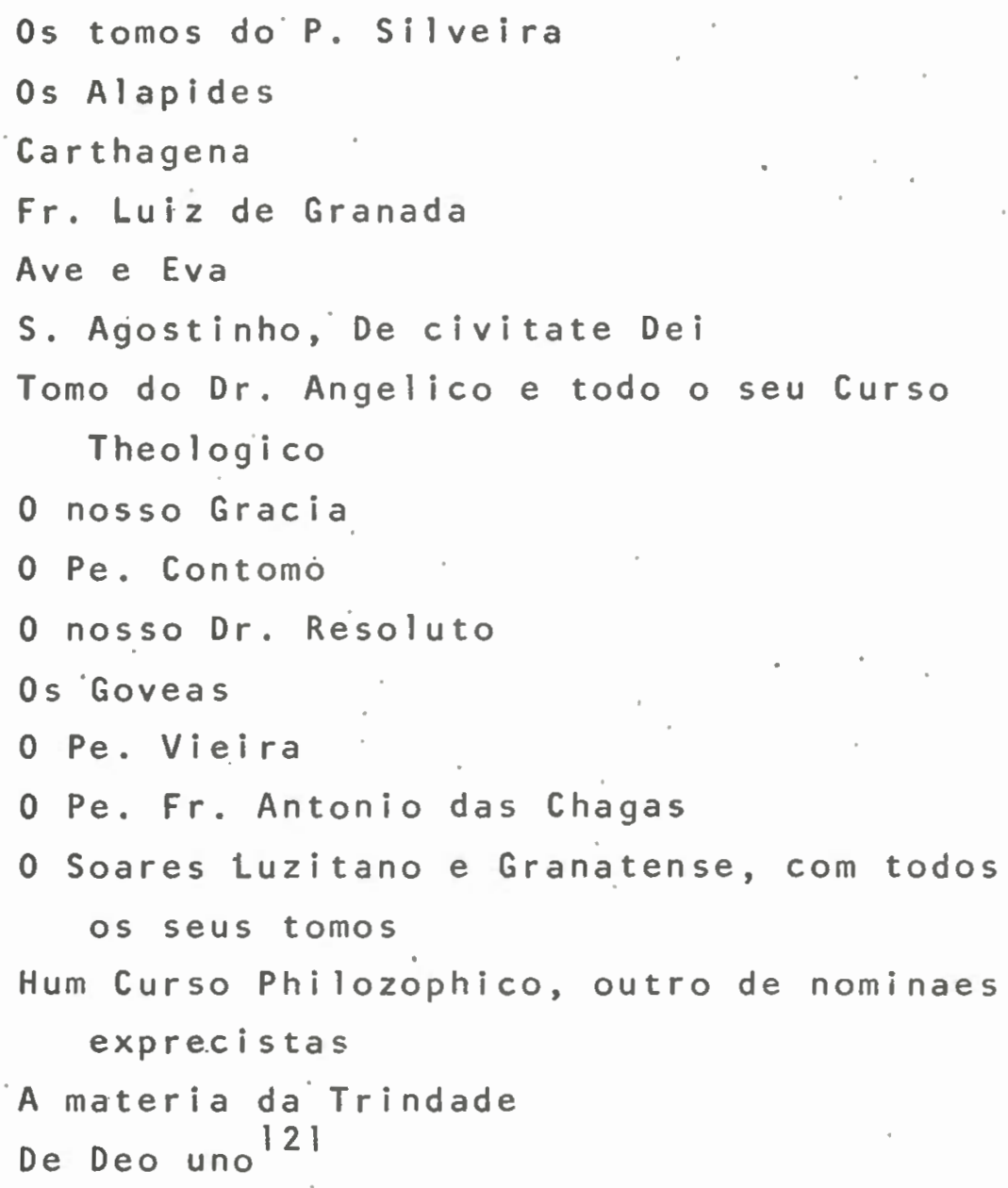

: Uma curiosa nota acompanha o encerramento desse catálogo e que diz: "Não consta, nem se acha que houvesse reli giozo algum que compuzesse livros nem tam pouco os mandasseimprimir". A nota vem assinada pelo prior do Convento, Fr. João de Assumpção. 0 mais de interesse nesses documentos trata de questões envolvendo a materialização das determinaçōes, quanto às escolas e classes, em situações e datas posteriores.

Ainda sobre recebimento de livros, destaque para a carta de D. Luiz Antonio de Souza, de São Paulo, 12 de julho de 1768 e dirigida a Pombal, dando conta do recebimento da Dedução chronologica e analitica, aproveitando ainda para de- 
sancar o ensino até aí àplicado na capitania pelos jesuítas. 122 Aqui a coação não se dava pelo senso prático como o demons: trado por D. Rodrigo de Souza Coutinho, mas pela cerrada hostilidade ao predomínio dos inacianos no campo da educação, reiterando o que atrás assinalamos.

o perfil das leituras setecentistas na Colônia, a partir de documentos publicados, remete-nos ao dirigismo estatal, o que inclui "sugestões" e interditos a um leitor considerado em segundo plano e dependente dos bons ofícios de seus superiores na Metrópole. Por essa mesma época é a "Copia do rol dos ornamentos de que consta a carta q. escreveo ao Ten. Ce1. Ajud. de Ordens Affonço Bote1ho de Sampayo e Souza:.. e vay copiada neste $L^{\circ}$ a $f .66^{\prime \prime}$, documento relacionado com a Camara da Vila de Santos, em 1769. Dentre os ornamento aí declarados, um nada surpreendente Missa1. 123 Em carta de São Paulo e assinada, a 31 de dezembro de 1769, pelo mesmo D. Luiz Antonio de Souza dirigindo-se ao Juiz de Fora de Santos, Joze Gomes Pinto de Moraes, recomenda-se "mandar Iimpar a Livraria para que se não arruine de todo com o cupim". 124 Mesmo missivista, mesmo destinatärio, carta de agosto de 1770 cita "Jacob de Castro materia Medica" como reforço à inteligência de argumento desenvolvido quanto a contratado res da pesca das baleias na província. 125 Mesmo missivista, desta. vez dirigindo-se ao Pe.Me. Fr. Manoel Ville1la, a quem faz eleição "para mandar fazer hũ exame junto com o Juiz de Fora dessa V.a em a livraria do Collegio por Ordens $q$, tenho para isso para efeito de separar aquelles livros, q contem as materias proibidas". Faz ver tambēm ao Juiz de Fora que 
cumpre determinações da Real Mesa Censória. As cartas são da mesma data: São Paulo, 26 de janeiro de $1771 .{ }^{126}$ Por fim, a mesma lembrança do assunto ao capitão mor de Mogi das Cruzes, ao Prior do Carmo de Mogi e, na mesma data, 29 de janeiro de 1771, extensiva ao Sargento-Mor de Itu. Para - guardião dos franciscanos em São Paulo, o cerco aos livros proibidos se fecha em março de 1771.127

Dos livros "sugeridos" ou interditos pela expressa detèrminação do Estado na vida dos cidadãos passamos àqueles que constavam das livrarias particulares, vale dizer, pela ação direta do interesse de um leitor colonial, condicionado ou não por aspectos legais que o Estado assume em detrimento do gosto pessoal. E assim chegamos ao último inventário destacado dentre os publicados pelo Arquivo do Estado de São Paulo em 1939 e a que já nos referimos no capítulo de leituras seiscentistas. Tal documento indica um modelo das leituras do século XVIII no Brasil a partir do horizonte mental de um bandeirante paulista nos começos do Setecentismo.

E o inventārio de Mạthias Rodrigues da Silva. Reaparecem, em grande estilo, e na esmagadora maioria, os livros típicos da ciência religiosa, o que jả era prática no século XVII. Assim, temos:

\author{
Despertador christiano \\ Floro christiano \\ Sermões da Semana Santa. \\ Orações evangelicas \\ Vida de, São Bento \\ Floro historico
}




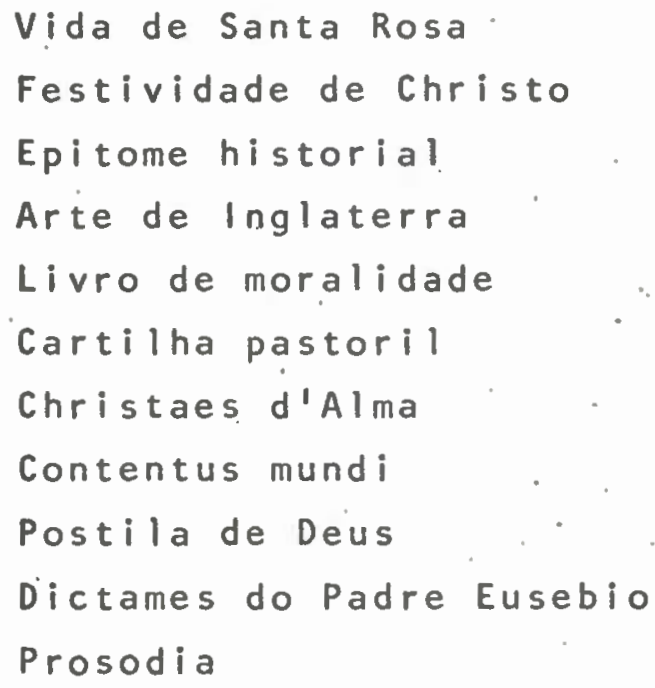

Como se pode notar, num documento de 1710 , dos dezessete títulos da relaçãọ, somente dois, "Arte de Inglaterra" e "Prosodia" escapam da categória doutrinária religiosa. 0 primeiro será, provavelmente, uma gramática do inglês, estudo com mecanismos de iinguagem para orientação e uso do falante, realçando sobretudo a base sintática do idioma, a exemplo da Gramātica inglesa ordenada em português, por Carlos Bernardo da Silva Teles de Menezes (Lisboa, Francisco Luis Ameno, 1762).. Jä a Prosodia in Vocabularium trilingue, 1atinum, 1usitanum et castellanum digesta é seguramente a ora do padre Bento(ou Benedito) Pereira, um dos livros de maior frequência e circulação nas livrarias setecentistas brasileiras. Suä primeira edição.ē de 1634 e já em 1750 estáva na décima edição, o que evidencia uma imensa popularidade do livro tambēm em Portugal. Os outros títulos da 1ivraria de Mathias Rodrigues da Silva denunciam seu perfil de leitor atrelado a um universo mental prevalente, o do estreitamento intelectual à base de condimentos ascëticos, místicos, doutrinários, enfim. O destaque vai para "Christacs 
d'Alma", com certeza Cristais de alma, frases do coração, retórica do sentimento, amantes desalinhos, etc., do padre Antonio de Escobar, carmelita calçado (1618-1681), obra cuja 1. ed. data de 1673 e que teve outras muitas em Portugal, para indignação de Verney, que a considerava, além de um título com gosto duvidoso, o signo da decadência literária e do prazer da. leitura no Portugal Setecentista. ${ }^{128}$

Essa tendência de predomínio da literatura religiosa ou mística, que se faz notar desde o século XVII, vai tomar corpo no século XVIII em termos quase absolutos. Grande foi a presença dos religiosos, com seus colégios e suas doutrinas no Brasil, no vértice mesmo da união Igreja-Estado, daị porque se pode explicar o avultado volume de livros nesse campo. De passagem, identificamos a maior parte das bibliotecas brasileiras constituidas por padres e bacharéis, alguns até possuindo ambos os títulos. Exemplo disso é a biblioteca do padre Dr. Bernardo Madeira, cidadão português morador em Vila Rica, inventariado em 6 de abril de 1756 no "Livro da Irmandade do Patriarca S. Francisco de Assis", que tinha "136 livros", a imensa maioria de obras de Religião, de que se destacava "I Escudo mariano". 129 


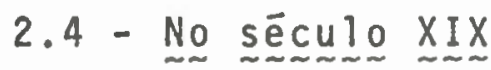

o processo de mudanças sociais, políticas e administrativas que se observa no Brasil, particularmente até o advento do Impërio, se faz acompanhar, de forma progressiva, por um conjunto de mudanças nos häbitos do leitor - primeiro, em termos quantitativos, pelo aumento de livros e bibliotecas; segundo, em termos-reiterativos, pela manutenção das tendências de leitura no século XVIII; e, terceiro, em termos valorativos, pela permanência consagradora de um universo sócio-cultural que aparenta pretender um estägio político autônomo ou independente.

De fato, a observação mais óbvia que deriva de nossa investigação das livrarias oitocentistas, nas fontes subsidiárias e notadamente a partir da análise dos inventários de bens no Brasil, è que o país parece mudar, aumentam e massificam-se as bibliotecas, ocorre um crescimento horizontal de títulos e de assuntos, com a variação e circularidade de livros populares desde o século XVIII e o acrescentamento de outros, novos e antigos, alguns até aparecendo pela primeira vez e antes ausentes das livrárias coloniais brasileiras. o que não muda é o perfil sociológico desse leitor, em geral um homem abastado ou de classe média, entre conservador e liberal, ainda preso ao limite da devoção religiosa e ao profissionalismo, seguramente curioso e interessado numa maior gama de interpretações do mundo à sua volta. 
o sêçulo XIX brasileiro começa, com efeito, pelo aguçamento, ainda proveniente do sëculo anterior, de um período conturbado em Portugal, desde o fim do reinado de D. Josê I e da sombra impressiva de Pombal, passando pela declaração de demência da rainha D. Maria I, desaguando na ascenção do Principe. Regente, (depois rei D. João VI) e precipitando-se na invasão das tropas de Napoleão a Lisboa. o que antes parecia dificil, demorado ou impossivel de acontecer, em termos de civilização, pôde afinal ser conhecido em pouco tempo no Brasil a partir da transferência da Corte, tangida pela füria napoleônica para o Rio de Janeiro em 1808 . Alçado em 1816 à condição de Reino Unido a Portugal e Algarves, o Brasil pôde afinal contar com melhoramentos sociais éfetivos que se vão ampliando, desde 1808, da modernização da malha urbana ao caráter fundador de novidades, como, por exemplo, a criação de um Jardin Botânico, de uma Biblioteca, de uma Tipografia e, em especial, de uma abertura dos portos às nações amigas. Tudo isso, sem dưvida, vem acelerar um sentimento eufórico de expansão sōcio-cultural, um gosto nascente pela natureza da nacionalidade e, o que nos vai interessar aqui, de uma mais ampla vontade de saber, de ler, de informar-se.. Assim, com a criação e disseminação da arte tipográfica, jornais, livros, confrarias e debates vieram a tornar-se elementos multiplicadores de uma caracteristica excepciona1: a passagem do Brasil à condição de país emergente num estágio incipiente de civilização.

Parece fora de dúvida que o Brasil oitocentista passa a ser visto e considerado como um universo mental diferente 
a partir da mudança poítica e administrativa. Mas não será da acepção exclusiva da transferência da Corte esse processo de transformą̧ão. A sociedade tambẻm se organiza, a educação se amplia, começam enfim a ceder algumas das mais significativas barreiras colonialistas ao nosso papel de gestores de um desenvolvimento nacional associado a um processo civilizatório que compreenda maior integração com idëias e culturas correntes no continente europeu. Tanto seră isso verdade que, no caso de nossa investigação documental, constata-se um aumento massivo de títulos e de autores que encontramos nas bibliotecas desde o Setecentismo a este período do século XIX, alguns dos quais absolutamente noviços ou ausentes das livrarias, ai incluídos os proscritos, como Locke ou Pascal.

Desde o princípio do século, pois, mesmo que a intenção (ou especulação) indutiva de leituras nem sempre correspondesse ao gosto püblico, è notāvel a preocupação reinol em fazer chegar aos brasileiros uma porção considerável de livros. Em São Paulo, por exemplo, carta do capitão general Antonio Manoel de Melo Castro e Mendonça, governador da província, datada de 18 de janeiro de 1801 , adverte o ministro da Fazenda D. Rodrigo de Souza Coutinho para a pouca importância aqui atribuida aos livros que havia recebido (e que deveria vender...) relacionados com Artes e Ciências. Destaca o missivista que "há tanta falta de compradores, quanto hă a negligencia, e'descuido que tem havido em se cultivar as Artes e as Sciencias:" completando não haver "quem se anime a comprar num só livro, de maneira que muitos dos que se tem espalhado, tem sido dados por mim..." 
Aliás, partem do mesmo capitã̀o general algumas reflexões mais azedas e, possivelmente, mais consequentes sobre a atitude de Lisboa em impor aqui um comércio artificial de livros ou especular maciçamente sobre uma notação de gosto de leitura e senso prático aplicados a um povo cuja experiência objetiva e técnica ainda seria um tanto reduzida. Duas outras cartas do capitão general são elucidativas das razões para o seu ceticismo e sua relutância em receber mais livros e, consequentemente, em atender às expressas determinações de Lisboa quanto ao envio de receita proveniente das vendas dos ditos produtos. Uma carta de 22 de janeiro de 1801, dirigida ao mesmo D. Rodrigo de Souza Coutinho, representa exemplar curioso de interpretação pedagógica. Nela, percebe-se um sensato juizo do quadro cultural na provincia de São Paulo quanto a um inadequado sentido de imposição de leituras, considerando-se justamente a clientela e o que me1hor se ajustaria ao leitor paulista desde fins do século XVIII aos primórdios do XIX. Vale a pena conhecer integralmente o teor da referida correspondência, pelo grau de percepção administrativa e reflexão sócio-cultural inscritos na ëpoca por um funcionário da Corte portuguesa no Brasil.

\section{ANNO DE 1801 \\ N: 19}

Sobre a recepção de Livros de Artes e Sciencias ILL. MO E Ex. MO SNR.' - Acompanhada do Avi zo N.: 26 de 22 de 8 br.: de 1800 , recebo a relação dos Impressos que em hum caixote me forão entregues com a importancia de $165 \$ 120 \mathrm{r}$. ${ }^{\mathrm{s}}$ coln ordem de a fazer vender pelos preços indicados 
na mesma relação, e de remetter o seu producto ao Official Maior da Secretaria, na forma do costume.

Eu já ponderei a V.Exa nos officios N. Os 13 e 15 a pouca extracção que actualmente tem nesta Capitania os ditos Impressos pelo nenhü gosto que há de se applicarem ao Estudo das Artes e Sciencias, de tal maneira q.' com muita difficuldade se pode conseguir que os Estudantes que se destinão à vida Eccleziastica frequentem os Estudos de Philosophia e Rethorica.

Ora, si estes Estudos tão essencialmente necessarios a quem se destina a semelhante estado não demovem aos candidatos a adquirillos, que se poderä conjecturar a respeito da Liçaó de Livros q.' bem q.' interessantes, entrão com tudo na. classe dos uteis e coriozos, que só tem lugar na Ordem dos conhecim. tos depois dos necessarios. Hé verdade q.' excellentes Memorias q.' se achão vertidas de Ordem de Sua Alteza augmentão a Massa geral dos conhecimentos da Nação; mas quem duvida, e V. Ex. ${ }^{a}$ melhor do que eu o sabe que estes conhecimentos devem. ser transmittidos com tal economia, que elles não ceguem pelo seu deslumbre, quando se intenta illuminar os Povos, aos quaes no momento em que dão os primr. os passos forado circulo da ignorancia em que tem jazido, hë precizo apropriar a Lição à sua capacidade, bem como a natureza pratica, destinando no leito dos animaes hum sustento jä elaborado para a nutriç̧ão dos pequenos filhos, a quem outro alimento mais forte, qual o que nutre o animal adulto, Ihes daria a morte, em lugar de lhes conservar a vida. (1) V. Ex. a melhor do que eu sabe, que huma serie de Memorias feitas em diffe- rentes sistemas com differentes fins, em differentes climas, e com diversa somma de conheci- 
mentos, são dignas da lição de hum sabio para dellas colligir debaixo de hum ponto de vista tudo quanto pode ser util ao seu paiz,e ao clima em que, vive, e que ainda podem ser interessantes ao Alunno, que depois de se instruir nos elementos de huma Arte, certo em seus principios, varia a manipulação, altera os seus processos, simplifica o seu trabalho, e faz outras muitas tentativas concernentes a tirar melhores, e mais vantajozos rezultados, com menor despeza, e menos desperdicio do tempo; mas não hë assim o que acontece ao homem leigo, que lendo as ditas Memorias, fica peior do que se achava d'antes; aparta-se da sua antiga rotina, ora quer seguir hum processo descripto n'huma, ora quer seguir o descripto, n'outra, e desta sorte sem. atinar com verdadr.: caminho, fica em peiores circunstancias depois da sua applicação. Tal hé - que tem succedido á muitos que se querem regular pelo que se acha escripto nas ditas Memorias; nas q. es pela maior parte, bem como em todos os processos das Artes, se não declarão as pequenas minucias que desprezadas transtornão e varião o seu rezultado. Se V. Ex. ${ }^{a}$ de ordem de S. A. R. me não determinasse, que revisse eu os Impressos, que se me enviavão, para os não fazer vender quando nelles se encontrassem quaesquer sentimentos oppostos aquella san e inalteravel doutriria, que tende a manter os Povos no doce, e suave vinculo da sociedade, regulada pela mais perfeita harmonia que rezulta da verdadeira e necessaria subordinação das differentes classes, de que se compoem; eu não teria occazião para inferir que V. Ex. ${ }^{a}$ não tem tomado conhecimento individual das differentes obras que se tem mandado para esta Capitania, e por consequencia não me attreveria a fazer es- 
tas reflexoens, que me dicta o meu zello, aquelle zello que me obriga a dezejar que em lugar de muitas destas obras, antes se imprimissem todas as Elementares, principiando pelas que são necessarias para o uzo das Escollas de primr.as letras, e depois as que são indispensaveis a qualquer homem que não se destina a maiores Estudos, como são Elementos de Historia, de Geographia, em fim de todas as mais Artes, e Sciencias, de maneira que iniciados os povos nos conhecimentos geraes, e que devem ser communs em toda a classe de pessoas, possão depois pela lição destes preciozos Impressos, fazer os maiores progressos, e tirarem della todas aquellas vantagen's que S. A. R. se propoz quando se dignou mandar pôr em execução tão util projecto.

Nestes termos reprezento a $V$. Ex. a se digne não enviar para esta Capitania mais remessa de Livros não sendo elles concebidos na $\mathrm{fr} .{ }^{\mathrm{a}}$ que tenho de dirigir a Real Prezença, mandando huma rela.̧āodos que necessariam. te se devem enviar para esta Capitania, ou sejão compostos de novo, ou feitos vulgares pelas Traduçoens, ou pelas re-impressoens; compromettendo-me com tudo a ver se posso dar sahida aos que cá se achão por aquelles meios que me parecem mais proprios, e mais adequados a excitar a curiozidade dos compradores, e tendo-o assim praticado, immediatamente mandarei entregar ao mencionado official Maior da Secretaria d'Estado a somma total do seu producto, na forma que V. Ex. a me recommenda.. D. ${ }^{S}$ g. ${ }^{\text {a V. Ex. }}{ }^{\text {a }}$ S. ${ }^{m}$ Paulo 22 de Janeiro de 1801. - 111. mo e Ex. mo Snr.' D. Rodrigo de Souza Coutinho.- Antonio Manoel de Mello Castro e Mendoģa. 131 
Trata-se, como se vê, de uma observação peculiar e muito pertinente ao caso, partindo, como partiu, de um governador de província, que não apenas adverte seu ministro da Fazenda na Corte para a impropriedade do envio de mais livros que não contemplem os interesses da freguesia no Brasil- livros destinados, de resto, muito mais a atender aos objetivos especulativos da Metrópole do que aos estritos sentidos da educação na Colônia. O governador propõe, em vez de matérias desconhecidas aqui, a remessa de outros livros, aqueles que julgava mais de acordo com as necessidades das primeiras letras na provincia, os que melhor se oferecessem ao gosto e ao desenvolvimento dos estudos em São Paulo, tanto mais que jâ enfrentava dificuldades só com o encaminhar os estudantes destinados à vida eclesiástica que estudassem as disciplinas atinentes à sua formação. De forma sutil, o missivista insinua a ignorância de D. Rodrigo de Souza Coutinho para com os livros que este ültimo mandava, impositivamente, para cá e encarece a atenção reinol para a urgência de acompanhar o estágio sỏcio-cultural da província seguindo-1he o curso das reais necessidades. Em linhas gerais, - governador demonstra uma notäve1 percepção da situação brasileira, particularizando o estágio da educação e das razões por que acredita ser melhor a Metrópole evitar o envio de mais livros.

Mas, afina1, que livros seriam esses causadores de tão amarga reflexão e acurado senso prâtico? Mais ou menos aqueles nossos conhecidos de fins do século XVIII, com uma tendência acentuada nos campos da ciência e da técnica fomenta- 
das em Portugal, o que faz aumentar, em quantidade e alternância de títulos, a produção de obras. As matérias são aquelas oriundas do espírito que gerou as sucessivas edições da Tipografia do Arco do Cego, dirigida por Fr. Veloso. 0 interesse, claro, era abrir aqui um mercado para o escoamento dessa produção, mercado extensivo de venda e consumo. Os títulos, com suas quantidades de exemplares e valores de venda ao público, vêm registrados por Castro e Mendonça em duas cartas dirigidas ao mesmo D. Rodrigo de Souza Coutinho e datadas de São Paulo, 6 de fevereiro e 13 de agosto de 1802 , compreendidos em duas relações

Relação dos Livros q.' existem em ser

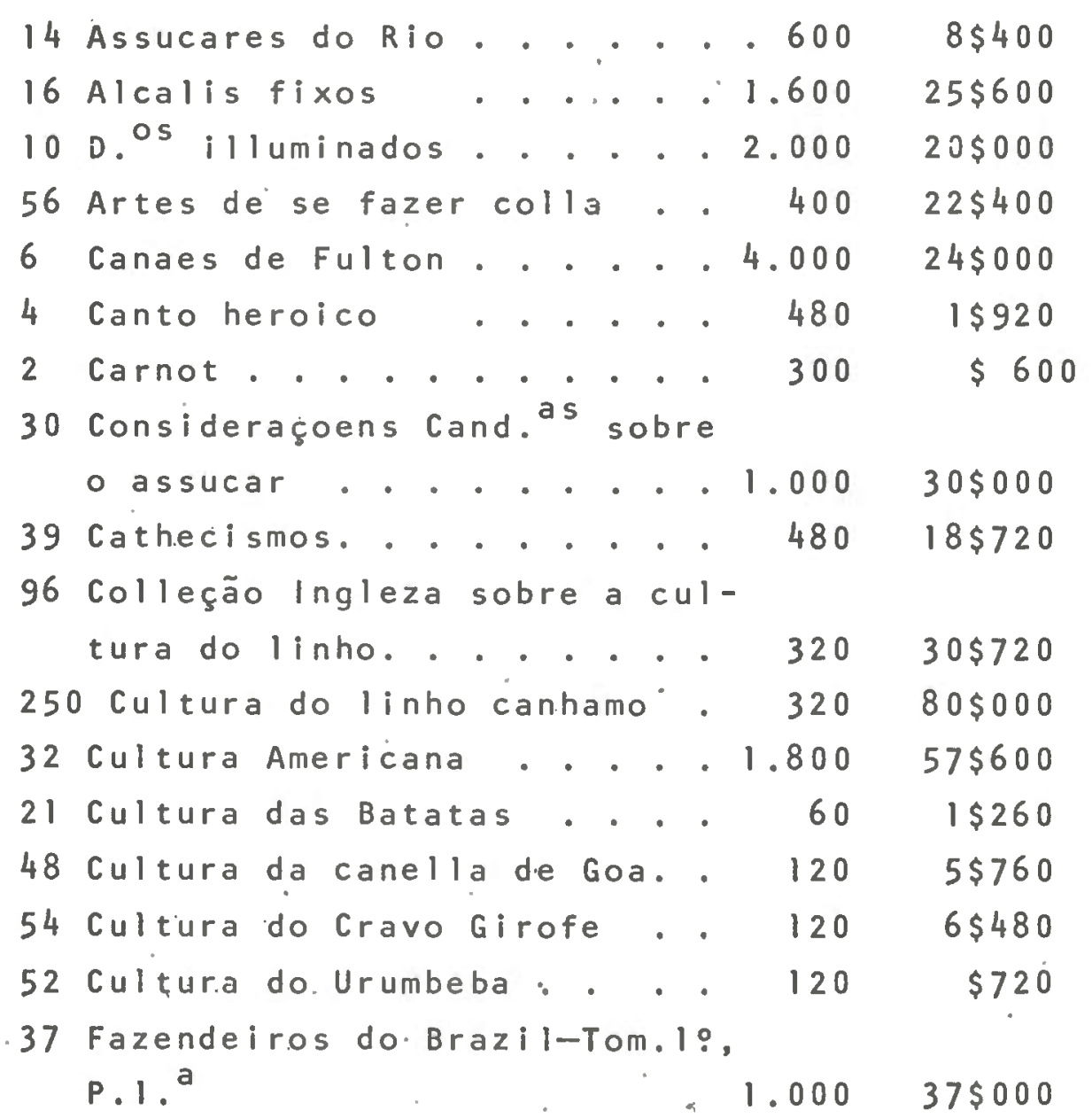


44 Ditos

- Tom.19, P.2.

1.600

$70 \$ 400$

67 D. os

Anil-Tom. 2:, P. 1.

1.200

$80 \$ 400$

6 D. 05 ,

Cáfë-Tom.3:, P.2.

1.200

$7 \$ 200$

11 Helmintologias Portug. com estampas pretas...... 1.200

$13 \$ 200$

55 Historias d'America . . . 600 $33 \$ 000$

11 Mineralogias de Bergman, 1.05 Tomos.

$960 \quad 10 \$ 560$

23 D. Os, 2. os

D. Os. 1.440

$33 \$ 120$

19 Memorias dos Algodoeiros, por Arruda

$600 \quad 11 \$ 400$

29 Memorias sobre os queijos de Roquefort

11 Pensões vitalicias.... 1.200 $13 \$ 200$

14 Quinografias, com estampas il-

luminadas........ . . 1.200

$10 \$ 800$

16 D. as, com estampas pretas. . 800

$12 \$ 800$

9 Relaçoens de Tripoli... . 80

$\$ 729$

32 Sciencias das Sombras... 960

$30 \$ 720$

11 Telegrafos . . . . . . 320

$3 \$ 520$

9. Cursos de Estudos...... 1.200

$10 \$ 800$ $729 \$ 160$

Relações dos Livros que existem em ser na mão do

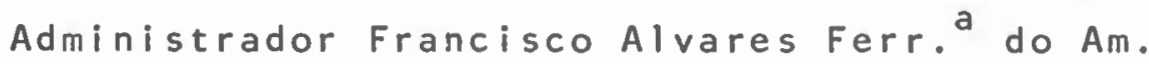

23 Arvores Assucareiras . . $240 \mathrm{r}$.

$5 \$ 520$

35 Assucares do Rio..... . $600 " 11$ $21 \$ 000$

20 Alcalis fixos....... . 1.600 ". $32 \$ 000$

9 D. Os illuminados.. . . 2.000"

$18 \$ 000$

53 Artes de fazer colla.. . $400 "$

$22 \$ 000$

5 Canaes de Fulton... . $4.000 "$

$20 \$ 000$

17 Canticos Heroicos . . . 480 "

$8 \$ 160$

8 D. os dos Jardins..... 600 "

$4 \$ 800$

66 Cartas do Manso ... . 60 "

$3 \$ 900$

38 Considerações Candidas sobre

$$
\text { a natureza do Assucar. .1.000." } 38 \$ 000
$$


37 Cathecismos da Doutrina . $480 \mathrm{r.}^{\mathrm{s}} 17 \$ 760$

109 Colleçoens Inglezas sobre

a cultura do 1: canamo. . 320 " $34 \$ 880$

39 Cultura Americana . . . 1.800 ․ $68 \$ 400$

95 Cultura das batatas. . . $320 " 30 \$ 400$

21 Instrucçoens sobre a cultura das batatas. . . 60 " 1 " $126 \$$

45 Cultura da Canella de Goa 120 " $5 \$ 400$

51 Cultura do Cravo Gerofre. 120 " $6 \$ 120$

50 Cultura das Urumbebas. . 120 " $6 \$ 000$

28 Culturas e Opulencia do

Brazil . . . . . . 960 " $26 \$ 880$

22 Discriçoens da Quina do

Brazil . . . . . . $200 " 4 \$ 400$

4 Edificios ruraes. . . $3.600 " 14 \$ 400$

9 Memorias sobre a pratica

de fazer salitre. . . 60 " 540

5 Elegias de Cardozo Latinas 120 " 600

55 Fazendeiros T.19P. ${ }^{\text {a Assucar } 1.000 " ~} 1$ " $55 \$ 000$

52 Fazendeiros. T.19P.2. ${ }^{a}$ As-

sucar . . . . . . $1.600 " 183 \$ 200$

45 Ditos T. 2\% P. 1. ${ }^{a}$ Anil. $1.200 " 1154 \$ 000$

51 Ditos T. 28 P. 2. Anil. $1.200 "$ " $61 \$ 200$

28 Ditos T. 39 P. 2. "Café . 1.200 " $38 \$ 600$

9 Helmintologias Portuguezas

em estampas pretas . . $1.200 " 10 \$ 800$

62 Historias d'America.. . $600 " 1137200$

10 Historias dos Principaes

Lazaretos....... . 400" $4 \$ 000$

17 Memorias dos Algodoeiros

por Arruda . . . . . 600 " $10 \$ 200$

26 Mineralogias de Bergman T.

2.?

$1.440 " 37 \$ 440$

25 Memorias sobre os Queijos

de Roquefort ..... $100 "$

$2 \$ 500$

21 Methodos de prevenir a peste 60 " $1 \$ 200$

2 Musgos ....... $1.000 " 2 \$ 000$ 


\begin{tabular}{|c|c|c|c|c|c|}
\hline & Pensoens Vitalicias. & . & .1 .200 & $r . s$ & 0.90 \\
\hline & Paladios Portuguezes & - & 600 & $" 1$ & $4 \$ 800$ \\
\hline & Panigrafia... & . & 480 & " & 480 \\
\hline & Guinografias com Estan & mpas & & & \\
\hline & illuminadas . . . & . . & .1 .200 & $"$ & $14 \$ 400$ \\
\hline & Ditas com $d .^{\text {as }}$ pretas & . & . 800 & $"$ & $15 \$ 200$ \\
\hline & Relaçoens de Tripoli & . & 80 & $"$ & $1 \$ 840$ \\
\hline & Respostas do Vieira & • & 60. & $"$ & $1 \$ 320$ \\
\hline & Sopas de Damfort. & . & 100 & " & 300 \\
\hline & Sciencias das sombras & . & 960 & "1 & $29 \$ 760$ \\
\hline & Tratado das Melhas & - & .1 .000 & $"$ & $4 \$ 000$ \\
\hline & Tabacologias... & . & 400 & $"$ & $8 \$ 000$ \\
\hline & Telegrafos.... & - & 320 & " & $2 \$ 880$ \\
\hline & & SOMM & & & 860 \\
\hline
\end{tabular}

Francisco Alvares Ferreira do Amaral. 133

E a mesma tendência dos livros encaminhados conforme Instrução do ministro da Fazenda D. Rodrigo de Souza Coutinho, ao capitão general Castro e Mendonça, em 4 de fevereiro de 1801, numa relação que leva a assinatura de Fr. Vellozo com data de 19 de janeiro do mesmo ano:

20 Cultura e opulencia do Brazil

12 Historia dos Lazaretos

25 Methodo de prevenir a peste

4 Potassa iluminadas

25 Respostas de Vieira

50 Carta de Manso

6 Sopa de Doniford

3 Tratado das Abelhas

4 Musgos

25 Descrição. da quina do Brazil

25 Tabasologias

12 Bergman

3 Lichenes 


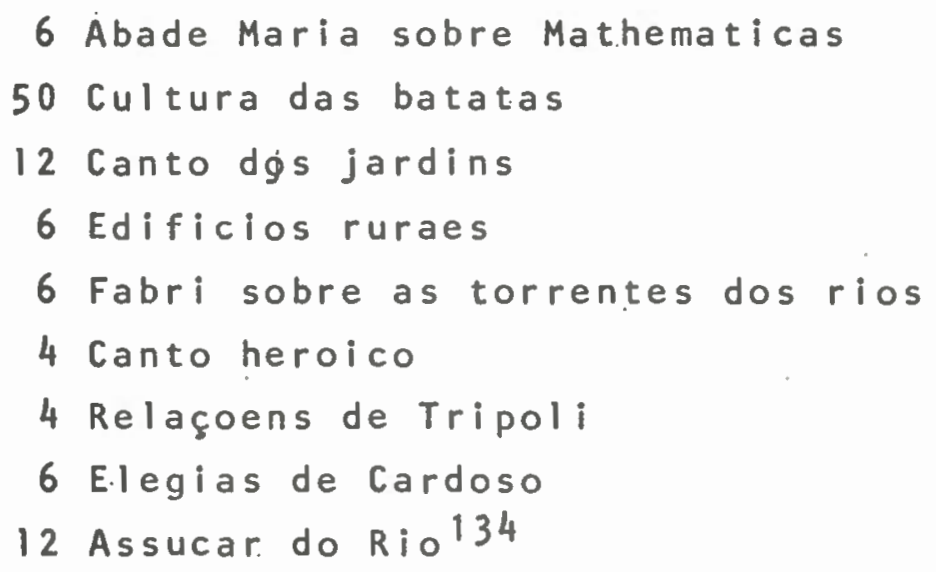

No final de 1802 , o capitão general Antonio Manoel de Mello e Castro Mendonça deixa o governo de São Paulo e instrui o seu sucessor Antonio José de França e Horta, atravês de uma "Memoria sobre o commercio, Mesa de Inspecçāo, caminho de Santos, agricultura e estado da literatura (professores e instrução)." 0 documento é de 28 de dezembro daquele ano e é natural que o ex-governador referencie o estágio de província não apenas quanto ao ensino, mas quanto aos próprios sistema e comércio dos livros que ele mesmo reconhecia como impossiveis de seguir, face a outros interesses despertados na Colônia. O novo governador oficia entäo ao Juiz de Fora da Vila de Cuyabá Dr. Gaspar da Silva Navarro, mandando dois caixotes que se achavam em São Paulo e que e.1e, Governador Antonio José presumia "conterem livros, semelhantes aos q. para aqui se remeterão de Lisboa, afim de se destribuirem, e venderem por conta da Impressão instituida pelo ex Ministro da Fazenda o Exm ${ }^{P}$ Snr. D. Rodrigo de. Souza Coutinho" 135 A carta é de 11 de julho de 1804 e, tal como o caráter relativo a São Paulo, a Metrópole intensificava sua determinação de estender a leitura dos livros editados pela Tipografia do Arco do Cego a todo o Brasil. 
$0 \cdot$ mesmo governador França e Horta interessado na disseminação de atos festivos pela chegada do Príncipe Regente D. João, ao Brasil, recomendava expressamente a alunos e professores de Filosofia, Retórica e Gramática, em 10 de março de 1808, que, na oportunidade dos festejos da mudança da familia real para o Rio de Janeiro, "nas tres noites de fogos dados pelo Corpo de Negocios, os estudantes de todas as classes darão hum Carro de Parnazo com Oitero em q' se repittão, e fação obras aluzivas a tão sublime assumpto."136 Ou seja, o governados impunha temas de composições poéticas aos alunos e instruía os professores da província de São Pau10 para dirigirem seus pupilos na ocasião da chegada do príncipe, de sorte que as composições e as homenagens pudessem ser aplaudidas pela população e, óbvio, bem recebidas pelo monarca. Claro, o estímulo à produçẳo teạtral ou às composições em poesia sugerem o conhecimento que professores e alunos deveriam ter de autores e obras correntes no século, segundo o gosto da época. Este gosto, em gera1, obedecia a determinações previstas em documentos oficiais, estabelecendo-se as disciplinas, matérias e autores que deveriam ser seguidos.

Do ponto de vista da evolução do teatro no Brasil, é relevante destacar as informaçōes histórias disponíveis. A literatura dramática teria aiguma acolhida em Minas Gerais, alcançando repercussão já na segunda década do século XIX. Prova disso é que, em 18il, na Casa de Opera de Ouro Preto, seria exibida a Escola de maridos, de Moliēre e, de igual forma, a ñpera de Metastăsio, Dido abandonada, no Tijuco, 
em 1815. O Tijuco tambēm assistiria, em.1818, à tragicomédia $\underline{0}$ salteador, durante os festejos de homenagem a D. João VI, na oportunidade do casamento de D: Pedro. Em 1819, representavam-se, na Casa de Opera de Sabarā, ao menos dois dramas: Zelo d'Amor e Maria Teresa Imperatriz da Austria. Em Vila Rica, o. naturalista Johann Pohl teria assistido, tambēm na Casa da Opera ouropretana, à tragédia Inês de Castro. Sabarā teria recebido, em 1823, companhias que encenaram, na Casa da Opera sabarense, Catarina Primeira, Imperatriz da Rússia. Finalmente, em Santa Luzia, Minas, 1825 , durante os festejos de aniversário de D. Pedro I, subiria à cena a ópera Enéias em Getūlia ${ }^{137}$ : E de prever- se que, a exemplo de Minas Gerais, dramas e comédias, vale ressaltar, obras literárias em texto teatral, tenham se espalhado pelo Brasil e, com elas, a vocação da leitura pelos brasileiros tenha se mantido, ou fortalecido.

o costume impositivo de leituras e de livros retoma o fôlego e se expande após a permanência do Príncipe Regente no RJ e, particularmente, após o advento da Impréssão Régia. Isso é o que se pode deduzir da carta encaminhada pelo Secretārio de Governo, em comunicado circular, a todas as Câmaras da capitania de São Paulo e aos escrivães, remetendo exemplares de leis e mais impressos"a vender" da Impressão Régia do Rio de Janeiro, por mandado de S.A.R. em 12 de setembro de 1810. 0 documento vem assinado por Manoel da $\mathrm{Cu}-$ nha de Azeredo Couto Souza Chichorro. 138

Não deixa de ser curioso o projeto governamental de estender livros e idéias de cunho prätico a uma população 
ainda desprovida de grandes conquistas no plano técnicoprático, profissional ou literärio. A propósito, è détalhe peculiar em nossas investigações não haver vultosas bibliotecas nos começos do sēculo XIX. As grandes livrarias vão se formando da segunda para a terceira década do Oitocentismo, em quantidade, variedade e importância de títulos, autores e assuntos. De qualquer forma, porëm, demonstra-se oportuno o conhecimento das características de leitura estimuladas pela ação direta do Reino, tanto em Lisboa quanto no Rio de Janeiro.

o século XIX, assim, irá ganhando foros interesse histórico, com a ampliação do ensino e com o desenvolvimento da tipografia entre nós. Data de 1809, por exemplo, a requisição de um professor de Filosofia para o seminário franciscano de Taubatẻ, São Paulo, circunstância, aliās, que assinala a continuidade do ensino dito avançado no Brasil Colônia. Tal ensino, antes considerado médio, veio sendo ministrado pelos franciscanos desde 1650 no convento de Santo Antônio no Rio de Janeiro, imprimido a todo o século XVIII e XIX, conforme salienta Basỉio Rower, OFM, na obra citada páginas da História franciscana no Brasil. Como os tiranciscanos, claro que os beneditinos e, sobretudo, os oratọianos e carmelitas, no século XIX, também desenvolvèram seus esforços em igual sentido. Alguma curiosidade reponta, entretanto, da natureza desses estudos, nem sempre contemplando a ordem e a versão oficial do ensino. Entre 1814 e 1818, segundo informa o mesmo Rower, sendo professor no convento dos franciscarios em Itu, São Paulo, o Fr. 
Santa Justina, este teria denunciado a subversão de Diogo Antonio Feijó, que ministrava aulas, no mesmo convento, de uma filosofia pouco ortodoxa, "pois nas suàs preleções misturava erros dogmáticos de Anglicanismo, Kantismo, Jansenismo e outras heresias."139

Ainda quanto à instrução pública, que sempre traz consigo reflexos, diretos e indiretos, da circulação de livros ou das tendências de leitura, lembramos os projetos para instalação de uma disciplina de Anatomia e Cirurgia em Vila Be1a, no Mato Grosso, planos que foram apresentados em 17 de outubro de 1808 e tambêm os estudos.militares e de Engenharịa, desde meados do século XVIII, na mesma província matogrossense, conforme Carlos Moura, op. cit. ${ }^{140}$.

Ao estudar as características da educação püblica em São Paulo e no Rio de Janeiro, observamos como é rigorosamente específico o universo de leituras decorrentes das orientações pedagógicas. Tanto no ensino prático, quanto no de Humanidades, o rigor censório era de molde a não permitir - desenvolvimento de processos educativos que não estivessem contemplados pela autoridade competente. Em outras palavras, não havia propriamente o desenvolvimento de um gosto, mas a obediência ao senso ideológico e às decisões superiores na ordem de leituras dirigidas.

Em São Paulo e no Rio, praticamente, os mestres deveriam estudar, aplicar conhecimentos e aferir a desenvoltura do aluno de acordo com os manuais recomendados pela autoridade superior. Assim, estudava-se pelo.s Elenentos de Geometria, de Euclides, Aritmética e Álgebra, de Bezout, Me- 
cầnica, de Bezout. A Otica e a Astronomia seriam entendidos através de textos de La Caille, o desenho segundo o

Essai statistique, de Balbi. Não espanta por isso que, na nossa investigação em fontes primárias, tenhamos encontrado, sempre, e desde o século XVIII, esses autores. A vigiiância, contudo, era frequente, de sorte a não permitir a . leitura de obras defesas. A censura passava por outro processo de mudança de órbita. No caso do estudo de Retórica e. Filosofia, muito havia que vigiar e punir. A Gramática Latina, obrigatória, básica para tọdo o ensino e que se estudava, normalmente, era aquela nossa conhecida de autoria do padre Antonio Pereira de Figueiredo, oratoriano das reformas pombalinas. Isso aconteceu praticamente por todo o Brasil Colônia.

No Rio de Janeiro, por exemplo, a Academia Militar advertia para os estudos de trabalhos de le Roy, inglês, e Delambre, francês, no caso dos estudos de Geodésia. Era um documento oficial que propunha isso, uma carta régia que determinava a metodologia a ser seguida pelos professores e ainda o modelo de leitura e de autor. Carta régia de 4 de dezembro de 1810, citada por Nizza da Silva em Cultura e Sociedade no Rio de Janeiro $^{141}$, lembra a obrigatoriedade do conhecimento de Lacroix para os principios de Aritmética e Algebra, dos Elementos Euer para $\mathbb{A} 1$ gebra e as explicações contidas na "excelente Geometria e Trigonometria retilinea de Legendre" para a boa formação do princípio matemático aos alunos. Paṛa a Geodésia, não deveria o professor adotar nenhum outro método ou modelo, pois a carta diz, textualmente, 
que o lente "não se esquecerä de dar exemplos tirados da cēlebre obra de Delambre:" No $4^{\circ}$ ano, de um total de 7 , o professor deveria formar seu compêndio de instrução pública com base em obras de Laplace, Lalande, Lacaille, Lacroix e Pinkerton, se quisesse escapar a castigos ou ser considerado revel no quadro das noções gerais de Geografia do globo. Para a Física, eramobrigatórios os Elementos de física do abade Hauy, "tendo também em vista o Compendio de física de Brisson." Para $5^{8}$ ano, o rigọ da carta régia permanecia, no particular das Ciências Exatas e em especial da Arte militar. São aî indicados o Manual topogräfico elaborado pe10 Arquivo Militar da França, completando o currículo de tática, estratégia, fortificações etc., a que se deveriam aduzir as obras.de Guy de Vernon, e de Cessac. No estudo da Química, para este mesmo $5^{\circ}$ ano, a carta determina os autores obrigatórios, devendo o mestre seguir "todos os métodos docimásticos para o conhecimento das minas, servindo-se das obras de Lavoisier, Vauquelin, Fourcroy, Lagrange, Chaptal, para formar o seu compêndio." Para $06^{\circ}$ e $07 \%$ anos ainda se impunham métodos segundo Bossut, Mul1er, para estudos de edifícioș e muralhas etc. Werner, Napion, Hally e Brochant, para os estudos de mineralogia. No $7^{\circ}$ ano, o nome de Rose para o estudo das minas e de Lineu, acompanhado de Jussieu e Lacepède, para os estudos de História Natural.

Em São Paulo, a situação não seria modificada. Embora aí não se dispusesse de uma Academia Militar, essa seria a tendência e o estilo dos estudos. Não tendo Academia, tinham os paulistas preferência pelo ensino eclesiástico, co- 
mo observa o governador Melo Castro e Mendonça, ao defender os estudos de Filosofia como "necessärios para a vida eclesiástica por que todos têm aqui.uma paixão predominante."142 Isso para indeferir o assentamento de uma cadeira de Geometria em SP, apesar de a carta régia de 19 de agosto de 1799 autorizar a criação e tendo embora um professor candidato, formado em Matemática, nada menos que Martim Francisco de Andrada Machado e Silva. E, aliâs, atendendo a essa prerrogativa de estudos eclesiästicos que o governador estimula a expansão do ensino de primeiras letras adaptando o "Estatuto que hāo de observar os mestres das escolas dos meninos nesta Capitania de S. Paulo, remetido pelo governador e capitão-general de Sẫo Paulo, Luis Antonio de Souza ao Conde de Oeiras em 12 de maio de 1768". O $\$ 7$ do Estatuto consiste em assegurar.

Que todos os Mestres sejam obrigados a ensinar pelo livro do Andrade, e seguir em tudo aquelas regras que no principio do dito livro se prescrevem pạra a boa direção das Escolas, e serä bom que tenhamoutros livros, como a Educação de um menino nobre; a tradução das obrigacooes civis de cicero, para que possam inspirar aos meninos as boas inclinações e o verdadeiro merecimento do Homem.

0 Andrade que o Estatuto refere è Manoel de Andrade, autor de um verdadeiro tratado pedagögico do século XVIII pombalino, a Nova escola para aprender a ler, escrever e contar, publicada em Lisboa, provavelmente em 1720 e obra de 
manuseio obrigatório pelos mestres de primeiras letras. Outros livros adotados impunham a característica de leitura seguida por professores e alunos: As Obrigações de Cícero e - Catecismo de Montpelier, de 1770, obra cujo título completo é Catecismos da diocese de Montpellier impressos por ordem do bispo Carlos Joaquim Colbert, traduzidos na lingua portuguesa, para por eles se ensinar a doutrina cristã aos meninos nas escolas dos reinos e dominios de portugal. Acrescentados com a ladainha e modos de ajudar à missa. A titulação segue a edição de Lisboa, 1815.

Outros livros recomendados eram a História do Antigo e Novo Testamento, de Antonio Pereira de Figueiredo Histöria de Portugal e os Apontamentos sobre a educação de um menino nobre (1734), de Martinho de Mendonça de Pina e Proença Homem, o pedagogo influenciado por Locke e autor iluminista portuguềs sensivel à necessidade de reformulação do pensamento pedagógico da ëpoca, especialmente no que se refere à nobreza e suas bases culturais. Ainda no particular das primeiras letras, Mello Castro e Mendonça defendia a adoção de uma gramática portuguesa, sugerindo a Arte de Gramática da Língua portuguesa, composta e oferecida ao marquês de Pombal por Antonio Jósé dos Reis Lobato, (Lisboa, 1771), ao lado de uma obra Regras de Ortografia de Pinheiro, "ou de qualquer outra, que para este fim se mandar imprimir." $\mathrm{Na}$ Matemātica, lä estava outra vez a recomendação para os Elementos de Bezout.

o estudo dos idiomas pouco se acentuou nesse período, em que pese os esforços de Martim Francisco em fazer correr 
o estudo. do francês "como língua geral, e mais util pelas muitas verdades necessárias ao bem do país, que podemos escolher dos escritos de seus säbios."144 Vigilantes, as autoridades temiam que o estudo do francês pudesse abrir o flanco à leitura de filósofos suspeitos. Para a Ilustração portuguesa não se deveria abrir espaço algum a idéias defesas nos reinos de portugal. Por isso a permanência dos clássicos. E da Gramática Latina de 'Antonio Pereira aperfeiçoada por Antonio Fèlix Mendes, ainda que sem a obrigatoriedade do método. Permanecia a gramâtica e mais livros de seletas para uso dos alunos em prosa. O livro básico era a Selecta latini sermonis exemplaria, scriptoribus probatissimis ad Christianae Juventutis usum olim collecta. E mais Cícero: Mar Tullii Ciceronis epistolae ad familiares denuo selectae, et emmendatae ad Lusitanae Juventutis commcdum, et institutionum. Em relatório de 1820, o professor Bento Francisco da Costa Aguiar, da Vila de Santos, afirma o uso de alguns desses livros, para a prosa, indicando ainda que "para tradução do verso, ensino os poetas Virgilio, Horácio, e Ovídio pois são os mais seguidos."145 Mesmo método parece ter seguido Francisco de Paula Simões, de Taubaté, que esclárece, em relatório à Secretaria de Governo em 1820 , dando o tom das tendências de instrução e leitura da provincia de São Paulo, à êpoca:

- livro elementar è o compendio de Gramática do Padre Antonio Pereira, ensinando-se desde então aos meninos a formar analogias. Dentro em 3 ou 4 meses, conforme a esfera de cada um, principiam a traduzir algumas histórias muito fäceis, 
como v.g. a Historia Sagrada de Sulpicio, e Romana de Eutröpio, e Aurēlio Victor

$$
(\ldots)
$$

Os autores, que se explicam, são os da melhor idade da lingua latina, ou bem os imediatos $\mathrm{Ne}-$ pote, César, Lívio, Salústio, Cícero, etc. E os poetas são Terêncio, Plauto, Ovídio, VirgiIio, Horácio. Por Plínio naturalista se dão os temas, e os autores da $2 a$ o ordem, que se explaniam, são Cürcio, Suetōnio, Patérculo, Tácito, etc.

o curso de primeiras letras era dado por professores régios, pagos atravês de coleta do Subsídio Leterário. Não apenas tais autores aparecem, como ainda há menção às Cartas de Plínio, às Fábulas de Fedro, às Metamorfoses de Ovídio, à Eneida de Virgílio. Os poetas só eram estudados quando os alunos já estavem bem adiantados e familiarizados com - estudo do latim em prosa, na pressuposição de que os poetas eram mais nobres e de mais dificil recepção. Isto decorre àinda da Instrução para os professores de Gramätica Latina, Grega, Hebraica e de Retórica, ordenadas e mandadas publicar por El-Rei Nosso Senhor para o uso das escolas novamente fundadas nestes reinos, e seus dominios, em Lisboa, 1759 .

A Retórica era a arte da nobreza dós instintos e da inteligência. Seus preceitos eram rigorosamente obedecidos, segundo a ordem de Cícero e Quintiliano. Este, em particular, era possivelmente o mais estudado, sobretudo a partir das suas Instituições organizadas por Rolin en 1754. Quintiliano, Aristóteles, Cícero e Longino, parece, continuavam 
entre os principais. Destes, talvez Quintiliano desponte como o autor mais representativo, sobretudo após a boa consideração de Verney. e das reformas pombalinas, autor tomado principalmente como modelo para o ensino e para uma nova visão da arte retōrica. Entre fins do século XVIII e inicio do XIX avultam as traduções e comentarios das Instituições, sendo Jerônimo Soares Barbosa, em Portugal, seu grande divulgador. Destaca-se aqui o papel das antologias ou dos compêndios manuais que traziam textos para anālise dos estudantes, em especial a obra de Heinécio Fundamenta Styli cultioris, como a que melhor serve à divulgação dos clássicos.

Relatório do Professor de Filosofia Racional e Moral, Francisco de Paula e 01iveira, da cidade de São Pau1o, redigido em 1820, radica o sentido metodológico dos estudos na província à época da Independência e dá mostras das tendências de leitura obrigatória na Colônia:

Os compêndios de que uso para a instrução dos mesmos alurios; são os geralmente adotados na Universidade de Coimbra, em Portugal, e no Brasil, quer dizer, Genuense; adicionando-o com algumas reflexões dos mais cēlebres, e iluminados filósofos, como João Locke, Dr. Dodrig, o abade Condillac, Carlos Bonnet, e Manuel Kant. 147

Dois desses nomes, em nosso.entender, são surpreendentes, por não pontificarem nas listas que temos acompanhado atè aqui nem nos inventärios do século XVIII. Tanto Locke, quanto Kant representam uma novidade e uma surpresa. Dife- 
rentes de Antonio Genovese (ou Genovesi, italiano conhecidissimo em Portugal e no Brasil como Genuense e cuja obra principal, ou mais notōria,seria as Instituições da lógica para o uso do principiante, impresso em Coimbra, 1786, numa tradução de Miguel Cardoso. Locke e Kant representam uma fatia do pensamento libertário e empirista, considerados por sua Lógica da indução e do experimentalismo em parte filósofos desacreditados na concepção do Estado e da moral vigentes.

Como Genuense e outros, os autores se notabilizaram no gosto popular a partir das características e modelos da instrução recebida. Vale dizer, no entanto, que se pratica aí uma leitura obediente, servil, fruto da coerção imposta como traço identificador da natureza leitora brasileira dos começos do século XIX, o que faz naturalmente supor fosse a correnteza natural dos modelos de instrução oriundos desde o século XVIII e, até, como vimos, do estreito teocratismo ou regalismo da instrução jesuítica ou secular.

Deve ser este o tom de obrigatoriedade na aplicação de matérias curriculares e de livros, por força da filosofia de educação vigente, em outras provincias brasileiras do século XIX. Tal filosofia se aplicaria, certamente, em Vila Rica, onde, por proposta do Barāo de Eschwege, em 16 de maio de 1813, deveriam ser criadas aulas de Matcmática e Princípio de Tática. O Desembargo do Paço,por ato de 25 de outubro do mesmo ano; autorizou o funcionamento de cadeiras de Latim, em Baependi; um curso de Vetcrinäria en Ouro Preto e, para Mariana, a concessão aparentemente mais gene- 
rosa: cursos de Mineralogia, Química, Zoologia e Metalurgia, Botânica, Física, Aritmética, Geometria e Cálculo. ${ }^{148}$ o modelo de leituras, ou os livros para consulta e estudo nesses cursos não seria diversos daqueles seguidos em São Paulo e Rio de Janeiro.

A sobrevivência, aliás, do modelo propugnado pela filosofia pombalina é o que se pode notar dos estatutos de educação propostos pelo bispo de olinda D.José Joaquim da Cunha de Azeredo Coutinho. São os "Estatutos do Recolhimento de Nossa Senhora da Glória do.lugar., da Boavista de Pernambuco" (para a educação, feminina) e os. "Estatutos do Seminārio Episcopal de Nossa Senhora das Graças da Cidade de 01 inda de pernambuco", (para a educãção masculina), ambos redigidos em 1798. No primeiro, salienta Nizza da Silva,

.. as idéias do bispo de Pernambuco sobre a
educaça das moças não difere daquelas expres-
sadas por Moliēre ou Fénelon e têm apenas como
objetivo o aprimoramento e a maior rentabilida-
de das duas funçöes primordiais da mulher: guar-
diã da economia doméstica, mentora dos filhos. 149

O Molière aí recolhido é o educador de Les Femmes Savantes, ato II, cena VII. Já Feneloné o mesmo do Traité sur I'éducation des filles, de que Azeredo Coutinho extrai as máximas de elocução formal sobre a educação das moças para defender um modelo de ensino que apenas cuide de dotar as futuras esposas e mães de atributos simples que mantenha - status quo, ou seja, privilegia a eterna subserviência ao marido, em façe do que a mulher não necessitaria adquirir 
muitas luzes intelectuais - reservadas estas ao universo masculino. Como aparece na p. 2 do "Estatuto" feminino, no juizo final sobre as mulheres: "Elas têm uma casa que governar, marido que fazer feliz e filhos que educar na virtude." Nizza da Silva observa que o bispo "suprime muitas passagens do Traité de Fenelon, mas que, quando o utiliza, o traduz literalmente." Não è sem ironia que a historiadora observa como "interessante o esforço de adaptação de um texto francês do século XVIII à sociedade pernambucana.'150 Sociedade pernambucana que, dois séculos decorridos do Tratado de Fenelon, condicionava as mulheres ao pouco caso da leitura, ou aprofundamento nas matérias intelectuais. Bastava não estar na preguiça ou lassidão dos lares, a mulher jâ satisfaria a.lgumas das exigências sociais...

Os homens, contemplados no outro "Estatuto...", seguiam as linhas gerais apontadas no modelo de instrução aplicado em São Paulo e Rio, conforme vimos. Os autores, com uma ou outra exclusão, seriam os mesmos clássicos estudados através da Gramática Latina - modelo de anālise e temperamento pedagógico da sociedade colonial. Alguma coisa é interessante observar da preocupação expressa no Estatuto. Aos alunos mais adiantados, o bispo recomendava que só passassem ao estudo dos poetas, aqueles

... de melhor nota, mas com muita sobriedade, tão somente para não ignorarem a versificação latina e poderem entender as belezas da arte; e Ihes fará ver as diferenças entre o estilo poético e a prosa; as qualidades dos versos, 
a sua medição, o uso das figuras poéticas, e
tudo quanto pertence a sua forma material. 151

Azeredo Coutinho não reconhecia obrigatoriedade em mandar os alunos fazerem versos. Para ele, o melhor seria "quando o estudante sabe bem a lingua latina, mandar-1he traduzir alguns dos poetas antigos melhores, como Lucrécio, Virgílio, Ovídio; Horācio, Catu1̣o."152 Aqui, afinal, um juízo de valor da parte do bispo, identificando como me1hores tais poetas. Destes, aliás, somente Lucrécio e Catulo não apàrecem na relação explícita dos professores régios de São Paulo, talvez compreendidos na rubrica "etc.". A Retórica sempre seria seguida de acordo com exemplos tirados de Quintiliano e Cícero, modelares no gênero. Azeredo Coutinho, e de resto toda a educação pública no Brasil do início do século XIX, seguia as pegadas de Vermey no Verdadeiro mëtodo de estudar. As reformas de Pombal não tiveram efeito supensivo na administração de D. Joăo VI. Sem projeto pedagógico desde D. Maria I, o reino de Portugal obedecia ao estabelecido, fazendo correrem as águas de uma educação e cultura que buscavam mesmo imprecisamente, definições.

Por compreendermos certos aspectos da instrução oitocentista em Pernambuco, é imperioso anotar algumas informações contidas num opúsculo incompleto "Revolução no Brasil", lastimavelmente apócrifo. Descontadas óbvias e preconceituosas impressões do anônimo autor, que assinala, quanto à instrução püblica pernambucana desde 1799, as disciplinas e professores que teriam constituỉo a então chamada Universidade de 01inda. Em numero de onze, as disciplinas eram: 
"Theologia Dogmatica, Historia Ecclesiastica, Theologia Moral, Philosophia Universal, Mathematicas, Rhetorica, Poetica, Língua Grega, Grammatica Latina, Cantochão, Primeiras letras e Dezenho". Os professores eram todos religiosos, em sua maioria, e três ex-religiosos. Logo, os livros que deviam circular, e que afinal (seria lógico supor) consubstanciariam osi Estatutos do Seminário publicados por Azeredo Coutinho, seriam aqueles considerados úteis e expurgados das matérias proibidas ou passíveis de instilar dúvidas ou ambiglidades nos estudantes. 153

Ainda a propösito de Azeredo Coutinho e de seu Seminario de Olinda, aliās, encontramos, na Divisão de Pesquisa Histórica da UFPE, uma carta do bispo, datada de Recife, 14 de janeiro de 1800, e destinada à Direção Geral de Estudos, a: Lisboa, protestanto contra o comportamento doprofessor José Fernandes de Gama, substituto de Gramätica Latina, no dito Seminário, a quem Azeredo Coutinho acusa de libertino, corruptor de uma menor e tradutor da "infame obra de Ovidio Ars amandi e que a fizera espalhar pelos seus amigos, não obstante ser ela proibida na mesma impressão." 0 zeloso doutrinador pérnambucano, que jā não gostava de Rousseau, agora também tinha em Index o Ovídio da Arte de amar-afeito ainda à política pombalina de disciplinamento dos estu- dos. Não apenas considera "infame" a Arte de amar ovidiana, como condena seu provâvel tradutor e o denuncia: "como pode ver V.S. nesse exemplo que remeto."154

A questão da instrução pública no Brasil ẻ ainda relevante, cm termos das dificuldades de extensão e adequação, 
pela natureza social dessas dificuldades e pela política de implantação pedagógica. Assim, é natural acreditar nas Instruções ditadas pela Diretoria das Escolas de Ensino Mútuo a Manoel Caetano Espinola, encarregado de instituir e dirigir. uma escola na cidade do Recife, obedecendo a portaria de 18 de julho de 1825. Em função dessa portaria, o encarregado observară a impropriedade de circulação de qualquer livro, compêndia ou papel, como objeto de lições ou para uso das escolas, se não forem aqueles aprovados pela Diretoria das mesmas escolas em àtendimento à determinação do Governo. Estāvamos em 1825, um ano após a promulgação da primeira constituição imperial, a nação autônoma jā era conhecedora de duas experiências revolucionārias apenas no século XIX e ainda éramos dependentes de disciplinamentos de cunho português na educação. 155

E interessante anotar o testemunho das gerais dificuldades, à época e desde entāo, que acompanham o evoluir da história da educação no Brasil. Em carta de 4 de setembro de 1825, Fr. Miguel do Sacramento Lopes concluị sua peroração sobre essas dificuldades e julga, com inquestionāvel disposição de espírito e isenção, o quadro que documenta a partir da provincia de Pernambuco. A carta do frade é documento exemplar porque denuncia não só as dificuldades operacionais do ensino, - a falta de bons honorários aos professores, a necessidade dé substituição do professor de Retórica "jā velho e entrevado" - como também aponta queixas contra a falta de polidez e civilidade dos alunos e a exiguidade de espaço das salas-de-aula, o que condenava os alunos, apinhados, ao prejuizo da educação: Considerando 
boçal a atitude do professor de latim, agora mais preocupado com as șutilezas do idioma do que com a beleza dos clássicos. Lamenta a existência de uma única aula de Filosofia Racional e Moral, dada pela Congregação do Oratório, onde há poucos padres e poucos alunos e cujas lições limitam-se "às sucintas regras de Genuense e á pequena Ethica de Iob". E acrescenta observaçñes para reformas que julga indispensáveis: "reduzir a Logica à metade do compendio; a Metafísica a menos da metade, ajuntando à Etica um estudo mais sério do Direito natural e das gentes." Exemplo mais contundente e notável do tom lastimoso do padre pernambucano vem no trecho:

As aulas de primeiras letras, tão necessárias á Mocidade estão commumente em lamentavel atrazamento. $0 s$ professores pela mor parte ignorão os primeiros rudimentos da Gramatica da lingua; e d'aqui os rapazes sem a mais leve $i-$ dèia da construcção e regencia da oração, e nenhum conhecimento da Orthografia, e Prosodia da Lingoa; d'aqui os barbarismos, os solecismos, os neologismos, e infinitos erros, a q. des dlos d'os tenros annos se vai habituando a mocidade. 156

A exemplo do estado da instrução em Pernambuco, inferimos uma igual correspondência na Bahia. Ali se instalara, desde o século XVI o primeiro colégio dos jesuítas, e mais os dos carmelitas e franciscanos. No século XIX, a Faculdade de Medicina começa a distinguir-se a partir do antigo Hospital 
militar criado em 1808. Não só. pela instrução propriamente dita, mas pela ação îndireta que se origina da instalação e desenvolvimento da tipografia de Silva Serva e da biblioteca pública se poderia presumir um ambiente eminentemente favorável à circulação de livros.

A carta oitava de Vilhena, curiosamente, lembra um tanto a do Fr. Miguel do Sacramento Lopes, quanto às dificulda- . des do estudo,à parca e nada constante retribuição ao trabatho dos professores, ao êxodo dos melhores alunos para o serviço militar, ou à própria lástima dos estudos, o que provoca um tom de lamento na oitava carta sotepolitana. ViThena dá notícia das aulas dos colègios baianos desde fins do século XVIII e, concentrado no começo do XIX, mostra as características dos estudos, com predominio da Gramätica portuguesa, rudimentos da Língua latina, estudos de sintaxe e. sỉlaba, Retórica, Matemåtica, Filosofia e Teologia moral, compreendendo sucessivamente as sete classes dos estudos. ${ }^{157}$ Vilhena observa ainda - daí seu mais fundo desgosto e certeira premonição - a constante de atrasos nos pagamentos aos professores, as caracteristicas pouco adiantadas do ensino público e a pouco valia atribuível aos profissionais da educação no Brasii. O trabalho das cartas vale muito como documento de época, embora fiquemos desamparados de informaçōes quanto aos títulos e livros que deviam circular. Falar nisso, o próprio Vilhera adverte que "aqui não aparecem livros."158

Não será difícil a interpretação da natureza desses estudos oitocentistas. O século XiX prolonga a agonia da 
experiência do Subsídio Literário e, em que pese a compreensão e o esforço dispendido pelo governo de D. João VI que para aqui se deslocara, a sịtuação da instrução brasileira não chegaria a despertar maiores entusiasmos e nem seria tão determinante assim no que tange à formação de leitores, não fosse a ação direta, enquanto consumidores de livros, dos cidadãos.

Estudando a trajetória intelectual do cônego Dr. Antônio Joaquim das Mercệs, que foi mestre de filosofia na Bahia do século XIX, os historiadores Francisco Pinheiro Lima Jr. e Dinorah d'Araujo Berbert de Castro põem em relevo as tendências de leitura do cônego, um ex-estudante de filosofia no Mosteiro de Sāo Bento no Rio de Janeiro, onde aprendeu Geometria e Física. Os autores preferidos pelo cônego, conforme ele próprio ressalta numa de suas cartas, serão aqueles típicos do estudo de Filosofia tanto no Brasil quanto em Portugal, desde o século XVIII: "Heinecio em Logica, e Ethica; Genuense em Metaphysica, Altieri em Arithimeticạ e Geometria; e Muschembroeck em Physica. "159 Jā co-" mo professor no Convento dos carmelitas na Bahia, entre 1818 e 1821, os reflexos desses estudos se evidenciampela qualidade dos autores que o mestre utilizava para as suas aulas. Aí serão manuseados o mesmo Heinecio para a Etica, o mesmo Genovesi, ou Genuense, para a Metafísica e, para a Lógica, um novo autor, Sigismundo Storchenau, a que se aduz Eduardo Job para o estudo da Etica, quando da experiência do cônego em Alagoas e na Paraíba, onde também ensinaria Geometria pelos métodos de Bezout e Euclides. 
Todos esses dados estão melhor apresentados no livro Padre Mestre Con. Dr. Antonio Joaquim das Mercês 1786-1854 mestre de Filosofia, de Dinorah d'Araujo Berbert de Castro e Francisco Pinheiro Lima Jr. ,que evidenciam também a recomendação, para o ensino de Filosofia no Convento do Carmo baiano, desde 1755, das obras de Fr. Manuel Ignacio Coutinho, compreendida esta Filosofia como a do extrato moral, e portanto teológico, na linha doutrinária de João Bacon. 160 Importa, para esclarecer sobre o temperamento liberal do padre mestre estudado, que este, na provincia paraibana, teria dado, segundo suas próprias declarações em carta reproduzida pelos autores do'livro citado, "certas explicações pe10. Contrato Social." Isso era ainda antes de 1826 - data do retorno do padre mestre à Bahia - e já pressupõe o levantamento do interdito a Rousseau.

Dos aspectos relacionados com. a instrução püblica no Brasil, passamos àqueles igualmente considerados como importantes no que se configuram os níveis de influência e estímulo à leitura colonial. O primeiro desses outros aspec-. tos diz respeito à instalação da tipografia no Brasil, ou seja, da Impressão Régia e seus previsívis desdobramentos parà uma certeira massificação do hâbito leitor brasileiro no oitocentos.

O capítulo da instalação da tipografia no Brasil oferece una sẻrie de questões de natureza política, cultural e econômica, validando estudos e levantamento polêmicos até hoje. Algumas circunstâncias dão condimento ao intenso debate em torno do assunto como, por exemplo, o fato de o pri- 
meiro impresso em língua portuguesa (Luzeiro evangélico, do padre Fr. João Bauptista Morelli de Castelnuovo) ter sido feito no México, em 1710. Um Alvarā de 20 de março de 1720 proibia no Brasil a circulação de "letras impressas" ${ }^{161}$, o que denuncia a política portuguesa de isolamento da Colônia, vista apenas como fornecedora de matérias-primas. Outra curiosidade, ainda do século XVIII, recai na experiência de Antonio Isidoro da Fonseca em tentar implantar aqui uma oficina de impressão. O mesmo Isidoro que, durante dez anos, de 1735 a 1745, fora impressor em Lisboa, tendo em seu currículo, entre outras, as Obras de Duarte Ribeiro de Macedo, a segunda edição das Notícias de Portugal, de Manuel Severim de Faria, a quinta edição da Vida de D. João de Castro, de Jacinto Freire de Andrade, mais o volume $1^{9}$ da Biblioteca 1usitana, de Barbosa Machado, em 1741 e, por estranha coincidência, alguns dos trabalhos de Antonio José da Silva. No Brasil, sobre Isidoro abateu-se duramente o intervencionismo português, impedindo a continuidade de um ofício que poderia ter antecipado significativas conquistas para a nossa cultura literäria.

A notícia da introdução da Imprensa entre nós deve, por isso mesmo, começar por Antonio Isidoro da Fonseca, no Rio de Janeiro, em 1747. Sem entrarmos no mérito das disputas de primazia editorial, a experiência da segunda oficina de Fonseca no Brasil, a despeito da mera notação de curiosidade histórica e apesar da frustração provocada pelo sufocamento de sua ação, trouxe dados para a consciência tardia dos colonizadores, que, uma vez no Brasil, trataram 
de efetivar, com a criação da Imprensa Régia, um movimento pendular no curso das idëias, produzindo efeitos no fluir do século XIX. Os livros do engenheiro militar brasileiro Josë Fernandes Pinto Alpoym, o Exame de artilheiros (Lisboa, Josē Antonio Plates, 1747) e o Exame de bombeiros (Madrid, Francisco Martinez Abad, 1748) aumentam a expectativa sobre as atividades de Isidoro no Brasil. Durante algum tempo supôs-se a possibilidade de estes livros terem sido impressos aqui, com referếncias falsas, em atenção à 'necessidade de despistamento das vigilias moțropolitanas. Os modernos estudos parecem ter sepultado definitivamente essa pretensão.

o impresso que não oferece dúvidas quanto a ter sido publicado na oficina brasileira de Isidoro è um romance histórico em 27 quadros e 24 páginas, in $4^{\circ}$, editado em 7 de fevereiro de 1747, com a șeguinte referência: Relação da entrada que fez o excellentissimo e reverendissimo senhor D.F. Antonio do Desterro Ma1heyro, Bispo do Rio de Janeiro, em o primeiro dia deste prezente Anno de 1747, havendo sido seis annos Bispo do Reyno de Angola, donde por nomiação de Sua Magestade, e Bulla Pontificia, foy promovido para esta diocese. Autor provável: Luiz Antonio Rosado da Cunha, Juiz de Fora e Provedor dos Defuntos e Auzentes, Capelas e residuos do Rio de Janeiro. o colofão indica Rio de Janeiro, na segunda oficina de Antonio Isidoro da Fonseca. Anno de M.DCC. XLVII .

Um segundo impresso feito por Antonio Isidoro da Fonseca é um resumo de tese apresentada por Francisco de Faria 
ao colégio dos jesuítas, no Rio, onde o autor era professor de Filosofia, depois membro da Academia dos Seletos. 0 volume tem as dimensões de $80 \times 70$, com o título Hoc est conclusiones metaphysicae de ente rea1i, praeside R.G.M. Francisco de Faria... Flumine Januari. Ex secunda typographia Antonii Isidori Da Fonseca Anno Domini MDCCXLVII. Cum facultate superiore.

Haveria ainda outra obra editada por Isidoro no Brasil, embora seja imprecisa este informe em virtude da.ausência do colofão. Era um romance heróico de 5 folhas, in folio, Em applauso do excellentissimo e reverendissimo senhor D. Frey Antonio do Desterro Malheiro, dignissimo bispo desta cidade. O ano provảvel é o próprio 1747 e desconhece-se a autoria. o embargo à novel atividade não tardaria. Todos os estudiosos dão a notícia da providência real, mandando seguir para Portugal a oficina e seu dono, correndo as despesas do duplo sequestro por conta do pröprio Isidoro. Em 1750, Antonio Isidoro da Fonseca, em termos patéticos, solicitaria licença para voltar ao Rio de Janeiro. Não adiantou: seu pedido foi marcado com o timbre real de "excusado".

Em 1807, foi a vez da consentida experiência calcográfica do padre Viegas, em Vila Rica. Ali foi editado um fo1heto de 18 páginas, sendo 15 delas em impressão. 0 opúsculo era um poema em 20 oitavas de Diogo de Vasconcelos homenageando o aniversārio do capitão-general Ataỉde e Melo. Viegas teria aprendido alguma coisa do ofício na tipografia do Arco do Cego, com o pröprio Fr: Veloso. Na forma tipo- 
gräfica, porēm, Minas Gerais sō conheceu as letras impressas em 1823, com o primeiro jornal "O Conciliador Mineiro", em 13 de outubro.

A Tipografia Calcográfica, Tipoplästica e Literāria do Arco do Cego, criada em 1800, teve decisiva penetração no Brasil e em todo o Reino, contribuindo para a divulgação de obras de cunho científico e de técnicas circulares desde fins do sêculo XVIII. Até o final de 1801, quando se transformou na Impressão Rëgia, transferindo-se os seus diretores para a nova casa, a Tipografia do Arco do Cego jă havia publicado cerca de 70 títulos, a maioria nos ramos das Ciências Naturais. Seu diretor principal, o brasileiro Fr: José Mariano da Conceição Veloso, chegou de volta ao Brasil em 1807 .

Dois ministros são tidos em importância no particular da implantação da imprensa no Brasil. D. Rodrigo de Souza Coutìnho, depois Conde de Linhares e Antonio de Araújo, o Conde da Barca, que trouxe uma caixa de tipos de Portugal. A Impressão Régia, aqui, foi inaugurada a 13 de maio de 1808. Do ponto de vista da evolução da tipografia e, especialmente, quanto ao modo de produção e divulgação da letra impressa influindo diretamente na expansão de um público leitor, a criação da Imprensa Régia estimulou a identidade leitora dos brasileiros, ampliando o universo e o interesse pela leitura e pela livre circulação das idéias. Estimulou tambêm a proliferação de outras tipografias, como a de Manuel Antonio Silva Serva, na Bahia (experiência notävel pela popularidade e pela vitória do empreendimento, editando leis, 
livros, jornais como "A Idade d'Ouro do Brazil" e revistas como "As Variedades ou ensaios de Literatura") e atividades de livreiros-editores, como o próprio Silva Serva, Paul Martin, Paulo Martins Filho e Plancher. A vida administrativa e social ganha a parceria indiscutível da impressão e da disseminação da cultura. Plancher, por exemplo, edita, em 1824, duas obras importantes e de larga circulação entre nós: a Constituição do Impërio e a Coleção de leis e decretos do Império do Brasil, alếm de outros posteriores documentos de interesse histörico.

A trajetória da Impressão Régia è das mais ricas, pois criou espaços para a edição de livros e periódicos - logo, ampliou o universo de leitores e aguçou a curiosidade püblica para o saber. Além de impressos de seu interesse imediato (leis, decretos, papéis, memórias de efeito localizado) fez divulgar o saber dos livros e das ideologias. Os jornais da época completam o ciclo de Gutemberg entre nós, ampliando a perspectiva histórica do Brasil Reino e fomentando o yêrtice da cultura bibliogräfica e periodística. Formalizam-se as profissões de livreiro e editor, com excepcionais situações de estabilidade. Muitos livros vão ser objeto de anüncios nos jornais e cria-se o hábito da ida às livrarias nascentes. A primeira metade do século XIX será, portanto, a representação de um momento histórico de luzes, da Impressão Rēgia e de uma florescente indústria editorial que dão suporte e potencialidade ao consumo de livros e ampliação de leituras.

A perspectiva alvissareira aberta com a Impressão Ré- 
gia aqui, acentuada com a Biblioteca Real e os correios e notícias do mundo europeu vão se completar, na Bahia, pela ação do Conde dos Arcos. Além da tipografia e do comércio de livros de Silva Serva, a novidade é a criação da Biblioteca Pública baiana, contando com acervos de doações e da incorporação da biblioteca particular do padre Francisco Agostinho Gomes, ex-conspirador de 1798. Neste sentido, è interessante a leitura do "Plano para o estabelecimento de uma biblioteca pública na cidade de S. Salvador, Bahia de Todos os Santos, offerecido à Approvação do I11ustrissimo e Excellentissimo Senhor Conde dos Arcos, Governador e Capitão General desta Capitania", por Silva Serva, editado em 1811, para evitar a incultura, pois "he só atravez á ignorancia dos póvos que se devem imputar as desgraças que os opprimem". 162

No jornalismo periódico, não nos devemos esquecer da experiência de Hipólito da Costa e da enorme contribuição desempenhada pe10"Correio Braziliense"(1808-1822), editado em Londres e com sensivel penetração no Brazil onde formou juízos críticos sobre as ações do Príncipe Regente depois rei.D. João VI. E desse experimento de combate que vão crescer e multiplicar os periódicos brasileiros, na voga do constitucionalismo e do livre debate das idéias, da ansiada giória das insurreições de $1789^{\circ}$ e 1817 , a o signo mültiplo da Independência de 1822 .

A intima relação entre imprensa e ideologia acompanha uma nem sempre livre e aberta circulação de livros e jornais. $\vec{E}$, poịs, de ideologia, ou, antes, de repressão ideológica 
que tratam muitas das proibiçōes ao comércio ou à divulgação de idéias e de livros no Brasil Reino, como se estivesse recuperada a sombria vocação paternalista e doutrịnária nos óbvios interesses do väcuo colonnizador. A circulação da imprensa periódica nunca, como sabemos, transcorreu de fórma pacífica no. Brasil. Houve inümeros interditos, como os què alcançaram "O Portuguez" e "O Campeão ou Amigo do Rei e do Povo", proibidos de circular; hostilizados pelo governo de D. João VI, respectivamente em 9 de julho de 1818 e 7 de dezembro de 1819.163 A Coroa primava, assim,pela ameaça ao livre trânsito das idéias, como antes, e em igual sentido, zelaram a Inquisição e o Regalismo.

De qualquer forma, é importante destacar o surgimento e evolução da imprensa periódica e suas previsíveis consequências na formação de um público leitor e crítico. Alguns desses jornais fizeram história pela postura combativa ou pela margem de notícias sobre os costumes e vida social no Brasil Reino. Por uma ordem mais ou menos cronológica, temos: "A Gazeta do Rio de Janeiro" (1808-1822), a "Idade d'Ouro do Brasil" (1811-1823), "As Variedades ou Ensaios de Literatura", "primeira revista 1iteräria do Brasil, de que sairam dois ünicos nümeros (1812), "O Patriota" (18131814, do Rio de Janeiro), "Correio Braziliense" (1808-1822). "Aurora Pernambucana" (1821, de Recife), "O Paraense", de Belém (1822), "O Conciliador do Maranhão", de São Luís (18211823), "Conciliador do Reino Unido.", do Rio de Janeiro (1821), "O Bem da Orden", do Rio de Janeiro. (1821), "O Seminärio Cívico", da Bahia (1821-1823), "Diārio Constitucional", do 
RJ (182i-1822), "Revérbero Constitucional Fluminense", do RJ (1821-1822), "Despertador Fluminense", do RJ (1821), "0 Maribondo", do RJ (1822), "Correio do Rio de Janeiro"(18221823), "Tamoio", do RJ (1823), "Sentinela da Liberdade na Guarita de Pernambuco", Recife (1824), "Typhis Pernambucano", Recife (1823-1824), "Diário de Pernambuco", de Recife (1825). O jornal "Aurora Fluminense", que ilustra a importante presença de Evaristo da Veiga no cenārio político e cultural brasileiro, já pertence a um período que escapa aos objetivos deste traba1ho, entre 1827 e 1835 .

Duas experiências de impressão avulta no Brasil oitocentista. A da prōpria Impressão Régia e a de Silva Serva na Bahia. Sobre a primeira, já se conhece boa parte da história. Seu primeiro impresso é um folheto de 27 páginas, divulgando o primeiro daqueles itens principais para o que foi criada: Relação dos despachos publicados na Corte pelo expediente da Secretaria de Estado dos Negöcios Estrangeiros e da Guerra no fastidioso dia dos annos de $\underline{S} \cdot \underline{A} \cdot \underline{R}$. 으 Principe Regente N.S. E de todos mais, que se tem expedido pela mesma Secretaria desde a feliz chegada de $\underline{\text { S.A. }}$. dos do Briasil até o dito dia.

Os impressos seguintes, com alguns intervalos de publicações de obras poéticas, de Economia e Estudos Sociais (de 1808 a 1822, à Impressão Régia atingiu uma marca de 1.713 títulos), seguem a voga das publicações de documentos reais; das secretarias de governo, ao lado de cartazes, sermões, panfletos, voḷantes etc. Algumas obras se destacariam desse conjunto, como o Tesouro dos meninos; as Licões de 
Filosofia contêm por demais dogmas de Aristóteles e dos tempos sombrios para que demonstre que seu Autor não è nem instruído nem judicioso; a Histöria de ilusōes extravagantes e influência sobrenatural; Leis comerciais do Brasil e Tratado das doenças dos negros. 0 interesse despertado para estudos de Retórica e Poética privilegiaram a publicação dos Ensaios de Pope, na tradução do Conde de Aguiar.

Além desses títulos, observa-se uma natural curiosidade pela publicação de livros extra os documentos oficiais. A relação primäria desses títulos se fez gradualmente, desde 1808. Neste ano, alëm da Relação dos despachos, tivemos a publicação de observações sobre o comércio franco do Brasil, por Josē da Silva Lisboa e a Memória histórica da invasão dos franceses em Portugal em 1807, sem autoria conhecida. Os anos seguintes registram algumas das mais significativas produções da Impressão Régia:

1809 - Elementos de Algebra, de Euler Elementos de Geometria de A.M. Le Gendre, ambos traduzidos por Manuel Ferreira de Araūjo Guimarães

1810 - observações sobre a prosperidade do estado pelos 1iberais princípios da nova legislação do Brasil (in $88,95 \mathrm{p.})$

Refutações das reclamaçōes contra 으 comërcio inglês, de Josē da Silva Lisboa

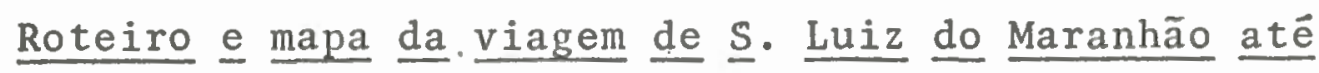
a Corte, de Sebastião Gomes da Silva Berford Preâmbulo: ou Ensaio filosöfico e politico sobre a 
capitania do Ceará para servir à sua história geral, de. João da Silva. Feijó

Tratado de Aritmetica, por Lacroix, trad. por Silva Torres

Tratado elementar de física (2 v. ilustrados, com 400 p. cada um) de Hally

Ensaio sobre a crítica, de Pope, trad. e anotado pe10 conde de Aguiar $200 \mathrm{p}$. in $4^{\circ}$ (Notas de José Bastos, do tradutor e outros e comentärio do Dr. Warburton).

Marília de Dirceu, partes $1-3,3 v$. in $8^{\circ}, 336 \mathrm{p}$. no total

O Diabo Coxo, verdades sonhadas e novellas de outra vida traduzidas a esta. Por Lesage. N. ed. T. $1^{\circ}$

1811 - Ensaios morais, de Pope, trad. Conde de Aguiar O Uruguai, de Basilio da Gama

Roteiro da cidade de Santa Maria de Belém do Grão Parä pelo rio Tocantins, de 01iveira Bastos

Obras completas de Manuel Maria Barbosa du Bocage Compêndio da riqueza das nações, de Adam Smith, trad. por Bento da Silva Lisboa (3 v., 1811-1812)

Paulo e Virginia, de Saint-Pierre

$1812^{\circ}$ - Elementos de á1gebra, de Lacroix, trad. por Francisco Correia da Silva Torres

Elementos de geometria descritiva extraidos da obra de Monge, por José Vitorino dos. Santos e Souza Tratado elementar de mecānica, de Francoeur, trad. 
por Saturnino da Costa Pereira

Ensaio sobre os perigos das sepulturas dentro das cidades e nos seus contornos, de José Correia. Picanço

Obras poéticas, pelo poeta de meados do sêculo XVIII Correia Garção

1813 - Tratado de óptica, de La Caille, trad, por Andrë Pinto.

Preleções philosophicas sobre a theorica do discurso e $\underline{\text { da }}$ linguagem, a esthetica, a diceósyna e cosmologia, de Silvestre. Pinheiro Ferreira

Aforismos sobre as hemorragias uterinas e convulsões puerperais, de Thomas Denman, trad, por Costa Barreto, por ordem do principe para a escola de medicina Tratado elementar de arte militar, de Gay de Vernon, trad. por João de Souza Pacheco Leitão

1814 - Elementos de astronomia, compilados por Araújo Guimarães para a Real Academia Militar

Compêndio de matéria mêdica, por José Maria Bomtempo Discurso fundamental sobre a população, por Herrenschwand, trad. por Luís Prates de Almeida Albuquerque

1815 - Memórias da vida pública de Lord Wellington, príncipe de Waterloo, duque de Victoria, duque de Wellington, duque de Ciudad Rodrigo, marechal general dos Exércitos de Portugal contra a invasão francesa, etc. trad. por Josē da Silva Lisboa, $\mathrm{cm} 2 \mathrm{v}$.

Primeiras linhas sobre o processo orphanológico, de José Pereira de Carvalho. 
Elementos de Geodésia, compilado por Araújo Guimarães História da donzela Teodora, trad. do espanhol por Carlos Ferreira Lisbonense

1816 - Filosofia química, de A. F. Fourcroy, trad. por Henriques de Paiva

Coleção de retratos de todos os homens que adquiriram nome pelo genio, talento, virtudes... desde o principio do mundo, retratos de Antonio de Carmo, gravados por João Josë de Souza

1817 - Corografia brasilica; ou, relação historico-geografica do Reino do Brasil, de Manuel Aires de Cazal

1818 - Obras, de Virgilio, trad. em versos portugueses por Antonio José de Lima Leitão (3v., 1818-1819)

Foram editados outros títulos que serviam aos interesses do Governo (Economia Politica, Geografia, Agrimensura, Medicina, Saúde Pública), outros à Academia Militar, como Desenho e Astronomia, que constavam do curriculum. E mais: livros para servirem ao comércio da livraria de Paulo Martim e outras livrarias cariocas e até atender a encomendas dos leitores. ${ }^{164}$ Foram editados também as Memórias Históricas do Rio de Janeiro, por Mons. Pizarro e Araujo e o poema Assunção, de Fr. Francisco de S. Carlos.

Alguns desses se destacariam na preferểncia popular, em virtude de um imediato interesse, como as primeiras 1inhas do processo orfanológico, "livro didático de leis que 
se tornou um trabalho modelo, atē o final do século."165 Outro destaque é que a primeira edição de obra literária feita pela Impressão Régia parece ter sido'a tradução de $\underline{0}$ Diabo coxo, verdades sonhadas e novelas de outra vida traduzidas a esta, de. Allain René Lesage (Rio de Janeiro, Impressão Régia, 1810). Lesage é também autor de outra obra de enorme popularidade no Brasil Colônia, as Aventuras de Gil Braz de Santillana. Ambas as novelas são de efeito moralizante, na tradição de livros e leitores vindós de influência editorial portuguesa.

Em sua maior parte, os livros saídos da Impressão Régia e mesmo os que foram ter edição em Portugal, tiveram aqui uma.considerāvel aceitação, como se pode comprovar pelas listas de obras indicadas nos inventārios de bens, documentos manuscritos que representam peça indiscutível de realismo histōrico.

Tão logo Portugal se viu livre do assédio francês, os livros voltaram a ser editados em Lisboa, pois a impressão $1 \vec{a}$ era bem mais barata e o mercado de consumo muito maior. Alguns títulos brasileiros foram lá editados: o Dicionário da lingua portuguesa, de Antonio Moraes e Silva (1813); os Sonetos sobre diversos assuntos, de Antonio Joaquim de Abreu (Lisboa, Reg. Of. Tip., 1815); uma reedição do poema As $\underline{\text { Ar- }}$ tes ; de Manuel. Inácio da Silva Alvarenga (1821); as Memóriás para servir à história do Reino do Brasil, do padre Luís Gonçalves dos Santos (Lisboa, 1825). E mesmo obras de José Bonifácio, publicados por ele mesmo em Lisboa, entre 1815 e 1816 . 
Após o advento dà Impressão Régia, outros empreendimentos tipográficos vão sendo estimulados e desenvolvem um sólido processo editorial no Rio de Janeiro e na Bahịa, sobretudo, o que demonstra a certeza de recompensa nas iniciativas. Em 1817, a Impressão Régia passa a chamar-se Rea1 0ficina Tipográfica. Em 1821, Régia Tipografia, depois Nova Oficina Tipogräfica e, finalmente, Tipografia Nacional. Em seguida, é privatizada com a denominação de Tipografia de Moreira e Garcez. Um bom número de livrarias vão se sucedendo em todo o país com destaque para as de Paul Martin, Plancher e Silva Serva, este na Bahia. Já em 1822, Manuel Joaquim da Silva Porto, livreiro e poeta, tradutor da Fedra de Racine, inicia sua cëlebre oficina Silva Porto e Companhia, com sensíveis contribuições no panorama da edição e do comércio de livros no Brasil. Borba de Moraes lembra que em 1820 Antọnio José Coimbra anunciava, na Bahia, que vendia livros e os encardenava, "de todas as qualida des." 166

Com a Independência e suas consequências, aumentam o interesse e o consumo de leituras politicas. Daí se explica, talvez, a notável massa de livros com títulos de matérias constitucionais, de feitio ainda burguês e aspirando a reformas, valendo ressaltar a circulação de obras como as de Benjamin Constant (especialmente La Politique constitutionel) editada por Plancher, 1818, em Paris), Jéremy Bentham. De Pradt, entre outros. Os jornais desempenham também importante papel, divulgando sonetos, extratos folhetinescos, resenhas e comentários políticos e culturais, trazendo fatos e opiniões de natureza administrativa, enfim, 
farto painel dos acontecimentos sociais da época. Os correios da Europa atiçam a imaginação liberal, fazendo avizinhar-se novos movimentos emancipacionistas em face das sucessivas crises do Reino no Impērio. Koster observaria, em 1810, a inexistềncia em Recife de tipografias e livrarias. Màis tarde, no entanto, segundo registra Hallewel, ali teríancirculado obras de revolucionários de 1817 e a de Fr. Caneca em 1824. ${ }^{167}$ Livrarias e tipografias concorrem, então, para servir aos interesses de leitura despertados nessa época. Livrarias que, em 1792, se reduziam a uma única, dispondo apenas de obras de Teologia, além de um vendedor isolado de obras da Medicina portuguesa, ${ }^{168}$ eram agora sete em 1822 .

Jä nos começos de Oitocentos, os anúncios de livros faziam afluir às livrarias pessoas letradas da Capital do Impērio e do resto do país, pessoas que buscavam nas lojas livros novos chegados nos'últimos vapores vindos da Europa. Os livreiros anunciavam nos jornais a ültima fornada de obras européias, formando assim potenciais leitores e influindo no espírito liberal e constitucionalista de então. Em 1823, segundo informa Laurence Hallewel, havia no Rio de Janeiro cerca de 13 livrarias, inclusive um vendedor especialista em livros religiosos localizado próximo ao convento da Ajuda ${ }^{169}$. Os movimentos de compra de livros e de estabelecimentos se davam de forma espontânea ou organizada. Evaristo e seu irmão João Pedro Ferreira da Veiga compravam em 1824 a tipografia de Silva Porto e anunciavam, no "Diārio Fluminense", um convite para subscrição de uma tradu- 
ção feita por Joaquim Cardoso Leão para L'Histoire du jure, de Aignon. 170 Por esse tempo, Plancher, com o cartel de ter editado em Paris autores importantes como Voltaire, (a obra completa em 42 volumes), Dante, Milton, Schelling e Walter Scott, dava seguimento à sua empresa no Rio de Janeiro. Ainda no Rio, os Almanaques davam conta das notícias de moda, cultura, sociedade e outros assuntos do Reino. 0 de 1811, por exemplo, anunciava que o n.l do primeiro jornal do Rio, a "Gazeta do Rio de Janeiro", de 10/9/1808, poderia ser encontrado na livraria de Paulo Martin Filho, "mercador de livros no fim da rua da Quitanda."

Aliás, grande foi a contribuição, para o evoluir do comércio de livros no Brasil, do francês paul Martin e de seu sucessor Paulo Martins Filho. O primeiro parece ter sido possuidor de uma das duas únicas livrarias registradas em fins do século XVIII no Rio de Janeiro. Morto em 1810 , sucedeu-o Paulo Martins Filho, com a atividade estendendo-se até 1823. E para este Paulo Martins Filho, pois, que a Impressão Régia editou várias traduções de novelas de sucesso no Oitocentos Brasileiro, como $\underline{0}$ Diabo coxo, de Le Sage, e os'romances, a maior parte traduzida do francês, que representam um mau gosto típico que atravessa todo a primeira metade do século XIX português, obviamente com extensão para o Brasil. Títulos como $\underline{0}$ Amor ofendido e vingado, Triste efeito de uma infidelidada (Impressão Régia, 1815); As Duas desafortunadas; e a História verdadeira da princesa Magalona. Assim se desenvolvia o comércio de Paul Martins e de seu sucessor e filho. Para divulgar os livros que ven - 
dia na loja da rua da Quitanda $n^{\circ} 34$, o empreendedor livreiro fazia propaganda das obras que tinha à disposição do público. Os anúncios indicam, em geral, o autor, o título e o preço de cada exemplar. Com o fim da censura a 28 de agosto de 1821, muitos desses anüncios foram lidos pelos brasileiros. Alguns títulos são curiosos e vale a pena transcrevê-1os:

Acontecimentos no Pará acerca da Constituição o amante da humanidade; ou meios de extinguir a mendacidade em Portugal

Apontamentos sobre os antigos abuzos do antigo governo de Portugal

Theodoro J. Biancardi: Cartas americanas, Manuel Borges Carneiro: Coleção de oito parabolas.

-.-.-.: Elogio

-.-.. : A magia e mais superstições desmacarada s

-.---. : Portugal regenerado, 3. ed.

Catecismo da Constituição Hespanhola

Concordia Nacional nacida da Constituição Josē Daniel: 0 balão

-.-.-. : Portugal convalecido

--.-.-. : Portugal enfermo por vicios e abusos de ambos os sexos

-.....: Prazer do luzitano

-..--.: Tizoura de Critica

-...-. : A verdade exposta a sua Magestade

Direitos do povo portuguez

Gomes Freire: Allegação de facto e direito sobre o processo de G.F.

-..... Analyse da sentença de G.F.

Meios de se pagar a divida publica

Memoria sobre as minas consideradas como fontes de riqueza nacional 
Reflexões philosophicas sobre a liberdade e a igualdade

Reflexões sobre o pacto social e sobre a Constituição de Portugal

Francisco de S. Luiz: "Synonimo da lingua portuguesa

Soares Franco: Ensaio sobre o melhoramento de Portugal e do Brazil

United States of America: Constituição dos EE. UU. 171

Esta parece ser a tendência de publicidade das obras oferecidas ao püblico brasileiro oitocentista. A voga constitucional alterna com o interesse de disciplinas teóricas tendo em vista a situação política. O fim da censura, embora parcial, ocorrido em 1821, facilitou a tarefa dos 1ivreiros em ampliar o acesso dos cidadãos a matérias antes vistas com esquivanças pelos potentados. Assim, a publicidade de Paulo Martins Filho podia fazer chegar aos leitores, obras como o Direito das gentes e do foro; ou, Principios da 1 ei natura1, de Vatel e o Contrato social, de Rousseau. Para a eficăcia de seu intento de marketing, o livreiro complementava a informação do anúncio com o seguinte despacho: "estas obras que outrora foram proibidas presentemente se tornam inteiramente clāssicas e necessārias a toda classe de pessoas, pois estão sendo citadas em todós os escritos verdadeiramente constitucionais." 172

A Revolução do Porto veio acelerar bruscas alterações na vida de portugueses è brasileiros, refletidas também na atitude politica e söcio-cultural dos dois povos. Convocados a formar uma Assembléia Constitucional, foram escolhi- 
dos representantes de Brasil e Portugal. Daí o interesse manifesto por constituições, como a dos Estados Unidos. A censura não arrefecera de todo, mas seu poder de interdito às consciências jâ não se fazia tão soberanamente. Em 21 de fevereiro de 1821 , a Junta Provisória do governo da Bahia decidira extinguir a censura por sua própria iniciati$v a$, conquanto nem sempre se tenha conseguido de todo bani-1a, o que parece fazer parte da tradição brasileira... Na decisão baiana, os crimes imputados às publicaçôes eram prescritos em lei ordinăria, sendo os principais o. incitamento à rebelião, ataques à religião ou à moral cristã, ou à figura das autoridades. Cipriano Barata, por causa de seu jornal "Sentinela da Liberdade na Guarita de Pernambuco", a partir de abril de 1821 , foi condenado à prisão perpétua. Ficou preso depois de cumprir sete anos da pena prevista. Outro jornalista, João Soares Lisboa, do "Correio do Rio de Janeịro", julgado por atentado ou incitamento, foi absolvido por um corpo de jurados isento de preconceitos. A abolição da censura favoreceria o livre curso das idéias políticas no país e isso se reflete, ou se deduz dos anúncios de titulos da livraria de Paulo Martins Filho:

A Europa e a America, 2 v.

A revolução atual na Espanha e suas consequencias

As obras de Deprat, em francês: Sobre as colonias e a revolução ora ocorrendo na America $2 v$.

Tres ültimos meses da América

Carta ao deputado em Cortes Luis Nicolau Fagundes Varela, escrita por um liberal, desta Corte 
Dissertação, em que se mostra, por um eleitor da paróquía, a necessidade da existência de sua Alteza Real no Brasil, para se constituir não só a desejada união com Portugal, mas a de reciprocos e iguais interesses Incontestāveis reflexões que um português europeu oferece aos sentimentais brasileiros sobre os seus futuros de Portugal

Aforismos domesticos para legitimos constitucionais; ou, Ciência do bom homem Ricardo, um trabalho escrito em linguagem acessivel a qualquer leitor, pelo grande imortal americano B. Franklin, que roubou o raio de Júpiter e o cetro da Tirania ${ }^{173}$.

Eram anunciados esses e outros títulos, para venda junto ao püblico. Das listas encaminhadaspelos livreiros constavam ainda A arte poética de Boileau, traduzida pelo 38 Conde de Ericeira e o Ensaio sobre a critica, de Pope, traduzido pela condessa de Oyenhausen.

As Obras poëticas de Francisdo Dias Gomes (Lisboa, 1799), As Obras poéticas jocosas e sérias de Antonio Joaquin de Carvalho (Lisboa, 1806-1807), as Poesias, de Pedro de. Andrade Caminha (Lisboa, 1791), os Versos de Bernardo Antonio de Sousa, o popular Belmiro (Lisboa, 1814), as Composições poéticas de Belchior Manuel Curvo Semedo (Lisboa, 1803(, as Rimas de Francisco Alvares da Nöbrega (Lisboa, 1801-1802), as Odes pindāricas, pöstumas de Elpino Nonacrien-. se, o famoso Antonio Diniz da Cruz e Silva (Coimbra, 1801), ‥ Urugai de Basilio (Lisboa, 1769), Afonso Africano, poema heróico de Vasco Mousinho de Quevedo Castelo Branco (Lisboa, 
1786), Lisboa destruída, poema de Pe. Teodoro de Almeida (Lisboa, 1803), Braganceida, poema em 12 cantos de Francisco Roque de Carva1ho, os Improvisos de Bocage (Lisboa, 1805; Rio, 1810). Os poemas de José Agostinho de Macedo (Newton; O Oriente: A meditação); além de uma Coleção de poesias inéditas dos melhores autores portugueses (Lisboa, 1809-1811) e de poetas como Manuel Joaquim Ribeiro, Francisco Manuel Gomes da Silveira Malhão, Antonio Ribeiro dos Santos (ou E1pino Duriense), Fr. José do Coração de Jesus (ou Almeno), assim se constitui a boa maioria dos anúncios populares, sobre mais ou menos novas vindas de Lisboa ao Rio de Janeiro do começo de XIX. Se levarmos em conta que "A Gazeta do Rio" teve sua circulação assegurada por quatorze anos (entre 1808 e 1822) e distribuída nas principais regiões do país, teremos concreta noticia da popularidade desses e de outros livros que certamente circularam no Brasil. Nossa investigação direta, aliăs, confirma uma inquestionável popularização dessas e de outras obras no Brasil de 0itocentos. Igualmente a pesquisa de livros antigos existentes em bibliotecas brasileiras atesta a popularidade de obras como as acima apontadas.

A matéria publicitária pode perfeitamente elucidar a1guns pontos, mais ou menos obscuros. O reproduzido acima, no nosso entendimento, versa, na sua totalidade, sobre assuntos direta ou indiretamente relacionados com a revolução de 1820 no Porto, que furçou a volta de D. João VI a Lisboa e impulsionou decisivamente a Independência do Brasil. Há, inclusive, referência direta a um dos deputados às Cortes Constitucionais em Lisboa, o paulista Luis Nicolau Fagundes 
Várela, avô do poeta, que assinalamos em outra parte deste trabalho. As obras de De Pradt pontuam no universo brasileiro oitocentista, como se pode verificar da peça de marketing da livraria Paulo Martins Filho. As análises, os debates; as discussões e reflexões, "incontestáveis" ou não, norteiam o comportamento político de deputados e observadores e servem como elemento de avaliação e leitura do período. O comércio de livros, assim, reflete e redimensiona, quando não provoca e instiga, esse comportamento. Pois é em atenção a esse gosto e esse interesse que as livrarias se organizam e buscam oferecer ao leitor os títulos que ele naturalmente procura. ' O editor e o livreiro, em última anāliśe, atendem às exigêncịas do tempo. As matêrias religiosas deram o grau de predominância nos séculos XVI, XVII e XVIII. Agora, do primeiro para o segundo quartel do sệculo XIX, as matérias políticas, as da atualidade e da contemporaneidade, parecem representar ou parecem promover o espirito de descoberta e livre debate das idéias características da época.

O comércio do livro no Brasil, nesta primeira metade do século XIX, é bastante peculiar. Haverià alguma coisa de importado, ou entrado no país como peçà de contrabando. Mas os livreiros do Rio, e os da Bahia, por exemplo, punham especial relevo na política de marketing, dispensando natural tratamento publicitärio às obras importantes recẻm-chegadas do espírito moderno da Europa. No caso dos títulos de Letras, por exemplo, destacam-se as traduções de Bocage, $\underline{0}$ Consörcio das flores, de Lacroix e Os jardins, de Delile. 
Também se comercializavam As plantas, poema de Ricardo Castel e as Fäbulas escolhidas, de La Fontaine, traduzidas pe10 padre Francisco Manoel de uma edição londrina. Deste mesmo tradutor eram anunciados Os mártires, ou o triunfo da religião cristã, de Chateaubriand, a partir da edição parisiense de 1816 - livro, aliás, muito popular no Brasil oitocentista.

O comércio de livros compreendia tambēm obras dramáticas,em vista do enorme prestígio do teatro no Brasil, com prevalência para autores consagrados, o que implica leitura e circulação de suas peças entre aficcionados e encenadores, destacando-se os nomes de Metastásio, Voltaire e Goldoni. Tal popularidade se pode atestar tambëm pela presença de alguns desses autores entre os livros constantes de nossa pesquisas nos inventários desde o sẻculo XVIII.

No Oitocentos brasileiro, são autores e peças igualmente populareș: Antonio Bressane Leite (ㅁ grande califa de Bagdad e A união venturosa), D. Gastão Fausto da Câmara Coutinho (․ Juramento dos Numes), que inaugura o teatro São João em 1813: Aí também aparecem peças sem declaração de autoria como Combate de Vimieiro; Os três gêmeos; a ópera Caçada de Henrique IV, entre outros. Em 1815, anunciava-se a encenação do Mágico de Valença, de Luís Xavier Pereira. E exemplos mais expressivos de representação teatral como a Ifigênia em Tauris, de Euripides, traduzido por Cruz e Silva, a Ifigênia em Aulis, de Racine, traduzido por Felinto Elisio; a obra de Maffei, Mërope, na tradução de Francisco José Freire, título também que pode ser atribuido a Voltaire, na tradução feita em 1786 . 
Seguindo as pegadas das excelentes informações tra zidas por Niza da Silva, Cultura e Sociedade no Rio.de Janeiro (1808-1821), registramos o comërcio de livros de dramaturgia e comédia como o Teatro estrangeiro, em 2 volumes, contendo o Cid de Corneille; o Avarento, de Molière; o jogador, de Regnard; $\underline{0}$ pai de familia, de Diderot; $\underline{\text { os }}$ dois amigos, ou o negociante de Lião, de Beaumarchais; A1zira, ou os americanos, de Voltaire; e Atreu e Tiestes, de Crebillon. Também se vendiam o Teatro cômico português, as comêdias traduzidas de Goldoni e Terêncio, (do primeiro, aliás, aqui atribuimos A mulher amorosa, e $\underline{A}$ viúva sagaz ou astuta, ou as quatro nações). Claro, não faltaria Metastāsio (A Gricelda, ou a rainha pastora). E parte do teatro nacional português como Loucuras da moda, de Luís Alvares e Azeredo e a comédia joco-séria Quem boa cama fizer nela se deitarä, de Silvestre Silvério da Silveira e Silva, pseudónimo de Manuel Josê de Paiva. Mais a "ficção cômica" Olinta, A beata fingida e Indústria contra finezas, esta ültima atribuída a Nicolau Luís, do teatro de cordel português. De Voltaire, circulavam para leitura e venda suas traduções portuguezas Mafoma, Os Citas, Mérope, Orestes, Sofonisba e Mariane. Além de Voitaire, comparecem nessa amostra também Racine (Atalia e Ifigênia em Aulis.); o abade Genest, (Penëlope): Houdar de la Motte (OS Macabeus), Arnauld (Eufêmia, ou o triunfo da religião de Faye1). Do teatro trágico português, havia autores como Manuel Caetano Pimenta de Aguiar (Virginia, Os dois irmãos inimigos), Manuel de Figueiredo (Osmia, ou a lusitana): Pato Moniz (A queda do despo- 
tismo), José Joaquim Bordalo (Jesua1do), Francisco Soares

Franco (Hermínia) e João Batista Gomes Jünior (Nova Castro).$^{174}$

No drama $\underline{0}$ Juramento dos Numes, "Para se representar na noite da abertura do Real Theatro de S. João em aplauso ao Augusto Nome de Sua Alteza Real o Principe Regente Nosso Senhor, por D. Gastão Fausto da Camara Coutinho", publicado pela Impressão Régia em 1813, o autor faz uma "Advertência" a um público especializado - a crítica - dirigindo-1he observações envoltas em juízos de ordem estílistịca, que denunciam a filiação do auțor a dramaturgos e comediógrafos da voga teatral. Lembra que a peça è alusiva à principal encenação da noite - Combate do Vimieiro - servindo-1he de "Prefação" e que

-He desnecessario lembrar aos Leitores judiciosos, que nas composiçoens deste genero, que servem mais para deleitar, que para instruir, não se deve exigir o severo cumprimento dos preceitos Dramaticaes: hajão vista a Voltaire, Methastasio, Moliere, Goldoni, e outros, que sendo aliăs tão prolixos na exacta perfeição das suas grandes obras o não quizerão ser naquellas de que trato. 175

Natura1mente, "Leitores judiciosos" serão os críticos. 0 autor do drama previamente defende seu trabalho, buscando correspondência com estilos autorizados por consagrados escritores, neles reconhecendo uma categoria que autonomize o conceito e a referência à sua peça. Esta prêvia defesa da obra se ajusta ao parágrafo final da "Advertência", onde se afirma que: 
Se me criminarem à cerca do estilo que sustento levantado, e por ventura improprio da Poesia Dramatica, responderei que a locução rasteira he vergonhosa na boca de huma Divindade, e que os objectos grandes devem ser grandemente tratados.

Não satisfeito, ainda com uma definitiva asserção que .1he garanta antecipadamente as graças do aceitamento critiCo, D. Gastão Coutinho recupera, com uma Ode 20 de Horácio, no Liv. 3, versos que consagrem o principio de sua defesa: "Nil parvum aut humile modo,/ Nil mortale loquar." 177

Dos entremezes mais populares, vendidos por Silva Serva no Rio, destacam-se os seguintes títulos: $\underline{0}$ médico $\underline{\text { e }}$ ․ boticário; Os dois mentírosos; o doutor sovina; A corrio1a; $\underline{\text { miseráve1; }}$ A mestra abelha; $\underline{\text { m trapaceiro; }}$ o poeta desvanecido; Virou-se o feitiço contra o feiticeiro; e $\underline{0}$ casamento.

Ainda sobre o comércio de 1ivros no Rio de Janeiro, Hallewe1 registra que, na rua dos Latoeiros, 12 , havia uma loja vendendo livros de Medicina, Cirurgia, História, Literatura, Artes, Ciências e Jurisprudência, o que ocupa, praticamente', todo um catálogo variado de publicações. Outra 1oja atendia na Rua Direita, 60. Evaristo da Veiga anunciava livros sobre Economia (Ricardo) e Politica, Governo e miscelâneas sobre as nações americanas, particularmente o México e os Estados Unidos. Spix e Martius diziam desconhecer livrarias na Bahia, onde não descobriram nenhuma produçāo da Literatura brasileira. 178 
No Maranhão, Jerônimo de Viveiros dedica todo o capítulo XXVI de seu História do comércio do Maranhão 1612 1895, ao assunto. Alí o comércio livreiro só se desenvolveria no periodo posterior à Independência, tendo sido nula a experiência anterior à quadra de tempo assinalada. Viveiros cita Henri Koster, que se queixava da canseira de providenciar remessa de uma caixa de livros em 1811. As exigências eram muitas para enviar ou receber livros notadamente se havia algum livro dentre os proibidos. o oficial maior da secretaria do governo, Antonio Marques da Costa Soares, viu-se impedido de receber da França o contrato social de Rousseau, conforme Viveiros apurou junto ao Arquivo da. Secretaria do Estado dos Negócios do Interior, Justiça e Segurança, Ofício $n^{8} 467$, de $1^{\circ}$ de agosto de 1822 , da Junta Governativa ao Administrador da Estiva da Cidade de São Luis, livro 17 .

Tal rigor não seria diferente em outras cidades da colönia, como Recife, segundo reclamava Antonio de Moraes Silva em carta a Cairu, de não haver, na capital pernambucana, "nenhum alfarrabista de cartilhas e livrinhos de Santa Bärbara". 179 , Entretanto, Viveiros observa que o Governo português remetera, em 1799, alguns livros para venda no Correio e que, dentre estes, constava um Curso de estudos para uso do comercio. Estes livros, aliäs, teriam as mesmas dificuldades de circulação apontada em Sạ̃o Paulo pelo governador o capitão general Antonio Manuel de Melo Castro e Mendonça:

Citando César Marques, Viveíros transcreve a observa- 
ção do governador Dom Diogo de Souza que., em carta a Lisboa, assegurava que"a extração dos livros dificultosamente poderia ter o êxito, que se desejava, atenta a-indiferença, ou para melhor dizer, repugnância dêstes povos a tôda a qualidade de aplicação literária," e que a venda dos livros na casa do administrador do correio excedeu a $20 \$ 000$.

A notícia concreta de livros à disposição de um público consumidor tambēm se extrai de um anúncio publicado em "O Conciliador do Maranhão" número 37, de 17 de novembro de 1821. O anúncio foi feito peḷo tipógrafo Côrte-Real, com a seguinte redação:

Francisco José Nunes Corte-Real, Compositor de Letras da Tipografia Nacional desta Cidade, residente na mesma Tipografia, tem para vender os seguintes impressos, publicados em Lisboa no corrente ano: "Memorial Patriótico, dirigido aos 'Ilustres Deputados" - "Jornal dos Debates, sobre a Revolução de Portugal para a Constituição Portuguesa" - "Destroço em ataque do Cordão da peste Periodiqueira, com a ordem do dia do Corcunda de mä fë" - "O Acōlito contra o Exorcista" - "A Jornada.do Exorcista" - "Parabēns à. Pátria, pelo Juramento da Constituição Portuguesa" - "Contrariedade, à Razão e nada mais". - Vendem-se na Tipografia, e na Loja de Bebidas de Vicente Cortezze.

o mesmo Corte-Real se encarrega de qualquer encomenda de Livros ou Papēis curiosos que se pretendam de Portugal. 180

o exemplo de Corte-Real foi imitado anos depois por outros tipógrafos, conforme se observa em 1833 e 1834 e daí 
sucessivamente: Talvez os livros do tipógrafo fossem, na verdade, os folhetos de circulação corrente nas duas primeiras décadas do século XIX, quando era norma discutir o processo constitucional, não apenas na Metrópole, como no Rio de Janeiro, particularmente em diatribes fomentadas pelos jornais da época.

Hâ, ainda, o registro de anüncios de livros singulares, cheios de graça e malícia, publicados já em 15 de agosto de 1829, no jornal "Estrela do Norte do Brasil",em S. Luiz:

Vende-se no Largo do Carmo, por preço cômodo, uma nova obra, em um volume que tem por titulo Compendio de observaçōes - dividido em quatro partes, que contêm as seguintes matérias - la. Método breve d'impinar papagaios à primeira carreira - 2a., O Verdadeiro fim dos machados nas portas. - 3a., Novo sistema de furtar terrenos e fontes. - 4a., Diferentes maneiras de fazer subornos, tudo muito bem observado por um Teólogo Carmelita." 181

"Ou este outro "anúncio", de funda e direta maledicência, também publicado no "Estrela do Norte do Brasil", na mesma edição de 15 de agosto de 1829:

Saiu à luz uma nova obra intitulada - Tratados d'Incestos - por Mr. de Candidat; um volume, dividido em três partes - la., Ecemplos d'lmoralidade - 2a., 0 auge da patifaria - 3a., Lições de pouca vergonha. - Vende-se na rua da Paz, ai junto do Escrivão Mendes dos Reis; preço comodo. 182 
$\mathrm{Na}$ ärea educativa, os comerciantes que se quisessem instruir em aulas de comércio poderiam fazê-10, no Maranhão, despertada a atenção reinol para com os guarda-1ivros ou caixeiros, em vista da necessidade de senso prático observada deșde a política pombalina do século XVIII. Um livro certamente circular no Maranhão, pelo menos conhecido e debatido pelos negociantes locais, obra rara escrita em 1813 pelo lavrador Raimundo José de Sousa Gayoso, e publicado em Paris, post-mortem de seu autor, em 1818, com o título Compềndio histórico-político dos pirincípios da lavoura do Maranhão, revela, no capítulo 5, um interesse localizado: a luta comercial entre fazendeiros maranhenses e os comerciantes. ingleses radicados em São Luiz. ${ }^{183}$

No Rio de Janeiro, ainda, o papel de Plancher como editor e livreiro não desmereceria o período oitocentista na tradição brasileira da impressão e do livro. Somente em 1824, entre papéis do governo imperial, plaquetas de consumo imediato e peças de propaganda, sairiam dos prelos uma Coleção de leis e decretos do Império e coisas da Alfầndega; a Constituição do Império do Brasil (o juramento da carta foi a 25 de março de 1824), e. mais A inviolabilidade da Independência, a glória do Império do Brasil, escrita por "Um Brasileiro" e o Império do Brasil, de M.V. Angliviel La Baumelle, com tradução do padre Luiz Gonçalves dos Santos, a partir do original de 1823. Entre uma folhinha de algibeira e um Anuário histórico brasiliense, também seria editado por Plancher um Guia da conversação brasileira e francesa, de G. Harmonière, obra de extraordinária raridade para os estudos de ambos os idiomas. 
No. entanto, o mais afortunado dos editores brasileiros no período do século XIX, aquele que combina os ofícios de impressor, livreiro e divulgador do livro, é mesmo Manuel Antonio da Silva Serva, português de Vila Real de Trás os Montes, instalado na Bahia desde 1797, vendendo móveis e posteriormente livros importados da Europa. Em 1809, Silva Serva consegue licença para trazer uma impressora de Londres, graças aos esforços do Conde dos Arcos. Começa a editar em 1811, com o Plano para o estabelecimento de uma bi-

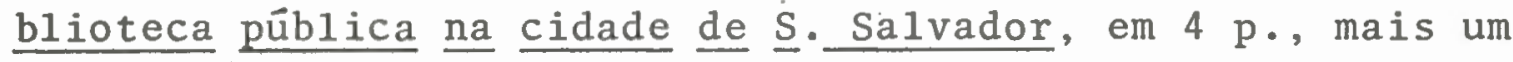
prospecto para jornal, uma Oração gratulatória do Príncipe Regente, por Inácio Josē de Macedo, em 11 páginas. Daí Silva Serva salta para o jornalismo periódico com "A Idade d' Ouro do Brasil" e "As Variedades ou Ensaios de Literatura" , desenvolvendo, em termos particulares, a mais produtiva trincheira de popularização da leitura no Brasil Oitocentista.

Basta um rápido lance de olhos no catálogo de publicações de Silva Serva, editado em 1812 (como livreiro, ele preparou um catálogo de obras para venda) para que se certifique do acerto e da importância que reveste essa primeira livraria e essa primeira imprensa particular na Bahia. Avaliando-se a mostra descritiva desse catálogo, não há como discordar do trabalho desenvolvido pelo livreiro e editor trasmontino. Detemo-nos em alguns títulos, particularmente os que interessam à área de Letras.. Entre as orações gratulatórias e os panegíriços de ocasião, (é bom não esquecer que Servą tinha una Junta. consória que furıciona atê 1820) a Tipografiabaiana edita também obras importantes que do- 
cumentam o espírito de uma época. Atento à natureza de publicações correntes na Europa, o livreiro baiano divulga obras como Principios gerais ou verdadeiro método para se aprender a ler, e a pronunciar com propriedade a língua francesa, em 24 páginas, tendo cömo epígrafe, na capa, uma sentença do pai da Retórica, Quintiliano, extraída de De Instit. Orator. 1ib. 12, c. II: "Omnia breviora reddet ordo, \& ratio, \& modus.". A obra sai em 1811 e é atribuída por Inocêncio a Diogo Soares da Silva e Bivar ${ }^{184}$. No mesmo ano, Silva Serva edita a curiosa e bastante popular observações sobre a franqueza da indústria e estabelecimento de fäbricas no Brasil, por José da Silva Lisboa, o visconde de Cairu. Deste mesmo autor e ainda em 1811, saem as Observações sobre a prosperidade do Estado pelos liberais princípios da nova legislação do Brasil, tomando como epígrafe versos da Eneida, de Virgilio: "Maior rerum nascitur ordo". Em 1811, ainda, sai o jornal "Idade d'Ouro do Brasil", de reconhecida importância, comentando aqui neste mesmo capítulo, junto com "As Variedades ou ensaios de literatura", publicada em 1812 (Parte I) e 1814 (Parte II), revista que se antecipa ao jornal "O Patriota", publicado pela Impressão Régia (1813), na divulgação da ciência literária no Brasil.

De 1812 também è a égloga de Antonio Joaquim de Carvalho, A guerra e a paz da Europa, obra que merecera publicação anterior, por Simão Tadeu Ferreira, em Lisboa, 1802. Igua1mente de 1812 é a obra de A. Smith, A Riqueza das Nações, traduzida por Bento da Silva Lisboa. No mesmo ano, saiu a primeira edição baiana do Marilia de Dirceu, por TAG., 
primeira parte, quarta edição. Berbert de Castro coloca em düvida se seria mesmo a 4 . ed. e fundamenta com boas razões sem prejuízo histórico. ${ }^{185}$ No mesmo ano, ainda a edição das Fábulas de Fedro; e também o Palafox em Saragoça, ou batalha de 10 de agosto do anno de 1808 , drama em três atos por A.X.F.A., autor identificado como Antonio Xavier Ferreira de Azevedo.

Em 1813, Silva Serva edita Viola de Lereno: Coleção das suas cantigas oferecidas aos seus amigos, volume I, de Domingos Caldas Barbosa. Berbert de Castro informa que eram oito folhetos de 32 páginas. A 1. ed. seria de 1798 , pela oficina Nunesiana, de Lisboa, sendo a segunda, tambëm de 1806 , na mesma cidade. ${ }^{186}$ Marỉlia de Dirceu voltara a ser publicada, segunda parte, dita terceira edição, em 1813, sendo, para Berbert de Castro, a sexta edição. ${ }^{187}$ A terceira parte sairá támbém em 1813, considerada por Silva Serva a segunda edição. A Escola nova, cristã e política, na qual se ensinam os primeiros rudimentos, que deve saber 을 mino cristão, e se lihe dão regras gerais para com facilidade, e

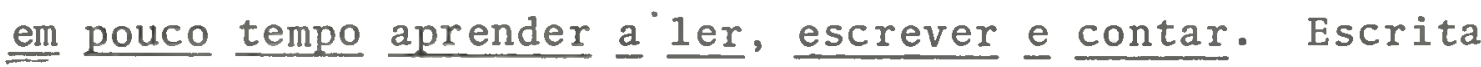
para uso de seus filhos por D. Leonor Tomásia de Sousa e Silva e oferecida aos meninos da escola, é título também saído dos prelos de Silva Serva em 1813. Berbert de Castro mostra concordância com Inocêncio de que esta obra verdadeiramente pertence a Francisco Luis Ameno que, sabemos, foi editor em Lisboa no século XVIII. A Escola nova se assemelha ao Catecismo de Montpelier qué, entre fins do século XVIII e meados do XIX era bastante popular por exer- 
cer uma dupla função: o ministêrio de doutrina de natureza religiosa o de ensinar a ler, escrever e contar, segundo os objetivos das normas regimentais das primeiras letras. Ainda de 1813 é a publicação de Paräfrase dos provérbios de Salomão em verso português, obra dedicada ao príncipe da Beira, e da autoria do mineiro José Elöi Ottoni, muito concorrida no século.

Em 1814, Silva Serva publica a Arte da gramatica portuguesa, ordenada em método breve, fácil e claro. Terceira impressão mais correcta e acrescentada. Para Berbert de Castro, a autoria dessa gramática pertence a Pedro José de Figueiredo, merecendo uma segunda édição, jā em 1817, pela mesma tipografia. ${ }^{188}$ o livro Finezas de Jesus sacramentado parece ser dos mais populares do periodo colonial. o títu10 completo é Finezas de Jesus sacramentado, para com os homens, e" ingratidões dos homens para com Jesus sacramentado. Pelo padre Fr. João José de Sta. Tereza, carmelita, nona edição, publicada em 1815. As Paráfrases de Ottoni voltam em reedição nes.te mesmo ano.

Em 1815, ainda, aparecem uma Horas portuguesas, uin verso, de Carlos do Vale Carneiro, que, parece, viveu na segunda metade do século XVII e publicou a obra com o título de Horas portuguesas de Officio da Virgem Nossa Senhora, e Ramalhete manual de diversas orações, (Lisboa, Domingos Carneiro, 1673, Ibidem, 1692). Hä registro, no entanto, de Horas portuguesas com Ofício da Imaculada Conceição, igualmentc em verso, atribuida a Francisco Vileila, Lisboa, 1780.189

De 1816, são os Rudimentos Gramaticaes, portugueses 
latinos: ou Lição proveitosa para as escolas e geralmente para todos da nação. Por Bernardo Josẽ da Costa e Aragão.

Em 1817, è a vez de Silva Serva editàr Andrômaca, tragédia de João Racine, traduzida pelo Dr. Antonio José de Lima Leitão, médico da Escola de Paris e Físico-mor da Capitania de Moçambique. Também de 1817 é a . Relação do festim que ao ilmo. exmo. senhor d. Marcos de Noronha Brito VIII Conde dos Arcos, (etc.) Derão os subscritores da Praça do Comérrcio (etc.o). E uma antologia onde aparecem uma "Ode pindârica", de Antonio José Osório de Pina Leitão; um "Elogio", de Domingos Borges de Barros; um "Elogio poético", de Paulo José de Melo Azevedo e Brito, etc. Neste mesmo ano, aparece as Institutiones metaphysicae in usum tironium scriptae, de Antonio Genuensi. De Eduardo Job, Silva Serva publica Institutiones Philosophiae practicae siva principia ethicae universalis, atque specialis, juris naturae, ac politicae. Editio prior brasilica, devendo ser a mesma edição de que se servia o ensino püblico na Bahia e Pernambuco.

Em 1817, surge Arte da gramatica portuguesa de Pedro José de Figueiredo. Silva Serva promove, em 1818, uma Tradução portugúesa do Poema Bucólico de José Rodrigues de Me10, feita, oferecida e consagrada por João Gualberto Ferreira dos Santos Reis,"professor Régio de Lingua Latina da freguesia do Senhor de Bonfim da Mata de S. João, natural desta cidade da Bahia."

Em 1818, publica-se uma Oração fúnebre nas exéquias da muito alta, muito poderosa, e fidelissima senhora D. Ma- 
ria I, recitada por Januärio da Cunha Barbosa; uma Ode pindarica oferecida à magestade de1 rey Nosso Senhor D. João VI no dia faustisimo da sua gloriosa aclamação, por Antonio José Osório de Pina Leitão. 1818 é o ano também da publicação da Arte poética de $Q$. Horacio Flacco, epístola aos pisões, traduzida em verso português por Antonio José de Lima Leitão, e de Alfonsíada, poema heróico da fundação da monarquia portuguesa pelo senhor rei D. Alfonso Henriques, oferecido à magestade fidelissima del rei nosso senhor D. João VI, por Antonio José Osório de Pina Leitão." Finalmente, sai pela Tipografia Silva Serva um Catálogo dos livros que se acham na Biblioteca Pública da cidade da Bahia, 1818. E uma Economia da vida humana Obra traduzida de um manuscrito indiano, escrita por antigo braname, a qual se acrescenta uma narração do modo em que o dito manuscrito se descobriu; e a esta se ajunta uma Carta de um cavalheiro inglês residente na China no ano de 1751 , escrita ao Marquês de ${ }^{* * *}$ e agora outra vez traduzida juntamente com o pequeno tratado mencionado, na 1ingua portuguesa, por Adolfo Standert \& c. $\underline{\xi} \underline{c}$. $\underline{\underline{c}}$ c. Composta na 1 íngua portuguesa por ***.

Por ültimo, em nosso interesse aqui, em 1819, ano também da morte de seu criador, a tipografia baiana lança uma Coleção de cartas para meninos, aprenderem a $\underline{1 e r}$, escrever letra de mão, de Cornélio Nepotes. Berbert de Casro acredita ser a obra Vitae excellentium imperatorum, "coleção de biografias de capitães estrangeiros, às quais geralmente se acrescentam as de Catão e Atico, obra das mais 
utilizadas nos centros de ensino, sem dúvida pelo seu esti10 conciso e claro, e sua latinidade pura. 190 E mais os Sermões e panegiricos recitados pelo presbitero Romualdo Antonio de Seixas, cavalheiro professo na Ordem de Cristo, e Cônego da Sé do Pará: Com dois discursos sobre a Filosofia. Encerram o ano de 1819 livros como Atalä ou os amores de dois selvagens no deserto, por Francisco Augusto Chateaubriand. Trad. ***.

Dessa forma, numa avaliação rāpida, pode-se perceber - quanto oferece a uma anālise das tendências e estilos de leitura no século XIX, a ordẹn de publicações da Tipografia Silva Serva. Hā obras que atendem a ofícios e profissões, como a Medicina e a Religião - mèrito, como vimos, natural da tradição editorial portuguesa. Ao todo, foram 176 títulos dá Tipografia, na vida de seu titulàr. . A orientação de imprensa seguida por Silva Serva, pode-se arguir, atentava para as variações e inclinações do gosto püblico, ou, até, por ousadia, antecipava e mesmo impunha um gosto dirigido. Não publicou muita coisa de História e Política. De Literatura, muitas traduções. Como Silva Serva, o mesmo certamente ocorreu no Rio de Janeiro, por empreendores livreiros como Paul Martin, Paulo Martins Filho e editores-1ivreiros como Silva Porto e Plancher. Por esṣe ângulo, os donos de $10 j a s$ ou estabelecimentos onde se vendiam ou se imprimiam livros no Brasil devem ser considerados como, independente de seu estilo de livros e orientação de leituras, os reais divulgadores do livro, orientadores, via politica eficiente de marketing, da leitura e, por extensão, do debate e circulação de idéias no Oitocentismo brasileiro. 
Um desses veĩculos importantes na transmissão cultural do oitocentismo, especialmente quanto a idéias e sugestões de leitura'é a primeira gazeta baiàna editada por Silva Serva a partir de 1812: "A Idade d'Ouro do Brasil". Em vārias de suas ediçōes, o jornal cita clássicos, comenta autores, contesta outros, utilizando-se sempre de passagens de obras como recurso retórico, i.e., como norma persuasiva.

Exemp10:- em resposta a uma carta de leitor sobre a natureza e gosto dos queijos de Rio de Contas (BA), o jornal contesta a opiniạo de Mawe quanto à excelência dos queijọs brasileiros. Ou seja, para reforçar sua impressão da qualidade do produto, o jornal vai buscar, para contestá-la, a impressão transmitida por John Mawe na obra sobre o Brasil ("Idade d'Ouro do Brazil", ano 1813, n 46). Em outra circunstância, contradita Helvécio (1812, n: 61).

Ainda como suporte de argumentação e lógica persuasiva, o jornal busca a companhia dos clássicos, citando Virgílio: "Não são próprias de uma gazeta tantas indagações, e diremos com Virgilio: Non nostrum inter vos tantas camponere liter (1818, n 56). Noutro lugar, faz alusão a passagens mitoiógicas, na öbvia interpretação cumulativa do exemplo associado à razão, em que refere a luta entre Hẻrcules e Anteu, cuja força só se exercia na terra: "0 Brasil é como Anteu, que só tem força no seu chão." (1817, n? 90).

No registro de uma representação no Teatro S. João que considera."bem tecida e filosófica comédia de Pedro 
Grande" (1812, suplemento do n.8 85), o jornal critica a atitude de incômodos assistentes do espetäculo, que faziam barulho e perturbavam a encenação e o trabalho dos atores. Menciona a representação da comédia Palafox, em homenagem ao Príncipe da Beira (1811, n 62). Deve tratar-se do drama em 3 atos de Antonio Xavier Ferreira de Azevedo que jả identificamos . Outra peça homenageia o mesmo Príncipe e o jornal pontua o comentário com lembrança a Os Lusíadas, recordando os feitos de Vasco da Gama na India, tecendo loas à obra de Camões, especialmente ao Canto 9, quando acusa "alguns espíritos superficiais (que) têm achado uma certa pedra de escândalo no canto nono de Camões, dizendo que uma ilha cheia de prazeres dos sentidos não è prêmio honesto, e proporcionado a grandes ações." Aqui se pratica um curioso estilo de jornalismo digressivo, pois o redator salta do comentārio específico sobre a peça encenada, que toma o heroísmo de Vasco da Gama como tema, para discorrer diretamente sobre a natureza e o estilo camoneano n'Os Lusíadas, Canto Nono. O. cronista, então, não deixa por menos, contratacando os moralistas enviesados, criticos do prazer. A esses: "respondemos afoitamente que Camões era talvez o maior sabio do seu sëculo, e que sabia muito bem que os homens não se levam senão por aquilo que thes fere os sentidos." E arremata, transcrevendo versos do próprio poema: "Os triunfos', a fronte coroada/ De palma, e louro; a glöria e maravilha/ Estes são os deleites desta ilha" (1813, suplemento do $\mathrm{n}^{\circ}$ 82). O gazeteiro desfecha um golpe mortal, matando a charada, desfrutāvel ainda hoje para as 
observações da Teoria da Literatura, considerando quanto ao criticar, pois é "mais de zorilo, que de bom critico parar na casca da letra, e não esquadrinhar o sentido". (1813, suplemento do $\mathrm{n}^{8} 82$ ).

A própria epígrafe de "Idade d'Ouro do Brasil" recorta a predominância analítica de obra literária: "Falai em tudo verdades/ A quem em tudo a deveis", versos de Sá de Miranda. Claro que ai se assume um certo sentido de moral, a moral como dogma numa sociedade pré-positivista, e que reina absoluta no arcabouço de doutrinas defendidas pelo jornalismo de "A Idade d'Ouro do Brazil". Assim ìrá o registṛo de Xenofonte, pai da história minuciosa, com riqueza de dados, que traduzirá o conceito ideológico do periódico. (1814, n 90).

o jornalismo se associa à literatura e até se confunde com ela na prática periodística do século XIX. A "Idade d'Ouro do Brasil" não foge a essa regra. Mas amplia a necessidade do registro, contemplando a fórmula da extensão de leituras aos cidadãos: Destaca que a Biblioteca Pública da Bahia recebeu para leitura periódicos ingleses ("Courier", "Morning Chronicle", "The Times", "The Weekly Messenger", "Repertory of Arts, and Manufactures", "The New Annual Register") e outras publicações de igual interesse e repercussão, como o próprio "Correio Braziliense" de Hipólito da Costa, o oponente deste, "O Investigador Português" e "A Gaze-. ta de Lisboa" (1817, $\left.\mathrm{n}^{\circ} 12\right)$.

No nümero 88, de 1812, "A Idade d'Ouro do Brasil" consigna um registro de enorme importância para a vida sócio- 
cultural da Bahia, sendo a tipografia Silva Serva e seu próprio criador, os maiores inspiradores da grande novidade:

A Biblicteca Publica recebeu os periódicos, e folhas de Londres até principio de setembro. Alëm daqueles, de que ela è subscritora, subscreveu de novo a um intitulado "O Espanhol". Este periódico parece bem escrito e divisa-se nele muita imparcialidade, e muita doutrina, que inspira aos povos o amor da pätria, e do governo; e que os faz detestar a mania revolucionária, e o subversivo sistema com que a França pretende infelicitar o mundo com o pretexto de. o regenerar.

Não requer maior perplexidade o óbvio conservadorismo do jornal. Silva Serva não pretendia indispor-se com um sistema que the facilitou praticamente a vida econômica e financeira, abrindo as portas à impressão na província e não investindo diretamente contra a natureza das publicações que saíam da Tipografia baiana. Estas, como vimos, são,em sua maioria, peças de cunho liberal ou conservador, sem qualquer resquício do espirito enciclopédico e revolucionário "com que a França pretende infelicitar o mundo com o pretexto de o regenerar". O mérito de Silva Serva, claro, não está na quadra valorativa de suas edições, com uma ideologia limitada de culto ao passado ie conservação de um presente de fundo reinol, não revolucionārio. Esse espỉrito, porém, não è de feitio imobilista e desertor. Fomenta a busca do conhecimento, atê mesmo com um certo traço ufanista, como no registro sobre a Biblioteca Pública da Bahia: "Nós 
temos a glória de sermos aplaudidos na Inglaterra pela nossa Biblioteca Publica, e dous periódicos de Londres provam com este monumento a delicadeza do nosso gosto, e o aumento das nossas luzes." (1812, n 49).

Mas nem tudo corria feliz para o lado do jornal. Queixava-se das poucas assinaturas, argumentando: "Se uma pequena folha, que está ao alcance de todos tem semelhante extração em uma cidade tão populosa, que extração poderá ter colunas em gránde centro, e de mais dificil inteligência?" (1812, n̊. 49). Salvador, à época, dispunha 118 mil almas num largo espaço territorial ainda inexplorado. A maior parte dos assinantes "são literatos, que nem precisam da gazeta, e dos estrangeiros aqui residentes". Reforçando o apelo ao pủblico na busca de mais subscritores, a "Idade d'Ouro do Brasil" cita Camões, justificando a preferência das letras, ante a queixa nacional dos portugueses: "que o prêmio não o dá a pätria, não/ Que quem não sabe a arte, não a estima". o perfil dos assinantes do jornal é mais ou menos igual aos dos que possuíam livrarias à época, conforme o's documentos de nossa pesquisa: negociantes, boticários, cirurgiões, padres, militares, médicos, bacharéis. O redator reafirma a vocação letrada do jornal, apresentando-o como sucedâneo do livro e destacando sua atuação como elemento decisivo na crônica histórica do Oitocentos brasileiro. ("A Idade d'Ouro do Brasil", 1812, n8 49).

Talvez daí se possa aferir uma correspondência de direção nos periódicos brasileiros do século XIX, a começar pelo prōprio",Correio Braziliense" e a "Gazeta do RJ"; ambos 
de 1808. Verifica-se uma grande vontade de perfilação com - livro na tarefa de transmissão da cultura literária,de par com a formação política e ideológica dos leitores. E, aliās, impressionanté a popularidade que a poesia, por exemplo, granjeou no jornalismo carioca do primeiro Oitocenos; o prestígio com que contavam os poetas na seção "Literatura" do jornal "O. Patriota", por exemplo, com a publicação de odes e celebrações, embora arranhadas essas celebrações pelas inócuas homenagens cada vez mais frequlentes aos poderosos de então. De qualquër sorte, a maior parte do perfil ideológico dos jornais era antecipada pelas epígrafes de extração literária. O jornal "O Carapuceiro", por exemplo, de 1820, periódico moral do Rio de Janeiro, trazia como epígrafe versos de Marcial (per accidens polit.). A epígrafe do número 1 do primeiro jornal impresso no Brasil, a "Gazeta do Rio de Janeiro", num säbado, 10 de setembro de 1808, eram versos de Horatio, Ode III, Lib. IV: Doctrina sed vim promovit insitam/ Rectique cultus pectora roborant. O mesmo jornal; depois, transcreve outra epígrafe, desta vez com versos de Antonio Ferreira: "Eu desta glória só fico contente,/ Que a minha terra amei, e a minha gente." Eram redatores do jornal o Fr. Tibürcio José da Rocha, o brigadeiro Manuel Ferreira de Araujo Guimarães e o Cônego Francisco Vieira Goulart.

Outros jornais e novas epígrafes notabilizaram-se identificando o perfil de leituras do século XIX, tomando-se - jornal como um sucedâneo previsível do livro. A "Ídade d'Ouro do Brasil", como vimos, trazia Sā'de Miranda ("Falai 
em tudo verdades/ A quem em tudo as deveis"), imutáve1, desde o nümero $1^{\circ}$, de 14 de maio de 1811. O "Semanário Cí̀vico" do Rio de Janeiro, na edição de $1^{8}$ de março de 1821 , uma quinta-feira, trazia sentença de Cicero como epígrafe: Ne quid sej fac. non audeat. A "Aurora Pernambucana", de Recife.-primeiro no jornalismo nordestino, depois da Bahia.cujo redator era Rodrigo da Fonseca Magalhães, trazia como epígrafe versos de, nada menos, Camões: "Depois da procelosa tempestade,/ Nocturna sombra, e sibilante vento, $/$ Tras a manhā serena claridade,/ Esperança de porto e salvamento". A "Aurora Pernambucana custava 80 réis, e prevenia o leitor com a advertência curiosa de "Sahirá quando puder". Era constitucionalista e monárquico. Já no primeiro jornal maranhense, "O Conciliador do Maranhão", cujo número 1 saiu em 10 de novembro de 1821, a epígrafe pertence a Virgílio e à Eneida, L. 6: Sit mihi faz audite loqui.

Alguns periódicos brasileiros, porëm, não adotaram nenhuma epígrafe. E o caso do primeiro jornal do Pará, "O Paraense", cujo número 1 data de março de 18 22; "O Brado Maranhense", também de 1822; o "Compilador Mineiro", primeiro jornal de Minas Gerais saido em Ouro Preto, numa segundafeira, 13 de outubro de 1823. Tambēm circularam sem epígrafes o "Clamor Nacional", do Rio de Janeiro, cujo número 1 data de 28 de junho de 1824; "O Espectador Brasileiro", também do Rio, redigido e editado por Plancher, com a primeira edição saindo em 19 de julho de 1824; "O Correio da Bahia" que circlilou de 1824 a 1829 . Outroṣ, ainda, não traziam epígrafe como mote ideológico de suas linhas de atuação: a 
"Gazeta Extraodinäria do Governo" de Recife, de 1822; a "Gazeta do Governo Temporário", tambêm de 1822; surpreendentemente, o próprio "Sentinela da Liberdade na Guarita de Pernambuco", de 1823; o "Registro Official do Governo de Pernambuco", cujo primeiro nümero é de 4 de agosto de 1824; e o "Diārio de Pernambuco", o mais antigo jornal brasileiro ainda em circulaçāo, que começou a saìr em 1825 .

A tradição de epígrafes, todavia, é seguida pela maioria dos periódicos oitocentistas. Por uma compreensíve1 ordem cronológica, temos: "O Constitucional", jornal baiano de 1822, que traz como epígrafe o antes proibidíssimo Mably, duma obra de 1792, T. 12, p. 67: "Le probleme le plus important en politique, c'est de trouver le moyen d'empecher que leur qui n'est pas port en gouvernement ne deviennents 1a prose de ceus qui les gouvernent." A "Gazeta Pernambucana", em seu número 1 , de 14 de setembro de 1822 , traz de novo Camões e o Canto Nono dos Lusiadas: "Dai na paz as leis"iguaes, constantes/ Que aos grandes não deem o dos pequenos/ E todos tereis mais, e nenhum menos." Jâ "O Conciliador Nacional", tambëm de Recife, nümero $1^{\text {P }}$ em 4 de julho de 1822, investe num pensador do moralismo utópico, pai do irracionalismo moderno, que è Erasmo: Admonere volumus, non mordere/ prodesse, non laedere. Típico jornal do liberalismo político, "O Conciliador Nacional", em seu número 36, de 4 de outubro de 1823, mantém a mesma epígrafe, acrescentando-1he a tradução que melhor facilita o acesso püblico ao Elogio da loucura: "Admonere volumus, non mordere/ prodesse, non laedere, /Queremos admoestar, e não 
morder,/ Ser ütil sem ofender".

0 veículo de oposição aos Andradas, periódico que saiu após a queda do Patriarca da Independência e de seus irmãos do ministërio imperial, "O Tamoio", de 1823, introduz o Voltaire de Alzire como patrono de um racionalismo anti-despótico: "Tu vois de ces tirans 1a fureur despotique; Ils pensent que pour eux le ciel fit 1 'Amerique".

Novos títulos de Pernambuco fundamentam a tradição leitora do Oitocentos brasileiro expressa no jornalismo periōdico. "O Marinbondo", de Recife - primeiro número, 25 dejulho de 1822, de um veículo da politica constitucionalista explícita - traz um soneto e hino de Pernambuco, sem autoria, no corpo do jornal e, como epigrafe, uma sentença de Mr. Thomas Jefferson: "A Justiça ultrajada/ vēla em todos os coraçoens". O "Diärio da Junta do Governo", depois "Diario da Junta do Governo de Pernambuco", jornal político-administrativo na órbita conservadora da politica imperial, traz, no primeiro nümero, de 8 de fevereiro de 1823; um resumo de ofício do general Labatut e trabalhos da Junta de Governo da Provincia. No número 17, de 18 de junho de 1823, inclui um artigo doutrinário e professoral chamado "O que he a Politica" e uma "Continuação de Aphorismos de Mr. Bonin". A epígrafe è uma interrogação proposta por Tito Lívio: Quid autem si vox libera/ non sit, liberum esse? 0 nümero 66 do jornal, de 4 de junho de 1825 , muda a epígrafe para aquela da gazeta "Aurora Pernambucana ("Depois de procelosa tempestade,/ Nocturna sombra, e sibilante vento,/ Traz a manhã serena claridade,/ Esperan- 
ça de porto e salvamento", de Camões). E possível que o jornal tenha modificado sua linha editorial, embora permanecendo monárquico. o curioso, porém, è que, no número 67 , - título vem alterado para, apenas,"Diário do Governo" e volta, naturalmente, a mesma interrogação exposta na epígrafe de Tito Lívio.

De Recife, ainda, é o "Escudo da Liberdade do Brasil", cujo número 1 é de uma terça-feira, 26 de julho de 1823. No córpo da edição, aparecem considerações sobre os negócios politicos brasileiros e a Terceira Sessão, de 6 de maio, da Assembléia Geral do Império. A epígrafe vem sem indicação transcritiva: "Rerum novus nascitur ordo/ Nasce entre nós huma nova ordem de cousas". "O Typhis Pernambucano" ê de 1824 e revisita Camões de Os Lusiadas, canto 5: "Uma nuvem, que os ares escurece,/ sobre nossas cabeças aparece". Por fim, "O Argos Pernambucano", nümero 2, de 7 de junho de 1824, no corpo do editorial, exprime uma certa malícia estóica, que caracterizaria a fibra do jornalismo de combate. E o caso de trecho do poema de Francisco Sá de Miranda: "Omem de um só parecer,/ De um só rosto, uma só fé;/ Dantes quebrar, que torcer;/ Ele tudo pode ser/ Mas da Corte omem não é". A edição traz ainda, numa "Carta $4=$ Terceira. conversação.", un exame de passagem de Cícero, em seu Tratado das leis, onde se defende a resistência e desobediência a leis injustas, numa provāvel antecipação da desobediência civil brasileira, completando-se com uma abordagem editorial das causas e das desídias provocadas por leis sābias ou injustas no raciocínio e no sentimento das nações. A epígrafe 
também exprime a linha editorial do periódico, reintroduzindo o Mably do Direito e dever do cidadão, Cart.4, p. 109: "Devemos refutar as objeçoens feitas as leis,/ como principio de uma feliz reforma".

Enfim, è ó jọnalismo da Confederação do Equador, trincheira ideológica emancipacionista, na vertente de todo pensamento não conformista, não cooptador, não subserviente, que não confundia sua visão crítica com os favores da administração imperial. Mais uma vez, porém, è o jorna1ismo municiando-se da Literatura, é a Literatura fornecendo meios de expressão político-ideológica, norma de transgressão e a transgressão da norma, feitas de um radicalismo que toma o signo de alteridade, de reforma, de revolução como código de uma nova sociedade.

o último periódico nessa curta abordagem é o "Argos da Lei", de São Luiz do Maranhão, sob a batuta de Manuel 0doriço Mendes: 0 primeiro número é de 7 de janeiro de 1825 . E o segundo jornal com o mesmo nome, tendo o anterior circulado em 1822, com pouca duração. O primado do racionalismo cristão expressa a linha editorial, tirada aqui pelo epígrafe de Antonio Ferreira: "Boas são as Leis, melhor o uso bom dellas".

A primeira experiência de jornalismo literärio no Brasil, na Bahia, "As Variedades ou ensaios de literatura" saiu pela primeira vez em janeiro de 1812 , com a segunda parte em 1814, tendo circulado apenas dois nümeros. Seu valor literário é bastante discutível. 
A Parte I abre com uma declaração de princípios ao público, evidenciando a natureza da publicação e as orientações que a revista naturalmente obedecerá. Propõe-se a divulgar

.. discursos sobre os costumes e as virtudes
moraes, e sociaes, algumas novellas de escolhi-
do gosto, e moral; extractos de historia anti-
ga, e moderna, nacional, ou estrangeira, resumo
de viagens; pedaços de Authores classicos Por-
tuguezes - quer em. proza, quer em verso - cuja
leitura tenda a formar gosto, e pureza na lingua-
gem; algumas anecdotas, e boas respostas, E c.

o Intróito da revista encerra a advertência de que procurarão seus editores orientar-se pela trilha da simplicidade, evitando a pompa e a circunstância do desmascaramento públịco, citando uma vez mais Virgílio, jā que não desejam cair na censura do "Poeta Venusino: Quid dignum tantum feret; \& c."

E, pois, uma publicação que deseja saciàr curiosidades leves num meio social ainda imberbe. Quer limpar dos vícios o corpo da sociedade, enaltecendo a moral e dando a ler resumos de novelas "de escolhido gosto", afeitas à moral e aos bons costumes, numa forma típica das "Variedades", da natureza miscelânica em trazer um pouco de tudo: história antiga, textos clāssicos, os bons autores portugueses, em prosa ou em verso, tomando como paradigma "a pureza da 1 inguagem". .

Essa Parte I traz um artigo "Sobre a Felicidade Do- 
mestica", um outro, curioso, "Da Navegação entre os antigos", onde se insinuam trechos clássicos, com nomeação de

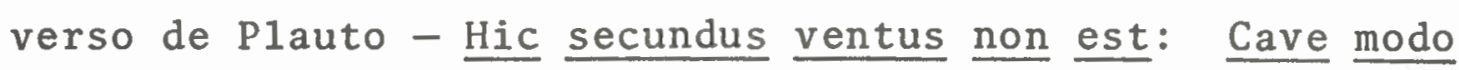
Versoriam - um extrato de viagem feita por Mr. Thiery, "Costumes, e usos do Mexico", um outro artigo sobre "Instrucção militar", um excerto da obra de Jacinto Freiré de Andrade, Vida de D. João de Castro, com o título de "Brioso Desafio", finalizando com "Anecdotas e bons ditos" e um comento moral, "Rasgo de Esperteza", salpicado de diplomas e memórias classicizantes.

A Parte II da revista traz uma novidade, que é o sumārio. Antecipa ao leitor o que este irá ler: "Quadro demonstrativo ou Chronologia da Philosophia Antiga"; "Teoria nova, e curioza sobre a origem dos Gregos"; "Das Sciencias, e das Bellas Letras"; "Observaçōes sobre a Política"; "Da Bondade"; "Da Conversação"; "Costumes, e usos do Mexico"; "Continuação do Extracto de Mr. Thierry"; "Doutrinas Militares"; e "Anedoctas, e bons ditos".

Abrindo o "Quadro demonstrativo ou cronologia da Filosofia antiga", citação de Condillac, um trecho da Histoire ancienne, L. 3, C. I. O artigo, em que pese seu autor, ou autores, advirtam não pretendex um esforço histórico abrangente da Filosofia, introduz, como numa cultura de almanaque, explicaçōes da natureza da Filosofia, sua raiz etimológica, seu conceito entre os antigos, o conceito moderno que terā, distribuindo a matéria pelas vārias escolas filosóficas, a grega superlativamente, começando pela Escola Jônica, destacando Tales de Mileto, mas nomeando to- 
dos os integrantes ou pensadores da dita escola, como Anaximandro, Anaximenes, Anaxágoras etc. Passa pela escola de Sócrates, dando informações sobre o propósito da filosofia socrática e estimulando o leitor a consultar outros autores que digam respeito ao filósofo. Cita, a propósito, Mr. Barthelemy, autor da Viagens do jovem Anacharsis, livro, aliás, de enorme popularịdade no Brasil. Depois de citar a escola de Cirene e dos sofistas, o artigo concentra sua atenção na Escola e na filosofia de Platão, tambêm chamada de Escola Acadêmicà. Vai aos Cínicos, aos Peripatéticos, aos Estóicos. Da Escola fundada por Pitágoras, passa a Demócrito Conde também manda os leitores consultar Huet, no livro Censura Philosophiae Cartesianae), aos Misantropos, aos Cëticos, aos Epicuristas e lança, no final, uma referência bibliográfica de autores consultados "e que podem ver-se". Lá estão, com a óbvia sugestão de leitura para os curiosos:

Adriano nas suas Dissertações ou discursos sobre Epictéto. Edição de Londres de 1739. Diogenes Laercio na "Vida dos Philosophos, versão de Schneider em Amsterdam 1761. Seneca o Philosopho versão de La Grange de Paris $1777^{\circ}$.

Tacito da edição de Brotier que tem por título - C. Cornelii Taciti Opera, recognovit, emendavit, supplementis explevit, notis, dissertationibus, tabulis geographicis illustravit Gabriel Brotier.

Plutarco nas Vidas dos homens illustres, e no seu tratado sobre as opiniões dos Philosophos da versão de M. Dacier em Maestricht 1778. 
Enchiridion ou Manual de Epicteto, correcto, e illustrado em Portuguez por Luiz Antonio de Azevedo Lisbonense.

Mr. de Condillac Curso de estudos: Liv..3: da Historia antiga.

Gaspar Scioppio nos seus Elementos da Philosophia Moral dos Estoicos, impressos em Moguncia em 1608 .

Cicero nas suas Questões Academicas, edição de Leyde de 1761 .

Lipsio, Physiologia stoica.

o Padre Rapin no Parallelo de Platão; A Aristoteles.

Viagens à Grecia pelo joven Anacharsis:

obra do erudito Mr. Barthelemy.

Mr. Foucher nas suas Dissertations sur la recherche de la vèrité, contenant l'histoire. E les principes de la Philosophie des Academicien. Paris 1693.

Biblioteque des anciens Philosophes.

Mr. l'Abbé Batteux na sua Morale d'Epicure tirée de ses propres écrits in 8: 1758.

Tableau de l'ancienne Grëce par Mr. Le Sage. Florença 1805 .

Philosophia de Epicuro por Gassendi, edição de Lyão. 192

Um outro artigo que poderíamos destacar da Parte II da revista é o. "Das Sciencias e das Bellas Letras", onde o articulista traça um perfil do bom prosador, citando naturalmente os clássicos como modelo de boa construção da 1 inguagem. E novamente o primado da eloquência, a valorização das musas, o cultivo dos bons, modos de escrita obediente a traços de um óbvio Neo-Classicismo. 
Não deixa de ser interessante a lista de autores sugeridos pela revista. Verifica-se um sentido rigoroso de busca de atualidade e de largueza do entendimento clássico. A maioria dos autores e obras citados não pertence ao século, ou seja, não pertence à contemporaneidade do redator doartigo. Em outras palavras, passa como atestado de bom gosto e autoridade, como recurso, inclusive, de natureza retórica estar na companhia dos antigos.

Assim, a citação bibliográfica serve como guia de leituras e como amostra estilística. O princípio docente, a postura professoral, a vocação de um gosto dirigido associado ao predicado horaciano do "docet cum delectare" indicam claramente que, até está parte do Oitocentismo, a cultura explicitamente valorizada era a que dizia respeito à tradição clāssica, ao espỉrito das Academias, ao código das conferências e palestras que orientem um público igual-mente aspirante ao 0limpo.das Letras. Sinal de que, pelo menos até o primeiro quartel do século XIX, o Brasil ainda estava firmemente ancorado na versão livresca do mundo, na sólida interpretação do universo como pátria da Antiguidade Clāssica.

$\mathrm{Na}$ abertura de um artigo publicado na"Revista do Instituto Arqueológico Histórico e Geogräfico Pernambucano,". v.50, (incluído, posteriormente, como capítulo do livro História das idéias da Faculdade de Direito do Recife), em que descreve a biblioteca dos Oratorianos em Pernambuco, Gláucio Veiga diz que "ao se iniciar o século XIX, parece não haver dúvida que, ao Norte do País, o centro de maior ativi- 
dade intelectual era o Convento dos Oratorianos, no Recife"193. E muito provável essa assertiva, uma vez que a Bahia, o Maranhão e o Pará, sem levar em conta situações isoladas, não apresentam, um projeto conjunto de irradiação cultural como certamente o foi a Congregação dos seguidores de'S. Felipe Néri em Pernambuco. Entretanto, no que diretamente nos interessa neste trabalho, a boa notícia concreta da Iivraria dos Oratorianos em Recife só se efetiva a partir de 1826, quando, segundo Pereira da Costa, a biblioteca abrigava cerca de quatro à cinco mil volumes. 194 Em 'que pese referir-se a um ano posterior ao arbitrariamente aqui fixado (1825), è-importante rever, de acordo com as informações disponiveis, quais as tendências e características das leituras feitas pelos seminaristas pernambucanos do século XIX, até porque è muito falha a notícia sobre a circularidade bibliogrāfica em Pernambuco.

A Congregação do Oratório foi extinta em 1830. Em 1831, o acervo da livraria se teria passado à biblioteca da Faculdade de Direiţo d.o. Recife - o que explica, certamente, a boa formação da biblioteca universitāria de hoje na primeira escola de leis no país. Em 1839, de acordo com o catálogo organizado por Umbelino Ferreira Catão, bibliotecário da Faculdade de Direito, haveria ali pouco mais de 3 mil e 500 volumes, onde "brilham os nomes de Aristóteles, de Hipócrates, de Newton, de Malebranche, de Homero, de Virgílio, de Sêneca, de Ovídio, de Terêncio, de Bossuet, do padre Manuel Bernardes", o que the conferiria a rubrica "Humanista" atribuída por Edson Nēri da Fonseca em Biblio- 
tecas e bibliotecários da Província. 194 Assinala-se a prevalência natural de obras em Religião e doutrina católica', com observância de boa quantidade de obras de Matemática e Ciências Naturais. Pela biblioteca circulariam obras de Newton (a tradução de um "Curso Matemático". e uma "Phizica", talvez a Philosophiae naturalis principa Mathematica em 3 volumes e a Opuscula Mathematica, philosophica et philologica, também em 3 volumes). E também de Newton uma Opera omnia que consta do catálogo. Levanta-se a possibilidade da existência, na livraria, da obra Teórica verdadeira das marés conforme a filosofia do incomparável cavalheiro Isaac Newton. Além de Newton, Wolff e Roberto Bayle compunham uma estante de naturalistas e filósofos presentes na estratégica biblioteca dos oratorianos. Wolff com seu "Elementos de Mathematica", ou Elementa Matheseos Universae, editado em 17i5, em 6 volumes. Ainda conforme o catálogo de 1839, a Iivraria oratoriana teria obras de Pourchot e Purcócio. 0 primeiro, Edmundo Pourchot, cartesiano, autor de uma Institutiones Philosophicae, não deveria mesmo faltar num acervo dirigido pelos reformadores da pedagogia portuguesa do século XVIII. No mesmo catálogo, não faltaria também o Genuense, ou Antonio Genovesi, com suas obras de Metafísica. Assim como o padre Baltasar Teles e sua provável Summa universae philosophiae. E, ainda, Rodrigo de Arriaga, com seu Cursus philosophicus. E Spanner, autor de uma "Sacra Escriptura", obra que cambém pode ser atribüída a João Diogo Spener ou a Jacob Philip Spener (1633-1705), este último fundador do pietismo. Wolff, 
Genovesi, Musschenbroek, o trio de autores de citação obrigatória na orientação do reformismo pombalino, constavam assim da livraria dos oratorianos de Pernambuco. De Muschenbroek, aliảs, anotamos uma "Physicae" e uma "Elementa", títulos cujo registro mais apropriado seria Disputationes Physica experimentalis, em 1 volume. Dentre os matemáticos e físicos, Keil e sua Introductio ad veram Physicam, publicada em primeira edição em 1720, também comparece na biblioteca.

Dos autores expressamentë religiosos, concorriam na livraria dos oratorianos de Pernambuco o dominicano Alexandre Natal (1639-1674); em 9 volumes; o oratoriano Baronio, com seus "Annales Eclesiastico" em 20 volumes. E o oratoriano Antonio Pereira de Figueiredo, travestido na pele do pseudônimo Francisco Sanches, com sua Defensa do Novo Método da. Gramatica 1atina contra o Anti-Prologo critico, obra pendular das eternas disputas que envolveram o reformi.smo pombalino da educação pública. Do mesmo Figueiredo, frequentava a livraria assinalada o livro Exercicios de lin-. gua latina e portuguesa, com elementos de análise gramatical do Latim, escandindo o verbo contra o espirito jesuitico. Além dos oratorianos, que pontuavam ṇa livraria, aparecem também autores até pouco ortodoxos em relação à prática religiosa vigente. Como o cardeal Tamburini, colocada no Index inquisitorial, ou Kisper, estigmatizado pela ortodoxia da Igreja. 0 padre Vicente Tosca com seu Compendium philosophicum, em 5 volumes, 1ã estava também compondo a estanté da Congregação do Oratório em Pernambuco. Tam- 
bếm Jacob Zallinger e sua "Philosophia": Lemonnier e seu "Curso filosófico" (provavelmente Pierre Charles Lemonier (1715-1799), astrônomo, autor de um Curso Philosophico Mo$\underline{\mathrm{ra1}}$.

Havia os escritores diletos à Ordem como Teodoro de Almeida, da Recreação Filosófica, Duns Scott e o tambëm oratoriano João Baptista de Castro, autor de uma Philosophia aristotelica restituta et ilustrata; Duhamel e François Jacquier (1711-1788), autor de uma obra de Filoșofia; e mais Luis Losada, físico, autor de um Curso Philosophico; Antonio Cordeiro (1641-1772), que escreveu o Cursus philosophicus conimbricensis. E o considerado Pedro da Fonseca (15481597) jesuíta refơrmador da Escolástica em Portugal com seus Libros Metaphycorum Aristóteles - Completam a descrição do catálogo dos Oratorianos, de 1839 , jả integrados os livros ao acervo da Faculdade de Direito do Recife, Gaspar Scioppio e Linneo, este autor do Systema natura. Manuel do Cenāculo Villas Boaș frequentava a livraria com uma "Instrução pastoral". E, com espaço aberto para dúvidas, em virtude da forte vocação reacionária do fundador do Seminário e da Congregação do Oratório em Pernambuco, Azeredó Coutinho, talvez circulassem na biblioteca Montesquieu, Bossuet, e Rosseau, com seu Principes politiques. Por ültimo, Condillac (Ouevres philosophiques), Prospero Lambertini, - papa Bento XIV, Martin Gerbert (Teologia Mora1) e Tournelly. Sem dúvida, uma excepcional contribuição ao conhecimento das tendências de leițura oitocentista em Pernambuco. 
No Rio de Janeiro, a biblioteca do Conde da Barca, desde 1808, alinhava obras importantíssimas da bibliografia portuguesa e européia. Essa biblioteca, aliās, forneceu grande parte do acervo da Biblioteca Real. Data de 27 de junho de 1810 a criação da Biblioteca Real, depois Nacional, no Rio, possivelmente contando, em termos aproximados, com os 60 mil volumes atribuidos pelos historiadores. A informação genêrica diz que a Biblioteca formada por $D$. João VI seria aquela provinda dos acervos sucedâneos da 1ivraria organizada por D. José I - a Real Biblioteca da Ajuda - do que sobrou do incêndio e terremoto de Lisboa em 18 de novembro de 1755. Em fins de 1807, o'príncipe regente D. João trouxe consigo, inclusive, a rica coleção do abade Santo Adrião de Sever, que a doara, em 1773, ao mesmo D. José. Outra rica coleção, a do Colégio,jesuíta de Todos os Santos, de Lisboa, teria sido incorporada também, mas, reduzidos a pó, seus acervos ficaram ẹn Lisboa já em 1804. De qualquer maneira, a que representa a Biblioteca Imperial do Rio de Janeiro contava cerca de $12 \mathrm{mil}$ volumes quando se constituiu em 1808, formando depois parte do acervo da Bib1ioteca Naciona1. 195

Voltando à biblioteca do conde da Barca, pontificavam na estante do aristocrata, por exemplo, a Henríada, de Voltaire, traduzida por. Tomás de Aquino Belo e Freitas (Rio de Janeiro, Impressão Régia, 1812), Os jardins, de Delille (Lis boa, 1800), Os ensaios morais, de Pope, na tradução do Conde de Aguiar (Rio de Janeiro, Impressão Rēgia, 1811) e mais livros antigos e raros, como os Poemas lusitanos, de Antio- 
nio Ferreira (Lisboa, 1598), Dos novíssimos, de D. Francisco Rolim de Moura (Lisboa, 1623), a Ulisséia, ou Lisboa edificada, poema heróico de Gabriel Pereira.de Castro (Lisboa, 1634) e uma Arte poética, de Felipe Nunes (Lisboa, 1615). Segundo Niza da Silva, o conde da Barca possuíria edições originais, reunindo autores como Clëment Marot, Alexander Pope, Milton, Thomas Ward, Thomas Gray, John Gay, Matthew Prior, John Ogilvie; Edmund Spenser, Petrarca, Pietro Bembo; Ludovico Ariosto, Aretino, Torquato Tasso, Alessandro Tassoni, Angelo Poliziano e Klopstock. ${ }^{196}$

Sobre as características culturais do Rio de Janeiro, Denis fala da antiga Biblioteca Imperial, que conteria, segundo suas impressōes, cerca de $48 \mathrm{mil}$. volumes em 1830 , destacando-se algumas preciosidades como uma grande coleção de Bíblias, em especial a de 1462, de Mogúncia,."que faria inveja às mais ricas bibliotecas das capitais da Europa" ${ }^{19 Z}$. Além: da que hoje é a Biblioteca Nacional, Denis cita a biblioteca do Mosteiro de São Bento, que ele não conheceu e nem sabia precisar o conteúdo e quantidade do acervo bibliográfico. A respeito da imprensa periódica, destaca o papel de Evaristo Ferreira da Veiga, de Bernardo.Vieira de Vasconcelos e de Januário da Cunha Barbosa como "garantia segura de talento", o que, vale dizer, do nosso ponto de vista, talento e garantia de leituras sistematizadas. ${ }^{198}$

0 primeiro cronista de Mato Grosso, José Barbosa de Sá, que chegou a Cuiabã por volta de 1723, faleceu em 1776 e cujo inventário de bens estende-se atē 1806 - inventärio publicado, transcrito e estudado por José de Mes- 
quita na "Revista do Instituto Histórịco. e Geogräfico do Mato Grosso", ano 27, t. 53,1945 - possuía uma biblioteca de cerca de 79 títulos e 131. volumes, a maioría composta de obras jurídicas, seguidas de Literatura, Religião; Histōria, Filosofia, Política, Educação e Linguistica.

De todos os titulos da livraria, ocupam particular atenção para os estudos cuiabanos, as Ordenáções do Reino, algo em torno de 18 obras, secundadas pelo Direito romano e canônico." Na ārea da Literatura, destacam-sè as obras de Camões, Diogo Bernardes e Jacinto Freire de Andrade, cujos títulos já são nossos conhecidos (os Lusíadas; 은 Lima;

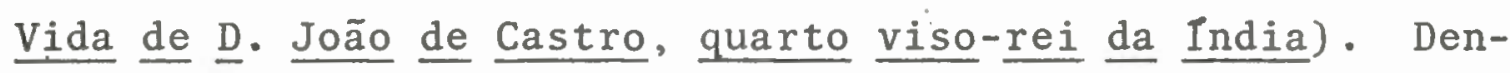
tre os barrocos, pontificam Lourenço Gracián e o padre Antonio Vieira. Na ärea religiosa, predominam a Teologia, com especial referência ao neo-platônico João Ericena Escoto. Ao lado da Física, relevante a presença da Metafísica, de Aristóteles. As obras'proibidas serão também frequentes na livraria de José Barbosa de Sá. Lá consta, por exemplo, a Vida do padre Belchior de Pontes, do português Manuel da Fonseca, obra publicada em Lisboa, 1752, mas interdj.tada pela Real Mesa Censória ém 10 de junho de 1771. Conforme a informação de Josè de Mesquita, no artigo citado, a livraria de Barbosa de Sá foi arrematada por João da Costa Siqueira, segundo cronista de Mato Grosso, um português integrado a mandonismo rural paulista. ${ }^{199}$ Carlos e Neusa Rosa encontraram, num "Inventário dos livros da Associação Literária Cuiabana" de 1912, a obra de Antonio de Souza de Macedo, Eva e Ave, ou Maria triunfante. Teatro da Eru- 
dição e da filosofia cristã, em que se representam os dois estados do mundo, caído em Eva e levantado em Ave, que os historiadores acreditam trabar-se de ex-libris de Barbosa de sá. 200

o leitor do século XIX, entretanto, não será rigorosamente $a^{2}$ meră reiteração de modelos exclusivos das produções saídas de um incremento tipográfico ou de uma doutrinação absolutista. Conforme vemos a partir de nossa investigação em inventários de bens, ele veste outras capas culturais. Um tanto porque este leitor não se nutre apenas das obras suas contemporâneas e nem exclui outras que o acompanhariam desde o centúria anterior. E certo que existe a proḅabilidade, a insinuação e até a suspeita de qưe muitos livros entraram no Brasil, com ou sem proibição, como peça de contrabando. O rastilho mais recente dessa quase-certeza está. inscrita no monumental trabalho já citado de Laẉrence Hallewell e, mesmo antes, no de Borba de Moraes. Teriam livros contrabandeados o padre Francisco Agostinho Gomes, de fins do século XVIII, começos do XIX (1803). E tambēm o líberal José Lino Coutinho, cujo inventärio, demonstra um curioso percurso do leitor atento ao que se passa à sua volta, sobretudo nos campos da Literatura, da Filosofia e da Educação. O próprio Coutinho atualiza um tanto Rousseau atravēs de sua obra Cartas sobre a educação de Cora, que adiante comentamos.

Essa mesma ordem de raciocinio, da não obrigatoriedade de leitura num universo único, localizado e de época, 
transparece do testamento deixado pelo cirurgião do exército Antonio Josē Vieira de Carvalho, mineiro falecido em 1818, cuja lista de livrós è objeto da análise de João Dornas Filho, no Anuário Brasileiro de Literatura, de 1939 e do mesmo Hallewell em 0.1ivro no Brasil.

A tipologia do cirurgião enquanto leitor seria aquela mais ou menos característica da que encontramos em nossa investigação nos documentos manuscritos nos inventários de bens. Carvalḥo tinha, ao, todo 69 livros, com a transcrição incorrendo nos mesmos equî́vocos, já apontados, dos escrivães. Do total dẹses livros, quase a metade. (28) se relaciona com o ramo da Medicina e Cirurgia e demonstra o cadinho profissional típico conforme assinalamos. Desses nos ocuparemos adiante, quando estudarmos a notação da biblio-: grafia médica e cirúrgica em capítulo pertinente. Assim, representam-se na livraria o The english Hippocrates, de - Thomas Sydenham (1624-168.9), e a obra médica băsica do inglês Francis Home (1719-1813). Também a Memöria da Academia Real de Cirurgia aparece como peça obrigatórịa numa estante referencial que tein no português Feliciano de Almeida, nos franceseśsabien Violet, George de La Faye (16991781) e Antoine.Petit de Maurienne (1722-1794) alguns dos principais autores. Pontificam o clinico e quimico holandês Boerhaave, ou Hermanus Boerhaave (1685-1739) em matéria mëdica, ao lado dos anatomistas franceses Raphael Bienvenue Sabatier (1732-1811): Cesar Verdier (16851759) e do dinamarquês Jacob Benignus Winslow (1699-1790). Ainda un best-seller do Setecentismo, Observaçoens sobre 
os partos e um especialissimo e pouco comum nas livrarias estudadas, "Compendio de ouvido". As farmacopéias de Londres e Edimburgo, as obras d.e obstetrícia de André Leuret (1703-1790), (o"inventor do forceps curvo") e Jean Bernard Jacobs, ( $\quad-1791)$, os trabalhos sobre inflamações de Feliciano de Almeida, a obra sobre febres de Antoine Fizes (1690-1765), a obra sobre edemas de Alexander Monro (16971767) e o popularíssimo Traité des maladies vênëriennes, de 1775, de Jean Baptiste Bressavin, igualmente comparecem na estante médica do cirurgiāo mineiro que em 1818; ainda tinham o consagrado trabalho de Sir John Pringle (1707-1782) sobre.moléstias dọs exércitos. Também havia na Bib1ioteca de Carvalho um especialista em.medicina tropical o francês, Jean Barthelemy Dazille (1732-1812), com sua obra Observations sur les maladies des nègres, de 1785 .

Dos 1 ivros sobre ciências, 7 ao todo, o nosso cirurgião, tinha Antoine Baumé (1728-1804), colaborador do Dictionnaire des arts e des métiers, e autor de manuais de Química; Jean Antoine' Claude, conde de Chaptal de Chatteloup, (1756-1832), os trabalhos de Botânica e Fistória natural de Félix de Avellar Brotero (1744-1828), que foi professor de botânica em Coimbra e'mais Lauri, 'Lineo, Vigier.

Outros livros do cirurgião escapavam às ciências mêdicas ou naturais afins, e eram da área de Linguística, 11 ao todo, sendo Dicionários, (2 franceses, 1 português cm dois volumes, um Inglês-Português, um Dicionārio médico Francês-Latim, um Dicionārio geogräfico italiano, um Di- 
cionảrio médico Francês-Latim; um Dicionário geográfico italiano, um Dicionário Espanhol-Italiano e um Dicionário Histórico da Medicina), uma gramática inglesa, e um outro best-seller setecentista que é o Mestre francês, ao lado do Dicionário de Domenico Vaneli ou Vandeli (1730-1816).

Por ûltimo, livros inespecificos, pertencentes às àreas de Letras, História e Ciências modernas, de que havia 23 volumes. o Orlando furioso de Ariosto, Camões, um "Theatro". de Corneille, obras de Crebillon (Prosper Joyot de Crebillon, 1674-1730), as de Racine e Pope (Ensaios moraes) e uma obra devocionária popular desde o século anterior, e matēria ascētica: os Gemidos da may de Deos, do Padre Teodoro de Almeida. E uma Política moral e civil, obras de Burant (que se supōe tratar-se do poeta quinhentista francês Gilles Durant), obras do Bispo de.Caraccioli, uma "Arte de porsolania", as "Aventuras do barão Munchausen", as de "Telémaque", de Fenelon, a Histoire universel de Bossuet (Jacques Benigne Bossuet, bispo de Meaux, 1627-1701), a Historia romana do inglês Laurence Echard (1671-1730). E', por fim, uma Economie generale sem indicação do autor, as cartas de Gangane11i (Giovanni Ganganelli, papa Clemente XIV,. 1705-1774), I dilios e morte de Abel, de Salomon Gessner (1730-1788), a Historia dos descobrimentos e conquistas dos portugueses e Malaca conquistada, esta última de Francisco de Sá de Menezes, obra representativa do orgulho expansionista português compulșado na tarefa da redenção cristã.

A idéia de um homem dedicado ao "gosto pelos conheci- 
mentos, a afeição pelas artes que embelezam a vida e o amor à liberdade constitucional" (trechos do epitáfio a ele consagrado pelo duque de Sussex, na Inglaterra) parecem notabilizar Hipólito José da Costa Pereira Furtado de Mendonça (1774-1823) como aquele brasileiro de mais enérgica constituição moral e de mais dignos princípios de zelo à verdade e amor à pátria. Formado em Coimbra, em Leis e Ciências Naturais, Hipólitó da Costa, patrono da imprensa brasileira, era um homem votado ao culto das Letras e das Ciências. Tal dedicação se exprime não só no esforço decidido pelo engrandecimento e autonomia do Brasil, como, igualmente, pela referência à leitura e ao gosto e prazer intelectual que se deve estender ao maior número de pessoas.

Na Narrativa da perseguição de Hipólito Josê da Costa Pereira Furtado de Mendonça, naturà1 da .Colônia do Sacramento, no Rio-da-Prata. Preso e processado pelo pretenso crime de fra-maçon ou pedreiro livre, cuja edição origina1 ë de Londres, impressa por W. Lewis, em 1811, de par com um violento libelo contra o autoritarismo dogmático e estreito da Inquisição, o narrador, como um repórter, passa em revista todos os esquematismos caracterizadores do projeto de trucidamento inquisitorial, o horror que o arbitrio nutre ao reino das idéias, ou sua natural aversão aos livros como condutor dessas idéias, citando, em alguns trechos, obras que, de forma direta ou indireta, teria lido. Em nota sobre o sequestro e apreensão de seus bens, na volta a Portugal após uma missão científica à Filadêlfia, nos EUA, Hipólito da Costa menciona o que trouxera de Londres: 
"uma coleção de livros para a Biblioteca Püblica, certas máquinas, que mandara construir em Inglaterra, livros e outros objetos, pertencentes à Impressão Régia, e outras coisas". 201

No interrogatório a que foi submetido - como em todos os interrogatórios, transparece a forma esquiva e ma1iciosa das perguntas - observa-se a predominância do espírito das reformas operadas pelo regime de Pombal na pedagogia portuguesa. O inquisidor busca conduzir o interrogado a contradições ou incoerências, pretextando um sumário de culpa ou direto incriminamento do réu. Repare-se o grau de importância atribuido aos livros para, por meio deles, provar a culpa do acusado de assentimento ou inoculação dos ideais dos pedreiros livres, os maçons, os pensadores de origem francesa. São perguntas que traem o ar maquiavêlico e a farsa armada nos tribunais, como aquela que resgata o autoritarismo contra a Gramática Latina do jesuita Manuel Ålvares, ou os livros interditos oriundos da França. A dura sessão de interrogatório expressa a natureza de terror contra pensadores, livroș e idéias:

Pergunta: Em que idade começou a estudar?

Resposta: Não poderei dizér com certeza.

P. : Fixe ao menos com probabilidade a ēpoca em que deixou o mestre de ler e escrever, para passar ao eștudo da gramātica latina?

R. : Seria aus nove anos.

P. : Sabe ou suspeita razão por, que de tão tenra idade o fizeram entrar para o estudo da gramātica latina? 
R. : Não.

P. : 0 compêndia da gramática latina era o antigo dos jesuitas ou algum dos modernos?

R. : O Novo Método do Padré Antonio Pereira.

P. : Que Iínguas mortas estudou à ém da latina?

R.: Grega.

P.: Os seus professores, quando lhe ensinavam a traduzir os clässicos gentios, faziam- Ihe observar os erros abominäveis que, muitas vezes, se propagam por esses livros, onde hả sempre mais ou menos vestígios das falsas superstições dos antigos?

R. : Sim.

P. : Que linguas vivas estudou?

R. : Todas aquelas que na Europa são mais necessārias, já pelas relações que as suas respectivas nações têm conosco, jä pelas obras cientificas que nessas línguas se acham escritas.

P.: Que motivos teve para estudar essas lifinguas?

R. : 0 desejo de, me pôr em estadc de poder aprender as ciências, o que não poderia bem fazer sem entender os livros que nessas línguas estão escritos.

P. : Quando começou a aprender as linguas vivas, sabia o perigo que havia na leitura dos i ivros impios que nessas línguas se acham escritos, principalmente no francês, inglês e alemão?

R. : Como o Tribunal do S. Ofício tem o cuidado de proibir os livros maus e deixar correr somente os bons, não devia eu presumir que me pudésse chegar à mão algum livro ímpio; portanto, nessa parte, tinha a.minha consciência 
sossegada, porque não podia supor, sem ofensa do crēdito daquele Tribunal, tão vigillante nos seus deveres, que consentiria chegar-me à mão livros dessa natureza.

P. : Que graus acadêmicos tem?

R. : Bacharel formado em Leis e bacharel em Filosofia, pela Universidade de Coimbra.

P. : Que mais estudos tem feito alēm destes, por que obteve os graus acadêmicos?

R. : Matemática, Geografia, História, e em geral, Belas Letras.

- P. : Os livros de que se serviu para esses estudos eram nacionais ou estrangeiros e quem eram seus autores?

R. : Eu costumei sempre lançar mão de qualquer livro que julgava bom, ou me inculcavam por tal, na matéria que queria estudar, sem me embaraçar de outrá coisa senão que fosse escrito em lingua que eu entendesse e quanto a referir os nomes dos autores, isso me è impossível, só pelo que diz respeito à minha faculdade principal, que é o Direito; quanto mais a respeito de todas as outras matërias, a que secundariamente me tenho aplicado, ou porque essas matērias tenham conexão com a jurisprudência, ou porque as quisesse só conhecer para. meu desenfado e recreação.

P. : Declare ao menos os compêndios ou livros elementares por que estudou?

R: : Pelo que toca aos estudos da Universidade de Coimbra, segui os compêndios aprovados pela mesma Universidade, e quanto aos outros estudos, não sendo öbrigado a seguir mëtodo particular, usava jä de uns já de outros livros, segundo o que julvaga mais conveniente, de maneira que referir um catälogo desses livros seria tão dificultoso que admiro haver quem 
suponha que um homem aplicado às letras possa satisfazer com exação a tal pergunta.

A partir daqui o interrogatório conduz o rêu a responder a questões ligadas à Teologia, à Metafísica e à Etica, sem menção direta a livros, obedecendo sempre ao esforço tấcito do inquisidor de confundir o interrogado. Hipólito, por esses exemplos e em demais passagens de sua Narrativa, demonstra uma invulgar segurança e um tirocinio fora do comum, com a presença de espîrito que não deve faltar aos retóricos. Sabe escapar de uma armadilha, como na resposta que dá sobre livros proibidos, alegando que não poderia ter à mão obras que o Tribunal do Santo Ofício, "tão vigilante nos seus deveres", já pusera fora de circulação. A idéia que nos chega, ao ler esses depoimentos, é que o narrador, ardiloso e precavido, tem consciềncia e juizo formados sobre o Tribunal da Inquisição e dos males causados à inteligência. Mas declara, em suas respostas, sem comprometer em profundidade seu pensamento, com ambígua disposição de ânimo, as palavras que o inquisidor, não gostando de as ouvir, deveria aceitar como expressão da verdade tal a fơrma como são ditas. E o réu não será arrogante ao lembrar ao juiz, em seu depoimento, que "referir um catálogo desses livros seria tão dificultoso que admiro haver quem suponha que um homem aplicado às letras possa satisfazer com exação a tal pergunta." Premia com sutileza e argúcia a pouca extração de inteligência do inquisidor a propósito da exigência de momorizar quais os livros elcmentares estudados pelo réu para alcançar seus títulos acadêmicos. 
Sem dúvida, o ato de ler não seria visto com bons olhos pela militância do arbítrio. E o próprio Hipólito da Costa quem confirma a nova idade do obscurantismo, reconhecendo que

... a má fé dos inquisidores em nada se manifesta mais do que no seu incessante zelo em perpetuar a ignorância. Todo mundo sabe que depois de haverem proibido, em um grạde catälogo, uma quase incrível multidão de livros, proibiram tambēm em geral todo e qualquer livró escrito por algum herege. 203

Ta1 fato levou ao deserto de idẻias e de reflexão. A pena imposta a quem lia livros proibidos, ainda nesses anos em que se deram a perseguição e o confinamento de Hipó1ito da Costa por sua suspeição de franco maçon, seriam a excomunhão e a infâmia, alẻm, claro, do degredo e da morte. A Maçonaria representava, em termos práticos, a disseminação do enciclopedismo. . Logo,para fazer/tais avanços, Estado e. Igreja estavam vigilantes. Nessa vocação absurda e nilista pelo obscurantismo, os fiẻis da cruzada inquisitorial chegam ao máximo da paixão pela sombra. Hipỏlito da Costa confirma essa declaração de voto no retorno ao medievalismo:

... o desejo de perpetuar a ignorância chegou ao ponto de que, quando os padres do Concílio de Trento deliberaram a publicação de um catálogo de livros proibidos, Luiz Beccatelli, Arcebispo de Ragusi, proferiu que não havia nessidade de livros, porque certamente se havia 
escrito mais do que era necessärio depois da invenção da imprensa, é que era muito melhor proibir inumeräveis livros sem. causa, do que ficar sem ter proibido um só que o merecesse ser. 204

Hả uma outra círcunstância de surpreender o leitor através das referências, implícitas ou explícitas, em textos produzidos para outros fins. Exemplo disso são as"Cartas de Marrocos," que a Biblioteca Nacional publicou em seus Anais. Horário e o poeta barroco Tomás Pinto Brandão seriam autores lidos pelo missivista em suas catilinārias contra Marcos Antônio Portugal. Em carta de 3 de julho de 1812, documento que se encontra arquivado em Lisboa, na Biblioteca da Ajuda (conforme Oliveira Lima, t. II; p. 1009), dirigindo-se a um amigo, Marrocos refere-se ao desafeto Portugal e aos autores acima referidos, utilizando-se da expressão horaciana risum teneatis, amici, concluindo pela pouca sensibilidade do criticado que "antes dando quatro fungadelas, voltou costas, e pôs-se a ler os versos de Tomás. Pinto Brandão. Que lảstima! ..."205

A alusão, a sätira e a caricatura parecem ter endereço certo na utilizaçã̃o da referência à Artè de furtar como título aplicado à classe dominante nos governos das províncias. No livro Os deputados brasileiros nas cortes de 1821 , o autor anuncia ter tido êxito a divulgação de que ia sair do prelo um resumo da obra atribuida ao padre vieira e dedicada ao barão de S. Lourenço, peça publicada no jornal "으 Campeão de Londres", de 16 de novembro de 1819. A am- 
biguidade da dedicatória è flagrante, tanto mais que era circular, na época, uma quadra que resgata as eternas querelas e a graça do povo contra os poderosos: "Quem furta pouco é ladrão/ Quem furta muito é barão/ Quem mais furta e esconde/ Passa de barão a visconde"206.

Martim Francisco, defendendo uma reorientação dos conteúdos da Filosofia Racional e Moral na província de São Paulo, nos começos do século XIX, cita Condorcet. Segundo ele:

Quanto à metafísica e moral, direi, como dizia Condorcet nos ültimos momentos de sua vida, que, sendo manifesta a imperfeição da anālise das faculdades intelectuais e morais do homem, cumpre dar uma nova anälise critica destas mesmas faculdades, refazer a ciència do entendimento humano desfigurado pelos sensualistas, banir esta metafísica dos sentidos que colocara - interesse e todas as paixões no trono da mora). 207

Um outro caso típico de impregnação de leituras pode observar-se em conhecido ditado que parece corrente na Bahia dos começos do século XIX, conforme aparece em cartalde Maria Bărbara a seu marido Luís Paulino d'Oliveira Pinto de França, deputado baiano às cortes constitucionais em Lisboa, por volta de 1821. Luís Paulino era deputado conservador e 
consta ter sido empurrado escadarias abaixo do palácio das Necessidades, 1ocal do Congresso, por Cipriano José Barata de Almeida, também deputado, de tendências republicanas, e constituinte em Lisboa. Maria Bärbara, escrevendo ao marido em 2 de março de 1822 , dä conta das notícias de sua casa, lamenta a "maldita rivalidade" de "homens pouco políticos", e lastima a sorte da Bahia e do marido, repetindo: "Perdião perdeu a pena, não hã mal que the não venha", di- : tado português, aproveitado como mote em conhecido vilancete camoneano. ${ }^{208} \mathrm{Na}$ mesma obra, em carta de Luís Paulino filho ao pai, datada -e Bahia, 3 de julho de 1922, aparece referência ao "Semanário cívico" e ao seu diretor Joaquim José de Souza Maia. 209 o Luís Paulino pai era soldado-poeta, tendo cultivado a poesia no "Jornal de Coimbra",(n. 2.2 publicado em out. 1813 e 41, 1845) e provavelmerte no Brasil. A forma de sua poesia denuncia o temperamento do autor e a matiz poética portuguesa.

Eis já dos mausoléus silêncio horrendo,

Me impede o respirar, a voz me esfria.

Eis chega a morte eterna, eis morre o dia,

Ao nada a natureza vai descendo.

No, da aniquilação, passo tremendo, Escudo-me de sã filosofia,

Terror humilde, o rosto näo m'enfia.

Como Catão morreu, eu vou morrendo!

Mas ah tu, d'alma, nobre qualidade, Saudade cruel co.'o sofrimento

Me arremessas às marés de ansiedade...

Mulher... filhos... amigos... num momento, No momento do adeus pra eternidade Vós sois o meu cuidado, o meu tormento! 210 
Outra forma de identificarmos as tendências e características de leituras no século XIX são os inventários de bens jā avaliados em publicações especializadas.

o inventārio e testamento do cônego Manoel Dendê Büs, cidadão português do Porto e vigário da freguezia da Conceiçäo da Praia em. Salvador, falecido em 1836, está no arquivo da Cúria de Salvador, livro de Obitos da Matriz da Conceição da Praia, 1834 a 1847. O monsenhor Manuel de Aguino Barbosa extraiu notícia de sua morte. 0 padre', que figura entre os nomes do movimento libertärio de 1822 e que nasceu em 6/12/1784, foi professor de Gramática latina na Bahia, nas comarcas de Jacobina e Cachoeira. Pelo documento do inventärio, constata-se que Bús tinha "3 estantes com treżentos e tantos liviros alëm de brochuras, folhetos", de que se destacam "5 volumes de Van Espen, quatro dito de Ferrary e tres de Bento": "14 do sacríficio da Missa, os quais pertencem ao Revmo. Sr. Vigärio Lourenço de Sa. Maga1hães Cardoso, que hä anos m'o emprestou. 211

Já no inventärio do padre Joaquim Gonçalves Cardozo, de 5 de agosto de 1829, utilizado por Kátia Matoso em seu estudo da tipologia social de inventários e testamentos na Bahia, há, na seção Documento. "Livroṣ" os seguintes títulos:

Latinos - missal Romanol Prozodia/ 2 menores Teatro eclesiasticol Officio de defuntos/ 6 Breviarios Portuguezes/ $17 \mathrm{v}$. Velho Testamento de Pereira/ 3 Novo Testamento Pereira/ 4 Historia de Gil Braz/ Noites clementinas/ Etenerario da Terra Santal Eva e Ave/. A Revolução de Françall 
2 Tesouro de Adultos/ Ordenando instruido/ Gusmão de Alfarachel Poezias de Paulino/ 2 Cartas do Papa Ganganeli/ Teologia moral/ Cartas de huma may a seu filho/ Horas annuaes/ Elementos de Syntaxe/ Horas da Semana Santa. 212

o. que consubstancia a tendência natural de Iivros religiosos, de doutrina e ascese, nos inventärios de padres. Livros, aliäs, bem próprios da geral correspondência de leituras no Brasil dos séculos XVIII e XIX. Novidades serão uma obra do Quinhentismo espanhol na América, a novela de cavalaria Vida de Gusmão de Alfarache e as Poesias, de Pau1ino. o padre Joaquim Gonçalves Cardoso seguia a voga dos autores da reforma oratoriana em Portugal. Sua biblioteca tem o Antonio Pereira de Figueiredo em sua base moral cristã e o polêmico autor de Elementos de sintaxe. As outras obras seguem o disciplinamento de estudos e a preferência de época: o Le Sage da História de Gil Braz de Santillana , as Noites clementinas, o Eva $\in$ Ave ou Maria triunfante de Antonio Ribeiro de Macedo, e as Cartas de uma mãe a seu filho:

No interior do inventário de Manoel Antonio Campello, de 1795, de Salvador., existente no Arquivo do Estado da $\mathrm{Ba}-$ hia, encontra-se uma Relação incompleta e catalogrä́fica de livros, começado em $\underline{M}$ e terminado em $R$. Muitos dos Iivros trazem data de publicação posterior a 1795 como as "Obras poeticas" de Ladislao Santos Titara (Bahia, 1827) e as "Poesias de João Gulberto Ferreira Santos Reis" (Bahia, $1827,2 \mathrm{v}$.$) , embora o inventärio se encerre na data de 1811$. 
Face à suspeição óbvia aplicada ao documento, por sua imprecisão e pela prôpria formalização do catálogo (bem ordenado bibliograficamente, com dados de autor, título, lugar de edição e,ano), caso extraordinário para as costumeiras e equivocadas anotações doṣ escrivães desses documentos, intuímos dever tratar-se de um catálogo da Biblioteca Pública da Bahia, ou de alguma outra do próprio século XIX. E boa lembrança que o "Plano para o estabelecimento de uma biblioteca publicada na cidade de S. Salvador" foi editado por Silva Serva em 1811. No mesmo ano, chegaram doações para sistematizar a Biblioteca. Terminando, como termina, em 1811, o pretenso inventário de Campello deve ser entendido como um dos catálogos da Biblioteca baiana, talvez um dos que se inspiraram naquele primeiro publicado pelo editor e livreiro Manuel Antonio de Silva Serva.

O catálogo sob análise começa pelas "Metamorfozes d'0vidio", numa tradução de Almeno, de Lisboa, 1803 e termina pela "Relação do estado político e espiritual do Império da China nos annos de 1655 e 1666", pelo padre Francisco Rougemont, editado em Lisboa, 1772. Organiza-se sempre pela indicação bibliogräfica de tîtulo, autor, lugar de edição e ano. Destacamos alguns desses títulos como, por exemplo, - Método gramatical para todas as linguas., de Amaro de Roboredo, edição de Lisboa, 1619: a Monarquia 1usitana, de Fr. Bernardo de Brito, edição lisboeta, 1690; o Naufrägio e 1 lastimoso sucesso da perdição de Manoel de Sousa de Sepủlveda, por Jerônimo Corte Real, editado em Lisboa, 1783; e Nobiliarquia portuguesa, trätado da nobreza hereditária 
e politica, por Antonio de Villas Boas Sampaio, editada em Lisboa, 1676; Noticias de Portugal, por Manoel Severim de Faria, obras acrescentadas por José Barbosa, èm Lisboa, 1740; Notícias históricas e práticas acerca do modo de defender os edificios dos estragos dos raios, por João Antonio Dalla Be11a, numa edição de Lisboa, 1773; a pouco frequente obra de Francisco de Brito Freire, Nova Lusitânia, história da guerra brazilica", editada em Lisboa, 1675; Novo methodo da gramätica grega, por Porto Rea1, Lisboa, 1760; Novo método da gramática latina, pelo Padre Manoel Monteiro, Lisboa, 1746; Novo método da gramática 1atina, por Antonio Venâncio da Costa, Lisboa, 1799; Novo atlas geogräfico, po1ítico e histórico de todos os Estados da Europa, Lisboa, 1800: Novo tratado de música métrica e rítmica", por Francisco Ignacio Solano, Lisboa, 1779; e. Obras värias por João Pinto Ribeiro, Coimbra, 1730.

Outras obras ainda se destacam no catálogo incluído no corpo do inventário de Manoel Antonio Campe1lo, identificando livros de circulação previsível desde o século XVIíl e que pontuariam, provavelmente, nas estantes baianas. E o caso da obra do oratoriano Antonio Pereira de Figueiredo, Observações sobre a língua e ortografia latina, editada em Lisboa, 1765: a Orthografia da lingua portugueza, por Luiz Caetano de Lima, Lisboa, 1736: Os estrangeiros no Lima, ou conversações eruditas, por Manoel Gomes de Lima Bezerra, Coimbra, 1785; Parnaso lusitano de divinos e humanos versos, por Madre Violante do Céo, Lisboa, 1733, em 2 volumes: Peregrinação de Fernão Mendes, edição de Lisboa, 1725; P1a- 
netário lusitano, pelo padre Euzebio da Veiga, Lisboa, 1758; Poemas 1usitanos, por Antonio Ferreira, Lisboa, 1791; Poesias de Pedro d'Andrade Caminha, publicadas pela. Academia, Lisboa, 1791; um rarissimo Primor e honra da vida soldadesca no Estado da India, pelo padre-mestre Fr. Antonio Freire, Lisboa, 1630; e as polêmicas Reflexões apologëticas à obra intitulada "Verdadeiro método d'estudar", por Nicolau Francez Siam, Lisboa, 1748.

E naturalmente um bem nutrido retrato do leitor brasileiro dos começos do século.XIX, alcançando títulos e autores desde o século XVII, alguns surpreendentemente raros, que dão a dimensão do interesse e do gosto por coleção de obras antigas, na Bahia. Pena que a imprecisão do documento nos lance em enviesados caminhos de indefinições. Mas, pela maior parte das pistas, somos levados a considerar o catälogo uma relação de livros, talvez até doação dos her- deirọ do próprio Manoel Antonio Campello, na década de 30 do século XIX.

Alguns tỉtulos, aliās, coincidem na relaçäo catalogrāfica apresentada pela Biblioteca Püblica da Bahia, em 26 de junho de 1831, num manuscrito que leva a assinatura do bibliotecário Vicente Ferreira de oliveira. Um dos títulos dessa relação é justamente o livro das "Metamorfoses d'ovidio", traduzidas por Almeno, volume 2. Outros títulos seguem a mesma coincidência, como a "Monarquia Luzitana por Fr. Bernardo de Brito", 39 tomo; "Principios de Direito mercantil por José da Siḷa Lisboa", volume 2; e "Quaresmal seleto" por José Barradas Furtado. Pode bom ser apc- 
nas uma mera e fortuita coincidência, mas não fica absurdo supor que se trate de trecho do catálogo da livraria pública baiana. 0 de 1831 deve ser o catảlogo mais disponível, uma vez que, em ofício de 31 de janeiro de 1851 , um relatório do bibliotecärio Antonio Joaquim Alvares de Amarato, ao assumir a biblioteca, relembra que ela foi criada com mais de 4 mil volumes oriundos de compra e doações de particula- . res, notadamente do seu criador o Conde dos Arcos, mais Manoel Luiz Alvares de Carvalho. Em 1820, segundo Spix e Martius, ela teria cerca de $12 \mathrm{mil}$ volumes. As Guerras da Independência extraviarain muitos livros e o catálogo de 1829 desapareceu. o relatório de Amarato fala ainda de um catālogo de 1834, que não encontramos no ARQUEB. 


\section{PERFIL DO LEITOR COLONIAL}

No interesse mais imediato desta tese, isto é, partindo da amostragem de livros dispostos em documentos manuscritos do século XVII ao XIX, vamos observar confirmaçōes e alteridades no comportamento do leitor brasileiro do período colonial. Embora permaneça ainda un tanto suhọrdinado ou obediente à leitura de compromisso, fiel às obras devotas, por força, talvez, do caráter introjetivo de modelos doutrinärios, (seja pela clausura intelectual jesuítica ou secular), esse leitor já conta com alguma percepção e autonomia na escolha de livros um tanto diversos dos incontáveis místicos e apologéticos, devocionários, sermonärios,. panegiristas e gratulatórios, que marcam a imensa maioria das obras publicadas à época. Nota-se, especialmente a partir da segunda metade do século XVIII, uma significativa impregnação das Ciências Naturais, da Matemática, da Física, da História, etc. Vale salientar, neste ponto, o avultado nümero de obras relacionadas com a área de Letras presentes nos documentos. oṣ inventários irão apontando então um leitor progressivamente variado em seu gosto e em sua curiosidade, alterando- se estes sentidos em cada período da situação colonial. Será sempre, entretanto, um leitor de extração rural ou burguesa, de formação liberal, tornando-se um tanto mais numeroso, eclético e reformista à medida em que se aproxima da passagem do século XVIII. para.o XIX. 
Grande parte da história brasileira é feita a partir do campo. O patriarcado rural, como sabemos, perdura até meados deste século e, na esfera direta de nosso assunto, é o campo que determina o alcance e as variaçōes da civilização. Daí pertencerem à origem rural os primeiros vagidos de cultura bibliográfica, o campo muito mais que as vilas e cidades, o livro assumindo então um papel de ornamento social ou burguês, na maioria das vezes atendendo a reclamos de ordem ético-cristã. Na.vàriegada forma do século XVIII, com o apogeu e declinnio da mineração e a expansão territorial, começam a tornar-se circulares ideais emancipacionistas, num sentimento tênue de nativismo, como demonstram os movimentos dos Mascates, em 1709, no Recife e dos Emboabas, em 1710, em Minas Gerais, completados pèlo ativismo ingênuo de um Felipe dos Santos, em 1720 ou de um Tiradentes, em 1789, nas Minas Gerais. Algumas dessas idéias de liberdade, atiçadas pelo espỉrito do Setecentos ilustrado, vão percorrer todo o século XVIII e agitar, em atmosfera febril, o século XIX no Brasil. Idéias e reflexões percorrem livros e cabeças daqueles leitores que predominam a este tempo, como os estudantes de Coimbra, os magistrados, poetas, mëdicos e sacerdotes, que formam uma elite ledora querendo mudanças ou.aperfeiçoamentos no corpo da sociedade. Pode dizer-se, num certo sentido, que a cultura literāria evolui da notação superficial, de moda cultural por lazer e ócio para uma caudal de sentimentos, convicções e posturas ideológicas mais consequentes. A cultura assume, assim, características de um valor moral, ou ético, em função de uma necessidade prática ou tecnicista, mas de 
fundo intelectual e humanista. Embora permaneça como signo de classe e distinção na escala social, a leitura não ficará apenas no redil de pura abstração mistica, ou do rigoroso automatismo tỉpico da vocação reinol.

Não serā fäcil disseminar outra ordem de valores e questionamentos numa base sócio-cultural que toma Religião ou Estado confundidos com vida intelectua1, numa intima relação que irá dominar os três primeiros sêculos da colonização portuguesa. Mas o brasileiro, dono daquela."inteligência quase primitiva", conforme a classificação de Fernando de Azevedo 213 praticarā também sua fórma de reconstruir ou desnormatizar a cosmovisão, permitindo vir à tona, e mesmo agudizando, uma sensibilidade que manterá viva curiosidade intelectual, naquilo que, ousamos perceber, será contemplado como um imaginärio, inchado de alusões e fantasias, rica teia do brasileiroleitor, alguém muito mais ligado às Letras e às Artes do que às Ciências Físicas e Naturais.

Nos fins, do século XVIII, a civilização portuguesa no Brasil já tem muito o que por à luz, na Metrópole e nas Colônias. Dos jesuítas, que nos inocularam a cultura literária fundada no' dogma, passamos aos oratorianos, ou às demais ordens patrocinadas pelo regalismo, que darão maior ênfase ao ensino e à pesquisa, privilegiando as áreas das Ciências Naturais, sobretudo a Botânica e a Zoologia e investindo, embora timidamente, numa possîvel civilização de técnicas mais modernas, como o Desenho, a Mineralogia, as Edificaçōes, a Arte militar. O Brasil, enquanto Colônia, força um pouco a situação de isolamento a que Portugal o condenara e reage, 
pela acumulação da cultura livresca, como uma forma de não sucumbir. Pode-se dizer, pois, que è justamente por essa sociologia esquiva da leitura, pelo consumo e circulação de livros, sem preconceitos, nas mais diversificadas áreas do saber, que a Colônia provocará algumas muảanças. Portanto, o Brasil será diferente das demais Colônias, visto por Portugal. Assim, menos que considerar um mal a forte cultura livresca aqui operada, temos que considerâ-la uma força inconsciente de reação ao dominio absolutista da Metrópole. Por ser o mais expressivo elemento de ligação entre a realidade objetiva e o imaginário libertador das formas retrógradas de dominio coloniai, a Literatura representa um esforço de reação ao abastardamento da inteligênçia que aqui nos quiseram impor e um elogio à utopia de.construção, pela via abstrata, de uma nova realidade. Isso, de uma ou de outra maneira, está refletido no consumo e nạ produção literária dos brasileiros.

Neste sentido, concluimos com Fernando de Azevedo, para quem "ạ Universidade e a circulação de livros impressos podiam constituir ameaça à unidade de padrão cultural e um perigo para o despotismo lusitano ${ }^{214}$. Pela leitura, os brasileiros poderiam chegar à insubordinação ćrítica, mesmo que, para isso, caminhasse por trilhas de uma cultura pseudo-humanista e aristocrática, de base rural, ou burguesa e urbana, distintiva de classes sociais estanques.

Uma vez aceita a certeza documental refletindo o homem, esta pesquisa vem ampliar o campo de investigações sobre a natureza antropológica brasileira na direção de uma cultura 
literária no Brasil Colônia, com a descrição do universo de leituras e de livros. Já descritos os documentos publicados pelo Arquivo Público de São Paulo e estudos colhidos em poucas fontes, investimos agora naqueles que foram objeto de nossa consulta direta, fixando-nos em. inventários de bens desde os mais antigos, ainda do sêculo XVII, em São Paulo, extensivamente até ao limite de 1850, por todo o Brasil. Assim, completa-se a recolha de dados disponiveis que identificam, ao nosso ver, o perfil do leitor colonial, a partir da análise de mais de 50 mil documentos.

Dessa investigação em fonte primária feita em todos os locais de guarda cultural brasileira, analisando, um a um, cada documento e selecionando aqueles que continham livros, para discriminação, observamos que a quase totalidade de inventários do século XVII incluindo bibliotecas se encontram no Arquivo do Estado de São Paulo (11 ao todo). Ali, inclusive, vimos documentos do século XVI, sem livros. Com data de 1687 e 1696, dois outros inventārios encontramos no Arquivo Nacional, no Rio. Os demais pontos de pesquisa não registram documentos do século XVII, com ou sem livros. Nesses pontos, vamos contar com documentos do século XVIII, especialmente Minas, nas cidades históricas. E de supor, no entanto, que núcleos importantes como a Bahia e Pernambucó, por exemp10, tenham tido e extraviado alguns inventários de bens do século XVII ou XVIII. A Bahia possui ainda uns poucos e imprescindiveis ao entendimento de nossa cultura, a grande maioria necessitando urgente restauração. Pernambuco, porém, parece ter perdido sua memória quanto a inventários de 
bens. Dos escassos documentos localizados em nossa pesquisa, um apenas, em microfilme, pertence ao sëculo XVIII - o do Bispo de 0linda, D. Tomās da Encarnação Costa e Lima, de 1784. Os demais datam de parte do século XIX, perdidos entre lacraias e escorpiōes no porão do Tribunal de Justiça, em Recife. Outros, do século XIX, ainda em bom estado, en-. contram-se no Primeiro Cartörio de orfãos da capital pernambucana. Com exceção, porém, daquele pertencente a D. Tomás da Encarnação, todos os demais documentos não apresentaram livros entre os bens dos inventariados.

Dos documentos seiscentistas aos da primeira metade do século XIX, observamos um retrato objetivo do modelo leitor brasileiro da Colônia ao Império. A pesquisa teve seu limite ampliado até o ano de 1850 em virtude da tentativa de compreender um maior espectro de tempo, tendo em vista a natureza do documento analisado. Assim, ultrapassamos. 1808, ou 1816, quando o Brasil passa à qualidade de Reino Unido a Portugal e Algarves, e tambër 1822, ou 1824 - data da nossa primeira constituição imperial. Atingimos até uma fase da consolidação dọ Brasil Impërio, no Segundo Reinado. Para a Literatura Brasileira é importante esse avanço porque pode oferecer outros elementos de avaliação, uma vez que estávamos em plena voga do Romantismo, com sua reconhecida base nacionalista e na fronteira de um discurso literärio autônomo. Ampliar a faixa de tempo serviu-nos como elemento de intermediação entre a característica autöctone e a alienigena de leituras. Tambèm porque, entre a morte e o inventário de uma pessoa, è possível localizar um interesse na livraria inven- 
tariada. Em outras palavras, um inventário de 1850 registra bens (vale dizer, livros) que o inventariado, falecido em 1800 ou 1810, por exemp1o, possuía. Por circunstâncias próprias às disputas de partilha, um documento dessa natureza pode durar, a ser concluído, de vinte a quarenta ou sessenta anos decorridos da morte do possuidor da biblioteca.

o inventärio é um documento muito peculiar, onde se sumariam todos os bens do falecido para, pela atribuição de valores a esses bens, chegar-se ao termo da partilha entre os herdeiros. Difere do testamento, onde não se obriga o testador ao registro de bens com riqueza de detalhes, nem a aplicar-lhes valores. Sendo manifestação de ültima vontade, - testamento é peça documental feita em vida pelo testador, para ter respeitados seus desejos quando morrer. Em nosso trabalho, o inventāirio revelou-se uma extraordinäria fonte de informações no que tange à constituição de bibliotecas - talvez a única com que pudéssemos contar para a riqueza de material que recolhemos. Consultamos outras peças documentais, como ofícios, cartas régias etc. em todo o país, mas é o inventário que melhor serve aos objetivos deste trabalho. 215

Algumas circunstâncias do inventário, sem dưvida, despertam interesse para várias manifestações de ensaio sociológico - e disto fez uma obra respeitável Alcântara Machado, em Vida e morte do bandeirante. 0 inventārio pode servir atẻ à literatura de ficção ou à poesia. Drummond transcreve o inventärio do padre Manoèl Rodrigues no poema "Bens e vária fortuna do padre Manoel Rodrigues, inconfidente", no livro A falta que ama, (que apomos como epigrafe em outro capi- 
tulo deste trabalho), tornando poesia uma mera relação de bens aqui aguçada por ser a personagem um conspirador, desafeto do Reino de Portugal. Outro mais largo uso fez Manuel de Oliveira Paiva no romance Dona Guidinha do Poço, no sécu10 XIX. No capitulo I do Livro Primeiro, salientando os dotes econômicos da heroina do Naturalismo regionalista cearense, Oliveira Paiva demonstra-se leitor explícito de inventários, conforme detalhe em grifo:

Margarida, isto é, a Guidinha, apesar de sua princesia, não casou tão cedo como era de supor. Parece que primeiro quis desfrutar a vidoca. Seu pai, o segundo Venceslau, capitão-mor da vila, possuía larga fortuna em gados, terras, ouro, escravos... Fora um rico e um mandão.

Aqui vai o resumo de uma relação ou nota do que se lhe achou, imperfeita e truncada como o são geralmente os inventärios, mas autêntica, encontrada num alfarrábio do padre Costinha, quase i legíve 1: 216

0 romancista reconhece as dificuldades, aqui apontadas, na leitura dos documentos, autenticando-a, porēm, quando da transcrição das listas de bens, embora afirme ser imperfeita e truncada "como o são geralmente os inventários". No inventário do capitão-mor, pai de Guidinha, relacicnam-se bens em "Ouro", "Prata", "Cobre", "Ferro", "Bens Móveis". Nada, contudo, transparece quanto à formação de bibliotcca. Em nossa descrição do perfil de leituras,mediante os 
inventärios de bens, não nos deteremos em aspectos histöricos, econômicos ou políticos que o documento pode sugerir. Nem sempre será dada ênfase à pessoa ou condição social do inventariado, aqui tomado apenas como um dado de pesquisa. Não obstante; destacamos alguns nomes que tenham uma real importância histórica e que, no interesse do confronto da pesquisa, são objeto de nosso estudo em particular, como é o caso do Marquês de Maricâ e de Evaristo da Veiga, cujos inventários pesquisamos e vão descritos, respectivamente, nos Capitulos 5 e 6 desta tese. Ou casos ainda como os do Brigadeiro Luis Antonio, do diplomata José Lino Coutinho e do lente de Direito Luís Nicolau Fagundes Varela (avô do poeta), que encontramos nos Arquivos da Bahia e do Judiciário de São Paulo. De outra sorte, a fixação da data limite em 1850 impediu-nos de descrever e anotar, para os fins deste trabalho., inventários importantes como os de José Bonifácio, Diogo Antonio Feijó e Tobias de Aguiar, justamente por serem documentos com datas de inventariação muito posterior a 1850. Tais documentos se encontram expostos no Museu do Arquivo do Judiciário, na Vila Leopoldina, em São Paulo.

Muiţos documentos trazem a indicação de livros feita de forma muito dificil ou mesmo impossivel de identificação. Evidenciam uma vaga descrição como "Livro de letra de forma", no inventário de Maria Pedrosa (Arquivo de São Paulo, ano 1645). Outros simplesmente registram "4 Obras de Moral", "1 livro da forma", "I Constituição". Ou a simples menção do autor, sem indicativo da obra, como"1 Besombes", "1 Larraga", "1 Bento Pereira" etc. Muito comum é a indicação 
da obra, sem autoria e sem o título completo, como "Mística cidade", "Pratica de ordinandos", "Comedias" etc. Também comum é a indicação do livro pelo assunto ou matẻria tratada como "l livro de moral", "Varios livros de doutrina", "13 livros classicos" etc. Impossivel, salvo em casos excepcionaìs, saber a edição. Destarte, a transcrição aqui deve ser compreendida como.um esforço de interpretação das leituras, por seu gênero, assunto ou autor, com a falha óbvia de uma informação incompleta. Por ser absolutamente-impossivel supri-1as; são inümeras as dificuldades de leitura paleogräfica dos documentos, face ao seu lastimável estado de conservação, guarda ou acesso.

Descrevendo-se o que predomina, de fato, nas leituras feitas pelos brasileiros do século XVII ao XIX, a partir dos documentos pesquisados, sem dúvida teríamos que o perfil de leituras no Brasil Colônia é de natureza recorrente ou especializada. Poucos inventários mostram um leitor com uma quantidade extraordinária de livros no século XVII, por exemp1o. As bibliotecas maicres vão sendo constituỉdas a partir do século XVIII, tanto em volume, quanto em variedade de assuntos ou diversidade de títulos. Ainda poucas são as obras pertencentes a ramos do conhecimento fora da especialização, ofício ou devoção do inventariado, o que, no século XVII, poderia ter assinalado uma caracteristica de leitura bem maịs eclética.

Devocionärios, livros de rezar, catecismos, manuais de missa, confessionärios, livros de elevação e doutrina ascética são os mais numerosos entre os bens arrolados como 
livros nesses inventārios. Como dissemos, na característica - da especificidade formativa de leitura, o magistrado tinha livros de Direito; o padre, os de Religião; o militar, os de Legislação portuguesa, Ordenações do Reino e seus Repertốrios, è muito mais os. de Religião; o doutor em Medicina, ou Cirurgião, tinha os livros próprios de sua especialidade. Fora deste quadro, leitores seriam os pequenos proprietários, . os fazendeiros, os boticários - vendedores profissionais de lịros de Farmácia, Quỉmica e Medicina. Enfim, leitores potenciais seriam os cidadãos de relevo social, aqueles da estreita fatia detentora do poder econômico. Dentre os pretos forros - circunstância muito frequente nos séculos XVIII e XIX - que alinhavam entre seus bens ouro, prata, imóveis e escravos, muito poucos deles tinham livros. Quando tinham, eram obras, em geral, pertencentes à Religião.

A observação mais concreta do perfil social do leitor brasileiro colonial é que este era abastado. E do sexo masculino. Raras são as mulheres que aparecem como inventariadas e, ainda assim, peló que parece, seus bens, sobretudo livros, teriam se originado de partilha anterior quando da morte do márido, ou irmão. Hă alguns casos de inventărios feitos sob sequestro, ou sob a norma juridica da decretação dó estado de demência do inventariado. Fazendeiros, padres, militares, médicos; bacharéis constituem um modelo mais pertinente dos leitores coloniais. Claro, a simples formalização do inventärio implicava em ter o inventariado posse de bens, sobretudo os de raiz, o ouro, a prata, os escravos e os móveis. Por isșo, predominam os ricos, aqueles com pos- 
ses suficientes para disposição de partilha. O que não significa necessariamente que todos os abastados tivessem Iivros em casa, ou que os livros não pudessem aparecer nos inventärios dos aparentemente pobres. Há casos em que à rubrica "Livros" abre o documento na forma introdutória da descrição dos bens, o que equivale tanto ao grau mensurävel de sua circunstância econōmica na partilha quanto à importância intelectual atribuída ao inventariado. Há outros casos em que um único livro aparece perdido como bem do inventariado, em meio a "Möveis", "Trastes", ou, atē, "Escravos". Não consideramos aqui o bem livro com valor econômico atribuído no documento, por não interessar aos estritos objetivos da pesquisa.

Entre os bens inventariados (com predomināncia para "Ouro", "Prata", "Ferramenta", "Cobre", "Latão", "Arame", "Bens de Raiz" e "Escravos", pela ordem), o escrivão lista em "Livros" a fortuna bibliogräfica do falecido. Essa 1ivraria, geralmente, é tipificada, como dissemos, pela natureza profissional ou funcional do inventariado. Nisso varia a especialização dos livros. Quando não se pressente a formação do inventariado, o acervo da livraria pontua pela matéria.religiosa, obras de devoção, manuais ascēticos ou místicos, como a testemunhar a extensa e intensiva presença dos ministros e missionários do Catolicismo no Brasil. Em número esmagador, sobretudo no século XVIII e em Minas Gerais, a grande maioria dos inventariados é constituída por padres. Logo, os livros serão aqueles indispensáveis ao ofício religioso. Depois dos padres, os militares, médicos, cirurgiócs 
e bacharéis completam o quadro dos leitores inventariados.

Essa, enfim, è uma característica marcante na tipologia dos livros coloniais, do século XVII ao XIX: os livros que a maior parte dos brasileiros liam são os pertencentes à Teologia Dogmática, à Hagiografia, à Ascética, ao Direito Canônico, às Constituiçọes de bispados e arcebispados, aos livros de Doutores da Igreja, Catecismos, Bíblias e manuais místicos ou ascëticos, às Ordenações do Reino, tratados de Direito, formulärios médicos, obras da farmacologia portuguesa. Alguns poucos fogem do assunto doutrinário ou funcional e vão aos aspectos do Direito português. Ou às questões relacionadas com a Ciência Médica ou à Literatura e Linguística, à História, à Geografia, às Ciências Naturais, embora o peso maior nessas äreas se dê a partir de fins do sêculo XVIII. Nesse sécu1o, aliás, vão aparecer, e até dominar, os clässicos latinos como Vírgilio, Ovídio e Horácio, manuais de Filosofia e Moral, compêndios de Filosofia ou Direito Natural, e enciclopédias, dicionārios e gramāticas de uso obrigatório para a leitura em lingua estrangeira. Hâ, ainda, no espaço do século XVIII, boa quantidade de vocabulärios, cartapácios de gêneros e sintaxes; volumes da rudimenta latina, gramáticas dó Latim e do Português, dicionários de particular interesse para versões do Francês (em maior número), do I taliano e do Espanhol.

o século XVII, no Brasil, em matêria de circulação de livros, registra um peso quase exclusivamente de obras de devoção ou doutrina religiosa. Raríssimos escapam a essa. predominância, como è o caso jä apontado das Novclas de 
Cervantes, das Peregrinações de Fernão Mendes Pinto, de uma Aritmética e das indispensáveis Ordenações do Reino de Portuga 1, com seus não menos inseparáveis Repertórios. 0 mais relacionado consigna a importância e oḅediência atribuídas às práticas de leitura moral, apontando para um modelo servil ao dogma, proveniente, por certo, da extraordinária presença dos oficiais da Religião, em particular os jesuitas, no meio social da Colônia.

Apenas São Paulo, em grau superlativo, e o Rio de Janeiro representam, pela guarda de documentos de época, esse século XVII brasileiro. Conforme acentuamos, não hã registro disponỉvel de documentação seiscentista em outros lugares de mais viva impregnação cultural do Brasil. Como esses documentos existentes descrevem uma enorme maioria de obras devocionārias - não exclusivas, no entanto, do século XVII, mas extensiva aos séculos XVIII e XIX - vão descritos ou analisados no capitulo respectivo, "Doutrinas e devoções". Assim, também quando tratam de matērias relacionadas com as Ciências do Direito, vão descritos ou analisados no capítulo correspondente, "Vade mecum e Ordenações". O mesmo se aplica às obras na relação direta com as Ciências Médicas, tratadas no capitulo "Aforismos e sangrias". Finalmente, as obras. que digam respeito à área de Letras, vão aparecer em descrição e anālise no capítulo correspondente, "Clássicos, moralistas e gramáticos".

Presentemente, seja porque pertençam aos mais diversos ramos do conhccimento, excetuando-se'a Rcligião, a Mediciṇa e Cirurgia, o Dircito e as Letras, detemo-nos cm alguns as- 
pectos consideräveis que configuram uma certa alteridade no perfil do leitor colonial brasileiro. Além desses sentidos de predominância óbvia, mudam-se os temperamentos e os gostos se alternam à medida em que avançamos na direção do 0itocentismo. Aí mesmo é que avultam muitos tỉtulos que tangenciam tal predominio e avançam na demonstração de um universo de leituras mais eclético e variegado, aparecendo títulos em História, Geografia, Descrição de Viagens, Ciências Naturais, Ciências Políticas e Sociais, Química, Física, Matemática etc.

No século XVII, apenas os documentos de São Paulo, encontrados no Arquivo Püblico, dão testemunho de uma regular transparência de títulos bibliográficos extra os do predominio religioso. São muito poucos, mas representativos da ampliação de tendências do leitor brasileiro, à época. Assim, no inventário de Mateus Leme, de 1633, aparece um "Tratado do prätico de Aritmética". (APSP. Inventários e testamentos. (1920), v.9). Em termos explicitos, é o único documento que denuncia uma conformação diferente no predominio de leituras. Os demais títulos podem indicar uma definição do leitor por outros ramos do conhecimento, como, ainda, atestar a recorrente frequência de leitura doutrinária. Catarina de Siqueira, inventariada em 1638, por exemplo, tinha "2 1ivros". (APSP. Inv. e test. (1921), v. 10). Manoel Preto, também em 1638, tinha "1 livro velho". (APSP. Inv. e test. (1921), v. 11) e Clemente Alvares, em inventário de 1641, aponta possuir "4 livros". sem qualquer outra identificação. (APSP. Inv. e test. (1921), v. 13). 
No inventārio de Domingos Afonso, de 1685 (APSP, Ordem 495), aparece apenas a referência "Livros", sem qualquer outra indicação de tỉtulos, autores ou assuntos. Vai aqui anotada unicamente para efeito de informação estatỉstica. Apesar da ausência de descrição, o mencionar-se "Livros" para a pesquisa, nomeia o inventariado como um leitor potencial, mesmo sem que se conheçam os tipos de livros que ele provavelmente leria. E notável, para nossa investigação, o fato de o inventariado possuir, entre seus bens mais valorizados, aqueles que, sem dủvida, atestam um conhecimento e um ácesso à cultura literárià ou filosófica, moral ou profissional, escritos esses livros tanto em. lingua estrangeira quanto em vernáculo.

Minas Gerais e São Paulo são os Estados que mais comparecem numa amostragem do Setecentos literário, em termos de constituição de bibliotecas. O Rio de Janeiro e a Bahia vêm a seguir e emparelham com os dois primeiros, se não na quantidade de volumes, certamente no alcance e importância das livrarias inventariadas. Outros locais contribuem também, embora em menor escala, como Mato Grosso, Rio Grande do. Sul, Ceará, Maranhão, Rio Grande do Norte, Pernambuco e Alagoas, todos, sem dúvida, importantíssimos para a perspectiva de descrição e extensão do leitorado brasileiro na Colônia.

De uma forma geral, o século XVIII brasileiro pode ser considerado, do ponto de vista das leituras e livrarias, o sécullo da rciteração religiosa, com os assinalados titulos e volumes de devoção e mística, acompanhados de 
perto pela circulação de obras de Medicina, do Direito e das Letras e Linglística. Grandes autores das Ciências Médicas aqui comparecem, a começar pelo pai da Medicina, Hipócrates. $\mathrm{Na}$ Medicina portuguesa, destaque para o best-seller Curvo Semedo e os frequentissimos livros da Farmacologia lusitana. Dos autores em Direito, alëm das indefectiveis Ordenações do Reino de Portugal com seus inseparáveis Repertórios, aparecem consagrados luminares do Direito português como os Supico de Moraes, os Cabedo, os Gama, os Nogueira, os Reinoso, os Pona, os Souza, os Sylva, com obras em Latim (predominantemente) e em vernáculo, que balizam os estudos das Ciências do Direito Civil, Canônico, Criminal etc.

Hă leitores setecentistas tipicamente latinizantes. Pela prática bibliográfica de edições em Latim, ou não, o certo é que grande parte das obras nas livrarias coloniais brasileiras aparecem na lỉngua dos clássicos. A razão principal é que o Latim era idioma universal até fins do século XVIII. Muitas vezes, por incūria dos escrivães, essas obras vêm grafadas em Português, mas representam edições em Latim, como em Francês ou Italiano. Há inventariados que só possuem clássicos do mundo romano e há os que os agregam aos gregos, estes em versões latinas. Há tambëm os leitores predominantemente francófilos, tanto no século XVIII como no XIX. Há uns poucos interesşados em livros ingleses, alemães ou suiços. Alguns poucos demonstram intẹresse no mundo italiano e espanhol. Numerosos são os leitores dos portugueses, por óbvio. Dos quinhentistas, Camões, Sá de Miranda, Rodrigues Lobo. Dos seiscentistas, Vieira e.Bernardes. Dos autores 
do século XVIII, os aprovados no mundo da reforma pombalina, como Teodoro de Almeida, Verney e Antonio Pereira de Figueiredo.

o século XVIII português, aliás, é o da pédagogia iluminista. Por isso a enorme quantidade de obras versando sobre aspectos provocados pela reforma pombalina, suas variaçổes, polêmicas, desdobramentos. As obras trazem interessantes repositōrios de informações dos autores antigos e modernos, clássicos, escolásticos, mecanicistás; cartesianos etc. Foi o século fundamentalmente do espírito polêmico, como atestam as inumeráveis réplicas e tréplicas trocadas entre reformadores e contra-reformadores da experiência regalista. Algumas dessas polêmicas resultaram em fenômenos estéreis de repercussão intelectual. Outras, pelo embate crítico que trouxeram e pela assunção (ou recusa) de postulados vigentes na pedagogia, trouxeram frutos, fermentando o século com o exercîcio do debate. Não assim a circunstância do interdito a obras e autores estrangeiros. Importantes pensadores sofreram o index secular português, caso de Hobbes, Spinoza, Rousseau, Diderot, entre outros. Foi também o século da crise da primeira escolästica portuguesa, com o declínio, ou a rediscussão da filosofia peripatética e sua influência no tomismo.

Muitos dos livros que circularam no Brasil Setecentista, praticamente, foram os recomendados e adotados por Pombal a partir de 1759 , aproveitando a voga dos oratorianos para desfechar contra os jesuitas o golpe de morte na estrutura do ensino nos domínios do Reino. Assim, livros de Antonio 
Pereira de Figueiredo (Exercicios da lingua latina e portuguesa, 1751; Novo Método da Gramática latina, 2 v., 1752 e 1753; Coleção de palavras familiares, 1755 e Novo Método de Gramática latina reduzida a compêndio, 1788), a lém da versão portugueșa que Figueiredó fez da Rỉblia, ganharam as platéias leitoras no Brasil Setecentista. A dedução cronológica do . estado da Universidade de Coimbra, foi peça da propaganda pombalina, feita pelos oratorianos, justamente para excluir - predominio dos jesuitas no ensino e por isso também è familiar às livrarias brasileiras. Os oratorianos serviram a Pombal, sobretudo atravếs da Real Mesa Censória, de que Antonio Pereira era titular. Pombal cerrou-1hes os dentes em 1768 e os oratorianos só voltaram a erguer-se em 1777, com a queda do Marquês.

Alèm de Antonio Pereira de Figueiredo, outros autores se notabilizaram no Brasil, na vaga das reformas pombalinas da instrução püblica: Francisco José Freire (o Cândido Lusitano), Antonio Alvares, Francisco Sanches, Teodcro de Almeida, Luiz Antonio Verney. e muitos outros são extensamente populares em nosso Setecentismo.

Em L'etras e Linguística, aliảs, è enorme a importância da amostragem do leitor setecentista influenciado pelas reformas pedagógicas. As bibliotecas do período registram clássicos latinos popularizados como Cícero, Virgílio, Ovídio e Horácio, seguidos, em menor escala, por Marcial, Juvenal e Sêneça. Quintiliano permanece mentor dos jogos retóricos, tal a frequencia com que aparece nas livrarias dos inventariados. Nos estudos de Gramática e Linglística geral, a 
Prosódia do padre Bento Pereira é, de longe, o livro mais regular nessas bibliotecas. Aparece em expressivo número, tanto no século XVIII quanto no XIX, e em tódo o Brasil. Seu interesse para o leitor à época talvez decorra da enorme popularidade alcançada também em Portugạl, talvez porque antecipe estudos do vocabulário das linguas portuguesa , latina e espanhola, com versão e significados das palavras nos respectivos idiomas, com ênfase nos caracteres morfo-sintáticos e prosódicos de cada um deles. Obra superlativa entre os manuais de estudos sintäticos, lexicais, morfológicos, dicionários e vocabulários encontrados entre os livros dos inventariados, demonstra um gosto e interesse do leitor colonial para com aspectos linguisticos e peculiar imediatismo de compreensão dos modelos idiomáticos ou, ainda, auxílio para leituras de obras em idioma estrangeiro. Há que destacar também a incidência, nos documentos, de grande número de dicionários Francês-Português, Português-Francês, Português-Italiano, Italiano-Português ou as sempre frequentes obras de gramăticas dessas línguas.

Em Literatura, comparecem os portugueses antes descritos, os moralistas brasileiros do século, como Matias Aires, Margarida da Orta, Nuno Marques Pereira e expressiva quantidade de obras francesas e, um tanto menor, italianas. Assim, comparecem Montesquieu, Mably, Voltaire, Rousseau, Le Sage, Marmontel, Fenèlon, ao lado de Dante, Petrarca e dos populares Goldoni e Metastásio, Da literatura inglesa, o autor mais frequente é mesmo Milton. Da espanhola, Cervantes e o significativo aparecimento de Lope e Calderón. Lope no 
inventārio de João Lopes Fiúza, 1741, na Bahia. Ca1derón também na Bahia e em Minas. Hä um surpreendente volume de Artes poéticas sem indicação de autoria. A imprecisão do informe no documento pode levar-nos a, pelo menos, seis possibilidades de autoria, desde Aristóteles a Boileau, Diogo Garcia Rengifo, Filipe Nunes (pseudônimo do Fr. Filipe das Chagas), Horácio, na tradução de Cândịdo Lusitano, e Francisco de Pina e de Melo. Desses autores, os dois últimos são bastante frequentes nas livrarias setecentistas no Brasil e autorizados reformistas pombalinos. E de crer tratar- se, pela maior circulação nos inventários descritos, de obra de horácio na versão consagrada por Francisco José Freire, o Cândido Lusitano. Seria surpreendente, mas não absurdo, que a Arte poética de Aristóteles, ou a de Boileau (sobretudo na tradução do quarto conde de Ericeira, em 1739) pudesse aqui ter circulado em Setecentos, ou mesmo a de Diogo Rengifo, que é de 1592 ou a de Filipe Nunes, que é de 1615. A imprecisão é muito grande, em virtude da confusa transcrição feịta pelos escrivães, que registravam apenas o título ou a matéria. Por exemplo, qual seria a Arte poetica espanhola que aparece no inventārio do Reverendo Francisco de Paula Meireles, 1794, em Ouro Preto (18 Ofício, maço 151, processo 3159)? E as vagas "Comedias castelhanas", no inventário de Francisco Lopes do Vale, 1783, Ouro Preto (18 of., 48/583)? Seria Calderón? Não se sabe. Pode-se presumir, pois os escrivães, neste sentido, raramente facilitam a tarefa de um seguro desvendamento.

As dificuldades de identificąço dos livros, por essa 
razão e capricho legisferante de escrivães ou juízes de órfãos, obriga o pesquisador a uma descodificação nem sempre plana, ampliando-se o fosso da análise e descrição. Assim, no inventậrio de João Martins da Cunha, 1751 (Casa Setecentista de Mariana, 19 of., 14/455), encontramos um "Larraga em portuguez", que associamos, pela prática, à obra Suma: ou Prontuário de Teologia moral, do padre espanhol Fr. Francisco Larraga, provavelmente a tradução feita por Manuel da Silva.Moraes em Coimbra. Contudo, seria impossivel determinar que obras pertenceriam a "13 livros clacicos". Somente pela dedução. Provavelmente, os best-sellers Virgilio, Horācio, Ovídio, Cícero. Em matéria de dificuldade, porém, a pior vem da anotação vaga e sumāria como "7 livros velhos" ou "3 livros", como aparece inscrita no inventārio de Maria Cardoso de Siqueira, 1725 (Casa Setecentista de Mariana, 19 of., 18/528). Como esse, hä inủmeros outros exemplos de anotações que só nos valem aqui como testemunho estatístico da circulação e guarda de livros por brasileiros zelosos de uma cultura incipiente ou por preocupados inventariantes, uma vez que os livros representavam, de qualquer forma, bens para efeito de partilha.

o homem brasileiro do Setecentos ê, em ủltima anälise, predominantemente o leitor de obras religiosas e de $\mathrm{Me}-$ dicina, Direito, Letras e Linguistica.

Não obstante, haverá sempre ạlgum interesse dos 1eitores que escape ao rigor de toda classificação, pontuando em campos virgens de nossa atenção oủ lembrança. Da mesma. maneira, haverā sitúações de esquecimento público a obras 
editadas na dada contemporaneidade do mesmo público.

Algumas obras representativas de autores brasileiros, publicadas no século XVIII, por exemplo, tiveram restrita ou nula circulação no Brasil à época ém que foram editadas. o caso mais singular, do ponto de vista da nossa literatura, é - de Música do Parnaso (1705), de Manoel Botelho de Oliveira, - que nos leva à consideração de que os leitores brasileiros do periodo colonial praticamente desconheceram o Barroco nativo em poesia. Ainda pouco conhecidos (ou, ao menos, não indicados em nossas pesquisas) são os Anais históricos da provincia do Maranhão, de Bernardo Pereira Berredo (Lisboa, Francisco Luiz Ameno, 1749), a Dissertação sobre o aㅣㅁㅗ (1788), de Vicente Coelho de Seabra; Memórias da História Natural de Quimica, Agricultura, Artes e Medicina (1790), de Manoel Joaquim Henriques de Paiva; Ensaio sobre o conércio de Portugal e suas colônias (1794) e Análise sobre a justiça do comércio de resgate dos escravos da costa d'Africa (1794); de Azeredo Coutinho; Eustáquidos (1798), de Santa Maria Itaparica e os Princípios de Direito mercantil (1798), de José da Silva Lisboa, obra que será bem divulgada e lida no século XIX. Na fronteira da dúvida se uma dada obra é ou não de autor brasileiro face à homonỉia de títulos, temos os Elementos de Química, de Vicente Coelho Seabra, Glaura (1798), de Silva Alvarenga, poderia ter sido conhecida no Brasil sob a referência vaga de "poesia de Silva Alvarenga" ou "Obras de Silva Alvarenga". Mas, não hã registro dessa possibilidade.

Caso curioso é o da não-publicação ou publicação tar- 
dia de obras escritas num mesmo século. Neste segundo tipo, inscrevem-se as Cartas chilenas, de Tomás Antonio Gonzaga, obra composta entre 1788 e 1789 e que só veio a conhecer impressão em 1845. Pode arguir-se que. o Brasil do século XVIII era ainda de origem rural e suas cidades parecidas com povoações dá Idade Mêdia européia, com ruas estreitas e concentração populacional nas vilas. Pode contrapor-se, no entanto, que Vila Rica era centro de uma cultura urbana na segunda metade do século, com seus teatros, escritores, políticos e bacharéis. Mas as Cartas chilenas, por óbvios motivos, não despertariam no colonizador um interesse imediato de publicação...

No pólo oposto, alguns dos autores brasileiros editados no século XVIII tiveram uma significativa aceitação no Brasil, presentes em muitas livrarias setecentistas. Neste caso, temos um Nuno Marques Pereira, com o Compêndio narrativo do peregrino da América (1728), Sebastião da Rocha Pita (Histōria da América portuguesa, de 1730), Apolinário da. Conceição (Primazia seráfica, de 1733), José Fernandes Pinto Alpoym (Exame de artilheiros, de 1744 e Exame de bombeiros, de 1748); Antonio de Santa Maria Jaboatão (Novo orbe seráfico brasilico, de 1751), Matias Aires de Ramos Eça (Ref1exões sobre a vaidade dos homens, de 1752); sua irmã Margarida da Orta (Aventuras de Diófanes, de 1772, também editado, em 1752, com o título Memórias de virtudes e formosura). C1áudio Manoel da Costa (sic = Orbas, de 1768), Basílio da Gama (Uruguai, de 1769), Silva Alvarenga (o Desertor das. Letras, de 1774), Santa Rita Durão (Caramuru, de 1781), An- 
tonio de Morais e Silva (Dicionārio da língua portuguesa, de 1787), Francisco de Melo Franco (Tratado da educação física dos meninos, de 1790), Tomás Antonio Gonzaga (Marilia de Dirceu, que teve quatro edições entre 1792 e 1800), Fr. Gaspar da Madre de Deus (Memórias para a História da capitania de S. Vicente, de 1797), Domingos Caldas Barbosa (Viola de Lereno, de 1798) e, finalmente, Fr. José Mariano da Conceição Veloso (ㅇ Fazendeiro do Brasil, de 1800).

Os livros encontrados nos inventärios de bens do sécu1o XIX não escapam a inda a uma certa predominância religiosa, com abertura, no entanto, para outros campos como das Ciênciàs Médicas, Direito, História, Geografia e Letras. A grande maioria das leituras encerra preocupações ou permanece na categoria doutrināria ou especializada, evidenciando-se um caráter transitivo para discipínas como Ciências Naturais, a Matemática, a Física e até algumas matérias das ciências mais contemporâneas do próprio século, como a Política Constitucional, a Economia Política, a Administração, a Diplomacia, entre outras. Vão aparecer também os jornais periódicos e os romances de gosto duvidoso, sobretudo da lavra francesa em tradução portuguesa. Daí resulta que o modelo típico do leitor oitocentista talvez não seja muito diferente daquele dos séculos anteriores. Entretanto, títulos e temas serão bem mais numerosos e diversificados do que se verificou nos outros períodos, o que põe em evidệncia uma sensivel demonstração de oportunidade dos 1eitores no conhecimento, até, das coisas brasileiras.

Histơria, Biografia, Ciências Naturais, Geografia, Ma- 
temātica; Química, Física e outras disciplinas ocupam um papel de destaque na amostragem da leitura do Oitocentos. Avulta o conhecimento enciclopédico oriundo do século XVIII e aqui reforçado como um incipiente desdobramento da influência cultural francesa. A maior parte da bibliografia reponta mesmo em Lingua portuguesa, seguida do Francês e do Latim. As matérias versadas em Inglês, Espanhol ou Italiano já denunciam um certo crescimento, mas ainda diminuto se postas em confronto com o Francès e o Pọrtuguês. Há, ainda, que notar uma raríssima bibliografia em alemão. E importante por em relevo a boa circulação de uma bibliografia brasileira, especialmente nós campos de História, Ciências e Literatura.

Permanece a dificuldade de identificação de muitos títulos, face à exiguidade de informação de muitos dos dados collhidos nos inventários. Há uma infinidade de títulos cuja autoria não conseguimos descodificar. Pela distinção, vamos encontrando indicações vagas de livros que, de um lado, podem receber os titulos mais diversos, como, em verdade, apontam para o interesse de leitura e o número considerável de livros em poder dos inventariados. Prova dessa reiterada indisposição com a forma de transcrever títulos de livros nos inventários, vimos, no Arquivo Público Estadual do Mato Grosso, em Cuiabā, anotaçōes como "2 1ivros pequenos", no inventärio do Tenente Coronel Manoel Leite de Moraes, 1819; "6 volumes de varios autores", na livraria quase exclusivamente de Direito do Dr. Manoel Francisco Jorge e Silva, 1820; "30 livros de varios authores", no. inventärio de Antonio 
Ferreira de Abreu, 1824; "Varios volumes destruncados", no inventário do padre Gabriel Nunes do Vale, 1831; "58 1ivros de varios autores", no inventário do capitão Josè Pereira dos Guimarães, 1832; e, por fim, "25 livros velhos" compunham a livraria do inventariado capitão Joaquim Fernandes Coè1ho, 1836 .

\section{1 - Leiiores padres, militares, médicos, bacharēis}

A julgar pela transparencia de uma sociologia do leitor aplicada à análise dos documentos objeto de nossa pesquisa direta, a composição da sociedade colonial brasileira, aqui percebida como consumidora de livros, teria como feição mais nitida a marca impressiva fornecida por seus principais elementos constitutivos: padres, militares, médicos e bacharéis. Pois não será outro o número e o modelo dos inventariados, a que, aliâs, condiciona, insinua e, meșmo, estimula a formação de bibliotecas unívocas ou especializadas, vale dizer, a predominância de determinadas linhas de pensamento, tendências e idéias circulares no Brasil Colônia. De extração, primeiramente; mais rural que urbana, essa sociedade irá formalizando, de maneira progressiva, um certo aburgesamento, difuso e não-consciente, feito até de forma servil na assunção de modelos culturais e de um tônus moral que terá na doutrina cristã e católica sua mais cara e intransponível prenda . 
Sem dúvida, a informação mais direta e concludente, que se pode extrair da amostragem e perfil do leitor colonial brasileiro è que esse leitor era formalmente articulado com doutrina, ofício ou profissão. Ninguem parecia ter o livro como objeto de um consumo prazeroso, mas como instrumento de apreensão formal de realidades práticas ou na esteira da abstração obediente ao dogma, à mỉstica católica, à devoção ascética. Não existe, talvez, no Brasil, o leitor que tome o livro como sujeito, como canal de fruição, como prazer em si mesmo. o livro, aqui, será visto como o código de modelos sócio-culturais concretos, com uma serventia mais ou menos imediata, como um fetiche, algo votado a despertar cismas ou cooptações, estados místicos imobilistas, purgações da culpa típica expressa na tradição ocidental judaico-cristã.

Assïm, serā natural observar que a imensa maioria dos leitores brasileiros da Colônia era formada por padres - em termos superlativos, em Minas Gerais - seguidos dos militares, bacharéis, cirurgiọes e médicos. A ordem dos livros, a tipologia das leituras, naturalmente, seguirá linha e estilo característicos de profissões ou atividades. Mesmo quando o documento não indica claramente a especialização do inventarịado, será fácil supor sua retidão aos estigmas culturais pela predominância dos livros presentes em suas estantes. E insuperảvel concluir que a vocação de indivíduos comuns numa iniciativa de leitura calcada na força moral de ascetas, místicos e moralistas, seguramente indica um desejo de "ser", "parecer" ou "permanecer" afinado com a expressão social do seu tempo. Dai se poder explicar, talvez, porque è vultosa 
a quantidade de obras presas às matérias da Religião e, em segundo e terceiro lugares, as das Ciências do Direito e da Saúde.

Embora não exista explỉcita determinação de atividades ou ofícios dos inventariados em documentos do século XVİ, é possível aprofundar, aî mesmo, a notação do leitor; irmanando-se a "autoridades" eclesiásticas ou seculares, pela "coincidência" de livros, que a todos seriam comuns. Em outros termos, o livro funcionaria como um código de classe, uma espécie de passaporte, biombo sócio-moral, muitas vezes sem outro valor que não o da própria existência circular. Assim, como, na maior parte, os leitores do século XVII têm traços semelhantes de perfil ou opção de leituras devocionārias, claro que todos esses leitores "pareceriam" iguais, seriam equitativos numa sociedade aparentemente nivelada. E o mais curioso é que tal tipo de "coincidência" não ocorre de maneira deliberada. Não existe uma determinação clara de agir segundo um projeto previamente orientado numa direção. 0 . que aumenta e intensifica o mito da "coincidência reiterativa".

- De qualquer sorte, a distribuição, por ofícios ou funções, exercidos pelos inventariados do livro com alguma nota e detalhe, aparece, no Brasil dos séculos XVIII e XIX, ganhando foros de autonomia e significado, em especial a partir do Oitocentos. Em Mato Grosso, por exemplo, os inventariados que se destacam incluem-se na composição típica jā assinalada. Enquanto possuidores de alguma, mesmo pouca, fortuná bibliográfica, distingucm-se.os capitães José de 
Vasconcelos Castelo Branco (1791), José Luís Monteiro (1819), José Pereira dos Guimarães (1832) e Joaquim. Fernandes Coelho (1836); os alferes Manoel de Barros Rodovalho e Silva (1824), Antônio Ferreira dos Santos (1825) e Benedito Peixoto de Azevedo (1849); o tenente-coronel Manoel Leite de Moraes (1819); - reverendo cônego Manoel Machado de Siqueira (1844); o revèrendo Antônio Tavares da Silva (1834) e. os padres Gabriel Nunes do Vale (1831) e José Gomes da Silva (1839). Por fim, - bacharel e primeiro cronista de Mato Grosso, Dr. José Barbosa de Sá (1776) e o Dr. Manoel Francisco Jorge e Silva $(1820)$.

Do municipio de Rio Grande, no Rio Grande do Sul, vão aparecer, nas categorias aqui mencionadas, os padres Antonio Joaquim Vieira (1817) e Duarte da Cruz Pinto (1826), os médicos Dr. Manoel José Tavares (1814) e Dr. Guilherme Josë Correia (1843) e o bacharel Dr. Firmiano José da Silva Falcão.(1806). De Rio Pardo (RS), inventariados são o tenente-coronel Antonio Xavier de Azambuja (1821) e o tenente-general Visconde de Pelotas (18.21) e o reverendo Vicente Pereira Fortes (1824). De Cachoeira do Sul (RS), temos o inventärio do padre Inácio Francisco Xavier dos Santos (1845). De Porto Alegre, os inventariados são, na maioria, padres: Manoel Henrique. (1766), José de Souza Soares (1812), Mateus da Silva Souza (1815) , reverendo Josê Luiz de Castro Vangeler (1819), João Francisco Garcia (1820), Domingos Francisco Pereira de Sá (1822), Manoel José da Costa (1824), Inácio dos Santos Pèreira (1827), José de Freitas e Castro (1841) e Francisco José-Pereira (1845). Em seguida, vêm os militares 
sargento-mor Francisco Barreto Pereira Pinto (1805), capitão João Antunes Pinto (1809), tenente Silvërio Albertino Leite de Oliveira Salvado (1814), tenente Anacleto Gomes da Silva e Souza e Azevedo (1819) e brigadeiro Manoel da Silva Freitas (1845). A composição social do leitor portoalegrense completa-se com os inventários do médico Dr. Manoel Ribeiro. de Miranda (1809) e do bacharel Dr. Manoel Antonio da Rocha Faria (1836).

No Nordeste, registram-se o primeiro testamento do padre Francisco Pereira de Lacerda, natural de São Luiz (1741) e o inventário do cônego Raimundo Josë Gomes, reitor do Seminărio de São Luiz (1836), no Maranhão. O registro cearense vai para o reverendo Manuel luis de França, da cidade de Baturité (1797) e para o reverendo Manoel Ribeiro Bessa de Holanda Cavalcante (1839) e os padres Antonio Josē da Silva (1836) e Manoel Severino Duarte (1849), todos de Fortaleza. Em Pernambuco, o ünico inventário, incluindo livros é justamente aquele que jâ mencionamos, que descreve os bens do bispo D. Thomas da Encarnação Costa Lima (1784). Em Alagoas, há o testamento do reverendo Francisco Antonio da Silva (1799). Sergipe registra o inventārio incompleto do reverendo Antonio Coèlhọ do Prado, de. Itabaiana (1846), o inventário do major João Correia (1829), de São Crïstóvão e o do reverendo Francisco Fernandes de Oliveira (1838), do municipio de Estância. E a Bahia é representada, na Capital, pelos inventắrios do sargento-mor João Lopes Fiúza (1741), do tenente-coranel Jacinto Ferreira Feíjó de Faria (1762), do padre Manoel Gonçalyes da Cruz (1763), do cônego João Perei- 
ra Barretó de Menezes (1799), do padre Joaquim Gonçalves Cardozo (1829) e do cônego Manoel Dendê Bús (1836).

Minas Gerais tem em São João Del Rey e Mariana a grande representáção de inventariados padres, provavelmente em virtude de ter sido instalado em Mariana um bispado já em meados do século XVIII. E, sem dúvida, notável o número de padres e cônegos, è todos com livros devocionärios, em sua maioria, nas provincias mineiras, com o natural destaque para $S$. João e Mariana, seguidos de Ouro Preto e Sabarä.

Das quase 700 caixas e maços do Arquivo Histórico do Museu Regional de São João Del Rey, concentrando toda a Comarca do Rio das Mortes e reunindo mais de 2 mil documentos relativos a São João, Tiradentes, Barbacena, Lagoa Dourada e arredores, grande parte dos inventários à formado por religiosos, sendo 1 bispo, 2 reverendos cônegos e os demais constituído por padres, inventários entre 1757 e 1849. Depois dos padres, a composição confirma outra vez os militares (15), sendo 1 coronel, 1 sargento-mor, 1 ajudante, 3 alferes e 9 capitães (entre os anos de 1744 e 1830). Os bacharéis vem em terceiro lugar na composição social dos inventariados-1eitores, com 1 desembargador e 8 bacharéis, entre 1750 e 1847 .

No conjunto dos $1^{\circ}$ e $2^{\circ}$ Ofícios de órfãos de Mariana - documentos que se encontram na Casa Setecentista - apresenta-se um quadro curioso na composição de leitores, majoritariamente padres (40), reverendos cônegos (23), e mais 1 - bispo, 2 arciprestes e 1 reverendo Dr. cônego magistra1, 
revielando ao todo 67 religiosos, desde o inventário mais an- tigo (1768) ao mais recente (1848). Surpreendentemente, seguem-se aos religiosos, em número expressivo, os militares (34) das mais diversas patentes, sendo capitāes (9), sargentos-mores (6), tenentes (6), alferes (5), capitães-mores (3), coronéis (2), tenentes-coronéis (2), brigadeiro (1) e guarda-mor (1), inventariados entre 1722 e 1850. A composição do quadro' se completa com os bacharéis, 5 ao todo, em inventários de 1766 a 1850 e, por fim, os médicos e cirurgiões, sendo 3 cirurgiões-mores e 1 médico-cirurgião.

Ouro Preto apresenta uma composição semelhante, com 26 padres e 1 reverendo, num espectro de tempo entre 1724 e 1846, e 11 militares ao todo, sendo 4 sargentos-mores, 3 capitães, 2 coronéis, 1 capitão-mor e 1 major, inventariados entre 1814 e 1844. Os bacharéis são 3, ao todo, sendo 1 deles desembargador. Não houve registro de mëdicos e cirurgiões na antiga Vila Rica, aỉ compreendendo-se também a documentação referente aos arredores e tambēm a Congonhas do Campo.

Sabará mantēm, mais ou menos, caracteristicas semelhantes às apresentadas por outros municípios mineiros. Os religiosos, mais uma vez, se destacam em número (19), sendo 2 reverendos e 17 padres, inventariados entre 1770 e 1849. Seguem-se aos religiosos os militares, (9), sendo 1 tenente-corone1, 3 tenentes, 2 coronéis, 1 särgento-mor e 2 capitães, inventariados entre 1749 e 1844. Em terceiro lugar, vem os médicos e cirurgiōes (3) e, em quarto, os bacharéis (2), sendo 1 destes comendador. 
Diamantina, por fim, desenvolve esse perfil de predominância dos oficiantes religiosos, tendo como inventariados os padres Pedro de Alcântara Santos (1814), Joaquim José de Godói (1821), Josê Jâcome Guieiro (1823), Antonio José Alves Pereira (1827), Francisco Josë Pimenta (1827), mais o reverendo Frutuoso Gomes da Costa (1817) e o brigadeiro Francisco Martins Pena (1818).

Em São Paulo e no Rio de Janeiro, não se alterará a margem de inventariados com a titulação jä observada, tipificando a natureza social do Brasil Colônia, com predominância para os religiosos. No século XVII, apenas dois padres, Pedro de Godoy, inventariado em 1691 (APRS, Ordem 498) e Domingos da Cunha, 1695 (APRS, Ordem 499). Nos séculos XVIII e XIX, a partir da documentação do Arquivo Público e dos arquivos da Cúria Metropolitana, de Campinas, Santos e Jundiar, evidentemente, os nümeros aumentarão substancialmente. Serão 49 padres, 1 arcebispo, 1 frade, 2 cônegos, 1 arcipreste. Os militares, de novo, vem a seguir, com 14 capitães, 12 tenentes, 3 sargentos-mores, 1 capitão-mor, 1 mestre-de-campo, 1 brigadeiro, 1 coronel e 1 guarda-mor. Completam o quadro, 1 fidalgo, I cirurgião, 2 boticários, 1 cirurgião-mor, 1 doutor matemático e 5 doutores, cuja formação exclusiva não conseguimos descobrir.

No Rio, do Arquivo Nacional e do arquivo do Mosteiro de São Bento, os números também são expressivos da tỉpologia social brasileira da Colônia. São 50 padres, seguidos por 6 capitãcs, 1 vice-almirante, 1 tenente, 1 coronel, 1 sargento, 1 cirurgião-mor, 2 boticärios, 3 , consclheiros, 3 douto- 
res, 2 comendadores e 1 bachare1. Alẻm disso, há o número tambëm expressivo de fazendeiros e cidadãos urbanos sem titulação aparente, alguns se destacando por suas livrarias exclusivamente com assuntos náuticos, ou da exclusiva estante em Ciências Matemátícas - o que não deixa de ser curioso, em termos de formação profissional, na indicação de 1eituras.

$\mathrm{Na}$ apreensão de características de leitura, que representem exceção à predominância já apontada, de livros afeitos a doutrina, ofício ou profissão, e tambëm aqueles relacionados com a ärea de Letras, que descrevemos em capitulos pertinentes; tomamos a maior parte dos inventariados-1eitores incomuns à apontada tipologia social do Brasil Colônia, e mesmo os tipificados, para uma demonstração da variedade que essas leituras vão atingir, sobretudo entre fins do século XVIII e meados do.XIX. Avulta, antes, aquela nossa observação de identificar um 1 ivro "Tratado de prätico de Aṛtmética", no inventário de Mateus Leme (1633), em São Paulo, como um elemento dissociativo de tendências do leitor, jä no século XVII. Concentramos nossa atenção na amostragem de títulos diferentes da óbvia preferência doutrinária ou profissional, agora, nos séculos XVIII e XIX.

Em Porto Alegre, o inventariado Joaquim José Vieira, 1784, tinha uma biblioteca mais experta para além das preocupações morais. Lá encontramos "2 1.ivros em espanhol de Arquitetura" e "2 1.ivros nauticos", o que radica um leitor atento para outras ciências, quem sabe até de seu estrito. interesse prático ou curioso. (APRS, Porto Alegre, $2^{\circ}$ of. 
Cível e Crime). Ainda de Porto Alegre, 1791, Francisco Rodrigues Viana tinha "2 livros Mixelaneas", enquanto Luiz Ferreira Velho, em 1794, tinha uns vagos "livros varios autóres" e "Livro" (APRS, POA, 29 Of. Cível e Crime, maço 1). No mesmo cartório e no mesmo maço 1, aparece Manoel Antonio de Araújo, 1796, com "Roteiro de navegação" e um "Livro manuscrito de curiosidades". Jä Miguel Rodrigues de Sá, 1798, entre livros de devoção e de moral, traz um "Economia da vida humana", obra de imaginária descrição da natureza humana, com uma tradução atribuída a "um manuscrito italiano, escrito por antigo brâmane". Foi reeditada por Silva Serva, na. Bahia, em 1818. Tambëm em Porto Alegre, Maria Jacinta da Ressurreição, 1800, comparece com um "Livro do Segredo da Natureza", obra popular desde o século XVII, conforme se vê no inventärio de Mateus Leme, de 1633, em São Paulo.

Da Primeira Vara de Familia de Porto Alegre, o Arquivo Público do Rio Grande do Sul tem o inventário de Custódio Ferreira de Oliveira Guimarães, 1800, que apresenta um "Divertimento de estudos", talvez o livro de João Pacheco publicado em 1738, alêm de um "Quadro da morte do marquês Graziollẹ" (APRS, 19 Of:, maço 2). Manoel Pereira Rosário, 1770, tinha um "Livro de Aritmetica" (APRS, POA, 19 Of., maço 3). Manoei da Silva Guimarães, 1783, a indicação vaga de "4 1ivros" (APRS, POA, $1^{9}$ Of., maço 8). Antero José Ferreira de Brito, 1787, entre obras de Direito,. Religião e Linguística, tinha um curioso "Dictionario social e patriotico", "1 tomo em italiano de varias materias", "Discursos sobre a llistoria universal em francês" - possivelmente a obra de Bossuet - 
e um título mais curioso ainda. "Alimentos puliticos em frances". Por fim, encerrando a contribuição gaúcha nessas matérias mais gerais, João Jozé de Sọza, em 1793, tinha uma "Taboadinha ingleza". No Rio Grande, Francisco Correia Pinto, 1793, tinha "2 livros do bom lavrador" (APRS, Rio Grande, maço 2).

Demonstra-se, assim, o leitór setecentista no Rio Grande do Sul como eclético e curioso. Interessa-se por publicações de gêneros diverśos, com destaque óbvio para os assuntos religiosos, de jurisprudência, os clássicos e os gramáticos e eruditos. Mas, circulavam livros que independem da rubrica religiosa ou de Direito. Livros de arquitetura, de náutica, de teatro. São singulares as ocupações de leitura em náutica e arquitetura, como são os "Livros do bom lavrador" e a "Taboadinha ingleza". Revela isso tudo uma particularização do leitor sulista, que avança um passo ao interesse convencional dos leitores do Setecentos, investindo em modelos científicos ou em áreas de conhecimento e interesse prático ou imediato, alterando um tanto a especialização do leitor à época.

Além dos títulos predominantemente em matéria religiosa, encontramos, no inventário do bispo D. Tomás da Encarnação Costa Lima, de 1784 , em cópia microfilmada pertencente à Divisão de Pesquisa Histórica da Universidade Federal de Pernambuco, maço 28, uma "Historia de auxilios de Serry" e una "Historia do Brazil de Barlēus" (sic =, Barley). Tambēm encontramos uma "Academia de estatua equestre", uma "Historia universal", uma "Historia dos imperadores 6 volumes", ao la- 
do das insuspeitíssimas obras do consentido Rolin, a "Histo- ria romana de Rolin 16 tomos" e "Rolin Historia antiga 12 tomos". Hä ainda uma surpreendente "Estoria natura" de Legrand e um "Metodo geografico em 8 volumes" de Langret.

Da vila de Cachoeira, documento do ARQUEB, é o inventārio de Luís Tavares dos Santos, de 1799, onde encontramos os livros "Vida de hum principe", "Historia da vida do Mescen", "U1pian", "Compendio historico de Coimbra", e uma "Historia Universal". E, de singular interèsse, as "Recriaçōes mathematicas", uma "Biblioteca", "Providencia sobre o terremoto" e "Portuga1 renascido". (ARQUEB, Judiciāria, 03/716/ $1180 / 1)$

De Cachoeira tambēm è o inventário de Luis Ribeiro de Sousa, 1799. Entre 1ivros de devoção e doutrina, ele tinha, tambēm, "Quatro ditos muito velhos sem valor" (ARQUEB, Judiciāria, 03/716/1180/2). Carlos Josē da Silva Guimarães, da mesma Cachoeira, 1799, tinha, alẻm de "Humas oras portuguezas", "Hum livro 1atino" (ARQUEB, Judiciāria, 02/701/1162/ 3). Já Félix Alves de Andrade, 1791, era um leitor mais compenetrado. Em que pese a quase ilegibilidade do documento, compreendemos uma "A obra do Mentor-moderno em seis tomos", "Memorias do ....... em dous quarto"; "A vida de Dom Afonso Bras de... em hum tomo" e "Hum tomo em quarto pequeno sobre..." (ARQUEB, Judiciāria, 02/706/1162/3). A identificação das obras é dificultada pelo estado do documento. Mesino assim, percebe-se um leitor afinado com.as leituras, particularmente na ārea de Letras. 
Assim, Cachoeira se apresenta de forma substantiva no plano do leitor setecentista baiano. o reçôncavo, rico em engenhos de açúcar, fez desenvolver-se uma burguesia urbana nascente, com seus bens imōveis e suaș livrarias. Além das convencionais obras devocionárias, de Direito e História, já vão aparecendo peças representativas do universo psicológico. e de interesse funcional ou intelectual do brasileiro no período. E, portanto, rico o século XVIII na Bahia, ainda que esta se ressinta da transferência do eixo politico e administrativo para o Rio de Janeiro ou Minas. Da Capital, Salvador, outros documentos vão revelando quadros novos na relação de leitores. Parte desse universo mental frutifica na ação revolucionäria dos Alfaiates em 1798. Transfere-se o núcleo irradiador de projetos e sensiveis mudanças no cenário da Colónia, mas o registro de circulação de livros al- cança significativos elementos que se acrescentam. ao cadinho cultural brasileiro, desde a simples menção a um único livro ao mais completo e rico dos inventärios em informações bibliogräficas,que indicam um repositório de influências direta ou indiretamente marcadas por processos ideológicos correntes na aventura setecentista.

E o caso do inventärio do Sargento-Mor João Lopes Fiú$z \dot{a}$, o segundo mais antigo que encontramos no Arquivo do Estado da Bahia, de 1741 (ARQUEB, Judiciāria, maço 623-4). 0 documento está muito estragado e de quase impossibilidade de 1eitura. Ele vem descrito tambëm por Vanderley Pinho, no livro História de um engenho do Recônicavo, que nos informa tratar-se de "senhor de Engenho do Baixo da Boca do Rio de 
Paramirim" 217 A predominância ainda é de obras espirituais, embora já denuncie um certo desenvolvimento de gosto e apuro intelectual do senhor de engenho - no ambiente rural da primeira metade do Setecentos. Vão, portanto, aparecendo, além dos previsíveis devocionários, alguma coisa como "História pontifical", "Escudo de cavaleiros", "Obras de Villa Mediana", "Banquete de Apo10", "Epitome chronologico, genealogico e historico". Os livros dos clássicos latinos, os sermonärios, os ascéticos, os hagiográficos, vão pontuando ao lado de obras como "Espejo de ... y agradecidos que contiene los 7 libros de beneficios", "Historia Universal", "O Condestave1 de Portugal D. Nuno Alves Pereira", "Vida da Princesa D. Joana", "Historiá de los movimientos y separación de Cataluña". Sempre na companhia dos costumeiros, alguns títulos surpreendentes como "Sinagoga de ... geral", "Mares do rei de Portugal", "La perla de Cataluña", "La estoria, das ordens", "Armonia politica", "Vida de D. João de Castro" e "Arte de navegar". Livros que praticamente só aqui vemos referidos, como "Ordem de bem casados", "Guerras civis de Granada", "... Da Florinda", "Juizo theologico digo Historia iusti", "Rebelião de Milão", "E1 sutil cordovês" e "Descrença politica". Assinam o documento, como avaliadores, datado de Bahia, 18 de dezembro de 1741, os prováveis livreiros Manuel Ferreira e Antonio Gomes de Sá.

Destarte, se não estivermos muito distantes da verdade face à imprecisão de um documento rigorosamente comido por traças, cuja dificuldade de decifração paleogrä́ica é flagrante e desalentadora, estamos diante de um autêntico leitor 
curioso e dos mais ricos e variados em suas caracteristicas de leitura. Se não há como negar a qualidade do inventário enquanto peça documenta1, em sua avaliação da desénvoḷura sócio-cultural do Recôncavo baiano, com o maior apuro se pode compreender o perfil das leituras setecentistas brasileiras, na Bahia, en 1741 , dele inferindo a variação de interesse do leitor. São assuntos de História e Política, como a Harmonia politica dos documentos divinos com as conveniências do Estado, de Antonio Sousa de Macedo, publicado antes de '1651, ou a Crónica' do Condestabre de Portugal D. Nuno Alvares Pereira, de Fernão Lopes, obra que se concentra na. atividade püblica e militar do aristocrata português; escrita em 1431 e publicada,pela primeira vez,em 1526.

No inventārio de José Valentim Duarte, de Salvador, 1758 (ARQUEB, Judiciāria, 633-9), vamos encontrar álguns titulos muito curiosos como "Arvore da vida", "Academia das Minas", "Suma de varoens ilustres". No do tenente-coronel Jacinto Ferreira Feijó de Faria, de Salvador, 1762 (ARQUEB, Judiciāria, 638-8), encontramos um "Methodo dos papas", um "Theatro dos triumphos", a "Historia da America portugueza" de Rocha Pitta, a "Nobiliarquia portugueza", "Aplausos natalicios, "Historia da Academia portugueza", (talvez a História da Academia de História, de Fernão Teles da Silva, publicada em 1727); ao lado de um livro muito frequente em nossas livrarias setecentistas, o Indiculo universa1, que contem distinctos em duas classes os nomes de quazi todas as coizas que ha no mundo. Feito em. Francez e Latim pelo P. Francisco Pomey, Fcito novamente Lusitano. (...) e publicado 
em Evora, 1716.

De impressionante valor e importância bibliogräfica, pela ordem variável de títulos e de assuntos, é a biblioteca de Manoel Dantas Barreto, inventariado em Salvador, 1768 (ARQUEB, Judiciária, 02/972/1441/01). Traz uma organização catalográfica curiosa e muito interessante quanto à intenção do escrivão ou do avaliador, dispondo os. livros por seções: "Livros de folio", "Livros de A - obras inteiras", "Livros de oitavo", "Livros latinos de folio", "Livros latinos de 4 ?" e "livros latinos de 8 ?", O que implica uma incipiente atividade indispensáve1. à Biblioteconomia. O estado geral do inventário é muito ruim, necessitando urgente trabalho de restauração, sobretudo por se tratar de um documento precioso em informações quanto à tendência leitora da Bahia Setecentista.

A livraria de Manoel Dantas Barreto é vária e diversificạda; contendo os esperados volumes de Medicina, Religião, Literatura moral, Retórica, História etc. e valiosíssima particularmente no campo de Letras. Nela, hâ uma Historia de Portuga 1 restaurado, do $3^{\circ}$ Conde de Ericeira, D. Luís de Menezes e uma Historia do imperador Carlos $\underline{\mathrm{V}}$ em 2 tomos, uma Biblioteca do mundo visive1 e invisivel e o Divertimento erudito, famosa e popularissima obra de Fr. João Pacheco (16771747), publicada entre 1734 e 1738 e que reúne textos alheios, de forma orgânica, para, por meio deles, provocar no leitor um sentido estético. Hā tambêm uma "Academia Singular", que tanto pode tratar-se de um volume contendo trabalhos da Acadomia dos Singulares de Lisboa, do inicio do sé- 
culo XVIII, quanto do livro de Fr. José de Jesus Maria, re- ligioso da Ordem de S. Francisco na Província da Arrábida, cujo título completo é Academia Singular e Universal, Historica, Moral e politica (...) Constitutiva de hum varão perfeito, desde o instante primeiro que se gera no ventre materno, atê o instante ultimo que no claustro da sepultura se resolve. Lisboa, of. Pedro Ferreira, 173.7.

Entre as chamadas "Obras inteiras" do inventārio de Manoel Dantas Barreto, consta uma pouco frequente Academia dos humildes e ignorantes, em 4 tomos, provavelmente a editada no mesmo ano do documento, 1768 , em Lisboa, 8 volumes, contendo tratados de 1759 a 1764. C1aro que não faltaria o "Methodo de estudar de Verney". ao lado de uma pouco frequente "Academia universal do padre..." e "Rudimentos de Historia, ou Elementos de História", "Memorial historial caste"1hano" e um "Parallelo de principes", cujo título completo é Paralelo de príncipes e varões ilustres antigos, obra de Francisco Soares. Toscano, editada, pela primeira vez; em 1621. Ou seja, observa-se, na livraria de Manoel Dantas Barreto, livros para todos os paladares, com destaque para uma Historia geral de Hespanha emı 26 tomos, Educação de meninos e a Biblioteca de Houdri em 4 tomos.

Na. Livraria proveniente do inventário de Antonio da Costa e de sua mulher Tereza Maria de Jesus, constituida majoritariamente por obras de Medicina e Cirurgia, em Salvador, 1784. (ARQUEB, Judiciāria, 03/1145/1614/09), observamos uma obra do filósofo francês Bernard dx Bovier de Fontencle (1657-1757), "De privilegiós" e um curioso título, único cm 
todas as bibliotecas que pesquisamos, "Las curiosidades de Paris", além do cabalistico manual antijudaico, "Sentinela contra os Iudaeos". Na de Martinho Duarte, de Salvador, 1790 (ARQUEB, Judiciäria, 651-8), vamos encontrar "1 Repertorio cronologico", "I Tratado histórico", "4 volumes de Hystoria geral dos castellanos!" e, por fim, um volume da "Suma de Instituta".

- leitor Antonio Manoel de Mello e Castro, de Salvador, inventariado em 1795, tinha uma biblioteca modesta e representativa de hábitos diversificados de leitura. Seu inventário de 1 ivros foi avaliado em 16 de novembro de 1795 por Joaquim Marques Pereira, livreiro baiano (ARQUEB, Judiciāria, 656-1). Aqui vão aparecer os volumes de viagens, tão comuns no século da Ilustração, quando era grande a curiosidade pela ciência, com grande aceitação das enciclopédias, o conhecimento de novos mundos, de uma geografia além da. que cerca imediatamente o homem. A livraria de Mello e Castro é ilustrativa desse desejo de conhecimento, pois inclui a "Voyage aux Indes et a la Chine em. 2 volumes" e a "Voyage de Georges Anson". Das viagens à História, inclui também "Historia de Denis de Mello" e "Memorias dos grandes de Portugal", além dos "Comentários da India de Albuquerque em 4 volumes", que deve tratar-se da obra Comentários do Grande Afonso de Albuauerque, cuja primeira edição è de 1557. Uma biblioteca movimentada em seus assuntos, retratando um leitor atento às matérias trazidas pelos livros, como um eco da Ilustração européia na província americana.

o ủltimo inventário objeto de nossa descrição $\mathrm{cm}$ ar- 
quivos da Bahia, referente ao século XVIII, pertence ao cônego João Pereira Barreto de Menezes, 1799 (ARQUEB, Judiciāria, 04/1762/2232/03) e indica uma das mais ricas bibliotecas da Bahia Setecentista. Apresenta grande dificuldade de decifração paleográfica, face ao estado do documento, com falta de folhas e muitas informações truncadas. E uma considerável livraria, com mais de 256 títulos, a maior parte de Direito. Alēm das obras de Religião e Jurisprudência, em sua maioria, encontramos outros títulos, como "Estatuto da Universidade", "Memoires de Mr. Dingoet", "Maid de le noble", "Amigo do Principe e da Patria", que escapam da classificação convencional.

Como observamos, o Brasil leitor do século XVIII avança e algumas vezes subverte as correntes de dominação jesuita ou regalista, manifestando um espirito curioso e interessado tanto em obras cientificas - que interferem e modificam:a figura passiva e bèletrista do leitor colonial dependente dos modismos da Metrópole - quanto numa perspectiva de leitura profissional em Direito ou Medicina, ou numa salutar curiosidade ilustrada por assuntos que vão das Ciências Naturais à História, à Geografia, à narrativa de viagens, à Matemâtica ou à Física. E assim que se prenuncia o espirito das leituras nos lugares de mais rica contribuição para a amostragem do Brasil leitor no Setecentos, caso especialmente de Minas Gerais, São Paulo, Rio de Janeiro e Bahia.

0 primeiro e mais rico contributo de Minas, vem das cidades de decisiva impregnação da ideologia cultural do sê- 
cuilo XVIII. Não será à toa que é Minas Gerais o eixo político-administrativo da Colônia tão logo fracassam as guerras do Oriente em que Portugal se viu a braços face à decadência de seu frustrado império. Foi para o Brasil, e para Minas - com a descoberta e exploração de ouro e diamantes - que a Métrópole observou a indispensável sequência de seu modela extrativo. A circulação de riquezas provocou em consequência uma grande movimentação da cultura e de livros. Centro do Brasil Setecentista, Minas Gerais tem em suas cidades históricas o núcleo dessa movimentação. Congonhas, Ouro Preto, Mariana, São João Del Rey, Barbacena, Tiradentes, Sabará e Diamantina contribuem com seus inventários de bens em livros que refletem a circularidade da cultura na região. Congonhas tem a documentação, que não se extraviou, recolhida ao Arquivo da Casa do Pilar em Ouro Preto. Barbacena e Tiradentes aparecem na faixa de influência da comarca, do Rio das Mortes, com documentação guardada no Arquivo Histórico do Museu Regional de São João De1 Rey. O Serro aparece enquanto documentação relativa apenas ao século XIX.

$\mathrm{Na}$ investigação que procedemos, percorrendo mais de 12 mil documentos mineiros, observamos uma significativa frequência de inventäriọs setecentistas, embora aqui só se nomeiem os que contêm o objeto de nossa busca, ou seja, 1ivros. A riqueza maior provêm de Mariana, seguida de São João e Ouro Preto. Sabarā, Diamantina e Tiradentes, nesta ordem, completam o quadro de maiores contribuições.

Saliente-se que Mariana, São João Del Rey e Caraça ainda têm as melhores bibliotecas das cidades mineiras, hoje 
sobreviventes: a do Palācio Arquiepiscopal, a Biblioteca Baptista Caetano de Almeida e Silva, criada em 27 de agosto de 1827, e a do Colégio do Caraça, situado na serra do mesmo nome, no municipio de Santa Bārbara. Este material tomamos como parte substantiva de nossa "Memória Bibliogräfica Brasileira (1500-1825)", em elaboração.

Das livrarias particulares, em Sabarā, o Museu do Ouro detém boa quantidade de documentos pertencentes aos antigos cartórios de $1^{\circ}$ e $2^{\circ}$ Ofícios de Orfãos. No Livro de Registro de Testamentos e Inventārios $n^{\circ} 5$, folha 26 , do $1^{9}$ ofício, encontramos o inventârio de José Vaz da Cunha, 1794, com registro, entre outros, dos livros indicados como "Fo1heto" e "Phinylenopla". Os demais documentos do $1^{9}$ ofício, poucos, indicam livros espirituais, de Teologia e Doutrina, conforme a convenção.

No $2^{\circ}$ Ofício de Sabarā, a documentação è muito maior. Os livros que predominam são os mesmos referentes à Religião. Fora disso, no inventārio de Anselmo da Silva Diniz, 1788 (Pacote 5), o. escrivão anotou apenas "14 livros muitos (sic) velhos de varios autores". No do coronel José Tavares Pereira estâ anotada uma "Cronica de Sister" (Pacote 7). 0 Dr. João Ferreira da Roza, 1742, tinha "7 livros de Serurgia" e um "Lunario perpetuo" (Pacote 9). "Francisco da Cruz, 1745, comparece com uma "Academia de singulares" e a "5a. parte da Monarquia lusitana" (Pacote, 17). O Rev. Dr. João Baptista Lopes, 1770, tinha una livraria consideráve1, pontuada por volumes de Direito e Filosofia moral. Além desses, aparecem " 2 volumes Exame dos pracceptores in $4^{\circ "} \mathrm{c}$ uma 
obra interessantíssima "Solan. Nova instrucção muzical in 4"1" (Pacote 21). Jả José da Silva Porto, 1744, tinha um "Sistema de Inglaterra" e um "Memorias militares in 48" (Pacote 46$)$.

Continuando o $2^{\circ}$. Ofỉcio de Sabarā, no Museu do Ouro, encontramos, no inventário do padre José Luỉs Soto, 1800, um "Capitão de Infantaria portugueza'in $4^{\circ}$. por André Ribeiro Coutinho", o "Exame de artilheiros por José Fernandes Pinto Aḷpoim", o "Educação de hum menino pobre"; obra de Martinho de Pina e Melo consagrada pela reforma pombalina. Também aparece uma curiosa "Doutrina do cavalo em Espanho1", "Infante ultimo entre a vida e a morte". "Maravilhas de Roma ja muito velho", uma "Replica satisfatoria do padre Feijó Bonaditino 2a. parte". e uma "Advertencia ao principe embaixador" (Pacote 49).

Destacam-se ai alguns títulos como as obras de Fr. Bernardo de Brito (1568-1617), Primeira Parte da Crônica de Cister (1.ed. 1602) e Primeira e segunda partes da Monarquia lusitana (editadas em i597. e 1609), o Lunārio perpëtuo, obra de inspiração moral escrita por Jerônimo Cortês, na segunda metade do' século XVIII, registrando fases da lua, horóscopos, partes do mundo, os elementos, os planetas, socorros da saúde, instruções agrícolas, conceitos e conseihos úteis para a vida doméstica e rural e vârios jogos de cartas. E una espécie de Almanaque do século, livro, aliās, de significativa penetração até fins do século XIX, ao menos, conforme evidencia trecho do romance Luzia-liomem, de Domingos 01 impio. E o caso de, referindo-se a episódios e consequências 
provocados pela seca de 1878 , no Cearā, o.autor registrar, no capitulo VI, o Lunário perpétuo, como um trágico prognóstico da seca cearense, a.pior no século XIX:

\begin{abstract}
Não havia mais esperança. Os horóscopos populares aceitos pela crendice como infaliveis: a experiência de Santa Luzia, as indicações do Lunärio pèrpētuo e tradição conservada pelos velhos mais atilados, eram negativas, e afirmavam uma seca pior que a de 1825, de sinistra impressão na memória dos sertanejos, pois olhos d'ägua, mananciais que nunca haviam estancado, jả não marejavam. 218
\end{abstract}

De Sabará, passamos a Diamantina, aos documentos existèntes, do $1^{\circ}$ e $2^{\circ}$ Ofício de Orfãos, no Arquivo da Biblioteca Antonio Torres. No $1^{\circ}$ Ofício, inventário do coronel Pau10 José Velho Barreto, 1797, anotamos "Elementos de Historia do Ab. Vallemont 5 tomos", a reiterativa "Educação de hum menino nobre", o "Compendio das epocas", de Antonio Pereira de 'Figueiredo, um "Texto da Instituta muito velho", uma "Vida do infante D. Henrique" e um "Dicionario geographico", numa biblioteca de consideráveis proporções, variada em matërias e autores, com grande quantidade de livros em Direito. Hả, ainda, uma obra com o título de "Mellado Geografia", um "Atlas abreviado", a "Deducção cronologia analitica 5 volumes", o "Compendio historico do Estado da Universidade de Coimbra... 4 volumes", "Discursos de Historia eclesiastica Fleury", "Discursos sobre a historia universal de Bossuet 3 tomos", "Vida de D. João de Castro" e uma "Noticia de Mitho- 
$\log$ ia". $^{\prime \prime}$

Quanto ao "Dicionario geographico" acima, é quase certo tratar-se de obra com regular circulação imposta pelos escaninhos pedagógicos pombalinos, o Diccionario Geografico ou Notícia Historica de todas as Cidades, Villas, Lugares e A1deas, Rios, Ribeira e Serras dos Reynos de Portugal e A1garve (...) Pelo P. Luiz Cardoso, da Congregação do Oratório de Lisboa, Academico Real do Numero da Historia Portugueza. Lisboa, Regia Off. Sylviana e Academia Real, 17471751. 2v. O Compêndio Histórico do estado da Universidade de Coimbra no tempo da invasão dos denominados jesuítas e dos estragos nas ciências e nos professores e diretores que as regiam pelas maquinações e publicações dos Novos Estatutós por eles fabricados è o título quilométrico, bem ao gosto da época, na retórica rococó do oratoriano, posteriormente franciscano, D. Fr. Manuel do Cenáculo Villas-Boas (17241814): tambēm 'autor de uma' Dedução cronológica. o Compêndio foi publicado em Lisboa, 1772, sob os auspicios da Junta de Providência Literäria. Hã registro para uma Dedução cronológica e analitica (Lisboa, Miguel Menescal da Costa, 1768), de autoria de José de Seabra da Silva (1732-1813), estadista português, membro da Junta de Providência Literāria, inspirado no regalismo pombalino, na onda do manifesto anti-jesuítiço. A Vida de D. João de Castro, quarto viso-rei da India é a obra consagrada de Jacinto Freire de Andrade (15971657), no exemplo calcado em Plutarco da biografia do varão ilustre, panegírico e expressão política da nação portuguesa, obra' publicada, pela primeira vez, en 1651. 
Outras obras, além das conhecidas de Direito, Medicina, Religião e Letras, vão aparecendo no inventärio do coronel Paulo José Velho Barreto, de Diamantina (Caixa 63, $1^{9}$ Ofício, Arquivo da Biblioteca Antonio Torres), como as $j \vec{a}$ vistas "Academia dos Humildes 6 volumes", "Historia universal",."Instruçoens politicas Bealfield em francez 3 volumes", "Reflexoens de um portuguez", "Provincias de P... em francez 4 volumes". Uma biblioteca representativa da época da Ilustração; jā nos fins do século XVIII. Há também uma "Historia de Portugal Sacheo 8 volumes", uma "Vida de Gerson", "keinecio... romana 2 tomos", "Elogios dos reis de Portugal", obra do Fr. Bernardo de Brito, "Historia cronologica da pri... do mundo", "Entrada...", "Estoria da America portugueza", naturalmente de Rocha Pita. Mais a "Cronica da provincia da Conceição de Portugal 2 volumes", "Ej... instituta", "Luma dos objeti...", "Nobiliarchia portugueza", "Historia cronologica dos papas" e "Geografia historica de Europa 2 volumes".

Sem dúvida, uma biblioteca representativa do Setecentos, variada e eclëtica nos assuntos, alëm de numerosa e com sensível especialização em obras do Direito português. 0 inventärio é um dos dois ünicos setecentistas com que Diamantina comparece nesta nossa amostragem.

De Diamantina, vamos para São João Del Rey, ondc é grande o número de documentos do século XVIII recolhidos ao Arquivo histórico do Museu Regional, compreendendo a antiga Conarca do Rio das Mortes, dos municiípios de São João, Bar bacena, Tiradentes, entre outros. O inventário de Arnaldo 
dos Santos, 1754, anotado na rubrica "Escravos" (Maço A-10), concentra uma livraria quase na totalidade de obras médicas. Surpreende um título como "Courel10 Economia dos..." que, apesar da imprecisão do informe truncado, pode sugerir matéria ou assunto diverso da área médica. No inventārio do Padre José Rodrigues da Cruz, 1780 (Maço B-3), uma biblioteca. razoavelmente grande e um tanto diversificada, onde se descam livros de Medicina e Religião, com espaço, porêm, para títulos como "Academia universal". - talvez a obra do padre Manuel Conciência, Academia universal de vária erudição, publicada em 1732, também presente no inventário de padre Cipriano José da Costa, ï95 (Maço C-2).

Na livraria do Cap. Bento Pereira de Sã, de São João Del Rey, 1767, (Maço B-3), encontramos a presente "Vida de Dom Joam de Castro", "Guerras Sivis (sic) de França", "Los reis novos de Toledo", "Asia portuguéza", "Primeira parte da Historia do imperador Carlos Quinto", "Portugal restaurado", obras que oscilam da História para a Genealogia ou o panegirico memorial de nobres ou reis. Na mesma linha, ainda, uma pouco frequente. "Grandezas de Roma", uma conhecida "Monarquia 1uzitana P. 1, 5, 6 e 7", "Europa portugueza", de Manoel de Faria e Souza, uma "Historia cronologica 3 tomos in 8"", uma "Vida de Dinis de Mello" e, por fim, uma "Corographia portugueza". Permanecem como leituras preferenciais os volumes de Doutrina e de Letras e Linguistica, mas confirmando um sensive1 interesse do inventariado em ampliar sua fortuna livresca.

Em alguns inventários, registram-se pouquíssimos, e 
às vezes; até um ünico livro. De qualquer forma, são aqui considerados não apenas para atender ao rigor da investigação ou a uma mera estatistica, mas tambēm porque trazem notícia do interesse bibiliográfico para a nossa compreensão do universomental e das tendências de leitura no Brasil Setecentista. Não parece ser o caso específico do inventariado Pedro de Almeida e Oliveira, de São João, 1747 (Maço P-1), que tinha uma livraria pequena, onde descobrimos uma "Vida do imperador Leopoldo", de difícil percepção. Como difícil tambëm, no inventārio de Manoel Téixeira da Cunha, 1793 (Maço $15)$, descobrir que sejam "4 tomos Novas Plantas", título, sem dúvida, intrigante que não parece tratar-se necessariamente de obra de Botânica:

Felipe Franco Madeira e Barbuda, tesoureiro da Provedoria, em São João Del Rey, tinha, em 1764, conforme seu inventārio de bens (Maço F-9), uma livraria basicamente de Direito. Entretanto, algumas obras vão insinuando uma certa variação de leitura, como a frequente "Cronica de Sister" (sic), ou uma "Historia.da.Galia \& Sam ...", uma "Carta dos estilos" e um "Volume truncado Arpetri \& Institute". Custódio da Silva Guimarães, 1774 (C-3) tinha apenas três livros, sendo um de Religião ("Ramalhete serafico"), um de Medicina ("Desengano de Medecina") e o livro típico da pedagogia pombalina, "Educação de hum menino nobre". Jä Manoel Antonio de Araújo, 1796 (Maço M-A), destaca-se por sua livraria médica, con algumas representativas exceções como "Maravilhosos inventos", e um "Rezumo apolineo". Maria da Conceição Vieira, 1787 (Maço M-10) tinha um "...... instituida ... Gomes 
Freire de Andrade", entre dois livros de devoção e um outro impossỉvel de decifração em vista da precariedade do documento.

No inventário do padre Joaquim José de Souza, 1795 (Maço J), dentre as previsíveis matériaṣ religiosas, uma "Histoire de 1 'Amerique 4 volumes in $8 \% "$, provavelmente a obra proibida de Raynal, o libelo-antijesuítico "Dedução cronologica 2 volumes in 8\%"; um "Methodo geografico e cartas 2 volumes in 8\%"; a conhecida obra de Vertot "Revoluf̧oens de Portugal in 8\%"; a "Jornada de Albuquerque in 8\%"; um "Discurso de Istoria universa 1 por Bossuet in 8\%"; uma "Roma antiga e moderna 2 volumes in 8\%"; um "Mapa de Portugal 3 volumes in $4^{\prime \prime \prime}$ e a popularissima obra de Jacinto Freire de Andrade, Vida de Dom João de Castro, Quarto Viso-Rei da India. Também na livraria do padre Joaquim José de Souza, vamos encontrar a "Historia tragico maritima 3 volumes in $4{ }^{\prime \prime}$, obra em verso ou drama épico que pode ser a ficção de Jerônimo Corte-Real consagrada à narrativa do naufrágio de Manuel de Sepülveda .e sua familia, ou a Historia TrágicoMarítima em que se escrevem chronologicamente os Naufrágios gue tiverão as Naos de Portugal, depois que se poz em exercicio a Navegação da India, de Bernardo Gomes de Brito, editada em Lisboa Occidental, of. da Congregação do Oratório, 1735. Hā, ainda, na livraria do padre Souza, uma "Historia universal por Fr. Manoel dos Anjos. in 49", "Dialogos de varias historias in 4\%", de Pedro de Mariz, mais "Parale1los de principes in 48", certamente a obra de Francisco Soares Toscano, Paralelos de principes c varões ilustres antigos, 
editada em 1623. Tambēm a i comparece a mitologia do "Theatro de 10 dioses 2 volumes in 4\%", uma "L'Arithmetique in 8:" e o fascínio das antologias como "Recueil des portraits in $8 \% "$ e "Recueil de conferencies in $8 \% "$. Hă, a té, naturalmente para boa informação ou curiosidade do padre Joaquim Jose de Souza, um "Indez dos livros proibidos in $8 \% "$, sem que a informação possa precisar se dos livros proibidos pelos jesuítas ou pelos seculares adeptos da Real Mesa Censória pombalina. Um homônimo do padre, aliás, tinha, em 1791, (Maço J), "8 1ivros in 88".

Um nada frequente "Livro de alveitaria" aparece no inventärio de Violante Moreira de Assunção, 1784 (Maço V-2). "6 livrinhos pequenos velhos", sem que se possa precisar a informação, constam do inventārio de Valeriano dos Prazeres Ribas, 1752 (Maço V 2). E também ưma obra fronteiriça entre História e Religião, "Braga triunfante", è o único livro constante do inventārio de Agostinho Gonçalves Luz, 1768 (A8). A obra d'"A restauraçam de Portugal" aparece no inventário do. capitão Roque de Souza Magalhães e o livro de "Fernão Mendes Pint.o",transitivo entre a História e a Ficção, aparece nó inventário do mesmo Cap. Roque de Souza Magalhães, 1785 (Maço R-4) è no de João Fortes Bustamante e Sá, 1777 (Maço "Josē 1").

o inventārio do bacharel Dr. José de Almeida e Faria, 1750 (Maço J-8) abre com "Livros"," em sua descrição de bens, - que demonstra interesse, inclusive financeiro, para efeito da partilha, na livraria do inventariado, com obras de Direito e alguns titulos em Letras e Linglística. Para a par- 
tilha de bens, Domingos Jorge Ribeiro, 1785 (Maço D-3) teve inventariados "1 jogo de Geografia 3 tomos", ao lado de "2 Catecismo de Montpelier". Joana Francisca Nunes, 1736 (Maço J div. 5), tinha, inespecificados, "72 Sermoens de Vieira e varias historias". 0 padre Jacinto Teixeira da Cunha de S. Paio, 1777 (Maço J 25), tambëm inespecificados, "9 livros usados", junto com "1 breviário". Mesma inespecificidade alcança a anotação de "7 livros velhos pequenos" no inventário de Manuel de Campos Machado, 1750 (Maço M 16).

No documento de João Fortes Bustamante e Să, jã anotado, constam também as "Obras varias de Joam Pinto Ribeiro", talvez as Obras varias, publicadas em 1729-1730, do jurisconsulto, politico e historiador português, autor de uma Preferência das Letras às Armas (1645), e a quem também se atribui a autoria de Arte de furtar. Vềm registradas duplamente, com a variação "Obras varias sobre varios casos de Joam Pinto Ribeiro". No do padre Antonio Alves Coelho, 1770 (Maço A-4), a "Arte Minima de Canto chão pergaminho in 4\%", obra que aparece igualmente no inventário do Rev. Dr. Ignacio José de Souza, 1796 (Maço I-28). O padre Antonio Gomes Pereira, 17.64 (Maço A-12), traz, entre seus bens, "6 volumes de livros pequenos e 2 de folio de varios autores". E Bento Josë Dias, 1785 (Maço B-1 cont.), um livro com título incompleto por efeito do dilaceramento do pape1: "Pensamento...". Seria de todo absurdo supor a obra de Pascal?

o capitão João Ribeiro Taborda, 1791 (Maço J-4), tinha uma formidável livraria de Direito, Religião e alguma. coisa de Medicina. Mas também um "Itincrario historial fo- 
lio". João da Fonte Barros, 1763 (Maço J-8 cont.), "2 tomos pequenos de Iono Vigier". O Rev. Dr. Ignacio José de Souza, 1798 (Maço I-28), "2 tomos Dialogos de variä instoria intit. Pedro de Morins" (sic), uma "Arte de cantoxão" jā mencionado e uma "Istoria ecclesiastica", que se pode interpretar como serido a de Bossuet, Fleury ou Ducreux, além de "16 libr. de $4^{9}$ mais varios sermoens". O Sarg.Mor Luiz Barbosa Brandão, 1756 (Maço L-1), "2 tomos Historia genealogica folio", "Estoria universal em pergaminho" e uma pouquíssimo concorrida "Tabuada de Garrido".

Em Ouro Preto, no Arquivo da Casa do Pilar, também investigamos a constituição de bibliotecas setecentistas em documentos oriundos dos Cartórios de $1^{\circ}$ e $2^{\circ}$ ofícios de Orfắos, relativos aos municipios de Ouro Preto e Congonhas do Campo. Do $1^{9}$ ofício de Ouro Preto é o inventārio de Afonso Manoel Fernandes de Araújo, 1751 (Códice 4, Auto 43), contendo:livros de doutrina, mas registrando, em especial, um "Exemplar politico", um "G__tos e rellacoens de Portugal", um "Vontade de ...", uma "Sylva de varia 1ição" e um "Sentinella contra os judeos". No inventārio de Caetano Francisco da Costa, 1788 (Códice 29, Auto 328), entre as festejadas obras de Direito, Religião e Letras, um solitārio "Regimento das terrapagoas (sic) minerais e mais varias ... curiosidades". . No de Bernarda de Vasconcelos Cunha, 1741 (25/255), "6 livros historicos", "50 volumes de livros de direito e curiosos", "... de varios autores" e "16 livros em pergaminho de varios autores". Também encontramos um "Sentinclla contra os judeos" no inventärio de Domingos Gonçalves da 
Cruz, 1723 (34/402). E "6 tomos in $12^{\circ}$ muito velhos", mais "4 volumes, in 48 de varios autores" no inventärio de Domingos Ribeiro Guimarạes, 1786 (34/405).

O inventariado Dr. Agostinho Monteiro de Barros, 1763 (16/149) confirma uma "Livraria da Advocacia do Defunto", denunciando a especialização bibliográfica associada a ofício. Mas, lá encontramos também uma "Monarchia pratica" e uma seção com "Livros historicos", onde se registram também obras de Doutrina e Letras. De qualquer forma, è uma estante de titulos interessantes, como o conhecido "3 tomos Theatro de los dioses in $44^{\circ "}$, "Historia ecclesiastica in $4 \% " \mathrm{e}$ uma raridade: a "Sciencia de Cortes in 4". Comparecem, ainda, a "Nobiliarquia portugueza in 48 " e uma outra mais concorrida obra "2 tomos Authiartr. de Macier in 48", uma "Historia cronologia dos papas 2 volumes in $8{ }^{\prime \prime}$ e o consagrado "Manoel de Faria.e Souza, Europa e Asia folio". Completam a relação uma "Cronica de Maiy folio", a "Vida de Alexandre Magno em pergaminho" e um livro pouco circular no Brasil, o "Casamento perfeito in $8{ }^{\circ ", ~ o b r a ~ d e ~ D i o g o ~ P a i v a ~ d e ~ A n d r a d e, ~}$ pela primeira vez editada em 1690, na tradição erudita e pagã que ilustra o moralismo doutrinärio do Concilio de Trento.

Assim, chegamos a uma conclusiva observação de que as leituras do Setecentos no Brasil, quando escapam da dominação de assuntos religiosos, médicos, de Direito, Filosofia ou Letras, ancoram quase sempre na matéria da História, ou genealogia, ou crônica eclesiástica e secular. Basta ver a livraria inscrita no inventário de Francisco Lopes Fernan- 
des, 1774 , de Ouro Preto (43/502), em que se reitera a nossa observação. Os títulos ou são de Religião ou de Histöria, como a "Estoria serafica chronologica da ordem de Sam Francisco da Provincia de Portugal", provavelmente História serafica da Ordem dos Frades menores na província de Portugal. editada em Lisboa, primeira parte, 1656; 2a. parte, 1666, obra do Fr. Manoel da Esperança, autor considerado como um dos mais concisos e harmônicos prosadores do século XVII. Tambēm aparece no mesmo inventärio uma "Chronica do muito al to e muito esclarecido principe D. Affonso Heriques primeiro rei de Portugal", atribuída a Fernão Lopes ou a Duarte Galvão, escritores e historiadores de fins do Quatrocentos e começo do Quinhentismo português.

"Fernam Mendes Pinto" comparece no inventārio de Manoel Ferreira da Fonseca Coelho, 1742 (46/504), junto a uma "Sinagoga dezenganada", uma "Noticia que he do..." e uma "Joya requissina". No inventário de Francisco Vieira Carneiro, 1790 (47/575), desponta uma "Africa portugueza ja uzada meia folha", obra do festejado Manuel de Faria e Sousa (1590-1649), autor tambëm de uma Europa portuguesa e de uma Asia portuguesa, todas editadas postumamente entre $1666 \mathrm{e}$ 1681. No de Antonio Francisco França, 1767 (57/684), encontramos uma "Chronica de Dom Manoe1", provavelmente a obra célebre de Damião de Góis, Crônica do Felicissimo Rei D. Manuel, cuja primeira edição é de 1566. No mesmo documento de Francisco Vieira Carneiro encontramos "2 tomos da Mellicia Pratica", "1 Birectorio Practico", "2 tomos da Coleção -Universa1", "1 Mel1ịcia Instruida", "1 Lugares Comuns", "De- 
zação (síc) de varios autores", "I Embaixada do Ilustrissimo Senhor Conde de Villa Mayor" e, finalmente, "I Perigrinassois (sic) de Fernando Mendes Pinto".

No inventário de Joam Roiz Seyra, 1789 (79/944, Casa do Pilar), um livro "... Reis de Toledo", um "Governo geral" e uma "Estoria universal in $4^{\circ}$ velho". No de João Francisco dos Reis, 1798 (79/950), dois exemplares de "Portugal restau-. rado", uma "Estoria universal", e, surpresa das surpresas, um livro com o curioso título de "Agricultura in 4\%". No inventảrio do Desembargador João Caetano Soares Barbosa, 1776 (88/1065), encontramos um "Del Rio. Desquisitione. agicas", um "Torreblau de magia", um "Capitão de infantaria portuguez" e "Varios livros de Mr. de ...". No do padre Manuel Ribeiro Soares, que foi vigärio da Igreja do Pilar, de Ouro Preto, $1788(102 / 1274)$, temos um "Historias Sebasticas", "Acadenia Singulares universal", "Dous livros Azias Portuguezas com muito uzo", uma "Historia universal", "Tres livros Theatro de los Dioses" e um livro muito pouco frequente nessas livrarias chamado "politicas Moral e Civil", além do previsivel "Governo de Mineiros".

Pedro Ferreira Murado, em 1777 (126/1574), tinha "Elementos geometricos", e uma "Taboada curiosa". O primeiro talvez seja o livro do padre Manuel de Campos, editado em Lisboa, 1735, cujo título completo é Elementos de Geomctria Plana e Sólida, o que, sem dúvida, adianta uma bela possibilidade de ampliação da cultura científica ao Brasil Colónia. Também pode ser os Elementos de Geometria, de Bezout ou de Euclides. 
No 29 Ofício do Cartório de Orfãos da antiga Vila Rica, no mesmo Arquivo da Casa do Pilar, encontramos, no inventārio de José Teixeira da Motta, 1787 (Códiçe 31/344), um "Fernão Mendes Pinto folio". No inventārio de Miguel Gonçalves de Aguiar, 1.754 (42/468), a anotação imprecisa de "8 livros de varios, autores", com que se encerra a contribuição setecentista em termos da constituição de bibliotecas e circulação de livros extraída dos documentos investigados em Ouro Preto:

Dá farta matéria documental encontrada na Casa Setecentista de Mariana nos ocupamos agora. E grande a quantidade de documentos do século XVIII, em excelente estado de conservação - fato a destacar de nossa pesquisa na antiga comarca de Ribeirão do Carmo, terra do poeta Cláudio Manoel da Costa e de inúmeros padres e cônegos, a percorrerem, quanto a livros, um notâvel sentido de diferenciação de máterias ou assuntos. São documentós dos Cartórios de $1^{\circ}$ e $2^{2}$ ofício da Vara de Familia ou de Orfãos.

Os livros tratam predominantemente de questões relacionadas com as ciências da Religião, Medicina, Direito, Letras e Linglística, observação que se aproveita e reitera no particular das bibliotecas setecentistas de todo o Brasil. Mas reservam algumas surpresas em títulos e assuntos que escapam a essa reiteração. Assim, no primeiro ofício, em Mariana, vamos encontrar, no inventário do Capitão Mor José de São Boaventura, 1757 (Códice 1.3, Auto 429), "Dous Gradus das Plantas", numa livraria típica de Medicina. No do Côncgo Dr. Antonio Amaro de Souza Coutinho, 1800 (42/960), livros como 
"Capitulos de cortes e leis in $4^{\circ}$ grande". "Enigma numerico in folio", o "28 tomo de Resumo de Febronio" que foi "cmprestado ao Rev. Dr. Ignacio de Souza Ferreira"; mais o "Comentarium analiticum de Caldas Pereira folio". No de Domingos de Moura, 1787 (49/1122), encontramos uma curiosa "Pratica de batabas" (sic), "2 livros 3 tomos Estoria da Tartaria", e "Elogios dos senhores reis de Portugal", provavelmente a obra de Fr. Bernardo de Brito (1568-1617), Elogios dos Reis de Portugal, cuja primeira edição data de 1603.

No inventário dẹ Francisco de O1iveira, 1763 (75/1591), temos a vaga anotação de "12 livros dévarios autores" e no do Rev. Con. Dŕ. Magistral João Roiz Cordeiro, 1792 (82/1756), a igual irrelevância descritiva de "15 livros insignificantes em pasta" e mais "28 livros". Do Ten. João da Cunha Vellozo, 1783 (92/1926), uma mais curiosa e intrigante anotação: "3 livros de galitos" (sic). "Jā no inventário do Capitão Joaquim José de Souza, 1798 (94/1926), vamos encontrar uma estante médica, com abertura para um "Curso quimico de Limiri velho" e uma "Estoria das plantas velho 2 tomos". Francisca Oliveira, 1787 (97/2025), tinha "Francisco Grueber folio 5 tomos", o mitológico "Theatro de los deozes folio 3 tomos", "Kux in 89" e "Sumas de Marta folio". E Izabel Cardoza, 1783 (102/2.117), tinha um "Euquenpio traduzido do espanhol", (provavelmente o livro de Tomás Kempis, De Imitatione Christi), "3 1ivros" e "2 livros mais".

0 Indicu10 universa 1, que antes anotamos, reaparece aqui no inventário de Manocl Cactano de Souza, 1787 (115/ 
2386), junto com uma curiosissima "Dicotnia de Terceiros". Um "Compendio de Estoria geral" fazia parte da pequena biblioteca de dois ünicos livros do Sargento-Mor Miguel da Costa Soares, em 1783 (124/2581). E o Reverendo Francisco de Paula Meireles, 1794 (151/3159), era dono de uma grandiosa e diversificada livraria, em que se destaca a "Fisica de Muyquembroek", o "Compendio botanico de Linneo 7 volumes", a "Aritmetica de Bezout 12 volumes", a "Trigonometria de Bezout 18 volumes", as "Taboas de logaritmos de Lá Caille 14 volumes", "4 volumes de Cercle"., um "Espetaculo de Bellas Artes", a "Geografia de La Croix truncada", um "Cathalogo das rainhas", um "Florilegii magni poliantea", um "Epitome cronologico geologico" - obra rarissima no Setecentos brasileiro - e um "Altionum romanum", igualmente raro. O padre tinha tambëm "l volume de estampas", uma "Biblioteca do mundo", a "Astronomia de La Land 3 volumes", "2 volumes da Real Ściença du governement" (sic), um "Thesoiro original" e umas "Memorias historicas do Carmo". Mais a obra de "Raphaelis Bonherba problemata", "Govierno funera1", "Martins estilus", a "Historia universalis de Milot", entre as obras mais gerais de Medicina, Religião, Letras e Linguistica.

No inventário do padre José Teixeira de Souza, 1768 $(149 / 3134)$, anotamos uma "Summa de...1atologia natural". No de Francisco Gomes da Cruz, 1769 (152/3183), um "Culto fúnebre sobre o suicídio" (sic), uma "Arte de navegar" e a popularỉssima "Educação de hum menino nobre". E entre as mais curiosidades das livrarias desse $1^{\circ}$ Ofício de Mariana, indício de leitura em campo que não se alinha diretamente nos 
ramos mais predominantes, teriamos a obra."Corioza de cartas", que aparece no inventário do Sargento-Mor José Correia de 01 iveira, 1794 (83/1761).

Do Cartōrio de $2{ }^{\circ}$ Ofício de Orfäos, Mariana registra a atividade do boticärio e livreiro Leonardo José Teixeira, 1790 (Casa Setecentista de Mariana, 29 Of., Códice 34, Auto 801), que tinha para venda "34 1ivros de Santa Barbara", cartilha muito popular e de impressionante circulação nas 1 ivrarias do século XVIII. Em 1722, o inventārio de João da Silva Rolim registrava "Livros.varios", uma "Cirurgia das especes dif. de morbo", um "Corofiz..la" (sic) e uma popular "Monarquia Iuzitana" do nosso conhecido Fr. Bernardo de Brito, obra circular desde a publicação da primeira (1597) e da segunda (1609) partes. (CSM, 45/1012). José Ribeiro Forte, $1793(43 / 978)$, contava, em seu inventärio, com "12 livros de varios autores". João Ferreira da Costa, 1786 (54/1230), tinha "7 livros'latinos". E o Sargento-Mor Antonio Duarte, 1761 (69/1517), tinha "Flores de Espanha", naturalmente a obra de Antonio de Sousa de Macedo Flores de España. Excelencias de Portugal, na inspiração da apologética nacionalista, cuja primeira edição é de 1631.

Lourenço Pereira Neves, no inventário de 1762 (CSM, $2^{8}$ Of., 73/1580), tinha uma "Descrição corografica do reino de Portugal" e um livro "in 4" Corte Real", talvez o Jerônimo Corte-Real do Naufrảgio de Sepúlveda, obra de estilo áu- Iico e de circunstância das tragédias de navegação, como vimos. Antonio Pereira Fragozo, 1753 (85/1826), traz inventariados um "Theatro de Lalande" e um "Thesouro metropolitano". 
Estevão Gonçalvés Costa, 1788 (87/18.71),"5 1ivros velhos de varios autores". Manoel Pereira Machado, 1764 (98/2085), uma "Cademia portugueza", uma "Historia chronologica", "Mayr (sic) dos reis" e "Estorias do Mexico". Thomaz Pereira de Araujo, 1743 (116/2327), "1 Ano estorico" e uma "Vida de Pedro de Basto": O Capitão-Mor Pedro Sacramento de Brito, 1722 $(132 / 2658)$, alinhava, entre seus bens, a intrincada anotação "Chronica dos reis de Portugal D. Fernando, Vida delrey D. João I e Antonia de Ganova" (sic). O primeiro livro deve ser o de Antonio Soares de Albergaria Chronica dos reis de Portugal, compreendendo desde o Conde D. Henrique a Filipe IV de Castela. Já o segundo deve tratar-se da Vida e acções del-rei D. João I, obra do $2^{\circ}$ conde de Ericeira, D. Fernando de Meneses, publicada em 1677 e na linha da melhor historiografia biográfica portuguesa do século XVII.. "Antonio de Ganova" è uma incógnita.

Biblioteca rara e diversificada tinha o Dr. José Pereira Ribeiro, inventariado em 1798 (Casa Setecentista de Mariana, 29 Ofício, 51/1162), com uma ordem extraordinäria de livros em língua francesa. Ai aparecem a Histoire generale de Millot, a Histoire generale d'Angleterre, de Raynal, junto às Deuvres de Gesnet, e títulos pouco frequentes como - "Ensaio sobre o comercio", os "Annales romaines", as "An- tiguidades de Portugal" e a "Macarronea". Aparecem também títulos costumeiros como "Vida de Dom João de Castro". E mais "Memoires de Ablancourt". "Cronica do Principe Dom João", provavelmente a obra do quinhentista Damião de Gois; "Iustino Febronio dous volumes", "Mocurs des Israelites", 
"Histoire de France", "Histoire de Angleterre", "Histoire sul'Amerique de Robertson quatro volumes", "Histoire de Portugal de Maugin". Da Histöria às Ciências, a biblioteca do Dr. Ribeiro alinhava uma "Geometrie de Bezout", uma "Aritmetica do dito" e um "Euclides Geometria". E a obra básica do espirito antijesuítico pombalino, as "Deducçoans Chronologicas com o Compendio Analitico seis volumes"; os "Estatutos da Universidade tres volumes", uma "Descrição de Portuga1", "Siecle de Louis quatorze tres volumes", um "Pome1la quatro volumes", um "Diccionario de Anecdotas dous volumes". E vêm as "Obras de Linguet sinco volumes", o "Carlos Doze por Volter" (sic), as "Meditaçoens de Hervei", uma "Historia da. America Ingleza em tres volumes" e um "Diccionario historico dos cultos religiosos sinco volumes" e uma "Noticia da Mithologia". Tambêm aparecem a obra de Pedro Mariz, "Dialogo de varias histôrias", as "Memorias Economicas da Açademia Real das Sciencias", um "D'iccionario historico oito volumes", as "Instituiçōes politicas de Bielfeld", uma "Historia Ecclesiastica quatorze volumes", uma "Historia de Portugal e de Espanha", a "Historia insulana" do padre Antonio Cordeiro (1641-1722) jä vista antes, sobre a ilha da Madeira. E continua a livraria, acrescentando obras como "Noticias de Portugal por Faria", "Pitta da America", um ilustrado "E1ementos de Quimica" ao lado de um "Compendio das Epocas", o popular "Fernão Mendes Pinto", "Elogios historicos", "Compendio da Historia de Hespanha dous volumes" e um livro pouco circular no Brasil, o "Tableau des Revolutions del'Europe" e outro menos comum: "Governo dos costumes". 
Não pāra aí a fortuna bibliográfica do Dr. Josê Pereira Ribeiro. Hā obras de "Linneo Philosophia Botanica", "Tissot ...", "Novo Atlas", uma "Biblioteca Lusitana quatro volumes", de Barbosa Machado, uma "Geografia moderna oito volumes", "História do destronamento de Alfonso Sexto dous volumes". E mais um "Ensaio sobre a Historia da Sociedade Civil dous volumes", uma "Historia da vida de Mafoma", "Elementos da Arte Militar", "Vida do papa Ganganelli" e uma "Arte da pintura". Adiante, uma "História das descobertas e conquistas dos Portugueses dous volumes", talvez a obra de Fernão Lopes de Castanheda (1500-1559), História do Descobrimento e Conquista da India pelos portugueses, publicada pela primeira vez entre 1551 e 1561. E uma "Descripção de ambas as Americas", uma "Historia de Paschoal Joze de Me11o", um "Regimento dos ..dores da Fazenda", uma "Noticia orbis antiqui", "Taboas chronologicas de ...", uma "Chronica de Dom Afonso Henriques", provavelmente a obra de André de Rezende, embora não se tenha notícia concreta de publicação, mas cujo título parece ser único e, portanto exclusivo do seu autor.

Tem, afina1, um pouco de tudo essa antiga e rica bib1ioteca marianense, cobrindo as mais variadas áreas do conhecimento, num ecletismo representativo do próprio século da Ilustração.

De Minas Gerais, afinal, passamos aos inventários setecentistas do Rio de Janeiro. No Mosteiro de São Bento, descobrimos um livro contendo espólios dos monges beneditinos de fins do século XVIII a XIX, O documento, aberto cm 
15 de agosto de 1795 e autorizado pelo Pregador Geral Fr. Luciano do Pilar, Dom Abade do Mosteiro, foi organizado pelo Fr. José de Santa Engräcia, que o numerou e o destinou a "servir a lançarem todos inventarios e leiloens dos monges falecidos exceptuando esta e a ultima folha em q. fizer o termo" 219 Por vezes, o livro registra o inventário e, logo após, a arrematação do bem; em outras, ambos estão reunidos. 0 primeiro inventário, sem livros, pertence ao P. Fr. José de São Venâncio, 1797, e o último, do Fr. Antônio de Santa Águeda Carneiro, de 3 de setembro de 1882. A prática de partilha dos bens arrecadados era. feita destinando-se um terço para contribuição à livraria do Mosteiro, um terço para obras da Igreja e o outro terço, para missas. E un interessantíssimo livro de espólio dos monges, onde aparece, conforme assinalamos, o beneditino Fr. Gaspar da Madre de Deus, e onde se obedecia à coleta de recursos para a compra de livros ou manutenção da' biblioteca do Mosteiro.

De três únicos inventários dos fins do século XVIII, com livros, verifica-se a tendência natural de obras devocionais, de Filosofia moral e Letras. No documento de Fr. Lourenço da Expectação, com a data declarada na terça do espólio, 16 de agosto de 1798 , encontramos os poucos exemplares que escapam à categoria de livros religiosos, objeto de análise posterior. São os seguintes; uma "História de Portugal 14 volumes", "Viagens de Athena 4 volumes in $8 \% "$, "Setença de Alçada no levante do Porto", "Revoluçoens de França 
2 tomos in 89", "Vida de Ernesto Gedeão", "Estrangeiros no Lima 2 volumes in 48", (a obra de Lima Bezerra, da Academia das Ciências, publicada em 1785, na linha de um certo internacionalismo, com diälogos entre homens de diversas nacionalidades), alêm de uma "Colleçam de viagem in $8 \% "$, uma "Descrição da cidade do Porto in 4"", "Revoluçoens romanas 3 tomos in $89 "$ e um controvertido "O porque de todas as cousas", peça țextual, mais que provâvel, do dogmatismo teológico. A biblioteca do Fr. Expectação mostra-se um tanto rica em seu elemento doutrinário e abre um certo espaço para obras como - "Dom Quixote de la Mancha" e uma "Philosophia de Duhan". A maior parte do contributo beneditino do Rio, contudo, encontra-se nas livrarias do sếculo XIX.

A contribuição mais expressiva do século XVIII no Rio de Janeiro, sem dúvida, é aquela guardada no Arquivo Nacional. Ali o sêculo XVIII mostra uma significativa participação do público leitor, pela constituição de bibliotecas representativas da Ilustração Setecentista, com tỉtulos em diversos campos do conhecimento e, em termos superlativos, nas ciências religiosas e do Direito e Medicina.

Começamos pelo inventảrio de Maria Bernarda de Araujo, 1798 (AN, Maço 478/N. 9215), que, entre quatro títulos de Doutrina e Ascese, tinha o "Tomo $2^{8}$ da Historia dos reis de Portugal". O Coronel Josē Victorino Coimbra, 1795 (AN, 474/ 9092), tinha um "Livro da Academia" e "Hum Livro Mariz dos Reizes $1^{9}$ tomo". Alexandre Alves Duarte e Azevedo, 1793 (AN, Caixa 3692/6), tinha uma "Aula pulpitica" e um "Regulamento militar". O Capitão Joaquim da Silva Lisboa e sua 
mulher Maria de Sä Freitas, 1796 (AN, Cx. 1115/1569-70), ti- nham "2 livros Elementos da Estoria 2 tomos" e os "Estatutos dos cavalheiros", a "Descrição da cidade do Porto" e uma "Estoria eclesiastica dos cimas (sic) de Inglaterra" (sic = Ingalaterra). O Capitão-Mor José dos Santos, 1793 (AN, Maço 473/9029), uma livraria mais compenetrada de títulos histó-. ricos ou curiosos, como "Arte de navegar", "Tratado completo da navegação", ao lado de uma "Taboada ingleza" e uma "Arithmetica", formando com uma "Istoria de Portugal restaurado", um "Regulamento da Cavalaria", uma "Istoria universal 2 tomos", a "Vida de Dom Nuno Alves Pereira", um exemplar da "Historia Sagrada truncado" e unas "Orações academicas" o substrato de interesse histórico do inventariado, interesse que se anplia na inclusão de outras ciências, como salientam uma "Trigonometria geometrica" e uma "Arte de cozinha".

No inventārio de Maria Eugenia do Bonsucesso, que era viūva do Cirurgião Mor Joaquim Josẹ da Silva, em 1793 (AN, Maço 473/9032), duas únicas obras transigem da corrente médica da biblioteca: "Analise de algebra" e um título curioso e raro, "Fiel companheiro". No de Manoel Josē Pinto de Macedo, 1795 (AN, Maço 475/9113), apenas um solitário "livro do Andrada sem valor", compunha a biblioteca do inventariado. Matias Alves da Silva, 1800 (AN, M. 308/5628), tinha "Secenta libros de varias materias e latinos do uzo", sem especificação de títulos ou assuntos. E o reverendo Francisco Correa Leal, 1786 (AN, Cx. 3606/220), entre as permanentes obras teológicas, ṇédicas e linguísticas, trazia, em seu inventário, uma "Guerra de Flandres", uma "Medalha dos emperadores", a 
"Historia de Plinio", "Geographia e Arth_inglesa", uma raridade chamada "Noticias astrologicas medicinais", um "Campus trigonometrico", uma "Nova instrução musical de Solano", e mais "Piximen. Div. Othica simbolica", "Cluvi... Geograph.", o livro de "Matins del Rio. Magicarum", o "Exame de Artilheiros" de Alpoym, a obra de Plinio em latim, "Plinii Historia", a jā consagrada "Arte de navegar". E segue a fortuna em livros do reverendo, incluindo os "Artefatos de Vasconcelos", "2 Dicionario de Agricultura", uma "Historia apologia", um "Itinerario da Italia", "8 Histoire du monde", "Almeida Summa opum", outro "2 Agricultura", uma "Arithmetica do Pereira", uma "Hobliar Asia portuguesa" e um livro de "Agricu1 tura".

O Dr. Manoel Antunes Suzano, 1783 (AN, Cx. 3629/22), tinha um filho padre, um filho advogado e um outro alferes, ou furriel. Da biblioteca do inventariado, a cada um dos filhos, na partilha, coube livros de sua específica função. Assim, por exemplo, o filho advogado, Dr. Joaquim José Suzano, da mesma profissão do pai, ficou com a maior parte dos livros, vale dizer, "258 volumes de varios livros de Direito", uma excelente estante de jurisprudência portuguesa e italiana. Mas, anotamos outros títulos extra os de Direito, como "Curia felipica em pergaminho folio pequeno", uma "Dissertasam sobre cambio folio", um "Felicio De Societat. bom uso in 48", um "Exame de bombeiros, vel.ho in $4^{\circ} 2$ volumes", uma "Dissertação castelhana" considerada na avaliação "Sem serventia" e um exemplar de "Mundo vezivel in $4^{\circ}$, velho". Foi avaliador dos bens em livros, cm 2 de março de 1783, Manuel 
Francisco Gomes, provavelmente um livreịio, que anotou 123 titulos e mais de 260 volumes no "Cathalogo da 1 ivraria do Dr. Manue1 Antonio Suzano".

Grande bibliioteca tambëm tinha o médico Dr. Jacinto José da Silva, conforme o documento de inventário e sequestro de seus bens, em 1793, quando da devassa ordenada pelo Conde de Resende, que punia os membros da Sociedade Literária dó Rio de Janeiro. Além do médico, a dissolução da entidade e execração de seus membros alcançaram o marquês de Maricá è o reincidente Silva Alvarenga. O inventārio de 1ivros e o sequestro de papéis de Jacinto José da Silva encontramos no Arquivo Nacional (C̣aixa 2257, n. 58) e vão aqui analisados no capítulo "Uma leitura revolucionária".

No inventärio de Gonçalo Josē Muzi, 1790 (AN. M. 491/ 9592), identificamos um "Plini Historia natural" e três obras de Linneo, "Species plantarum 2 tomos", "Botanica" e "Sistema natura 4 tomos" e mais uma "Historia naturalle 12 tomos". Tambēm encontramos uma "Recherches sur 1e ... 2 tomos", um "Dicionnaire de Chimie 2 tomos", um "Dictionnaire de Phizique 2 tomos", um "Cours d'hịstoire naturel 7 tomos", um "Dictionnaire d'histoire naturel 9 tomos" e uma "Famile des plantes 2 tomos". Hā, ainda, uma obra incomum nas 1 ivrarias setecentistas, "Memoires de la Chine 3. tomos", ao lado de um "Dictionnaire botanique", uma "Reflexoins botanicás" e um surpreendente "Diccionario do comercio" e outra mais surpreendente "La scienza" pa..aetoga 4 tomos", sem contar os "44 livros truncados e outros' jä.podres", declarados "sem valor" pelo provāvel livreiro e avaliador Veríssimo 
Fernandes de Paiva. Inācia Angelica de Assumpção, 1791 (AN, - M. 2295/456), tinha inventariada uma "Historia tragica maritima tomo 2:", certamente o livro de Bernardo Gomes de Brito, cujo volume $2 \vec{e}$ de 1736 .

o Cirurgiāo-Mor Antonio Josē Pinto, 1798 (AN, M. 188/ 3737 ), demonstra uma definitiva assunção da natureza enciclopẻdica e da Ilustração francesả em sua livraria, com a circulação de livros como "Enciclopedie portative 2 tomos", "Histoire naturel de 1 'homme malde de Lè Clere 2 tomos", "Dictionnaire d'histoire naturel 12 tomos", "Histoire naturel de Bufon 28 tomos", "Dictionnaire de Chimique de Macquer 4 tomos". Ainda, pontuando numa numerosa e variada estante de Medicina, obras bảsicas como "Memoires de 1'Academie de Prusse 9 tomos, faltando o tomo 2", um "Essai sur les aliments 2 tomos", um curiosíssimo e absolutamente raro "Tableau de 1 'amour conjugale 2 tomos" e uma não menos rara "Recherche sur la nature de 1'homme de Fabre". E seguramente a methor e mais rica biblioteca colonial brasileira no ramo da Medicina, particularmente em títulos franceses - que, sem dūvida, evidencia a França como o maior centro de dissemina-ção da cultura médica no mundo.

Afora a Medicina, a livraria do cirurgião-mor Antonio Josë Pinto abria-se para outras matërias, como Religião e Letras. Aí encontramos, ainda, uma "Science de gouvernement 8 tomos", uma "Histoire profane 6 tomos", "Histoire romaine 13 livros (faltando 1, 6, 7)", "Histoire del'Amërique t. 19 e 118" e um "Compondio historico de Coimbra", convivendo com um "Cuisenier Bourgeou", um "Modo de bem estudar" - segura- 
mente o Verdadeiro metodo de estudar, de Verney - uma "Biblioteca elementar", "Liçons de navigation", "Elementos de Meliot tomos 2,3,5,6,9" e "Elements de Histoire 5 tomos". Completam a seção de miscelânia da livraria do nosso cirurgião-mor. de 1798, uma "Histoire universe1 8 tomos", "Interets des nations de 1'Europe 4 tomos", "Histoire de Suede 3 tomos", "Histoire de 1'Eglise 4 tomos", "Voiages de Gentil 3 tomos", uma outra "Histoire universel 2 tomos", "Histoire des empereurs 12 tomos", uma "Histoire ancienne 14 tomos", uma provâvel disciplina de ensaio político chamada "Idée d'un bon gouvernement 3 tomos", quatro obras de conhecimento geogräfico - "Metodo geografico 2 tomos", Geografie de La Croix tomo 2", "Geografie abregée" e "Dictionario geografico" - além de uma raríssima "Instrução sobre os corpos celestes". Sem dúvida, uma extraordinária biblioteca, servida por títulos e assuntos os mais variados, avaliada pelo livreiro Manoel Jorge da Silva.

Uma "Estoria do reino de Portugal em castelhano" comparece no inventário do tenente-coronel João da Costa Pinheiro, 1797 (AN, M. 469/8966). No de Antonio Pereira Ferreira, 1798 (AN, M. 434/8384), temos uma "Genealogia da Casa Real de Portugal folia tomo 6", um "Epitome cronologico in $4^{\circ}$ foIịo", uma "Analices de Algebra in 4"" e um "Vigier Istoria das plantas in $88^{\circ} 2$ tomos". Foi livreiro avaliador, em 28 de março de 1798, Manoel Jorge da Ssilva Pereira. E no inventārio de Nicolau da Costa Guimarães, 1796 (AN, Cx. $892 /$ 3488), encontramos "Flores de Espanha", "Estoria das guerras civis de Fráça", um inusitado "Oraclo de la Europa", junto 
a "Flores claves estorial" e, finalmente, uma "Politica moral e civil tomo $5^{\prime \prime}$.

Em São Paulo, nossa investigação percorreu documentos existente's no Arquivo Público e no Arquivo do Tribunal de Justiça, na Cúria Metropolitana, compreendendo inventariados da Cidade de São Paulo e de muitos municipios do interior do Estado, como Itu, Mogi das Cruzes, Guaratinguetá, Pindamonhangaba, entre outros. Tambëm pesquisamos em Santos, Jundiaí e Campinas, onde encontramos documentos, com livros, apenas os relativos ao século XIX.

Do Arquivo da Cúria, colhemos informações relacionadas com livros de tombos da Catedral da Sé. Vimos obras em documentos da paróquia de Nossa Senhora da Assunção, entre 1747 e 1876, com listas de livros religiosos e da doutrina para uso exclusivo dos ministros eclesiásticos, como "Missais", "Diretorio do coro", "Breviario", "Pontifical romano" etc.

No Arquivo do Tribunal de Justiça do Estado de São Paulo, localizado no bairro Vila Leopoldina, na Capital, pesquisamos inventários basicamente do século XIX. Encontramos uns poucos do século XVIII sem que contivessem 1ivros. Num único documento do século XVIII incluindo livraria, o inventário do Tenente Francisco Nobre da Luz, de 1770 (Caixa 173, $1^{9}$ ofício da Vara de Familia), encontramos una "Arte pratica de filosofos" e uma "Arte de cosinha".

Ond c mais se concentra a documentação setecentista referente a São Paulo é mesmo no Arquivo Público do Estado. 
A predominância de livrarias é, naturalmente, das matérias religiosas, e de Medicina ou Direito, mas registramos alguns títulos separados da tendência predominante. Assim, no inventārio de Escolástica da Silva, 1747 (Ordem 520), encontramos um "Noticias do Brazil", de curiosa e difícil identificação, (uma vez que o Notícia do Brasil, de Gabriel Soares de Souza só vem a ser publicado no século XIX), e no de Mecia Francisca de Almeida, 1749 (Ordem 522), "3 Livros uzados". Francisco de Godoy Preto, em 1750 (Ordem 52.3), tinha inventariado "Hum volume de Esțoria", enquanto Francisco Rodrigues Penteado e sua mulher Ana Ribeiro Leite, em 1757 (Ordem 533), tinham "Instituttos 12 tomos" e "Varias ad institutas".

No inventărio de Narciso Pereira Lopes, 1767 Cordem 545), avulta um só livro "In $4^{\circ}$ Vida do principe Theodosio". Mas, no do Fr. Manoel da Ressurreição", 1789 (Ordem 561), destacam-se do caudal de obras devocionärias, livros incomuns nas livrarias setecentistas, como "4 volumes Ethica portugueza de Mourato" e outros. Tambëm se destacam uma "Bibliotheque de aucteurs de c'siecle", "Revolutions d'Portugal par 1'abbë Vertot", "Vida de D. João de Castro", "Diccionario geografico 3 volumes", "Histoire des ordres monastiques 3 volumes", e mais alguns titulos, previsiveis ou não, como "3 volumes Dedução chronologica por Joze de Seabra", "2 volumes Provas da mesma por Joze de Seabra", um raro "3 volumes Vies de philosophes", outro "2 volumes Traité historique, et dogmatique par Langlet", o.s "11 volumes Vida, e Decadas de Barros e Couto", "4 volumes Bibliotheque d'un 
homme de gout" e "2 volumes Historia de Fr. Ger... em castel hano".

Seguem-se, no inventārio da numerosa biblioteca do Fr. Manoel da' Ressurreição, obras como "Fabulas chronolog... Joannis Musantile", os "3 volumes do Verdadeiro metodo de estudar", "2 volumes Memorias historicas do ministerio do pulpito 2 jogos", uma raridade que è a "Collecção de editaes da Meza Censória", acrescentada de um "Plano para os estudos do Rio de Janeiro", "4 volumes Deducção chronologica Folio", e "12 volumes Instrucção da mocidade Traduzido por Josë Joaquim de Nossa Senhora". E mais "6 volumes Melange de 1'Histoire naturelle par...", "4 volumes l'Espectacle de la nature", "32 volumes Histoire naturelle par Buffon", acompanhadas de obras raras como "Censures, et conclusionis de Sacrée Faculté de Theologie de Paris", "4 volumes Diccionaire historique", "2 volumes Institutions Bielfeld", um interessante "Traité de l'opinion par Gilbert" em 9 volumes, a "Species plantarum 6 volumes" de Caroli Linaei, um exemplar declarado da "Gazeta de Madrid", "2 volumes Problema historique", uma obra única com o título de "Questão politica", "Reflexoens de um portuguez", "2 volumes Chronica dos nossos monarcas" e "Portugal restaurado 4 volumes", este ültimo a Histöria de Portugal restaurado de D. Luís de Meneses, publicado em 1678-1679.

Permanecem acrescentados aos sempre presentes livros de Doutrina, nesta livraria do frade paulistano, "4 volumes Souza Historia dos romanos", "12 volumes Papeis varios", "8 volumes Estatutos da Univerșidade de. Coimbra 2 jogos" e 
"Guerra de 1762", "Le Cardina1 Richilieu", "29 volumes Le Clerci Bibliotheque ancienne et moderne", a obra de "Rezende de Antquitati...", certamente a obra de André de Resende (1500?-1573), De Antiquitatibas Lusitaniae, publicada em 1593, "Providencias do terremoto", mais "24 volumes Diccionaire des sciences", "26 volumes Bibliotheque universelle", "27 volumes Bibliotheque choisie", "14 volumes Memoires de clergé de France". Ainda, vamos registrando "14 volumes Pagi Breviarium historicum", "Santa Anna Rifert Chronica dos Carmelitas 2 volumes", "4 volumes Le Cardina1 de Noailles", "6 volumes Bruren Diccionaire geographique" e um exemplar do "Index 1ibrorum prohibitorum". Por ültimo, "2 volumes Langlet Tablettes chronologiques", uma "Colleção das leis contra os jacobeos", "Diccionaire geografique" e "8 volumes Instructiones de Mons. de Goifrons". "Trata-se, sem dúvida, de uma das maiores bibliotecas coloniais, composta de 375 títulos, com 11.548 volumes, distribuídos pelas matérias que aqui apontamos e mais as pertinentes à análise que se faz em itens dedicados à descrição, anotação e mapeamento de obras em Religião, Medicina, Direito, Letras e Linglistica.

Continuando a investigação em documentos paulistas do Arquivo Público do Estado, observamos a existência da obra do brasileiro Alpoym, "Exame de bombeiros" com 6 estampas", no inventário de Paulino Ayres de Aguirre, 1798 (Ordem 570). No de Thereza de Souza/Manuel Francisco Medeiros, 1749 (Ordem 613), anotamos "Centurias", talvez a obra de Amato Lusitano, (pscudônimo do médico português João Rodrigucs de Caste1o Branco (1511-1568), Centuriae, publicada em 1551. 
E no dè João Pereira Pacheco 1751 (Ordem 620), um "Livro de Fernando Mendes Pinto", o que confirma aqui a notável popularidade das peregrinações e de seu autor, no século XVIII brasileiro. Em 1773, o defunto Antonio Fortes de Bustamante 'Sá e Leme, deixava inventariados um "Exame de ingenios 2 tomos", "Theatro de los dioses", "Direitorio patrio", "Maris Historia dos Reis de Portugal", "Estoria de varias guerras da Europa" e um "Livro terceiro e quarto da Instituza", com a anotação adicional rezando "que por desmantelado não tem valor". Mais "2 tomos Historia de Thomaz Koulikan", "Portugal lastimado", e "Monarquia luzitana 1 tomo". O inventärio de Antonio Rodrigues Montezinho, de 1796 (Ordem 634) anota apenas dois titulos: "8 livros de varios autores pertencentes a Naotica e Engenharia" e "8 livros Historia da Igreja". o Arcebispo da Sé de São Paulo, Mateus Lourenço de Carvalho, deixava, em 1782, por inventärio (Ordem 638), além de 1ivros de doutrina e moral, "2 volumes in $8^{\circ}$ Portugal restaurado" e "in $8^{\circ}$ Vida de D. João de Castro". Manoel Antonio Barreto, 1791 (Ordem 650) deixava um "Seram politico", obra de Fr. Lucas de Santa Catarina (1660-1740), escrita em 1695 e publicada em 1704 com o título de Serão politico, abuso emendado, na linha dos prosadores e moralistas antigongóricos. No mesmo inventārio, encontramos "O livro de Cister", na verdade a Cronica de Cister, de Fr. Bernardo de Brito e mais uma "Regras da cavalaria" e, novamente, a "Vida de Dom João de Castro", de Jacinto Freire de Andrade.

Na considerável, I ivraria do Arcipreste João Machado Henriques, reverendo português scrvindo en São Paulo, por 
seu inventärio de 1756 (Ordem 655), observamos "1 tomo Monarquia luzitana em portuguez" e "1 tomo Historia de França em frances", "Hũa jornada de1 rey Dom Pedro em portugues", "1 Sentinela contra judeos, pequeno" e um curiosíssimo e raro "Tratado de arte do 1ar", "1 tomo verdadeiro alveitaria", uma "Historia do emperador Carlos Quinto, espanhol jocozo" e "1 tomo Europa portugueza". No inventário de João Rodrigues Vaz, 1746 (Ordem 659), descobrimos um "Portugal illustrado" e no de Matheus do Livramento Bastos; 17.23. (Ordem 669), títulos como "Arte de cozinha" e "2 Engenheiro portuguez", este último obra de Manuel de Azevedo Fortes (16601749), engenheiro e técnico luso. Rósa da Silva de Morais, 1751 (Ordem 680), tinha "3 tomos das Guerras civis de França", um "Serão politico", "0 ... da cavalaria", uma "Vida de - Dom João de Castro". Já o Cap. Francisco de Almeida Albernaz, 1749 (Ordem 726), tinha "Pcrtugal ilustrado" e Escolästica Godoy da Silva, 1737 (Ordem 734), "2 tomos Portugal restaurado ja velhos", acompanhados de "2 tomos Padre Carva1ho Corografia portugueza". No inventārio de João Lago Paes, 1731 (Ordem 737), aparecem "Hum livro de Historia universal" e uma "Monarquia luzitana" e, finalmente, no do Fidalgo da Casa Rea]. André Alves de Castro, 1765 (Ordem 744), constam "3 volumes Theatro de los Dioses" e "l volume Reis Novos".

Assim se descreve o repertório das leituras setecentistas no Brasil Colônia. Na maior parte, como dissemos, as livrarias anotadas dos inventários de bens evidenciam um leitor de obras devocionais, a que se segue um leitor cspecializado, num interesse profissional, de obras das Ciências 
Mëdicas e do Direito. No gera1, esse mesmo leitor, busca ampliar um universo de conhecimento, pela ilustração via cultura científica, histórica ou literária. O leque de leituras, então, alterna uma opção por obras dás Ciências Naturais, ou matemáticas, físicas ou químicas e exercitam uma alteridade do interesse curioso por assuntos linguísticos, até como auxilio na compreensão e açepção do que importa saber em idiomas estrangeiros. Em termos estatisticos, o leitor brasileiro de Setecentos é amplo 'e variado, com a predominância de leituras nas äreas que descrevemos, mas aberto o suficiente para o entendimento do que se passava na Europa civilizada, descontados os percalços histöricos já nossos conhecidos. Como peça de contrabando ou como mercadoria comum, o livro no Brasil Colonial não nos impediu de um incipiente aperfeiçoamento técnico ou cultural. Ao contrário, efetivamente, favoreceu-nos o acesso à cultura e à ciência.

Outros títulos vão acrescentar, no século XIX brasileiro, o perfil do leitor colọnial. o Arquivo Público do Mato Grosso, em Cuiabã, tem documentos que facilitam a identificação e as características do leitor cuiabano. Assim, encontramos, no inventärio de José Dias Paes, 1803, uma "Vida del réy D. Pedro de Portugal". Também encontramos um "Portugal restaurado", que deve ser a História de Portugal restaurado, obra cuja primeira edição é de 1679 (1. parte) e 1698 (2. parte), do $3^{\circ}$ Conde de Ericeira, D. Luís de Menezes (16321690), e "4 volumes em francês in 4 pri no inventário do alferes Manoel de Barros. Rodovalho e Silva, 1824; um "Tratado 
de Aritmetica", "3 tomos Apendices diplomatico historico" e, mais, "25 livros velhos", nọ inventārio do capitão Joaquim Fernandes Coelho, 1836. E, no inventärio do alferés Benedito Peixoto de Azevedo, 1849, "Elementos de Aritmetica" e um "Folhe to Rudimentos aritmeticos".

Já a livraria de D. Ana Benevenuta d'Albuquerque, inventariada em 1845, é bem mais rica e se distingue das demais por ser um tanto variada e numerosa. Nela se destacam, em matéria histö́rica, "25 volumes de Historia universal Segur", "5 volumes Historia de Washington", um "Curso de Historia por Guizot", certamente a obra de historiografia portuguesa de François Guizot (1797-1874); e "2 volumes Historia do descobrimento da America". Em politica, "2 volumes em broxura Diarias das Sessões do ano 1826 in folio", "2 volumes Actas da Assembléia Constituinte", talvez as Actas das Sessões da Assemblêia Geral, Constituinte e Legislativa do Impërio do Brasil (Rio de Janeiro, Typ. Nacional, 1823, 2 t. em 1 v. in $4^{\circ}$ ). No mesmo inventário, um "Ramalhete politico", "2 volumes Actas legislativas" e, em atençã̉o à voga do constitucionalismo, "3 volumes Curso de Politica por Benjamin Constant". Outras matérias comparecem na biblioteca de D. Ana Benevenuta, como um "Manual diplomatico", a indefectivel obra em "6 volumes Viagens de Antenor na Grecia" e mais um "Say Ecomonia politica", seguido por "5 volumes Smith Economia politica". Completam o acervo "2 volumes Geographia Bena e Giraldes" e um "Dicionario geografico".

De Cuiabá, passando aos documentos localizados no Arquivo Público do Rio Grande do Sul, encontramos uma igual 
tendência de títulos, autores e matërias oitocentistas, mes- mo quando a transcrição documenta 1 não exprima diretamente autor, obra ou matéria.

0 município de Rio Grande introduz essa perspectiva. 0 padre Duarte da Cruz Pinto, inventariado em 1826 (APRS, Rio Grande, maço 11), tinha "16 livros latinos". Maria José da Conceição e José Alves Guimarães, num inyentârio de 1829 (ma-. ço 13), tinha "8 livros de varias obras". Alexandre Antonio de Lima e Ana Maria Joaquina, 1830 (maço" 13), "2 livros". Cláudio Josê Ribeiro, 1836 (maço 16), "4 1ivros diferentes" e "5 folhetos". E Josë Maria Mendes, 1836 (maço 16), tambëm tinha "5 1ivros truncados". Mas Maria José Gomes de Me1lo, 1834 (maço 16) tinha, declarados em seu inventário, "7 1ivros de Historia do Brazil", provavelmente a obra de Southey ou a de Beauchamp.

Ainda no municipio de Rio Grande, conforme o inventário do.Dr. Firmaño José da Silva'Falcão, 1806 (APRS, Rio Grande, Maço 3), circularam livros como um "Dicionario geografico", "4 viagens de Altina" e, como sempre inespecificados, "4 livros manuscritos". No inventärio do Dr. Manoel José Tavares, 1814 (APRS, R. Grande, maço 5), encontramos um "Aviso a gente do mar". No de Félix da Costa Furtado de Mendonça, 1819 (APRS, R. Grande, maço 8), os "Comentarios do grande Affonso de Albuquerque 4 volumes", que é, na verdade, obra de Brás de Albuquerque (1501-1581), filho de Afonso, que, por mercê de D. João III, tomou o nome do pai. A primeira edição.da obra é de 1557. No mesmo inventário, um "Discurso fundamental sobre a população", obra presumivelmen- 
te de Maithus, uma "Historia de Portugal em 16 volumes" - de - difícil identificação de autoria, face à variedade de autores para o mesmo tîtulo - uma "Arte de cozinha", "Fernão Mendes Pinto", uma curiosissima "Arte de agradar na conversação", uma "Taboada curiosa", uma "Relação politica do conde Duque de Olivares", "Memoria sobre a cultura de oliveira", "Taboas chronologicas" e uma "Vida de Carlos 12 da Suecia", possivelmente a obra de Voltaire. Outros títulos completam - acervo da biblioteca de Félix Furtado de Mendonça: "Historia da Russia no tempo O Grande", "Memoria historica da invasão dos franceses", (talvez a obra já editada pela Impressão Régia no Rio de Janeiro),e uma obra rara, talvez do século XVI, a "Esfera de Sacrobosco". No inventärin de Nicolau Ignacio da Silva, de 1823 (APRS, R. Grande, maço 9), aparece uma "Istoria universal dos terremotos" e, inespecificados, "4 livros manuscritos".

Rio Grande parece ter sido de fato uma cidade onde se lia muito, sobretudo no século passado. Pela documentação disponíve1, é seguramente à que mais se distingue no número e na variedade dos liṿros, com exceção das cidades histöricas mineiras. No inventário de Francisco Antonio Duarte, 1824 (APRS, R. Grande, maço 10), por exempio, constam "10 volumes do Investigador portuguez de 1815 a 1818", ou "0 Investigador Português na Inglaterra", jornal literärio, político, \& c., periódico com que Portugal entre 1811 e 1819, buscavạ responder aos ataques de Hipólito da Costa no "Correio Braziliense". O jornal dirigidó por José Liberato Freire de Carvalho funcionou por 23 volumes ao todo. Foi 
editado em Londres, fundado por. Bernardo José de Abrantes e Castro, seu redator até 1814. Ainda no inventário de Francisco Antônio Duarte, "7 volumes Historia do Brazil", provavelmente a obra de Beauchamp ou a de Robert Southey, além de ".3 volumes Memorias politicas", "2 volumes Botanica de Brotèro", "Manoal pratico", "Quimica de Seabra" - obra de Vicente Coelho de Seabra Silva e Teles, quimico e economista brasileiro (1764-1804). E mais "Dialogos de Historia de Portugal", "4 volumes broxura Economia de José da Silva Lisboa", uma "Historia natural em francez", "Elementos de Pharmacia Quimica e Botanica" e uma curiosíssima "Estoria critica do teatro", ao lado de uma "liistoria geografica da cidade do Porto". O livro de "Vezuth da navegação", "Segredo da natureza", uma "Vida de Luís XVI", "Viagens de Gibraltar" e, inespecificados, " 32 volumes de diversos autores truncados sem valor" encerram a livraria de Francisco Duarte.

No inventário de Joaquim Centena da Silva Braga, 1838 (APRS, R. Grande, maço 17), encontramos "2 volumes Algebra e calculo de Bezout", um surpreendente "Rezumo da historia dos Estados Unidos", mais "10 volumes Revolução francesa por Fantin" e um livro de "Rechard Botanique" e "3 volumes Martens Diplomacia". Jä Inácio José Bernardes, tambẻm de Rio Grande, 1838 (APRS, maço 17) tinha "1 livro velho em espanhol", uma "Vida de Bonaparte", uma "Historia do imperio da Russia" e a obra de Jacinto Freire de Andrade, "Vida de D. João de Castro, 4 volumes", seguida de um "Dicionario botanico etcetera", uma "Descrição da cidade do Porto", uma "Economia rural 2 volumes", uma "Historia georgiana" e, fi- 
na1mente, um "Parallelo dos costumes d'este seculo". Isso tudo denuncia o interesse do leitor variando para outras direções, estilos e técnicas de comunicação humana.

O Dr. Guilherme José Correia, inventariado em 1843 (APRS, R. Grande, maço.21) tinha uma livraria bem razoável, com significativos titulos em Medicina e Cirurgia e alguma coisa em Direito e Linglística. No que escapa dessas rubricas, o perfil de leituras do homem brasileiro do sul poderia sẹr compreendido pela presença, nesse documento, de livros como "Compendio das epocas e sucessos ilustres da historia geral por Antonio Pereira de Figueiredo", um "Etude de la nature de Jacques", "Fatos memoraveis da historia de Portugal S.A.M.", "Introductiones a Zoologia por Francisco Antonio Ribeiro de Paiva", a "Algebra de Bezout 2 volumes", e mais um "Compendio de Geografia por Cazado Giraldes", um "Dicionario historico de Chandon \& Delandens 13 volumes", um livro de "Bornin Doctrina social", um expressivo e pouco comum "Dicionario das origens 2 volumes" e a obra de "Richard Novos elementos de Botanica". Outros títulos e autores igualmente comparecem nessa amostragem do acervo hibliográfico do Dr. Guilherme José Correia, de Rio Grande. Assim, "Melo Franco Educação phisica doṣ meninos" e um indecifrável "Sen... Sistema natural volume $2 "$ " "Manual completo de Physica e de Meteorologia", um "Taverner Manual de Chimica", um "Manual completo de Chimica geral", "Mezal Elementos de Botanique", "Viagens de Antenor", "Gabinete do naturalista", "Rezumo historico da vida de Affonso de Albuquerque" e "Historia do rei D. João VI". Entre os livros de broxura, uma 
"Revista enciclopedica" e os nada frequentes "Manual do cidadão brasileiro volume 5 e 6" e "Instrução para o viajante sobre a maneira de melhor conservar os objetos de Historia natural". O médico Dr. Guilherme José Correia; inventariado em 1843, tinha, por fim, "Rezumo de Historia de Portugal por Monte Verde", "Elementos de Geografia e Astronomia politica por Manoe1 Ignacio Soares Lisboa" - talvez a obra Elementos de Geografia astronômica, política e física, editada pela Impressão Régia, no Rio de Janeiro, 1830,65 p. in $8^{\circ}$, cujo autor, brasileiro, traduziu as sátiras de Horácio em 1834, pela mesma Impressão. Outros títulos são a "Historia da Revolução Franceza em 1830" e um "Manual do fazendeiro".

o inventārio de Josē Joaquim Gomes da Costa e Silva, tambêm de 1843 (APRS, R. Grande, maço 21), traz uma menor livraria que a anterior, mas revela um leitor curioso acerca de questões ligadas sobretudo à Histöria e à Literatura. Assim, encontramos um "Rezumo dos Estados Unidos", "2 volumes Campanha da Russia", um "Cidadão luzitano", um. "Tratado da tirania" e, muito provavelmente, a obra de Mons. Fizarro e Araújo, as "Memorias das historias do Rio de Janeiro".

Mas a maior biblioteca do século XIX na cidade de Rio Grande, depois, obviamente, da de Ána Joaquina Ferreira e Francisço Xavier Ferreira, que adiante descrevemos, deve ser a de Antonio Carneiro, inventariado em 1847 (APRS, R. Grande, maço 23). Nela, pontuam livros versados em quase todas as especialidades, perfilando um gosto do inventariado o mais eclético possivel. Além dos títulos nas rubricas dominantes, como Medicina, Direito, Religião, Letras, também aqui 
aparecem obras de História, Biografia, Geografia, Ciências Naturais e outras, conforme ilustra a relação abaixo:

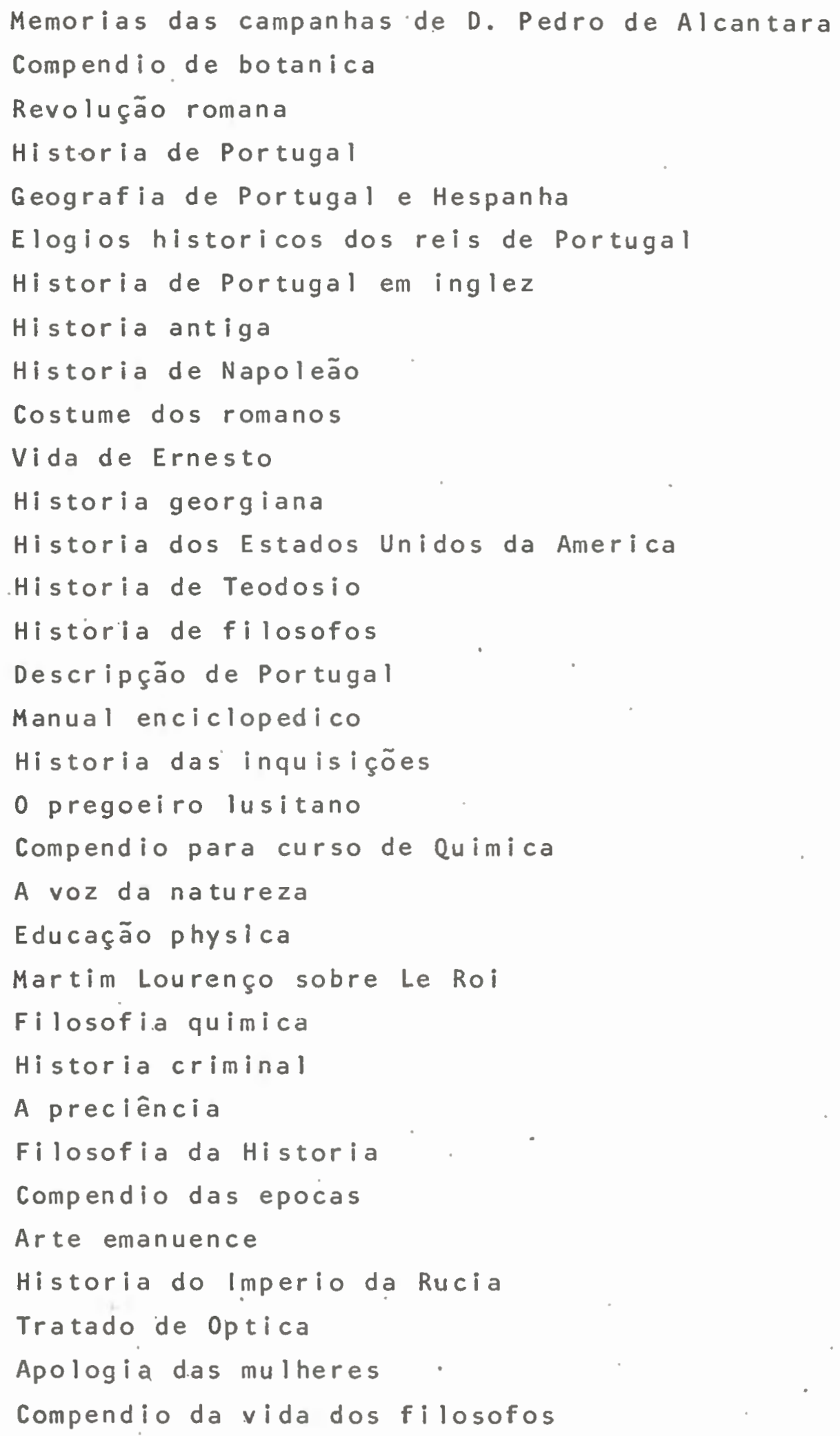




\author{
Cidadão luzitano \\ Aritmetica pratica \\ - Investigador portuguez \\ Chimica de Seabra \\ Historia de inglaterra \\ Biblioteca elementar \\ Manual do cidadão \\ Geometria de Vilella \\ As Frutas do Brazil \\ Taboada curioza \\ Historia romana \\ Descripção compendiosa \\ Vida de Fablas \\ Revista historica de Portugal \\ Dicionario botanico \\ Tratado chimico phisico \\ Desgraçado Napoleão dicertação
}

Como se observa, a livraria de Antonio Carneiro, em Rio Grande, era, de fato, rica e variada, atendendo a um certo ecletismo de gosto e interesse cultural e bibliográfico. Nela vão aparecer títulos de História e Geografia, Biografia histórica, ao lado de periódicos como a "Revista historica de Portugal" e "O Investigador Portuguez", dicionários de Botânica, manuais de Quimica e Física e um título curioso como "As Frutas do.Brazil". Os Elogios históricos dos reis de Portuga1, do Fr. Bernardo de Brito, a Descrição do Reino de Portugal, de Duarte Nunes de Leão (1. ed. 1610), o Compêndio das ëpocas, de Antonio Pereira de Figueiredo, os Elementos de Química, do brasileiro Vicente Coelho de Seabra Silva e Teles e talvez a tradução feita por Gibbon, em 2 volumes, 1751, para a obra de Jerônimo Osório (The llistory of Portu- 
gal during the reign of Emmanue1, containing a11 their dis- coveries, from the coast of Africk to the farthest parts of China etc., fazem parte do inventário de Antônio Carneiro, de Rio Grande (RS). E uma livraria de época, certamente inc.luindo publicações correntes jā na terceira e quarta décadas do século XIX, combinando talvez com algumas obras anti-. gas. Não existe um peso específico numa determinada área, embora proliférem as novelas francesas em traduçōes portuguesas, de gosto duvidoso, ao lado de livros importantes da bibliografia de ficção e poesia, dos clássicos e neo-classícos. Há, ainda, muita coisa de Medicina e Direito, Legislação e tîtulos significativos de constituições, incluindo a brasileira.

O ủ1timo documento da cidade de Rio Grande, existente no Arquivo Público do Rio Grande do Sul, em Porto Alegre, com data limite de 1850, é o inventário de Joaquim Gomes de Mello (APRS, Rio Grande, maço 26). Contém uma livraria basicamente formada por títulos religiosos e literärios, onde se destacam um "Livro indispensavel" e uma "Historia de creação do mundo". Há também uma "Administração do Marquez de Pombal", uma "Campanha da Rucia", uma "Historia de Roma", uma "Historia de naufragios" e uma "Historia de Alexandre". Destaca-se, como uma das características do leitor eclético do século XIX, a inclusão de mapas geográficos, como "Atala geographico" e "Atalas modernc". A livraria de Joaquim Gomes de Me1lo inclui ainda um título, no mínimo, intrigante: "Oculus politicus", ao lado de outro-igualmente curioso, "Escola politica". As obras de viagem, predominantes no sé- 
culo XVIII, ampliam-se ao XIX e frequentam quase todas as 1i- vrarias da época. O inventärio de Joaquim Gomes de Me11o, em 1850, registra uma "Viagem ao interior da Nova Holanda" título, sem dúvida, incomum e talvez exclusivo de Rio Grande, já que não régistramos outro nos inventārios que pesquisamos. 0 leitor preocupava-se com o estilo de composição de cartas, daí o aparecimento, em sua biblioțeca, de um "Formolario ou estilo de cartas". Dois folhetos políticos encerram o peril das obras em destaque da estante riograndense: "Folheto cathecismo politico" e "Folheto Defesa de Joaquim Manoel de Figueiredo".

Do ponto de vista de nossa investigação, depois de Rio Grande e, naturalmente, Porto Alegre, Pelotas é o município mais representativo. Essa representatividade não se manifesta em números de bibliotecas como em Rio Grande, mas, de qualquer forma, desperta interesse óbvio pela disposição pelotense à leitura. Pode ser anotada alguma coisa inespecífica como "12 livros velhos de varios autores", no inventário de Josẹ de Aguiar Peixato, 1810 (APRS, Pelotas, Estante 25, maço 1), ou "17. livros de varios autores truncados", no inventärio de Pedro José Gonçalves, 1824 (APRS, Pelotas, maço 8), ou, ainda, "63 volumes de livros", no inventário de Pedro Simão. Froyal, 1825 (APRS, Pelotas, maço 8), "15 livros velhos" nọ inventário de José Vaz de Matos, 1830 (APRS, Pclotas, maço 11), ou "6 livros latinos", no inventário de Antônio Pereira (APRS, Pelotas, maço 8). No documento de Manocl Vieira, 1825 (APRS, Pelotás, maço 8), jä se nota uma indicação precisa do perfil de leitores: "2 livros nauticos". 
No de Tereza Angélica de Sá, 18228 (APRS, Pelotas, maço 10), encontramos uma "historia de Portugal" e um exemplar de "Cavalaria".

A biblioteca mais rica de Pelotas pertence a Inácio José Bernardes, 1838 (APRS, Pelotas, maço 15) e segue a caracteristica convencional de uma estante mëdica, registrando, contudo, outras obras de diferente especialidade, onde pon- . tificam livros de Literatura e Religião. Os títulos médicos e.cirúrgicos que aparecem na livraria dè Inācio José Bernardes são aqueles consagrados desde o. século XVIII, revelando o oficio do inventariado e seu permanente interesse em atualizar-se na ciência de sua especialização. Outros títulos, poucos, comparecem nessa amostragem:

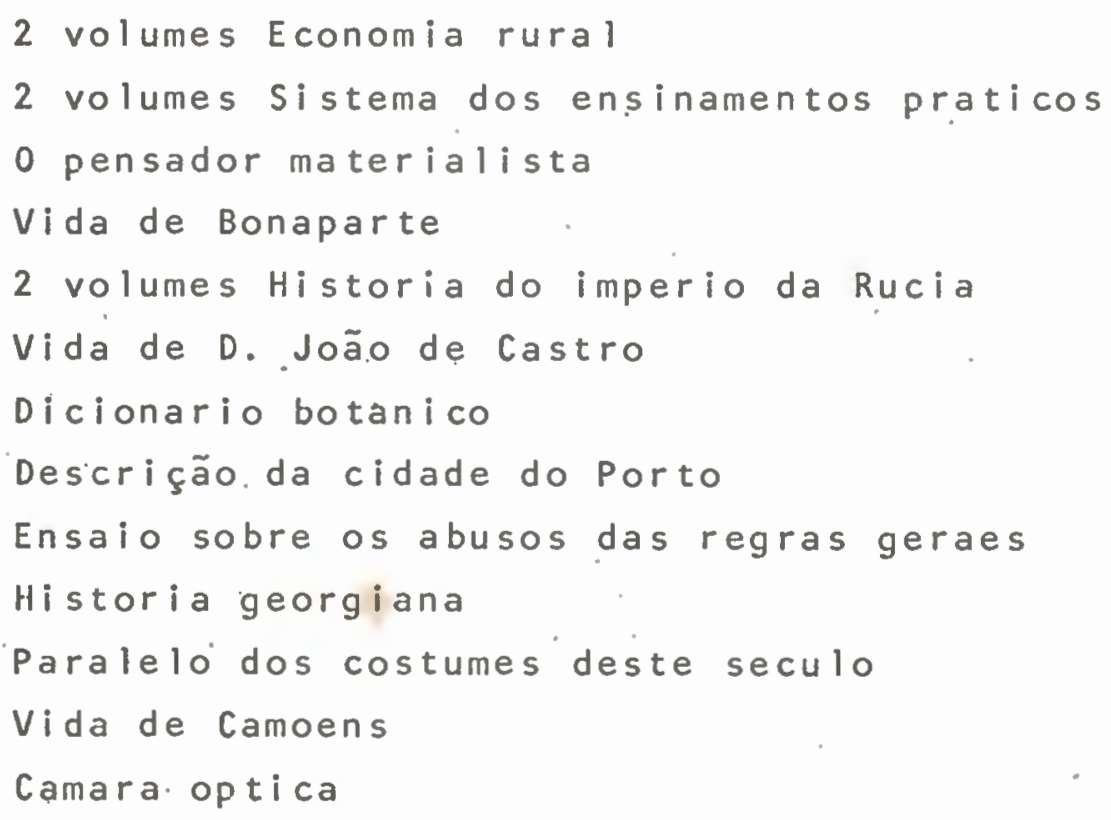

Em nosso entendimento, é bem uma livraria atenta ao modelo de leituras do século. Tem alguma coisa de sentido prático, aliada à curiosidade histórica, à Política, à Geografia 
e às Ciências Naturais.

Poucos também são os. livros de David Pamplona Corte Real, 1846 (APRS, Pèlotas, maço 17), mas igualmente variados em títulos e especialidades. E o curioso é que, nessa relação de livros, não há predomínio em determinado campo. A biblioteca tinha exatos dois títulos em História, um em Educação, um em Botânica, um em Agricultura, um em Química, um em Genealogia, cinco em Farmácia, um em Medicina, um em Retórica, além dé "48 volumes de diversas obrás incompletas". Seguramente, uma estante díversa e típica de um século de curiosos. Os títulos. fora da rubrica doutrināria ou profissional confirmam tal juizo. São:

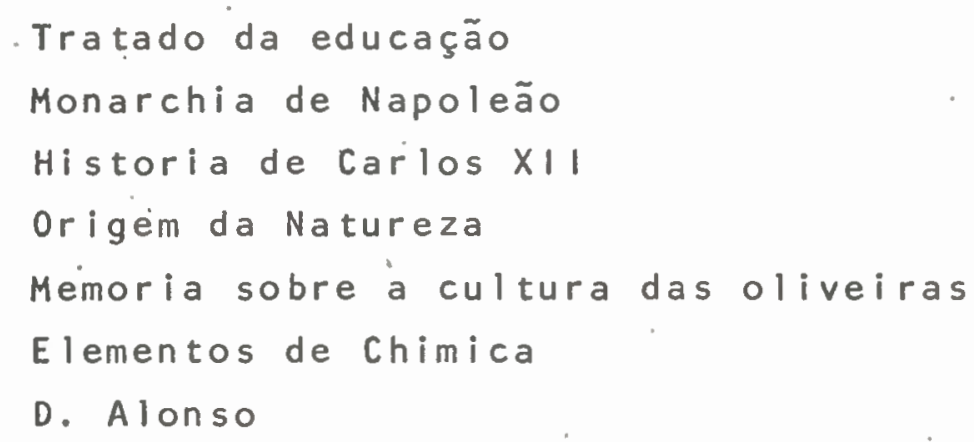

o último documento de Pelotas, por nós examinado, data de 1847 e pertence ao inventário de Tomás Francisco Flores (APRS, Pelotas, maço 1). Da pequena livraria, constam uma "Economia politica de Ganilh em 2 volumes", uma coleção inusitadà de "Sofismas politicos", um "Atlas geografico" e um "Mappa da provincia". Sem dūvida, um leitor de Jurisprudência, com atenção e aspectos políticos e geográficos, leitor típico, aliās, do século XIX. 
A tipologia de leituras do periodo oitocentista apresenta as características jä basicamente apontadas, decorrentes da investigação em documentos de fonte primária. Alguns títulos, contudo, permanecem sem indicação precisa, além da autoria, ou da matéria que versam. Assim: "3 livros de autores", no inventário de Francisco de Ávila da Rosa, 1819, de Piratini (APRS, Piratini, maço 2), ou "11 livros de varios autores", no inventário de Salvador Antônio Anes, 1830 (APRS, Pirátini, maço 3). Mas também indicam uma notável preocupação com as notícias e circunstâncias históricas no mesmo século, como no inventário de Manoel Gomes Guimarães, 1846, de Piratini, maço 6 , onde se anota, na livraria, as "Memorias historicas da Revolução do Porto", um "Ensaio historico e pratico sobre Portugal", uma "Historia do Brazil em 11 volumes" (Beauchamp? Southey?) e um "Manual do cidadão em 5 volumes". Completa o perfil dessas leituras um livro que, a rigor, não é de ler, mas de ver: o "Atlas grande por Ba 1 bi".

A inexatidão dos títulos, corrente em todo o país, observa-se com frequência, também no Rio Grande do Sul. Dessá forma, no inventário de Escolástica Joaquina dos Santos, 1808, de Rio Pardo (APRS, Rio Pardo, maço 6), lê-se, apenas, que ela tinha "2 livrinhos pequenos". Mas também se verificam leituras especificas, como é possível depreender da anălise do inventário do Tenente Coronel Antonio Xavier de $\Lambda$ zambuja, de Rio Pardo, 1820 (Idem, maço 12), onde encontramos desde títulos de interesse imediato da função profissional do inventariado - "Tratado sobre a disciplina, e operaçoens das 
tropas" - a títulos da curiosidade científica ou devocionário, como "O Viajante universal em 17 volumes", ou curiosidade histórica como. "Historia geral de Portugal de Lacred em 6 volumes" (a obra de La Clêde). Ou o elogio histórico como "2 volumes Dignissimo portuguez". E demais curiosidades, como "Noticia da.1ey da natureza" e "Almanak de Portugal".

Ainda de Rio Pardo é o inventário do Tenente General Visconde de Pelotas, 1821 (maço 13). A predominância é de obras de Doutrina e Literatura, mas igualmente salienta-se desde o interesse direto da formação profissional do inventariado - "Principios de Tatica em 2 volumes", "Desenho de fortificação", "Tatica de Azevedo em 2. volumes", "Guerra da França", "O capitão de Inglaterra" e "Arte da guerra em 3 volumes" - a obras como "Historia da Russia 2 tomos", "Historia de Alexandre 2 tomos", "Historia de Portugal 10 volumes", "Historia de Theodosio", "Historia de D. João de Ċastro", "Historia universal em 9 volumes". Obras de politica como "Despedida de Mancha110", "Comentario de Cesar", "Economia politica", "Principe Eugênio" e "Espirito de Mr. Nicolle em 2 volumes". Finalmente, entre Ciência e Religião, comparece o célebre "Viajante universal em 35 volumes".

Seguimos com o perfil do leitor oitocentista no Rio Grande do Sul. No inventário de Maria Cândida da Fontoura, 1832 (APRS, Cachoeira do Sul, maço 5), encontramos um "Compendio das artes e sciencias". Como sempre inespecificados, lá estão também "2 livros" no doc. de Ma. Constantina de Avellar, 1836 e "20 livros velhos" no de José Ignacio dos Santos, 1837 (naço 6). Ou, ainda, "9 livros, alguns de Dou- 
trina evangelica", com Ignacio Francisco Xavier dos Santos, 1845 (maço 8). Com dados incompletos, também, encontramos "6 livros" no inventário de José Joaquim Bittencourt, 1823, de Caçapava do Su1 (APRS, Estante 90, maço 2); e "2 1ivros" no inv. de Francisco Jacinto Galvão, 1844 em Triunfo (APRS, Es$\tan t e .140$; maço 2).

Tendência para leitura científica vamos observar na reduzida livraria de Francisco José da Silva, 1808, no município de São José do Norte (APRS, Estante 130, maço 2). São três únicos livros, dois de Matemática e um de Naútica: "Livro de Aritmetica", "Taboada de Redusão" e um "Livro de Nautica". Em São José do Norte, ainda, encontramos um "Aviso a gente do mar", na livraria predominantemente médica de Ana Ludovina da Conceição, 1825 (APRS, S. José do Norte, maço 5). E uma "Porção de livros pertencentes a Nautica", no inventário de José Francisco da Cruz, 1838 (APRS, S. José do Norte, maço 8). Uma "Taboadinha velha" é o único livro inscrito no inventärio de Felício Josē da Silva, 1842 (APRS, S. José do Norte, maço 9). E no inventário de José Antônio Santiago, 1843 (APRS, S. José do Norte, maço 10), vamcs encontrar a anotação vaga de "15 1ivros" e, adiante, um "Roteiro de Pimentel" (a Arte prática de navegar, e roteiro das viagens e costas marítimas do Brasil, Guiné etc. - ed. 1699 - do cosmógrafo português Manuel Pimentel (1650-1719), um "Regimento provisional da Marinha" e um "Tratado de leis sobre os navios mercantes": Sem dūvida, açula nossa a tenção o interesse demonstrado pelos gaúchos com questões nảuticas c de Marinha, sendo singular o fato de encontrarmos expressiva 
quantidade de títulos nessa categoria em vários documentos do Rio Grande do Sul.

Em Porto Alegre, os títulos e os livros são em maior nümero, obviamente, que nos outros lugares do Estado, rivalizando, em importância, com o município de Rio Grande. No inventário de José Carneiro Geraldes, 1806 (APRS, POA, maço 3), encontramos uma obra singularíssima e rara nas livrarias brasileiras, que é o "Cozinheiro moderno". Numa biblioteca que reproduz os costumeiros títụlos de Religiāo, ressaltam "2 tomos Discurso da Historia universal", um "Caderno da tragedia e morte de Sezar" e "3 Mappas da Europa". Em documento do mesmo ano, encontram-se, entre os bens de José Custório da Silva Santos (APRS, POA, maço 3), "l1 1ivrinhos". Tambēm sem indicação direta, "21 livros latinos" e "11 livros portuguezes" constam do inventārio de Maria Francisca das Dores, 1809 (APRS, POA; maço 3), mas encontramos "4. livros de taboadinha", no inventário de João Rođrigues de Lima Fogaça, 1812 (APRS, POA, maço 3). "10, livros" compunham toda a fortuna bibliográfica de Joaquina Januária de Jesus, 1823 (APRS, POA, maço 6); "1 livro", no inventārio do Ten. Silvério Albertino Leite de Oliveira Salvado, 1814 (APRS, POA, maço 23); "8 livros de diferentes autores", no de João Gabriel de Sampaio, 1808 (APRS, POA, maço 17), entre outros. Com Francisco Antônio Rodrigues Viana, 1831 (APRS, POA, maço 17), encontramos uma "Estoria de Theodosio", "Carlos 12, 2 volumes", uma "Historia da Revolução Francesa 2 volumes", um. "Livro da Natureza, 2 volumes", "2 Aritmeticas de Carvalho", "3 Escollas de politica", "Instruçoens mili- 
tares sobre infantaria, 2 volumes", "Memórias de artilharia", "3 Cadernos de Instruçoens militares" e uma obra já consagrada no Brasil Colônia - "Segredos da Natureza". Custódio Ferreira de 01iveira Guimarães, 1800 (APRS, maço 147), tinha, entre livros de Religião e Letras, um "Quadro da morte do mảrquês Graziol1e".

O Arquivo Püblico do Rio Gránde. do. Sul tem, ainda de Porto Alegre, a documentação referente ao $1^{8}$ Cartório da Vara de Família. Começa com inventärios do século XVIII e do século XIX, com "2 livrinhos", no inventārio de Manoel Dias de Almeida, 1801 (Maço 14-B), segue com "2 livros de $8^{8}$ jä usados", no de Manoel Duarte Santarém, 1802 (Maço 15), "9 1ivros no inv. de Manoel de Azevedo, 1808 (M. 19-B), "13 1ivros de varios aut." no de Antonia Maria de Jesus, 1809 (M. 20). Jä no inventārio de Francisco Josē de Azévedo, 1807 (Maço 19-A), uma pequena livraria é composta de 3.únicos livros, todos pertencentes às ciências matemäticas: "Matematica", "4 1ivros de Geometria" e "Aritmetica". No inventārio do Dr. Manoel Ribeiro de Miranda, 1809 (M. 20), vamos encontrar "10 volumes Sistema dos conhecimentos chimicos...", um "Tratado elementar de Mineralogia de Brocant", "9 volumes Sistema da Natureza de Serico", uma obra surpreendente que é a "Fitologia de Darwin com estampas", acompanhada de "4 volumes Zoonomia" do mesmo Darwin, " 5 volumes.Dicionario universal de geografia Rulet" (sic), "2 volumes Manual de mineralogia de Bergman", "Elementos fisico-chimicos", uma "Atrografia de alkales de Veloso" (sic), completados com "19 folhetos"; "29 volumes apartados de diversos autores" e "12 volumes" separados de diversos au- 
tores".

- $1^{\circ}$ Cartório de Porto Alegre, com sua documentação recolhida ao APRS, continua com Manoel Lopes de Carvalho, cujo inventário data de 1811 (Maço 21-A). Há títulos curiosos na livraria do inventariado, como um "Guia de viajantes", um "Armazem de sobrás", um "Manobreiro dos movimentos nauticos", a obra de Fulton - "Tratado da navegação por canaes", o best-seller "Revolução da Françạ" em 3 volumes, mais um "Regimento provisional da Esquadra Rea1", uma "Trigonometria plana e esférica", um exemplar do rarissimo "Cultura americana" e os, tambēm raros, "Discurços apresentados a Meza da Agricultura". Jả a biblioteca do Reverendo José Luiz dé Castro Vangeler, cujo inventärio ē de 1819 (M. 22), começa a relação de livros com uma "A sciencia do governo 8 tomos", mas se destaca pela proeminência de obras de Direj.to $e$, naturalmente, Doutrina religiosa e Teologia. E uma livraria típica de livros antigos, alguns provavelmente do século XVII, a maioria do XVIII. Dela recolhemos, p. ex., un titulo surpreendente como "Delelum Modo de pensar", seguido de títulos mais ou menos comuns das bibliotecas de Setecentos e meados de Oitocentos, como "Decadas de Couto 3 tomos", "Historia da Universidade de Coimbra 2 tomos", "Compendio historico de Coimbra", "Dicionario de homens ilustres 5 tomos", "Dicionario geografico", "Indice chronologico de João Pedro Rib. 4 tomos", "Descrição da cidade do Porto" (sic = Discur so). 0 interesse do reverendo por matéria pedagógica é demonstrado por títulos como "Gribel Theoria da educação 3 tomos", "Beumonte Theoria da educação 2 tomos, "Discursos so- 
bre a educação" e un título algo frequente nas livrarias oitocentista: "Instrução de hum pai a seu filho". Há, ainda; um "Manifesto ana1itico de França" e um de ambígua decifração: "Papeis varios 4 tomos", que tanto pode ser de livro, ou reunião de documentos pertencentes ao inventariado, em quatro tomos de manuscritos.

o inventário de Joaquim Francisco Alves, tambēm de Porto'Alegre, 1815 (Maço 23) abre com livros, o que radica a importância atribuída à livraria do inventariado, '1ivros, em sua maioria, de Direito, com três únicos exemplares pertencentes a campos diferentes: um "Elementos de Aritmetica", um "Aritmetica" e "2 volumes Istoria elementar de Antonio Pereira". A livraria do Pe. Matheus da Silva Souza, 1815 (Maço 24) segue a linha das obras doutrinārias, com um único 1 ivro de referência memoria1, um "Elogio historico 2 tomos". No de Francisco Pinto de Queiroz Sarmento, Porto Alegre, 1817 (Maço 25) predominam obras na ärea das Letras e Linguística, mas encontramos um "Observaçoens sobre o comercio mercantil" que talvez seja a obra de Cairu. No de Antonio do Rego Chaves, 1819 (Maço 26), aparece um "Manual mineralogico". E no inventārio de Manoel Lopes Macieira, 1823 (Maço 32), hã uná única obra, "1 Livro de mappas do giobo".

José Antonio do Vale, tambēm de Porto Alegre, no inventärio de seus bens com data de 1824 (APRS, maço 34) apresenta uma particular opção pela leitura de obras cicntificas, de Matemática, Geografia'e Nāutica. Encontramos ai um "Novo livro,de Matemātica", "Cartas 'fisico matematicas" livro de religião do oratọnio de Tcodoro de Almeida (Lisboa, 
1784). Nèle, hã uma carta físico-matemática sobre a teoria da - pólvora em geral e o estabelecimento da melhor extensão das peças om particular. A obra foi redigida em 1769. Fazem parte da livraria, ainda, um "Dicionario geografico", um "Atlas universa1", uma "Taboadinha de Nautica em inglez", uma "Descripção avulsa dos instrumentos, folheto", uma cuṛiosíssima obra, de difícil identificação, "Agulha de Maria", . uma "Taboada ou diferença de latitude em inglez", além de um manual pedagógico característico de primeịras letras "Compendio das leçoens que se devem fazer nas aulas", obra raríssima nas livrarias brasileiras, pelo menos do que conseguimos descobrir em nossa invéstigação.

O padre Manoel José. da Costa, 1824 (Maço 34) tinha, entre seus consagrados volumes de Doutrina, um título provávelmente atribuido a Bossuet, "2 tomos Historia univerçal", que pode também ser a História universal antiga e moderna de João Baptista da Costa (1700-1779) ou a História e cronológica da Igreja de Portuga1, de Santa Rosa de Viterbo. Outro padre, Ignacio dos Santos Pereira, em inventārio de 182.7 (Maço 39), traz implícita a referência de uma livraria.considerável, composta de "104 livros latinos e espanhois grandes e pequenos velhọ". Manoel Marques Aveiro, 1835 (Maço 56), tinha uma "Estoria completa de'Portugal em 16 volumes por Mr. de. La Cled", um nada convencional "Manual de engenharia", um exemplar da "Cronica de D. Pedro I rei de Portugal" e um raríssimo "Balão aos abitantes da lua", provavelmente livro de ficção, alēm de"2 folhetos truncados de Novo Castro". Antonio Martins Barbosa,'1836 (Maço 57), cra leitor 
opcional de Ciências Humanas, e em sua livraria destacam-se "10 tomos Historia geografica", "2. tomos Historia romana", talvez a obra de Tito Lívio, trad. por Josê Vitorino Barreto Feio (1782-1850), publicada em 1829 e uma "Noticia mitologica". O Dr. Manoel Antonio da Rocha Faria, 1836 (Maço 58) era leitor de obras jurídicas, mas há em seu inventārio livros destacados como um "Projeto de codigo comercial" e um já conhecido "Rezumo da Historia dos Estados Unidos da America". Hả, na livraria, ainda, "2 volumes Corografia brasilica", certamente a obra de Ayres de Casal Corografia brasilica ou relação histórico-geográfica do Reino do Brasil, editada no Rio de Janeiro, pela Impressão Rëgia, em 1817.

Ainda no $1^{\circ}$ Cartório de Porto Alegre, documentação existente no Arquivo Público do Rio Grande do Sul, destacam-se nesta nossa amostragem desde Maria da Penha da França Franciony, 1837 (Maço 60) com seus inespecificos "5 livros de varias obras" a Custódia de Almeida Castro, 1838 (Maço 60) com suas "Leçoens do comercio" e "17 livros destruncados". Joaquim Coelho das Neves, 1838 (Maço 61) tambëm comparece, tendo sido levantados em seu inventário uma "Postila do comercio", um "Guarda livros modernc em 3 volumes", uma "Historia franceza em 7 volumes", alëm de "8 livros de autores diversos" e "9 folhetos em broxura". Seguem-se Manoel Pereira da Costa, 1838 (Maço 62) com "3 livros", sem identificação de matéria ou autoria e Maria Josepha Barreto Pereira Pinto, 1838 (Maço 62) que tinha "6 livros de Historia destruncados". Ana Cândida Vieira de Camargo, 1839 (Maço 62), alinhava entre seus bens um "Catecismo geogr.", "Atlas ele- 
mentar", "Viagens do BR por horster", um "Atlas moderno", uma "Arte da guerra em 3 volumes", "Vida de D. João de Castro", "Vida do principe Eugenio", "Historia de Theodosio, o Grande", "Historia universal por Millot 9 volumes", "Hist. de Nap. ou a campanha. da Russia 4 vol." e uma "Corografia. brazilica em 2 volumes" de Cazal, ao lado de obras como "Tratado de tatica" e "Tatica de Bohan em 2 volumes", "Principios de economia politica" e "Liberdade dos mares", "Sistema da Natureza em 4 volumes", "Espirito do despotismo" e "Diario de S. Helena em 8 volumes".

Hâ títulos bem diversificados e alguns a té que só aparecem nessas livrarias do Oitocentos em Porto Alegre e em outros municipios do Rio Grande do Sul. Dois volumes das "Memorias da cidade de Lyon pelo abade Montelon" e um "Manual do tabelião" aparecem no inventário de Luiz Caetano José da Rocha, 1839 (Maço 63). Um curiosíssimo folheto, "Instrução de cassadores" aparece no de João Antonio de Noronha, 1840 (Maço 64). Compõem a livraria de Luiz Manoe1. Gonçalves Lopes, 1840 (M. 65) "9 livros de diferentes obras", mas no inventário de Bārbara Correa da Câmara, 1841 (M. 66), surge um surpreendente "Mozêo brazileiro" (sic) e uma "Historia da Russia 2 volumes". A "Enciclopedia metodica de Diderot e D'Alembert" concorre, com. 3 volumes, ao lado de outras obras como "Viagem do Capitão Cook em 15 tomos", "Atlas historico chronologico de Lesage", "Memorias historico politicas das viagens "do conde Ferrier 2 tomos", no inventário de Maria Eúfrazia da Silveira, 1841 (M. 67), que conta ainda com livros de "Historia de Pọtugal só 14 tomos 
comido de traça", uma "Historia do Brazil em 10 tomos" e "0 pregoeiro luzitano em 4 tomos", completados com a "Viagem de Platon a Italia em 3 tomos". Manoel José Esteves, em 1843 (M. 78) tịnha inventariados um "Tratado de navegação", um livro de "Logaritmos", "24 folhetos diversos", "Taboadinhas de redução" e."5 Cartas geograficas".

O inventārio de Francisco Dias Moreira, 1844 (M. 78) traz uma obra curiosa, de identificação nada fácil, um "Dicionario de termos técnicos da Historia Natural". E também um "Dicionario de termos tecnicos de Geografia portatil em italiano", "6 volumes Dicionario universal em francez" e inusitados "2 volumes Le Proprietaire architetique de Urbain Vihy". Um "Nouveaux elements de Geographie", um "Atlas geografico des enfans", ao lado de "2 volumes Opusculos chimicos e fisicos em francez". Há, também, um "Tratado do conhecimento e cultura dos jacintos", e mais outros títulos, num total geral de 157, que merecem uma atenção especial, particularmente para predominância da língua francesa e face à amostragem de um leitor dedicado em especial às Ciências $\mathrm{Na-}$ turais. Completam o inventário de Francisco Dias Moreira, de 1844:

2 volumes Agriculture complete ou l'arte d'amilia... les terres

L'Agriculture simplifiee selon les regles des anciens

Essai sur le, blanchiment des toiles

Education des enfans

Essai sur l'ami.tiation des terres

3 volumes Lettres d'une mere a son fils 
Suite de l'Ami des enfans

L'Ami de l'adolescentes

Aritmetica de Bezout

2 volumes Le parfait negociant

Elementos de comercio

Essai sur le commercie de Rugne

El secretario de Banco em francez e espanhol

Nova escola para aprender a ler,e escrever e contar

Folheto A liberdade dos mares ou o governo inglez

Historia de Napoleão por Ardant

Historia de Portugal restaurado

Rezumo historico do Brazil àtë 1828

Catecismo historico por Fleury

Biblioteca dos teatros

Memoria sobre o restabelecimento da provincia do Espirito Santo

Relação dos festejos do Rio de Janeiro pela acclamação de D. João VI - fol he to

Finalmente, completando o perfil de leituras oitocentistas no Rio Grande do Sul, atē o ano limite de 1850 e referente ao Cartōrio do $1^{8}$ ofício de Porto Alegre, temos, com Manoe1 Antonio da Costa Guerreiro, 1844 (Maço'72), uma "Postila sobre o comercio", um "Atlas geografico", um "Sistema da Natureza 2 volumes", "Meditaçoens sobre os romos dos imperios", um "Monarcha perfeito", um "Compendio scientifico para a mocidade", "Combinaçoens sobre cambio", "Regras da praça" "um periỏdico famoso dos começos do século XIX na Bahia, "Capião brasileiro, 4 folhetos", que vem a ser, na verdade, "O campeão brazileiro". Periódico mensal, político, histórico e literārio. Bahia, viūva Serva e filhos, 1830, $\mathrm{n}^{8} 4$, alcm de "Diversos folhetos em brochura". Com o Brigadeiro. Manoel da Silva Freire, 1845 (M. 73) temos "88 
folhetos muito velhos" e "44 livros encadernados". Com Gaspar Fros da Silva, 1846 (M. 76-A), temos um "Gabinete historico", um "Atlas moderno", uma "Historia dos judeos", um "Rezumo da historia do Brazil", (talvez a obra de F. Denis, Résumé de '1' Históire du Brésil), um "Guarda livros moderno", uma "Arithmetica de Santos Carvalho", uma obra raríssima com - título de "Ideas geraes para os.meninos" e os convencionais. "Folhetos diversos". Finalmente, com Hermano Cordes, 1847 (Maço 76-B), temos "28 volumes impressos", inventariados com a costumeira incompletude de dados pelos escrivães.

Do Rio Grande do Sul passamos ao Maranhão com a documentação pesquisada no arquivo do Tribunal de Justiça, em São Luiz. No inventário de Joaquim Clemente Duarte, 1840 , encontramos anotados "51 volumes do Viajante universa1", "2 Almanak", "3 Mentores liberais", um "Folheto foral de Lisboa", um "Perfeito pedagogo", una inusitada "Estoria da Tartaria", uma "Vida de D. João de Castro", uma "Escola politica", um folhe to "Memorias de Ioureiro", que parece ser Memo-

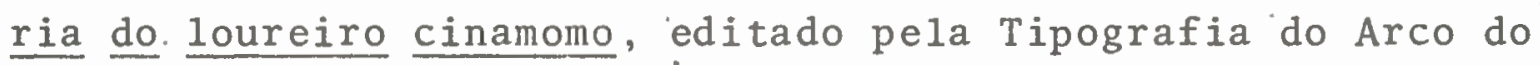
Cego. Registra-se também um original manuscrito, embora sem muita notoriedade, do Desembargador José da Silva Loureiro Borges da Camara, "Memoria sobre a agricultura do Brasil. Por fim, entre um "Folheto dos sebastianistas" e um pouco frequente "Estatuto do Colegio de Mafra", o restante da livraria de Joaquim Clemente Duarte, de São Luiz do Maranhão, revela um leitor de obras devocionais e literärias.

Do Maranhão ao Cearā, onde pesquisamos no Arquivo Pü- 
blico Estadual em Fortaleza, O inventärio do vigärio do município de Fortaleza, Reverendo Manoel Ribeiro Bessa de Holanda Cavalcante, 1839 (Pac. 18), entre um "Dicionario de Moraes 2 volumes", uma "Constituição do bispado" e um "Flos sanctorum 2 volumes", registramos o montante inespecificado de "115 volumes de diversas obras tanto em portuguez como em latim". No inventärio do padre Manoel Severino Duarte, também de Fortaleza, 1849 (Pacote 161), encontramos "O Federalista", periōdico pernambucano editado por volta de 1831 por. Antonio José de Miranda Falcão na Typ. do Diário.

Em Alagoas, no Arquivo Público do Estado, no inventário de João Joaquim de Oliveira, 1839, do município de Porto das Pedras, registramos entre uns poucos livros os "Anaes das sesmarias" e "Varios Curços Politicos" (sic), alëm das tradicionais obras de Medicina, Letras e Linguística.

Em Sergipe, mais precisamente na cidade de São Cristóvão, o Cartório do $2^{\circ}$ ofício ainda concentra boa quantidade de documentação referente ao século XIX. 0 inventārio de Manoel Clemente Cavalcante de Albuquerque, 1826, descreve uma expressiva biblioteca, onde se destacam, especialmente, "3 volumes dá Riqueza das naçoens", certamente a obra de Adam Smith, que veio a tornar-se a bíblia capitalista e cuja identificação original é An enquiry into the Nature and causes of the wealth of nations A Imprensa Régia fez uma tradução brasileira, em 1811, por Bento da Silva Lisboa. Uma "Economia politica de Ganilh em 2 volumes", um livro de "João Baptista Economia 2'volumes", que. deve ser Jean Baptiste 
Say, economista francês; uma "Vida de Washington", uma "Historia de Carlos Quinto 4 volumes", uma "Historia dos Tratados de Paz" e mais

\author{
Benjamin Constant Curso de politica 12 volumes \\ os judeos no decimo nono seculo \\ 2 volumes Politica da Europa \\ 6 volumes Historia da França \\ Goldsmith Historia da Terra 8 volumes \\ Analyse do espectador \\ Historia da Inglaterra 2 volumes \\ Historia da Revolução de França 11 volumes
}

No mesmo cartório sergipano, no inventário de Justino José Lisboa, 1845 (Pacote 13, Cart. 29 Of. S. Crist.), registra-se uma "Aritmetica de Bezout". E "4 livros" no inventārio do major João Correa, 1829 (28 of., pacotilha 6).

Ainda de Sergipe, no Arquivo do Judiciärio, em Aracaju, localizamos um curioso "Folheto de plano para um navio merçante" no inventário de Pascoal de Sousa Neri, do município de Estância, cartório do $2^{9}$ ofício, 1843 (Pacote 36).

$\mathrm{Na}$ Bahia, começamos pelo inventário dos bens do Brigadeiro Manuel Pedro de Freitas Guimarães, nos anos de 1824/ 1830 , documento feito em. vida ainda do brigadeiro, interposto judicialmente e recolhido como louco ao Hospital Militar da Bahia. Os inventariantes foram os curadores João Pereira da Costa e Gonçalo José Rodrigues. No documento, da Capital, encontrado no Arquivo Público do Estado da Bahia, encontramos registrados "43 livros muito usados, e de diversas obras". 
(ARQUE B, 02/98/143/8, Capita1).

Dos documentos do município de Cachoeira que estão no Arquivo Público, em Salvador, destacamos, no inventário de Francisco José de Melo Lobo, 1819 (ARQUEB, 2/934/1403/4) um livro de "Gait de credito 1 tomo obra inteira". De Cachoeira, tambëm, è o inventärio de José Dias de Afonseca, 1821 (ARQUEB, 02/936/1405/15) com livros predominantemente de Direito, mas com indicação de outras leituras como "1 tomo de Escola Mercantil, em broxura". a obra 'editada por Fr. Veloso na Typ. do Arco do Cego e anotada como "1 tomo de Alographia dos Alkalis fixos obra de Francisco Jozé Mariano" e "1 tomo de Dicionario de Agricultura em 4"", "1 tomo de Anseid de Commercio", "1 tomo de Stracha de Mercatura", "3 tomos de Cartas Fizico Mathematicas em $8{ }^{\circ "}$, "1 tomo de Curso Mathematico", "1 Fazendeiro do Brazil em $4^{\circ}$ e broxura", (não se pode ter certeza se é a edição de 1798-1806 5.t. $11 \mathrm{v}$. A BN tem edição incompleta dessa data mas in $8^{\circ}$ ), "9 tomos de Annaes das Sciencias e das Artes em broxura", "5 tomos de Cours de Physique": No inventário de Anselmo Dias, 1834 (ARQUEB, 02/964/1433/6), a anotação insó1i de "Huma estante pintada de vermelho com alguns livros já truncados".

Da documentação relativa a Cachoeira existente no Arquivo Regional da própria cidade no recôncavo baiano, encontramos, no inventário de Manoel Bernardino Alvares da Silva, de 1812 (Arq. Reg. Cach., 01/30/30/246 a 251), "1 pouco de livros velhos sem valor" e no do Pe. Aleixo Alves Maciel, do distrito de Santíssimo Cor. de Jesus do Pedrão, 1813, "1 
Livraria e 3 Breviarios" (Arq. Reg. Cach.; 01/93/93/782 a 796).

Os documentos da comarca de Salvador estão todos no Arquivo Público. No inventário de João Pinto de Sousa, 1836 (ARQUEB, 05/1962/2434/07), a anotação "Quatro livros nauticos usados". No de Manoel Gomes de Almeida, 1849 (ARQUEB, 04/ 1624/2093/03), registrann-se "Diversas obras de que se compõe a livraria". Manoel Antonio de Silveira, em 1849 (Id, 04/ 1624/2093/01), tinha "Dois livros Tractado da navegação, hum no idioma Inglez, e outro em Portugues" e "Tres mappas geograficos hum maior, e. dois menores", constituindo os ünicos livros de que dispunha o inventariado. Joaquim Antonio de Araújo, 1849 (ID, 04/1683/2153/24), tinha, alêm dos clássicos, um Breviário "e outros livros muito velhos e traçados", "Quatro Arithimeticas velhas" e "Doze exemplares de Escolla Brazileira, em broxura". E Antonio Gonçalves de Albuquerque, $185^{\circ}$ (ID, 03/1472/1941/40) tinha "3 tomos de Kesumo Chronologico" e "1 tomo de mapa do tido resumo".

Uma das maiores bibliotecas desse Oitocentos brasileiro vem a ser a do inventariado José Barbosa de 0liveira, 1824, de Salvador (ARQUEB, 02/100/147/02). São cerca de 465 títulos de obras as mais diversas e certamente mais de 1000 volumes. Predominam, como de häbito, as obras de Direito, a evidenciar, talvez, a formação do finado. Fora das categorias específicas de Direito, Medicina, Letras e Linguistica e Religião, anotamos os títulos seguintes: 
Defeza dos rios de Levante

in folio Colegio abreviado

Estatutos da ordem de Christo.

3 volumes Estatutos da Universidade

Instruçoens das minas

Histoire de Henry quatri cima

Epitome de Faria

In folio Pensioni de Lectione et condit

Re _are Observationis practicas

Synopsis chronologica

5 tomos Memoires sous le jacobinisme

2 volumes Verdadeiro methodo de estudar

3 volumes Mappa de Portugal

4 volumes Traitez de l'études

Histoire des Flagelhans

Scisma de Inglaterra

Discurso sobre a inutilidade dos espunsorios

...tique des Flagellans

La vie du Pape Clement XIV

Auctoritë du Roi

Marca de concordia

9 tomos Dictionnaire historique

3 tomos Institution politique

12 volumes Geographie de Naise..t

16 volumes Histoire romaine

Dictionnaire geographique

Lambertini Institutiones economica

5 tomos Deducção chronologica

Colleç̧ão dos jacobeos segillistas

2 tomos Histoire Universelle

2 tomos Solozano Politica Indianna

Portugal renascido (Historia de Port. renascido)

Zachi De salario

26 tomos Dictionnaire des sciences

3 tomos Negra controversia

Stracha De mercatura

2 tomos Mercuriali legitima 


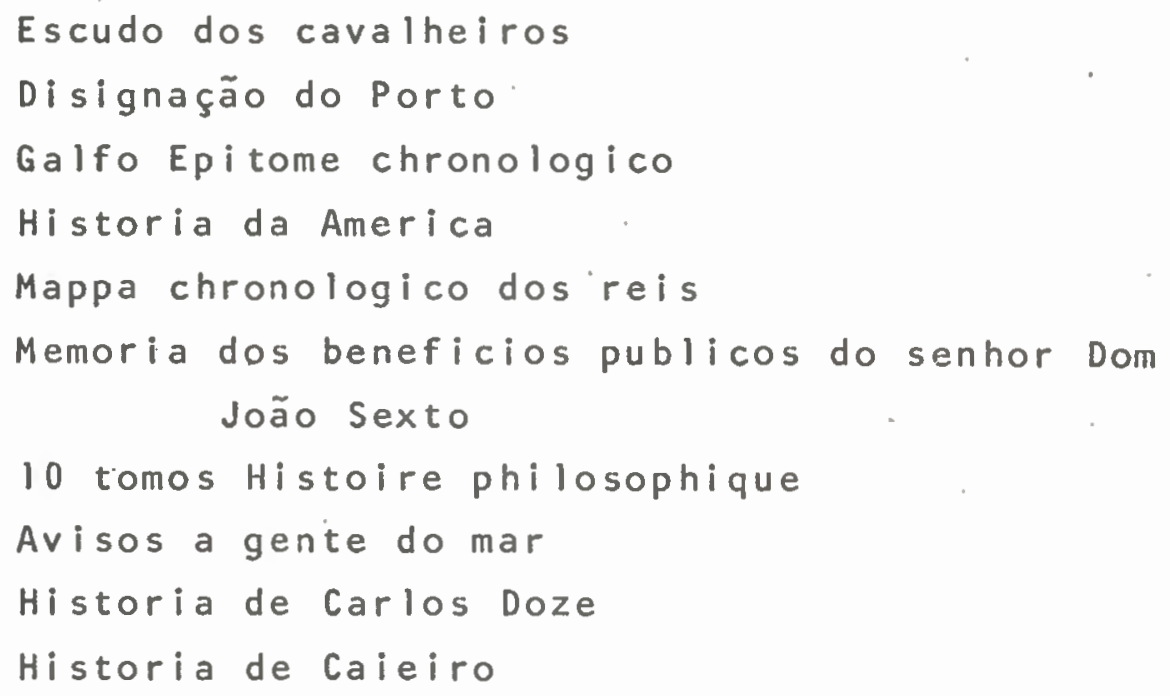

Destacam-se, dessa relação, alguns títulos, como os Estatutos da Universidade de Coimbra e Dedução cronológica e analítica do estado da Universidade de Coimbra, de José de Seabra e Silva (1732-1813), editados em 1768, Lisboa, Migue1 Manescal da Costa, obras estimuladas pẹla Junta de Providência Literária, do regalismo pombalino, peças responsáveis pelo desaguadouro das reformas operadas no ensino público nos domínios do reino de Portuga1. Destaque também para a obra de Manuel de Faria e Sousa (1590-1649), Epitome de las historias portuguesas (1..ed. 1628), para o 1 ivro de João Batista de Castro, polígrafo português (1700-1775), Mappa de Portuga1, esćrito sob o pseudônimo de Custódio Jesam Barata (autor tambēm de um Espelho da eloquência portuguesa) e, fị-. nalmente, o livro de Sebastião da Rocha Pita (1660-1738) História da América portuguesa, cuja primeira edição data de. 1730 .

Da Bahia para o Rio de Janeiro, vamos encontrar un Livro de Espölios dos Monges do Mosteiro de São Bento, desde 
fins do século dezoito atẻ o ano de 1882. Na referida peça documental, conforme jä foi assinalado, localizamos até um inventärio de Gaspar da Madre de Deus. A predominância óbvia é de livros de Teologia, livros de horas e de disciplina mística, como é próprio das ordens de, recolhimento e ascese. Mas no inventärio do Dr. Luciano do Pilar, sem data registrada, mas seguramente entre os anos de 1802 e 1804 , anotamos um perfil eclético de leituras, com obras de Linguística e Filosofia no meio da vaga devocionäria. Assim, registramos um "Elementos da Historia por Pedro José da Conceição", "Revolutions de Portugal" (a obra de Veṛtot, por certo), uma "Instrução para bem estudar", uma "Hiistoria dos protestantes", uma "História romana" (talvez de Tito Lívio), "Eleméntos da historia 9 volumes", "Politica moral 6 volumes", "Historia do reino de Aragão", um surpreendente "Elementos das construções", uma "Biblioteca do Mundo", "Noticias de Bento: Joze Labré" e uma "Arte pratica de navegar" (certamente a Arte pratica de navegar, e roteiro das viagens e costas marítimas do Brasil, Guiné, etc. (1699) de Manoel Pimental $(1650-1719)$.

No inventário do Fr. Jose da Madre de Deus Rego, de 12 de outubro de 1804, anotamos também "Alguns tomos avulsos da História romana" (novamente Tito Livio) e uma "Republica romana", uma "Geografia moderna de Lacrois" (sic) e "Revoluçoens de Portugal de Vertot", um "Correio geral da Europa" e .uma "Historia das revoluçoens romanas 2 tomos". E mais: "Cartas de hũa may a seu filho", "Dicionario geographico", "Revoluçoens da Suecịa 4 tomos", "Espirito da encyclopedia 7 
tomos", "Deducção chronologica 5 tomos" e, finalmente, "Relação das honras funebres d'el rey D. João 5 '".

o Padre Mestre Jubilado Fŕr. José de Jesus Maria Campos, inventariado em 18 de maio de 1807 , tinha registro de uma boa estante, incluindo a "Chronica de Cister", de Bernardo de Brito, autor frequente em todo o Brasil Colonial, com vārias obras e sucessivas edições dos sềculos XVII e XVIII, como é - caso dos "Elogios do rei de Portugal". "Descripção do Porto", "Barbadinho Methodo de éstudar" (o livro de Verney), "Diccionario historico 2 tomos", "Revoluçoens romanas 2 tomos", "Historia romana de Rollin" (Charles Rollin, hist. fr:, 1661-1741), "Compendio de geographia", ao lado de obras mais ou menos incomuns nessas livrarias brasileiras, como uma "Bibliotheca historica", uma "Escola de estudos 3 tomos". Já o Fr. Domingos da Conceição Sanches, cujo inventärio è de 3 de julho de 1808 , tinha anotados "Dois livros velhos" e "Hum livro de geographia". E o Fr. José do Bom Sucesso Alvarenga, em inventário sem data, tinha, inespecificados, "Livros varios 106 volumes"." "Dois livros pequenos" e "nove livros", além de "Hum jogo de Breviarios". Com a mesma ausência dé especificação são os "Quarenta e oito livros" no invv. do Fr. Antonio. Joaquim dos Prazeres, igualmente sem data.

No inventärio do Fr. José Ignacio de Santa Maphalda, em 17 de maio de 1820, uma "Historia do Brazil 7 volumes in 8:" (provavelmente a de R. Southey ed. cm 1810 os dois ültimos v. sendo em 1817 e 1818 ou a de Andrcw Grant, de 1809 (London, Henry Colburn). A de James Handerson ê de 1821). 
e "Viajante universal 5 volumes. in $8^{\circ "}$ e uns pouco conuns "Ensaios sobre a extensão in $8{ }^{\circ}$ " (sic). No de Fr. Francisco de S. Thereza Machado, na época D. Abade, falecido em 30 de julho de 1825, "Huns poucos de livros". No de Fr. Mariano de Santa Bárbara, faleçido na "povoação de Nazareth, provincia da Bahia", em 16 de abril de 1826, um "Roteiro brasili-. co" (seria o Roteiro do Brasil, de Pero Lopes de Sousa No de Fr. Francisco de Paula de Santa Gertrudes Magna, falecido em 3 de novembro de 1833, uma grande coleção de sermonários e de obras teológicas, mais uma "Politica de Bielfield 3 volumes", um "Dicionario geografico 2 volumes", além de um "Volume de diferentes materias truncadas". E no inventārio do Fr. Francisco Ignacio de Santa Clara, falecido em 6 de janeiro de 1834, aparece "Huma Aritmetica de Besout".

Há ainda livros que escapam a um compreensivel determinismo teológico nas livrarias dos monges beneditinos do Rio de Janeiro. Embora poucos, vão aparecendo certas aberturas de leituras em outros campos do conhecimento. No, inventário do Geral Fr. Pedro do Nascimento, de uma casa dá Ilha do Governador, falecido. em 8 de janeiro de 1838, "1 Jogo Historia Universal 'de Millot". O Abade Fr. José Polycarpo de Santa Gertrudis, num inventärio sem data, entre 1838 e 1845 , detinha seguramente a maior das bibliotecas oitocentistas do Mosteiro. E também a mais rica das livrarias dos monges, com titulos os mais variados. Ali anotamos uma "Enciclopedia de.Filicio, folio, em 58 volumes", um "Atlas geograficas 2 volumes" (șic), uma "Historia natural 2 volumes", uma "Dita por Quintiliano 2 volumes" (sic) não seria Plínio?), e 
Sistema de Chimica por Fourcro il volumes (sic) Dicionario methologico (sic)

Fernão Mendes. Pinto

Butanica

Compendio de geografia 2 volumes

Taboas de logaritimos por Francisco Callet

Historia cronologica de Basoens por Vallemont Novo Dicionario de historia natural 18 volumes Dicionario historico 20 volumes.

Historia natural dicionaria

Castrolographia 4 volumes

Elementos. de Chimica por Chapilol 3 volumes

Elementos de Deologia por Tracis 4 volumes

Elementos de Giena por Mello Franco

Geografia . compendio

Historia de Portugal 16 volumes

Dicionario de historia natural 2 volumes

Mathematicas mecanicas compendio

Estudos da natureza por Sampierre (sic)

Lições de natureza por Felice 4 volumes

Euclides geometria

Dicionario geografico de Vosien

Historia de Simão de Nantoa

Fazendeiro do Brasil 3 volumes

Destaque para a edição do Fazendeiro do Brasil coligida $\underline{\text { de }}$ memórias estrangeiras por Fr. José Mariano da Conccição Vellnso, Lisboa,1798-1806,5 t. e $11 \mathrm{v}$. in $8^{\circ}$ e provavelmente da obra de Hist. de Villas Boas e Sampaio (1629-1701); Nobiliarquia portuguesa. tratado da nobreza hereditária, politica 1. ed., Lisboa, Of. Francisco Villela, 1076 in 4\%. Hä cdições 
de 1727, of. Férreiriana; e 1728, por Filipe de Sousa Vilela. Mais

Engenheiro portuguez por Azevedo (livro de Azevevo Fortes)

Ensaios da historia filosofica por Demiron 2 vol. Mapa geograficos = um maço

Dicionario de sciencias e artes 3 volumes

Imperio do Brazil por Labonense

Estudo de geografia

Atlas geograficos (sic)

Elementos de Fisica 3 volumes

Elementos ou principios chimicos

Teoria da natureza humana por Lacavile

Nobiliarchia portugueza

Compendio de Botanica 2 volumes

Viagens. Anaxarces 9 volumes (sic)

Lineu Filosofia natural 2 volumes

Geografia moderna 15 volumes

Bisu (sic) Arithmetica 2 volumes

Biblioteca portatica (sic)

Generos e especies de plantas

Manual de agricultura

Dicionario da historia natural 6 volumes

Filosofia chimica

Dicionario da historia natural 17 volumes

Novo dicionario da historia natural T. 24

Deducção cronologica de siabra 5 volumes

Élementos, da historia antiga por Volemont (sic)

4 volumes.

Livros truncados 34

Grande coleção de bruxuras 34

Sem dúvida, uma considerável livraria de amplos títulos, com destaque para Religião, Letras e Linglística e Ciĉncias naturais. Já o inventário da Livraria do Fr. Manoel $\mathrm{Na-}$ tividade Lemos, com data de arrematação em 26 de maio de 1845, 
traz um "Compendio d'Arithmetica", uma "Historia da Philosophia", uma "Historia da Inglaterra", um surpreendente "Compendio scientifico brasileiro" e "Huma collecção de folhetos", alëm de um "Almanak geral", "Noçoens de geographia" (seria a obra Breves noções de geogr. univ. etc., de 1845?) e "Os varoens ilustres" (talvez, os Retratos e elogios dos varões e donas que ilustraram a nação portuguesa, de 1817) e "Costumes dos romanos". O Irmão Paulo da Conceição Moura; com inventārio de data provável entre 1845 e 1853 , tinha "9 volumes Revista trimensa1", "5 volumes do jovem viajante", "2 volumes Diccionario geografico", e "Hũa porção de folhetos". Finalmente, o Irmão Leigo Fr. Francisco de Santa Escolástica, com inventário de 1845 a 1853 , tinha "O estensor brasileiro" e "12 números do Panorama". "0 Panorama",jornal literário e instrutivo da sociedade propagadora des conhecimentos úteis (vol. 1, publicado de maio a dezembro de 1837, Lisboa, Typ. da Soc., 1837) ou revista literária (1837-1868) em que Herculano era um dos principais redatores e onde publicou trechos de sua obra. O Irmão Francisco de Santa Escolästica tinha, ainda, uma "Vida de D. João de Castro", "Eternidade memorial", uma inusitada "Historia geral dos añimaes", uma "Discrição tipographica (sic) do Porto" (Descrição topográfica e histórica da cidade do Porto, obra do Pe. Agostinho Rabelo da Costa ( -1791), doutor em Tcologia e um dos historiógrafos portugueses do século XVIII). Por fim, "Quadros historicos de Castilho" (na verdade, Quadros da história de Portuga1, de Antonio Fcliciano de Casti. 1 ho (1800-1875), publicado cm 1839), al cm de um "Mappa de 
Poirtugal e sua planta", uma "Historia de Portugal", "alguns volumes do Universo pitoresco" e "Hum volume do Museu pitoresco".

Sem dúvida, um perfil de leituras considerāvel, numa ordem monástica. Existe ainda una singular caracteristica na partilha dos bens dos beneditinos. A meação obedecia a uma divisão curiosa que incluía inicialmente o mosteiro como o primeiro beneficiário. Para a livraria do próprio mosteiro sempre ficava uma terça dos beins. Tảivez isso, em parte, explique a enorme quantidade de livros incorporados à biblioteca dos beneditinos, no Rio, depois do catálogo organizado por Gaspar da Madre de Deus, no século XVIII. Além da predominância religiosa dos livros dos monges, nota-se, pela avaliação desses inventários, uma preocupação mais abrangente, de inclusão de títulos em Histốria e Geografia, Ciências Naturais e Curiosidades.

Essa mesma predominância de assuntos religiosos, abrindo, entretanto, para outros títulos, vamos encontrar nos documentos pesquisados no Arquivo Nacional.

E igual, contudo, a dificuldade e imprecisão em identificar os livros no Rio de Janeiro. As anotações, com dados incompletos, vêm em ordem estatística por autor, matéria ou pretenso título. No inventärio de Eugenio José da Silva Teixeira,1834 (Cx. 1134, n. 9289), "Livros velhos e com falta de folhas". No do Conselheiro José Joaquim Pereira Leite, 1835 (AN, CX. 4171, n. 2068) aparecem "13 livros de diferentes autores muito uzados e antigos". E no de Bernardo de 
Souza Dias, 1845 (AN, Cx. 3605, n. 2293), encontramos, à f1. - $17 \mathrm{v}$ do documento, a seguinte anotação: "23 livros inclusive dois folhetos contendo Medicina, Historia, Politica e Gramatica portugueza". Percorrendo as follhas deste documento, porém, na seção concerneṇte à arrecadação, f1. 23, encontramos aiguns titulos que talvez devam tratar-se dos mesmos anotados anteriormente, em que pese virem sem indicação de matéria ou autoria. Assim, achamos um "Compendio historico (talvez a obra polêmica do Inst. de Prev. Lit. contra os jesuitas de Coimbra e uma "Escola de politica", um "Compendio das epocas" mais dois outros', que são "Applicações das moedas" e "Applicações da moral a politica".

O inventário do bacharel Domingos de Freitas Rangel, 1817 (AN, Maço 2298, n. 2426), jā traz algumas informaçōes um tanto mais detalhadas. Ali temos uma "Geografia", um "Euclides tomo $19 "$ - que deve tratar-se dos Elementos de Geometria de Euclides, filósofo e matemático grego (450-380) fundador da escola estocástica, cuja base fundamentál é a arte da controvérsia. 'Como avaliadores de bens e livros, aparecem Manoel Joaquim da Silva Porto e Manoel Mondillo, tratando-se o primeiro do célebre livreiro e editor cariocaportuguês, estabèlecido no Rio e cuja trajetória empresarial faz parte do desenvolvimento e evolução da tipografia e do comércio de livros no Brasil. No inventärio do Vice-Almirante Francisco Antonio da Silva Pacheco, 1827 (AN, maço 2298, n. 249.9), encontramos "4 tomos Viagens de ..ode", "4 Campanhas dos francezes em diferentes paizes", "8 muito estragados Gabincte historico", " Corographia do Brazil estraga- 
dos" (novamente a obra de Aires de Cazal), "2 Descoberta do Novo Mexico", "Historia do rey Dom Manuel" e "Economia politica $2 "$.

No inventảrio do cônego Antonio Francisco Gomes, 1827 (AN, Cx. 3633, n. 7), encontramos "3 folhetos de objeitos diferentes" e "Estatutos da capella do Rio de Janeiro". No do padre José Joaquim de Lacerda, 1831 (AN, Cx. 1126, n. 9336), "hum Atlas pequeno". No do cirurgião-mor Francisco Manoel Ferrão, 1805 (AN, Cx. 1126, n. 9329), a livraria típica especializada em Medicina e Cirurgia, mas com possibilidade e abertura para livros como "Revolução de França", alêm de uns poucos títulos em religião.

No inventärio de Francisco Manoel Pereira, 1838 (AN, cx: 4126, n. 1163), registra-se uma pequena livraria quase toda em nảutica e ciência matemática. Com exceção de uma. obra de "Medicina de Le Roy", a livraria se compõe de "5 tomos de diversas obras truncadas" e mais "Arte de navegar por Pimentel", "O manobreiro ou ensaio sobre a theoria", "Tratado pratico das manobras dos navios", "Makays navegator" e mais "2 tomos Curso de Mathematica" e "Taboa de logarithmos".

- O inventário de Maria Ângela Maciel, 1827 (AN, cx. 5279, n. 8706/07), traz "8 tomos Historia autor Pizarro todos novos e em bom estado", naturalmente as Memórias históricas do Rio de Janeiro e das províncias anexas à jurisdição do vicerei do Estado do Brasil, dedicadas à el-rei n.s.d. João VI, pelo monsenhor José de Souza Azevedo Pizarro e Araújo, editadas pela Impressão Regia e Nac. em 1820/22,9 t. em 5 v. in 
$4^{\circ}$. Mas os inventários no Arquivo Nacional revelam também algumas surpresas, não só em termos dos tĩtulos de livros apresentados, como ainda dos avaliadores. No documento da livraria do capitão Antonio de Souza Macedo, 1832 (AN, maço 491, n. 9589), encontramos um "Livro grande de ensino de cavallos" e um outro "Livro mais pequeno para se conhecer as qualidades dos cavallos". Fr. Theodoro José de Sá, inventariado em 1817 (AN, cx. 1118, n. 8566), tem uma livraria que sẹ compõe de três únicos títulos: "Piloto africano", "Arte de navegar" (talvez a de Pimente1) e "Folhetos de direito mercantil". O avaliador da livraria è um "artista nāutico" chamado Manoel José Pereira Maia. Mas, que seria um artista näutico em 1817? Um desenhista, um ilustrador um gravurista?

0 inventário de João Cespedes Barbosa, 1818 (AN, cx. 1118, n. 8579), aponta uma "Geografia brazilica 2 tomos em meio folio", uma "Memoria de Lord Wellington em 2 volumes" (talvez a obra editada pela Expressão Regia), uma "Istoria da America 3. volumes in 49!", um "Compendio sobre a siencia in 8\%" e um "Conhecimento da mitologia in 4\%". No de José de Azevedo Nunes, 1819 (AN, maço 188, n. 3732), um popular "Jogo de sortes": E o inventārio de João Mathias da Rosa, 1.834 (An, maço 119, n. 2384) registra "4 tomos de Thezouro de adultos", "10 tomos Historia do Brazil, faltando tomo 1", "6 tomos Ilha incognita", "3 tomos. Chronica do Imperador Clarimundo", obra de João de Barros (1. ed., 1522, novela de Cavalaria, uma variante ëpica do destino histórico de Portuga1. Clarimundo era Imperador da Hungria e Constantinopla 
e progenitor de Sancho, avô de D. Afonso Henriques. A nove-

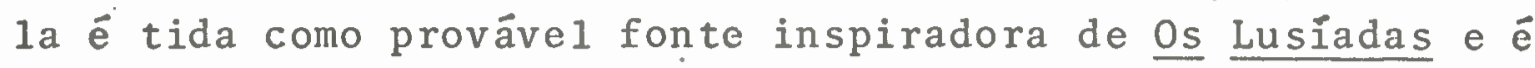
seguramente influenciada pelo Amadis de Gauia. A Crônica do Imperador Clarimundo foi editada, pela primeira vez, em Lisboa, Of. João de Barreira, 1522 e reeditada, sucessivamente, em 1553 ou $1555,1601,1742,1791$ e 1843. Completa a estante "6 tomos Viagens de Antenor" e "5 volumes Elementos da Historia". Já o inventário de Leocadia Rosa do Bonsucesso, 1830 (AN, Cx. 898, n. 229), continha "2 Duzias de taboada", o que pode revelar indícios de que a inventariada fosse comerciante ou viúva de comerciante.

Por fim, no inventário do cônego José Luiz de Freitas, feito em 1847 (AN, Cx. 4171, n. 2063), temos um "Elemens de 1'histoire 5 volumes", uma "Histoire d'Espagne et de Portuga1 2 volumes", uma "Historia generica 11 volumes (faltando volume 1)" e mais, abrangendo Histōria e Política, as "Actas das sessões das Camaras", "Tactiques des Assemblées 2 volumes", "Portrait politique des papes 2 volumes", "Theorie des revolutions 4 volumes", "Concordat de l'Amérique avec Rome", "Ca thecismo historico", "Langelia, Introduction des sciences 2 volumes" e "Revolution française, truncada 2 volumes". São avaliadores dos livros do cônégo. José Luiz de Freitas, os livreiros Antonio Innocencio Pimenta, Francisco José de Paula e Ignacio Theodoro Machado, que advertem para o estado arruinado da maior parte da livraria, declaração que se destina naturalmente à increpação do valor atribuído a cada título. 
Com base na contínua massa de informações oferecidas pelos inventários brasileiros do século XIX, o processo de leituras oitocentistas acentua e horizontaiiza uma certa preferēncia de assuntos ou autores correntes desde o.século anterior, embora em número bem maior e já evidenciado de títủios e matérias. Isso se observa nos lugares de maior índice de guarda documental do país, como o Rio de Janeiro, São Paulo e Minas Gerais. Muitos desses titulos, em quantidade nada desprezível e que enseja uma clara dimensão do interesse püblico em livros e temas de sua contemporaneidade, pertencem ao próprio século XIX, alguns, até, editados pela Impressão Régia implantada no Rio de Janeiro em 1810. Outros, editados em Lisboa e muitos outros, ainda, editados na França completarão um escorço da bibliografia disponíve1. A tendência de leituras, extra aquela já observada que privilegia os assuntos doutrinários, especializados ou na área de Lẹtras e Filosofia, não parece afastar-se muito daquela apresentada no curso deste capítulo, como a opção por leituras das ciências modernas, onde irão pontificar disciplinas como a Política, a Economia e a Administração, além das consagradas História, Geografia, Ciências Naturais e Arte Militar. Avultam, neste particular, um número considerável de autores e de títulos que acrescentam um dado seguro de mais movimentação e variedade nos campos das novas Ciências.

Assim, no Rio de Janeiro, não constituiria novidade o aparecimento de títulos como "2 tomos Principio conservador, por Mizard" ou "Dicionario analytico'de economia politica, por Ganilh", ou "Industria francesa,por Chaptal", ou, ainda, 
"2 volumes Riqueza comercial, por Simoens", entre outros, no inventário do Comendador Antonio Silva Teles, 1840 (AN, Maço 469/6964). Também não surpreenderia, a esse tempo, a circulação de obras como "Tables of several european enchanges", em 2 volumes, editado em 1802, presente no inventário de Manuel de Souza Ribeiro Guimarães, de 1829 (AN, Maço 469/8949), numa livraria que reitera a tendência de títulos conforme vimos e que apresenta a peculiaridade de ter como avaliadores, nada menos que o jornalista Evaristo Ferreira da Veiga, secundado por João Pedro da Veiga e outros.

Autores como Jéremy Bentham, De Pradt, Benjamin Constant, Duvernet (com sua "Histoire de la Sorbonne" em 2 volumes), Beauchamp ("Memoires sur 1a Revolution de France", em 2 volumes'), Benjamin Franklin, vão pontuar ao lado de outros, Jean Baptiste Say, Sismondi, Charles Darwin, Euclides, Bezout, Lineo, Buffon, jā célebres desde o Setecentismo, nas livrarias do século XIX brasileiro. Aqui se irá processando um aumento extraordinário de interesse em matérias constitucionais, em assuntos da Política internacional, da Sociologia, da Educação, além das matérias já frequentes, como as assinaladas Botânica, Zoologia, Química, Física e Matemätica, com todos os seus já célebres autores. Nota-se, também, que vão se intensificando, aos poucos, os.títulos em In-. glês e, sobretudo, em Francès, quase esquecido o rigor axiológico outrora concedido exclusivamente ao Latim - pátria linguística universal para o tratamento de quase todos os assuntos. Alguns títulos vão se caracterizando como curiosos ou surpreendentes nesisas relações, como a "Historia cri- 
tica do magnetismo animal", em 2 volumes, ou um "Estudo de guitarra", que aparecem no inventário de José Antonio de Carvalho, 1833 (AN, M. 303/5594), no, Rio de Janeiro. 0 interesse pelo conhecimento de si mesmos enquanto pessoas integradas à nacionalidade, faz o leitor inventariado ter em casa um "Beauchamp Histoire du Brésil, 3 volumes", como no inventārio de João Mendes Viana, 1831 (AN, M. 2294/406), que ainda abriga questionamentos ou escrúpulos quanto à interpretação da ciência política de seu tempo, expressos em livros como "Morale apliquée a la politique", em 2 volumes, "De la responsabilité ministerielle" ou "Du principe conservateur", ou, ainda, o livro de Ganilh, "Du Pouvoir et de l'oposition". No mesmo documento, aliās, hâ um "Diccionnaire portatif del inginieur, edição 1768" e um "Guarda-livros moderno" que antecipam também um interesse do inventariado em cịências da experiência prática. Outro título diz meîhor da preocupação monetária na certa vigente, como expressa um "Tratado de dinheiro de cambio, velho".

Nisso seguramente se diferencia o século XIX de seus anteriores: a variação em número de livros e no interesse por novos' conhecimentos demonstrado pelo leitor. Em nümero, a propósito, sobretudo quanto mais avança em datas mais recentes até à primeira metade do período, vão aparecendo títulos e mais títulos muitos diversamente dos acentuados no século XVIII. Assim, reponta, no inventário de Luiz Achille Brunet, 1843 (AN, Cx. 2749/133) algo como "Noveaux elemens d'liygiens", em 2 volumes, de Charles Lande, e títulos inteiramente despercebidos no Setecentismo. Tamböm representa 
importância a circulação do jornalismo periódico, como o representado pelo "O Patriota do Rio de Janeiro", no inventário de Antonio Martins Bandeira, 1821 (AN, Maço 100/1904). Se tomarmos os títulos que ilustram essa decisiva mudança da órbita de leituras, diferentes das prevalências apontadas nos ramos da História, Geografia, Política, etc., apenas concentrados em ciências contemporâneas do inventariado, vamos reconhecer a incidência de livros e matérias novos como o "Tratado de Hidrodinamica por Bassent, in $8^{\circ}$ ", no inventärio de Ana Joaquina Lea1, 1814 (AN, Maço 916/4077) e o."Traité de 1'ornament des jardins", no inventárịo de José Coelho Massedeṛ, 1834 (AN, Maço 106/2020), ou, neste último documento, uma "Correspondence de D. Pedro premier du Brezil par Eugene de Monglave", uma surpreendente "Defensa de los pueblos", ou um "Tratado general de monedas, pezos, medidas y cambios por Martens". São, ainda, insólitos títulos como o "Tractado pratico dos paizes quentes", em brochura, no inventário de Florêncio Antônio Barreto, 1832 (AN, maço 427/8282).

Uma caracterização leitora pelo novo não se circunscreve apenas ao Rio de Janeiro, como também a Minas e São Paulo. Em Ouro Preto, no inventário de Pedro da Costa Fonseca, 1840 (Casa do Pilar, 19 Of., 112/1433), aparece um folheto "Instruç̧am para as eleiçoens", ou, um outro, "Relatorio da Comissão de verita das Prisoens do Rio de Janciro". O espírito enciclopédico não se evade de todo e, aliãs, amplia-se na direção de outros conhecimentos e outros tratadistas. D'Alenbert, no entanto, está presente no iṇventärio de Joaquim Ve11ozo de Miranda, de 1816, em Ouro Preto (19 Of., 34/380), 
como autor de um "Elemento da Muzica". Há, no mesmo documento, um livro com título curioso: "Predio rustico". No espaço de autores brasileiros, alguns vão mesmo se destacar, pela raridade. E o caso do "Compendio da Quimica de Torres Homem", que aparece no inventārio de Maria Francisca de Paula, 1845, de Ouro Preto (29 of., 44/491).

$\mathrm{Na}$ composição dos leitores de Minas Gerais, Mariana, talvez, não desponte bem enquanto representação do século XIX - valendo, mais, pelo aparato documental do século anterior. Alguns títulos, contudo, além dos que tornam circulares as ciências desde o Setecentismo, vão se destacar, como ẹ o caso de um "Dicionario da industria", que aparece no inventärio do bispo D. Fr. José da Santíssima Trindade, em 1935 (CSM, 19 Of., 130/2732), ou o do "Tratado sobre o relogio de sol", no inventário do padre Francisco Xavier de França, em 1828 (CSM, 19 of., 151/3176).

'Em sabarā, no inventārio de Tereza Gomes Gayo, 1806, encontramos uma "Arte de carpinteiro", o que, provavelmente, amplia o perfil do leịtor colonial brasileiro para matérias um tanto mais na esteira do senso prático. O interesse pelo noticiārio jornalístico ou um "Magazin da Universidade de Dublin" se acentua, com "Revistas periodicas de diversas colleçoens 5 volumes", conforme registra a livraria transcrita no inventärio do Dr. Ricardo Collier, um irlandês caprichosamente habitante das imediações do Rio das Velhas, falecido em 1841 (Sabarä, 19 Of., Pacote 71). O curioso de alguns títulos confunde até à ạtribuição das matêrias que. versam certos livros. Como descodificar, por exemplo, a in- 
formação de "Arte de Trilhantes varios", no inventärio de Valeriano Manso dos Reis, de 1842 (Sabará, 18 Of., pac. 75), ou de uma "Escola brasileira por José da Silva Lisboa", no inventärio do padre mestre Mariano de Souza Silvino, de 1844 (Sabará, $1^{9}$ of., pacote 76$)$ ?

Em Diamantina, a preocupação com matérias de Administração Comercial se presentifica em livros como "3 volumes Negociante inglez" e "2 volumes Mementos do comercio", no inventärio do brigadeiro Francisco Martins Pena, de 1818 (Diamantina, Biblioteca Antonio Torres, $1^{9}$ Of., Cx. 19). Outros são os interesses surpreendidos da análise da livraria de Felipe Neri Lopes, de 1836 (Diamantina, $1^{\text {9 }}$ of., Cx. 21), expresșos por títulos que vão de uma "Higiene de Rouviere" a um "Arte de tingir pelles", outro "Arte de dourar e pintar" e a um "Tratado da distilação", um "Cozinheiro imperial por Viarde", um "Cozinheiro real por Piert" e uma "Obra cozinheirạ". Também curiosos è o "Perfeito caçador com estampas, in 8\%" e o "Homem dos campos em francez, in 8\%", presentes no inventário de Caetano Lopes de Miranda, 1837 (Diamantina, $2^{q}$ of., Cx. 25).

Não menos surpreendente uma "Historia da revolução de Minas", no inventārio de Manuel Jủlio de Souza, de São João De1 Rèy, 1849 (SJ, $1^{\circ}$ Of., maço 13). Assim também um "Perfeito pedagogo, de meio $4^{\circ "}$ na livraria de Manuel Lins Sa1danha de Miranda, ainda de São João, 1807 (SJ, $1^{\circ}$ of., M-2). Surpresa igualmente um "Tratado dos escrupulos" inventariado com o coronel Simão da Silva Pereira, de 1830 (SJ, $1^{\circ}$ of.', S-1). Ana Pimenta de Moraes, de 1837, alinha, cntre "Livros", 
praticamente, uma verdadeira estante de partituras musicais, constando de "10 sinfonias por varios autores"; "5 overtures por varios autores"; "Missa com grande'orquestra por Antonio dos Santos"; "Missa com grande orquestra por Padre Joam Moreira"; "Mais credos, sinfonias, flautim, Estabat Mirter e outras musicas". (SJ, A-8). O padre Joaquim José Maya, inventariado em 1817 (SJ, J-4), tinha uma "Ciencia das pessoas de cortesia". Por fim, de São João Del Rey, ainda, o padre Joaquim Mariano da Costa, inventariado em 1823, tinha a obra de Fr. Gaspar da Madre de Deus, "Memoria da capitania de S. Vicente" (SJ, J-16).

Finalmente, por São Paulo, fechamos nossa amostragem da natureza do leitor colonial brasileiro a partir de títulos de livros extra os da predominância em ramos como Religião, Direito, Medicina e Letras. Serä mantida a mesma frequência, nessa perspectiva, de títulos em História e Geografia, Ciências Físicas e Naturais, mais a Química, a Matemática, a Economia Política, e os panegíricos, curiosidades, elogios ou anti-elogios históricos (em que reponta emblematicamente, a figura de Napoleão).

Começamos por Campinas, com documentos do Arquivo do Tribunal de Justiça, sob a administração do Centro de Memória da UNICAMP. O padre Jacinto José Pereira, inventariado

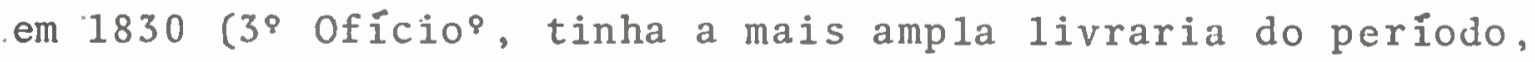
com inuitos títulos aqui considerados, em especial, nos campos da Zoologia, da Física, da Botânica etc. Títulos mais curiosos, entretanto, encontram-se na livraria do Comendador Francisco, Alvares Machado, de 1846 (UNICAMP, Arquivo 
Tribunal de Justiça, Lista 92): "Cozinheiro parisiense", "Idade critica das mulheres", "Manual de gravisseur" e "13 volumes Archivos das descubertas".

Em São Paulo, dos dọcumentos sob a guarda do Arquivo do Tribunal Judiciārio, o $1^{\circ}$ of do tenente-coronè Josè Marcelino Vasconcelos, 1813, com alguns títulos tambëm incomuns da voga nas livrarias oitocentistas. Hä um "Construction des noutes" e um "Machisses a vapeur", um "Manual de astronomia", "Manuaes do fundidor" e um curiosíssimo "Manual sobre estrada de ferro". Hä, ainda, uma "Escola fundamental" no inventārio de Antonio Floriano Alvim, 1823 (SP, Arq. Trib. Just., 19 Of., Cx. 105). Na 1ivraria de Antonio Marques Fortuna, inventariado em 1812, consta uma "Arte de brilhantes vernizes" e um raro folheto "Tratado do comercio de Portugal e da Rucia". (SP, Arq. Trib. Just., $1^{8}$ of., Cx. 146). O registro final do Oitocentismo: vai para o jornalismo periödico igualmente circular em São Paulo do século XIX, como demonstra a existência de "2 Magazine em inglez" e "Universal magasine" no inventärio do tenente-coronel Francisco Compton d'Elboux, 1816 (SP, Arq. Trib. Just., $1^{8}$ of., Cx. 173). 


\section{2 - Doutrinas e devoções \\ "o que lề livros espirituais, paga o dizimo a Deus; e o.que lê os profanos, paga o tergo ao diabo"}

. Nuno Marques Pereira (*)

Em vista dos documentos de fonte primária de que nos servimos, o perfil do leitor colonial é, em termos substantivos, concebido à luz da doutrina religiosa. Postos em cotejo, os dados da pesquisa demonstram um insuperâvel vigor das'leituras de caräter devocionário, místico, ascëtico ou dogmático. E isso desde o século XVII. Não parece diferente o que sucederia no universo mental do Quinhentismo, uma vez que inventários deste periodo, conquanto não indiquem a formação de bibliotecas, refletem, pela transparència de outros bens, a forte impregnação da natureza cultural cristã e católica, quanto mais incidente na equivalência de uma sóIida conformação medieval.

o Seiscentos brasileiro, como vimos, quanto a livros, estende a influência doutrinâria da Companhia de Jesus, como um salto do medievalismo para o espírito barroco, sem enunciar qualquer manifestação renascentista ou antropocêntri-

(*) Prólogo do Compêndio narrativo do Peregrino da América, in: Moralistas do seculo XVIII. Rio de Janeiro, $\mathrm{PUC} / \mathrm{C} \overline{\mathrm{FC}}, 1979, \mathrm{p} .21$. 
ca visível. Diverge da experiência colonizadora espanhola na América, justamente pela recusa ao conhecimento do imaginário, dos livros de fantasiosas aventuras em que, fica evidente, foram múltiplos e pródigos os leitores hispanoamericanos, colonizadores e colonizados. Aqui, salvo raras tolerâncias, o predomínio e o privilégio do ler será exclusivo de ministros da Companhia enquanto os poucos consorciados, tipos sociais formados à sombra da dominação EstadoIgreja, obviamente, serão seus êmulos. As poucas obras que escapam ao exclusivismo doutrinário - caso das Novelas exemplares, de Cervantes, Peregrinações, de Fernão Mendes Pinto, Ordenações do Reino, Tratado prätico de Aritmética, de forma explicita, conforme nossa àvaliaçāo dos documentos publicados pelo APSP - não seriam de molde a interferir na massa devocionária prevalente. E até poderiam ensejar um certo afervoramento místico, uma vez que são obras inscritas numa linha de respeito à hierarquia católica ou presas ao interesse prático do leitor.

Assim, se tivéssemos que definir, pelo número estatistico, o perfil do leitor colonial brasileiro, é certo que teriamos esse leitor basicamente de obras morais e devocionárias, esmagadoramente, até começos do sēculo XIX. Em última anālise, duraria este predomínio por todo o perïodo colonial, e mesmo depois de o Brasil tornar-se Reino Unido a Portugal e Algarves. Cremos jä haver demonstrado isso, quando da amostragem dos títulos bibliográficos anotados a partir dos Inventärios e Testamentos publicados pelo ヘrquivo Püblico de São Paulo a partir de 1920 , reunindo uma documen- 
tação cuja data mais antiga é 1.578, papéis que pertenceram - ao $1^{\circ}$ Cartório de Orfãos da Capital. Numa räpida memória, os títulos que ali pontuam sāo os atinentes a essa dimensão projetiva e intensiva da Religião sobre a sociedade:

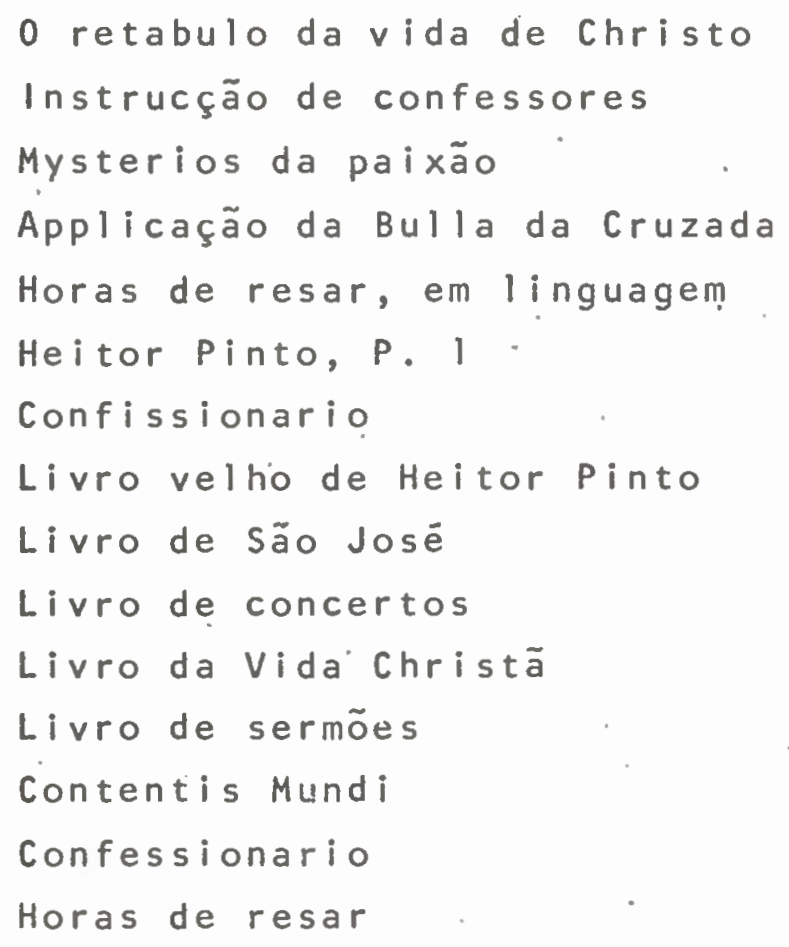

Assim, num espaço possível entre 1603 e 1688 , datas dos documentos mais antigo e recente entre os Inventários e Testamentos publicados pelio Arquivo de Sāo Paulo, demonstram-se, na faixa de setenta a oitenta porcento a.maioria de títulos religiosos. A mesma relação é previsível, se não for mais ampla a dominação, nos documentos que pesquisamos em fonte primária, em. São Paulo e no Rio de Janeiro.

No Arquivo Nacional, dos dois ünicos documentos seiscentistas incluindo livros, ambos registram apenas titulos de devoção e doutrina. O primeiro é o inventário de Manoel da Silva, de 1687 (AN, Maço 2334, processo 699), cidadão na- 
tural de Leiria, Portugal e morador no Rio. Na descrição de seus bens, constam "Livros curiosos e de casos". A indicação, embora pouco esclarecedora, constata a permanência, há trezentos anos, de uma pequena livraria, com destaque para as costumeiras referências religiosas, os chamados livros "de casos" e os "curiosos" que compreendem aspectos mais genéricos do conhecimento. O outro inventariado, Salvador Freire de Aguiar, de 1698 (AN, Maço 2314, n. 1033), tinha "Vinte e cinco livros de Sam Patr.", "Hum Hinoro espiritual" e "Tres Hinoros.1atinos". Em que pese a pouca precisão dos informes, localizamos um leitor, no Rio de Janeiro, claramente identificado com a leitura de matêrias devocionais, obras da Patrística e de Moral, e hinários monásticos, o que o indicia como fiel observante da disciplina eclesiāstica.

No Arquivo Público de São Paulo, hã uma curiosa transcrição num documento chamado "Registro de Officios etc. do Convento e Jesuítas". A despeito da dificuldade de leitura paleogräfica, anotamos o seguinte trecho, com os väcuos apresentados pelo documento: "0 ano de 1693... estrago das doenças... bicha... religiosos da Companhia de Jesus... Para remedio uma 'Adoração perpetua". Se não parecer de todo bizarro, poderíamos surpreender aí uma receita, no mínimo; insólita para os doentes atacados por vermes. E possível que um bem curado religioso, em sua fogosa vertigem ascética e mística, estivesse recomendando a leitura de um livro chamado "Adoração perpetua" para sanar malefícios da verminose? Ou seria uma prātica espiritual, ou observação de catccismo como forma de cura para um fiel acamado? Ou um ato de con- 
trição prescrito para purgação de vermes, pecados e males? Difícil solução.

Dentre os inventärios do século XVII, objeto de nossa pesquisa direta no Arquivo paulista, o mais antigo data de 1675 e registra os bens deixados por Barnabé de Mello (APSP, Ordem 491). Entre as posses mais economicamente disputäveis pelos herdeiros, figuram como "Livros" um "Bacullo pastoral, digo espirituais" (sic); "1 Livro... Senhora Santana"; "Rainha da adano (?)" e "Espelho... Senhora Sant'Ana". 0 documento, muito estragado, torna difícil a identificação dessas obras, mas, pelas características, è seguro indicar obras de cunho dogmático ou místico, a exemplo do Báculo pastoral de flores e exemplos (1624), extrato moral de Francisco Saraiva de Souza, muito popular no Brasil Colônia.

Manuel Nunes da Rosa, de 1677 (APSP, Ordem 492), tinha um "Libro velho Flos sanctorum"; a "Obra de Luis de Graveson e 4 santos": as "Epistolas de Guevara"; "... da May de Jesus"; "Milagre de Sara"; e "Partes do Brazil". Afora este último, com o título curioso de "Partes do Brazil",cuja autoria não conseguimos atinar e que pode levar-nos afoitamente a atribuí-1o a matéria de natureza geogräfica e pode tambëm ater-se ao cunho religioso, os demais livros pertencem mesmo à Religião. Relevante è a presença do místico espanhol Antonio de Guevara, autor conhecido desde o sêculo XVI, e suas Epístolas, de pouco frequente circulação no Brasil, mas um dos livros preferidos que vieram na colonização espanhola à América: O aparecimento, aqui pela primeira vez, 
da obra de culminação hagiogräfica, que ê. o Flos sanctorum, é igualmente relevante por se tratar de um dos mais presentes na relação de livros constantes do perfill do leitor co1onial. Ficamos na dúvida a qual dos flos sanctorum o documento refere, se seria o do Fr. Diogo do Rosário, se o do 'Pe. Paulo de Portoalegre ou o do Herman Campos, todos do século XVI. O título mais aproximado parece ser o de Fr. Rosảrio na edição de 1567. e considerado o melhor escrito, o que autorizaria a probabilidade de ser esta a obra, reeditada ou ainda em circulação no século seguinte, que o inventärio trancreve. O Flos Sanctorum è uma peça literäria muito coceituada desde o século XVI ao XIX, pertencente à versão hagiográfica ibérica, com vistás a incutir no fiel uma aguda sensibilidade ascética. Seu traço marcante é a ingenuidade na narrativa de uma espécie de gesta católica. Na obra de Fr. Diogo do Rosärio, o estilo desse tipo de obra vem manifeșto na expressão de uma poesia simples, lembrando aspectos sobrenaturais, o que explica, talvez, suas vărias reedições.

A imprecisão do informe no documento deixa margem a muitás dúvidas. Quanto à obra "... da May de Jesus", è provâvel tratar-se de catecismo de orações, a exemplo do que foi feito por Teodoro de Almeida em 1785, Gemidos da Mãe de Deus aflita, um best-seller no século XVIII.

- O mesmo místico Guevara e suas Epístolas voltam no inventärio de Francisco Nunes de Siqueira, de 1681 (APSP, Ordem 493). E singular que o documento abra com a rubrica "Livros", o que pode dàr.o mote de importância atribuída à 
livraria ou seu interesse pecuniário para os efeitos de partilha. E uma típica biblioteca de Direito, com as exceções aqui assinaladas da praxe de leitura religiosa:

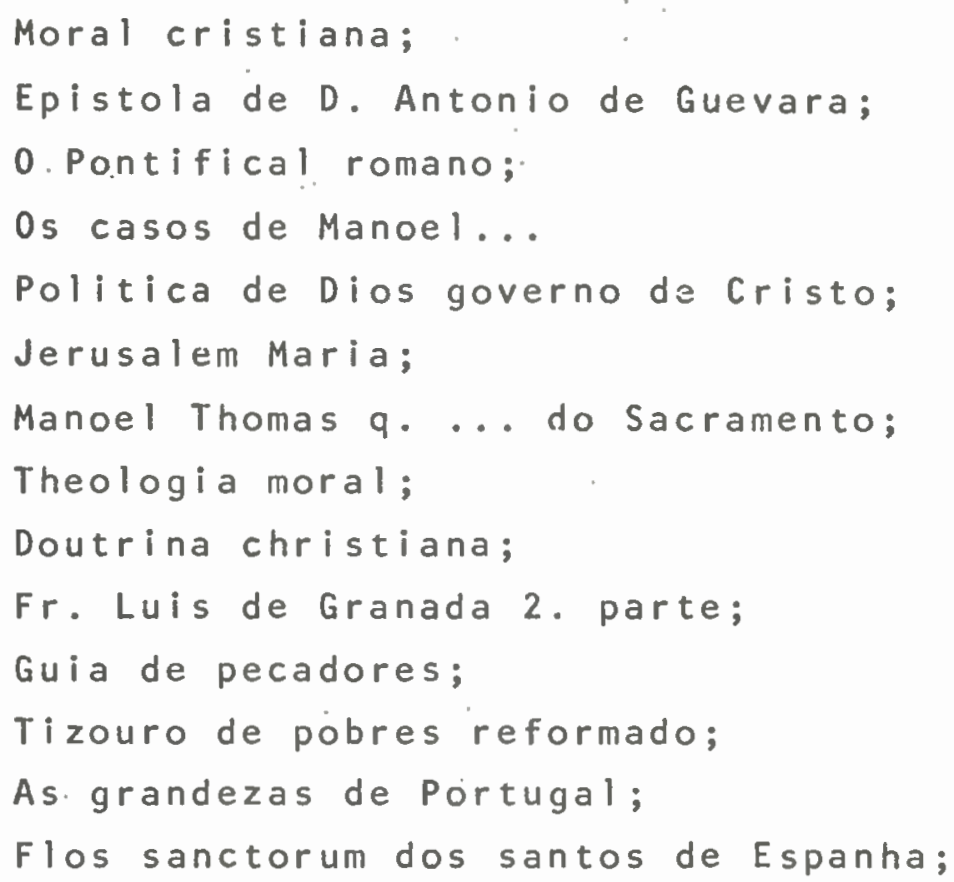

Sem dưvida, aqui nos deparamos com a maior biblioteca brasileira do século XVII, pelo menos em vista dos documentos de época por nós encontrados. São, ao todo, 25 títulos é com uma razoảvel variação de assuntos, predominando a vocação de leitura doutrinária e as obras de Direito que certamente serviriam ao ofício do inventariado.

Pontuam, no inventārio, sob a ótica religiosa, obras de devoção, as cartas ascéticas de Guevara e Granada, as ma- têrias de Hagiografia e Doutrina, ressaltando-se o indefectível Guia de pecadores e exortação à virtude, do mesmo Fr. Luís de Granada, entre outras obras como a Doutrina cristiana, de S. Francisco Xavier, publicada em. 1557. 
Antonio Bicudo, num inventärio de 1686, Antonio da Rocha do Couto/Ascensão de Pinho, de 1687 (APSP, Ordem 496) e mais João Rodrigues Pinto, de 1689' (APSP, Ordem 497) compõem - perfil do leitor tradicionalmente inscrito na fórmula doutrināria. do Catolicismo. O primeiro inventariado traz, em sua estante, uma "Bula". Os segundos, "2 Livros, Hũ Temporal eterno e outro Ramillete espiritual". Por fim, o terceiro inventariado, tinha descrita, como bem, na rubrica "Livros", uma "Bula assinada pelo bispo de Hisponia". Alguns títulos, aí, começam a despontar, ensejando uma continuidade, às vezes, espantosa por tódo o século XVIII. E o caso do $\underline{\text { Diferença entre o temporal }}$ e o eterno, do padre João Eusébio Nieremberg, do Ramalhete espiritual, das obras mais freqüentemente inscritas nas relações de bens inventariados no século XVIII e XIX. E, mesmo, da bula de Santo Agostinho, um dos doutores da Igreja de mais amplo conhecimento pelos 1eitores coloniais brasileiros no setecentos.

Os padres Pedro de Godoy da Silva, inventariado em 1691 (APSP, Ordem 498) e Domingos da Cunha, em 1695 (APSP, Ordem 499) completam o quadro seiscentista extraído dos documentos pesquisados diretamente no Arquivo do Estado de São Paulo. Não destoam, ambos, da característica de leitor de ofício eclesiästico. 0 primeiro aparece com livros convencionalmente atrelados à doutrina moral e evangêlica, como "Hum Breviario ja velho", "Hum Quaderno de rezas", um "Cirimonial", "Hum Oficio de defuntos", "Dous Caminhos de virtude", "Dous tomos de moral do Pe. Bento Remigio", "Hũ Tratado de confessores" e "Hũ Livrinho do Officio de Nossa Senhora". 
Breviários, cerimoniais de missa, cadernos de rezas, ofícios para encomendação de almas, tomos de moral, manual prātico para confesșores, rezas à Virgem, todos esses assuntos serão costumeiros no perfil de leitura doutrinária. Tal se observa também no inventārio do Pe. Domingos da Cunha, onde se insinuam "Hũ Breviario"; "Hũ Livrinho"; "Hũ Breviario velho"; "Hũ Concilio Tridentino"; "Sete Iivros velhos"; e "Hũ Livro grande velho". A aparição do modelo de explicação ou análise teólógica das doutrinas do Cọncỉlio de Trento è aqui representativa, pois se trata de título bastante comum entre os hảbitos de leitura dos brasileiros, especialmente dos religiosos.

Por essa amostragem, mesmo breve, rigorosa quanto à tótalidade e exação do material encontrado, como conceituaremos o modelo de leituras no Brasil de Seiscentos?

Em primeiro lugar, o leitor brasileiro seiscentista è aqui tomado nos referenciais inscritos em documentos de São Paulo e Rio de Janeiro, que representam, de qualquer forma, um espelho do que teriam lido os brasileiros das demais regiões no período colonial - se delas existissem os documentos esclarecedores. Em segundo, o leitón, no sẻculo XVII,è reconhecido pela pouca quantidade, ainda, dos livros. Em terceiro, esse leitor, preliminarmente, orienta-se pela leitura ou segmento ideológico dos assuntos religiosos e doutrinärios. A que se poderia atribuir essa "preferência"? Em grande parte, ao peso da influência colonizadora jesuítica, com seus colégios e sua intensa participação intelectual e censora no meio colonial e numa sociedade ainda em formação e sem juízo crítico ou id́cológico. 
Avaliando o modelo de leitor pelos títulos encontrados nos documentos, teríamos um perfil de leituras, fundamentalmente,de formação religiosa, seguido de uma busca de atualização funcional e, por último, aquele leitor curioso da informação da cultura literária ou da evolução intelectual.

Assim, o leitor do século XVII è prevalentemente um místico ou asceta; um ảoutor em leis e um letrado curioso. Organiza-se social e espiritualmente de acordo com a cultura literäria impressiva dos fatores doutrinấrios dominantes numa sociedade moralmente dependente de confessores, patronos ou mentores, arrimando-se numa coerciva unção moralizadora. Aí predomina a literatura mística de um Heitor Pinto, ou Guevara, ou Granada, a ascética de um Contemptus mundi e a orientação de um Guia de pecadores. Fora do redil teocêntrico, o leitor exercitaria sua cosmovisão lendo os livros prôprios do seu ofício profissional, aqui predominando os do Direito português. Por último, experimentações ecléticas como a leitura de elementos de Aritmética, a curiosidade biológica ou religiosa, de um "Segredos da Natureza " ou a prosa histórica fantasiosa de uma obra que transita entre a Ficção e a História propriamente dita, caso das Peregrinações de Fernão Mendes Pinto - livro que serä tambẻm muito popular nos séculos XVIII e XIX no Brasil.

De qualquer maneira, não hã como negar que as obras indicadas reforçam o que antes dissemos de que o brasileiro lia razoave1mente, embora preso à vocação espiritual e mística da leitura. O Brasil Seiscentista é de natureza a introduzir hăbitos e comportamentos dessa prática do ler. 
A grande quantidade de obras de Religião que circulam nesses inventärios, alêm da coerção naturalmente determinada pela predominância do espírito religioso e dogmático, pe10 aparato ideológico da imposição de leituras; tambēm pode ser atribuída a uma circunstância prática: a maioria dos livros circulares e impressos eram obras eclesiásticas ou educacionais. Logo, tal coerção se exercitava ainda no forno. A matéria religiosa tinha prevalência sobre as demais. 0 texto passa,assim, por uma notação de.sacralidade, em que é interdita qualquer forma de questionamento. Esse texto será, especialmente, abstrato, numa abstração que se distancie ao máximo da realidade - jā que a Contra-Reforma aborrece o imediato, a realidade contingente, fazendo convergir a filosofia moral num ponto único, não conflitual e sem espaços dialēticos ou hermerıêuticos, senão na mão única do dirigismo interpretativo, do tipo Deus ex machina. A leitura atravessa então estágios de valorização do rigor da forma, privilegiando o código mais que o significado, interessando muito mais a pompa formal do que a análise do conteúdo.

A leitura de obras religiosas obedece, desde a Ratio studiorum escrita pelo Geral da Companhia de Jesus Cláudio - Aquaviva em 1599; à ordem e à disçiplina ećlesiāsticas, sem questionamentos. Daî a obediência servil, a memorização, a recitação, a repetição, o que conduz a um conceito generalista do mundo, a uma superficialidade de cosmovisão, ao verbalismo oco, à padronização do pensamento. A leitura redutora, imitativa, alienada, desprovida de qualquer mecanismo crítico, compromete a expansão do conhecimento sistemático no Brasil Colônia, como o vê Fernando de Azevedo, para quem 
o livre exame, o espírito de anālise e de critica, a paixão da pesquisa e o gosto da aventura intelectual, que apenas amanheciam na Europa, teriam sem dūvida alargado. o nosso horizonte mental (...) A nossa cultura ficou sem pensamento e sem substancia, quase exclusivamente limitada às letras. 220

Isto significa que as livrarias religiosas estavam presas a um dirigismo esquemático que tinha em mira, exclusivamente, o rigor da doutrina e a unilateralidade hermenêutica do mundo. o espólio de dogma, parece, não se furtava ao vezo da totalidade absolutista, determinando uma quase exclusiva ordem bibliográfica nas estantes. As bibliotecas na Província franciscana, por exemplo, foram assim relacionadas, com pouca margem a variações, como, se pode ver num documento de 1648, assinado por Fr. Jácome da Purificação, de 24 de abril, transcrito por Fr. Venâncio Wileke no estudo sobre o "Convento de Santo Antonio do Ipojuca" em Pernambuco:

Acharam-se nesta livraria 90 livros, digo 200 livros com os pequenos. Entre os quais as glosas ordinärias entram en seis volumes, as partes de sagrada teologia em cinco volumes, as obras de Sto. Agostinho em cinco volumes, as obras de São Bernardo em dois, o Incógnito, as obras de Moral de Diana em dois volumes grandes (...) Da Casa da Paraíba estão nesta onze livros; os mais deste convento como os mais se perderam com os sucessos da guerra. 22

A mostra representativa de um püblico leitor identificado com a formulação ćtica ou, antes, moral do mundo e do 
homem, sọ a ótica da doutrina religiosa, percorre e perpetua-se no sêculo XVIII, jä agora não mais de molde a absolutizar uma única tendencia de leitura, mas convivendo com a expressa por outros ramos do conhecimento, que igualmente se presentificam. Em.um outro ponto, mais ou menos comum é a abertura que se verifica nas notações bibliogräficás do Brasil Colônia.

Começamos o exame dessa possibilidade, avaliando documentos do século XVIII existentes no Arquivo Püblico do Estado do Mato Grosso, em Cuiabã. Dois documentos são os inventários do capitão José de Vasconcellos Castelo Branco (APMT, ano 1791) e de Antônio Francisco Neves (APMT, 1796), ambos com poucos livros nas respectivas bibliotecas e apresentando semelhantes modelos e características de leitura. Entre os livros do capitão Castelo Branco, todos sem indicação de autoria, figuram "3 t. Historia de Portugal", que concluímos tratar-se da obra do terceiro conde de Ericeira, D. Luís de Menezes, História de Portugal restaurado, obra de ampla circulação no Brasil Setecentista. Os outros títulos, todos religiosos, da livraria do mesmo capitão, completam a fortuna bibliogräfica inventariada, a saber: "6 t. Escritura do Novo Testamento", provavelmente a Bỉblia organizada por Antonio Pereira de Figueiredo; "Livro segundo das almas"; "2 t. Retiro espiritual"; "Oras da Semana Santa"; e "Diario christão". Jâ no inventārio de Antonio Francisco Neves, de inteiro teor moral e doutrinārio, encontramos, na "Livraria": "18 t. Estoria sagrada em portuguez", podendo mesmo ser aquela escrita por Domingos Caldas Barbosa e publicada 
em 1792, a' Historia sagrada em verso; "Horas da Semana Santa"; "Horas da Quaresma"; "Diario christão"; e "Compendio christão". Não chegam a surpreender certas coincidências, tendo em vista a maciça dominação do dogma catōlico na tradição social brasileira do período. Ambos os leitores demonstram uma natural equivalência de opção por títulos religiosos, tributários de um certo afervoramento da moral cristã e cató1 ica.

De Cuiabā, ainda, é o inventảrio de José Barbosa de Sā, primeiro cronista do Mato Grosso, em 1776. Advogado, tinha 123 livros, os mais de Direito e Religião. Neste campo, destacam-se um "Theatro de los dioses de la gentilidad" e mais um "Lugares comuns de letras humanas" e um "Appendiz ao Teatro de los dioses, traduzido do toscano e castelhano por D. Diogo d'Agreda" ("e novamente traduzido em portuguez, e disposto por Alfabeto por Balthazar Luis", Lisboa, 1744). São obras, na verdade, que envolvem assuntos de Mitologia cristã, na esteira um tanto óbvia da ascese católica. A Biblinteca Nacional, no Rio de Janeiro, tem a Primeira parte del teatro de los dioses, por Fr. Baltasar de Vitória, Barcelona, 1702 e 1722. A Segunda parte é de Madrid, 1657 e a Terceira, de Fr. Juan Bautista de Aguillar, è de Barcelona, 1702 e 1722 . O segundo cronista de Cuiabä, Joaquim da Costa Siqueira, demonstra-se leitor apenas de 16 livros de Escritura Sagrada.

Do Rio Grande do Sul, encontramos, no Arquivo Püblico do Estado, em Porto Alegre, dentre os documentos da cidade de Rio Grande, o inventärio de Francisco Corrcia Pinto, 1.793. 
Nele inclui-se, ao 1ado de uma "Moral evangelica", um títu10 bastante curioso e de decifração ambígua: "2 Livros do bom lavrador" (APRS, Rio Grande, Maço 2). Esses "livros do bom lavrador" demonstrariam a qualificação do inventariado como homem do campo - um agricultor preocupado com as circunstâncias da lavra na terra - ou seria um título a mais a cuidar da messe doutrinária, da "lavra" messiânica do fiel?

O inventārio de Miguel Rodrigues de Sá, de 1798, traz um exemplar das Horas da Semana Santa, do padre Francisco Maria Sarmento ao lado de um "Livro de Proverbios de Salomão", um."Peregrino da America", "Sermoens de Nossa Senhora" e "O Felis independente", livro igualmente muito popular no Brasil Colônia, cujo título compileto é o Feliz independente do Mundo e da Fortuna, novela do esquivo moralismo típico do século XVIII e de autoria do padre Teodoro de Almeida, obra que concilia a estrita base moral católica com o estilo neoclâssịco, numa narrativa ingênua que combina o maravilhoso cristão com o preciosismo cientificista na descrição do real, mais ou menos na órbita de uma obra onde muitas do mesmo tipo buscaram inspiração: as Aventuras de Telêmaco, de Fénelon. A pouca base filosófica do romance não impediu sua imensa popularidade, tendo alcançado värias reedições, inclusive em francês e ém espanhol. 0 Feliz independente é ainda conhecido por suas pretensões epopéicas, atribuindo ao herói vertigens simbólicas e místicas, numa linguagem de abstrações despropositadas. E a típica moral de prédica e da abulia ascética que tanto povoou o imaginário culpado da civilização ibérica. 
O Feliz independente vai aparecer também no inventário de Custodio Ferreira de Oliveira Guimarães, de 1800 (APRS, POA, Estante 2, 1a. Vara de Família, Maço 147), junto com um "Quadro da morte do marquês Graziolle", uma curiosa obra de efeito moral, o Breve aparelho para ajudar a bem morrer, do Padre Estévan de Castro e, finalmente, "Dezenganos do bosque", que achamos deve tratar-se da obra de Soror Maria do Céu, Enganos do bosque, desenganos do rio (Lisboa, 1736; 2.ed., 1741), novela de uma intensa impregnação medieval, tendo como personagens alegóricas a Alma, chamada Preciosa; Deus, que é o Reii; Ilha encoberta, também chamada de Abismo do Nada; Amor humano $=$ Bem-me-Quer; e Narciso = Amor próprio. Considerada grande poeta conceptista do Seiscentos, é também como contista de forte combinação alegórica que a Soror Maria do Céu tem seu nome lembrado entre os escritores dos séculos XVII e XVIII português.

Em Porto Alegre, o inventário do padre Manoel Henrique, de 1766, indica a leitura comprometida com o sacerdócio e a doutrina católica. Doịs livros logo aparecem à folha 2 verso: um Catecismo e um Mestre da vida, obra esta de autoria do Fr. João Franco (APRS, Porto Alegre, $2^{\circ}$ of. Cível e Crime, Maço 1). Já.o inventariado Joaquim José Vieira, de 1784 , tinha livros em outros ramos do conhecimento. No estrito da preocupação moral religiosa, os livros relacionados são a "Vida de Senhora Santana", a obra frequentemente circular Imitação de Christo, de Thomas de Kempis, uma "Vida de S. Francisco de Assis em espanhol" e um "Peregrino da América", de Nuno Marques Pereira, obra que transita entre a moral religio- 
sa e a 1iteratura de ficção, dentro mesmo da tradição doutrinária do século XVIII (APRS, POA, 2\% Of. Cível e Crime, Maço 1). Também de Porto Alegre é o inventärio de Francisco Freire de. Amorim, de 1791, com umas "Oras marianas usadas". A tradição de Livros de Horas permanece no inventärio de Luiz Ferreira Velho, de 1794 (APRS, POA, 2॰ Of. Cível e Crime, Maço 1).

Do mesmo $2^{\circ}$ Ofício, no município de Porto Alegre, Maço 2, são os inventārios de Manoel Antonio de Rezende, 1795, e Miguel Rodrigues de Sã, 1798, com indicação de livros entre os bens levados a inventário. Manoel Antonio de Rezende tinha, alêm de um "Mestre da vida", umas "Oras portuguezas" e, por fim, umas "Oras em bom uso". As Horas portuguesas, com um Ofício da Imaculada Conceição e, mais um Ofício de S. José, foi escrito em verso por Francisco Vilela, publicado em Lisboa, 1780 , recuperando a convenção dos Livros de Horas, obras de uma atmosfera de piedade, inspirados na tradição litúrgica, escritas em latim, ou numa língua viva, adotando o bilingüismo e até o trilingüismo. Traziam laudes, ofícios, reverências sacras, geralmente a Nossa Senhora, às Chagas de Cristo, à Paixão, ao Espírito Santo, incluindo 1adainhas e penitências. São livrinhos devocionais, fortemente marcados pela mítica católico-medieval, com demonstrações de permanência até fins do século XIX.

Ainda de Porto Alegre, Cartório do $1^{9}$ ofício, o inventário de Jeronymo Dornelles de Menezes, 1772, assinala um único 1ivro: "Eva e Áve", (APRS, Maço 4) certamente a obra de Antonio de Sousa de Macedo, Eva e Ave ou Maria triunfante. 
Teatro de erudição e da filosofia cristã, em que se representam os dois estados do mundo, caído em Eva e levantado em Ave (1. ed. 1676), peça literária de sentido moral, assumindo questões relacionadas com o pecado original, a noção de Queda e de Ressurreição, tomando como referências e personagens alégóricas, Eva e Maria Santíssima. Do mesmo cartōrio, é o inventário de Antero José Ferreira de Brito, 1787, com uma estante predominantemente de Direito, mas com aberturas para Letras e Religião. Neste último campo, apenas dois livros estão inscritos: uma "Biblia", possivelmente a vertida em português pelo oratoriano Antonio Pereira de Figueiredo e "4 breviarios", obras de consulta e manuseio obrigatórios por religiosos ou fiēis (APRS, Maço 9-A). Por fim, também pertencente ao Cartório do $1^{\circ}$ Ofício de Porto Alegre, no documento de João Josē de Souza, de 1793, aparecem as indefectíveis Horas marianas, do mesmo padre Francisco Maria Sarmento.

No Maranhão, acompanhamos o registro do primeiro testamento do clérigo Francisco Pereíra de Lacerda; natural de São Luiz, com data de 1741. Compõe-no uma "Livraria de 1ivros de Direito e alguns livros de materia eclesiástica, como tambêm alguns sermonārios" (Tribunal de Justiça, São Luiz, "Lívro de Registro de Testamentos, 1756-1769"). Conquanto o documento não explicite quais os livros constantes da biblioteca do padre maranhense, a tendência natural quanto a obras de Religião indica uma predominância de disciplinas ascéticas e místicas, livros de devoção, como as Horas marianas e os mais que seriam Bỉblias, breviārios, obras dos Santos Doutores da Igreja, etc. 
No Ceará,o único inventário referente ao século XVIII, no Arquivo Público, em Fortaleza, pertence ao reverendo Manuel Luís de França, de 1797, mas documento vinculado à sede da comarca de Baturité, no interior cearense. Todas as obras constantes da livraria do inventariado se vinculam aos assuntos religiosos, com destaque para "1 Comento do Concilio", "3 tomos do padre Calatayude" e "1 Hymnodia Luzitana". E fácil notar, mesmo em razão de um solitário exemplar de documento de época, o imperioso sentido de leituras no Cearä, evidenciando um leitor, a exemplo do padre França, em pleno Setecentismo, identificado, ainda, com a literatura dogmātica, mística ou ascética. Toda a livraria do reverendo, sem uma única exceção, privilegia os assuntos religiosos, o que se pode completar na seguinte relação:

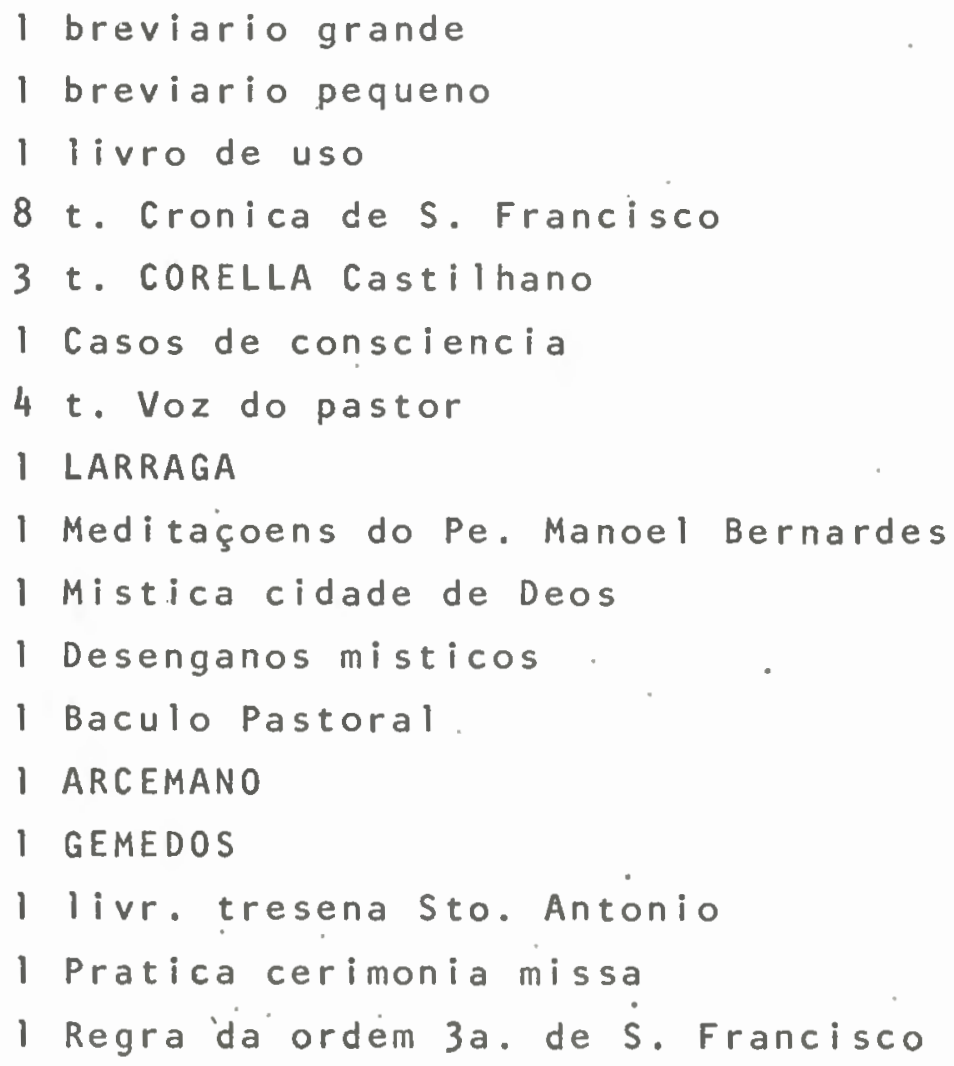


1 peq. do ofício - latim. Ma. Sant.

l"oficios nossos

1 Levitico

Observa-se, por essa amostragem, a norma de leitura seguida especialmente por padres no Brasil. Além dos breviários, dos classificados como "livrosde uso", os comentadores de aspectos doutrinários como Jaime Corella, teólogos como - padre espanhol Fr. Francisco Larraga, com sua Summa: ou Prontuário de Teologia Moral, numa possível tradução de Manuel da Silva Moraes (Coimbra, Of. Antonio Simoens Ferreira, 1749) ou a do Fr. Inácio de S. Carlos, editada no Porto, em data imprecisa do século XVIII. Também frequientam essas 1ivrarias sermonistas consagrados como o padre Manoel Bernardes, autor dos Exercícios espirituais ou meditações da via purgativa: sobre a malicia do pecado, vaidade do mundo, misérias da vida humana, Eq quatro novissimos do Homem, obra editada pela primeira vez em 1686, reeditada em 1706 e com sucessivas reedições ao longo do século XVIII. E desenvolvida na forma consagrada da orą̧ão. mental, para instilar elementos ascéticos no leitor. Notabiliza-se, também, nesse inventário do padre cearense, A voz do pastor, discursos familiares de hum parocho aos seus freguezes para todos os Domingos do ano, obra traduzida do francês por D.I.D.M.D.D., de autoria desconhecida; que teve uma 2a. edição, em 4 volumes, em Lisboa, na tipografia de J.F.M. de Campos,.1816-1818. Sobre os breviārios, hã que salientar-se que eram publicações próprias do uso oficial de sacerdotes e fıëis, normalmente conhecidos pela classificação de Breviärio romano, publicados geralmen- 
te em 4 tomos, valendo cada um para cada estação do ano. Também expressivo nessa biblioteca do padre cearense, é o aparecimento do Báculo pastoral de flores e exemplos (1.ed. 1624; 2. parte na ed. 1703), de Francisco Saraiva de Sousa, na 1inha do moralismo literärio português dos séculos XVII e XVIII, e dá Mistica cidade de Deus, da madre Soror Maria de Jesus. de Agreda, livro dos mais populares no Brasil Colônia, extensivo ao século XIX.

Em Nata1, o livro de "Notas e Testamentos" existente no Instituto Histórico e Geográfico do. Rio Grande do Norte, registra uma curiosíssima e impagável livraria no testamento de Albino Duarte de Oliveira. O documento traz data imprecisa, mas é seguro pertencer ao século XVIII, pois a referência deve compreender um espectro de' tempo entre 1767-1792; ou 1799-1800, nos dois volumes do referido livro de Notas. - O inventariado tinha "1 livro antigo", "Uma obra portugueza", "3 espanholas dos reis de Toledo", "1 Historico de Toledo" (...) "está emprestado ao Capitão Bernardo Castro Freire", "Outro livro ja velho". Entre mais livros religiosos como a "Imitação de Christo", "1 Mestre da vida", "O pecador convertido" e um livro popular de retórica, "2 profanos Livro de divertimento de estudiosos". D inventariado, peuvre de 1.ui, tinha a maioria de seus livros emprestados, o que representa seguramente a perda deles para outrem. o registro é interessantissimo, pois traz anotados: a"Historia do futuro, emprestado ao reverendo vigário desta cidade", "l Larraga que emprestei a muitos annos ao. Capitão Manue1 pinto de Castro quase novo" e "1 A Vida da veneravel madre Mariana 
da Purificação emprestado a Antonio Gomes Freire Official". Trata-se do primeiro registro pủblico, declarado em testamento, de uma verdadeira biblioteca volante com livros emprestados cujo dono, sutilmente, parece não acreditar muito na devolução e reintegração patrimonial.

Na Divisão de Pesquisa Histỏrica da Universidade Federal de Pernambuco, entre microfilmes copiados de arquivos portugueses, especificamente versados em assuntos pernambucanos, consta cỏpia do inventảrio do bispo D. Thomas da Encarnação Costa Lima, datado de 5 de maio de 1784 (Maço 28). E considerâvel a livraria do bispo, a maior parte, öbvio, de títulos em Religião.

Os livros de Doutrina a $\vec{i}$ encontrados correspondem à característica mais geral da disciplina catôlica, com indicio, entretanto, da apreensão erudita dos títulos, incluindo as obras de doutores da Igreja, comentadores de casos religiosos ou doutrinadores. Hả um título de "Direito canonico", relacionado junto com outros títulos pouco comuns como "Petra Cont. Apo. bibliocos", "Hieronimo Stridenti 4 v." e outros confarme a relação abaixo:

PETRO de. Marca. de Concordia

Benedict XIV..in ... IuY

CRISPUM. Coment ad Rituale

BARBOSA. In CONC.

BARTI. Teolog. discipt. 3 t.

AGUIRRE. In conc. 6 t.

GAVENT. Herati Com. 2 t.

CATHECISM Serimion. episcop. $2 \mathrm{t}$. 
GOMEZ. Discipl. ecclesiast. $2 t$. NATALIS, Alexandre in Tract. $2 \mathrm{t}$. VAN ESPEN. Dir. Canonico. $5 \mathrm{t}$.

CRISPUM. Comm, ad rituale BOLARIUM Romano $14 \mathrm{v}$. PONTIFICI Romano $3 \mathrm{t}$. TENNERDI Opus teolog. $8 \mathrm{v}$. A LAPIDE Expe. $13 \mathrm{v}$.

Divi Bernardi Opera omnia Divi Joannis Chrisostomi 5 t. São Gregorio $2 \mathrm{t}$.

CALMET. Di serti sico Siripot $2 t$. CALMET. Decisiones Biblia PAGET. Institution. Cathol. 2 t. GIATINO in Concilio $3 \mathrm{t}$. MORANI. Com. de sacramenti

MISSAL Romano

Const. da Bahia

Coronica de Sto. Agostinho

PELAFOR. Estoria Real Sagrada

Divi Ancelmi opera

RE.IFENSTUEL. In canonico $5 \mathrm{v}$.

Cronica de Santo Antonio do Brazil

Historia ecclesiastica de Fleury

MEMORIAS para a historia ecclesiastica.

Historia dos autores sagrados ecclesiasticos

AMORT. Elementi juris canonici

C CENI. Preductionis $5 \mathrm{t}$.

WIT. Teologico $7 \mathrm{t}$.

CENNIFER De an dignitate ecclesiae Expanis 2 t.

FERRARIS. Bibliotheca moralis $8 \mathrm{t}$.

Pedro LOMBARDI. Mestre das sentenças

GALEMART. Ad conc. Trident.

GOTI. Religionis Christan $6 \mathrm{t}$.

Tratado do estudo dos concilios

Sta. Maria: Advertencias para a critica 3 t.

Fray Len. Resol. Dogmat. 
CONCION. TheOlOgico $2 \mathrm{t}$.

PROCESSIONALE ROManUm $13 \mathrm{t}$.

CORPUS JURIS CANONICI 2 t.

Concordancia dos santos padres $2 \mathrm{v}$.

De suprema autoritate pontificum

['ERMINIER. De atributis $7 \mathrm{t}$.

CONCENCIM Teologia $6 \mathrm{t}$.

obrigações ecclesiasticas

Arte de furtar

Diferença entre temporal e eterno

Compendio da Bula

MASSILON. Sermoens $12 x$.

Conducta de confessores $2 \mathrm{v}$.

Cathecismo.de MOMPLIER

Provas de De Ducrë Cronologica $6 \mathrm{t}$.

Idem. Cronologia analitica

Felis independente $3 \mathrm{t}$.

Estoria variação de Igreja

NAVARRo. Manoal de confeçoens

Avizos espirituais 2 v.

Cathecismo romano

Conferencias de ANGERS

L'ERMIER. Tractatus de sacramentis $3 t$.

Discurso sobre a Historia ecclesiastica

PEREIRA. In concilio

STO. TOMAZ DE AQUINO Opera omnia

Livro dos salmos $2 \mathrm{v}$.

0 Novo Testamento $6 \mathrm{t}$.

Varios liyros truncados da Academia Leturgica

i Missal de quarto

De vario romano

A obra de BARBOSA 24 t.

A obra de BENEDICTO XIV. 12 t.

BORONIO. $38 \mathrm{t}$.

A exposição de Sto. Agostinho $13 \mathrm{v}$.

Trata-se, como se pode notar; de uma rica bibliografia 
religiosa; basilar da natureza de leituras disciplinar e ritualística do sẻculo XVIII. Como bem compenetrado ministro da Religião Católica, ele prôprio autor de uma Histỏria Ecclesiae Lusitanae (1759), o bispo pernambucano não evidencia qualquer autor polêmico ou proibido, atendo-se a um perfil de leituras que apenas demonstra o aparato formal de matêrias diretamente vinculadas ao ofício religioso. Pode dizer-se que a estante de D. Tomás da Encarnação representa um modelo caracteristico das obras de doutrina circular no Brasil. Destacam-se obras de Agostinho Barbosa (1590-1649), jurisconsulto português especialista em Direito Canônico, autor de $\underline{\mathrm{Re}}$ missiones doctorum in varia loca Concilii Tridentini, cuja primeira edição data de 1618, tratando de questões genẻricas do Direito vinculado ao espirito das determinações ào Concílio de Trento. Esta talvez seja a referência atribuida ao "BARBOSA. In conc.", no inventärio do bispo. jả a referência à "obra de BARBOSA 24 t." talvez inclua dois outros tîtulos que notabilizaram Agostinho Barbosa e que o tornaram autor muito freqüente nas bibliotecas brasileiras do Setecentos, obras em que discute aspectos mais especificos da jurisprudência canônica, a partir do poder desempenhado pelos bispos, $\circ^{\circ}$ De officio et potestate episcopi tripartita descriptio, de 1623; e pelos padres - De officio et potestate parochi, de 1632. Outro renomado doutor em leis canônicas ê o Van Espen, que aparece no inventärio como "VAN ESPEN. Dir. Canonico 5 t.", autor igualmente popular no sëculo XVIII brasileiro. O mesmo se dả com Cornclio A Lapide, cêlebre comentarista de aspectos legais e histôricos da tradição cristã e catôlica. E, da mesma forma, com tratadistas como Alexandre 
Natalis e Augusto Calmet, estudiosos como Anacleto Reiffenstuel, sermonistas como Massillon e bibliógrafos da moral cristã como Lucius Ferraris. Doutores da Igreja, como São Bernardo, São João Crisóstomo, São Gregório Nazianzeno, Santo Agostinho e Santo Tomás de Aquino completam o quadro erudito da ética cristã presente na biblioteca de D. Tomäs da Encarnação Costa Lima.

Alguns livros vão ser popularíssimos nas livrarias setecentistas, como a própria História eclesiástica de Claude Fleury (1640-1723), traduzida em português, em 1753, e também conhecida como Catecismo histórico; a Arte de furtar, atribuída ao padre Antonio Vieira, preciosa peça de efeito moral para incutir no leitor sãos princípios de direção de comportamento, ou a Diferença entre o temporal e 을 eterno, do padre João Eusébio Nieremberg, publicada em Lisboa, Of. Herdeiros de Antonio Pedrozo Galram, 1741; a Conduta de Confessores no tribunal da penitência, obra traduzida do francês do padre Rogério Daon, e editada em Lisboa, Of. Luisiana, 1780; e o sempre presente Catecismo de Montpellier, de que já tratamos antes, neste trabalho. Obras populares no século XVIII brasileiro serāo ainda os Avisos espirituais, $\underline{0}$ Feliz independente do mundo e da fortuna, (3 v., 1779; 2.ed. 1786) do oratoriano Teodoro de Almeida (1722-1804) e o Novo Testamento, na versão apresentada pelo também oratoriano Antonio Pereira de Figueiredo. Todas essas obras pontificam pelo modelo de filosofia moral introduzido nas estantes brasileiras como forma de restaurar uma ordem medievalizante de cultura cristã fundada.na recorrente prática da oração mental, da dịciplina aścética, da rigidez doutrinária segundo o caráter do absolutismo hierárquico da Igreja. 
Esta è, mais ou menos, a explícita tendência que vamos encontrar também no testamento do reverendo Francisco Antonio da Silva, com data prováṿel de 1799, documento que consta do arquivo do Instituto Histórico e Geogräfico de Alagoas, em Maceió. Entre os livros expressamente declarados para fins de partilha entre os herdeiros do padre, dominam os assuntos de Teologia Dogmätica.e de outros aspectos doutrinārios e místicos, com destaque para uma "Arte de Cantocham", e "8 livros de varios titulos" e uma "Arte de conhecer os Evangelhos". Hä mais "2 v. Teologia Moral", "2 v. LARRAGA", um indecifrävel "Gradinal", uma "Regra cleriga", um "Batisterio", um "Breviario" e "4 t. breviarios novos". Em que pese ser uma livraria pequena, se equiparada à pertencente ao bispo de Pernambuco acima descrita, nota-se uma assinalada e estrita vocação para títulos de ordem moral ou para o atendimento direto das funções do inventariado.

Na Bahia, documento encontrado no Arquivo Público do Estado, em Salvador, o inventärio de Luís Tavares dos Santos, (ARQUEB, 03/716/1180/1). de Cachoeira, ano de 1799; demonstra um leitor de títulos variados, abrangendo obras nos campos da Religião, Direito, História e Letras. Entre o elogio histórico e a súmula moral, destacamọs uma "Historia sagrada", repetida com detalhe em "Os 7 tomos da Historia sagrada", mais "2 tom. de Ferreira a institut", uma "Logica do padre Barreto", uma "Chave de Gabinete dos principes", uma indicação do autor sem menção a obra, "Guasin", o "Theatro critico univer- 
sal de Feijó", uma "Nova instrucção de enfermos" e, por fim, - uma "Vida de S. João Nepomuceno". Alguns desses títulos não apresentam facilidades na identificação de autoria, mas serả fäcil apreender-1hes o sentido estilístico e a determinação de leitura nos termos da Moral ou da Ascese.

o recôncavo baiano, entre fins do sẻculo XVIII e meados do XIX, manifesta interesse na cultura bibliogräfica. Luis Ribeiro de Sousa, num inventärio de 1799, inclui livros de devoção e doutrina, "Hum missal uzado": "Hum jogo de Missario com capa dourada" e "Quatro ditos muito velhos sem valor" (ARQUEB, Judiciāria, 03/716/1180/02). Carlos Josẻ da Silva Guimarães, da mesma Cachoeira, em documento de 1799 , indicava apenas dois títulos, sendo um "Humas oras Portuguezas"- muito provavelmente a nossa conhecida Horas portuguesas, feita por Francisco.Vilela, editada em Lisboa, 1788 e o outro, apontado apenas como "Hum livro latino"' (ARQUEB, Judiciạria, 03/716/1180/6). Josefa Quitéria do Sacramento, de 1788, apresentava, entre seus bens, "Hum Missal romano em bom uzo" (ARQUEB, Judic-iâria, 03/701/1162/3). A livraria de Fêlix Alves de Andrade, apesar da quase ilegibilidade do inventârio de 1791, compreende uma "Obra do mentor moderno em seis tomos", "Historia de Gil Blas em quatro volumes", uma "Escola do mundo em Tres tomos pequenos", uma "Aventuras de ..." (ARQUEB, Judiciäria, 02/706/1162/3). A ordem moral permanece como opção presuntiva de leitura expressa em narrativas do tipo Histôria de Gil Brảs de Santillana, de Alain-Renê Le Sage (1688-1747); escritor moralista francês, muito bem conhecido no Brasil pelas traduções do Histōria de Gil Brảs, 
ou. Gil Blás e de o diabo coxo (Le diable boiteux), traduzido no Brasil pela Impressão Régia, em 1811. A referência incompleta de "Aventuras de ..." pode representar a obra de Fénelon bastante circular no Brasil Colonial - Aventuras de Telemâco - ou, no original francês, Aventures de Telemaque, como tambëm pode ser a obra Aventuras de Diófanes, da brasileira Margarida da Orta, reedição de 1772 da original publicada em 1752, com o título de Memórias de virtudes e formosurá.

Na mesma sintonia d obras exalçando virtudes morais e reiterando o ofício fiel da observância aos dogmas e doutrinas da civilização católića, Paulo de Almeida, na Capital, Salvador, num inventārío de 1752, tinha "Hum missal" (ARQUEB, Judiciāria, 03/1006/1475/08) . Teotônio da Costa Maciel, támbêm de Salvador, em 1761, apresentava "Dous livros de rezão." (ARQUEB, Judiciária, 05/1992/2463/3). Antonio Mendes de Amorim, de Cachoeira, à folha 6 do inventário, tinha uma História sagrada (Cachoeira, Arq. reg. Maço 01/02/02/09 a 14). Manoel José Moreira Guimarães, tambêm de Cachoeira, 1786, à f1. 13 verso do inventário, tinha "21 livros de Santa Barbara". (Cachoeira, Arq. Reg., Maçó 01/14/14/103 a 109). Antonio Fëlix Pereira, de Cachoeira, 1749, à folha 29 do inventário, demonstra uma estante com a esmagadora opção de leitura em Direito, mas indicando uma "Biblia" entre os livros extra jurisprudência. (Cachoeira, Arq. Reg., Maço 01/20/20/168 a 177). Antonio do Rego Pinto, de S. Josē das Itapororocas, à folha 9 do inventário de 1779 , acusa a posse de "1 Missal romano"(Cachoeira, Arq. Reg., Maço 01/86/86/711 a 718), o mesino acontecendo com Ana Maria da Rocha Passos, de Santos Estevão do Jacuípe, folha 16 do documento de 1796 (Cachoeira, Arq.Reg., Maço 01/98/ 
98/848 a 859). Finalmente, Bernardo de Azevedo, tambêm de Santo Estêvão do Jacuỉpe, tinha, em 1769, umas "Oras portuguezas" (Cachoeira, Arquivo Regional, Documento em fase de restauração) .

Dos documentos baianos relacionados com a Capital, a predominância em tỉtulos parece ceder um tanto, da Religião para o Direito e, mesmo, para a Literatura e a Linguistica. 0 mais antigo deles ê o inventårio de Jcão Britto de Pazzy, de 1739 (ARQUEB, Judiciärio, 622-7). Do's oito títulos declarados, somente dois pertencem à matẻria ou disciplina religiosa. Ambos são livros bastante circulares no Brasil Setecentista e revelam uma mesma disposição para matêrias do Direito Canônico e de aspectos morais: a "Constituição do Arcebispado da Bahia", obra cuja autoria ê atribuỉda ao seu organizador, o bispo Sebastião Monteiro da Vide, com o título completo de Constituições primeiras do Arcebispado da Bahia, cuja primeira edição ê 1719 e 2. ed. 1720. O outro livro, "Mystica cid. de Dioz - 3 t." ê da autoria de uma religiosa franciscana espanhola, Soror Maria de Jesus de Agreda (16021665), notabilizada por suas visões de êxtase mistico e por uma intens'a correspondência trocada com o monarca Felipe IV. 0 título completo da obra ê Maria Santíssima, mistica cidade de Deus, editada originalmente em Coimbra, na Oficina Francisco de 01iveira,'1651. Hâ vảrias reedições no sêculo XVIII. Foi obra denunciada à Inquisição como impostora, fruto dos maquiavêlicos meandros da política inquisitóriäl. Espêcie de devoção e faṇtasia novelesca, desenvolve uma certa biografia de viagens, de traço extremamente votado à ascese e ao êxtase. 
Em espanhol, talvez, tenha circulado mais frequentemente no século XVIII uma edição com o comprido título de Mistica ciudad de Dios, milagro de su omnipotencia, y. abismo de 1a gracia, historia divina $y$ vida de la Virgen Madre de Dios, reyna y señora nuestra Maria Santissima, editado em Amberes, Henrico y Cornelịo Verdușsen, 1708, 2 v. Há, entretanto, uma obra homônima atribuída ao Fr. Pedro de Jesus Maria José, Mística cidade de Deus, impressa em Lisboa, na Oficina Miguel Manescal da Costa, em 1746, donde pode provir uma certa confusão no atribuir-se o título a uma ou outro. Em que 'pese a maioria dos inventários que incluem a obra não indicar sua autoria, acreditamos tratar-se da que mais circula nesse periodo do Setecentos, ou seja, a da franciscana espanhola. Ou, talvez, o Fr. Pedro de Jesus Maria José seja o tradutor de Mistica cidade de Deus para a língua portuguesa.

No rico inventārio do Sargento-Mor João Lopes Fiúza, de 1741 (ARQueB, Judiciária, Capita1, 623-4), vamos encontrar uma considerävel quantidade de obras de cunho religioso, que não poderiam faltar "ao ambiente castelão de um potentado ru'ral daquele meado do século XVIII", segundo a observação de Wanderley Pinho, op.cit.22 Das obras estritamentes escolhidas no campo da Religião, temos:

\footnotetext{
Historia Pontifical

David perseguido, em pergaminho Tesouro seräfico, pergamịnho Temporal e Etèrno, pergaminho Rosa de Nazareth, em pergaminho Honras Cristãs, em pergaminho
} 
Correção de Abusos, ém pergaminho

Lenitivo da dor

Exposição de Mantica

Sinagoga de ... geral, em pergaminho

Vida del V.P. Maestro Fr. Juan de .... em pergaminho

Da Floresta, do Pe. Bernardes em pasta

Lacorte Santa em pasta

Flos Sanctorum de Ribadeneyra em pasta

Eva e Ave de Macedo em. pasta

La. Perla de Cataluña em pastá

La estoria das ordens... em pergaminho

Alivio de Tristes em pergamino

Ordem de bem casados em pergaminho

Gritos das Almas do Purgatório em pergaminho

Vida de $S$. João Batista em pergaminho

De escolha de temor de Deus em pergaminho

Carta de guia de cazados em pergaminho

Noites de Young em pergaminho

Seräfica Portuguesa em pasta

Aparelho para bem inorrer em pergaminho

Juizo theologico digo Historia justi

Doctrina christiana em pergaminho

Da vida del R.P. de S. José em pergaminho

Amores divinos em pergaminho

Coro celeste

Juizo teologico.

Casos de Consciencia de Manuel Rodrigues

Repüblica e politica cristã

Balido das. Igrejas de Portugal

Tratados de Amor Divino

Explicação da Bula de Sta. Cruzada

Ponte Segura

Mundano Constrangido

Eneas La penitentia

Rosa de Vinijida

Pão partido em pequeninos.

$\therefore$ da indulgência

Finezas del ... 
o documento, muito estragado, dificulta uma segura identifịcação. A grande maioria das obras, sem dưvida, pertencem ao universo religioso, algumas de uma sólida popularidade, conforme vimos, caso da Diferença entre o temporal e 으 éterno, de autoria do padre João Eusëbio Nieremberg, editada em.1741. Surpreende o aparecimento de uma obra pouco freqüente nesses inventärios, Maria Rosa de Nazarê, do jesuíta luso-brasileiro Alexandre de Gusmão, editado em Lisboa, 1715, na tradição hagiográfica, obra de louvor e meditação envolvendo os mistêrios do culto à Virgem Maria. A literatura moral, combinada com a exposição clara e a ordem de recursos retóricos, tambẻm está presente com a popularíssima obra do padre Manoel Bernardes, Nova Floresta, ou silva de värios apotegmas e ditos sentenciosos espirituais e morais; com reflexões, em que o útil da doutrina se acompanha com o vário da erudição assim divina como humana, reunião de apólogos, distribuídos por cinco volumosos tomos, cuja primeira edição se dã entre 1708 e 1728. O livro é ilustrado por citações eruditas carregadas de forte condimento doutrinärio, alçando à categoria de problemas e resoluções do espírito as questões polêmicas de matérias religiosas, obedecida a convenção de novelas de proveito e exemplo. As alegorias se sustentam em substantivos que dão o estofo dos assuntos tratados: "Amizade", Dignidade", "Honra", "Justiça", etc., distribuídos em ordem alfabética. Outros livros aqui presentes identificam - tom da leitura tradicionalmente voltada à ascese. Caso do Flos sanctorum, de Ribadeneyra, provavelmente obra publicada cm fins do século XVII, ou Eva e Ave ou Maria triunfánte, 
do jâ mencionado Antonio de Sousa de Macedo. Também é o caso daquela obra cujo título preciosista è objeto da troça de Verney no Verdadeiro método de estudar: o Ailivio de tristes, consolação de queixosos, editado em 1672 e 1674 e com värias reedições tanto no século XVII quanto, no XVIII. Outro títu10 surpreendente, pela pouca frequência com que transita nos inventários e certamente raro no universo de leituras do Setecentos, è a Carta de Guia de Casados, obra de D. Francisco Manue1, publicado pela primeira vez em 1651, um misto de modelo do bem viver conjugal, mesclando regras da vida prātica, erudição clássica, modelos de boa esposa e mãe, relações com filhos e criados, cuidados com a casa e coin o marido, fuga ào atavio da superfluidade, tudo acrescentado com viva fantasia e humor, através de anedotas e sentenças ao gosto do senso moral da época. A obra pode igualmente ser tomada como signo adventício, feito de forma sutil e maliciosa, da psicologia feminina, em que o A., não raro, manifesta um sentido da ética machista hierarquizada. Noites de Young, mais popular e seguramente dos mais presentes nos inventários do Setecentos brasileiro, ë obra do poeta português do sëculo XVIII, Vicente Carlos 0liveira, tambëm autor de Lisboa Restaurada. Emportuguês ou francês, Noites de Young, vem a ser um livro de poesia ascética, feita dentro de uma retórica cristã densamente influenciada pelos poetas místicos ibéricos.

A indicação "Serafica Portugesa em pasta", transcrita no inventārio de João Lopes Fiưza, pode significar a História seräfica da Ordem dos frades menores na província de Portugal, 
escrita pelo Fr. Manuel da Esperança ( -1760), obra publi. cada em 1656 e 1666, em duas partes. Quanto à Doctrina christiana, parece fora de dúvida ser a obra de S. Francisco Xavier, publicada em Lisboa, 1557. Por fim, ainda por destacar é.a obra do padre Manoel Bernardes, Pão partido em pequeninos pedaços, que toma o simbolo da ressurreição para sintonizar o pensamento cristão de obediência e molde à disciplina eclesiástica, escrita no limpido estilo característico do moralismo vigente. Uma de suas últimas edições, mạis precisamente a quarta impressão, è de Lisboà Ocidental, Ofício da Congregação de Oratōrio, 1737 .

Por último, vale referir a cirćulação de Finezas de Jesus Sacramentado, para com os homens e ingratidão dos homens para com Jesus Sacramentado, do padre Fr. João José de Santa Tereza, carmelita, obra que teve uma nona edição em 1818, na Tipografia Silva Serva, e de Harmonia politica dos documentos divinos com as conveniências do Estado, de Antonio Sousa de Macèdo, cuja primeira edição foi feita em Lisboa, 1651.

O. inventārio de Josê Valentim Duarte, de 1755 ( ARQUEB, Judiciāria, Capital, 633-9), segue uma ordem similar de leituras de cúnho religioso e moral, com títulos coincidentes como"3 t. de David perseguido", "2 livros Mistica cidade de Deos", ao lado de outros menos encontradiços nos demais documentos: "1 livro Arvore da Vida", "Floresta do Pe. Conciencia", "1 livro de Moral do Pe. Remigio" e "1 Hora latina". Destacamos a Floresta Novíssima de vārias ações sentenciosas e ilustradas com todo o gênero de erudição, em 2 volumes, saí- 
dos em Lisboa Ocidental, 1735-1737, obra do oratoriano padre - Manuel Consciência (1669-1739), na esteira dos apotegmas morais de outro oratoriano, o padre Manuel Bernardes, e usando como fontes primeiras os ditos de Sêneca, de poetas latinos e da Bíblia para extrair um fundo sentencioso com que busca incutir, no espírito do leitor, um certo sentido estóico dạ Cristandade. No mesmo documento, hã uma transcrição. "Sam... riano". Serā título de natureza mística, devocionário do culto à Maria Santíssima, provaveḷmente o Santuário mariano, obra na linha da historiografia eclesiāstica, da autoria de Fr. Agostinho de Santa Maria (1642-1728), editada entre 1707 e 1723 .

Continuando a seriaçāo religiosa na Bahia, tomamos o inventário do tenente-coronel Jacinto Ferreịa Feijó de Faria, de 1762 (ARQUEB, Judiciāria, Capita1, 638-8). Constam como obras vinculadas a esse campo, uma "Biblia em concordata", "Breviario em 2 t.", "Horas latinas grandes", "Horas latinas pequenas", o "Peregrino da America", uma "Vida de Maria Vitoria", a curiosa.obra do jesuita Alexandre de Gusmão, "Predestinado peregrino", um "Methodo dos papas", "Compendio de doutrinas", o "Promptuario moral" do padre Larraga, "Theatro dos triumphos", "Zodiacus divinos", "Capuchinho Morez", "Flores de devoçam. Få. Barbosa" e um "Sumario da... Dona Leonor". O avaliador dos livros, para efeitos da partilha, foi Antonio Gomes da Silva.

Os títulos são mais ou menos comuns a outros documentos. Dẹstacamos a.Bíblia cm portuguềs, talvez até a primeira edição cm vernāculo dọ Velho Testamentó, feita na Batávia (atual 
Jacarta), na Holanda, em 1748 e 1753, pelo tradutor português radicado nos Países Baixos, João Ferreira de Almeida. O mesmo tradutor, aliás, um pregador evangêlico, falecido em 1691 na Ilha de Java (atual Indonésia), é responsāvel pela edição encomendada pela Companhia das Indias Orientais para uso nas conquistas dos territórios tomados a Portugal -, do Novo Testamento, em português, feita em 1681, na cidade de Amsterdam. Destacamos tạmbêm a novela típica do moralismo.lusitano, a Histōria do Predestinado Peregrino e seu irmão Precito, (1.ed. Lisboa, 1682) do padre Alexandre de Gusmão, S.J.., (1629-1724), o mesmo jesuíta diretor do Seminārio de Belém, na vila de Cachoeira, província da Bahia, desde o século XVII. A obra refunde conceitos da moral religiosa, bebidos em São Paulo e Santo Agostinho, e é considerada a primeira novela escrita no Brasil. Tem personagens alegóricas como o próprio Predestinado, seu irmão Precito, a mulher que se chama Razão e os fillhos, Bom Desejo e Reta Intenção, todos clivados pela mesma moral entre Jerusalèm (o Cêu) e Babilônia (o Inferno). Tudo dentro da sacralidade da peregrinação, do Egito à Babilônia, incluindo intrigas e conflitos típicos das narrativas de fundo moral, com os efeitos e resultados das açōes humanas conduzindo.à condenação, ao saçrifício ou à bem-aventurança.

Na mesma linha novelistica de efeito moral da peregrinação ascêtica, é o Compêndio narrativo do Peregrino da América, do brasileiro Nuno Marques Pereira (1652-1731), que publicou sua obra, pela primeira vez em 1728 , com outras reedições no próprio século $(1731,1752,1760,1765)$. Barro- 
quista na forma, o Peregrino é de extraordināria popularida- de no Brasil Setecentista, ainda que sua tessitura seja prejudicada pelos vícios de uma prosa arrastada. São interessantes alguns trechos da narrativa, sobretudo onde o autor considera características de estilo e conteúdo moral. Este ủltimo, aliás, é antecipado pelo próprio título da obra: Compendio narrativo do Peregrino da Amërica em que se tratam vá-

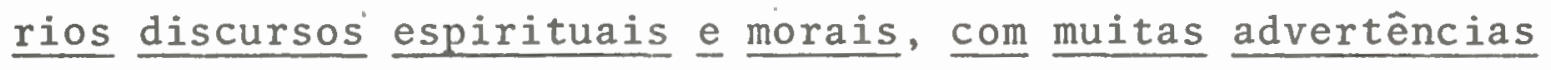
e documentos contra os abusos, que se acham introduzidos pela maiícia diabólica no Estado do Brasil. O livro é dedicado à Virgem da Vitória, chamada de "Imperatriz do Céu e Rainha do mundo, Senhora dà piedade e Mãe de Deus". Num pró10go ao leitor, Nuno Marques Pereira começa citando passagens da Biblia e de Santo Agostinho, e outros doutores da Igreja como São Pedro Crisólogo, Santo Ambrósio e Santo Tomás, como a arrimar-se na companhia de incontestados doutrinadores. Defende sua obra e os objetivos de edificação moral do homem do século XVIII, uma vez que, tomando como suas palavras de "um contemplativo", considera que aquele "que lề livros espirituais, paga o dízimo a Deus; e o que 1ê os profanos, paga o terço, ao diabo". No mesmo prólogo, o autor completa, pela persuasão de sẹ discurso moral, a voga da leitura ascética, recusando os estilos "pagãos" da literatura barroca:

... estando eu em casa de um amigo lendo o Bäculo pastoral, entrou um destes loucos peripatéticos, desvanecido com presunções de discreto; e sabendo do título do livro, me disse que nenhum hómem de juízo se ocupava em ler livro tão vulgar. E ouvindo eu, se não blásfêmia, proposição tão mal 
soante, lhe perguntei: "Pois que livro se hä de ler?" E logo me respondeu, mui ufano: "Gôngora, Quevedo, Criticōn; Para todos, de Mantalvan; Retiro de cuidados, Florinda, Cristais da alma; novelas e comédias; porque estes livros ensinam a falar." "Pois eu entendo, senhor" lhe disse,que esses livros e outros semelhantes ensinam a falar, para pecar; e este e outros espirituais ensinam a orar, para salvar."1223

Quanto ao "Compendio de doutrinas" presente no inventário de Jacinto Ferreira Feijó de Faria, talvez possamos presumir tratar-se do Compêndio de Doutrina Cristã (Lisboa, 1559), de Fr. Luís de Granada, contendo artigos do Credo católico, os mandamentos, a artè de orar, os sacramentos e mistérios da missa. A. suposição talvez não seja absurda, face às sucessivas reedições e o gosto püblico pela obra do célebre dominicano que tinha no leitor uma espécie de parceiro, .escrevendo sempre num estilo conciso e fluente, com a clareza capaz de cooptar leitores, sem abastardar a maneira de escrever.

No inventārio do padre Manoel Gonçalves da Cruz, de 1763 (ARQUEB, Judiciäria, Capita1, 639-1), não constitui surpresa o fato de todos os títulos da livraria do inventariado virem versados em matéria religiosa, mais especialmente, obras que servem ao ofício do reverendo; como "Thesouro espiritual", "Baptisterio", "Repertorio", "Diretor funebre", "Sermoens", "Mestre da vida", "Ripanço" e "Larraga".

Pode arguir-se que "Repertorio" esteja mais na orientação de uma estante de Direito, suplemento às inumeráveis 
Ordenações do Reino de Portugal que nos chegaram. Mas também pode vincular-se à disciplina religiosa, em virtude da heterodoxia na anotação expressa pelos escrivães, ou por causa mesmo da ambiguidade de o título servir à Religião enquanto área de conhecimento em Direito Canônico, por exemp1o. o "Diretor funebre", indicado no inventärio, deve ser, na verdade, o livro do espanhol Fr. Francisco de Jesus Maria Sarmento, Diretório fúnebre e reformado, para as cerimônias e cantochão do ofício de defuntos, enterro e procissão das almas: modo para se oficiar e administrar com perfeição o sacrossanto viático aos enfermos: obra utilíssima para os pärocos, regentes do coro e mais eclesiásticos.

0 mais importante documento de inventariação de 1ivros na Bahia Setecentista é, sem dúvida, o pertencente a Manoel Dantas Barreto, de 1768 (ARQUEB; Judiciária, Capital, 02/972/1441/01). Em que pese seu estado 1astimável, em a1guns pontos, corroido pela broca, torna-se ainda mais interessante em razão da disposição feita, por escrivão ou avaliador, distribuindo a livraria por "Livros de folio", "Obras inteiras" etc. A predominância óbvia de assuntos doutrinärios confirma o perfil do leitor colonial brasileiro, sepetindo, no estrito sentido da Ascese, da Mística, da Hagiografia etc., a relação de livros modelạr das opções de leitura caudatária do afervoramento místico. Este, como sabemos, vem produzido pelo rigor dos axiomas cristãos defendidos e divulgados pelos incontáveis soldados da Reforma instalados na civilização brasilcira.

Descrevendo, a partir deste ponto, somente os títulos 
que ampliem o universo de leituras doutrinärias - sem esquecer; por óbvio, de mencionar a percorrente disposição dos títulos já convencionais - vamos observar, no mesmo inventârio de Manoel Dantas Barreto, de Salvador, um sensivel equilîbrio na manutenção das tendências até aqui orientadas no cartel de leituras de devoçã், de par com um notável senso de ampliação de títulos, no mesmo ramo de conhecimento. Trata-se, para um documento de 1768 , que registra títulos correntes deside os fins do Seiscentos e atẻ o própric curso do século XVIII, de uma das três maiores bibliotecas setecentistas no Brasil.

o inventário confirma "AGREDA. Mystica cidade de Deos, 3 t." e vai, aos poucos, introduzindo o conhecimento de outros títulos em matẻria devocional. Assim ê o caso de uma "Bibliotheca do mundo visivel e invisivel, $1 \mathrm{t}$. com pouco uso", e dos "Exércitos do Pe. Afonço Roiz, 1 t. com bastante uso", "Obras do padre Mancel Ribeiro Rocha: 3 livros port.; Arabes socorro dos fieis; Ethiope resgatado; Pratica dos oratorios". Aqui aparecem ainda as "Obras espirituais do Pe. Antonio das Chagas", ou, antes, Fr. Antônio das Chagas (16311682) que foi poeta gongórico, na linha da poesia épica, até chegar à ordem dos franciscanos, para onde também converteu seu estilo de escrever, assimilando uma poesia do intimismo ascético e piedoso, com uma espiritualidade próxima da piedade formal presente na Imitação de Cristo, por exemplo. Suas Cartas espirituais (1684 e 1687, duas partes, 100 e 268 cartas, respectivamente) são, certamente, as "Obras espirituais" referidas no documento de Manoel Dantas Barreto e que corresrespondon a umà freqüente popularidade no Brasil Colônia. 
Hä, ainda, no documento, uma "Academia singular", a que jā fizemos menção, e um "Flos sanctorum do Pe. Rozario, 2 t. port. com pouco uso", este que é tido como o mais bem escrito volume da vida dos santos, pelo Fr. Diogo do Rosário, dominićano portuguếs $(-1580)$, publicado em Braga no ano de 1567 , com outras reedições, guardando a ingenuidade inerente ao tipo, narrando, inclusive, trechos da vida de Cristo. Também aparece no inventärio a obra do padre Nicolau Fernandes Collares, Descrição do tormentoso cabo da enganosa esperança à hora da morte, talvez a edição saída em Lisboa Ocidental, na oficina de Antonio Pedrozo Galrão, 17181720, em 2 volumes. E'os Exercicios de perfeição e virtudes cristãs, do padre Afonso Rodrigues, jesuíta de Valladolid, traduzido por Fr. Pedro de S. Clara e editado em Lisboa, oficina Miguel Manescal da Costa, 1749, com nova edição em 1772. Assim como tambëm Luz de verdades católicas, obra do padre Laparra e Govierno general, moral y politico, do padre Andres Ferres de Valdecebro, editado em Madrid, Imp. de Bernardo de Villa Diego, 1683. Outros títulos, no inventärio de Manoel Dantas Barreto, continuam a pontificar pela raridade, como um "Dialogo sagrado sobre o Gènesis, 2 t.", a "Obra do padre Luiz de la Puente", "Familia Regula... do padre Arbiol", obras de Feijó e Segneri, "Filosofia moral, em castelhano", "Vida de São Joam da Cruz", "Hinario espiritual", "Antonio Augustin, castelhano", "Historia panegirica da vida de ...", "Obras de Zabilet, castelhano", "Exemplos morais, e humanos", "Sumna de Casos de Consciencia, castelhano", "Discursos morais", "Meure da morte e medianeira da vida, 2 t.", "E1 pastor de noche buená", e "Meditaçoens da infancia de Christo". 
Outros, ainda, serão de regular circulação no século XVIII, como as três obras do oratoriano padre Manuel Consciência (1669-1739) que aparecem no documento: a Academia universal de vária erudição (1732), a Floresta novissima de sentenciosas ações ( 2 v., 1735-1737, na esteira do padre Bernardes da Nova Floresta, agora compreendendo heróis da Antiguidade e da Idade Moderna) e A mocidade enganada e desenganada ( $6 \mathrm{v}$., 1729-1738), tudo dentro da melhor tradição de disciplina moral setecentista.

Na mesma linha, estão a palavira de Deus desatada, a Introduçāo à vida devota, a Arte de furtar, as Reflexōes sobre a vaidade dos homens, o Aparelho eucaristico, os Exercicios espirituais de Santo Inácio, em castelhano, as Armas da castidade, o Compêndio de exercicios espirituais, mais o Caminho do Céu e a Corte celeste, sem dúvida, exprimindo a ordem moral, mística e ascética que representam o desaguadouro natural das leituras cujo vigor e notação estática :validam o ar de abstração que o homem brasileiro, inspirado e devotado à disciplina eclesiástica, certamente foi assimilando até meados do século XIX:

Outros títulos se destacam, tambëm, por sua raridade curiosa. A Escola de curial de várias lições dedicadas à Virgem Nossa Senhora do Desterro, do Dr. Fradique Espínola, editada em Lisboa, Of. Manoel Lopes Ferreira e Cia., 1698, em 4 volumes. Ou o Tesouro espiritual, "que tanto pode ser Tesouro espiritual com sèu comento teológico e duas práticas espirituais e uma breve exposição do Pater noster, editado em 1624, como Tesouro espiritual da novena do glorioso s. 
Antonio de Pádua, revelada e ensinada pelo mesmo santo a uma nobre matrona sua devota, obra do brasileiro Faustino de Afonseca Freire e Melo, editada em Lisboa Ocidental, of. da Música, 1740 .

$\mathrm{Na}$ livraria dos inventariados Antonio da Costa e Tereza Maria de Jesus, de 17.84, (ARQUEB, Judiciāria, Capita1, 03/ 1145/1614/09), ocorre algo, às vezes, excludente no panorama documenta1. Trata-se de uma biblioteca mëdico-cirúrgica e farmacológica, com alguns títulos que poderiam gerar uma certa confusão atributiva, como "Santuario anatomico" ou "Correição de abuzos", eventualmente confundidos com alguma matéria de natureza mora1. A ünica obra, concretamente, na ordem dos assuntos religiosos seria "Praticas espirituais". Essa mesma situação, agora uma livraria com predominância em obras de Direito, no inventārio de Martinho Duarte, de 1790 (ARQUEB, Judiciäria, Capita1, 651-8), só vamos encontrar, de títulos em Religião, apenas "1 v. de Sacram. glor. mund.", "1 v. de Basilia Pontificia", "2 v. de Remigio", "3 v. de Breviario mor.", "5 v. do Catecismo de Mont,", "2 v. de Biblia sacra e concord.". E no inventärio de Antonio Manoel de Me1lo e Castro, de 1795 (ARQUEB, Judiciäria, Capita1, 656-1), ava1iados por Joaquim Marques, com data de 16 de novembro de 1795, vamos encontrar uma "Bible de Zoyan,.., 1 v.", um "Director espiritua1, 1 v.", "Horas latinas, 1 v.", "Ripanço. Da Semana Santa, Iv.", "Manual para a Confissão, 1 v.", "Novena de Sta. Anna, 1 v.", "Oficio de santos, 1 v." e "Oficio de N.'Sra., 1 v.". 
0 ūltimo documento relativo à Bahia Setecentista pertence ao cônego Dr. João Pereira Barreto de Menezes, 1799, com uma livraria indicativa, talvez, de dupla função do inventariado, fundamentalmente com títulos em Direito e Religião. Salientam-se, quanto a títulos doutrinários, os mesmós de regular circulação no século, junto a alguns outros cujas matérias assinalam um acrescentamento de obras ao patrimônio bibliográfico em devoção e moral. São eles um Teatro crítico e eclesiástico, do espanhol Benito'Feijó, um "Diretorio eucarístico" e outros que tipificam a disciplina eclesiástica que o reverendo deveria seguir:

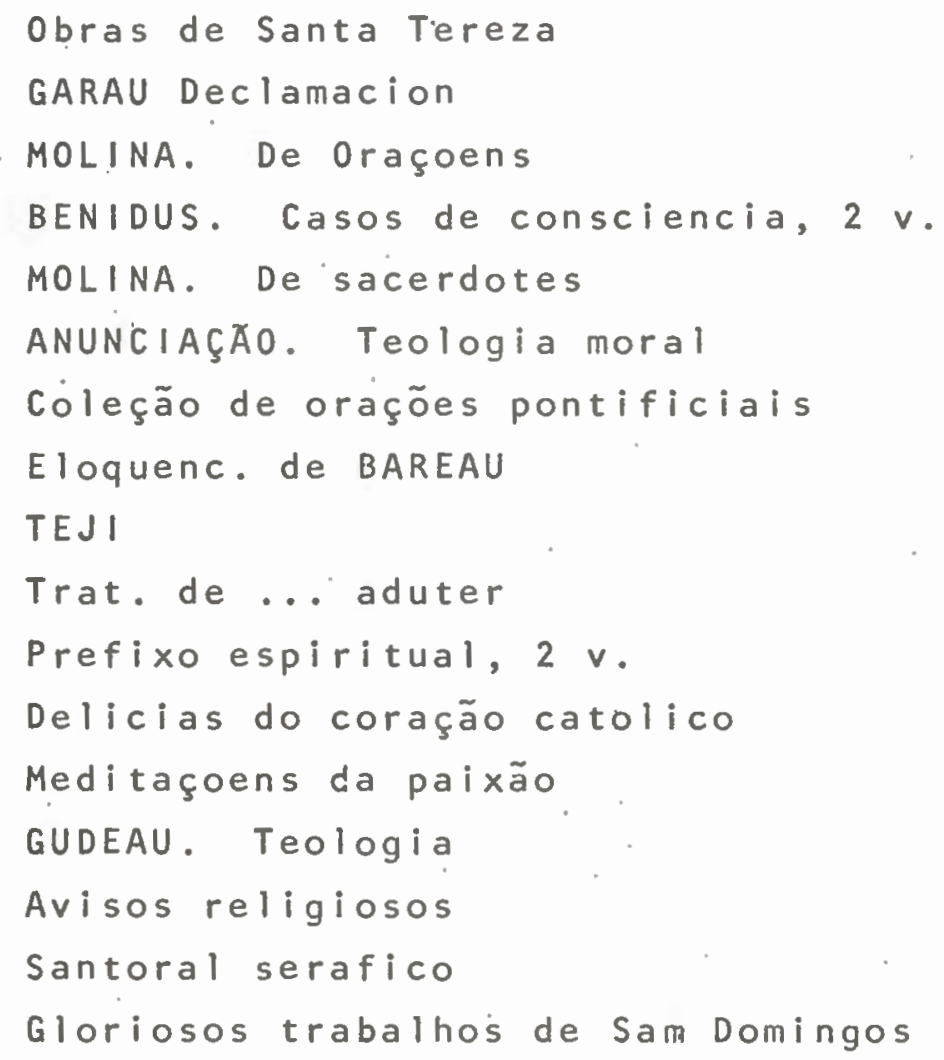

Completam a relação de livros com títulos pouco conuns em doutrina e devoção, neste inventắrio do cônego Barreto 
de Menezes, um Sacerdote instruído nos ritos e cerimônias da Missa, um Tribunal de confessores, do mistico Vigant e Instrução de cerimônias e prätica do sacramento da penitência. (ARQUEB, Judiciāria, 04/1762/2232/03).

O século XVIII brasileiro é, compreensivelmente, o de mais rica distribuição e frequência de livros, em especial. no ramo da Religião. Minas Gerais desempenha uma extraordinária contribuição nesse esforço de amostragem do perfil das leituras coloniais, e mais extraordinária ainda é a guarda desses documentos nas cidades históricas Mariana, Ouro Preto, Sabará, São João Del Rey, Barbacena, Tiradentes e Diamantina.

Neste ūltimo município, guardados num arquivo da Biblioteca Antônio Torres, encontran-se documentos dos Cartórios do $1^{8}$ e $2^{\circ}$ ofícios de orfãos. Em que pese a sobrevivẽncia de apenas dois documentos, de fins do século.XVIII, não podemos desprezar a hipótese de uma ampla circulação de 1ivros numa região jā nossa conhecida pelo interesse despertado em Portugal na lavra de ouro e diamantes. Os dois únicos inventārios de bens constando livros, em Diamantina, pertencem a Henrique Pereira Brandão, de 1796, (Diamantina, 29 0fício. Caixa 40 ) e ao coronel Paulo. José Velho Barreto, de 1797 (Diamantina, 19 Ofício, Caixa 63). O primeiro descreve - registro normal de uma única obra na prevalência doutrinária: o Tesouro de cerimônias, do padre João Campello de Macedo, editado primeiramente em Lisboa, Of. Diogo Soares de Bulhōes, 1688, com nova ediçāo na Of. Antonio Pedrozo Galrão, 1697 e muitas reedições no século XVIII, tal a extensa popularidade do livro no Setecentismo Brasileiro. 
o inventārio do coronel Paulo José Velho Barreto ilustra a tendência de leituras de Moral, Ascese, Teologia Dogmática, Direito Canônico, Hagiografia e Filosofia moral corrente no século XVIII brasileiro, em especial notando-se a característica dessas leituras entre os inventariados militares. A livraria do coronel Velho Barreto é, assim, muito. bem servida em títulos de natureza doutrinária e moral, como a Tentativa teológica com Apêndix, do padre Antonio Barbọa, em 2 volumes, e a Demonstração teológica, canônica e histórica do direito dos metropolitanos de Portugal para confirmarem e mandarem sagrar os bispos sufragadores, do oratoriano padre Antonio Pereira de Figueiredo, editada em Lisboa, na Régia of. Typogräfica, 1769. Assim também é o portugal sacro-profano, do padre Paulo Dias de Niza, publicado em Lisboa, na Oficina Miguel Manescal da Costa, 1767, em 3 volumes, ou a Practica de el confessionario, y explicación de las proposiciones con demandas por la Santidad de N.S.P. Inocencio $\underline{X I} Y$ Alejandro VII, do Fr. Jaime de Corella, editado em Lisboa, na Of. Manuel Lopẹs Ferreira, 1695, em duas partes, à época na quarta impressão. Fecha estè quadro de títulos incomuns de, doutrina religiosa, o Templo teológico, especulativo e prātico aonde se verá uma breve suma da Teologia Es peculativa e Moral, do padre Franconiano Almeida Favorino, publicado em Lisboa Ocidental, na Of. Manuel Fernandes da Costa; 1736, ao lado de um "Martirologio romano", "O costume dos cristaons", um "Trofeo de gloria nobilitante" e "Epistolas cecerinis".

Em Sabará, no Museu do Ouro: trabalhamos com mais de 
40 registros de documentos, entre caixas e Livros de Registros, movimentando cerca de 400 processos, documentação referente aos séculos XVIII e XIX. Curiosamente, o cartório do $2^{\circ}$ Ofício de Sabará é bem mais rico em dados e inventários do que o $1^{9}$. Neste último, aliás, começando pelo inventário do padre Manoel Coelho de Araujo, de 1779 (Sabará, Museu do.Ouro, "Livro de Registro de Inventärios, L, n 5"), identificamos todos os livros anotados no documento como art:iculados com a disciplina eclesiästica, obras de importância ao ofício do reverendo inventariado. Alguns títulos de doutrina, incomuns à vaga corrente, estão relacionados: um "Banquete espiritual", um "Livro dos exorcisados". e as "Diligencias da Bula". Do $2^{\circ}$ Ofício de Sabará, o inventārio de José da Silva Porto, de 1744 (Museu do Ouro, 29 Of., Pacote 45), traz um Exame de ordenandos, pregadores e confessores, obra atribuída a Felix Potestas e a Antonio Batista Viçoso, ambos muito frequentes no Setecentismo. Na sequência, o inventärio de Josë Leite Guimarães, de 1745, tem um "Ecercicio de perfeição" (Museu do Ouro, Pac, 15). E, finalmente, Francisco da Cruz, inventariado em 1745, mantém as caracteristicas dos títulos doutrinários, mostrando alguns novos em igual matéria: "Gritos da alma", "Itinerārio da Terra Santa", "Pensamentos christãos" e mais obras ascéticas, indicadas no inventário,como "Livrinho" da Senhora Santana, Santo Antonio e São José.

Como muitos, o leitor Antonio de Freitas Cardozo, inventariado em 1766,. (Museu do Ouro, 29 ofício, Pac, 23), radica a característica de leituras comuns a Minas Gerais e a 
todo o Brasil do sëculo XVIII. Das obras relacionadas na rubrica "Livros" no documento, apenas uma, com o curioso título de "Defezoens de Supremo" talvez escape à concentração doutrinária. As demais pertencẹm claramente à expressão de espiritualidade cristã, em que se destacamum Guia de penitentes e duas obras do padre Manoel Bernardes: Arnas da castidade e Luz e calor (Lisboa, 1696), esta ü1tima inserindo aspectos da Teologia mediante interpretações da Psicologia moral e ascética e personagens alegóricas (Alma, Inteligência, Memória) que dialogam, em apólogos piedosos, sobre a existência humana, com o fim de incutir no leitor a mística da perfeição.

o maior inventārio pertencente ao Setecentismo sabarense è mesmo o do Rev. Dr. João Baptista Lopes, de 1770 . (Sabarā, Museu do Ouro, 2: Ofício, Pac. 21): E uma biblioteca que combina títulos, primeiro em Direito e, segundo,em Religião, na vertente provável da atuação do inventariado, como religioso e como magistrado, ou bacharel. De fato, a grande maioria das obras são diplomas de legislação e jurisprudência, alternando com espiritualidade e moral. Nestes ủltimos campos, em nossa apreciação de títulos novos, observamos :

Tamburini Opera moralia, fol.

Laiman. Theol. moral, fol.

3 v. Borcalin, Theol. moral, fol.

$3 v$. Conferencias de Corella

Exemplo teologico

Sabino, Lux moral 
Becano, Theolo. escolastica

Lus mor. observ, in 4 ?

Praxi ecclesiastica e secular, velho

3 v. Seculo p.

Breviario franciscano

Navarro, opera moral, in 8 :

Sacras alegaçoens, in 8 ?

4 v: Bay. Theologia, in 8:

Horen. peq. velho

Ponte segura para o golfo da vida, in 8:

Meditaçoens das Domingas

Nadariannes celestis, in 8 ?

Reformação christam, in 8 :

o padre Antonio Carneiro Leão, de Sabará, inventariado em 1784 (Museu do Ourc, 29 Of., Pac. 39), tinha todos os livros na catégoria doutrinária respeitante ao 'seu ofício, com destaque, pela natureza incomum de" títulos, para um "Mestre da morte jä usado" e um "Lux Morato, já usado". Uma mesma esmagadora maioria para obras em Religião, abrindo um pouco" para disciplinas nas äreas de Literatura, Filosofia e Linguística, vamos encontrar no inventärio do padre Thomas de Moura, de 1785 (Museu do Ouro, 29 Of., Pac. 3), 1ivraria que cobre praticamente toda a seara religiosa, com livros de Doutrina, Mora1, Dogma, Ascese, Mística, Direito Canônico, etc. Os destaques são:

Soares de pinitensia, folio

2 t. Soares Cursus filosoficos, fol., velhos Nogueira, Expositio Beato cruciato, fol.

3 t. Decretales de Gratiano de Gregorio IV e Bonifacio VIII pontificados, in folio

3 t. de Castro Pol., fol. 
2 t. Pisinelli Mune., fol.

Picinelle Lumina Reflexa, fol.

Amora dos Anjos Seremonias, in 4\%

11 t. de Cornelio A Lapide, fol., muito velho

Gradus ad parnasum, in 8 :

2 t. Delacroix, Teol. moral, fol. muito velho

3 t. Ripaleta. Teol. expeculativa, fol. perg. velho

5 Teol. Concionatoria, lat., velho

2 t. Sermoens Fr. José de Lima, in 4: em perg. muito velho

Sermoens Fr. Vic. da Luz, 4:, perg., velho

Ceo mistico, 4:, perg., veltio

Stromas Predicaveis, 4 , perg., vel ho

Sermoens da Quaresma de Fr. José de Souza, 4:, perg. vellho

Campello de seremonias, 4\%, perg., velho

Sermoens de Fr. Antonio Lopes Cabrali Poncarpia, 4:, perg., velho

Vida de S. Caetano, 4: perg., velho

Filos. de Rocato, muito velho

Biblioteca secreta de pregadores, in $8:$ velho

Encerrando a contribuição do $2^{\circ}$ Ofício de Sabarā, no plano bibliográfico do século XVIII, a livraria do padre José Luiz Soto, inventariado em 1800 (Museu do Ouro, 2: Of., Pac. 49), concentra obras em Religião e Letras. Entre as primeiras, destacam-se, pelo invulgar da titulação, uma "Explicação dos dialogos", umas "Decísoens sacramentaes de Theologia", um "Manuel das ceremonias sagradas", seguidos de "Paraiso serafico por Fr. João Baptista de S. Antonio, já velho", "Cidade da consciencia por Pe. Balthazar da Encarnação, jā velho"; "Graças da Graça em portuguez por Dr. Josë Boneta, já velho", "Remedio de pecadores, jä muito velho" c "Infante ultimo entre a vida.e a morte". 
Em Sâo João De1 Rey, os documentos de inventārios de bens encontram-se no Arquivo do Museu Regional. São mais de 2 mil documentos do século XVIII e XIX, pertencentes aos Cartórios de $1^{8}$ e $2^{\circ}$ Ofícios da Comarca do Rio das Mortes, que compreende, além de $\mathrm{S}$. João, os municípios de Tiradentes e Barbacena. Nem todo documento, claro, indica livros como bens, mas é significativo o número das livrarias do Setecentos e Oitocentos naquela região. As estantes que mais se notabilizam são às mesmas identificadas anteriormente: os livros de Religião, destacados aqui os títulos pouco frequentes em livrarias já inventariadas.

O padre José Rodrigues da Cruz, inventariado em 1780 (Maço B-3), tinha uma estante bem nutrida em obras de natureza doutrinäria, com relevo para uma "Vida da Roza...", o "Levitico eclesiastico", "Teatro de Garrido", "Historia dos milagres de Rozane", "Azambuja das cerimonias da missa rezada", "Acçoens episcopaes", "Vida do padre Vieira", "Incen. do amor segundo...", "Flores de devoção", "Livro de Pascone Dominis", "Contra a perfidia dos judeos", "Floresta espanhola" e "Meditaçoens dos misterios da fé".

Como dissemos antes, Minas Gerais, São Paulo e Rio de Janeiro concentram a maior estatística em nưmero de inventários do século XVIII. Especialmente no que se refere a títulos em doutrina e devoção, sem dúvida, é Minas um singular repositório bibliográfico, avultando o número de religiosos e, consequientemente, de sua influência no corpo social, vale dizer, na impregnação de leituraș. A Religião ocupa, no Brasil, papel de extraordinäria importância histórica, ca- 
bendo a ela - ou, por medo dela... - grande parte dos espólios de bens de particulares. Como era mister, nos documentos analisados, o falecido, em testamento, praticamente destinava um terço de suas posses à Igreja, traduzido esse terço em número de missas rezadas em sua homenagem fúnebre e em doações inquẹtionáveis: Essa prodigalidade, manifesta em termos materiais, claro que seria reproduzida no tocante à formação de bibliotecas doutrinárias.

Na sequência da avaliação desse quadro em Minas, vamos observar, relativamente a títulos novos, descontados os de recorrente passagem nos documentos jā analisados, a1guns contributos à ampliação do nosso conhecimento de obras devocionárias e da moral religiosa vigente. Assim è que outros inventārios implicam títulos diferentes. "Silva de varias liçoens", "Notisias das religioens da Conxinchina", "Infante peregrino", "Exemplos morais de Joam Pires de Monte A1vim", "Solidades de la vida e de los enganhos del mundo", "Massimas del padre Garavanto, 1a. e 2a. partes", estão relacionados no inventário do Capitão Bento Pereira de Sã, de 1767 (Arquivo do Museu Regional de São Joāo Del Rey, Maço B3), ao lado de uma "Vida do padre Anxeta" - talvez a obra do padre Simão de Vasconcelos (1597-1671), com o título completo de Vida do venerável padre Josē de Anchieta da Companhia de Jesus - e uma "Chronica geral de Sam Bento".

"Lacort Sant. 4 t.", "Postilla Manus Christi" e "2 v. Peculios de Manus Christi" são tîtulos diferentes da predominância jā vista, conforme aparecem no inventārio de Pedro de Almeida e Oliveira, de $1747^{\circ}$ (SJ, Arquivo Histórico, Maço 
P-1 ou P-2), que tinha; tambēm, umas "Obras da Madre Soror Maria de Jesus". No inventário do padre Joaquim Josē de Souza, de 1795 (SJ, Arq. Hist., Maço J), em meio à extensa relação de títulos devocionais comuns, registram-se um "Monte Libano, 2 v. in. 88", certamente a obra do padre Josë Barbosa Leitão, Monte Líbano místico, seguida de outros títulos mais ou menos incomuns, como è o caso do Combate espiritual, de D. Lourenço Scupoli, traduzido por D. Thomas Bequeman, Lisboa, of. Joș Freire, 1761, e de outros: .

Istoria do Senhor Jesus de Bouças, in 4:

Conciones sacros de Corduba, fol.

Suma de Sam Thomaz, $17 \mathrm{v}$. in 8 ?

Cabo da Boa Esperança, 2 v., in 4 :

Livro dos moribundos, in 8 ?

Dissertação theologica de Fr. Manoel do Senaculo

Sciencia da salvaçam, in 8 ?

Istruzioni per confessori, 2 v. in 8:

Chiavo de oro

Premia Tonsura, in 8 :

Anumpciações evangelicas, 5. v. in 4\%

Colleçam das sete dores

E de registrar-se como a recepção de obras de efeito moral e retórica de convencimento sobre a inexorabilidade nas relações vida-morte tem uma largueza de interpretação e de fixação modelar nas leituras setecentistas, com extensão óbvià ao período do Oitocentos. Num espaço provâvel de oitenta ou cem anos, um mesmo título será comum a várias dēcadas, e em muitas bibliotecas, conforme fica demonstrado da avaliaÇão dos inventariados, afeitos ou não ao ofício religiosos e, seguramente, estendendo-se por todo o Brasil. Alguns desses 
inventariados só dispõem de uma única obra e esta, sem dưvida, será de natureza doutrinária, como os infinitos "Missal.", "Breviário", "Horas" etc. Outros dispõem de uma mais ampla disposição bibliográfica, excetuando algumas obras em outras áreas do conhecimento. Outros, ainda, alinham uns poucos títulos, na maior parte comuns às demais estantes religiosas, como uma "Prostetaçam de fé" ou o "Pecador convertido" no inventārio de Ponciano Pereira da Silva 1795 (SJ, Arquivo Histórico; Maço ( -3 ). As vezes, o título pode levar-nos a dúvidas. de atribuição. Por exemp10, o "Pecador convertido" expresso no documento, tanto pode ser Pecador convertido ao caminho da verdade, instruído com os documentos mais importantes para a observância dia lei de Deus, obra do Fr. Manoel de Deus, editada em Coimbra, Of. Antonio Simões Ferreira, 1728, ou o Pecador convertido pelas chagas do Senhor Jesus, escrita pelo Fr. Antonio Castro Feijó de Barbosa.

: A sucessão reiterativa permanece por todos os inventários de São João Del Rey, de Minas Gerais, São Paulo, Rio de Janeiro, Bahia e Pernambuco, alcançando, afinal, todo o Brasil leitor. Assim, por óbvio, descartamos aqui repisar ta1 reiteração, fixando-nos na indiçação de títulos novos, que traduzem e verticalizam a tendência de leituras, mas abrem nossa compreensão de abrangência de obras, autores e variação das matérias doutrinárias.

Grande parte desses títulos alcançam uma invulgar popularidade nos séculos XVIII e XIX, no Brasil, fazendo crer num fenômeno de seriação best-sellèr, uma verdadeira biblio- 
teca gerạl de livros de devoção e doutrina, até fins do 0itocentismo e, mesmo, atē princípios deste século.

Em O Cabeleira, de 1876 , a propósito de justificar o romance como peça histórica do século XVIII, Franklin Tảvora põe em cena uma personagem de valor secundaríssimo no plano da obra: o bispo de Recife e 01 inda D. Tomäs da Encarnação Costa Lima, aqui tido como grande orador, dono de "singela eloquência", leitor das "Cartas de Canganelli" - obra, aliâs, de surpreendente frequência nas bibliotecas brasileiras do Setecentos - e leitor de outras obras objeto de peculiares reflexões eclesiâsticas. Diz Távora, à página 53 do romance, sublinhando as excelências piedosas de D. Tomás da Encarnação: "O devoto bispo havia-se inspirado naquela passagem que um dos primeiros luminares das letras portuguesas, frei Luís de Sousa, nos deixou em sua imortal História de $\underline{\text { s. }}$ Domingos". 224

Muitos outros exemplos poderiam servir, ainda, de comprovação e eficácia do inventãrio como peça documental e histórica e, em termos superlativos, da extraordināria vocação leitora do brasileiro na direção de matérias doutrinārias, místicas ou ascéticas. Na abertura do capítulo I do Livro Segundo de D. Guidinha do poço 2 quando trata de dona Ângela, mãe de Guidinha, Oliveira Paiva lembra que a personagem "acabava de enrolar as Horas marianas na sua capa de couro, dando um nó na respectiva correia". ${ }^{225}$ o romance data de 1889 , publicado incompletamentè na "Revista Brasileira", por José Veríssimo, em capítulos esparsos (sua edição integral só se daria, por iniciativa de Lúcia Miguel Percira, cm 1952). 
Donde concluir pela popularidade de Horas marianas, obra do Fr. Francisco de Jesus Maria Sarmento, que alcançaria, em 1820 uma trigésima edição. Em outros termos, vale dizer da intensa popularidade das obras do ciclo de rezar perdurando, no mínimo, até fins do século XIX, ou, a julgar por alguns depoimentos, até começos deste século, pois um exemplar de Horas marianas estaria entre os bens do indigitado Antonio Conselheịro, o que põe em evidência simbólica o costume social da oração e recolhimento místico confirmando-se na tradição de leituras devotas, tradição, aliás, inscrita na antropologia cultural brasileira.

Outros tïtulos, ainda, poderiam ser aqui alinhados, e os muitos novos demonstrariam uma circular prevalência em hảbitos 1eitores, reproduzindo, quase ao limite da obsessão, uma clara tendência de leitura articulada com prätica sóciocultural no Brasil Colônia. Alguns desses tỉtulos são curiosos e raros, como uma "Sirurgia da'salvação por Nuntius Nicole", "Copulla florida in 4 " e "Flagelo do pecado, in 4\%", presentes na livraria quase exclusivamente formada de obras devotas do padre Cipriano Josê da Costa, inventariado em 1795 , (Arquivo S. João Del Rey, Maço C-2)'. Ou, ainda, um singularíssimo e raro "Horacio evangelico in $12 \% "$ no inventário do capitão João Ribeiro Taborda, de 1791 (Arquivo S. João, Maço $\mathrm{J}-4)$, numa livraria cheia de títulos de doutrina, onde pontua tambēm um exemplar de "Sermōes do Ilmo. Sr. bispo da cidade do Rio de Janeiro, in 4\%". De 1777 é o inventário de João Fortes Bustamante e Sá, no mesmo diapasão de obras reiterativamente doutrinärias, onde se destaca uma obra do bra- 
sileiro Antonio da Cunha Brochado, sob o pseudônimo de "hum padre da Companhia de Jesus", o Retiro espiritual para um dia de cada mês, muito útil para a reforma dos costumes e para dispor-se com uma santa vida para uma boa morte, traduzido do francês por José Altamirano editado em Coimbra, of. Antonio Simões Ferreira, 1741.

Neșse Indice de popularização, os títulos vão se sucedendo. "Narciso a Fonte" aparece no inventário do reverendo Dr. Ignácio José de Souza, 1798 (Arquivo S. João De1 Rey, Maço I-28), onde se conciliam estantes de Religião e Direito, notabilizando o inventariado como religioso e bachare1. A obra Pequenos na Terra, grandes no Céu, do Fr. Apolinário da Conceição, editada em Lisboa Ocidental, of. da Música, 1732, em 5 volumes, aparece no inventārio do sargento-mor Luiz Barbosa Brandão, de 1756 (Arquivo S. João De1 Rey, Maço L-1). E umas "Obras de Madre Thereza de Jesus", junto com "Innocencia prodigiosa" e "Thesouro de prudentes" constam da livraria de André Figueiredo da Silveira, inventariado em 1760 (Ouro Preto, Casa do Pilar, $1^{\circ}$ Ofício, Códice 11, Auto 99). Como curiosidade, também, a obra Desejos de Job, do padre Francisco de Mattos, certamente a editada em Lisboa, Of. Pascoal da Silva, 1716, encontra-se no inventário de Manoel Ferreira da Fonseca Coelho, de 1742 (OP, Casa do Pilar $1^{\circ}$ Of. 46/504), junto a "Dezengano de pecadores", "Vozes do Ceo e sucessos de Portugal", uma "Queixa do amor divino" e uma "Joya requissima", entre outros títulos novos e os frequentes nas demais livrarias.

Títulos incomuns vão apàrecer tambèm no inventário de 
Manoel da Silveira Peixoto, de 1741. (OP, Casa do Pilar, $1^{\circ}$ Of., 121/1529), como "Retiro de cuidados", "Vozes do Ceo", "Gostos para Todos", "Florinda", "Guia dos Casados" e um singular Trabalhos de Jesus, do Fr. Tomé de Jesus (1529-1583), editado em Lisboa em duas partes (1602 e 1609), com outras reedições e, inclusive, traduções em outros idiomas.

A maior biblioteca mineira em títulos e matērias religiosas é, sem dúvida, a indicada no inventārio do padre Manoel Ribeiro Soares, documento de 1785 do 19 Ofício de Ouro Preto (OP, Casa do Pilar, 102/1274). Implica a demonstração inequivoca do interesse e gosto de leituras do inventariado, compreendendo, praticamente, todos os luminares da ciência teológica e dogmática da ëpoca, concentrando um dos maiores números de obras descritas em nossa investigação. Como em igual documento de Manoel Dantas Barreto, da Bahia, traz indicação catalográfica peculiar, abrindo com "Livros de Fo1io", depois "Livros de $4^{\circ}$, com capa de pergaminho", "Livros de $8^{\circ}$ com Capa de Pergaminho", "Livros de $4^{\circ}$ com capas de Pasta" e, por fim, "Livros de $8^{\circ}$ com capas de Pasta". São muitos e variados os títulos da livraria do reverendo de Vila. Rica. Alguns deles se destacam, em nossa descrição, pela pouca extração em documentos semelhantes, ou pela curiosa raridade de seu aparecimento. E o caso de Poliantcia sacra, do padre Andreas Spanner, editada em Veneza, na Tipografia Balleoniana, 1741, em 2 volumes, e registrado nesse inventārio mineiro. Ou da Introdução à vida devota, de S. Francisco de Sales, ou, ainda, do Aureo trono episcopal colocado nas minas de ouro, de D. Fr. Manoel da Luz, cditado 
em Lisboa, por Miguel Menescal da Costa, 1749. A maior parte dos titulos, todavia, è a descrita no corpo deste traba1 ho.

0 28 Ofício de Ouro Preto, embora em menor número que - do $1^{\circ}$, contribui com documentos de época para a nossa mais ampla compreensão do perfil de leituras do Setecentismo brasileiro, especialmente em Minas. No mais agudo dessa contribuição, reponta um universo de Doutrina e Moral, universo privilegiado em virtude da ativa presença de padres, cônegos e outros religiosos católicos nas cidades históricas de mais sensível guarda cultural. Alguns poucos títulos escapam à predominância jā apontada. Hā um tîtulo novo, "Martires do Marrocos" no inventário de José Teixeira da Motta, de 1787 (OP, Casa do Pilar,.29 Of., 31/344) e um "Signal dos predestinados" entre os bens de Manoel de Abreu Soares, inventariado em 1752 (OP, Casa do Pilar, 29 Of., 61/690), o que faz con-fluir para Minas outras obras numa mesma e exclusiva teia de apreensão da cultura livresca doutrinäria.

Na Cúria Metropolitana de Mariana, consultando o testamento de Salvador Furtado de Mendonça, do século XVII, nada encontramos no interesse direto deste trabalho, ou seja, nada consta no documento quanto a uma perspectiva do leitor colonial seiscentista. Ali tambëm percorremos livros de tombos e de devassas, autos de sequestros e outros documentos, anotando, apenas, exemplares do Missal Romano nos inventärios das igrejas de Nossa Senhora da Conceição das Dores (1730) e de Nossa Senhora da Conceição e São. Caetano de Itaubira, Nossa Senhora de São João Del Rey, Nossa Senhora do Pilar, Nos-- 
sa Senhoṛa da Conceição do Rosārio da Villa de São José e Nossa Senhora do Bom Despacho do Córrego. O Missal, áliás, é livro de espantosa circulação em todo o país, presente na maior parte das livrarias do Setecentos e Oitocentos no Brasil.

Na mesma Cūria de Mariana, documento referente à Cathedral da Sé, (Prateleira P, Livro 16 (1749-1904), folhas 5,6 $10 v, 12 v, 51$ e 73), anotamos o registro de devocionários, missais, bíblias, breviários, pontificais para missa, rituais romanos, manuais martirológicos, livros de cantochão, confessionários, diretórios espirituais, antifonários, psaltériuns romanos e teatros eclesiásticos, na linha óbvia das tendências de literatura antes encontradas. Os documentos da Cúria relacionam, sucessivamente, ano após ano, as obras existentes na Catedral onde oficiou o conjurado cônego Luís Vieira da Silva, dono de famosa livraria de autores proibidos. Entre os títulos relacionados da Sé de Mariana, destaca-se um "Psalterium romanom", certamente setecentista, mas livro de antiga lembrança jã que teve sua primeira edição em 1457 , por ninguëm menos que Gutemberg.

A quase exclusiva guarda de documentos dos séculos XVIII e XIX encontra-se na Casa Setecentista de Mariana, documentos pertencentes aos Cartórios do $1^{\circ}$ e $2^{\circ}$ Ofícios de Orfãos da comarca. E um número expressivo de inventärios, muitos deles em excelente estado de conservação, que validam ainda a busca de informações e ajudam. à preservar a memória brasilcira. o 19 Ofício é bem mais rico de documentação, variando e regulando em quantidade os referentes aos séculos' XVIII c XIX. 
Dessa maior parte, muitos descrevem livros como bem de partiTha e, desșes livros, repita-se, a contribuição mais densa $\vec{e}$, sem dúvida, da bibliografia doutrinäria e moral. Alguns títulos são aqui destacados, como o Sol nascido no Ocidente e posto ao nascer do Sol Santo Antonio português, de Bräs Luís de Abreu, publicado em Coimbra, Of. Josē Antunes da Silva, 1725 , conforme aparece no inventärio de Antonio Alves de Carvalho, de 1792 (CSM, 1\% Of., 39/905). E tambëm destaque - Enigma numérico predicable explicado em cinco tratados, de Fr. Juan de Mora, publicado em Lisboa Ocidental, of. Pedro Ferreira, 1718, no inventário do cônego Dr. Antonio Amaro de Souza Coutinho, 1800 (CSM, 19 Of., 42/960).

Algumas bibliotecas, na acepção quase exclusiva de títulos religiosos, trazem alguma particularidade de interesse não convencional. E o caso da inventariada do padre Francisco Vieira Alves, de 1787 (CSM, 19 Of., 75/1587), que traz uma expressivá coleção de sermonärios. Outras sintonizam apenas com a mesma febre ascética ou mística decorrente do apetite dógmätico da cultura religiosa. Manuel Caetano de Souza, inventariado em 1787 (CSM, IP Of., 115/2386), não fugiria a essa regra, alinhando, entre seus títulos pouco frequentes, um Ordo verborum e sacrosanctu Concilio Tridentinum, por Francisco Freire da Silva. O reverendo Francisco de Pau1a. Meire11es, num inventärio de 1794 (CSM, 19 Of., 151/3159), entre muitas obras consagradas de doutrina, outras pouco comuns como "Biblioteca secreta dos pregadores", "Obsequios divinos ao sagrado temp1o" e um "Clamores evangelicos", tambóm possuía livros de reconhecida, mas pouco comun, importância 
na bibliografia doutrinäria, como o Troféu evangélico exposto em quinze sermōes históricos, morais \& panegiricos, que

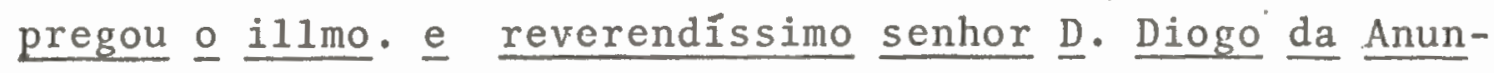
ciação Justiniano, publicada em Lisboa, Of. Miguel Deslandes, 1699, uma primeira parte, ou Fênix gloriosa entre aromas da devoção renascida e em anuais diários eternizada em práticas e sermões políticos, panegíricos e morais, espécie de coletânea com os melhores autores da prosa portuguesa de devoção, publicada em Lisboa Ocidental, Of. Bernardo da Costa e Of. Miguel Rodrigues, 1727-1730, em 2 volumes.

Uma das ûltimas curiosidades dessa bibliografia devocionâria oriunda do século XVIII brasileiro vem de Mariana, ainda, no inventärio de Francisco Gomes da Cruz, de 1769 (CSM, 19 Of., 152/3183), que indica um "Cul to funebre sobre - suicidio". E, do 2 Ofício marianense, avulta em importância a indicação de "34 livros de Santa Barbara", o que indicia como provável mercador de livros o inventariado Leonardo José Teixeira, de 1790 (CSM, 28 of., 34/801). Por todo o século XVIII, os títulos serão mais ou menos frequentes. João da Silva Rolim, de 1722 (CSM, $2^{8}$ of., 45/1012), tinha, por exemp1o, "Poderes do amor", junto a uma "Rosa franciscana". E Josë Alexandre de Oliveira, em inventärio de 1762 (CSM, 28 Of., 57/1284), tinha um "Desengano de pecadores", livro muito comum às bibliotecas brasileiras coloniais.

Em matëria de títulos de doutrina, São Paulo vem logo a seguir de Minas Gerais, quanto ao número de documentos e aos documentos incluindo livros, no setecentismo brasileiro. 
Foram vistos inventārios e fontes primärias afins, relativas a todo o Estado, no Arquivo Público, na capital, no Arquivo do Judiciărio, sob a responsabilidade da Divisão de Arquivo da UNICAMP, em Campinas, e nos arquivos do Judiciário de Jundiaí e Pủblico de Santos, além da documentação relativa a toda a Cúria Metropolitana de São Paulo.

Justamente na Cúria Metropolitana, no bairro de Higienópolis, encontramos um "Livro de Tombo da Parochia da Sé", de 1747 , registrando, à p. 5v, "5 Missaes. velhos e desencadernados", "3 Cadernos de missas de defuntos velhos e desencardenados" e "1 livro dos oficios de defuntos". Na mesma instituição, agora avaliando um livro da "Sé - Receitas e Despesas", para os anos entre 1748 e 1817, encontramos, na referência ao século XVIIL, três registros de despesas que identificam a circulação de livros na Sé de São Paulo. A Despesa de 1763 foi feita para encadernar um Missa1 Romano: a Despesa de 1794, para a encardenação de um "Diretorio martirologio do Choro" e de um "Livro dos Evangelhos, e Epistolas"; e, finalmente, ạ Despesa de 1788, para encardenação de um "Livro para coro".

0 único inventärio concretamente, da Catedral da Sé de São Paulo, referente à paróquia de Nossa Senhora da Assunção, lamentavelmente não indica com precisão a data, mas reconhecemos ser do século XVIII, em vista das características do documento e pela proximidade da anotação com a data de início dos registros de base: 1747. Os livros constantes do acervo dà referida Catedral, à êpoca do documento, são aproximados das tendências de leitura verificadas no Brasil 
Colônia e estão transcritos no "Inventário da Catedral da Sé páginas $29 \mathrm{v}$ e 30 .

Para a descrição de inventários de São Paulo, tomamos a informação, aliās procedente, de que todos os documentos dos séculos XVII e XVIII estão no Arquivo Público e que os do século XIX̣ estariam então na guarda do Arquivo do Judiciärio,localizado num galpão no bairro de Vila Leopoldina, cidade de São Paulo. No entanto, embora poucos, encontramos alguns inventärios do século XVIII no imenso estoque documental das Varas de Famỉlia no Arquivo do Judiciärio. Um deles, o do Tenente Francisco Nobre da Luz, de 1770 (SP, Arq. do Judiciário, $1^{9}$ ofício, Caixa 173) apresentou livros como bens para os efeitos da partilha entre os herdeiros. Desses livros, sete títulos ao todo, seis pertencem à doutrina católica, sendo a exceção uma "Arte de cosinha". Os espirituais seguem a vertente de títulos bastante circulares no Brasil Setecentista: "Horas latinas", "Horas latinas pequeno", "Horas portuguezas usado", "Luz da verdade", "Arte pratica de filósofos" e uma "Coleçam espiritual".

No Arquivo Pủblico de São Paulo, logo nos deparamos com uma considerävel quantidade de documentos do século XVII e XVIII. Neste último periodo, as obras e os títulos religiosos șão tambẻm de traço marcante. Começam pelo inventário de Matheus de Leão, de 1703 (APSP, Ordem 500), onde localizamos "Hũas obras (ou oras) portuguezas uzadas". O padre Cosme Gonçalves Moreira, inventariado em 1713, claro que teria seus bens con livros traduzidos na ordem moral e ascética, aliás necessários ao seu ofício. Não são muitos, mas repro- 
sentativos quanto à nossa avaliação: "Hum Livro Perfeccion de1 cristiano", "Los estados de la espiritual Hierusalem", "Combate espiritual", "1 livro de Casos morales", "Las cinco pedras de David" e "Sermones". Como se pode notar, a predominância dos tîtulos é em espanhol (APSP, Ordem 502). José Madeira Salvạdores, cujo inventārio data de 1733, registra como obras religiosas todos os títulos declarados: "Livro Floresta secreta", "Cartas do Padre Vieyra", "Sermoens do Padre Vieyra", "Bacul1o pastoral" e "Bautisterịo". (APSP, Ordem 5.12). Este último título, talvez, deve tratar-se do Bautistério e cerimonial de sacramentos da Santa Madre Igreja Romana, sem indicação de autoria, que encontramos também no catálogo organizado por Fr. Gaspar da Madre de Deus, entre 1763 e 1766, para a biblioteca do Mosteiro de São Bento do Rio de Janeiro.

Permanece em São Paulo - como, de resto, em todo o Brasil - o zelo (e, talvez, o temor) de classe nas relações do indivíduo com a instituição Igreja. Se tal zelo não obstava e, mesmo, se excedia em disposiçōes testamentārias de deixar à Igreja bens imóveis e pecủlio para missas, claro que ficaria mais explícito ainda na forma de leituras e de livros. Logo, os brasileiros coloniais seguem tendo as mesmas obras em suas livrarias, numa clara dependência do discurso eclesiạstico, temerosos e obedientes à unção doutrinária amplamente manifesta num meio social ainda difuso e sem outra organicidade que não a estimulada pela Igreja.

E aqui chegamos àquela que è a mais versada livraria doutrinária do século XVIII no Brasil. Pertence ao Fr. Ma- 
noel da Ressurreição, inventariado em 1789, em São Paulo (APSP, Ordem 561). São cerca de 375 títulos e 11 mil 548 volumes, a óbvia maioria em disciplinas de Teologia Dogmática, Ascese, Moral e sermonärios, com ênfase especial na quase absoluta ordem de leitura dos Doutores da Igreja, a Bíblia em vários idiomas, místicos como S.João da Cruz, dicionārios da Teologia e da Bíblia, catecismos de moral e mais os teólogos da praxe bibliográfica vigente, prosadores como Bossuet, apologistas, doutores de Direito Canônico, versões de. Concilio Tridentino e, surpresa das surpresas, um "Catecismo brazilico" e um "Index librorum prohibitorum". Completam a magnifica estante do frade paulista títulos em Letras, Filosofia e Direito.

Novos títulos de livros vão acentuando a característica das matérias estudadas pelo leitor setecentista no Brasil. "Delicias da alma" e "Contra o vicio de murmuraçam" no inventārio de Antonio Coelho Cerqueira, de 1737 (APSP, Ordem 634). "Chave do Ceu", "Primeiro arco", "Corvo de pomba" e "Oraculo" no inventário de Madalena de Moraes, de 1756 (APSP, Ordem 638). "Praxis ecclesiastica", "Pratica dos vizitadores, pequeno","Esercicios da piedade", "Crisis del mundo" e "Alma instruida" no inventário do reverendo português Arcipreste João Machado Henriques, 1756 (APSP, Ordem 655). Essa ordem de leituras atravessa todo o século XVIII, praticamente de 1701 a 1800 . Ignez Pedrosa de Barros, por exemplo, cujos bens e nome estão intimamente ligados à Casa Grande do Tatuapé, monumento tombado em São Paulo, tem scu inventārio datado de 1715 (APSP, Ordem 677) registrando i- 
guais menções em espiritualidade, com Bartolomeu de Quental, Manue1 Bernardes, Antonio Vieira, que se amplia com um manifesto teológico do tipo "Hum livro Explicação da escritura contra os judeos".

Alguns leitores, no entanto, se distinguem por incluir em suas bibliotecas obras de pouca circulação no Brasil, como João de Pontas, inventariado em 1747 (APSP, Ordem 667) cujoacervo, todo ele, vem versado em matérias espirituais, com a distinção de títulos como "Aforismo confessariorum", "Livro castelhano Declaración curioza", "castelhano, Ver, oir o ler" e, finalmente, "In $4^{\circ}$, castelhano, "Pratica del amor de Dios". Assim um pouco é o inventärio do mestre de campo Antonio Raposo da Silva, de 1738 (APSP, Ordem 691) com seus títulos comuns e uma "Fragoa do amor divino". Ou, ainda, Maria Domingues de Pontes, inventariada em 1737 (APSP, Ordem 714), que tinha um livro de "Casos raros de confissão". Ou 'o padre Antonïo Âlvares Rocha, num inventārio de 1732 (APSP, Ordem 727), com obras chamadas "Epigramata sacra", "Estrada romana", "Roma, ilustrada" e "Comentarium apocalico" (sic). Finalmente, "Oraculo profetico" e "Palavra de Deos desatada", respectivamente nos inventários de João Barbosa de Siqueira, em 1745 (APSP, Ordem 732) e João Dias da Silva, 1727 (APSP, Ordem 733). O Fidalgo da Casa Real André Alves de Castro fecha essa nossa amostragem dos livros circulares em São Pau1o Setecentista, num inventärio de 1765 (APSP,Ordem 744), com um título igualmente incomum: "1 v. Soledade do mundo".

No Rio de Janeiro, nossa pesquisa começa descrevendo os livros constantes do "Livro de Espólios dos Monges" do 
Mosteirode São Bento, documento encontrado entre os papéis existentes no Arquivo do Mosteiro. Organizou-o o Fr. José de Santa Engrácia em 1795, com o seguinte intróito: "O Fr. Joze de Santa Engracia numerey este livro que deve servir a lançarem. todos os inventarios e leiloens dos monges falecidos exceptuando esta e a ultima folha em q. fizer o termo". Datado de "Mosteiro de S. Bento do Rio de Janeiro; 15 de abr' de 1795", ou seja em agosto de 1795. Era D. Abade à época o Pregador Geral Fr. Luciano do Pilar. o livro registra, por vezes, o inventārio dos bens do monge falecido e, logo após, a arrematação de alguns desses mesmos bens. Em outras vezes, ambos os registros vêm reunidos. O primeiro inventário registrado é o do P. Fr. José de S. Venâncio, que não tinha livros a descrever. Na prática da partilha dos bens arrecadados, porém, coube, dos $278 \$ 580$ arrecadados, 1 terço para a livraria do Mosteiro, sendo os outros dois terços destinados às obras da Igreja e às missas em homenagem fúnebre do inventariado. A data da arrematação e os certificados referentes ao documento dos bens do Fr. José de S. Venâncio è de 26 de junho de. 1797 .

0 primeiro inventário que identifica bens em livros é - de Fr. Lourenço da Expectação, de 1798 (data da terça do espólio: 16 de agosto de 1798, "Livro do Espólio dos Monges" Most. S: Bento, F1. 3 a 5v.). E uma grande biblioteca, com as obras típicas de nosso conhecimento em Doutrina, Ascese e Moral, com destaque para "Murga. De beneficiis, 5 v. fol.", "O porque de todas as couzas", "Avisos e reflexoens, in 8 " e "Empresas de S. Bento por Fr. João dos Prazeres". 
A documentação do Arquivo Nacional, no Rio de Janeiro, com anotação de livrarias do século XVIII, restringe-se, pela quase totalidade, às duas últimas décadas do período. E sem dúvida, curiosa essa perspectiva, como se validasse a existência ou recolha de peças documentais somente a partir dessa faixa de tempo, ou, o que é mais legitimo supor, os leitores só̉ se tenham manifestado por essa época. o que não muda, seguramente, é a clara transparência de leituras devocionais, a situação colonial impondo modelos sócio-culturais tornando a moral católica norma disciplinar e teocêntrica. 0 mesmo fenômeno das terça's em dinheiro para inumeräveis missas de encomendação das almas e doação de terrenos e bens imóveis confirmam um certo servilismo prê-intelectual, as estantes de livros se prestando apenas a atestar uma formal obediência à disciplina eclesiāstica. No Rio, todavia, os inventārios são em número menor do que os existentes em Minas e São Paulo e abrem muito mais a outras disposições de um leitor de fins do século XVIII, interessado, também, em outras áreas do conhecimento especifico.

o documento de bens do Dr. Manoel Antunes Suzano, de 1783 (AN, Cx. 3629, N. 22), ë peça preciosa para a nossa compreensão de determinados modelos da cultura e da sociedade carioca dos fins do século XVIII. 0 inventariado tinha um filho padre, um filho advogado, um filho furriel, ou alferes. Sua livraria é uma das maiores do Rio de Janeiro à época, conforme se pode notar a partir da anälise do documento. Cada un dos herdeiros levou em livros aqueles mais de acordo com sua formação, ou intcresse imediato. Co- 
mo o falecido era advogado, naturalmente que a maior parte da biblioteca foi para o filho bacharel.

Algumas curiosidades expressas em títulos são o "Compendio das esposas" no inventärio do capitão-mor José dos Santos, de 1793 (AN, maço 473, n. 9029), "Humas sacras comedias". no inventärio de Maria Teresa do Monte do Carmo, de 1795 (AN, Cx. 1126, n. 9335), "Soliloquios a Jesus Christo", "Flores claves estorial" e "Claustro dominicano" no inventārio de Nicolau da Costa Guimarães, de 1796 (AN, Cx. 892, n. 3488 ) e dois registros de Horas portuguezas, um da autoria de Francisco Vilela (Lisboa, 1780) e o outro Horas portuguesas de Oficio da Virgem Nossa Senhora e Ramalhete manual de diversas orações, de Carıos do Vale Carneiro (Lisboa, Domingos Carneiro, 1673; 1815, pela Tipografia Silva Serva, na Bahia). Uma ủltima novidade, no Rio dé Janeiro, é a frequência do avaliador e livreiro Manoel Jorge da Silva Pereira, de que não encontramos maiores referências.

o mesmo despojamento crítico e a regular abundância de bibliotecas religiosas estão presentes no perfil do leitor oitocentista. Muitas características de leitura irão permanecer, sobretudo até. o primeiro quartel do século XIX, ampliando o espectro de dominação cultural imprimida pelos ministros das várias ordens religiosas no Brasil. Conforme vimos em outro ponto deste trabalho, as livrarias oitocentistas são em número bem maior que no sẻculo anterior, variando e diversificando titulos e assuntos, acrescentando novos autores e novas äreas de interesse. o costume.e a tradição de obras devocionais, no entanto, parece ter uma presença definitiva 
e ássegurada ao longo de todo o.período, limite em 1850. Segundo dispomos, aqui, a iniciativa da descrição de títulos não recorrentes, pondo em relevo novas nomeações de matérias doutrinärias e devocionais, observamos não ser em grande nūmero os títulos diversos dos registrados até esta parte de nossa pesquisa. Isto se dá não porque diminuam os volumes de livros religiosos, mas porque eles se repetem, em todo o Brasil. Ou porque o interesse do leitor brasileiro oitocentista tem subliminarmente se distribuído por outras ciências. Em última anālise, pode dizer-se que esse leitor brasileiro do século XIX tem muito mais livrarias, mantendo as tendências de leitura dos séculos anteriores e ampliando seu horizonte cultural e bibliográfico para alēm de uma exclusividade hipertrofiante.

Títulos diferentes vão aparecer, por exemplo, no inventário do alferes Manoel de Barros Rodovalho e Silva, de 1824, como "ị $4^{\circ}$ Sermoens do Fr. Antonio de S. Eliseu em portuguez", "Exerciucios de sacerdotes em latim" (APMT, Cartório do 1? 0fício Família, Inventärio, ano 1824). Também em Mato Grosso, Cuiabā, aparece. um "Jornal eclesiastico de Roma", em 2 volumés, no irventário de D. Ana Benevenuta d'Albuquerque, de 1845 (APMT, Inv., 1: of., 1845). No inventário do reverendo Antonio Tavares da Silva, de 1834, vai aparecer um curioso "Enfermo assistido" e um curiosíssimo "Dicionario da Biblia" e "Discurso sobre as obrigaçoens ecclesiasticas"(APMT, 1: Of., 1834 ).

No Rio.Grande do Sul, municipio de Rio Grande, inventārio de Felix da Costa Furtado de Mendonça", de 1819, (APRS, 
Rio Grande, Maço 8) vão aparecer como títulos incomuns, na àrea de Religião, um "Voz de Christo pela boca dos pastores, 2 v."; "Gemidos da tristeza"; "Pantheon sacro das festas do anno, 3 v.":; "Moral de Collet, 5 v."; "Tribunal theologico"; "Epistolas seletas de S. Jeronimo"; "Enfermo assistido"; "Discurso sobre o fogo elemental"; "Sermoens do Pe. Amaro"; "Sermoens de Andrade"; "Jacob Meursius"; "Sermoens de Pontas".

Ainda no município de Rio Grande, encontramos, no inventário de Nicolau Ignacio da Silva, de 1823 (APRS, Rio Grande, Maço 9), como títulos incomuns, "3 Instrução geral em pratica de cathecismo", um "Cathecismo historico" e "Sermoens quadragesimais". No de Francisco Antonio Duarte, de 1824 (APRS, Rio Grande, Maço 10), encontramos "Das heresias de Richarand" e "Penitencia dos fracos". No de Joaquim Centena da. Sịlva Braga, de 1838 (APRS, Rio Grande, Maço 17), constam, entre livros publicados na língua francesa, uma obra "3 v. Moral universal de Olbak". Ṇo de Inácío José Bernardes, de 1838 (APRS, Rio Grande, Maço 17), constam uma "Historias proveitozas, destroncado" e uma "Cartas de huma peruviana" certamente a obra da Madame de Grafignay. O Dr. Guilherme José Correia, de 18.43 (APRS, Rio Grande, Maço 21) tinha "Religião por Racine": Antonio Carneiro, de 1847, tinha uma "Doutrina da Igreja" (APRS, Rio Grande, Maço 21). E Joaquim Gomes de Mello, ainda de Rio Grande, inventariado em 1850 (APRS, Rio Grande, Maço 26) tinha "Jesus Christo perante o seculo"; "Historia da variação das igrejas"; "Exposição de doutrina"; "Sacerdote santificado" e "Evangelho em triunfo". 
De Rio Pardo, o inventário do tenente coronel Antonio Xavier de Azambuja, em 1820 (APRS, Rio Pardo, Maço 12) traz obras doutrinárias com títulos não frequentes nos documentos observados desde o século XVII: "Meditação de atributos divinos, 4v."; "Vida de Christo"; "2 Conselhos, e maximas de Salomão"; "Methodo de falar com Deos". De Rio Pardo tambēm $\vec{e}$ o inventário do tenente-general e Visconde de Pelotas, 1821 (APRS, Rio Pardo, Maço 13) que tinha uma pouco frequente "Escolla do mundo, 4 v." e uma "Obra pia".

Em Cachoeira do Sul, no inventário do padre Inācio Francisco Xavier dos Santos, de 1845, (APRS, Cachoeira do Sul, Maço 7), consta, à folha 14 do documento, que o inventariado tinha "9 1ivros, alguns de Doutrina evangelica". Em Santo Antonio da Patrulha, Ana Joaquina de Jesus, inventariada em 1823, acusava ter "2 Vida de Christo, usados": e "2 Vida desenganada" (APRS, Santo Antonio da Patrulha, Estante 60, Maço 1). Em Jaguarão, no inventário de Ana Maria da Conceição, 1816, constava um "Ritual de Batismo" (APRS, Jaguarão, Maço 2).

De Porto Alegre, o inventārio de José Carneiro Geraldes, em 1806, registra uma obra com o título pouco comum em nossa investigação, que é o "Espirito do cristianismo" (APRS, POA, Maço 3), além de uma "Palestina da penitencia" e "Reino . da Babilonia". Francisco Angonio Rodrigues Viana, inventariado em 1831 (APRS, POA, Maço 7) acusava ter uma "Escolla nova christã". João Pințo da Costa e Antonio Simão de Espíndola, inventariados em 1801, tinham um "Teatro do mundo", "um "Direito divino" (APRS; POA, 1 Cartórịo, Maço 15). Ma- 
noel Lopes de Carvalho, no inventário de 1811, também tinha um "Pantheon sacro" (APRS, POA, Maço 21-A, 18 Ofïcio). O Reverendo José Luiz de Castro Vangler, de 1819, tinha um "Livro das superstiçoens", um "Compendio abreviado à Santa Biblia, 2 t." e uma "Instruçõens sobre a verdade da religião; uma "Historia do Novo e Velho Testamento", o "Pensamento theologico de Gomin"; "Ensayos da moral, 2 t.": "Firulli. Theologia moral"; "Montanli, Theologia"; "Larraga reformado, 3 t."; "Daois, 2 t.a"; "Colleção academia liturgica, 6 t."; "Manoal do christão"; "O verdadeiro pregador" e "Flos sanctorum abreviado, 2 t." (APRS, $1^{\circ}$ of. POA, Maço 22).

Continuando com Porto Alegre, no inventário de Joaquim Francisco Alves, de 1814, anotamos uma "Doutrina da Igreja défendida pelos jesuitas", e "Papeis do bispo de Ma1aca" (APRS, 1: Of. POA, Maço 23). O padre Matheus da Silva Souza, inventariado em 1815, traz um "Novo $\in$ Velho Testamento do Pe. Sarmento:, 34 t.":" "Sermoens novos" e "Sermoens originais, 2 t." APRS, $1^{9}$ of. POA, Maço 24). O reverendo Domingos Francisco Pereira de Sá, de 1822, tem "1 t. Ordem Berborão" (APSP, $1^{\text {? }}$ Of. POA, Maço 30) e José Antonio do Vale, inventariado em 1824, uma "Agulha de Maria" (APRS, 19 of. POA, Maço 34). O padre Manoel José da Costa, em inventärio de 1824, apresenta uma obra com o curioso titulo de "Apocalipse" , e outra com o título de "Tratado da existencia de Deus" (APRS, $1^{\circ}$ Of. POA, Maço 34). E no inventārio de Barbara Correa da Câmara, 1841, anotamos "Proverbios de Salomão" (APRS, $1^{\circ}$ Of. POA, Maço 66j.

Manoel Josë Esteves, em 1843, tinha um "Novo Testamen- 
to em hespanhol" (APRS, 18 Of. POA, Maço 71). Francisco Dias Moreira, 1844, uma "Bib1ia em espanhol" e "Novo Testamento em italiano" e mais "L'Histoire des Vieux et de Noveaux Testament": "2 v. Lettres de Saint François de Sales"; "2 v. Vie de Saint François de Sales"; "4,v. Opuscules et lettres de François de Sales"; "Introduction de la vie devote par Saint. François de.Sales"; "Opuscules de Saint François de Sales"; "Epitres et evangiles"; "Letres de Saint Jerome"; "Opusculo theologico das constituiçoens beneditinas"; "Heures nouvelles - moral christã"; "3 v. Traité de l'amour de Dieu"; "Avisos e refleçoens sobre o que deve obrar hum religioso para satisfazer ao seo estado":; "Les Apopheiques ou les belles paroles des saints"; "2 v. Paralello de moeurs dé la siècle de la morale de Jesus Christe"; "Retracte espirituelle pour un jour de chaque mois"; "Cour des prones a l'usage des cures de la Compagnie"; e "Opusculo em latim dos familiares do Santo oficio". (APRS, $1^{\circ}$ Of. POA, Maço 71). E Gaspar Fros da Silva, 1846, tinha "2 v. Instrucçoens sobre os misterios de Nossa Senhora".

Em São Luiz, no Arquivo do Tribunal de Justiça do Maranhão, encontramos, no inventärio de Joaquim Clemente Duarte, títulos novos de doutrina como "Arte da boa morte", "Memoria do Senhor dos Passos", "Oficio que dão os homens", "Sermonārio de preces" e uma "Recopilação da Estoria Sagrada".

No Arquivo Público do Ceará, do município de Fortaleza; - inventärio do padre Manoel Severino Duarte em 1849, traz, de novidade em títulos de doutrina, uma obra de "Cantus no- 
vu's" e uma "Theologia do Pe. Monte" (APC, Fortaleza, Pacote 161, Cartório de Orfãos).

O inventariado. Josē Barbosa de 01iveira, 1824, de Salvador, (ARQUEB, 02/100/147/02), tinha um "Vetus canonicum codex", "3 v. Institutionum Droit Ecclesiastique", "Exercices de Pietá Patr. Mobili"; "Oeuvres de Nicole, Morale"; "Exercices de Pietē"; "Oeuvres Nicole Daçaloge Lettres"; "Oeuvres Nicole Dacaloge Simbole"; "Oeuvres Nicole Dacalogue - Novalles Littuis"; "Nicole Oraison"; "Vida do Beato Luzo": "SELVAGIO, Institutionum canonicarum"; Anaditus Jus Canonicum"; "23 v. Histoire ecclesiastique"; "Analyse benedictina"; "Lettres du Pape"; "De antiqua Ecclesias disciplina"; "Dictionnaire des ordres religieuses"; "La vie du Pape Clement XIV"; 2. t. "Bernardo Jus Ecclesiasticum"; "EYBEEL, Jus ecclesiasticum": "4 t. Institutiones Theologicae Pothier"; "Le ecclesiastique citoyen"; "LORNIN, Psa1morum"; "... des ceremonies de I'Eglise"; "Benedicti quatuordecim quaestiones canonicae"; "BARUFFALDO, Do rituale"; "CAVAlLIERI, Liturgia";. "Retractos dos jesuitas"; "Historia de la Bible": "POSTELO, Biblia regularia"; "Collecção dos jacobeos segillistas": "Dictionnaire des cases de conscience": "Dictionnaire de herésies"; "Diccionario de la Bible"; "Praxis ecclesiastica"; "Tribunal confessorio"; "Ofice divin"; "Missale festivo"; "Tratés de la Religion"; "Barrio pontificum"; "Pontificiale romanum"; "Novum directorium"; e"Ritus Hierarchia ecclesiastica".

Francisco de Paula Vieira, inventariado em 1837, em Diamantina, tinha uma "Casa mistica, 2 v., fol." (Arq. Bibl- 
Ant. Torres, 19. Of., Caixa 22) : "Retrato dos papas por le Laurentil, 2 v. in 8)". Manoel Pires de Figueiredo, também de Diamantina, em 1818, tinha "25 t. 4\%'Biblia de Carier (Arq. Bibli. Ant. Tores, 19 Of., Caixa 60) :e "Suma da origem ecclesiastica, latino"; "Dicionario da Biblia"; "Deveres ecclesiasticos": "Exposiçoens sobre a doutrina catolica": "Bueno. Dos pontifices". Caetano Lopes de Miranda, de 1837 (Arq. Bibl. Ant. Torres, 29 of., Cx. 25) tinha "Alma sobre o calvario em francez"; "Apocalipse em francez, in 88"; "Alma elevada a Deos em francez"; "Pastoral sobre os cabileiros em latim e francez"; "L'Abē Noir sobre a Authoridade ecclesiastica e poder temporal", 2 v."; "Proverbios de Salomão"; "Pequena Quaresma de Massillon, 2 exs.". E Valentim de Barros Couto, (Ar. Bibl. Ant. Torres, 2: Of., Caixa 85), ainda de Diamantina, tinha em 1843, conforme inventārio, um "Canticum ecclesiasticum".

Em Sabará, o padre Manoel José Caetano, inventariado em 1817, tinha um "Dicionario de Concilios"; "2 v. Sermoens do Arcebispo de Roam": "2 v. Instruçoens familiares de Geraldes em francez"; "Sermoens Fr. Pedro da Conceiçam"; "Comento do Concilio Tridentino"; "6 v. Estoria sagrada de Suplicio Seveso" (Arq. Museu do Ouro, 2? Of. Pacote 55). o Dr. Jacinto Correia, tambëm de Sabará, inṿentariado em 1815, tinha "Corpus Juris canonici": "Manual de cerimonias sacras" (Arq. Museu do Ouro, 18 Of., Pacote 56). Ana Romana, de 1818, tinha uma "Vida de Jose do Egito, in 4"" e "Exortaçoens de S. Antonio, muito veḷho" (Museu do Ouro, $2^{8}$ of., Pacote 58). o cel. Francisco de Paula Barbosa, inventariado em 1832, ti- 
nha "Obras de D. Bartholomeu de Las Casas" (Museu do Ouro, 28. Of., Pacote 62). O Dr. Ricardo Collier, em 1841, um irlandês que morreu em Sabará, tinha uma "Verdade da religiäo revelada"; "Liberdade do Evangelho",; "Biblia com pinturas"; "Biblia grega"; "Biblia espanhola"; "Regeneração e vontade divina": "Sobre a fé": "Reflexões sobre a vontade da' religião": (Museu do Ouro, 28 Of., Pacote 71). O padre mestre Mariano de Souza Silvino, 1844, tinha "O devoto da oração ". (Museu do Ouro, 29 Of., Pacote 76).

De São João Del Rey, no Arquivo do Museu Regional, encontramos, no inventario do Pe. Manoel da Cunha, 1813, (Arq. Museu Regional, M-15), "Diccionario teologico", "Elevaçoens a Deos, 2 v."; "Tradição da Igreja"; "Constituçoens de Bento decimo quarto"; "Rel. christã meditata, 6 v."; "Biblia de Saci comentada em francez"; "Arte de tocar o coração no pulpito, 3 v."; "Arte de tocar o coração no confessionario"; "Profissão de fé"; "Religião primitiva"; "Annos christaons, 6 v."; "Cathecismo do patriarca de Lisboa"; "Sentimentos christãons": "Gemidos de hum coração christão"; "Ceremonias do bispo de Coimbra, bem usado.

No inventário do padre Feliciano Pitta de Castro, de 1802 (Arq. Museu Regional S. João, F-6), vamos encontrar "in $8^{\circ}$ Vida de São Simão de Rochas": "2 t. Sèrmoens Mendes Freire da Conceição - outro do padre Francesco de Sta. Maria"; "Fizionomia dos sagrados da nasenza"; "Deretorio para a Scisma italiana"; "Sucessos de pratica"; "Discursos sacros do Pe. Fr. Bernardo Castello Branco"; "Obras de predica"; "Fe- 
rial quaresmal", O padre Josē da Silveira Xavier, inventariado em 1820 (S. João, J-14) demonstrava ter uma obra chamada "Irman do Rosario". Manoel Lins Saldanha de Miranda, em inventário de $1807^{\prime}$ (S. João, M-2), demonstrava "2 meio $4{ }^{\circ}$ Moribundo socorrido"; "4 Dinis ecclesiastico dos anos de 1797, 1799, 1800": "Vida de Santa Quiteria, meio 4""; "Tesouro de paciencia"; "Afetos e consideraçoens devotas sobre os quatro novissimos acrescentados aos Exercicios da primeira semana do patriarcha Santo Ignacio, in 8\%"; "Instrução para receber com fruto o saćramento da penitencia".

O Dr. Agostinho Pita de Castro, inventariado em 1816 (Barbacena, Maço A-22), tinha uma "Sentensa sobre a Sysma do..."; "Vitas canonic.":; "Reflexoens de Alorna contra o Theatro critico de Feijó, 2 t."; "Natalos: Preceito e arte de preparar os pregadores"; "Trombeta evangelica"; "Avizos de Santa Thereza, 2 v."; "Obras moraes de Viva, 6 t. in 48"; "Theologia de Clemencis, 7 t."; "Teologia de R. pter, 6 t. in 8 ". . O padre Anacleto Pereira da Silva, inventariado em 1820 (Sãọ João, A-22), tinha "2 v. Declaração do Concilio Tridentido de João Gallemont". E Ana Pimenta de Moraes, em inventário de 1837, (S. João, A-8), tinha "Oficio de violetas por Jose Joaquim Emerico", junto a muitas obras de partituras musicais.

Títulos incomuns nos documentos oitocentistas, temos também no inventário de Ana Maria de Jesus, de 1808 (Arq. Casa do Pilar, Ouro Preto, Códice 22 , Auto $231,1^{\circ}$ Of.), como "Virtuosa portugueza, in $8{ }^{\circ "}$; "A vida das mulheres ilustres da Escriptura Sagrada, in 4 " $-;$ "Viridario de Mendonça, 
in 8\%": "Escada mistica de Jacob, in 4\%"; "Excelencias de S. José, fol."; "Alfabeto mariano"; "Expurgatorio da Theologia moral, latim, in 4\%"; "Cronica de Cristiano, in 4\%"; "Obsequios aos templos, in 4". O padre João Pimenta da Costa, inventariado em.1816 (Códice 80, Auto 968, $1^{\circ}$ of.), tinha "Tractatus de conciliis in genera, in $8 \% "$. No inven-. taŕio de Pedro Dias de Carvalho, de 1826. (Códice 125, Auto 1560), há um "Metodo de empregar santamente o tempo, em portuguez". No inventário do padre Manoel Dias da Costa Lana, 1816 (141/1781, 1' Of.) hā "2 t. Documentos de S. Mateus"; "4 Doutrinás practicas do Pe. Pedro de Calata"; um surpreendente "2 t. Tractado de Theologia juridica": "Obrigaçoens das pessoas do mundo"; "Triunfo da inocencia"; "Relação da convenção de João Maier": "Preparação parạ antes da Missa". E, entre os bens do capitão-mor Antonio Agostinho Lobo Leite Pereira, 1815, hã umas "Obrigaçoens das pessoas do mundo" (29 Of., 4/42); e "Thesouro de paciencia". Finalmente, Pedro da Costa Fonseca, inventariado em 1840 ( $1^{\circ}$ Of.,. $112 /$ 1433) tinha "Hijo de David".

Incomuns tambēm são alguns títulos que aparecem em Mariana no inventário de José Luís de Brito, 1835 ( $1^{\circ}$ of. Mariana, 9/339): "Formosura de Deos". No do. Cônego Jacinto Ferreira dos Santos, de 1814 (23/609), "Constitutio unigenitus, 3 v., fol." e "Sermão pregado na profissão de hũa religioza". Tambēm pouro frequente è a "Analogia sacra" que aparece no inventário do padre Antonio Gomes Pereira, de 1847. (Mariana, 19 Of., Códice 38, Auto 881). O padre Antonio Joaquim Flores, inventariado em 1831 (CSM, 18' of. 42/952), tinha "Offi- 
cia propria panetorum". No inventärio do demente Cap. Josē Fernandes Maurício, de 1814 (CSM, 1? of., 66/1417), consta. uma "Escola pontanea cristam": "Dissertação theologica juridica sobre os juros". E no do padre Antonio Gonçalves do Vale, 1834, (CSM, 1ค Of., 72/1532), constamuma obra chamada "Segredo necessario"; "Relaxação dos jesuitas"; e "Interpretação do Concilio". O Reverendo José Ferreira de Azevedo, inventariado em 1814, (CSM, 1ค of., 93/1948), tinha "Escudo de Estado de Justiça". O padre Antonio. Joaquim de Souza Caldas, de 1848, (CSM, 19 Of., 100/2087), tinha "Ensaio sobre a supremacia do papa". 0 alferes Domingos Teixeira Borba, num inventārio de 1807, (CSM, 1 Of., 104/2163), tinha "Consolação de Pozilarunis" è "O ultimo instante". O Arcipreste Raimundo da Silva Cardoso, inventariado em 1822 (CSM, 18 Of., 125/3612), tinha "Aignande. Discursos morais em italiano": "Imitação da Santissima Virgini"; "Biblia em inglez": "Sermoens do Santissimo Sacramento por Espinhosa". O padre Francisco Xavier de França, em inventário de 1828, demonstra ter uma obra de pouca frequência, "Ceọ de graça e inferno custoso" (CSM, 1' Of., 107/2190).Tinha "Balthasinio in Concilium Tridentinum, in 8\%"; "Gallemart in Concilium Tridentinum, ịn 4\%"; "Cathecismus ex Dicteto Concilii Tridentini, in 12\%"; "Feijo, Cartas, $4 \mathrm{v}$. in $4 \% "$; "Espirito de Santa Tereza, em francez, in 89"; "Siqueira, Escola dos bons costumes, 4 v. in 12\%"; "Monacilli, Formularium practicum fori ecclesiastici, in 8\%"; "Novas observaçoens sobre os diferentes methodos de pregar, in 129"; "Ordo perpetum divini officii in 18:"; "Devoçoins... na vida e na morte, 
in 12\%: "Historia da Biblia e 1 pequeno Dicionario da mesma em francez, in 189"; "Primazia. serafica na America, in 129"; "Aureo trono, e Relaçāo da entrada do $1^{\circ}$ bispo o Sr. D. Fr. Mañoel da Cruz, in 12:"; "Discurso apologetico por Jose Gomes da Cruz. sobre as excomunhoens contra o cabido de Lisboa; in 12:"; "A Portu, Opus 1iturgiam, in 128"; "Benevenuti, Formula applicandi Scripturam, in 18\%": "S. Carlos Borromeu, Livrinho de avisos para viver cristamente, in 18\%"; "Berti, De theologicis disputinis, 3 v., fo1,"; "La Croix, Supplementum ad Theologiam, fol.". Por fim, o Capitão José Pereira de Souza, em inventārio de 1814 (CSM, 28 of., 44/991), demonstrava ter "Dezertação theologica juridica sobre os juros, in 12:"; "Espelho da confição, in 12\%"; e "Apologia critica a varios modos de vida em hespanhol, in $12{ }^{\prime \prime}$.

O padre José Fierreira de Souza, inventariado em 1811 (CSM, 28 Of., 45/1009), tinha tambëm alguns títulos de doutrina não frequentes nos documentos analisados, como, por exemplo, uma "Colleção de fração de sigilo". No inventário do cônego João Moreira Duarte, de 1845 (CSM, 29 of., 54/1219), registram-se títulos incomuns como "Alma contemplando as grandezas de.Deos". No de Francisco Xavier Carneiro, 1840, (CSM, 29. Of., 59/1346), hã um surpreendente "Profecias de Isaías" e uṃ "A sciencia das sombras relativas". Antonia Angélica da Anunciação, inventariada em 1849 (CSM, 28 Of., 87/1859), tinha um curioso livro chamado "Espiritual do mundo". O Comendador Francisco Soares Bernardes, inventariado em 1816 (CSM, 28 Of., 120/2421), tinha "De Juridiction Ecclesiastica": "Funiculo aurco em.castellano"; "Amoral canticum Ma- 
rianum". Finalmente, o cônego Inācio José de Souza Ferreira, 1830 (CSM, 28 Of., 140/2850), tinha uma "Declaração do clero da França, quatro volumes", "Officium Hebdomada Sancta"; "Sandino, Historia Tancilio Sacra"; "Theologo e orador christão dois. volumes"; "Colleção das Leis e Sentenças na Pastoral do Bispo de Coimbra"; "Suplicatio ad Beatissimam Virginem"; "Confrontação da Doutrinação da Igreja com a da Sociedade de Jesus"; "Conduite des Ames"; "Sebastianno Brant"; "Roza Franciscana"; "Guida, ó vero scorte de Granata"; "Tractatus de integra sacramentäli Confessione": "Regra da Ordern da Santissima Trindade"; "Methodo para devoção das Almas dois volumes"; "Economicon sacro": "Douven de Re Sacra, em taroa. dois volumes"; "Honorante Praxis Secretaria Tribunalis": "Alexii chorilii de Christianna Ecclesia politica quatro volumes".

Os títulos acima evidenciam a permanência de leituras em devoção e doutrina, por todo o Brasil do século XIX, numa demonstração superlativa de "preferência" por livros vasados numa linguagem è filosofia sem grande exigência intelectual. Tal dominação, de ordem filosófica, literária e moral pode apontar para um certo despojamento crítico do leitor colonial brasileiro, despojamento este que indicia o homem colonial como um ser psicologicamente na dependência de marcos enviesados de prātica cultural. Submetendo-se ao dogma e sem maiores aberturas para outros horizontes de interpretação do mundo, o leitor brasileiro atê o Oitocentos incorre na possibilidade deser visto como alguém cuja rouquidão mental e ideológica só se desfarā na medida em que dispuser de outros mecanismos de oricntação cultural e bibliográfica. 
De fato, è asfixiante o predominio de leituras condicionadas ao rigor axiomático da Religiāo católica. o leitor, assim, ao invếs de exegeta - que, em ưitima anālise, é a expectativa que toda leitura deve provocar - não passa de mero e compulsivo reprodutor de símbolos e ícones feitos para, justamente, alimentā-10 de solidão e passividade, para não falar de circunstâncias mais graves, como o auto-mutilamento e a consciência culpada ad eternum. Não passam em julgado essas considerações, face à ortodoxia das matérias tidas e mantidas nas estantes coloniais brasileiras. Salvo alguns autores cujo exame mais consentâneo com a História ou a Poesia e a Prosa o tempo cura e dá a medida exata de permanência - caso, claríssimo, dós eternos Santo Agostinho, Vieira, Bernardes, Tereza de Jesus, Bossuet, entre outros, cuja literatura pontifica ainda hoje sem maior estrago - não resta dúvida que o Brasil leitor muito se perdeu em títulos e matêrịas de Doutrina a mais excludente e aleatória, títulos e matérias que serviram para aumentar a pressão de afervoramentos místicos e ascéticos tão em voga até 1830, mais ou menos. Os séntidos que operaram umạ sintomática prevalência de espíritos doutrinários no Brasil devem ser debitados, em parte, às leituras de pouca extração crítica que observamos como características na Colônia. Mas, o leitor colonial não está preso-apenas ao dogma e ao ensimesmamento místico. Ele se adianta em outros ramos do conhecimento, como veremos a seguir. 


\section{3:3- Aforismos e sangrias}

"aqui acharão os alveitares remēdios para cavalgaduras, o caçador para os cães, o pastor para o gado" $(*)$

(*)Gabriel Grisley, prólogo de Desengano para a Medicina, apud SANTOS FILHO, Licurgo. Histöria geral da Medicina brasileira, $v$. 1, p: 344

Outras caracteristicas de leitura no Brasil Colonia1, em razão do interesse prätico progressivamente demonstrado pelo leitor, são as de natureza médica e da jurisprudência portuguesa. As Ciências Médicas, muito mais que as do Direito e, certamente, igual às da ārea de Letras, têm na variedade e permanência de seus títulos uma indicação segura da leitura comprometida com ofício ou profissão. Registram-se, embora em menor escala, tambëm nas livrarias dos leigos. 0 século XVII não aparece nesta nossa amostragem, uma vez que os livros aí descritos são, em sua maioria, religiosos e da História, da Literatura e, até, da Matemätica. Mas o século XVIII é ilustrativo desse interesse do leitor, o que denuncia uma sensivel popularização de temas e assuntos médicocirürgicos e uma intensa e extensa penetração de autores profissionais por todo o Brasil Colônia.

A lógica de popularidade das obras médico-cirúrgicás, encontra-se, de um 1ado, numa necessidade prätica do saber 
pü̉blico quanto a situaçōes elementares entre sintomas, presumível diagnóstico, aplicação de remédios à base de ervas e a cura como resultado final. Dai a maior partedesses 1 ivros tratarem de assuntos mais ou menos comuns e virem na forma de uma Medicina popular, em linguagem acessível ao leigo e orientada para suprir a enorme carência de profissionais especializados. De outro lado, o que estilisticamente se representa na maioria dos compêndios e manuais de Medicina que para aqui vieram é uma preocupação de ordem moral, naturalmente sob a guarda e vigilante mister do ministério eclesiästico. Os títulos dos livros são grandes, na linha de um rococó ou de um gongorismo tardio, procurando antecipar ao leitor tudo o que.ele terā na leitura do livro. A epígrafe de Grisiey, acima, ilustra a norma dessas obras. São verdadeiros guias de orientação prática, com alguma erudịção ná forma dos aforismos, mas mandando seguir à risca conselhos médicos de aplicação de sangrias e outros métodos prèvistos desde Hipócrates e Galeno.

Começamos, no séculó XVIII, com títulos como Luz verdadeira, e recopilado exame de toda a cirurgia, de Antonio Ferreira (1626-1689), editada primeiramente em Lisboa, na of. Domingos Carneiro, 1670, com outras edições em 1705 e 1757, que aparece no inventário de Mateus de Leão, em 1703 (APSP, São Paulo, Ordem 500). E interessante notar como grande parte dessas obras coloniais, e não apenas na ärca médico-cirürgica, gostam de exprimir um persuasivo "verdadeiro" como forma de comprometer o leitor na direção da obra.

Grande partẹ dos títulos são de Cirurgia, certamente 
pela enorme popularização e necessidade de cirurgiões, uma vez que a profissão mëdica requeria um diploma acadêmico e universitärio, ao passo que cirurgiōes podiam ser formados com noções elementares de Anatomia, experimentado nas atividades präticas de sangrias como norma de purgação de males orgânicos mais simples. Muitos tỉtulos vão acompanhar essa tendência de profissionalização de cirurgiões. Para as matérias médico-cirúrgicas, algumas vezes, os próprios reli giosos concorriam, no sentido de contribuir para a difusão de conhecimentos aos leigos, como a expressa em polêmicas como a Correção de abusos introduzidos contra o Verdadeiro mé todo da Medicina, obra em 3 tomos da autoria do Fr. Manue1 de'Azevedo, que aparece no inventārio do Sargento-Mor João Lopes Fiúza, na Bahia, em 1741 (ARQUEB, Capita1, 623-4). Percebe-se jâ uma significativa tendência à circulação de obras escritas em latim, mas traduzidas em linguagem, conı o Sintagma cirúrgico-teórico-prätico de João de Vigo traduzido' e acrescentado "com um tratado de feridas, e um catálogo de remẻdios para muitas e värias enfermidades do corpo humano" por José Ferreira de Moura, clínico em Lisboa e cirurgião no Rio de Janeiro, obra publicada em Lisboa, na Of. Deslandesiana, 1713. O Olivro de Vigo aparece no inventärio de João Rodrigues Gondinho, 1744, em São João De1 Rey (ArqHist., Maço J-15).

Aos poucos, os livros vão se tornando peça de consulta obrigatória por oficiais cirúrgicos, médicos e pessoas leigas, a ponto de muitos se tornarem best-sellers coloniais, como é o caso da Poliantéia Mcdicinal notícias galênicas é 
químicas, repartidas em três tratados, de João Curvo Semedo, (1635-1719), editada em Lisboa, Of. Miguel Deslandes, 1695 , que aparece em inventários como o de Duarté Geraldo Teixeira, em São João Del Rey, 1746 (Arq. Hist., Maço D-3) .

A obra de Curvo, teve mais quatro edições na primeira metade do século XVIII (em 1703, 1716, 1727, 1741), o que celebra uma popularidade atestada na própria eficácia social da Medicina popular. A exemplo da Poliantéia Medicinal, outras obras de Curvo Semedo:e de outros consagrados autores atravessam todo o período setecentisța e vão até aos meados do sēculo XIX num Brasil cheio de curiosidades por exemplos präticos na cura de enfermidades mais comuns, à base de ervas nativas, ou seguindo a prática de curandeiros e cirurgiões. No mesmo inventārio de Duarte Geraldo Teixeira, outros títulos antecipam a regular circulação de obras médico-cirúrgicas que acompanharão o häbito leitor brasileiro no Setecentismọ e Oitocentismo. E c caso da Madeira ilustrada, método de conhecer e curar o morbo gälico, obra de Duarte Madeira Arrais, sobre a sifilis, editada em Lisboa em 1642, com sucessivas reedições em $1674,1683,1715,1751$ etc. O autor era físico-mor de D. João IV e seu livro é muito popular no Brasil.

Outras obras vão ampliando o perfil das leituras mōdicas brasileiras. Em São Paulo, num inventārio de 1746, Manoel José da Cunha (APSP, Ordem 651) confirma a expressiva popularidade de títulos como "Clave de oro medicinal" ou, mais ainda, Arte com vida, ou Vida com Arte, muito curiosa, necessária e proveitosa, nāo só a médicos c cirurgiões, mas ainda a toda a pessoa de qualquer estado condição que sc- 
ja, primcipalmente aos casados; e mais que a todos aos noivos de pouco tempo; em a qual se encontra um regimento de paridas, obra de Manuel da Silva Leitão, que a oferece à Imaculada Conceição, declarando-se "seu escravo", publicada em Lisboa, Of. Antonio Pedroso Galrão, 1738. Pelo título comprido, que antecipa toda a matêria do livro, percebe-se o interesse do autor em tornar sua obra acessivel à leitura de leigos, prática, aliās, que se verifica na maior parte das obras no ramo da Medicina e Cirurgia com circulação no Brasil. Outros títulos presentes no inventäriode Manoel José da Cunha vão confirmando a popularização que as obras de Medicina e Cirurgia vão alcançar no Brasil, sobretudo aquelas que mais se apresentam com uma linguagemsimples, de fácil compreensão e assimilação pelo leitor, potencialmente clínico de si mesmo, mediante diagnósticos simples e formulação e aplicação de remédios caseiros. Nessa linha estão ainda obras como Âncora medicinal para conservar a vida com saúde, publicada pela 1. vez em 1721, de Franciscó da Fonseca Henriques, chamado o Mirandela (1665-1731), que alcançou reedições de sua obra em 1731, 1749 e 1754, entre outras. No inventário de Manuẹ Josê da Cunha, em São Paulo, 1746, autores e matérias vão se sucedendo, atestando uma freqüente composição de estante médica no Brasil Colônia: "Madame Furguete. Recopilação de remedios escolhidos, meio 4"." "Dr. Francisco Nunes, Principios de cirurgia, in 4"." "Medicina e Cirurgia racional do licenciado João de Vigo, castellano, in $4{ }^{\circ}$ ", acompanhados de obras mais frequentes nas livrarias setecentistas brasileiras, como Luz da verdadeira cirurgia, 
do 1icenciado Pedro Gago, Apologia e verdadeiro uso da água ardente do Reino, pelo licenciado Francisco Correa, Desenga. no para a. Medicina, ou botica para todo o pai de familias, do médico alemão Gabriel Grisley (Lisboa, Of. Henrique Va1ente de O1iveira, 1656, reeditado em 1690, 1714, 1754), que consta ter clinicado em Lisboa no século XVII. Assim, pelo que parece, o autor de uma obra médiça escreve para ser seguido, à distância, pelos que precisam de uma assistência elementar, à base de ervas, sangrias ou suadouros. 0 livro, dessa forma, desempenha um papel utilíssimo como manual de curas ou receituário de atividades, algumas vezes psicológicas, como norma de orientação médico-cirúrgica, que assista o paciente, sobretudo em.face da enorme disparidade na relação médico - população.

Em nosso entendimento, a maior parte desses títulos obedece a um singular mister na penetração do universo leitor. De um lado, trazem os aforismos médicos, a celebração do pensamento dos doutores, a começar pelo paị da Medicina, Hipócrates, seguido por Claudio Galeno e outros. De outro, a medicina clinica mais geral e diretamente vinculada às necessidades práticas de cura ou suspensão parcial dos males identificados por cịrurgiões, pesquisadorese viajantes. Outros títulos tambēm traduziriam uma notaçãoprātica na órbita profissional, i.e., de doutor para doutor, acercade questões mais ou menosabrangentes relacionadas com a prätica oficial da Medicina e da Cirurgia.

o inventário de Manuel José da Cunha (SP, 1746) é ainda rico em obras quase completas de um único autor, como o 
"Dr. Ribeyra", títulos in $4^{\circ}$ como "2 livros Cirurgia Natural infalivel", "de Cirurgia Rhetorica Quimica reformada", "Medicina de Ribeyra", "Remedios deploráveis" e "Consultas médicas", "T. 1 Theatro cirūrgico anatômico dó corpo", "CIàí cula regulina", "Medicina elemental" e. "Escrutinio médico". Traz também títulos curiosos como "Illustração e publicação dos desafetos segredos do Dr. Curvo", "Arcanismo antigali co", "Medicina insensive1 e legal ou Theatro de febres entrementes conylicas", "Escola medica", "Restauração da.Medicina antiga". E se completa, no inventário, um painel de livros médicos de certa obediência à prescrição formulató ria de remédios da farmacologia difundida e de uma formal decisão do leitor-paciente. no seguir regras totêmicas dos conselhos e orientações por profissional - autor, médico, clínico, cirurgião, farmacêutico. Assim, encerram o inventārio do paulista Manuel José da Cunha, títulos como "Thesouro medico", "Cirurgia sagrada, Metodo experimental e racional", "Theatro da saude ou experimentos mëdicos", "Febrologia cirurgica", "Reflexoens anticolicas (experimento medico)" e "3 1ivros de Clavis mëdicos cirúrgicas veneraveis".

Mai's que nas āreas de Direitọ e Letras, as Ciências Médicas tiveram no Brasil um extraordinärio círculo de obras para leitura e orientação das pessoas, emparticular no campo da Cirurgia ou da Medicina popular, com textos simples, buscando determinar, no espírito do leitor, uma ordem de atividades mentais e físicas para controlar determinados males mais comuns: Alguns títulos seguem uma linha de acréscimo às matérias médicas e cirúrgicas, surprecndendo pela varic- 
dade e enriquecendo as estantes, denunciando a franca popularização do conhecimento empírico e experimental dos seus autores. No inventário de Antonio Pereira Fragozo, de 1753, em Mariana (CSM, $2^{\circ}$ of., Cod. 85/1826), por exemplo, muitos tîtulos.não-freqüentes nas outras livrarias demonstram o interesse do leitor na extensão de seu conhecimento. Assim. será um "Prospero Marcusiano em lingua latina", seguido de outros muitos que representam uma novidade na relação. E o exemp1o típico da variedade com que costumavam pontuar as iivrarias setecentistas na ārea médica. Descrevemos alguns desses títulos para verificarmos a geral tendência de acréscentamento a outras obiras mais conhecidas:

Lourenço Ester 2 t.

T. medica

Jacobo, De exasto, 2 t.

Elvesias, 2 t.

Pedro Gago

Carlos Lusi tano

Theatro cirurgico

Febrologia cirurgica

Magigel Amendes

Manifulas

Aureola medica

Medicina científica

Inventos simples

Al conismo

Caricula

Cirurgia invencida 


\author{
Segredos medicos \\ Remedios de Texados \\ Theatro de Lal ande \\ Escotismo medico \\ Consultas medicas \\ El icone templo \\ Tratado que serve de preservação \\ Thesouro metropol itano \\ Exame breve de Cirurgia \\ Flores de Guerido \\ Flexil de universo
}

Estes são os títulos de livros que não se manifestam muito nas demais livrarias setecentistas. Representam, no entanto, a continuidade de um modelo de produção cultural da área médico-cirúrgica, com toques dẹ marketing convencional à época, chamando a atenção do leitor para determinados efeitos e destacando a importância de cada obra por um certo traço apologético. No mesmo inventärio de Antonio Pereira Fragozo, também se descrevem obras de reconhecida circula Ção no Brasil Colônia, como, por exemplo, a Relação cirúrgi ca e médica, de João Cardoso de Miranda, publicada em Lisboa, 1741; orientando o leitor e potencial paciente no tratamento dos males provocados pelo escorbuto, o chamado "mal de Loanda". O título completo é, como de häbito, comprido e antecipador das virtudes dos "conselhos médicos": Relação cirúrgica e- médica, na qual se trata é declara especialmente um novo método para curar a infecção escorbútica, ou mal 
de Luanda, e todos os seus produtos, fazendo para isto mani festos dois especificos e mui particulares remédios. Outros títulos serão igualmente conhecidos e provavelmente obrigatórios das estantes coloniais brasileiras. Como os Aforismos, de·Hipöcrates, sistematizador das matérias médicas em patologia e Terapêtica, com base lógica, liberto da confu são e arte difusa oriunda de manifestos divinos ou abstratos. Hipócrates, em termos latentes, antecipa a experiência empirica, uma vez que tudo o que disse foi combase na observaçã் do homem e de seus mecanismos orgânicos de ação e reação. Devidamente autorizados pelo Pai da Medicina, inúme ros autores preconizaram noçōes de Higiene e da prätica da sangria como normas de dẹbelar crises agudas de depreciaçã́o orgânica do homem. Há também uma edição dos Aforismos, de Hermann Boerhaave (1668-1738), que certamente teve divu1ga ção regular no Brasil. No inventárịo que descrevemos, por fim, três outros títulos são lembrados comsingular notoriedade, sob o ângulo do leitor. As Obras varias de Avicena. ou Abou-Ali-Hossein-Ben-Abdallah-Ben-Sima (980-1036), mëdico do Xá da Pérsia; uma "Ápologia", que julgamos tratar-se de Apologia contra o Diálogo crítico que imprimiu o Médico Antônio Antunes, do Rio de Janeiro, debaixo do nome de José de Aragão Espanha, contra 을édio que, para o escorbuto, feito em cozimento, traz o livro intitulado Relação Cirúrgi ca e Médica que saiu à Iuz em 1748, seu A. 으 Licenciado João Cardoso de Miranda, título com que o autor polemiza com seu colega brasileiro.

Os títulos compridos, aliās; concorrem para provocar 
no leitor o imediato interesse ou empatia com a obra. Nisso, a edição de livros de natureza médica segue a linha das publicações em Doutrina. Bem menor, porể, tal tendência se manifestarả em Letras e, menor ainda, na área do Direito. Ao menos nas transcrições dos inventários, as obras de Direito, muitas vezes, são nomeadas apenas pelo seu autor, número de tomos ou volumes e, em outras vezes, pelo título mesmo do 1 ivro, cujas edições, entretanto, não apresentam os mesmos modelos seguidos em Religião e Medicina. Veja-se,por exemplo, o nome do 1 ivro que encerra essa nossa descriçãodo inventário de Antonio Pereira Fragozo, de Mariana, 1753, numa linha tão ao gosto da época de acirradas polêmicas. o tîtu10 antecipa ao leitor, não só a matéria da obra que este tem em mãos, como ainda faz referência ao estilo em que foi composto, distribuição da matéria e objețivos que pretende alcançar: Diälogos criticos aos dois tratados da Nova Cirurgia, que o Doutor D. Antonio de Monravā e Roca, catedrätico de Anatomia, que foi no Hospital Real de Todos os Santos, na cidade de Lisboa, deu à Luz no ano de 1725. Em que principalmente se 1he confutam seis máximas apócrifas, por ma1 fundadas na razão experimental, na qual diz as funda: como sạo, "으 não haver Espiritos, nem calor natural nem faculda des no corpo humano, o fenômeno da evacuação mensal uterina, o do movimento voluntário, e o não ser o ar precisamente necessārio para a vida. Ultimamente se expõe um argumento, cm que se prova concorrer o. pai na geração do filho como causa ativa e como dispositiva. Tudo em forma de diälogo entre locutores dois cirurgiōes, um galênico, e monrovista outro. 
o livro foi escrito por Manuel dos Santos, cirurgião formado em Lisboa e residente em Pernambuco. A primeira parte editada em Lisboa, Of. Francisco Luís Ameno, 1750.

Outros destaques de títulos vão para o inventārio de Arnaldo dos Santos, de 1754, em São João Del Rey (Arq. Hist. Maço A-10), que tinha um "Portugal médico", "Castro de matéria médica", "Farmacopéia de Bernardes", "2 t. Sirurgia de Martines", "2 livros médicos de Dom Gaspar Branco", uma "Sirurgia de Fragozo" e mais obras de conhecimento imediato e regular freqüência das outras livrarias. E o caso de Castelo Forte contra todas as enfermidades que perseguem o corpo humano, e tesouro admirāve1 onde se acharão os remédios para elas, etc., de João Lopes Correia, editado em Lisboa, Of. da Música, 1723, o t. I e em 1726, na of. de Pedro Ferreira, o t. II. A biblioteca de Arnaldo dos Santos tinha justamente $\circ 2^{\circ} \mathrm{t}$. O inventariado tinha tambēm uma obra de Cláudio Galeno, a mais importante referênciade.Medicina Antiga depois de Hipócrates, autor de De curandi ratione per sanguinis missionem, em que recomenda a sangria como forma de purificação das infecções do organismo, e de De constitutione artis medicas, De locis affectis etc. Uma outra obra bem conhecida do leitor brasileiro de ciências médicas é a Cirurgia reformada, de Feliciano de Almeida, editada em Lisboa, Of. Deslandesiana, 1715 e reeditada em 1738.

De 1757, o iventārio do capitạo-mor José de S. Boaventura, em Mariana (CSM, 1; of., 13/429), traz alguns tỉtulos de obras, pelo que parece; não muitó freqüentes cmoutras 1 ivrarias, como "Pratica de Souza", "Idalgo, Cirurgia", "Dio- 
nisio de Çă", "Calvo medico", "Medicina e cirurgia de Felipe Barbosa", "Anatomia de Martins" e "Materia medica". Dois outros livros pertencem a uma tipologia maìs comum no perfil de leituras na área farmacológica portuguesa. Um deles, bastante conhecido no Brasil, tem título quilométrico: Farmacopéia Ulissiponense, galênica e quỉmica, que contểm os principios, definições e termos gerais; e um lexicon univer sal dos termos farmacêtuticos, com as preparações quimicas e composições galênicas, de que se usa neste reino, e virtudes e doses dos medicamentos quimicos: um tratado de eleição, descrição, doses e virtudes dos purgantes vegetais e das drogas modernas de ambas as Indias e Brasil: um vocabulärio universal, 1atino e poirtuguês, de todas as drogas animais, vegetais e minerais, assim modernas, como antigas. Seu autor é o francês Jean Vigier e a obra foi puolicacia, en prímeira edição, em Lisboa, Of. Pascoal da Silva, 1716. o outro 1ivro de regular circulação no Brasil, presente no inventário do capitão-mor José de S. Boaventura, éa 'sparmacopea de Palacio".

No inventário de Felipe Rodrigues Vellozo, 1762, en Ouro Preto (Casa do Pilar, 57/681) registra-se um Iivro de Pedanius Dioscōrides, médico e botânico grego do I século da era cristã e tido como o codificador da matéria médica. Além de Dioscórides, o inventariado tinha também uma Farmacopéia lusitana de D. Caetano de Santo Antonio, edicino ciecoimimbra, 1704 .

João da Fonte Barros, de São João Del Rey, inventariado em 1763 (Arq. Hist., maço J-8), tinha um Collectaneo Phar- 
maceutico, editado em Coimbra, Of. Antonio Simões Ferreira, 17.35, com segunda edição no Porto, 1768 , e mais"2 tomos pequenos de Iono Vigier", talvez os livros que se supôs não haverem , circulado no Brasil. Jean. Vigier, boticário francês que morou em Lisboa nos começos do século XVIII, é autor da Farmacopéia U1issiponense, tambëm de invulgar popularidade no Brasil Setecentista.

O baiano Manoel Dantas Barreto, inventariado em 1768 (ARQUEB, Judiciāria, Capital, 02/972/1441/01) tinha um pouquíssimo freqüente "E1 mundo enga n.ado por Corfalli Medicos" e um muito comum nas demais livrarias: Tratado da conservação da saūde dos povos, de Antonio Ribeiro Sanches, editado em Paris, 1756. O mineiro de Sabarā, Dr. João Baptista Lopes, inventariado em 1770 (Museu do Ouro, 29 of., Pac. 21), entre uma "Medicina in 4\%" e uma "Cirurgia methodica in $4^{\circ "}$ na voga de obras conhecidas do público e que constavam de outras bibliotecas do Setecentos brasileiro, tinha também uma Medicina lusitana: socorro délfico aos clamores da natureza humana para total profligação de seus males, editada em Amsterdā, Of. Miguel Diaz, 1710, com reedições em 1731 e 1750, obra da autoria de Francisco da Fonseca Henriques (1665-1731), alcunhado "Mirandela", em virtude de ter nascido em Mirandela, Trás-os-ikntes. o também mineiro, de Mariana, Luiz dos Santos Pinto, em inventáriode 1774 (CSM, 29 Of., Cod. 129/2602) tinha um "Collegio medicinal" e um "Sumo tezouró de Cirurgia" - títulos de pouca descrição em outros inventários brasileiros.

En 1775, o inventário de Luiz Barbosa dos Santos, de 
São João Del Rey, descreve uma obra indicada pelo nome apenas de seu autor, "Gabriel Falópio", (1523-1562), que, segundo SANTOS FILHO; na História geral da Medicina brasileira, era "professor em Pisa, umdos experimentadores de substâncias tóxicas em condenados à morte (e) descreveu o aparèlho genital feminino e o feto". ${ }^{226}$ Além de "Gabriel Fal1opio", o inventariado Luiz Barbosa dos Santos tinha um "Lazaro Zivirêo", um volume "Para curar carnuzidades" e uma "Palestra farmacêtica". (Arq. Hist. Museu São João Del Rey, Maço L-1).

Joaquim Francisco Nogueira, inventariado em 1770 (Mariana, CSM, 19 of., 131/2737), tinha 3 livros na ärea médico-cirúrgica: um "Consultationes medicas", um "Poseollo cirúrgico" e uma "Cirurgia anatomica". João Fortes Bustamante e Sá, em 1777, na cidade de São João Del Rey (Arq. Hist., Maço Josê-I), tinha também títulos pouco comuns em outras livràrias, como um "Fol. Epitome cirurgico", e mais "in 4"" os seguintes: "Cirurgia de ouvido muito velho", "Materia medica de Jacó de Castro", "Materia cirurgica de Jacó de Castro" e "Saguete Comei, Decisoens medicas".

Os livros vão se sucedendo, com titulos reiterativos ou não, nas disciplinas médicas que orientaram os brasileiros coloniais. No inventário de Manoel de Jesus Pereira, em São João De1 Rey, 1781 (Arq. Hist., Maço 13), constam a obra de João Curvo Semedo (1635-1719) estigmatizada (face ao título gongórico) por Vernéy no Verdadeiro método de estudar e, no entanto, um dos best-sellers no Brasil Colônia: Atalaia da vida contra as hostilidades da morte, fortificada 
e guarnecida com tantos defensores, quantos são os remédios, que no decurso de cinquenta e oito anos experimentou o doutor João Curvo Semedo, publicada, pela primeira vez, em 1720 e reeditada em 1754 (Lisboa, Of. Ferreiriana). Ainda, no mesmó inventário, entre um "Moforte", um "Tragore" e uma "Ora cirurgica", a livraria mineira indicava um dos títulos mais expressivos e de decisiva circuḷação entre nōs, a obra de Francisco Morato Roma (1588-1668) com uma das titulações mais curiosas dentre as encontradas na tradição de tîtulos longos e um tanto rococós da edição em lingua portuguesa: Luz da medicina prätica, racional e metódica, guia de enfermeiros, dividida em três partes. Diretório de principiantes, e sumärio de remédios para acudir e remediar os achaques do corpo humano, começando do mais a1to da cabeça descendo atè o mais baixo das plantas dos pés. Obra muito ưtil e necessāria não só para os professores da Arte da Medicina e Cirurgia, mas também para todo o pai de família; de que se poderão aproveitar pobres e ricos na falta de médicos doutos, conforme. reza a capa da edição de 1753, a que provavelmente constaria do irventärio aqui descrito. A primeira edição de Luz da Medicina. é de Lisboa, Of. Henrique Valente de Oliveira, '1664, a que se seguiram outras, em Lisboa e Coimbra, em $1672,1700,1712,1726,1753$. O título da obra confirma nossa observação quanto ao perfil ideológico desses livros de Medicina, ou seja, servir de sucedāneo, na prätica de uma Medicina popular e democratizada e "na falta de médicos doutos".

Outro 1 ivro extraordinariamente popular nas estantes 
setecentistas de Medicina, Cirurgia e Farmäcia, em particular da bibliografia portuguesa, é o Tesouro apolíneo, galếnico, químico, cirürgico, farmacêutico, ou compêndio de remédios para ricos e pobres. Dividido em três partes, do mesmo Jean Vigier, em edição de Lisboa, Of. Real Deslande siana, 1714. Este, como o Luz da Medicina, pelo caráter antevisto no título, adianta a natureza dupla de peça publicitäria quanto ao conteúdo e tratamento das matérias, incluindo, ainda, indicaçōes de estilo e sentido da' publicação, com a circunstância adicional de dirigir-se, simbolicamente, a todos os püblicos, "pobres e ricos", que poderão aplicar remédios desde que adquiram o livro e possam municiar-se de informações que orientem pacientes na purgação de seus males. Em escala considerável no Brasil, cujo aparecimento desfaz a impressão manifesta por Licurco Santos Filho, em obra citada, de que outros livros de Vigier, alēm da Farmacopēia U1issiponense, "parece não circularam no Brasil", 27 - Tésouro apolíneo está presente, por exemplo, no inventário do vigário do Pilar padre Manoel Ribeiro Soares, em Ouro Preto, 1795 (Casa do Pilar, 18 Of., 102/1274).

Certamente, nossa compreensão histórica da formação médica no Brasil deve ser repensada a partir de algumas considerações em torno da biblioteca geral de livros nessecampo específico. Muitos são os tïtulos e matérias novos que se vão acrescentando, no próprio sēculo XVIII e, muito mais ainda, no século XIX, redimensionando a interpretação que temos do. Brasil leitor no período colonial. Para não trans- 
gredirmos muito a notação desses títulos e, consequéentemente, afugentar o leitor desta tese, demonstraremos apenas alguns dos mais representativos indicios de que homem brasileiro da Colônia, em matéria devocional e agora em matéria médica, seguramente ampliava, em número de obras e de volumes, o universo de conhecimento em sua escolha direta de leituras. E sintomático, por exemplo, que a bibliografia médica encontrada neste perfil do leitor brasileiro da Colônia, em princípio, até meados da oitava década do século XVIII, seja numa esmagadora circulação de obras em Iingua portuguesa e, quando obra estrangeira, em tradução vernācula, quando se supōe o interesse do editor e dos autores na popularidade de seus trabalhos, em serenilidos e estudados e servirem de orientação. numa espēcie de "cursoà distância" das práticas clínicas mais convencionais. A partir de 1780 , aumentando de 1790 até meados do séçulo XIX, é forte a presença, como já notamos, da bibliografia médica em língua francesa. Neste particular, segundo nossa pesquisa, avulta a contribuição do Rio de Janeiro, especialmente em inventārios como o do Cirurgião-Mor Antonio José Pinto, de 1798 , dono de uma excepcional bibliografia médico-cirúrgica, exprimindo, em titulos novos, a continuidade referencial de leituras numa matéria que the serve de base institucional, por seu oficio, sua curiosidade e desejo de atualizar-se. Rio de Janeiro, Minas e Bahia são as maiores representações a esse tempo e nesse particular universo de leituras.

0 invéntário de Antonio da Costa e sua mulher Tereza Maria de Jesus, de 1784, cm Salvador (ARQUEB, Capital, 03/ 
1145/1614/09) è modelar nessa perspectiva de obras e volumes novos, acrescentando ao patrimônio bibliográfico brasileiro cerca de 100 novos títulos. Alguns deles - e por só podermos descrever os mais relevantes - se destacam numa relação especialmente rica. Assim, "Tratado das operaçoens", "Desterro cirúrgico dos falsos", "Santuario anatomico", "Medicina e cirurgia mistica", "Tratado das infermidades", "Recetuario lusitano" são alguns desses novos tîtulos, assim como "Enxame dos buticarios", "Essai sur les maladies"," Armamentario cirurgico", "Historias cirurgicas", "Anatomia compuesta", "Floresta.medica", "Ipocrates lusitano", "Frutos da medecina" e "Estatutos da cirurgia". Outros titulos ainda mereceriam alguma menção, por seu aspecto curioso e raro, como uma "Biblioteca manual medico pratica", um "Diārio universal da Medicina", uma obra em espanhol "Nueva farmacologica universal" e duas peças da farmacologia em voga: a "Farmacologia Londinensis" e a "Farmacologia contemporanea". Dos títulos mais ou menos pertencentesà convenção de boa circularidade de leitura e consulta pelos brasileiros dos sẻ́culos XVIII e XIX, o primeiro deles é o consagrado Erärio mineral, do brásileiro Luis Gomes Ferreira, publicado em Lisboa, of. Miguel Rodrigues, 1735 e considerado o segundo tratado de medicina nacional èm língua portuguesa. Além dele, hä, no inventärio descrito, um Princípio de cirurgia, de Jorge de Lafaye, em 2 tomos, editado em Paris, 1739, que teve edição portuguesa em 1787, traduzido por Simão José de Carvaiho, um Tratado da peste, de João Curvo Semedo e una significativa coleção farmacológica. Uma è a Farmacopéia 
Bateana, aumentada com os segredos Goddardianos ... e acrescentada com um aditamento de várias formas ou receitas. Dadas à luz por um professor da mesma arte, obra atribuída a D. Caetano de Santo Antonio e a D. Fr. Antonio dos Mártires. A este último se refere a edição acima, publicada em Pamplona, Herederos de Martinez, 1763. A referência "Bateana". é decorrente de Jorge Bateo, médico de Carlos II, reida Inglaterra e que seria autor de um sem-número de fórmulas de medicamentos. Outra é a Farmacopéia tubalense quỉmico-ga lênica, da autoria de Manuel Rodrigues Coelho, editada em Lisboa, of. Antonio de Sousa da Silva, 1735 e reimpressa em Roma, of. Balio Geredini, 1760. Por fim, o casal Antonio da Costa tinha o Codex medicamentarius seu farmacopea parisiensis ex mandato Facultatis Medicinae parisiensis, in lucem edita M. Philippo Harduin de St. Jacques, decano, 1638 .

o inventariado Manuel Antonio de Araujo, em 1796, em São João Del Rey (Arq. Hist. maço M-A) apresenta uma extensa relação de títulos diferenciados. Ali encontramos, por exemp1o, um "Secreto cirurgico", um "Estado de cona", um "Instrumento medico", entre alguns outros representativos da tendência de aumentar e variar a ordem de livros nas estantes médicas coloniais brasileiras. Assim tambëm serā vista a "Pharmacopée Royale in 4\%", presente no inventärio do padre Joaquim José de Souza, 1795, tambêm em São João Del Rey (Arq.'Hist., Maço J).

Ao ládo de um "Tirosinio, velho", e de um "Aquilipio, Medicina velha", o inventārio do capitão Joaquim José de Souza, de 1798, em Mariana (CSM, 1' of., 94/1962) relaciona 
duas obras de invulgar popularidade no universo da bibliografia farmacológica no Brasil. Ele tinha, por exemplo, uma Farmacopëia geral para o Reino e Domínios de Portugal, publicada por ordem de Sua Magestade, editada em Lisboa, Regia Of. Tip., 1794, da autoria do Dr. Francisco Tavares obra imposta por D. Maria I como código único da farmacologia para Portugal e todos os seus domínios - e tambẻm uma popularíssima Farmacopéia dogmätica, médico-química e teórico-prätica, escrita pelo beneditino Fr. João de Jesus Maria e editada em 2 volumes no.Porto, Of. Antonio Alvares Ribeiro Guimarães, 1772 .

O reverendo Francisco de Paula Meireles, inventariado em 1794, em Mariana (CSM, 1ㅇ․, 151/3159), tinha uma nada convencional "Doutrina das enfermidades venéreas". O Dr.Josē Pereira Ribeiro, tambēm de Mariana, inventariado em 1798 . (CSM, 28 Of., 51/1162), tinha uma "Arte de conservar 1a santể, 2 v.", umá "Ilustração medica" e uma "Cirurgia classica". Maria Eugênia do Bonsucesso, no Rio de Janeiro, em inventārio de 1793 (AN, maço 473/3032), tinha uma "Infermidades dos exercitos", uma "Memoria da peste" e um "Methodo de restituir a vida". E Gonçalo Josē Muzzi, do Rio de Janeiro, 1790 (AN, 491/9592), tinha umas "Indagações sobre el pulço", "Pharmacie de Baumé, 3 t.", "Abregè de 1a Medecine", "Nosologie de Sauvages, 3 t.", "Principe de Medesina", "Maladies des femmes, 6 t." e a célebre obra de Tissot, muito popular no Brasil, no original e na tradução portuguesa, Avis au peuple, contendo ensinamentos de primeiros socorros e sobre crianças, epidemias, envenenamentos etc. 
Para nossa investigação, a maior biblioteca setecentista brasileira na ārea mẻdica è a do Cirurgião-Mor Antonio José Pinto, de inventārio em. 1798, no Rio (AN, 188/3737). São perto de 150 títulos só em matérịa médico-cirürgica, muita coisa da bibliografia francesa ("Maladies des enfans de Undervod", "Maladies venerienes de Hunter", "Traitē de. la gangrene de Quesnay" etc.) e alguma coisa de curiosidade na bibliografia portuguesa, como "Despedida da medecina aos portuguezes" e um "Compendio da arte de partear". Uma das raridades na estante $\vec{e}$ uma obra singular escrita em francês: "Tableau de 1 'amour conjugale".

No sēculo XIX, muitos dos títulos relacionados nas 1ivrarias brasileiras serão oriundos do Setecentismo. Alguns leitores se destacarão, naturalmente, pela introdução de autores e matérias diversificadas, diferentes muitos deles das características do século anterior. Alguns volumes novos sẹ apresentarão ao conhecimențo da natureza leitora do brasileiro, como a Farmacopea lisbonense, ou coleção dos simp1ices, preparações e composições mais eficazes e de maior uso, do notório mẻdico e acadêmico Manuel Joaquim Henriques de Paiva,' obra publicada em 1780, reeditada em 1802, conforme aparece no inventärio de José Dias Paes, 1803, em Cuiabả (APMT). Autores como Plenck, Cullen, Sturmann, Sabatier, Huster vão pontuando nas Iivrarias do Mato Grosso, do Rio Grande do Sul, de Minas, da Bahia, Rio de Janeiroe São Pau10. Uma obra popular de Guilherme Buchan, na tradução de Manuel Joaquim Henriques de Paiva, aparecc no inventärio de Francisco Antonio Duarte, 1824, do município de Rio Grande (RS) (APRS, R. Grande, Maço 10). Trata-se da Medicina do- 
méstica, ou tratado de prevenir e curar as enfermidades, com - regimento e medicamentos simples, escrito em inglês pelo Dr. Guilherme Buchan, traduzido em português com värias notas e observações concernentes ao clima de Portugal e do Brasil, com o receituärio correspondente, e um apêndice sobre os hospitais navais, publicada em Lisboa, Of. Morazziana, 1788, em 4 tomos, e numa segunda (1802), terceira (1825) e quarta (1841) edições, o que atesta sua popularidade. Na opinião de Licurgo Santos Filho,op. cit., "este manual de Medicina popular teve grande aceitação no país e somente cedeu o lugar na preferência, em meados do século XIX, ao Dicionärio de Medicina Popular do Dr. Chernovitz". 228

No mesmo inventário de Francisco Antonio Duarte, hā uma outra obra igualmente popular no Brasil; o Tratado completo de Medicina operatória, de Antonio de Almeida, editado em Lisboa, 1800, em 4 tomos. No do Dr. Guilherme José Correia, 1843, que tinha uma respeitável estante médica, aparece o Tratado da educação física dos meninos, para uso da nação portuguesa, publicado por ordem da Academia Real das Ciências de Lisboa, por Francisco de Melo Franco, médico em Lisboa, correspondente do número da mesma sociedade, obra de 1790. (APRS, R. Grande, Maço 21). E em Porto Alegre, no inventärio do Dr. Mancel Ribeiro de Miranda, 1809 (APRS, POA, Maço 20), aparece. uma "Dissertaçãoda febre simples de Fordice", em 3 v. e "2.v. Medicina theoretica de Gregory".

Em Minas, Pedro Manuel Sentciro dos Reis, inventariado 
em 1801, em São João De1 Rey (Arq. Hist:, maço P-1) tinha uma "Farmacopéia edinburgensi in 39" e outra popular peça da farmacologia portuguesa, a Farmacopéia portuense; em a qual se acham muitas das composiçōes que estão em uso ... tiradas das farmacopēias de Londres, de Edinburgo, de Paris, etc., editada no Porto, 1766 e obra da autoria do cirurgiāo Antônio Rodrigues Portugal. O capitão Luiz Ferreira da Silva, tambēm de São João Del Rey, 1810 (Arq. Hist., maço L-3) tinha um "Elementos de Farmacia por Manuel Joaquim Henriques de Paiva". Na antiga Vila Rica, Maria Vitoria de Jesus, inventaria em 1808, tinha um Tratado único das bexigas e sarampo, composto por Simão Pinheiro Morão, médico recifense, com o anagrama de Romão Mósia Reinhipo, publicado em Lisboa, na Of. João Galrão, 1683, e considerada a primeira obra médica brasileira escrita em vernáculo, sobre uma epidemia das doenças em Pernambuco. O inventārio tinha tambēm uma "Arte de tratar a si mesmo das enfermidades venerias por Monsieur Barb. in f1.". (Ouro Preto, Casa do Pilar, 1\% of., 124/1553).

Assim, pode dizer-se, a literatura médica do século XIX perpetua e amplia a conhecida desde o setecentismo. A1tera-se um tanto o comportamento do autor, antes essencialmente preocupado em ser o "médico.à'distância", escrevendo tratados para servir como manuais de orientação prática do leitor-paciente. No Oitocentismo, percebemos uma maior abrangência de títulos, matérias, autores e visão de tratamento das questões de natureza médico-cirúrgica e farmaco1ógica, ưue passaun por consideraçōes de ordem histōrica, uma vez que - Brasil jã não estaria tão à margem da constância de pro- 
fissionais de origem acadêmica, porque aqui jả se abria uma Escola de Medicina e já se podia implantar uma filosofia de consulta e receituário mëdicos diretamente, sem apelar para a orientação à distância. 0 livro então sofre algumas muţações de perspectiva, os autores desenvolvem e aplicam aqui mesmo suas teses, exercitam uma visão critica dos costumes e dos delicados problemas sociais sob uma ótica mais de acordo com a troca de experiências, com a discussão mais aguda de questōes um tanto mais especializadas.

E șingular que a bibliografia em vernáculo ainda pontifica, paralelamente à chegada de títulos em francês.

A bibliografia francesa, aliās, serā um tanto maior à medida em que nos aproximamos do final do século XVIII e em toda a metade do século XIX. A leitura médica cumpre assimum elemento de ampliação do empirismo cientifico da Medicina e da Cirurgia, fazendo acessivel aos leitores os graus de esclarecimento de que ele seguramente necessita, uma vez que as bibliotecas eram formadas para suprir a carência de profissionais médicos em número compatível com a necessidade e o aparecimento de pacientes. 


\section{4- Vade-mecum e Ordenações}

Pode dizer-se, no caso da bibliografia jurídica no Brasil Colônia, que ela é solidamente conformada a uma disposição estilística, que se irá repetindo ao longo dos anos e das bibliotecas. Uma relação típica de livros de Direito, dos começos do século XVIII, por exemp1o, antecipa o perfil das demais estantes no mesmo período, com títulos, assuntos e autores consagrados do Direito Português, nas áreas do Cíve1, do Crime, da Família e Orfãos, do Direito Canōnico etc. Nos séculos XVII e XVIII, a natureza das publicações obedece a um certo formalismo jurídico, com erudição e rigor de anālise, patenteando o saber e estabelecendo juízos de valor e crítica à Filosofia do Direito. Diferentes do modelo das obras em Ciências Médicas - dirigidas a um público, as mais das vezes, leigo, em atenção à necessidade prätica de orientação do leitor - os livros de Direito se dirigem a um público especializado, de doutores e bacharéis, ou curiosos com decisiva inclinação ao estudo das Leis. Em outras palavras, a ordenação bibliográfica em Direito é aqui restrita a, no máximo; três centenas de títulos; ao passo que em Religião è mil vezes superior e em Medicina ou Letras, também maíor, tornando mais ou menos comuns a todas as estantes do Direito os títulos disponíveis. No século XIX, as matérias juridicas obedecem a um certo ordenamento prático, a1terando-se a anterior prevalência da teoria e da erudição. em benefício de assuntos bem mais próximos do Direito Posi- 
tivo, de molde a traduzir explicações dảs tortuosas questões das leis em vigor. Assim, ao invēs de considerações sobre - Direito Nátural, o Direito Romano, o Direito Cánônico, a Filosofia do Direito, os textos que se punham à mãodos 1eitores e estudiosos serviam como imediata fonte de consulta e consumo de ensinamentos bem mais simples acerca da legislação portuguesa; úteis ao foro e ao aperfeiçoamentodos magistrados.

Boa parte das obras que circulam nas bibliotecas brasileiras do Setecentos e Oitocentos têm uma origem conven cional: o Reino. São as ordenações' e seus inseparáveis repertórios das leis vigentes e das "extravagantes". Assim, aparecem nos inventários de bens objeto de nossa pesquisa as ordens emanadas da Corte portuguesa. Serão as Ordenações manuelinas, afonsinas, joaninas, as dos séculos XVI, XVII, XVIII e as da contemporareidade do leitor estudioso da Justiça reinol. Os outros títulos dizem respeito a autores consagrados do Direito português, indicados habitualmente por seus sobrenomes familiares a inventariantes, escrivães, enfim, a um público leitor especializado. Assim, são comuns as bibliotecas brasileiras com indicativo de possuírem obras de Gama, Supico, Castro, Cardozo, Guerreiro, Vanguerve etc. Muitas vezes, essas 1 ivrarias abrem a descrição de bens dos inventariados, o que confere uma importância pecuniária, para os efeitos da partilha, dos "1ivros de Direito do falecido". As estantes jurídicas, no geral, indicam apcnas, como títulos presentes e em poșse do inventariado, os seus principais autores, o que equivale a un código conve- 
niado entre escrivão, avaliador e consumidor dos livros.

A primeira estante de obras em Direito e Legislação que aparece em nossa investigação, è aquela do paulista Francisco Nunes de Siqueira, no ano de 1681 (APSP, Ordem 493), com a singularidade já apontada de abrir-se o documento pela rubrica "Livros". Trata-se de uma razoável livraria, evidenciando, provavelmente, o ofíciodo inventariado. Ela antecipa, conforme dissemos, a ordem de aparecimento de alguns títulos no ramo do Direito português que serão bem populares nos séculos XVIII e XIX brasileiros. São:

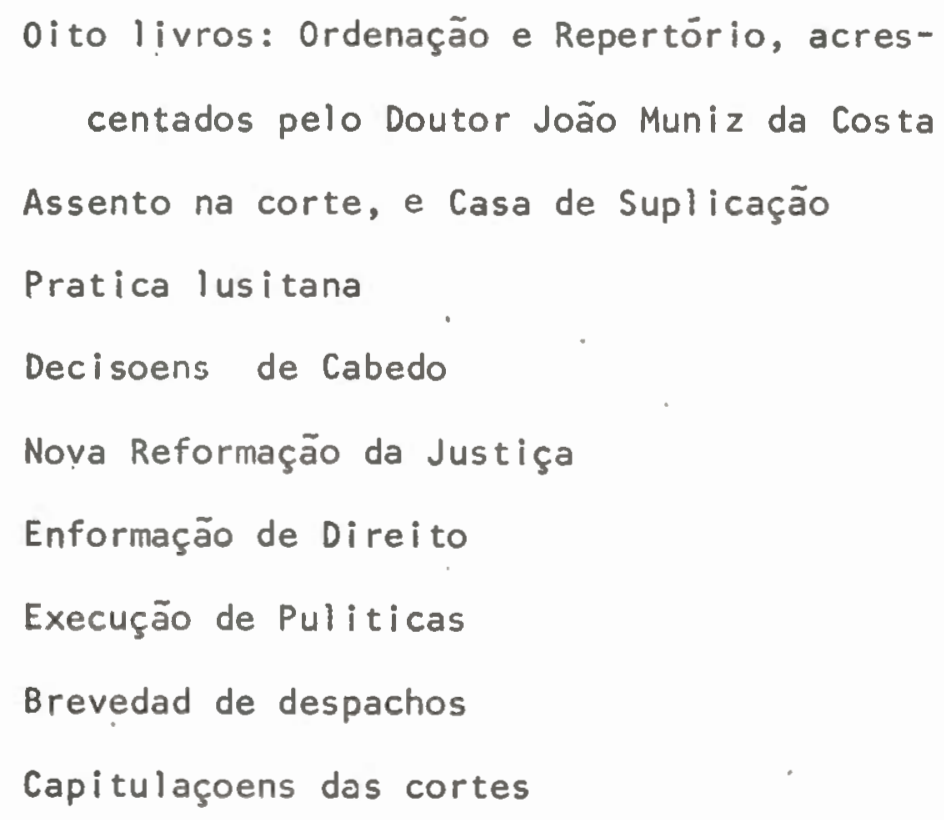

Destacam-se, nesta lista, as Ordenações do Reino de Portugal e seus sucessivos Repertórios, contendo a suma legisferante portuguesa, e a obra de Supico de Moraes, o Assento da Casa de Suplicação e do Cíve1, peça de inquestionavel popularidade no decorrer do XVII e XVIII séculos. Outros livros de obrigatória presença nas estantes brasilei ras são as Decisões', de Miguel de Cabedo (1525-1627) que; além de magistrado, notabilizou-se em seu tempo como pocta e 
humanista, e a Prätica Iusitana, nas äreas do Direito civil e criminal. Surpreende aqui, como título curioso, a Execução de políticas, que não nos foi possívelidentificar esti1o ou autoria. Como sempre, reforça-se nossa impressão de dificuldade na indicação de obras em vista da esquiva anotação dos escrivães nos documentos ou da pouca noticia biblioteconômica a respeito da maior parte desses títulos.

Num considerável número de vezes, o inventariado só possui livros de Direito. Noutras, dispõe de uma biblioteca ampla de conhecimentos, em que o destaque natural irá para títulos jurídicos. Noutras, ainda, tendo ou não somente obras de jurisprudência, o inventariado declara os livros pela maior parte da composição da biblioteca, ou seja, simplesmente indica "toda a Livraria. de Direito do Falecido". No Maranhão, acompanhamos o registro do testamento de Franciscọ Pereìra de Lacerda, clêrigo maranhense, em 1741, com uma "Livraria de Iivros de Direito e alguns livros de matéria ecliesiāstica, como tambēm alguns sermonarios". Num segundo testamento, entre 1756. e 1759, o mesmo clérigo põe em evidência que "também sou possuidor de huma livraria os mais deles de Direito", com a recomendação de "meus testamenteiros mandaram avaliar por pessoa de inteligência para saber Q valor deles". (Tribunal de Justiça do Maranhão, São Luiz, "Livru de Registro de Testamentos, 1756-1759").

0 mais antigo inventário setecentista incluindo 1ivros de Direito é o de Joāo Brito de Pazzy, 1739, na Bahia (ARQUEB, Capita1, 622-7). E1e tinhà as costumeiras "Ordonações", os mesmos "Repertórios" e acrescenta mais as obras 
de "Caminha, De libelo", "Paiva e Pona", "Vanguerve, Pratica judicial" e "Pratica criminal". O segundo mais antigo, também da Bahia, da cidade de Cachoeira, no Recôncavo baiano, pertence a Antonio Félix Pereira, 1749 (Arq. Reg. Cachoeira, 01/20/20/168 a 177). E uma surpreendente livraria com títulos os mais distintos cobrindo as vārias linhas do Direito português. Como observamos no que toca ao estilo das obras inscritas no inventário de Francisco Nunes de Siqueira, de 1681, aqui também podemosafirmar a caracteristica de leituras de jurisprudência no Brasil Setecentista como norma geralmente seguida e como amostragemde uma biblioteca geral em obras de Direito. Em outros termos, a relação de livros constantes da biblioteca de Antonio Félix Pereira, na primeira metade do século XVIII, é perfeitamente exemplar das tendências do leitor colonial quanto a títulos jurídicos. A lista é um tanto comprida, mas serve ao nosso propósito de identificar o perfil de leituras no campo do Direito, na Colônia:

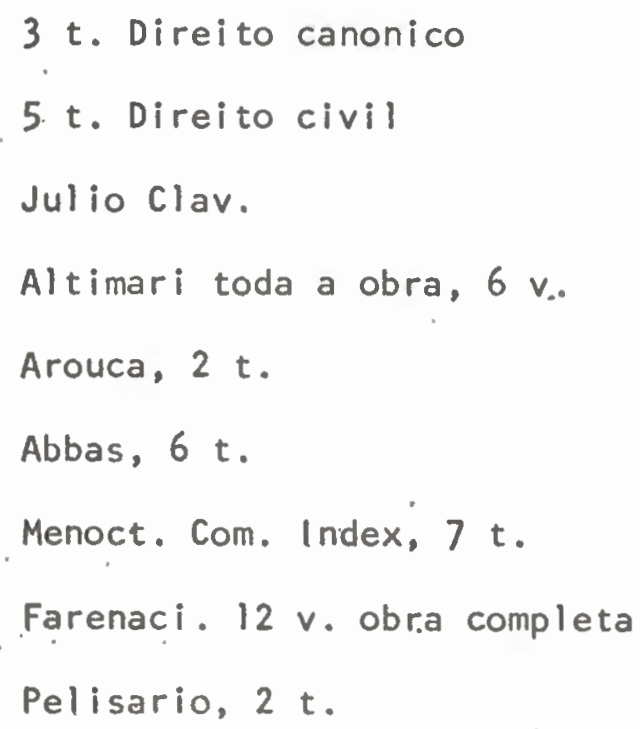


Guagino

Olea

A. Barbosa, 8 t.

Novarium Summa Bolar

T. Valasco

Boler

Lopes. Epit. Sanct.

Vanguerve, 5a. parte

Padilha

Aegidio, 2 t.

01 iva, 2 t.

oliveira

Conciol.

Sol sapientia

Pinto Ribeiro

Nogue i rol

Guerreiro, 3 t.

Epilogo jurídico

Phoebo, 2 t.

Pegas

Decisoens de $P$. Romanno, $5 \mathrm{t}$.

Caeleval de judiciis

Math. de .. criminal

Cabedo

Gregorio Lopez, 4 t.

Mascardo, 3 t.

Sanchez, 5 t.

Portheo de substat. 
Daois, $2 t$.

Gomez Ayron, 3 t.

Salgado, 2 t.

Valensuela, 2 t.

Capyeio Latro

Strach, de mercatura

Fragoso, 3 t.

Gratiano, 6 t.

Cordeyro, Dubitatio

Sylva, $4 t$.

Pegas Forense, $7 \mathrm{t}$.

Mendes a Castro

Gama

Pereyra. Decis.

Reynoso

Gabriel. Conclus.

Pinh. De testamentis

Pinelo. De bon mater

Cardoso. In praxe

Portugal, 2 t.

Decis. Justinian.

Macedo

Themudo

Ord. peq., 3 t.

Sylva. De sufrag.

Leytam. De jure lusitan.

Leytam. Finium Ragund.

Valasco. Consult. 


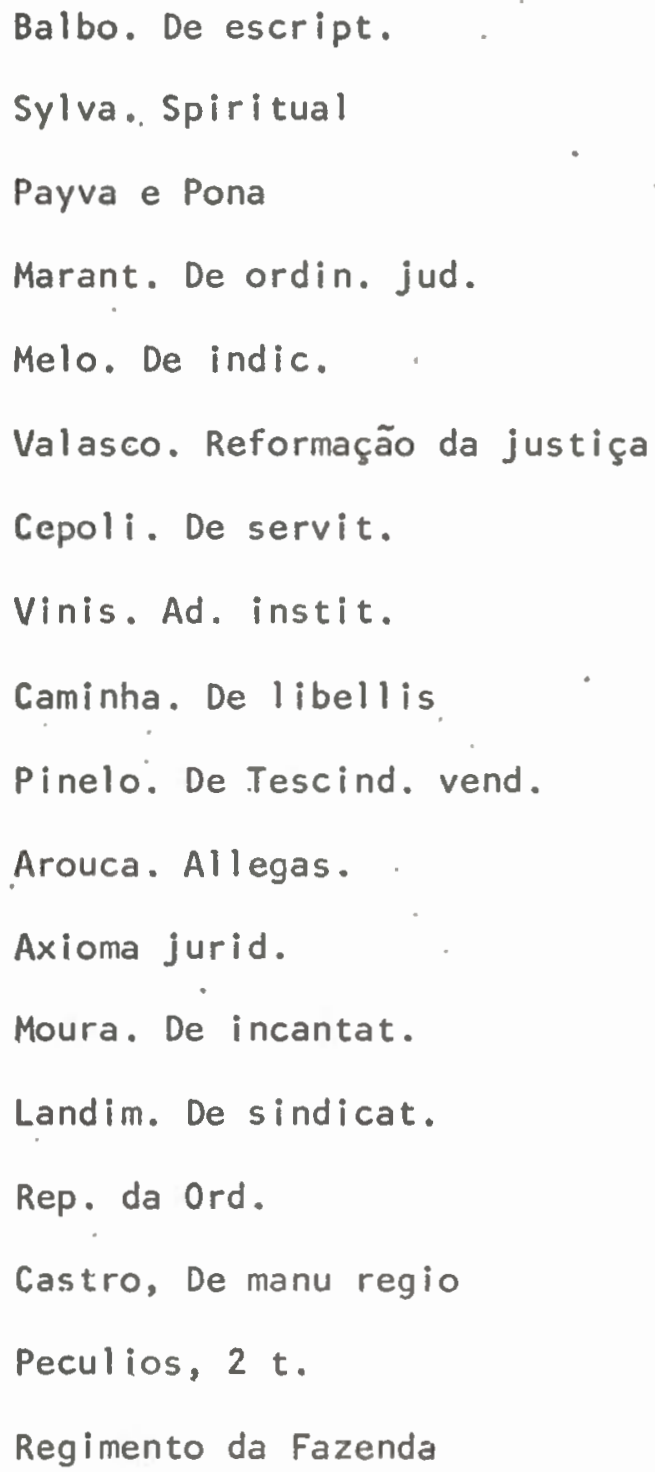

Como se pode notar, è uma estante bäsica do Direito português, compreendendo disciplinas do foro particular e público e incluindo vários autores nas particularidades intrínsecas da teoria jurỉdica, conforme indicaçãodesde o século XVII. O estilo é o da anālise eruditadoṣ diplomas 1egais presentes na cultura e civilização portuguesas, a partir de experiências percebidas ou vivenciadas nos campos cível, criminal ou institucional. A mesma ordem será seguida nas leituras brasileiras do Setecentos. Alguma variação, evidentemente, observa-se-áde uma paraoutra biblioteca, com o acréscimo de outros tantos, autores. No inventārio do Dr. Jo- 
sé de Almeida é Faria, 1750, de São João Del Rey (Arq. Hist. maço J-8), aberta a descrição de bens pela rubrica "Livros", temos algumas novidades em termos de nomes da mesma jurisprudência teórica portuguesa. Assim, fazem parte do elenco de outros nomes agregados ao patrimônio da bibliografia jurídica, em Minas, "2 t. Exclusione", "2 Forentios", "Leotardi", "Canserii", "Martins da Costa", "Copula. De servitutibus", "Pratica de alegationibus", "Gratia de beneficiis", "Pandecta de jure civili", "Coelho. De sindicatu" e "Coelho. De letra editionibus".

A contribuição de novos autores e títulos, sem dúvida, vem acrescentar ao universo de leituras brasileiras uma situação de permanência pelo estudo da ordemjuridica oriunda de Portugal. Värios aspectos sociais, políticos e éticos da justiça serão objeto de consideração e juizo de valor. o estudo das leis redimensiona a prática da Justiça, ou sua eficiência no corpo social. Assim, em nosso interesse, novos títulos ensejam a oportunidade de verificar como o sentimento público de leis justas está ou não adequado à ordem de publicações no campo do Direito. Pode ser fruto de dinâmica social o esforço erudito em interpretar filosoficamente essas leis. E o leitor, não de todo passivo, certamente não se furtarà à consideração das conveniências ou constrangimentos de leis que, em última análise, devem servir à cidadania e não o seu conträrio.

Novos títulos; enfim, vamos encontrar nas livrarias brasileiras dos sëculos XVIII e XIX: Como no inventärio do Arcipreste João Machado Henriques, reverendo português resi- 
dente em. São Paulo e falecido em 1756 (APSP, Ordem 655). Das obras que testemunham uma circulação garantida do ramo do Direito entre os leitores coloniais, novos títulos são"1 t. de Calderon criminal", "1 t. Amato nos concellos"e "1 t. Ordenação de Saragosa": O Dr. Agostinho Monteiro de Barros, de Ouro Preto, inventariado em 1763 (Casa do Pilar, 16/149), tinha, alêm dos costumeiros tïtulos, mais um "Lomey, 2 t.", "Capia, Latr.", "4 t. Fontanella. Opera omnia", "Seop ad Gratianno" e "4 t. Solano. Cogitação forense e index de Pegas". Antonio de Freitas Cardoso, inventariado em 1766, em Sabará (Museu do Ouro, $2^{\circ}$ of., Pac. 23) tinha uma obra rara nas estantes brasileiras: "Defezoens de Supremo". Felipe Franco Madeira e Barbuda, em inventário de 1764, em São João Del Rey, onde era tesoureiro da Provedoria (Arq. Hist., maço F-9), tinha uma "Biblioteca juris consultationes", um "Carualho. De testamentis" e um livro de "Amador Rodrigues. De executionibus". 0 reverendo Dr. João Batista Lopes, em inventärio de 1770, em Sabará (Museu do Ouro, 2: Of., Pac. 21), tinha värios títulos de pouca frequêencia nas bibliotecas brasileiras, destacando-se um "Ozorio. de patronatu regio", um "Gusman. De nul.", "4 v. Molina. De Iustitia de jure, fol.", "Cordeiro. Dubitationes in foro frequentes"e um "Lexicon juridicum in 4\%". Manoel Borges da Silva, de Salvador, inventariado em 1772 (ARQUEB, 642-5), tinha os costumeiros títulos, mais um "Epilogo juridico" e um "Moncada".

E vão se sucedendo, assim, as estantes jurídicas brasileiras com novos autores e novos assuntos. Manuel Teixeira de Carvalho, em 1774, Ouro Preto (Casa do Pilar, 104/1312), 
tinha livros novos como "De Siano", "Mincigelli", "Peregrino da jure" e "Felipe Dessius". José Carreada Silva, inventariado em 1771, em São Paulo (APSP, Ordem 707), tinha os títulos frequentes, mais um "Gatta", um "Berthalano" e um "Aripine1". O Desembargador João Caetano Barbosa, em 1776, Quro Preto (Casa do Pilar, 88/1065), tinha inventariados livros comuns à área do Direito, próprios do seu ofício, destacando-se como incomuns "Escobar, De ratiocion.", "De1 Rio. Desquisitionis", "Gobii. De sucessiones"e um "Novum Tratinsuciis", seguidos de um "Remissoens doctorum".

Uma característica flagrantena constituiçãodessas bibliotecas juridicas no Brasil Colônia reside na atribuição pecuniāria ao livro, para efeitos da partilha, nos inventários. Por isso, alguns documentos abrem a descrição de bens do inventariado justamente pela relação dos livros de Direito: Algumas bibliotecas serão quase exclusivas nesses títulos, como a do bacharel Manoel Antunes Suzano, no Rio de.Janeiro, que deixou a um dos seus herdeiros, também bacharel, o espölio de 300 ṿolumes, declarados no inventário. Os títulos dessa livraria carioca do século XVIII cobrem, praticamente, todos os ramos conhecidos do Direíto à época, com destaque para autores consagrados em popularidade: Paiva e Pona; Vanguerve Cabral, Remígio. Themudo, Egídio, Solorzano, Mendes a Castro, Gama e Cabedo.

No século XIX, observa-se, primeiramente, uma tendência de perpetuar autores e matërias considerados nobres no tratamento de questões importantes do universo juridico, salientando-se ai a Teoria, a História e afilosofia do llirei- 
to. Aos poucos, porém, as bibliotecas oitocentistas vão intensificando um projeto de mudanças na órbita das antigas prevalências, optando por um perfil de leituras mais comprometidas com a natureza prática do Direito positivo. Tomam vulto autores e assuntos com um estilo e uma tëcnica novos nà abordagem das questões jurídicas diretamente úteis e orientados no sentido do esclarecimento sobre os intrincados meandros do foro civil, de familia e criminal.

Outras informações e novidades acentuarão a bibliografia jurî̉ica, que se irā acrescentando em número e em profundidade ao patrimônio da Legislação e da jurisprudência oriundos da experiência europêia. Alguns títulos em francês, em espanho1, o universo das constituições, estudos sobre $\mathrm{Na-}$ vegação, Marinha, Comércio, Administração, Trabalho, Diplomacia etc., tudo isso será incorporado ao patrimônio comum da cultura jurídica, de par com os tratados dos doutos e com as obras de ordenamento moral orientado pela disciplina eclesiástica ou pelo espirito secular. Da primeira para a segunda década do Oitocentos brasileiros, as leituras corresponderão ao processo histórico de pleitos püblicos e debates sobre política constitucional, organizaçāo jurídicado Estado, legislação para os mecanismos sociais de mudança, inclusive do regime institucional. A partir dai, essas bibliotecas. no Brasil traduzirão melhor a gama de assuntos, o maior volume de informações e de debate sobre leis que acompanharão a História e refletirão, șem dưvida, os projetos idcológicos inscritos no corpo social. Tratadistas como Jércmy Bentham, De Pradt, Benjanin Constant serão freqüentes na 
imensa maioria das estantes oitocentistas. Os interditos como Montesquieu serão presentes, junto aos modernos e contemporâneos, na interpretação das leis, novas e.antigas, que digam respeito à curiosidade e ao desejo de saber demonstrados pelos brasileiros do século XIX. 


\section{5 - clāssicos, moralistas e gramāticos}

A Literatura clássica e as obras de Lingửstica que representam a predominância entre os títulos de maior circulação no Brasil Colônia não aparecem nas livrarias brasileiras sob o ângulo de uma preferência puramente literária. São elas resultado da clara doutrinação moral que parece dominar todo o panorama da cultura brașileira atẻ meados do século XIX: Assim, autores como Cícero, Ovídio, Horäcio, Virgílio verdadeiros best-sellers coloniais - não se fazem presentes por sua obra strito sensu, senão pela imanência doutrināria pércebida por moralistas e doutrinadores atentos à dissemináção educacional e da cultura nos reinos e domínios de Portugal. Assim, se o Brasil lia Aristóteles e Platão, 1ia-os por força da interpretação doutrinâria de suas obras feitas por doutores da Igreja com a autoridade de um Santo Tomás de Aquino e um Santo Agostinho, respectivamente. Não será difícil suprender a impregnação de modelos clássicos nos prosadores e poetas ascetas e misticos da civilização ibérica. Em outros termos, pode dizer-se que os moralistas e doutrinadores católicos tomam, pelo estilo, pelo apuro da linguagem, pela forma limpa e clara, os clássicos e os utilizam para veicular toda a ideologia do Dogma, da Ascese, da Mística e sobretudo da Filosofia moral que investe na redenção do homem e sua subordinação aos escaninhos tautológicos da doutrina cristã. 
Assim se verifica com um Fr. Luiz de Granada profundamente influenciado por Cícero, autor possivelmente preferido entre os moralistas, exatamente por ser ele, tambëm, de um moralismo contingente à civilização pagä romana. 0 exercício, símbolo translativo da semântica grega de Ascesis, também serve ao doutrinador na tarefa de interferir, de forma sutil, nas impressões e ideologias que importam a ele inculcar no espirito do leitor. Subrepticiamente, diz que aproxima o leitor dos clässicos, recomenda-os e os divulga, mas porque esses autores, devidamente expurgados de circunstâncias textuais ambiguas ou explicitamente contraditórias, servem aos objetivos doutrinårios. A doutrina usa o estilo, usa o modelo, usa a técnica e è como usưfrutâria dos clássicos que se sente autorizada a desenvolver mecanismos de interpretação do mundo inteiramente reacionäriós. E; aliảs, pela Filosofia moral que Cícero melhor se presentifica no plano da literatura clässica. Começa justamente por Cícero, inquestionavelmente pagão, mas com viabilidades hermenêuticas santas, a divulgação de obras literärias e filosóficas. Mais moralista que metafísico, Cícero não desenvolve seus textos pela margem de indeterminação, ou pela-dúvida existencial, ou pela ambiguidade de conceitos. Daỉ ser ele o prỉncipe dos filosófos para os exegetas cristãos e, talvez, por isso, seja tão popular na civilização brasileira tributária da obediência ao princípio da não-abstração mundana, mas do dogma, da certeza católica. Essa preocupaçã̃o moral com o bcm, com a virtude, com o saber político que anatematiza a paixão fa- 
zem de Cícero o pensador emblemático que serve como ícone devidamente adaptado - aos objetivos morais da cristandade.

Em que pese essa enviesada porção moral de que a 1 eitura de obras clāssicas se acha inchada, é bom registrar a importância que implica essas leituras no Brasil Colônia. Em matëria de Letras, a civilização leitora brasileira tem nos clássicos um de seus pilares. Pode ser que o resultado disso seja um balofismo intelectual, sem outros reflexos na cultura a não ser a do pröprio registro circular de livros: Convén não esquecer, entretanto, que ẻ da leitura de clássicos como Ovídio, Horácio e da íilosofia do sublime em Longino que a cultura literäria brasileira se pôde afirmar na Escola Mineira, por exemplo. Não deve, assim, ser considerada irrelevante ou apenas estatística a espantosa presença dos clässicos entre as obras de Letras nas 1 iv rarias setecentistas e oitocentistas entre nós.

o brasileiro, portanto, 1 eu, e muito, a 1iteratura produzida pelo gếnio clảssico. Fora disso, leu as obras de eficiente circularidade en sua ëpoca, como as Novelas de Cervantes, as Peregrinaçōes de Fernão Mendes Pinto, comëdias e entremeses, como pudemos verificar na anâlise dos documentos seiscentistas existentes no Arquivo Público de São Paulo. No século XVIII, a leitura de obras literärias basicamente se voltou para a produção ficcional de ordem moralista, como ilustra a enorme popularidade de títulos como as Aventuras de Telêmaco, de Fenelon, as Reflexões sobre a vaidade dos homens, de Matias Aires, a Mistica cidade de Dous, da madre Ma- 
ria de Agreda, o Compêndio narrativo do peregrino da Amërica, de Nuno Marques Pereira, a. História de Gil Blas de Santillana, de Allain Le Sage, o Feliz independente e a roda da Fortuna, de Teodoro de Almeida. São, todos eles, ficcionistas comprometidos muito mais com a, Religião do que, propriamente, com a Literatura. Com fato social, no entanto, importa muito pouco essa classificação. Importa saber que livros. eram lidos, os que estavam presentes em quase todas as bibliotecas brasileiras do periodo colonial.' E isso, sem dūvida, esses livros são fato representativo. Eram considerados peças literärias e como tal consumidos amplamente no Brasil. A ôbvia influência doutrinâria em muito ajudou nessa popularização da ficção moralista, assim como influenciou decisivamente ná composição de estantes em que os clāssicos representam marca impressiva de gosto e erudição pelas Letras. Dessa sorte, face ao conhecimento que hoje dispomos da natureza social brasileira e das características de consumo de livros e de métodos de instrução no Brasil, no plano particular da cidadania e do empenho pessoal pelo hảbito de leituras em Letras, avulta o interesse demonstrado por brasileiros da Colônia pelos livros e pelo reino das idẻias por estes representado. Não nos surpreende, pois, no centro de São paulo, ou ãs margens do Tócantins, sobretudo entre fins do século XVIII, começo do XIX, encontrar riqueza bibliogräfica clássica como, em especial, Virgílio, Ovídio, lloräcio, Terêncio, Cícero e Tito Lỉvio.

Conhecendo-se circunstâncias e opções de leitura no 
Brasil setecentista, por exemplo, não constitui qualquer - surpresa a circulação de obras de Camõestalỵez até a edição "princeps" de Os Lusiadas, especialmente por ser Camões autor consagrado da preferência de leitura no Brasil.

Como vimos em outro ponto deste trabalho, o Brasil não conheceu alguns autores, seja em Latim ou Português. Não encontramos registro da circulação de um Gil Vicente ou Bernardim Ribeiro ou Gomes de Zurara, por exemplo. Não tivemos, como os espanhöis, a oportunidade de ler as novelas de cavalaria, com exceção de El Gusmản de Alfarache, de Matéo Alemān e da Histôria de Carlos Magno, ou do Palmerim de Inglaterra, somente circulares aqui, e em raras vezes, no século XVIII. Gil Vicente foi publicado no mesmo sēculo XVI de sua consagração oficial e praticamente a cultura colonial brasileira não o conheceu. O D. Quixote foi publicado em 1605, mas sô no sẻculo XVIII é que régistramos a circulação da obra entre os brasileiros. Os mais conhecidos livros de cavalaria que seguiram a trajetória colonizadora hispanoamericana (Tirant 1e Blanch, 1490; Histôria del cabailero de Dios que avia por nombre caballero Cifar, 1512; Palmerim de Oliva, 1511; Cuatro 1ibros de Amadis de Gaula, 1508; Las sergas de Esplandiän, 1510; Lisuarte de Grécia, 1514; Don Florise1 de Niquea, 1532; Amadis de Grécia, 1530 etc.) náo tiveram acolhida (ou a permissão) no Brasil. o ciclo carolingio, aberto com a Histöria de Carlos Magno y de los doce pares, que gozou de extraordināria extensão e popularidade entre o püblico hispanoamericano e cuja primcira edição data 
de 1525, somente nos aparece, raramente, em meados do Sctecentismo. O mesmo registro para o ciclo de Palmerim, de que só conhecemos o Palmerim de Inglaterra. E não se pense que o rigor censōrio espanhol seria diferente do português. Em Valadolid, 1559, editou-se um indice de livros proibidos, vẳidos para toda a civilização de Espanha. Entre conquistadores e conquistados, no entanto, os livros religiosos competiam.com as novelas de cavalaria no gosto e na opção de leitura. Se era popular um livro como Instrucción de la mujer christiana, que indicava quais os livros que se deviam ou não ler, publicado em 1524, tambẻm o era uma novela como Belianis de Grécia, editado em 1547, ou E1 caballero de la Cruz o Lepoleno, de 1521 . A diferença mais ou menos nïtida está na ideologia colonizadora espanhola e portuguesa. Ao passo que na civilizaçáo espanhola "los libros siguen al conquistador desde 1501 , y quizas aun antes, el clero 11 evó consigo misales, breviarios, biblias, y otras classes de libros religiosos, gramaticas y dicionarios", conforme a informaçāo de Leonard, em Los 1ibros del conquistador, ${ }^{229}$ aqui já salientamos isso, Portugal não sô demorou em assumir seu feudo exploratório, como ainda retardou'e tornou muito dificil a regularidade na circulação da cultura literária. Para aqui vieram conquistadores impulsionados pela crônica renascentista, mas com a cabeça povoada por idéias e costumes da I dade Média.

E se perdemos a leituradireta das novelas de cavalaria, tambëm as perdemos na forma indireta. Os livros que 
Quixote (aliäs, D. Alonso Quijano, el Bueno) lia e que o - "perderam" são alguns dos mais expressivos exemplares do ciclo fantasioso em Espanha, justamente o Amadis, o Libro del muy esforçado caballero Palmerin de Inglaterra, hijo del rey Dón Duardos, a Crónica del invencible caballero Flosanbel de Lucea, a Crōnica del excelentissimo principe Don Florise1 de Niquea, e mais El caballero de 1a Cruz; Espejo de caballerias, Las Sergas de Esplandiản, Florismarte de Hircania, entre outros.

Os resultados mais diretos de nossa investigação em inventārios de bens apontam o leitor brasileiro da Colônia significativamente mais representativo e numeroso a partir do século XVIII. E neste sêculo, aliảs, que registramos a constituiçāo de bibliotecas clâssicas, ampliando o universo de leituras para as obras de ficção moralista, filosofia moral, poesia épica e lírica, um pouco de texto dramático, narrativa de viagens com uma pitada de imaginação, além dos ensaios filosóficos que recuperam a visão do homem natural própria do Renascimento. Neste sẻculo tambẻm ê que aparecerão as três novelas do ciclo de cavalaria que observamos antes: a Histōria de Carlos Magno, o Palmerim de Inglaterra e El Gusmän de Alfarache. Depois dos titulos em Literatura e Filosofia, os que mais avultam no Setecentismo brasileiro são os dicionârios, gramáticas, compêndios, manuais e exercícios rudimentares do Latim, do Portugues e do Francês, em especial. Basicamente, todos os idiomas conhecidos e bem divulgados à época estarão aqui representados. Hă dicionārios, com dupla função no 
conhecimento do 1éxico, como P̣ortuguês-Francês e vice-versa, Português-Espanhol, Portugụês-Italiano, Portugues-Inglês etc.

Se no Setecentismo temos um agudo senso de observaçāo das estantes formadas com tîtulos diversos, o sêculo XVII ē, ainda, tỉmido nas ciências 1 iterärias'e o sẻculo XIX reitera muitos títulos setecentistas e aponta outros muitos, até em sua contemporaneidade.

No inventärio dos bens de Francisco Nunes de Siqueira, de 1681 (APSP, Ordem 493), dois títulos são, sem dúvida, surpreendentes, justamente os dois últimos transcritos no documento, que revela um livraria rica em titulos de Direito e Religião. São um livro de Comẻdias e um outro de Entremeses.

A despeito das dificuldades na identificaçao das obras, decorrentes, sobretudo, da obscuridade com que vêm transcritos os.títulos pelo escrivão, pertencem ambos à literatura dramática, o que significa reconhecer a identidade de um leitor, no Seiscentos, de obras no gênero cômico e bur1esco. "Comêdias", tal como vemos grafado no documento, pode referir-se tanto ao teatro português quanto ao espanhol.

A dificuldade aumenta se questionarmos as caracteristicas de outros documentos pesquisados, do sêculo XVII ao XIX, onde não aparece qualquer vestígio de comediógrafos espanhơis (alèm de um ủnicolópe e un Calderôn no século XVIII). Muito especialmente, esse desconhecimento se acentua quanto ao teatro português. Então, votamos pela possibilidade de 
que a transcrição "Hū de comedias", no inventärio, deva tratar-se de obra de comẻdias espanholas.

Quanto à outra obra, de Entremezes, a prätica dos esçrivães - preocupados tão-somente em listar caba bem para efeito de avaliação e desdobramento do inventärio em partilha e meação - mais uma vez impede uma definição clara. 0 "outro de Entr..." parece tratar-se do gênero farsesco, curta representaçāo de carảter jocoso e burlesco. A informação truncada não facilita a tarefa de desvendamento, mas deve indicar, não um título, mas o estilo de representaçāo cômica, provavelmente obra de origem ibërica.

Apenas dois títulos escapam â classificação da doutrina catōlica no inventẩio do padre Pedro de Godoy, de 1691 (APSP, Ordem 498). São exatamente.uma Arte 1atina talvez a obra de Manuel Alvares, S.J., estigmatizada por Ver= ney e proibida de circular nos reinos de Portugal sob a égide de D. José I - e uma Rudimenta, provavelmente Anotaçōes ad Rudimenta Gramatical, de João Nunes Freire, comentador do padre Alvares, editado no. Porto em 1643. Ambos os títulos são de consulta obrigatória no ensino jesuítico e revelam uma crescente popularidade e intensa procura dos estudos clāssicos e da gramātica latina, conforme ratificam os documentos setecentistas. Compreende-se, a propösito, essa frequente procura dos estudos de explicação do Latiın, em virtude da dominaçáo docente da Companhia de Jesus em Coimbra c por ser o Latim idioma universal, literảria e liturgicamente. Assim, tcmos um pü̉blico leitor, a partir deste sēculo 
XVII, que introduz a voga de estudos 1 inguisticos, aqui pe- lo Latim e seus modelos de construção sintâtica ou suas explicações estilisticas. Quanto à. Literatura, as Novelas de Cervantes e as Peregrinações de Fernão Mendes Pinto aparecem em inventärios paulistas do Seiscentos, conforme vimos. A leitura de Cervantes, em 1638, näo deixa de ser um bom indicativo do gosto literârio nativo, abrindo a prỏpria popularidade do autor de $\underline{\text { D }}$ Quixote, obra presente no sẻculo XVIII. As Comédias e os Entremezes afirmam um leitor atraido pelo gênero teatral, em constante movimento desde a representação em festas e folguedos populares a partir do sêculo XVI, com Anchieta.

No sêculo XVIII, como dissemos a caracteristica de leitura mais frequente é a dos clássicos, ao lado dos estudos 1 ingulisticos. A leitura dos clâssicos pode aparecer como atestado de erudição e cultura do Ieitor, e igualmente como norma e modelo postulados pela instrução pública no Brasil, vale dizer, pelo caräter impositivo de valores morais conjugados ao bom gosto no estilo de escrever e na organização do discurso provenientes do Latim. Pela ordem, autores como Virgĩlio, Ovídio, Cĩcero, Horäcio, Suetônio, Marcial, Terêncio e Sêneca serão bem populares no Brasil Setecentista e frequentam habitualmente as estantes coloniais. Filosófos como Aristôteles e Platão nāo surpreendem também pela aparição, assim como Quintiliano, pelas lições da Retōrica. E Quinto Cúrcio, pelo estilo épico, contando os feitos de Alexảndre; Homerọ, que cantou Aquiles e Trỏia; Tito Lívio, que 
cantou os feitos de Roma; L Lucano, que cantou os feitos de César. Sem dūvida, são os clássicos que dão o sentido de permanência e prestígio das Letras, assi tidas em boa conta pelos jesuitas e docentes na instrução pública brasileira da Colônia. A Eneida, as Éclogas e as Geórgicas, de Virgilio, As Metamorfoses e Os Tristes, de Ovỉdio e a poesia e a Arte poética de Horācio, em ediçōes comentadas sobretudo em Latim e Francês, são verdadeiros best-sellers no Brasil Ćolonia, percorrendo as livrarias até o oitocentos e ilustrando o perfil do leitor brasileiro.

E curioso tambẻm notar o interesse desse leitor por manuais e compêndios de gramäticas, dicionảrios de Português, Latim, Francês, Espanhol, Italiano e, mesmo, Inglês. A razão desse nümero talvez se dê por força da necessidade de leituras em outros idiomas. o campeão de aparecimento, nos inventários de bens no Brasil, ẻ uma obra do lexicógrafo português. Bento Pereira, SJ., comentador da Arte-1atina do padre Manuel Alvares, S.J. : a Prosodia in vocabularium tri1ingue, latinum, 1usitanum et castellanum digesta, cuja primeira edição data de 1634 em Evora, tendo alcançado a dẻcima em 1750. A obra aparece nos inventärios, em geral, com o designativo "Prosodia de Bento Pereira", ou "Prosodia Latina", "Prosodia in vocabularium" ou, simpiesmente, "Prosodia". De - longe, è o livro mais consultado e frequente nas livrarias setecentistas brasileiras, aquele que mais comparece cm nossa amostragem, no sêculo Xivili. Cerca de vinte vezes aparece só em Minas Gerais, sucessivamenté, desde o inventärio de 
Romão de Oliveira Gago, 1738 (Mariana, CSM, 2ค OF. 91/1959)

- ao do reverendo Pe. Bernardo Martins Meira, em 1799 (São João Del Rey, Arq. Hist. , Maço B-3). Tambêm vai aparecer no mais antigo inventârio de São Paulo, o do padre Cosme Gonçalves Moreira, 1713. (ASP, Ordem 502) e, com uma frequência sintomātica do interesse aqui despertado, na Bahia, no Rio de Janeiro e no Rio Grande do Sul.

Depois da Prosôdia, um dos livros de mais surpreendente circulação no Brasil ê o Secretärió português compendiosamente instruỉdo no modo de escrever, de Francisco Josề Freire, o Cândido Lusitano notabilizado pela reforma dos estudos levada a efeito por Pombal. A obra de regular circulação entre nós, deve ser em segunda edição, 1746, Lisboa, of. Miguel Rodrigues. O Secretärio português é popularissimo em todos os pontos do Setecentismo brasileiro e úm dos seus aparecimentos mais antigos encontra-se no inventário de Rosa da Silva de Morais, de 1751 (APSP, Ordem 680), seguindo-se no inventārio de Manuel Dantas Barreto, em 1768 , na Bahia (ARQUEB, Judiciảria, Capita1, 02/972/1441/01).

0 estudo da ortografia da 1 ingua portuguesa, sua origem e evolúção, tambëm aparece sucessivamente nos inventärıs de livrarias brasileiras do periodo colonial. A "Ortografia de Madureira", ou Ortografia da lingua portuguesa, de João de Madureira Feijo, publicada em 1739 é, de todas, a mais popular, conforme atesta um aparecimento no inventärio de Manoel Dantas Barreto em 1768, como em outras datas e em outras livrarias brasileiras do Setecentos. As Ortografias de 
Luís Caetano de Lima (ed. 1736), Monte Carmelo (ed. 1767) e de Antonio Josē dos Reis Lobato (ed. 1770) concorrem para a divulgação e popularidade dos estudos linglísticos entre os leitores brasileiros coloniais. Na mesma proporção de popularidade é o Septem 1inguarum de Calepino, reformado por Fácciolatti, que aparece, por exemplo, no inventário de Mateus de Leão, em São Paulo, 1703 (APSP, Ordem 500), e em todo o país. São tambẻm comuns os estudos das gramảticas latina e portuguesa, expressos em vārias "Artes", em que pontificam as do padre Alvares, S.J., a de Madureira, a de Antonio Pereira Figueiredo, a de Verney. As gramāticas das 1 inguas francesa, italiana e espanhola tambẻm ocorrem com regularidade nas 1 ivrarias coloniais.

Autores portugueses, populares no trato das questões de natureza 1 inguística, na montagem de dicionảrios, vocabu1ārios, lẻxicos e.gramáticas, que tenham ou não alterado a naturail tendência de fazer preceder o Latim sobre os idiomas nacionais, estão presentes nos inventārios brasileiros, como certifica a enorme popularidade de um Bluteau, de um Madureira, competindo com um Antonio Pereira, com um Francisco Josē Freire, com um Verney, entre outros. Alguns tîtulos, tal como anotados nos inventảrios, dão margem a confusōes de autoria. No inventảrio do Dr. Josē Pereira Rjbciro em Mariana, 17.98 (CSM, 29 OF., 51/1162), por exemplo, há uma transcrição curiosa de "Orthografia e origem da língua portuguesa", que não soubemos a quem atribuir, se a Duarte Nunes de Leão, autor de umạ Orthografia (ed. 1576) c tam- 
bẻm de una Origem da 1ingua portuguesa (ed. 1606) ou a outrem. Pode tratar-se de equívoco do escrivão registrando dois livros como se fosse um só, ou pode ser apenas ortogräfỉa da 1 ingua portuguesa ou ainda, Origem da lingua portuguesa. De qualquer sorțe, a transcrição e o inventärio demonstram a correta circularidade de títulos entre os estudos de Lingtística e Gramätica do Português, em obediencia à voga desses estudos desde o sẻculo XVI ao XVIII.

No que toca especificamente à Literatura, è singular o modelo de opçáo de 1 eitura dos brasileiros coloniais. Vai da épica de Homero à de Virgỉio e à de Milton. No drama, registramos um raro Moliére, o popularíssimo Metastásio e um solitärio Lope de Vega, este no inventảrio do SargentoMor João Lopes Fiüza, 1741, na Bahia (ARQUEB, Capital, 623-4). Entre os comediógrafos, parece popular Calderón de 1a Barca e seus Autos sacramentales, que aparecem, em 6 t., no inventärio de Manuel Dantas Barreto, 1768, na Bahia (ARQUEB, Capital 02/972/1441/01, e tambëm Goldoni, cujas comédias aparecem em todo lugar. Os autores renascentistas Ariosto (Orlando furioso) e Tasso (Jerusalëm libertada) também são bastante expressivos nas livrarias setecentistas e oitocentistas. O D. Quixote e as Novelas exemplares, de Cervantes são igualmente populares. Assim como o Camões de Os Lusíadas e das Rimas, com notas e comentários de estudiosos da época, alóm de Sá de Miranda (ㅁbras) e Rodrigues Lobo (Corte na Aldeia), os quinhentis.tas preferidos entre os portugucses. Bocage c João Xavicr de Matos circulam com re- 
gularidade nesses inventärios de bens do sẻculo XVIII e XIX - no Brasil. Entre os autores Iuso-brasileiros, permanecem os moralistas Alexandre de Gusmão, do Predestinado Peregrino Nuno Marques Pereira, com seu Compêndio narrativo do Peregrino da Amêrica, Matias Aires de Ramos Eça, com Reflexões sobre a vaidade dos homens e um pouco as Aventuras de Diófanes, de Margarida da Orta.. Dos. poetas, referência explicíta é dadá a Clāudio Manoel da Costa, no inventário de João Fortes Bustamante e Sã, de 1777, em.São João De1 Rey (Arq. Hist. Maço Josê-I), que descreve, entre os bens, um "Livro de $8^{\circ}$ de Poesias compostas pelo Dr. Claudio Manoel da Costa", certamente as Obras de Cláudio, editadas em Coimbra,'1768. O Caramuru, de Santa Rita Durão, o Uruguai, de Basilio da Gama tambëm são bastante circulares no periodo. Dos luso-brasileiros, ainda são igualmente populares Vieira, Alexandre de Gusmáo e Antônio Josẻ da Silva.

Alguns livros sao verdadeiros achados no meio da maioria de clâssicos, moralistas e gramảticos. Ë o caso, por exemplo, de um exemplar de "Side campiador" no inventário de Manuel Pereira Machado, 1764, em Mariana (CSM, 2: OF. 98/2085). 'Em Minas e na Bahia,registramos a circulaçao do italiano André Alciati, jurisconsulto e moralista italiano (1492-1550), por uma única obra, Emblemata, cuja primeira edição data de 1522 e foi obra de invulgar popularidade cm Portugal. Emblema e una representação alegórica enunciada atravēs de mảximas de efeito moral. 0 estilo exerceu influência em poetas quinhentistas como Sá de Miranda c Ca- 
mões e, naturalmente, estendeu-se atê os neoclässicos, como - o português João Xavier de Mattos que cita nominalmente Alciati em suas Rimas, V. III, abertura: "Lede pois os Emblemas de Alciati; E achando um cão, que está ladrando à lua,/ Esse serā o vossọ e o'meu retrato". 230

No capitulo de Letras, as estantes coloniais brasileiras desenvolveram uma variação de natureza estilística, por seções de Linguistica, de Literatura e Filosofia, que poderíamos compreender como gêneros seguintes: Literatura Mora1; Bibliotecas, Seletas e Antologias; Dicionários, Gramātıcas, kudimentas, Cartapácios; CLâssicos, Neo-clássicos, poetas, prosadores, filosófos; Retōrica, Lógica, etc.

Entre os clässicos, cuja leitura se fazia majoritariamente emLatim, o sẻculo XVIII abre com os consagrados Terêncio, Marcial, Suetônio, Sêneca, Lucano, Aristóteles e Famiano, além de uma curıosa "Epigramata sacra", no inventario do padre Antonio Ålvares Rocha, de 1732 , em São Paulo (APSP, Ordem 727). TaL ordem seră, regularmente, seguida nas demais Livrarias setecentistas no Brasil. Marcial encontra-se na Iivraria inventariada de Romão de Oliveira Gago, 1738, Mariana, (CSM, 29 Of. 91/1959). Aristôteles, "Las obras de P. Virgîlio", "Cicero. De oficiss" e um "Comento de Oracio" estão no inventārio de João Fiủza em 1741, na Bahia (ARQUEB, Capita (, 623-4). Marcial e um ovídio, de $\underline{\text { s }}$ Tristes e das Metamorfoses, encontram-se no inventärio de Manuel Dantas Barreto; 1768, Salvador (ARQUEB, Capita1, 02/972/1441/01). Quinto Cúrcio. e umas Seletas estão no inventảrio do Capitão 
Manuel Dias de Sã, 1\%51; em São João De1 Key (Arq. Hist., Maço M-9). No testamento de Luiz de Vasconcelos Lobo, natural de Viseu e morador em São Luiz, com data de 1752, o testador declara que "deixo a Diogo Rangel de Macedo todos os meus livros, e declaro que alguns estão fora (...) em casa do ouvidor geral, trez, e entre os mesmos se acharam um Virgilio poṛtuguez" (Tribuna $\perp$ de Justiça, São Luız, "Livro de Registro de Testamentos 1751-1756"). A ūnica obra nomeada, "Vịgilio portuguez", deve tratar-se da Eneida portuguesa, versaio de João Franco Barreto, editada pela primeira vez em Lisboa, 1664.

Na relação de clássicos, ainda, que circularam no Brasil Setecentista, temos um "Voccio" e um "Comento conversação literal de todás as obras de Oracio" no inventário de Antorio da Costa de Oliveira, 1791 Curo Preto, Casa do Pi1ar, 19 of., 1./8). "Poesias de Horace Latin et François, V.", "Virgỉio'latino e frances, 4.v", "Anacreonte, Sapho e B., 2 v". "Comedias de Terêncio" "Amintas e Sapho", "Milton, 3 v.", "Cicero 9 v." e um "Dialogo moral de Platão"encontram-se inventariados na livraria do Dr. Josê Pereira Ribeiro, 1798, de Mariana (CSM, 29 Of., 51/1162). 0 inventariado Francisco de Godoy Preto, 17๖0, em São Paulo, (APSP, Ordem 523) tinha um "Horacio Manual de poctas". Agostinho Duarte do Rego, 1752 , em São Paulo APSP, Ordem 528), entre os clássicos jâ nomeados, tinha tambẻm "2 Quintilianos" numa livraria toda ela formada, à exceção de um "Concilio Tridentino", de titulos em Letras. O Fr. Manocl da Ressurrei- 
ção, 1789, em São Pau1o, (APSP, Ordem 561), tinha "Horatiis Flaciis Remata, 4 Jogos, 1 v.", "7 v. Quintiliano da institituição do orador. Trad. Vicente Lisbonense", "Fabulas de Phedro" e "Platoni opera". O Arcipreste João Machado Henriques, reverendo português, inventariado em 1756, São Pau10 (APSP, Ordem 655), tinha um "Commentario de Aristotelis de Generatione ad corraitsone". E Ignacio Costa Cintra, 1776, ainda de São Paulo (APSP, Ordem 710), tinha um "Tacito" e um "Cornelio". O reverendo Francisco Correa Lea1, 1786, no Rio de Janeiro (AN, 3606/220), tinha uma "Historia de Plinio", talvez em Português e uma mesma obra do mesmo autor, em Latim: "Plinii Historis", mais um "Aristotelis. Politica" e um "Suetonio, Commentarii".

O século XIX traz alguns outros títulos clássicos como "2 v. Iliada de Homero" no inventário de D. Ana Benevenuta d'Albuquerque, 1845, em Cuiabá (APMT, 1845). Um "Tito Livio" permanece no inventário de Joaquim Antonio de Araujo, 1849, de S."Francisco do Conde, Bahia (ARQueb, Judiciāria, 04/1683/ 2153/24). Já no inventário de Manuel Pires de Figueiredo, de Diamantina, em 1827 (Diamantina, Bibl. Antonio Torres, 19 Of., Cx. 60) constam um "Tacito em frances" e as "Satiras de Juvena1". Manue1 José Caetano, de Sabará, 1817 (Museu do Ouro, 28 of., Pac. 55) tinha um "Plauto comentado" e um "Comento de Salustio de Tito Livio". Finalmente, quanto a esta regularidade na circulação dos autores clássicos, especialmente latinos, na composição das bibliotecas coloniais brasileiras, que o século X'IX corteja e perpetua, temos um "Longinus. De sublime in $8{ }^{\prime \prime}$ no inventário do padre João Soares de Araujo, de Mariana, 1821 (CSM, 1. Of.; 107/2190). 
O leitor oitocentista no Brasil, no particular de Letras e Filosofia, alèm de manter a tendência do estudo dos clássicos, incorpora novos autores, alguns do próprio sēcu10 e outros editados no século anterior mas com circulação assegurada apenas no período seguinte. Como frisamos anteriormente, o século XIX representa um crescimento horizontal e vertical no campo da aquisição bibliográfica e no âmbito das Letras es'se esforço se fará notar pelo acréscimo de títulos, estilos e autores antes desconhecidos nos inventários de bens setecentistas.

o surgimento de outros autores que não os clássicos latinos, sobretudo - nas bibliotecas coloniais brasileiras é uma circunstância curiosa e significativa do interesse que a própria produção literária parecia representar no universo cultural da Colônia, A prosa de ficção e a poesia correm pa- relhas com as narrativas da gesta cristã e ai costuman pontificar quinhentistas consagrados, seiscentistas do panegírico e da prosa barroca, (as mais das vezes, gongórica) e os autores do Setecentos. Assim, no inventário do Sargento-Mor João Lopes Fiúza, 1741, Bahia, jā referido, comparecem uma História insulana, do padre Antonio Cordeiro (1641-1722), reproduzindo a trajetória (cara ao espirito das novelas de cavalaria ou dos espíritos picarescos) de amores desgraçados, impressa originalmente em Amberes, of. João Meursio, 1635 e em Lisboa, 1717, e outras obras que vicejarão no interesse leitor do Setecentos brasileiro: "Fêniz da Lusitania", "Lope de Vega", a célebre novela de cavalaria, "El Gusmān de A. faracha", "Comedias", "Poesias de Paul Glza.", "Sá de Miran- 
da", "Comedias singulares de Lixa", "D. Quixote", "El sutil cordovês" e um volume de "Entremezes". D. Tomás da Encarnação Costa Lima, bispo de Olinda, inventariado em 1784 (UFPE, Div. Pesq. Hist., cópia microfilmada do Inv.), tinha um "Camoens" e um "Gabriel Pereira da Costa, 2 t.". Este ūltimo, támbēm conhecido como autor de obras de jurisprudência, é o . autor do poema épico em 10 cantos. Ulisséia ou Lisboa edificada, cuja primeira edição é de 1636 e é título muito conhecido no Brasil Setecentista. Composto em oitava rima, o poema toma o mítico Ulisses como o heröi e epônimo da cidade de Lisboa, cantada pelo autor, num esforço de abertura quinhentista a exemplo da febre heróica e ética inspirada em Homero.

Os Autos sacramertales, de Calderón em 6 tomos, as $\underline{0}-$ bras do doutor Francisco de Sä de Miranda, em castelhano, a História de Carlos Doze, rei da Suécia, uma obra de Supico de Moraes (muito possivelmente a Coleção de vārios apotegmas) e a Corte na Aldeia e Noites de inverno, obra composta por Francisco Rodrigues Lobo em 16 diálogos em prosa numa linha nostālgica da idade dourada portuguêsa e publicada em 1619, estão no inventário de Manuel Dantas Barreto, 1763, da Bahia (ARQUEB, Capita1, 02/972/1441/01). As obras de Montesquieu em francês, as Obras poéticas de Gerson e as obras métricas de Duarte Ribeiro se encontram no inventário do cel. Paulo Josē Veiho Barreto, 1797, de Diamantina (Bibl. Ant. Torres, 19 Of:, Cx. 63). A novela de cavalaria do ciclo carolíngeo, aqui indicada como "2 livros Carlos Magno", seguida de umas "Comedias", "Poesia de Antonio' de Sousa de Macedo" e "Costa Leite Poesia" fazẹ parte do inventário de bens de Francisco 
da Cruz, de Sabará, 1745 (Museu do Ouro, 2॰ Of., Pac. 17). E "Muraena destemida" encontra-se no inventārio do Dr. João Batista Lopes, 1770, também de Sabará (Museu do Ouro, 2\% Of., Pac. 21)

Alguns títulós e autores são mesmo surpreendentes nessa relação de obras literárias nas bibliotecas setecentistas brasileiras. Assim é o caso das "Puezias de Salazar", provavelmente um volume do poeta e dramaturgo espanhol Agustín Salazar y Torrés (1624-1675) que aparece no inventário do padre Bernardo Martins Meira, 1799, de São João dèl Rey (Arq. Hist. Maço B-3). Surpresa tambēm será o aparecimento de um "Exame de ingenios, 2 t." no inventário de Antonio Fortes de Bustamente Sá e Leme, 1773, São Paulo (APSP, Ordem 632), que não será abṣurdo supor tratar-se da obra básica do barroquismo Arte de ingenio - Tratado de la agudeza, em que se exexplican todos $10 s$ modos $y$ diferencias de conceptos, do jesuíta: espanhoi Baltazar Graciān y Morales (1601-1658), publicada em Lisboa, 1659, com a importância de tornar polêmicas algumas considerações teóricas sobre a prática do verso. Um "Livro Florinda" consta do inventário de Antônio Coelho Cerqueira, de 1737, em São Paulo (APSP; Ordem 634) e talvez seja o curioso título defendido pelo interlocutor de Nuno Marqués Pereira, que o refere no prólogo do Compêndio narrativo do Pexegrino da América, ironizado-o como exemplo de obra "que ensina a falar para pecar". Ao lado das Novelas exemplares, de Cervantes e de um "Livro de Novelas de Geraldo Escobar", um curiosíssimo "Gostos para todos". ilustra a ordem de surpresas desses inventários, como o que descrevemos com Manuel do Prado Siqueira, 1749, de São Paulo (APSP, Ordem 702). 
São muitas as relações de livros, pois, que circularam no Brasil Colônia no campo da Literatura, da Linguística e da Filosofia. A base moral que orientou a formação das bibliotecas brasileiras não impediu, apesar disso, a concentração de obras imprescindiveis na formação do pensamento político e cultural - alguns até contribuindo na constituição intelectual de revolucionärios, como os livros dos Alfaiates ou dos conspiradores de Minas, ou os de Pernambuco no século XỊX: No campo da ficção moral, por exemplo, em que pontificam os jâ conhecidos Peregrino da América, Predestinado peregrino, Mística cidade de Deus, Aventuras de Telêmaco, História de Gil Blas de Santillana e ofFeliz independente do mundo e da fortuna, todos impregnados da doutrina da peregrinação como signo da ascese cristã, além de uma Reflexões sobre a vaidade dos homens, de Matias Aires, também proporcionam a oportunidade da leitura as Meditações,a Nova floresta, Luz e calor e Armas da castidade, de um Bernardes; a História do futuro e a Arte de furtar, de um Vieira. Outras obras de Bernardes e Vieira, de Bossuet e de S. Juan de la Cruz, de Santa Tereza e de outros certamente elevam a questão da literatura moral para além de seu imediato jogo de interesse: a persuasão para o final trágico do Homem fora de um Deus cristão, Todopoderoso e vigilante. Transfere, muitas vezes, a questão da órbita puramente moral e doutrinária para a avaliação estética, uma vez que muitos deles são textos literários de primeira qualidade. Em Vieira, por exemplo, impressiona a sintaxe. Em Bernardes, impressiona o simbolismo imanente, a força de organização do discurso. 
Ambos, Vicira e Bernardes, verberam em água límpida das instituições oratórias de um Quintiliano, ou de um Cicero, bebem na magia do verso de um Virgílio, ovỉdio ou Horäcio, fazem uso da beleza do idioma para impressionar seus leitores-ouvintes, mas se notabilizam pela extraordinäria concentração e pela variada gama de vocábulos de que se servem. Em certo sentido, esquecemo-nos do compromisso do conteúdo e fixamonos na beleza da forma, na riqueza de símbolos e imagens, na força da argumentação persuasiva, na sintaxe e no lëxico e isso, é claro, tem tudo a ver com à natureza de evolução da linguagem literária objeto de nosso trabalho.

. Quanto aos títulos de seletas, bibliotecas ou antologias, que trazem amiūde uma forma concentrada do ler vários autores num único volume, por exemplo, è sintomática a popularidade desses estilos acadêmicos, que a nècessidade de erudição, associada ao saber, divulgou no seio da sociedade colonial. Bibliotecas latinas, seletas em Português e em Latim, documentos das Academias (Academia da Estátua Equestre, Academia dos Singulares, Academia universal, Academia dos Humildes e Ignorantes etc.) a natureza enciclopédica de livros como a Recriação filosófica do padre Teodoro de Almeida e o Divertimento erudito, do padre João Pacheco, as Conversações familiares sobre a eloquencia do pülpito, do padre Antonio Pereira de Figueiredo, o próprio Verdadeiro método de estudar, de Verney, todos esses livros, sem dúvida, desenvolveram un caráter de irradiação cultural, trazendo ao 1eitor, de forma indireta, juízos críticos sobre obras e autores que o leitor deveria levar em consideração e formar sua 
própria maneira de julgar e formar sua própria estante. Em outras palavras, seletas, antologias e mesmo peças individuais refletindo aspectos da Literatura em vārias obras e autores contribuíram para o redimensionamento da leitura, apresentando novos autores, novas formas de ler e compreender.

No caso de Dicionārios, Gramáticas, Rudimentas, Cartapācios etc., julgamos de fundamental importância sua presença no universo leitor brasileiro, desempenhando, em certa medida - e pela raiz lógica da argumentação com que muitos deles penetraram no conceito do público leitor - aquele papel que os livros de Medicina desempenharam: servir de manual de orientação para curar males contraídos pelo corpo.

As obras de linguagem purgaram dúvidas do córpo cultural. Muitos foram os dicionários, gramäticas e cartapácios circulares no Brasil e não apenas no estrito interesse do idioma português. Hã inúmeras gramāticas do Francês, do Italiano, do Espanhol. Bluteau, por exemplo, aparece con seu Dicionário em todos os pontos de formação de bibliotecas no Brasil. A Gramātica francesa e a Gramática italiana, de Lima estão em Pernambuço, por exemplo, no inventário já descrito do 'bispo'D. Tomás da Encarnação Costa Lima, onde registramos tạbém livros circulares como o bicionärio latino e francês e francês e latino. Do mestre francès consta do inventário também descrito do baiano Luiz Tavares dos Santos, de Cachoeira, 1799. Um pouco frequente Método gramatical em português, ao lado de um Cartapácio de Rudimenta e um "Mapa de Gramätica" aparecem 
no inventário do também baiano João Lopes Fiúza, em 1741. - Manuais de sintaxe por Antonio Rodrigues Dantas, gramāticas latinas explicadas por Madureira Feijó e Antônio Pereira, Vocabulários nos idiomas mais conhecidos e até uma "Arte de cartas missivas", que aparece no inventário do padre Josē Rodrigues da Cruz, 1780; em São João Del Rey (Arq. Hist., Maço B-3), ë imensa mesmo a contribuị̧ão desse ramo da Linguística descritiva no Brasil e é impressionante o nümero de publicações no gênero circulando nas bibliotecas inventariadas. 


\section{4. - OS LIVROS DAS ORDENS E OS LIVROS QUE O MARQUES QUIS VER}

Contra la tesis romäntica, aün en boga, es necesario insistir que ni el auctor ni la obra. son los objetivos finales de los Inquisidores, sino el lector, cuya hermenëutica depende enteramente de la época. (*)

Fonte inestimāvel para o conhecimento do perfil de 1eituras no Brasil Colônia são as bibliotecas das ordens religiosas. A predominância óbvia dos títulos de natureza doutrinária, mística, ascétíca, dogmática, não impede, muitas vezes, a circulação de outros pertencentes às Letras Clássicas, à História e ao Direito, por exemplo. Os títulos religiosos se repetem com frequência em uma ou outra livraria, de sorte que é possível interpretar a constịtuição de uma bibliografia geral e comum a todas as ordens. As maiores dessas bibliotecas - Beneditinos, no Rio e na Bahia; Franciscanos em São Paulo; Jesuitas, no Rio de Janeiro - representam o maior repositório de títulos, autores e matérias dos livros antigos. Algumas curiosidades ensejam uma avalịação mais acurada do fenômeno das livrarias religiosas, mesmo nas pequenas bibliotecas, seja pela raridade de alguns volumes, seja pelas circunstâncias em que foram constituídas,. seja pelo grau de permanên-

MARQuÉ, Antonio. "Libros prohibidos en e1" siglo XVI". In: "ArborCiencia, pensamiento y cultura". Madrid, 1985, p. 99. 
cia histórica de seus acervos. A maior dessas curiosidades é, sem dúvida, a organização catalogräfica da biblioteca do Mosteiro de São Bento, no Rio de Janeiro, feita pelo D. Abade Fr. Gaspar da Madre de Deus, entre 1763 e 1766, por exigência do Marquês de Pombal e enviada a Lisboa. Cópia do manuscrito original, tambëm manuscrita, encontra-se no Arquivo do Mosteiro carioca e nos serviu para a amostragem das tendências de leitura à época, entre os beneditinos.

Alguns títulos que escapam da massa devocionária desses livros, são interessantes de pôr em relevo. O Museu de Arte Sacra, de Salvador, que reúne parte do acervo oriundo do, Arcebispado, tem, por exemplo, um.curioso Satyrae equitis Domini, de Francisco Botelho de Moraes e Vasconcelos (16701747), publicado em. Salamanca, of. Nicolau José Villargordo, 1.740. O autor è um poeta e satírico português que viveu na Espanha e escreveu em castelhano. Os carmelitas de Santos (SP), num inventário que encontramos no Carmo de Belo Horizonte (MG), registram, em seu acervo bibliográfico, uma Philosophia baconica, em 2 tomos, folio, uma Arte da Música, in $4^{\circ}$ e um "Marcial velho". Os franciscanos de Salvador e da vila de Itanhaêm, em São Paulo, têm suas bibliotecas orientadas apenas por títulos de doutrina e de moral, ressaltando-se as obras de quase todos os Doutores da Igreja no acervo do Convento de S. Francisco, na Bahia. Os capuchinhos, tambè̉m da Bahia, têm três obras monumentais de Santo Tomás de Aquino, em edições dos séculos XVI e XVII. Uma Praedicatorum e narrationes, editada em Antuerpia, of. Christophorum Platinum, 1578, uma Quaestiones disputatae, editada em Lugdu- 
ni, 1557 e uma Summa Theologicae, de Lugduni, Joannis Girim, 1663, em 3 volumes. O Convento do Carmo, de Salvador, tem um Conceptos del amor de Dios, da Madre Teresa de. Jesus, editado em Bruxelas, Roger Velpin Y Huberto Antonin, 1612 obra singular da literatura mística sobre os Cantares de Sa1omão. O Carmo baiano também dispõe de um Lexicon manvale hebraicum et chaldaicum, de Johanes Simonis, editado em Halae Magdeburgicae, 1771, com 1100 páginas, E, com surpresa, encontramos no acervo dos carmelitas baịanos, uma edição da $\underline{L}$ 'Eneide, de Virgílio Mantuano, publicada em Venetia, of. Batista Sessa \& Fratelli, 1576, com um comentário em italiano por Giovanni Fabrini da Fighine.

Outras bibliotecas confirmam, em número e variedade, o interesse pela leitura demonstrado pelas ordens religiosas no Brasil. Na Residência Episcopal de Mariana, em Minas Gerais, hã uma grande riqueza bibliográfica do sêculo XVIII. A ordem de preferência que se observa na estante marianense è a da predominância doutrināria e da filosofia moral, abrindo espaços para outras āreas do conhecimento como expressam um Cannochiale aristotelico, de Don Martin Thesauro, editado em Madrid, Antonio Marin, 1741, ou Satirae de Juvenalis e Persii Flacci, edição de Paris, J. Barbou, 1771. Os lazaristas do Colégio do Caraça, no município mineiro de Santa Bărbara, também dispõem de uma arrojada livraria, salva em parte do acervo maior de 30 mil volumes, parcialmente destruidos por um incêndio em 1968. Dentre os $14 \mathrm{mil}$ volumes que se salvaram, muitos têm importância, para a própria história do livro no Brasil, como uma Vida y hechos del ingenioso ca- 
vallero Don Quixote de 1a Mancha, de Miguel de Cervantes Saavadra (1547-1616), publicado na Antuerpia, Of. Henrico'y Cornelio Verdussen, 1697, em 2 volumes. Além do Quixote, a biblioteca do Caraça tem uma Arte de gramática da língua brasílica, do padre Luís Figueira (1573-1643), publicada em Lisboa, Of. Miguel Deslandes, 1687, uma edição"prínceps"da Vida do veneráve1 padre José de Anchieta, do padre Simão de Vasconcelos (1597-1671), de Lịsboa, Of. João da Costa, 1672 e uma Scripta, de Sêneca, editada em Paris, of. Michaelem Sonnium, 1599. Edições quinhentistas de Platão, Aristóteles, Ptolomeu, Plutarco, P1ínio Segundo e Santo Tomás de Aquino representam, com segurança, o predominio e bom gosto de títulos bem diversos e da variedade que ilustram o apuro de leitores entre os religiosos no Brasil. De Aristóteles, aliás, dois volumes enriquecem mais ainda o acervo dos lazaristas do Caraça. Um Dialectica Aristotelis, edição de Lião, Sebastião Gryphe, 1547 e um Rettorica et poetica. Tradotte di greco in lingua vulgare fiorentina da Bernardo Segni, de Florença, Lorenzo Torrentino, 1549. Por fim, destaque-se que a biblioteca do Caraça dispõe, ainda, de um incunábulo, de 1489, da Historia Naturale. Tradocta di lingua latina in fiorentina per Christophoro Landino, editado em Veneza, Of. Bartolamio di Zani de Portesio.

Outra rica biblioteca ê. a do Colégio Cristo Rei, dos jesuítas em São Leopoldo, RS. E também uma estante de tîtulos expressivos, particularmente em Letras, edições dos séculos XVII e XVIII. Destacam-se alguns desses títulos, como Le Rime de Petrarca, em 2, volumes, editado em 1768, II 
malmantile racquistato, La Gerusalemme liberata e Aminta, de Torquato Tasso, editados em 1768, Le Commedie, de Goldoni, editado em 1756-1758, em 13 volumes e La Divina commedia, de Dante, editada em 1768, em 2 volumes. Autores como Alessandro Tassoni, La Fontaine, Milton, Goëthe, Schlegel, Klopstock, Montesquieu, Fichte, Kant e outros, inclusive clássicoś como Terêncio e Horácio, concorrem com os autores eclesiásticos caros ao espirito doutrinário das ordens religiosas.

A biblioteca da Faculdade de Direito da Universidade de São Paulo, no Largo de São Francisco, é herdeira de uma tradição leitora extraordinária, que è a dos franciscanos em São Paulo. Forma hoje um espólio gràndioso de títulos sobretudo dos estudos jurídicos, passando por Religião, História, Geografia, Educação, Literatura, Linguística etc. Tem nomes como os de Rousseau, Condorcet, Fénelon, Volney; Buffen, Sterne, Milton e Pope, Shakespeare e Erasmo, alẻm dos indispensäveis clássicos.

Mas as estantes que despertam nosso maior interesse no capitulo presente pertencem aos jesuitas e aos beneditinos, especialmente, no Rio de Janeiro. A dos jesuitas apresenta perto de 1 mil títulos diferentes, com mais de 4 mil e 500 volumes. São peças da avaliação e sequestro dos bens dos militantes da Companhia de Jesus, no Rio, ato feito em 1775 . A maior parte do acervo, claro, está na linha dos assuntos teológicos, doutrinārios, dogmāticos, místicos e ascéticos. Alguns títulos escapam a essa predominância e são os seguintes: 
Noticias de Portugal de Severim

Divertimento Erudito dous jogos de dous tomos

Kirquere de Matematica.

Suplemento Cronicorum

Historia Peruanna

Sentido Metaforico de Montoy

Davilla Guerras de Franca

Poncio de Filosofia

Arte de Reinar

Virgilios Minelios

Camoens sem capa

Maranham e Armazonas.

Jorge Castrioto

Cronica de Serra de Ossa

Imperador Carlos quinto dous tomos

Portugal restaurado

Academia Literaria

Arte Militar

Cornelio Tacito Opera

Seneca Opera

Virgilios de Lacerda

Oratio Opera

Valerio Maximo

Plinio Historia Natural

Aritstot. Opera

Platone Opera.

Bloteau

Chronica de Cister

Castrioto Luzitano

Geografia Hist.

Historia In Solana

Faustos Lusitanos

Teatro da Caza de Souza

Academia Literaria.

Comento de Horatio

- Novelas de Servantes

Exame de bombeiras 
Orinoco llustrado

Viagem do Mundo de Discartes

Cornelio Tacito

Onomatografia

Parnazo Poetico

Suetonio Comentado

Logica de Aristoteles

Navegação Explecativa

Palacio de Eloquencia

Luziadas de Camoens

Sanação poemat

Suetoneos de Almeida.

Fior da Latinidade

Fizica de Aristo

Retorica de Soares

Poema do Pastor Fido

Nova Arte de Conseitos

Quintiliani

Marcial Epigramas

Tito Livio

Cicero de offici is

Horatio Poem

Terencio

Salusticis

Ovidio Metam.

Livros de Gramatica de varios Autores

Alguns desses 1 ivros constituem surpresa, em nossa investigação, pela raridade de sua aparição èm outras bibliotecas. E o caso de uma "Academia Literaria", de um "Valerio Maximo", de um "Castrioto Luzitano", de uma "Navegação Explecativa" e, especialmente, de uma "Viagem do Mundo de Discartes" e de um "Poema do Pastor Fido". Em muitos inventários de bens e nas outras fontes de que dispomos em nossa inves- 
tigação, não registramos a circulação de um Descartes ou de um Guarini. Outra curiosidade desses autos de avaliação e confisco dos livros dos jesuitas è o registro, em separado, dos chamados "Livros prohibidos que se achavão entre os mais". Eles vêm sem atribuição de valor pecuniắrio e claramente expressam a antinomia reinol contra os malfadados docentes da Companhia de Jesus. Os títulos pertencem a autores jesuítas ou são seus recomendados, o que basta para a censura.e 0 interdito. Entre esses "Proibidos" figuram um "Brazilia Ponteficia", um "Historia da Companhia", um "Biblioteca dos Escritores da Companhia" e um surpreendente "Gongora". Os mais são da prática teológica e eclesiástica da Companhia de Jesus, de que não escapam, inclusive, uns "Exercicios de Santo Inacio oito tomos". Ao todo, 64 títulos, 118 volumes in $8^{\circ}$ "de varios Autores e materias constetuiçoens, regras letras e outras materias todos pertencentes a Companhia". 231

Mas o documento original de mais vivo interesse no plano desta nossa investigação é o catálogo da Bibḷioteca do Mosteiro de São Bento do Rio de Janeiro, preparado por Fr. Gaspar da Madre de Deus, que consultamos em cópia manuscrita fiel do que foi enviado a Lisboa, para censura, por ordem do Marquês de Pombal. Os livros que o Marquês quis ver são, em maioria óbvia, ligados ao espírito monāstico, alguns raros com a tarja de "Proibido" anotada no próprio documento; como as obras de Francisco Salgado de Somoza, "De regia protectione" e "De suplicatione".Praticamente não hâ nenhum dos interditados, por exemp1o, na relação dos "separa- 
dos" da biblioteca dos jesuítas. Outros, sim, como o segregado Manuel Alvares, SJ., da Arte latina estão no Index pombalino. Entre os títulos dissociados da estrita dominação doutrināria e eclesiástica, destacam-se:

Academia dos Singulares de Lisboa

Arte da gramatica por um author benedictino

Additamenta ad logicam conimbricensem data á

R.P. Josepho à Costa

Arte latina

Baya centro Dragma para a Música para se representar no Theatro em Lisboa

Ambrosios Calepinus. Septem linguarum

André Puig. Arithmetica especulativa, e arte de Algebra

Andres Ferres, de Valdecebro. Governo geral moral, e politico das feras, animais silvestres, e das aves mais generosas, e nobres, com particular taboa para sermoens

Antonio da Cruz. Recopillação da Cirurgia

Antonio de Naiera. Navegação especulativa, e pratica comercial, a outras curiosidades

Antonio Gonsalves. Recopilação da cirurgia de Cruz acrescentada

Antonio Henriques Gomes. Academias moras de - las musas

Antonius de Souza de Macedo. Luzitania liberata

Antonius Mayr, S.J. Philosophia peripatetica

Augustinus Barboza. Dictionarium luzitanico-

lattinum

Augustinus... Dictionarium historicum, criticum, chronologicum

Balthazar Telles, S.J. Summa philosophia

Baya cento Dragma para a Musica para se representar no Theatro em Lisboa 
Bartholomeu Rodrigues Chorro. Curiosas advertencias da boa gramatica

Basilis Varen de Soto. Addiçoens a Historia das guerras civis de França de Eurico Catarino Davilla

Benedictus Pereyra, S.J. Prosodia in vocabularium bilingue

Bernardo de Brito. Chronica de Cister

Bernardo Pereira de Berredo. Annaes historicos do Estado do Maranhão

Francisco de Quevedo Villegas. Obras varias em proza, e verso

\section{:----, obras em proza}

Gabriel Pereira Angulo. Direção de secretarios de senhores, manejo de papeis de ministros, formularios de cartas com respostas, oficios de contador, e outras curiosidades

Jacob de Castro Sarmento. Theorica verdadeyra das marez conforme a philosophia do incomparavel cavalleyro Isaac Newton

João Bautista Bonavie. Descripção da terra com estampas

João Dias Remigio. Arte poetica española com hũa ... sylva $\varepsilon$ c.

João Eusebio Nieremberg, S.J. Obras philosophicas, ethicas, politicas y physicas

Luis Caetano de Lima. Orthographia da lingua portugueza

Luis de Camoens. Rimas varias $\varepsilon$ sonetos

-...... Cançoens, ... e sextilhas

Elegias, e.......

-...-. Eclogas em 2 Partes

-...-... Luziadas

Lourenço de S. Nicolau. Arte, e uzo da Architectura

Sebastião da Rochá Pitta. Historia da America portugueza 
São tîtulos mais ou menos comuns aos encontrados nas outras livrarias brasileiras do século XVIII. Alguns, naturalmente, se destacam pelo inusitado e pela raridade, como um "Drama para se representar no Teatro de Lisboa", ou, um chamado Governo geral, moral e politico das feras, animais $\underline{\text { silvestres }} \underline{\text { e das }}$ aves mais generosas e nobres, com particular täbua para sermōes, de Andres Ferres de Valdecebro. 0bras de Medicina è Cirurgia, de Navegação, de Matemātica, Poesia morạl, Filosofia aristotêlica, Dicionārios, Gramāticas, História è Geografia representam parte do patrimônio bibliográfico que enriquece, ainda hoje, a bibiioteca do Mosteiro de São Bento, no Rio. Duas obras de Quevedo, o Francisco de Quevedo Villegas, pai do conceptismo barroco hispânico, são o melhor testemunho do interesse monāstico por peças literárias: Obras varias em prosa e verso e obras em prosa. Não hā como desprezar o interesse histó̀rico e documental do catálogo preparado por Gaspar da Madre de Deus e não há como desprezá-1o também quanto ao prôprio valor demonstrado pelas obras que compõem o mesmo catálogo. Os livros exprimem häbitos e comportamentos e, entre os monges, cresce em importância, a leitura de uma Arte poética española, de João Dias Remígio, por exemplo, e das Canções, de umas "Elegias", "Eclogas em 2 partes" e das Rimas varias \& sonetos, de Luis de Camões, poeta fundador do léxico português, o renascentista do entusiasmo humano pelas façanhas do Homem e pelo saber dos antigos, associados ao conhecimento, que liberta e faz evoluir.

As leituras nas ordens religiosas brasileiras nom scm- 
pre sufocavam o estímulo ao exercício do pensar. Bacon, por exemplo, era protestante, reconhecia o papel educador dos jesuitas e, no entanto, estava entre os livros do Convento do Carmo de Santos (SP), como vimos. 0 mesmo Bacon entre os filósofos de obras defesas estigmatizados pela politica de Portugal. Não só Bacon, como ainda Hobbes, Huyghens Leibniz, Newton, Descartes e Galileu, cujas idéias ou descobertas eram objeto de duro combate no âmbito da cultura eclesiástica e secular. A tradição de muita leitura doutrināria tinha a possibilidade de transformar o Brasil mais beato do que culto. As aberturas representadas, nas estantes religiosas, - Newton, adaptado pór Jacob de Castro Sarmento na biblioteca beneditina e Descartes, como vimos, na jesuita - por obras de filósofos cujas idéias pudessen ampliar o universo mental e psicológico, claro que constitui fato extremamente significativo de mudança e de lógica na atitude eclesiástica: Próibição de livros nem sempre foi vitoriosa, inclusive no Brasil. Dois livros proibidos, a Mistica cidade de Deus, de Soror Maria de Ágreda e História de Gil Blas de Santillana, tiveram ampla circulação e foram dois best-sellers coloniais aqui. O Voltaire, o Rousseau, o Hobbes, o Spinoza que o marquês de Pombal condenara à fogueira, em 1770, bem poderiam, sutilmente, circular no Brasil, entre títulos insuspeitos de leitura devocionária.

Por ủltimo, alguns dos autores proibidos de circular, interditos pela censura secular pombalina, com reflexos óbvios até meados do século XIX, justificaram uma peça singular, que encontramos no v. 35 dos "Autos do Cartório de $1^{\text {9 }}$ 
Ofício de Santos", organizados pelo Dr. Costa e Silva Sobrinho. E um "Auto da Devaça geral do presente anno dé 1805 q. mandou fazer o Juiz vereador o Ten. Luis Antonio da Fonseca Guimaräes na forma da ordenação respectiva", com o seguinte teor:

Item se älguma pessoa de qualquer qualidade ou priminencia que seja, detem, comonica, destribue, ou por outro titulo ou modo espalha debaixo de qualquer protesto que seja os livros reprovados cujos autores são os seguintes = Adão Taneiro, Alonço Rodrigues, Amadis Gimenio, Matheos Maya, Antonio Dianna, Carlos Renelato Baluarte, Claudio Laero, Estevão Fagundes, Francisco Soares Luzitano, Gabriel Vasques, João Marem, João Martins do Prado, Leandro do Santiçimo Sacramento, Leandro Lução. Mathias da Maya, Thomas Furtado, Thomas Zantoērio e todos os livros e papeis dos jacobeos ou defença da sua infame pratica todos os livros que se seguem e defendem os custumes dos Armeiros de que se trata na instrução ao oficio de Provedor da coroa; todos os mais que se seguem e defendem as propoziçoens de Direito e vinte huma dos iluminados proibidos todos na sentença da Real Meza Sençoria de 24 de janeiro de 1769 por que se deve perguntar nesta devaça na forma determinada da mesma sentença e para selebrar a verdade e serem castigados os que se provarem.delinquentes nos crimes contidos nos itens desta devassa.

Boa parte desses autores citados são jesuitas. Outra parte, não citada, de autores defesos, será constituida de "jacobeos", ou "iluminados". A noção reinol de ataque fron- 
tàl ao enciclopedismo e à Ilustração francesa produziu efeitos na constituição das bibliotecas. Mas não deve ter sido tão cumprida à risca, uma vez que, em 1805, o vigilante Juiz vereador mandava vigiar e punir provấveis recalcitrantes. A censura tinha, tambëm, pernas curtas... 


\section{UMA LEITURA REVOLUCIONARIA}

\section{BENS E VARIA FORTUNA}

DO PADRE MANUEL RODRIGUES, INCONFI DENTE

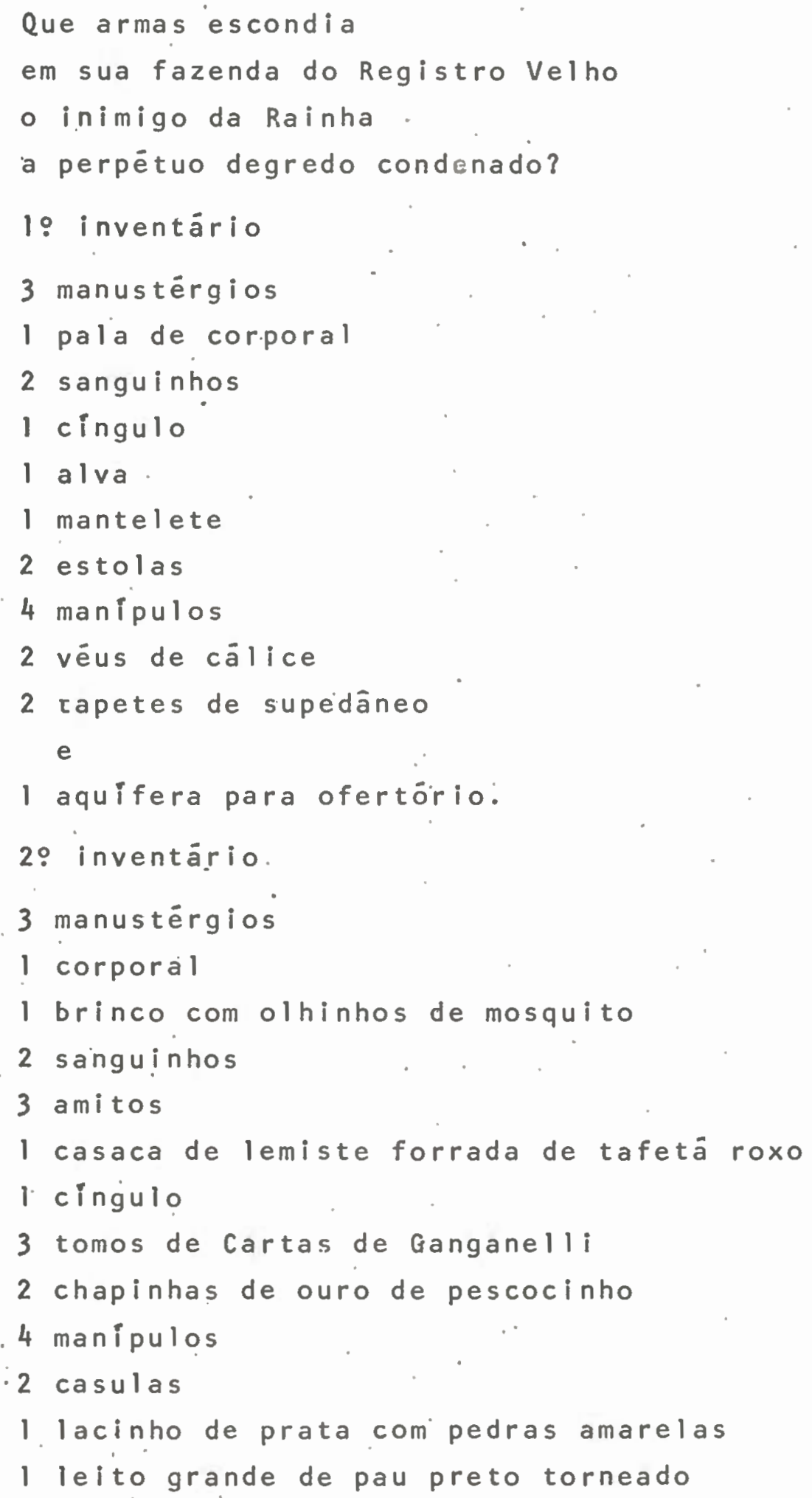


1 mantelete

l bacia grande que terá de peso meia árroba

1 dita pequena de urinar

I tomo de Obras Poēticas de Garção

1 aquífera para ofertörio

2 tapetes de supedâneo

1 jaleco de cetim de flores

1 pápa de pelo branco dé lã

2 prequiceiros cobertos de couro

1 tomo de Instruções para cultura de amoreiras

4 camisas de bretanha

1 calção de veludo preto

I chorão com seu jaleco de ganga

1 tomo da Recreação Fi losōfica

1 dito da Arte de Navegar

l loba de gala

4. palas

1 alva.

I negro por nome Caetano de nação ángola

3 breviários

1 óculo de papelão de ver ao longe

- que tudo importa

em degredo por toda a vida na llha do Príncipe aliàs comutado pela clemência do Príncipe Nosso Senhor*

E possível entrever relações de afinidade entre as obras lidas e as ações revolucionārias de conspiradores ou inconfidentes, mas não se pode dar um peso excedente a essa atribui* ANDRADE, Carlos Drumond de." A Falta que ama. In:
Rio de Janeiro, Editora Nova Aguiliar, 1983. (p.414-415) 
ção. Não se póde dizer que, sob a capa de todo revolucionário encontra-se um leitor comprometido com projeto ideológico diretamente absorvido das leituras. A enígrafe acima, o poema de Drummond sobre o primeiro inventậrio do inconfidente padre Manue1 Rodrigues, não expressa a vocação ou destino do inventariado para qualquer ação conspiratória. Que livros lia o padre? as Cartas de Gangane11i, as Obras poéticas, 1 tomo de Instruções para a cultura das amoreiras, uma Recreação Filosófica do oratoriano Teodoro de Almeida, uma Arte de navegar, de Manuel pimentel e mais 3 . Breviários do uso próprio ao ofício do reverendo. Rigorosamente, nenhuma obra interdita pela censura inquisitorial ou secular, nenhuma sutileza ou entrélinha de incentivo à subversăo e à violência anti-governo. Por isso mesmo a interrogação maliciosa de Drummond na abertura do poema: "Que armas escondia/em sua fazenda" de Registro Ve1ho/o inimigo da Rainha/a perpétuo degredo condenado?" Alinhados os bens do padre e seus livros sem qualquer laivo ou ranço que estimulasse conspiração, inconfidência ou alta traição aos propósitos do Reino de Portugal, o poeta conclui pela injustiça reinol contra um homem simples, um pobre fazendeiro e ministro da religião católịca em Minas Gerais, e insinuando pela. linguagem própria dos escrivães na nota de avaliação dos bens descritos: "o que tudo importa/em degredo por toda a vida na Ilha do Príncipe/aliás comutado pela clemência do Príncipe Nosno Senhor."

A ambiguidade inscrita no verbo "importa" dá o tom de perplexidade, valor atributivo, juízo de valor aplicados à ação revolucionária no caso dos nossos lẹtores inventariados, 
comprometidos ou não com uma leitura que estimule a reflexão e - arrojo na prática de mudança social e política. Importa relacionar diretamente os livros a projetos ou mentores de movimentos libertadores? Se assim for, não parece indicativo da liderança em grupo de conspiradores apenas um Missal, que aparece entre os bens da familia de Tiradentes, precisamente no inventário de Antonia da Encarnação Xavier, tendo como inventariante o marido Domingos da Silva dos Santos, pais de Joaquim José da Silva Xavier, $3^{9}$ filho do casal da Fazenda Pombal, em São João Del Rey, 1756. ${ }^{232}$ Também não parece uma indicação direta de motivos conspiratórios os 4 Missais romanos e a Sacra de Evange1ho, encontrados numa relação de prata e ornamentos - pertencentes ao saque feito aos insurgentes nos povos do lado ocidental do rio Uruguay, no ano de 1817 , e que, nas palavras do capitão Alexandre José de Campos, em 13 de agosto de 1817, "por ordem do marechal comandante da provincia de Missões conduzi à villa de Porto Alegre". Os dois livros foram encontrados, respectivamente, no Povo de Jupeju e nos Povos de Santa Maria e São Xavier. Nenhum outro livro registrou-se nos Povos de Cruz, S. Thomé, S. Borja, Nossa Senhora da Conceiçāo, São Carlos, Santos Mártires, Apóstolos e São José. 233

- Embora não tenhamos uma explícita demonstração de compromisso entre a memória letrada brasileira e sua correlação com mecanismos e propósitos revolucionários, podemos identificar na corrente de obras de conspiradores um certo sentido, ainda que indireto, da sua prática política. Em outros termos, é possível reconhecer que os livros em mãos de pessoas envolvidas com situações de mudança.social por via revolucionária, 
na verdade, representem uma certa identidade de propósitos, pela maturaçäo de questōes encontradas nesses livros, pela reflexão provocada por essas leituras, pela curiosa e dusada atitude humana em ver, na prätica, efeitos de suas idéias e compromissos. Idéias, obviamente, bebidas em 1ivros de acurado șenso crítico da observação e dinâmica social. Talvez por isso, José Veríssimo, a despeito de não adotar qualquer rigor documenta1, afirma que "Bequimão, o cabeça dos motins de 1684 , possuía e 1ia livros de história de revoluções" 234 Não nassa por àbsurda a possibilidade. E at $\ddot{e}$ natural perceber nas ações de homens envolvidos em idéias e atitudes de mudança político-social um resultado das leituras que fez, dos livros que o encantaram, das mutaçōes ideológicas provocadas por esses livros e leituras. E até fácil rastrear influências de Rousseau, dos autores da Revolução Francesa e da Revolução Americana no trabalho pạfletārio, ideológico e prático do estóico Fr. Caneca.

Do 1 ado documental, registram-se alguns compromissos de leitura nos conspiradores da Inconfidência Mineira e da Conjuração dos Alfaiates. Em Minas, Alvarenga Peixoto tinha 18 tomos, sendo 7 obras de Metastásio e 1 Miscelânia moral do Padre Manue1 e, defesos, apenas Crẻbi11on(3) e Vo1taire(7);0 Ce1. José Resende Costa lia a Henriade, de Voltaire; o cônego Luiz Vieira dos Santos, dono da mais extensa e rica biblioteca entre os inconfidentes, tinha seus Descartes, Montesquicu, Diderot, d'Alembert, Condillac, Voltaire e Mably, entre outros, combinados com clâssicos da envergadura de Anacreonte, Demóstenes, Terêncio, Catulo, Propércio, Horäcio, Ovídio, Cíccro, Quintiliano, Sêneca; Suetōnio e poetas e dramaturgos da Idade 
Moderna, como o renascentista Tasso e os classicistas Corneille, Racine e Milton. No entanto, Cláudio Manoel da Costa, um dos nomes principais do movimento, provavelmente assassinado nas masmorras de Vila Rica, o poeta festejado do Neo-classicismo brasileiro, não tinha qualquer livro de inspiração de doutrina revolucionária. Tinha, antes, suas obras de Direito e Devoção mística ou ascética, além de destacados "Dom Francisco de Quevedo, quatro tomos", "Lourenço Graciān, Idéia da agudeza"-certamente a obra de Baltazar Graciăn, barroquista espanhol- "Caldas Pereira, um tomo", "Obras de Camões, um tomo", "Dicionário. novo da Língua espanhola e francesa, dois tomos" e "Sonho, poema erótico". 235 A nota de sequestro dos livros indica, ainda, "na quarta coluna da estante da parte direita, quarenta tomos; na quinta da mesma, quarenta e quatro tomos de livros; quarta coluna da estante da parte esquerda, quarenta e nove livros, na mesma estante da quinta coluna, quarenta e seis". E improvável, numa peça de natureza acusatória e incriminadora como um auto de Séquestro, que esses livros não-nomeados contivessem matérias de doutrina revolucionária. Claro que, se existissem, seriam os primeiros indicados justamente para indiciar o réu como leitor de obras defesas e, consequentemente, envolvido, sem apelação, .no movimento emancipacionista de 1789 .

Os outros conspiradores do esforço revolucionário mineiro, como Cláudio, não demonstram maior compromisso com obras defesas ou sujeitas a correlações de estímulo à sublevação. Ironicamente, a maior parte de seus livros são de natureza moral religiosa, destacando-se alguns no campo das Letras, como, no Auto de Sequestro do padre Carlos Correia de Toledo, uma "Gramá- 
tica Portuguesá e Inglesa", "Elementos de Poesia", "Exercício da Língua Latina", "Lógica de Verney", "Rimas de Joāo Xavier", "Arte explicada de Madureira", "Ovídio Triste" e um "Compêndio de Metamorfose de Ovídio". 236 o mesmo se aplica ao padre Manuel Rodrigues da Costa, cujos títulos, além das matérias devocionais, sāo qualificativos de um leitor assente com sua época, com uma livraria no modelo setecentista, mas sem indício direto de obras "revolucionārias" ou interditas. Além das disciplinạs afins ao ofício reỉigioso, o padre Costa tinha "Fernão Mendes Pinto", "Agulha de Marear", "Popi, oito volumes", "Geografia de Langle", "Arte de navegar", "Quintiliano Retórica", "Milton, três tomos" "Recreação Filosófica, cinco volumes", completados por títulos convencionais, sem qualquer implicação com outra doutrina que não a da moral religiosa: "Fducação de meninos, dois volumes", "Dicionärio de linguas" e "Instruções para a cultura das Amoreiras" 237 Finalmente, Domingos Fernandes da Cruz, em maio de 1789 , teve seus livros inventariados sob sequéstro e a descrição deles só indica títulos devocionais.

Dos inconfidentes mineiros, não resta a menor düvida de que a maior, e mais versada e diversificada em títulos, das bibliotecas, era a do. Cônego Luís Vieira dos Santos, estudada com propriedade por Eduardo Frieiro em $\underline{0}$ Diabo na 1ivraria do Conềgo: Além das obras de textos sagrados, teológicos e canônicos, a estante diversa do religioso marianense dispunha de "Livros de Histöria", "Livros de Jurisprudência", "Livros de Sciencia" e "Livros de Litteratura". Verifica-se alguma confusão na classificação deșses livros, anarecendo, por cxemñlo. un "Etude de la Nature" e um "Dictionnaire Geographique", en- 
tre as obras ná seçāo "Literatura". De qualquer forma, importa confirmar a opinião de Frieiro, para quem "a 1ista dos 1ivros sequestrados mostra que o seu possuidor era um: espírito altamente cultivado e receptivo, uma inteligência aberta aos mais variados aspectos do saber". ${ }^{238}$ E possivel que a incriminação do cônego se tenha dado mais pela acusação de possuir "um livrinho francês, relativo ao levante desta terra, no qual se diz que podiam os habitantes viver sobre si, sem dependênciado comércio para o nosso reino, à imitação do que fizeram os Americanos aos Ingleses", conforme avalia Taunay num artigo publicado no "Jornal do Comércio" do Rio de Janeiro em janeiro de 1943, "Boatos sobre os inconfidentes mineiros (1789)" 239 Mas - fato de registrar em sua livraria um nümero expressivo de obras consideradas defesas no entendimento do regalismo não padece düvida de que lhe trouxe mais problemas e aumenta a curiosidade histórica sobre um leitor preocunado com a natureza conjuntiva entre ação e reflexão. Se os livros fazem o homem, se a biblioteca de uma pessoa indica sua formação e seus juízos de valor, de crítica e de anälise, claro está que o cônego seria então o instruído leitor que queria ver na prática alguns efeitos de suas leituras. A livraria do cônego da Sé de. Mariana tinha seus livros abertos nas áreas do conhecimentodos estudos linguísticos, com os costumeiros dicionārios e gramáticas, boa parte deles em latim ou em Francês. Os clássicos são comuns, mas a livraria do cônego acrescenta um Manílio è um Ausônio em seu espōliọ. Os pọpulares Matastásio, Benito Feijō, Francisco José. Frcire, Vóssius tambēm se faziam represcntar. E a Ilustração francesa, 1ibelo acusatōrio das téndên- 
cias ideológicas do inconfidente, tịnha segura representação, com Raynal e Mabily à frente. Mably e Rayna1, aliās, que funcionaram como os principais autores de obras defesas, na peça acusatória que Antonio Diniz da Cruz e Silva fez a Silva Alvarenga. A Histoire philosophique et politique, de Raynal e os Direitos do cidadão, de Mably constituíram os principais móveis da condenação a Manuel Inácio da Silva Alvarenga, "porquanto lia e dava a ler essas doutrinas subversivas a seus discípulos na au1a de retórica: e poética, que mantinha no Rio de Janeiro". 240's

A partir dos documentos de sequestro dos bens dos inconfidentes mineiros em 1789 , sobretudo em termos da extraordināria biblioteca do cônego Luiz Vieira dos Santos - não tanto pelos 800 volumes e mais pela variedade dos seus 270 títulos temos o conhecimento de um espectro de leituras setencentistas comprometidas com o espírito "do Diabo", segundo Voltaire, espírito revolucionário posto em livros de uma expressa filosofia racionalista, de um circular enciclopedismo e de um contagiante naturalismo cientificista. Não serà à toa que a repressão à Inconfidência ocorre em plena regência de D. Maria I, rainha absolutizada pelo viés da doutrina moral o mais rigorosa e fechada possível. o cônego era professor de Filosofia na Sé de Mariána; Silva Alvarenga, professor de Retórica e Poética no Rio; C1áudio, mentor intelectual e. Tiradentes pedira tradução do "Levante da América Inglesa"; Domingos Vidal Barbosa sabia de cor pedaços do Raynal da Histoire philosophique êt politique; e Gonzaga, de quem se anotou "quarenta e três livros de folha de vários autores, franceses, portugueses e latinos; Item sete ditos de meia folha; da mesma qualidade; Item quaren- 
ta e três de quarto, dos mesmos". 241 E significativa a influência da cultura francesa nos movimentos emanicipacionistas brasileiros. Era-o na Inconfidência Mineira e na Conjuração dos Alfaiates, na Bahia, em 1798. A biblioteca do cônego, sobretudo, é representativa do ideário politico e libertário próprio do perfil do leitor do período da'Ilustração Setecentista. Livraria que, peio conjunto e diversidade de títulos e assuntos e pelo número de volumes, ē provavelmente a mais expressiva dentre as encontradas em nossa investigação, em fontes primārias ou secundárias, por seus títulos ros mais variados campos do conhecimento, em especial no que toca às influências de leitura comprometida com ideais libertadores na perspectiva da Revolução Francesa.

Outros envolvidos com movimentos tidos como sublevadores da ordem institucional tiveram seus livros postos em auto de sequestro, onde a nota de proporção em gravidade e culpa, sem dúvida, seriam as matérias e autores inscritos no esquivo index da anti-Ilustração portuguesa. E o caso dos membros da Sociedạde Literäria do Rio de Janeiro, acusados de 1ivres-pensadores, de divulgar idéias dos franceses e de oferecer ambíguas relações da Filosofia pura contrária à ivisão única do Estado e da Religião - tọtens intocáveis pela norma moral vigente. Os principais nomes 1igados à extinta Sociedade em 1794 foram o pocta Manue1 Inäcio Silva Alvarenga, o médico Jacinto José da Silva e o bachare1 e autor de máximas e adágios Mariano José Percira da Fonseca, o Marquês de Maricã. A biblioteca de Silva Alvarenga era rica sobretudo em obras 1 iterárias, concorrendo $\mathrm{cm}$ importância uma Ópera, de Ludovico Aristo, La Jeruzalcm Libcrata, 
de Tasso, as Oeuvres morales, de La Rochefoucauld, Romans et contes par Mr. Voltaire, obras de. Terêncio, Scarron, Verney, Bluteau, Guarini, Cícero, Quintiliano, um curioso D. Quixote em francês, a bora proibida e no entanto popularíssima no Brasi.1 - História de Gil Blas de Santillane, de Alain Le Sage. E Marmonte1, Corneille, livros de Direito, uma rara Enciclopédia poẻtica, os Diālogos, de Platāo, poetas, prosadores e Filósofos, em especial os franceses. Reincidente em movimentos subversivos, Silva Alvarenga tem remexidas suas estantes, em busca de títulos que pusessem em suspeição sua atividade de professor, mentor intelectual da juventude no Rio de Janeiro. Logo, autores como Mably e Raynal, Voltaire e Rousseau, presentes em sua biblioteca, o denunciavam, no entendimento dos ministros e desembargadores a mando do Reino de Portugal, como decidido seguidor das idéias contrárià à ordem püblica defendida pela Corte Portuguesa e seus prepostos no Brasil.

Curiosa circunstância envolveu o médico Jacinto José da Silva no movimento da Sociedade Literäria do Rio de Janeiro:as ácidas críticas, por meio de trovas populares, dirigidas aos frades franciscanos, especialmente contra um padre mestre Fr. Raymundo e contra um Fr. Inácio, do convento de Santo Antonio.' Misto de crítico ao Estado e à representação eclesiástica, o Dr. Jacinto José da Silva foi preso em 3 de janeiro de 1795 , sendo Desembargador e Ouvidor Geral do Crime Francisco Álvares de Andrade e Governador da Fortaleza da Conccição, ( para onde foi recolhido o réu), Francisco dos Santos Xavier. Entre os papéis do médico., encontram-sc vãrios sonetos e décimas, peças satíricas, correspondência ativa e passiva, com destaque pirri'lluma 
cópia de carta escrita a Manoel José Curvo Semedo sobre a "pouça sahida que tem. tido huma frasqueira de remédiosque havia remetido", um "rol de livros que possue", documentos como "Hum escrito de Catarina de Tal com algumas galantarias que mostra ser amatorio" e muitos escritos médicos, da autoria do próprio Dr. Jacinto José da Silva, a saber:

Hum caderno pequeno de 4: e hum discurso sobre haver umas epidemias ou da origem porque apelidão algumas molestias por isso

Uma cōpia no borrão de hum discurso sobre o mau achạdo de curativos dos médicos e cirurgioens desta cidade pelo frequente uzo de agua de Inglaterra e quina em toda qualidade de infermidade

Hum discurso medico sobre huma enfermidade de vida sedentaria

Ainda entre os papéis recolhidos do Dr. Jacinto José da Silva, encontram-se "Hum caderninho de oitavo de sonetos e versos feitos pelo Alvarenga na sua poezia", sonetos laudatórios ao Marquês de Lavradio, sảtiras a José de Souza Meireles e ao padre Fr. Inācio "por hum seu grande amigo Diabo" e, aqui com maior peso para a condenação de Jacinto Josë da Silva,"Hum caderninho de quarto com várias desimas em que se satiriza algumas providências dadas no atual governo do Ilustríssimo e excellentissimo senhor Conde Vise Rey". Jacinto José da Silya ( -1827) era formado pela escola de Montpelier, em 1778,clinicou, viveu e morreu no Rio de Janeiro, tendo sido o Quintão, na Sociedade Literária do Rio de Janciro. Como Alvarenga c 
Maricá, sofreu processo sumärio e, sem julgamento, penou na Fortaleza da Conceição atē 1797 quando a Coroa mandou libertar a todos os implicados da soturna acusação de pombalișmo e simpatias pela Revolução Francesa. Seus 1ivros, no entanto, não denunciam um leitor especialmente versado em autores da Ilustração e do enciclopedismo revolucionário do Setecentos. Médico, a maioria das obras que constituem sua estante,pela descrição do "Auto de Inventário e Sequestro dos bens do Dr. Jacinto José da Silva, por mandado do Conde Vice'Rei do 'Estado, na rua do Rozärio - 6 de dezembro de 1794"(Arquivo Nacional, Cx. 2257/58), a maioria dos livros é característica de obras médicas, com Hipócrates, Galeno, autores de Medicina, Cirurgia, Física, Química e Ciências naturais. Registra-se também ali uma "História dos Cenchos de Martinho Luter, in fol." Boa parte dos livros é em Latim, outra em Francês e, pequena parte,em Português. Hā um Espírito das 1eis, de Montesquieu, em Francês, ao lado de dicionários e obras de cunho prático e de curiosidade científica. Lineo, Buffon, Tissot, Boerhave, Sabatieir são autores destacados, em Latim e em Francês. Dos 1ivros portugueses, destacam-se "32 folhetos dos jornaes enciclopedicos de Lx. a", um "Triunfo da eloquência, poema epico de Joze Anastácio da Costa, in 8\%, alēm de uma obra do médico portụguês João Curvo Semedo, Compêndio dos segredos medicinais. No sequestro feito em 1794 dos "bens que forão achados do bachare1 Mariano Josē Pereira da Fonseca extrahido do respectivo processo", confirma-sẹ o Marquês de Maricá bcm mais envolvido com autores considerados defesos como Vatel, de $\underline{0}$ Direito das gentes, as Obras de Crébillon, 2 t. em francês c a $1-$ 
guns volumes de uma coleção de obras de Voltaire. A variação é significativa na livraria do futuro Marquês, incluindo umas Reflexöes sobre 으 que pode agradar e desagrador no comércio do mundo, em francês, 3 volumes in $8^{\circ}$, Boileau, o Guarini de 0 Pastor Fido, o poema "As Estaçoens", de Thompson, Milton de $\underline{0}$ paraiso perdido, obras médicas e cirúrgicas, poesias de Metastásiọ; o Roman comique, de Scarron, as Orações fúnebres de Flechier e até um título que poderia lembrar um certo pombalismo, como "Os jesuitas criminosos de leza Magestade", em Francês. Há também um "Espírito das tragédias", um livro de Samuel Ricard, Arte de bem formar os livros de contas, em partidas do-

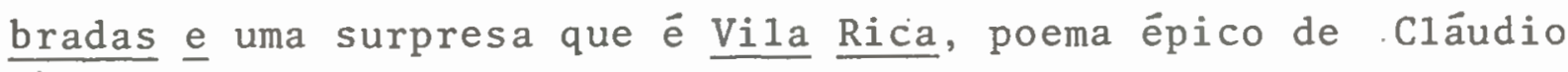
Manoel da Costa, volume in $4^{\circ}$, que as informações históricas disponíveis registram como sendo publicado apenas em 1813, pelo jornal "O Patriota", mas obra escrita jā em 1773. 0 que não surpreende nessa biblioteca aprendida entre os bens do Marquês - de Mạicá é a. obra em que certamente se inspirou para compor suas Máximas: os Pensamentos, māximás, reflexões morais de Francisco Sexto, duque de Ba Rochefoucauld, em.Francês.

Jā os conspiradores baianos da Conjuração dos Alfaiates, em 1798, muitos foram autores populares no Brasil Ditocentista, passadà a experiência em que se viram envolvidos. Domingos 3orges de Barros, depois visconde da Pedra Branca, é autor, por exemplo, de um Dicionário Francês-português; português-francês, editado em Paris, 1812; traduziu um poema de G. Legouré, o merecimento das mulheres (Paris, 1819) e publicou, em 1825, sua mais famosa obra, sob pseudônimo, poesias oferecidas às senhoras brasilciras por um baiano. Outros insurgentes de 1798 também autores 
foram o.padre Francisco Agostinho Gomes, do Escudo da Liberdade, 1822; Cipriano José Barata de Almeida, tribuno e jornalista, em 1823, dos "Sentinela da Liberdade na Guarita de Pernambuco" e "Sentinela da Liberdade à beira do mar da Praia Grande". O mais célebre dos conjurados baianos, depois alçado à proa do Brasil Reino, foi o visconde de Cairu, Jose da Silva Lisboa, polígrafo e ministro, autor de um best-seller nos começos e meados do século XIX, o princípios de Direito Mercantil e $\underline{\text { leis }}$ da Marinha.

No sequestro dos bens na chamada Inconfiência Baiana, de 1798, entre os bens de Lucas Dantas de Amorim Torres, em 28 de setembro de 1798, só se registrou um único livro "espanhol de cronologia e ja velho". Já Cipriano José Barata de Almeida, preso nas cadeias da Relação da Bahia, teve auto de sequestro de seus bens feito em 22 de setembro de 1798, por ordem do Dr. Francisco Sabino Alvares da Costa Pinto e autorização do Governador Capitão General da Capitania Fernando José de Portuga1. Entre os livros, um certamente defeso, a "História das revoluçoens acontecidas no Governo da Repüblica Romana", em 2 tomos. Tinha uma popularíssima Arte de se tratar a $\underline{\text { si mesmo }}$

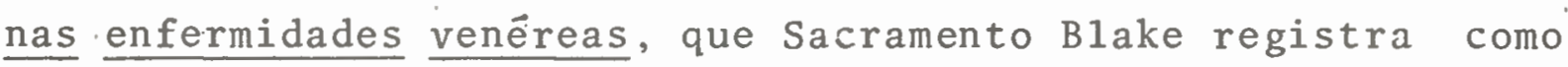
sendo de Godde de Liancourt, depois traduzida por Caetano Lopes de Moura, também inconfidente baiano; em Paris, 1837, ou 1839. Tal título existe nas livrarias setecentistas e oitocentistas brasileiras, sem indicação e às vezes com indicação de autoria mas com título alterado. Os livros de Cipriano Barata são mais ou menos comuns às estantes brasileiras coloniais, excetuando-se, por destaque, uma "Tragedic burgeoise", Eucli- 
des e Besout, de Geometria e Matemätica, a Metafísica de Genuenses e os Elementos de Medicina prática de Guilherme Cullen estão presentes na livraria do mais teimoso conjurado baiano, que ainda tinha as oeuvres de M. L'Abbé de Condillac, em três tomos.

Entre os livros sequestrados ao tenente Hermógenes Francisco de Aguillar, em 5 de janeiro de 1799, obras de circular frequência no perfil de leituras brasileiras setecentistas, livros de Doutrina moral como as Lettres d'une peruvienne, de Madame de Gravigné e Le Diable boiteux, de Alain Le Sage, e ás Aventures de Telemaque, de Fénelon. Histórias de viagens, os clássicos Ovídio e Quintiliano; a Prosódia, de Bento Pereira etc. Comprometedor, apenas, seria o Dictionnaire philosophique, de Voltaire.

A razão maior de barrar a circulação de livros ou indiciar réus por crime de possuir em suas bibliotecas autores interditos é o que deve orientar as peças de sequestro e apreensão de bens feitas nos domínios do Reino de Portugal. No sequestro feito aos. bens do Marquês de Maricá, por exemplo, o Conde de Rezende despacha diretamente seu representante para que descreya os bens "com toda a individuação, e clareza, debaixo de seus competentes títulos". Assim, determina ao Desembargador João de Figueiredo:

Ao mesmo tempo fara Vmce. inventärio de todos os livros, e papeis que nelas houverem, tendo especial cuidado de averiguar com a maior exatidão, e escrupulo as materias de que eles tratão, e achando algũas que se dirijão a semear, e propagar novas opinioens. e doutrinas a respeito da Religião, e Governo Eclesiástico, e político me informará com elas. 242 
0 mesmo espírito de vasculhar influências ou difusão de idéias contrárias à Religião e ao Estado encontra-se nos inquéritos e depoimentos prestados pelos inconfidentes da Bahia. Parte do inquérito feito pelo Desemḅargador "Francisco Sabino Alvares da Costa Pinto ao Ten. Hermógenes Francisco de Aguillar è representativa de nossa caracterização:

Perguntado se elle declarante nunca teve noticia de huns cadernos traduzidos da lingoa. Franceza, cuja materia era concebida em forma de dialogo, e versava sobre a religião, e sobre o Estado, e que se conservavão na casa de Luis Pires, e nas. de outras muitas pessoas desta cidade, onde eram vistos e lidos?

Disse que nunca teve noticia de semelhantes cadernos, nunca os vio, e nem os ouvio ler.

Perguntado se elle declarante conservava alguma obra de P.olitica, emque se tratasse materia pertencente ao Estado, se empregava nesta lição ou se tinha feito alguma tradução a este respeito de lingoa estranha para a nacional?

Disse que nunca produzio obra alguma desta natureza nem Jamais se enterteve em semelhante lição, empregando-se unicamente no governo de sua casa; nem tinha os necessarios conhecimentos para emprehender tradução.de lingoa estranha pois a de que tinha alguma noção, era a franceza, e que apenas the bastava para perceber algum livro.

E logo o dito Ministro apresentou ao declarante, vinte quartos de papel escritos, que tresmalhada- 
mente, lhe farão achados na sua casa, e são as que vão juntos ao apenso a estas perguntas no todo com - n? 1 os quais principião por hum discurso preliminar e pela seguinte inscripção = Quadro da Política actual, parellelo.com a dos antigos seos vicios, obstaculos que ella offerece à prosperidade, e grandeza dos povos.

E lhe pérguntou se a letra em que estava escrita a maior parte dos ditos quartos de papel era delle declarante, de quem era a outra, em que estavão escritas algumas paginas; se era obra original, ou traduzida de lingoa estranha; qual era o seo author; e se erão, ou não os proprios, que elle conservava em seo poder ao tempo de sua prisão?

Disse que a letra, em que se acha a maior parte dos ditos quartos de papel, he propria delle declarante, e a reconhecer por tal; que a outra das poucas paginas, escritas por diferente mão, he de hum primo delle declarante, Manoel Pereira de Mello, Tenente do mesmo segundo Regimento de linha o qual assim o praticou de mandato delle declarante; que a obra he no seo original escrita na lingoa francesa por Monsieur Guibert, e o seo principal objecto, he hum ensaio geral sobre a Tatica, de que vem a ser introdução a parte, que se apresenta; que elle declarante foi que traduziu não so a referida introdução, porem mais da metade da dita obra, com o unico distino de se adiantar nos. conhecimentos da sua profissão militar, sem ter a menor lembrança de transgredir as obrigaçoens defiel vassalo, que reconhece, e protesta; e que para fazer certa esta sua esclusiva, requer lhe sejão procurados na sua mesma caza, ou na mão do official que ser abusca, os cadernos seguintes, que bem mostrão, o objecto deste livro, e da sua tradução.

outrossim lhe apresentou o dito Ministro, outro caderno, que igualmente the foi achado entre os 
seos papeis, e vi junto ao appenso do n: V com a inscrição seguinte = Helloize e Ábeillard

\section{5}

E The perguntou o dito Ministro donde lhe tinha vindo esta tradução, que no seo original he do reprovado João Jacques Rousseau, se tambēm tinha sido feita por elle declarante, e de quem he a letra em que se acha escrita?

Disse que hum rapaz do Reino, que não conhece, senão de vista, foi o que em certa ocazião lhe deo o dito caderno, chamando-lhe, e por isso não sabe sè he tradução, nem quem a fez, e nem de quem he a letra em que se acha escrito. 243

Em trecho adiante, o rêu se defende dizendo que a obra de Guibert é usada na Milícia e não é obra condenada. Observamos que, nos autos do processo, o Ministro chama He11oize e Abeililard de "Obra em versio heróico". No auto de exame dos 23 cadernos, há uma referência ao Essai general de tatique de Mr. Guibert. Finalmente, o auto reconhece: "os mencionados cadernos continhão huma tradução fiel da dita obra, tanto na dedicatória e discurso preliminar que a precede, como no contexto que faz o seo objecto principal" 2.44 .

No auto de Inquērito a Francisco Munis Barreto de Aragão, professor de Gramätica em Rio de Contas, comarca de Jacobina, sāo 1 ivros achados em sua casa, constantes em inventärio c scquestro:

3. e 4 t. de. Jullia, oú. a nova Heloize de Rousseau

2.t. de obras escolhidas de João Baptista Rous seau 
Perguntado a que fim conservava elle declarante em seo poder aquelles cadernos sediciozos, e mais papeis respectivos a constituịção franceza, e por que motivo sendo perguntado a este respeito tão repetidamente e por tantos modos se firmou em huma redonda negativa, agora desfeita, e convencida?

Respondeo que o seo. fim não era outro mais do que ler, sem se distinar a algumas sinistras intençoens contra.o Estado

Nas perguntas ao sergento Luiz. Gonzada das Virgens: se o réu tinha conhecimento da lingua latina. "Respondéo que não e que nada conhecia de literatura. Lia só o que importava à Cirurgial.

No inquērito feito ao pa livre Jozé de Freitas Sacato:

Preguntado se elle declarante vio esse livro que tem indicado, algumas vezes essessabe a sua configuração e o seo titulo?

Dice que elle declarante o vio algumas vezes em poder do dito Luis Pires, ese compunha de cadernos em quarto, que periodicamente passavão das mãos dos tradutores para o dito Luis pires, que pela ordem os hia ajuntando, eos lia naprezença delle declaranete, edos mais, que ali concorrião, concebida asua materia em forma de dialogo, emque hum dos actores, tinha onome de Eugenio, eoquelhe respondia era hua fantasma

Perguntado sobre o systema deste livro, visto que elle declarante o ouio ler algumas vezes? Dice que era hum systema de dez abuso contra a Religião, econtra o Estado, que constituia o homem nascido do acazo, e dependente so de ley do seo 
arbitrio, eque buscava as couzas, que lhe erão necessarias, segundo o toque dasua sensação; que se havia hum Dẻos, ou era moldado ao coração dos homens, visto que os dezejos de huns, erão conträrios aos dos outros, ou não fazia apreço das suas supplicas, e que em fím negava asubordinação aos soberanos.

\section{1}

Perguntado especificamente sobre as pessoas que costumavão assistir, e assistirão effeitivamente a leitura deste livro?

Dice que hum dos principais era o Tenente Hermogenes de Aguillar, porser oque o traduzia, juntamente com o Padre Francisco Agostinho Gomes, em caza deste... (Mais Pedro Leão, Pedro Alexandrino, João de Freitas, Manoel Joaquim, Domingos Pedro, Gonçalo Gonçalves) 245

No V. 36, p. 305 dos Anaes do ARQUEB, contendo os "Autos de Devassa do Levantamento e Sedição Intentados na Bahia em 179.', perguntas a Francisco Barreto de Aragão sobre os livros qua possuía e lia

"Respondeo que em certo tempo possuio certos manuscritos, traduzidos de huma obra de Volney, de lingua franceza, intitulada A Revolução dos Tempos passados"246

Entre os pậês achados em poder dé Luiz Gonzaga das Virgens, um sinal de abjuração: 
"Detesto a religião franceza (...) não conheço Calvino e Lutero por certo não tenho o sentido do Dialogo atribuido a delirio da doutrina de Lutero' 247

Entre as anotaçôes manuscritas do Padre Francisco Agostinho Gomes, constavam as seguintes:

o Breviario e missal serão reformados e traduzidos no idioma (mutilado)

$$
\text { (...) }
$$

Todos os ecleziasticos estudarão a doutrina de Santo Agostinho

$$
(\ldots)
$$

Para instrução dos primeíros rudimentos da Religião servirão os cathecismos de CORTIM; e de LEBERT, que foi impresso em Genova, e para a Sagrada Escritura os excriptos ACER.

$$
(\ldots)
$$

os penegiricos dos santos ficarão para sempre abọlidos, e so se farão sermões doutrinais evangeli $\cos ^{24.3}$

Finalmente, entre os papéis achados em poder de Luiz Gonzaga das Virgens e Veiga, soldado do $1^{\circ}$ Regimento, 4a. Companhia, e conjurado dos Alfaites, 1798, figurava um "Quaderno manuscrito, quetem por titulo, França convenção nacional, falla de Boissy d'Anglas, sobre a Politica da Republica Franceza para comas Naçoens Estrangeiras, adoptada pela Convenção, com huma declaração aos principaes do povo francez, 30 de janeiro de $1795^{\prime \prime}$.

Assim, pode notar-se aqui a íntima correlação existentc entre os revolucionärios brasileiros e.algumas das mais expressi- 
vas obras da filosofia e das Letras. Concluimos por essa convicção em vista das conveniências observadas por inquisidores, representantes do governo português e pelos próprios leitores e réus sobre crime por ideologia e advogar princîpios colhidos em obras literárias de sua opção ideológica. Embora nem sempre de forma explícita, muitas idéias expendidas nesses dócu- mentos são as de um leitor e intérprete do dinamismo social que muitos livros defenderam. Os pensamentos em matéria de doutrina, por exemplo, do padre baiano Francisco Agostinho Gomes, certamente the vieram da leitura e reflexão crítica orientada por um gosto e por uma acepção formal do juízo crítico que a leitura proporciona. Muitos dos boletins da sedição de 1798, afixados nas igrejas e nas corporações renresentam, de par com o poder da comunicação exprimindo-se a despeito do rigor censório, o resuitado lógico do poder persuasivo dạ leitura e dos autores tidos em consideração pelos insurgentes baianos. A Fala de Boissy d'Anglas, texto presente entre os papéis de Luiz Gonzaga Vargens, era um repositório de incitamento à luta e à resistência contra o poder organizado, tal como o próprio texto fizera acirrar as contradições da situação interna francesa em 1795. 
6. - UM PUBLICISTA, IM POLITICO-MILITAR, UM DIPLOMATA, UM BISPO, UM PROFESSOR. E UM COMERCIANTE DO SECULO XIX

A natureza de leituras oitocentistas, sobretudo a partir do segundo quartel do século XIX, apresenta alguns traços muito peculiares. Tomamos como elemento de avaliação, para esse fim, os inventários de Evaristo Ferreira da Veiga, 1837 (AN. Maço 442,n.8532), publicista famoso já no período imperial brasileiro, editor do jorna1 "Aurora fluminense", entre 1827 e 1835; Genebra de Barros Leite, viúva e herdeira dos bens e livros do Brigadeiro Luís Antonio de Souza, inventariada em 1838 (Arq. Judiciärio SP, ${ }^{\circ}$ of. cx.45/531 a 533); o médico e diplomata baiano, denutado às Cortes Constitucionais em Lisboa, 1821, José. Lino Coutinho, falecido em 183.6 (ARQUEB, Judiciária, côpia xerox); o bispo D. Fr. José da Santíssima Trindade, de Mariana, inventariado em 1835(CSM, $1^{9}$ of. 130/2732);

- Dr. Luís Nicolau Fagundes V́arela, homônimo e avô do poeta romântico brasileiro, que foi professor na Faculdade de Direito do Largo S. Francisco em São Paulo, inventariado em 1836 (Árq. Judiciário SP, 19 of., cx. 167); e, finalmente, o casal de comerciantes Ana Joaquina Ferreira e Francsico Xavier Ferreira, da comarca de Rio Grande, inventariados em 1838. (APRS; Rio Grande, Estante 12 , maço $18 / 4.22$ ).

Todos os documentos nertencem a uma mesma ẹpoca, entre 1835 e 1838 e representam, em variedade ou especialização dos títulos ou assuntos dos livros, o perfil de leituras brasileiras no século XIX. A maior delas, invulgạ̣ quanto à disnosição dc obras e volumes ê a do casal de comerciantes de Rio Grande, RS, eles mesmos donos de uma tipografia, conforme nossa investigaf̧ão in limine no documento original. Muitos dos livros e au- 
tores relacionados nessas livrarias oitocentistas são oriundos do século XVIII, em particular os clássicos, os títulos em História e Ciências Naturais, Físicas, Químicas e Matemáticas, os de Direito, Medicina, Religião, Literatura, Filosofia e Linguística. Ou seja, cobrem, praticamente, todos os ramos do conhecimento produzido até, mais ou menos, o primeiro quartel. do século.

O inventário de Evaristo da Veiga tem como avaliadores Ágostinho de Freitas Guimarães e João Batista dos Santos, com data de 16 de junho de 1837. E uma biblioteca mais próxima de títulos contemporâneos do inventariado, máxime prevalência em História, Política, Ciências e Letras. São cerca de 120 títulos diferentes e alguns surpreendem até por uma inusitada auto-referencialidade, como a "Colleção das Auroras F1uminenses dêsde o seu começo até o fim do anno de 1834, in fol". Alguns outros vão pontuando na relação dos livros do publicista carioca, como as "Obras completas de Shakespeare em inglez bella edição in $8^{\circ}$ grande, 8 v.", "Os animaes fallando. Poema épico por Caste em italiano", "Corografia brazilica do Pe. Aires,ultima edição, $8^{\circ}$ grande, 2 v.", ou a "Historia do Brazil por Armitage em inglez, $8^{\circ}$ grande, $2 \mathrm{v} . "$ e as "Obras poeticas do Pe. Caldas, picado, in $8^{8}$ grande, 2 v.". O interesse de Evaristo da Veiga pela Revolução Americana e pelos Estados Unidos vem expresso em títulos como" 2 Annaes dos Estados Unidos por Seybert, traduzido em francez por Scheffer, uzado, in $8^{\circ}$ grande". A política constitucional federativa e republicana parece também estar na órbita do interesse do jornalista, que tinha um "Applicações da moral à política por Droz", "Dos anti- 
gos governos federativos por Saint Croix em Francez" e "O Federalista ou a nova constituição dos Estados Unidos de 1788, em inglez, 8\%". 0 herói legalista do mito americano também não faltaria na estante de Evaristo da Veiga, que tinha as"Varias obras de Franklin em inglez, in $8{ }^{\circ} "$. Condorcet, Mirabeau, Benjamin Constant, Pope, Adam Smith, Chateaubriand, Saint Hilaire, Say, Becaria, De Tracy, Edmund Burke, Félix Brotero e Garret são alguns dos autores destacados na relação de obras da biblioteca do publicista brasileiro, que tinha também um tratado de um seu contemporâneo e colega, "Considerações sobre - Jury por Justiniano José da Rocha, brochura, in $8^{\circ}$ grande". Maquiave1, Plutarco, Cayru, José Bonifácio ("Poezias avulsas de Americo. Elisio") e outros autores e títulos graves não impedem que o leitor Evaristo da Veiga faça horas de recreio com uma "Collecção de anedoctas divertidas". Em suma, estamos diante de uma legítima biblioteca geral ilustrativa do estilo de leituras brasileiras do Oitocentos.

Os 320 títulos, aproximadamente, compreendendo cerca de 4 mil volumes, da biblioteca de D. Genebra de Barros Leite, viúva do brigadeiro Luís Antônio de Sousa, são também expressão modelar da natureza e característica do leitor brasileiro no século XIX. De tradicional família paulista, oriundo do patriarcado rural aristocrático, o brigadeiro Luís Antônio e sua viúva, ora inventariada, denunciam, por essa descrição de livros e biblioteca, uma singular evidência da continuidade da língua francesa como idioma internacional para divulgação de conhecimentos. Grande parte das obras na livraria aqui descrita ven versada em Francês, ainda que seu autor e o assunto 
tratado .nem sempre sejam nativos dà França. Livros desde o século XVII, populares no Brasil, estāo relacionados na biblioteca paulista. Dos clássicos aos contemporâneos, concentram preferência do leitor ora analisado obras nos campos da Literatura, História, Direito e Política. História Antiga e Moderna dão a ênfase dos assuntos da livraria e assim registramos de Plutarco a Lacretelle, de Hume a Sismondi, de Tito Lívio a Volney, de Pedro de Mariz a Guisot, de Severim de Faria a Sousa Pinto. Em Letras, novamente os clässicos Cornélio, Valérius Máximus, Lucrécio, Ovídio) são destaques, ombreando com renascentistas como Dante, Petrarca, Tasso e Ariosto, Sá de Miranda, ou Camões, neo-clássicos como Cláudio Manoel da Costa, árcades como Elpino Duriense, Felinto Elísio, ou Domingos dos Reis Quita. Os nomes vão se sucedendo, intensificando a impressão de un gosto particular de leituras em Poesia, surpreenderdo mesmo com obras de Policiano, Le stanse di Orfeo, ou II fiore de $1 \mathrm{a}$ poesia italiana, por Caesano. Boileau, Milton traduzido por Targini, O Hissope, de Diniz, Lebrum, o teatro de Racine, Cornei11e: e Molière, Voltaire, Regnard, Rousseau, Beranger, o Belisārio, de Marmontel, Les jardins, de Delille. E Pascal, Montesquieu, Fénelon, Bossuet, Massillon, La Rochefoucauld, Erasmo, Montaine. Politica constitucional e Ciências do Direito acrescem em importância e número essa biblioteca de São Paulo, rica ainda nas áreas comuns a outras livrarias, como Matemätica (Euclides, Bêzout), Ciências Naturais (Humboldt $\mathfrak{L}$ Bonp̣pland, Brotero e Cuvier). O Direito positivo português, com autores antígos e contemporâncos do sçculo XIX, narcam, de forma definitiva, junto com uma coleção de dicionários e gramáticas, obras de João de Barros, Fernão Mendes Pinto e de um novelista romântico 
como Waiter Scott, a estante brasileira sensíve1 à extensão de obras literārias de reconhecida importância, a testemunhar um sentido vertical, em termos estëticos, no perfil do leitor.

Um tîtulo da livraria do Dr. José Lino Coutinho serviria como exemplo de sua constituição inteira: a Biblioteca de um homem de gosto, em 5 volumes. 0 inventário do conhecidó deputado às Cortes Constitucionais reunidas em Lisboa Pós-Revolução do Porto oferece a oporținidade dé conhecermos a formação intelectual e humana mediante o perfil de sua biblioteca. Devotado ideōlogo da educação consoante rigorosas disciplinas morais, o mêdico e diplomata baiano deixou, num liṿro publicado postumamente, Cartas sobre a educação de Cora, certos modelos e reflexões direta ou indiretamente na influência de Rousseau, trazendo conselhos a Cora, sua filha natural,sobre questões ligadas à instrução, à leitura de livros, ao amor, ao casamento, à educação dos filhos etc., compreendendo um espectro de tempo dos 7 atê depois dos 14 anos.

Os livros de Lino Coutinho não serão muito distintos das outras bibliotecas oitocentistas. Distinguem-se, entretanto, as obras em Filosofia, Economia politica, Direito e Literatura, um ou oútró compêndio em Educação, evidenciando o învèntariado como um leitor e politico liberal. vảo despontar, nesses campos, autores como Jean Duplan, John Spurzheim, Henry Thornton, Condorcet, d'Alembert, Montesquieu, Mirabeau, Holbach, De Pradt, Racine, Jeremy Bentham, Benjamin Frankiin e Thomas Jefferson. Alguns livros são curiosos e raros, como os Elementos da Gramātica inglesa, de Jonathas Abbot, Ensaios sobre 
a Constituição de Inglaterra, Ensaio sobre os princípios elementares da Educação, de Spurzheim, Ensaio sobre as garantias individuais por P.C.F. Daunon e, ainda, um Tableau historique des progrès de 1'esprit humain e uma Memoire en faveur de la liberté des cultes, par Alexandre Venit. Voltaire,Ganilh, Chateaubriand, Le Pagé (autor de um Droit politique), Turgot e Jean-Baptiste Say vão completar o horizonte ampliado e liberal das leituras do deputado constitucionalista de 1821 , ao 1ado dos clássicos de sempre (Sêneca, P1utarco), dos consagrados Racine, Erasmo, Camões e dos títulos surpreendentes como uma "Gramătica das Grammaticas, dois volumes" e um "La Folie espagnole par Pigault, 4 v." e dos convencionais livros de Medicina, próprios ao ofício do inventariado baiano.

O bispo D: Fr. José da Santíssima Trindade, de Mariana, inventariado em 1835, tinha cerca de 520 títulos de livros, reunidos em, mais ou menos, 900 volumes. Trata-se de uma biblioțeca bāsica de Doutrina e Moral, com aberturas significativas para os campos das Ciências Naturais, do Direito e Ficção Mơralista. Os títulọs em Doutrina repetem, em termos, aqueles destacados em nossa investigação desde o século XVII, inicialmente e sobretudo no século XVIII. Grande coleção de sermonários, obras de Teologia Dogmätica, do Direito Canônico,de História e Literatura eclesiástica: pontificam na biblioteca do prelado marianense. As obras de Ciências Naturais são, a1gumas vezes, surnreendentes, como uma Description des plantes de l'Amérique par Charles Plemier e uma Historia das plantas, em 4 t. Surpreendente também é o añarecimento de uma obra como A La Science du gouuerne nuer, por M.R.M. A estante cm Di- 
reito consagra os autores notabilizados do Direito português, como Pegas, Domingos Antunes, Cujacii, entre outros. Vão se tornando contumazes, então, familiares ao gosto e ao estilo das leituras oitocentistas autores populares no Setecentismo, como Lineo. Alguma raridade transparece da relação de livros, como uma "Exposição literäria por Alexandre Eratal, 4 v." ou um "Tractado da satira como deve repreender o próximo", ou, ainda, uma "Arte oratoria reduzida em exemplos, 4 v.".

A biblioteca do Dr. Luís Nicolau Fagundes Varela,inventariado em 1836, exprime o estilo mais geral das leituras oitocentistas no Brasil. Como magistrado, professor de Direito no Largo São Francisco, em São Paulo, tinha parte, mas não a maioria, do seu acervo em títulos de Jurisprudência, Legislação, Filosofia do Direito etc.,abrindo espaço para obras como "Amours de Sapho", "Art de traduire" II Decameron de Boccaccio, Orlando furioso de Tasso, entre outros. Não admira que, nessa estante, pudesse ter se exercitado, mais tarde, o "neto poeta, homônimo do inventariado. Afinal, são cerca de 360 títulos diferentes, com boa indicação de obras literärias, da Filosofia, como a de Locke, do Gouvernment civil, e da Literatura, como Les liaisons dangereuses, de Chaderlos de Léclos, ao lado de umas Lettres de Ganganel1i, por exemplo. E, de fato, uma biblioteca bem diversificada de assuntos e, pelo visto, com títulos e autores mais articulados com o século XVIII. do que, propriamente com o XIX. Destacam-se muito as obras literárias, talvez em maior número, excepcionalmente um Goethe, do Werther e as Bucólicas," de Virgílio, numa relação ondc cabem também as Pocsias de Nicolau Tolentino: Assim, com obras 
em Religiāo, Medicina, Direito, História, Filosofia, Ciências e Literatura, na maior parte livros antigos, a estante do Dr. Luỉs Nicolau Fagundes Varela adianta nossa observação de ver no leitor oitocentista brasileiros alguém que investe na leitura e no livro com uma voracidade consumidora, denunciando, entretanto, um respeito e um gosto quase totêmico pelas obras literárias, em prosa ou poesia.

Por fim, nessa curta amostragem das tendências de leitura no Brasil Oitocentista, segundo o cotejo dos seis inventários selecionados, com os inventariados de formação cultural diferenciada, chegamos à biblioteca de Ana Joaquina Ferreira e seu marido Francisco Xavier Ferreira, em documento do $1^{8}$ Cartório do município de Rio Grande, no Rio Grande do Șul,em 1838, sendo inventariante José Xavier Ferreira. (APRS,P. Grande,422/ 18): Na descrição que procedemos ao documento, registra-se a profissão dos inventariados. Eles eram comerciantes, inclusive de livros, em Rio Grande. Hä referências explícitas a gêneros de botica de propriedade de Ana Joaquina e seu marido. A biblioteca do casal é das mais ricas e variadas, possivelmente a maior em número de volumes, de matérias e de autores diversificados, no Brásil do século XIX, ao menos até ao limite definido em nossa pesquisa. 0 modelo de leituras parece não destoar das verificadas anteriormente e que orientam o gosto literärio e a aferição intelectual do leitor brasileiro em fins do período colonial. São obras cobrindo os mais distintos setores de um conhecimento multiforme, especialmonte a Literatura, de origem francesa ou portuguesa, a que se acrescentam autores e assuntos relacionados com a Filosofia, o Direito, a Economia 
política e as Ciências Naturais, Físicas, Químicas e Matemâticas. Em nümeros, 760 títulos, em termos aproximados, e mais de 2 mil volumes, avaliados por João Batista de Figueiredo Valadares e Antonio José Domingues, constituem a bem servida biblioteca riograndense do século XIX.

Dela constam a Arte de amar, de Ovídio, um."Paine1 do amor conjugal, 4 volumes", um "Sallustio", uma "Consciência 1iteraria", "Poemas de Voltaire", "Belezzas de Lord Byron", uma obra de "Mabli sobre a Legislação" e um curiosíssimo "Manual de compor as bebidas", uma "Arte de governar um Estado" e "Os Archivos do Scanda1o", uma "Expedição de Lord Byron a Grecia"e úma "Historia das raças humanas". A obra do interdito Volnei, Ruinas, está presente no inventārio de Ana Joaquina e Francisco Xavier, de Rio Grande, seguida de transcriçōes pouco frequentes nos inventários brasileiros, como um "Resumo da Historia de Buenos Aires", a Esopaida, de Antonio José da Silva e uma História da Repúb1ica do Haiti. Também o. Emile, de Rousseau, um nada freqüente "Codigo dos Livreiros, 2 v.", relacionam-se junto à Ilíada e à Odisséia de Homero. o clássico Tibulo, com suas Elegias, junta-se à Madame de Stäe1, a uns "Papeis achados na casa de Robespierre, 3. $v^{\prime \prime}$, a estudos sobre as Antilhas Francésas e a um "Curiosidade e Indiscrição". A biblioteca se amplia em número de títulos e os autores, clássicos, renascentistas, maneiristas, neo-clässicos, igualmente se multiplicarāo. E impressionante a quantidade e distinção desses títulıs. Assim, Caramuru, de Basilio da. Gama, popular desde o século de sua publicação, sc alinha às pocsias oferecidas às scnhoras brasileiras por um baiano, de Domingos Borges. de Barros, editadas 
em 1825, na descrição de um universo aberto de possibilidades de leitura. Em que pese serem os inventariados comerciantes, nāo parece que os Iivros aqui dispostos no inventärio pertençam ao comércio, em virtude da pouca indicação de volumes, na maioria 1 volume para cada obra.

Arte de tirar nódoas, obra de virtudes escancaradamente práticas, estâ no inventário, seguida de um "Ovidio Triste em Latim e Francês". La Fontaine, obras de Medicina e História, comparecem junto a uma "Constituição Militar". Cícero, junto a Camões, a que se seguem uma "Gramātica francessa", umas "Indagações sobre a população" e uma "Revista Enciclopedica". No interesse mais específico dạ ärea de Letras, convém destacar que, em Literatura e Linguística, o inventário de Ana Joaquina e Francisco Xavier representa uma amostragem inequívoca de popularização de contos, romances, novelas e poesias, em Latim, Francês e Português. Praticamente, todos os nomes consagrados encontram-se representados nessa biblioteca de Rio Grande, não faltando mesmo as de extrato moral, como a História de Gil Blas de Santillane, que parece assentar definitivamente sua popularidade no Brasil. Autores ingleses, franceses, alemães, portugueses e brasileiros estão reunidos na relação presente de livros, numa demonstração de que o século XIX, em termos concretos, horizontaliza o hábito de ler e robustece a convicção nossa num apuro técnico e na curiosidade intelectual refazendo o caráter do leitor brasileiro - objeto final do nosso estudo. 


\section{CONCLUSAOO}

Estudar o perfil de leituras brasileiras na fase colonial jâ foi tentado, em artigos e livros, por distinguidos historiadores de nossa cultura, muitas vezes com apurado senso de observação'e análise. Alguns desses estudos permitem o acesso público:a zonas obscuras e, mais que tudo, preenchem lacunas sólidas do desconhecimento nacional sobre questóes reiacionadas com sua própria memória. Este trabalho, atento aos limites de seu próprio devir, pretendeu ampliar o estudo do perfil do leitor colonial, mediante o desenvolvimento de uma perspectiva histórica e sociológica, tomando o cidadão brasileiro, na forma dos documentos de inventários de bens, como consumidor direto do livro no Brasil. Avaliando a potencialidade desse leitor através da descrição de tendẽncias de suas bibliotecas, estabelecemos uma geral apresentação de livros e leituras mais freqüentes nos séculos XVII, XVIII e XIX brasileiros, fixando-nos numa base de evidências inquestionäveis, que são as fontes primárias de que nos servimos nessá descrição. Um segundo momento deste trabalho, que fazia parte de sua intenção original e mais ambiciosa, buscarà investir no estudo das influências que livros e leituras no Brasil Colônia exerceram na produção intelectual nativa do período: Serâ, portanto, estudo complementar, e já em curso, de caráter intertextual, com vistas à correlação de influências entre obras, autores.e leitores-autores na produção literāria brasileira. 
0 interesse deste trabalho, do ponto de vista prático, consiste, primeiramente, no resgate, feito de forma cientifica e documentada: da memória cultural brasileira no campo do livro na quadra colonial, mediante a análise e descrição da cultura literäria revelada nas bibliotecas coloniais. Assim, é importante destacar seu valor como instrumento de observação na Sociologia da Cultura e da Literatura em nosso país. Algumas vezes, a observação da circularidade do livro, com frequiência além do razoávele forçou-nos a um juízo de valor que não nos furtamos a realizar - embora não tenha sido este o procedimento convencional no corpo desta tese, uma vez que seus objetivos, claramente expostos, privilegiaram muito mais a descrição constitutiva das bibliotecas brasileiras, dos hābitos de leitura no Brasil, do que a antecipação de fenômenos psicológicos dessa leitura e desses hábitos. Isso poderiá gerar uma expectativa de impossível concretização na atualidade, qual fosse o estabelécimento, crítico, obra a obra, da natureza conceitual do leitor na Colônia. Em nosso entendimento, este trabalho vale, num vpimeixo momento, por estabelecer um verdadeiro mapeamento da cultura bibliográfica no Brasil Colônia, do Quinhentos ao Oitocentos, com fichamento bibliográfico e organização, embora incipiente, de dados referentes à perspectiva do leitor brasileiro no período.

A metodologia, as referências bibliogrä́icas e a anotação das bibliotecas coloniais - tarefa que exigiu do pesquisador sete anos de peregrinação por arquivos, institutos históricos, museus e bibliotecas de todo o pais - cumpriram os espaços previamente delimitados e outros espaços foram abertos. 
para dar vez ao objeto final da pesquisa.e do desenvolvimento de uma referencialidade clara do Brasil em termos de seu autoconhecimento enquanto povo leitor. Por todos os arquivos, as fontes primeiras como cartas régias, ordens régias, papéis, notas e autos de sequestro; testamentos,1ivros de Termo, Alfândegas e Tombo e demais peças documentais que formalmente tinham a aparência de servir aos efeitos e desdobramenmentos desta tese, todas essas fontes foram consultadas. A que melhor se adequou ao nosso esforço foram os. inventários de bens, de inestimável sentido historiográfico e extraordinārio testemunho das afirmações aqui expendidas.

Dessa forma, chegamos a algumas consideraçẽos que serão, nesta parte, mencionadas. Primeiro, que o leitor brasileiro em Quinhentos praticamente inexistiu, ou existiu em niveis bem diminutos de regularidade e permanência. Leitores foram os Jesuítas que para aqui vieram, e mesmo estes tinham pouco 1ivros, conforme ficou demonstrado no capitulo de abertura deste trabalho. Ao conträrio do século XVI espanhol onde a literatura religiosa e doutrinária conviveu com as novelas de cavalaria e tornou massivos leitores os colonizadores e colonizados, a experiência portuguesa foi retardada e esquiva até 1549 e daî formalmente tímida e sem maiores demonstrações de arrojo e implantação de um projeto civilizatório. Faltaram livros de doutrina entre os jesuítas, a educação, pelo viés dogmático e medievalista, se arrastava e éramos um povo concentrado nos estratos sociais de párias portugueses, religiosos comprometidos com o rigor escatológico e aborígenes grosseiramente submetidos a uma colonização nada pacífica ou com intenções de civilidade cultural. 
O Brasil 1eitor começa efetivamente a organizar-se a partir do século XVII. Do ponto de vista de nossa demonstração em fontes primárias, os inventários de bens dé São Paulo e Rio de Janeiro evidenciam um leitor brasileiro predominantemente mistico ou ascético, com ampliações do raio 1 iterário na direção de um Cervantes, de um Heitor Pinto, de um Thomás de Kempis, de um Fernāo Mendes Pinto e de um escasso, mas expressivo, interesse pelo teatro espanhol de comédias.

No Séculó XVIII, quando avultam em quantidade e qualidade os títulos, autores e disciplinas descritos, os livros identificam um leitor mais, atento às Ciências Naturais, à Matemática, à.Física, à Química, aos ensaios em Filosofia e Educação e, è claro, à Literatura e Lingüística. E o século da Ilustração, sobretudo francesa, importando verificar o número impressionante de títulos de obras que consagram as reformas na instrução pública, os aspectos polêmicos dessas reformas, o enciclopedismo, "a curiosidade expressa pelas narrativas de viagens, a proliferação de clássicos latinos como ovídio, Virgílio, Horácio e Quintiliano, sobretudo. As bibliotecas ganham maior número de obras literárias e filosóficas, de estudos linguísticos e filo1ógicos, daí a extraordinária profusão de dicionärios, gramāticas, cartapäcios de sintaxe, de sílabas, de gêneros etc. Tal circunstância, no entanto, não elidiu o predomínio da base moral, superlativamente católica, que se verifica mesmo em campos aparentemente dissociados, como a Medicina, o Direito, a llistória e as Letras. Investigamos a possibilidade da existência de livros que circulassem mesmo interditados pela censura da Igreja ou do Estado e encontramos muito poucos resultados e traços 
de desobediências, explicitamente, nos documentos. Mas é certo que muitos dos livros no Brasil entraram como peça de contrabando, em vista da má vontade reinol de aqui implantar uma política cultural que efetivamente contemplasse a circulação de outros ramos do conhecimento. O leitor em potencial no Brasil será aquele esculpido numa espécie de molde da convenção de costumes e tendências de sua leitura comprometida com a moral e com o afervoramento mítico, seja na órbita eclesiásţica (predominante), seja na secular. Há exceções conferíveis, é claro. Alguns livros, emblematicamente, circularam no Brasil ao arrepio das vontades reinóis. Livros que escapam ao rigor censório e vão iluminar a inteligência de muitos brasileiros.

- ̣̂ século XIX começa com o advento da Tipografia, da Biblioteca Nacional, da abertura dos portos às nações amigas. 0 livro, peça questionada pelo sistema oficial como obrigatoriamente impresso em Portugal, passa a sê-1o também no Brasil. Cresce naturalmente a demanda, livrarias comerciais se abrem e proliferam, impressorés pạticulares se estabelecem, as idéias circulam com um pouco mais de atributo do exercício da cidadania. A política constitucional, os sucessivos gabinetes, a volta de D. João VI.a Portugal, a ascensão de D. Pedro I, o Brasil Histórico auxilia o Brasil da cultura literária. Por isso talvez se explique a grande quantidade de volumes e de títulos nas bibliotecas oitocentistas. A Literatura brasileira ganha foros de autonomia discreta e.ja se mostra bem mais çonstante nas bibliotecas. Permanece a orientação de leituras doutrinárias ou dẹ devoção mística e obras como o peregrino da 
América, as Reflexōes sobre a vaidade dos homens e poucas outras, de brasileiros, são autênticos best-sellers coloniais,estendendo-se do Setecentismo ao 0itocentismo a base de sua circularidade. Mas o século XIX tambëm è o século das técnicas crescentes, das curiosidades politicas e administrativas. Superam-se os obstáculos da mordaça censória e muitos livros, nos mais distintos campos, fazem a revolução de Gutemberg chegar amplamente a um sentido massivo na plataforma do consumo.

leitor brasileiro é bem mais amplo, aberto, variado em seus interesses de leitura e debate.

Por fim, o que este trabalho procurou desenvolver 'foi também uma aproximação interativa do leitor colonial com o texto disponível à época e seus desdobramentos para uma avaliação sem preconceitos, hoje. O leitor integrado ao texto, no século XVIII, por exemplo, responde à integração em que o texto manifesta o desejo de fazer-se próximo ao leitor, no caso específico da Medicina prática e popular. Essa interação, no entanto, tal como a observamos aqui, não obedece a processos exclusivamente psicológicos, nem se verifica, por redução, ao mecanismo psicológico puro e simples. Para este trabalho importou nem sempre investigar o "porque", mas o "que" da leitura. Não privilegiamos uma dada teoria, nem sempre aplicável aos casos descritos. Mesmo sutil, a interação texto-1eitor e vice-versa foi aqui vista como um fato muito mais articulado com a Sociologia do que com a Psicologia. No campo estrito da tese, numa macro-ärea como a de Letras Vernáculas, o que transcende em importância, na ótica deste "Perfil do leitor colonia1", é sua intima relação com a realidade documental, apon- 
tando peças 1iterärias que, concretamente, interferiram no processo de formação e absorção de matêrias e/ou gêneros como a Prosa e a.Poesia, e de autores populares, häbitos e gosto estético desenvolvidos no Brasil. 


\section{BIBLIOGRAFIA}

1. A CONGREGAÇÃo do Oratörio - sua traça primitiva. Coloquo, 44. Lisboa, 1967.

2. A FILosofia no Brasil. São Paulo, Ed. Convĩvio, 1982.

3. A. IMPRENSA brasileira no sécul XIX: revista de cultura Vozes. Petrópolis, Vozes, Outubro 1980.

4. A POLITICA Cultural da época de D.João III. Coimbra, Instituto de Filosofia, 1969, LXXXIV, 1003 p.

5. ABBEVILLE, Claude d'. Histōria da missão dos padres capuchinhos na Ilha do Maranhão e terras circunvizinhas. Belo Horizonte, Ed. Itatiaia, são Paulo, EDUSP, 1975. 297 p.

6. ABRAMO, Márcio. o libro no Brasil, alguns dados sobre a sua histōria e sua evolução, Revista de Cultura Vozes 65 (3): 5-17 (Abr. 1971).

7. ABREU, Capistrano de. Ensaios e estudos. 4 séries. Rio de Janeiro, Civilização Brasileira - MEC, 1975, 4 vol.

8. ----.. Denunciações e confissões do Santo Ofício na Bahia. $\mathrm{s} / \mathrm{l}, \mathrm{s} / \mathrm{d}$.

9. -..--. Matérias e achegas para a história e geografiá do Brasil. Rio de Janeiro, Imprensa Nacional, s/a.

10. AGASSIS, L. Carry. Viagem ao Brasil. São Paulo, Cia.Ed. Nacional, 1938.

11. AGUIAR, Durval Vieira de. Descripções practicas da Província da Bahia. Bahia, Typographia do "Diário da Bahia", 1988. 
12. AIRES, Matias. Reflexões sobre a vaidade dos homens e Carta sobre a fortuna. Prefácios, fixação do texto e notas por Jacinto do Prado Coelho e Violeta Crespo Figueiredo. Lisboa, Casa. da Moeda, 1980.

13. ALBUM da Imprensa da Bahia, organizado pelo Bacharel José Gabriel de Lemos Britto. Bahia, Typ. Bahiana, 1908 .

14. ALIGHIERI, Dante. A Divina Comédia. Trad. introd. e notas de Cristiano Martins. BH, Itatiaia, SP, EDUSP, 1976. $823 \mathrm{p}$.

15. ALINCOURT, Luiz d'. Memōria sobre a viagem do porto de Santos à Cidade de Cuiabá. São Paulo, Com. IV. Centenário, 1954. $207 \mathrm{p}$.

15. ALMANACH para a cidade da Bahia 1812. Salvador, silva Serva, 1811; edição facsimilar, Conselho Estadual de Cultura, 1973.

16. ALMANAK administrativo, comercial e industrial da província da Bahia para o ano de 1873, compilado por Albino Rodrigues Pimenta. Bahia, Typografia de Oliveira Mendes, 1873.

17. ALMANAK da provincia da Bahia, organizado por Antonio Freire. Bahia, litho-typographia de João Gonçalves Tourinho, 1881 .

18. ALMÁNAQUE da cidade do Rio de Janeiro 1799; reimpr. Revista do Instituto histórico e. geográfico brasileiro 267: 93-215. Rio de Janeiro, 1940.

18. ALMANAQUE da cidade do Rio de Janeiro para os anos de 1792 a 1794. Rio de Janeiro, 1940.

20. ALMEIDA, Figueira de. Histōria do ensino secundário no Brasil. Riọ de Janeiro, Liv. Jacinto, 1936. 
21. ALMEIDA, Miguel Osório de. A mentalidade Ciẹtífica no Brasil. Rio de Janeiro, "Folha Médica", setembro 1920.

22. ALMEIDA, Pires de : İ'instruction publique au Brésil. Rio de Janeiro, Leuzinger e Filhos, 1889.

23. ALORNA, Marquesa de Poesias. Seleção, prefácio e notas Hernani Cidade. Lisboa, sá da Costa, 1941. 203 p.

24. ALVES, Maria Teresa Abelha. A dialectica da camuflagem nas obras do diabinho da mão furada. Lisboa, Imp. Nac. - Casa da Moeda, 1983. 245 p.

25. ALVES CAMARA, Antonio. A Bahia de Todos os Santos. Rio de Janeiro, H. Lombaerts, 1890. 98 p.

26. -----. Anais comemorativos das festas do 10 centenário do Seminārio de elinda, Recife, 1921.

27. ---... Anais dà imprensa periódica brasileira. Revista do IHGB, Rio de Janeiro, 1908.

28. ----. Anais do parlamento brasileiro 1823. Rio de Janeiro. $1876.6 \mathrm{v}$.

29. AMARAL, Brás do. História da Bahia do Império à República , Imprensa Official do Estado, 1923.

30. --.-. Resenha histörica da Bahia. Bahia, Tipografia Naval, 1941. $215 \mathrm{p}$.

31. AMARAL, Breno Ferraz do. José Bonifácio. São Paulo, 1968 .

32. ------. O Patriarca da Independência. São Paulo, Clube do Livro, 1972.

33: AMARAL, Brăs do. Cartas, informações, fragmentos históricos e sermães. Rio de Janeiro, ABL, 1933.

34. ----.. Informações e fragmentos históricos. Rio de Jane1ro, Imp. Nacional, 1886. $115 \mathrm{p}$. 
35. ANCHIETA, José de. Auto representado na festa de São Lourenço. Rio de janeiro,MEC/SNT, 1973. 43 p.

36. --.-. Cartas - Correspondência ativa e passiva. São Paulo, Ed. Loyola, 1984. 504 p.

37. .--... Lírica espanhola. São Paulo, Ed. Loyola, 1984. $168 \mathrm{p}$.

38. -.-- Na festa de São Lourenço. Trad. em versos por Guilherme de Almeida. São Paulo, comissão do IV Centenário da cidade de são Paulo, 1954, 71 p.

39. -----. Teatro Anchieta. São Paulo, Ed. Loyola, 1977. $372 \mathrm{p}$.

40. ANDRADE, Almir de. Aspectos da Cultura Brasileira. Rio de Janeiro, Schimidt, 1934.

41. ANDRADE, Antônio Alberto de. Verney e a cultura de seu Tempo. Coimbra, 1966.

42: -----. A reforma pombalina dos estudos secundários no Brasil. São Paulo, Ed. Saraiva, EDUSP, 1978. 226 p.

43. --...-. Contributos para a histōria da mentalidade pedagōgica portuguesa. Lisboa, Imp. Nac. Casa da Moeda, 1982.

44. ANDRADE, Ayres de. Francisco Manuel da silva e seu tempo. Rio de Janeiro, 1967, $2 \mathrm{v}$.

45. ANONIMO. Lazarillo de Tormes. Madrid, Aguilar, 1972, 283 p.

46. ANÔNIMO. Poema del Cid. Buenos Alres, Editorial Losada S.A., 249 p.

47. 150 Anos de Tipografla Ofiacial. No sesquicentenário da Imprensa Nacional. Rio de Janeiro, 1958. (Fac. Similes de folhas de rosto e Capa dos Livros de 1808 a 1959).

48. ANSELMO, Arthur. Origens da Imprensa em Portugal. Lisboa, Imprensa Nacional - Casa da Moeda, 1981. 510 p.

49. ANTOLOGIA Colonial Portuguesa. Lisboa, Agência Geral das Colonias, 1946. 
50. ANTQLOGIA da Poesia Portuguesa' (séc. XII - séc XX). Intr., Seleção e notas de Alexandre Pinheiro Torres Porto, ello \& Irmão, 1977. 2 v.

51. ANTONIL, André João. Cultura e opulência no Brasil. Salvador, Liv. Progresso, 1955, 233 p.

52. ANUÁRIO da Imprensa Brasileira. DIP, Rio de Janeiro, 1941.

53. ANUÅrIO do Museu da Inconfidência. João Gomes Teixeira, Cãssio Larario e Tarquínio J.B. Oliveira. o primeiro Impresso em Minas Gerais. Centro de estudos do ciclo do ouro. Casa dos Contos. Ouro Preto,1977.

54. ANUÁRIO Estatístico no Brasil. V. III, p.563 - Rio de Janeiro, 1916. Artigo sobre as bibliotecas existentes no Brasil 1907-1912.

55. ARÃo, Manuel. Histōria da maçonaria no Brasil. Recife, 1926.

56. ARARIPE Jr. Obra critica de Araripe Jūnior. Rio de Janeiro, MEC, Fundação Casa de Rui Barbosa, 1971. 5.V.

57. ARAUJO, Antonio. Catecismo brasilico da doutrina cristã. 2 imp. Lisboa, 1626.

58. ARCHIVo dos Estado de são Paulo. Publicação official de documentos interessantes para a história e costumes de S. Paulo. 1894, V. 11897, v. 29.

59. ARISTÓteles. Arte retórica e arte poética - Trad. Antônio Pinto de carvalho. SP, Difusão Européia do Livro, $1964,329 \mathrm{p}$.

60. ARMITAGE. História do Brasil. Rio de Janeiro, 1837.

61. ARQUIVO NACIONAL . Ordém Régia 6 de julho de 1747. Catálogo das cartas rêgias...1662 - 1821. Publicações do* Arquivo Nacional, I. Rio de Janeiro, 1922.

62. AS VARIEDADES ou ensaios de literatura. Introdução de Renato Berbert de Castro. Reedição fac-similar. Salvador, ARQUEB, 1982. 
63. ARRIAGA. História da Revoluçãa do Porto 1820. Porto, 1886.

64. ATLAS Cultural do Brasil, dir. Arthur Cezar Ferreira Reis. (Brasilia), FENAME, 1972.

65. AUGEL, Noema Parente. Wisitante estrangeiros na Bahia Oitocentista. São Paulo, Cultrix, Brasilia, INL, 1980. 269 p.

67. AUTo de inventário e avaliação dos livros achados no colégio dos Jesuitas do Rio de Janeiro e sequestrados em 1775. Rio de Janeiro, Rev. do Inst. Hist. e Geog., v. 301,1973 .

68. Autos da Devassa da Inconfidência Mineira. Rio de Janeiro, 1936/1937, 7 vol.

69. AVELLAR, Hélio de Alcantara. História Administrativa do Brasil, a administração pombalina. 2 ed. Brasilia, Fundação, Centro de Formação do Servidor Público Ed. da Universidade de Brasilia, 1983. v. 5.

70. AVILA, Afonso. Resíduos seiscentistas em Minas. Belo Horizonte, Centro de Estudos Mineiros, 1967. 2 v.

71. -----. o teatro em Minas Gerais: Séculos XVIII e XIX Ouro Preto, Prefeitura Municipal, 1978.

72. AzEVEDo, Fernando de. A Cultura Brasileira. 5 ed., São Paulo, Melhoramentos/EDUSP, 1971.

73. --.-. A transmissão da cultura. Melhoramentos/MEC, 1976 .

74. AZEVEDo, J. Lūcio de. Os jesuítas no Grão Pará. Coimbra, 1930 .

75. ----. Novas epanáforas. Lisboa, 1932.

76. AZEVEDO, M. P. Moreira de. A instrução pública nos tempos Coloniais no Brasil. Revista do Instituto Histórico e Geográfiço Brasileiro, v. 55. p.2, 1892. 
77. AzEVEDo M.P.Moreira de. O Rio de Janéiro. Rio de Janeiro, 1877.2 v.

78. AZEVEDo, Moreira de. Origem e desenvolvimento da imprensa no Rio de Janeiro, Revista do IHGB 20 (2) 169.

79. AZEVEDO FILHO, Leodegário A. A poética de Anchieta. Rio de Janeiro, ráfica Carioca, 1962.

80. ------. Anchieta. Idade Média e Barroco. Rio de Janeiro, Gernasa, 1966.

81. AZEVEDO FILHO, Leodegário A. de \& ELIA, Silvio. As poesias de Anchieta em português : estabelecimento do texto e apreciação literária. Rio de Janeiro, Antares, Brasilia, INL/ Pro-memória, 1983. 170 p.

82. BAENA, L.M Ensaio Geográfico sobre a província do Pará $\mathrm{s} / \mathrm{l}, \mathrm{s} / \mathrm{d}$.

83. BAIÃO, Antonio. Episídios dramáticos da Inquisição Portuguesa. $s / 1, s / d$.

84. BANDEIRA, Manuel. Apresentação da poesia brasileira. Rio de Janeiro, Ediouro, \$967. 451 p.

85. BARATA, Manuel Cardoso. Fastos paraenses. Rev. do Inst. Hist. Geog. Bras. v.77

86. Efemérides paraenses. Idem, v.77.

87. BARBALHO, Nelson. Cronologia pernambucana: subsidios para a histöria do Agreste e do sertão. Recife, Centro de Estudos de História Municipal/ FIAM, 1982.3. $12 \mathrm{v}$.

88. BARBOSA, Antônio da Cunhà - Origem e desenvolvimento da imprensa colonial brasileira, Revista do IHGB 63 (239)-

89: BARBOSA, Januário da cunha. Parnaso brasileiro. Rio de Janeiro, Tipografiá Imperial; 1829. 
90. BARBUDA, Petro Júlio. Literatura brasileira- Bahia, 1916.

91. BARLÉU, Gaspar. História dos feitos recentemente praticados durante oito anos no Brasil. Belo Horizonte, Ed. Itatiaia, São Paulo, EDUSP, 1974. 409 p.

92. BARRETO, Dalmo Freire. "De Brasiliae rebus pluribus: O primeiro livro impresso no Brasil", Revista do IHGB .314: 51 - 74 (Jan/Mar. 1977).

100. BARRETO, João Franco. Eneida portuguesa, com introdução, notas, atualização e estabeleciemnto do texto por Justino Mendes de Almeida, Lisboa, Imp. Nac - Casa da Moeda, 1981. 640 p.

101. BARRETO, Luis Felipe. Descobrimento e Renascimento: formas de ser e pensar nos séculos XV e XVI. Lisboa, Imprensa Nacional - Casa da Moeda. 1983. 327 p.

102. BARRETO, Plínio. " A Cultura Jurídica no Brasil," São Pau1o, "Estado de São Pauio", n.2, 1922.

103. BARRoS, Vicente: Ideologia e pensamento de José Bonifácio . Rio de Janeiro, zahar, 1977.

104. BARRos, Borges de. Anais do Arquivo público da Bahia $\mathrm{s} / \mathrm{l}, \mathrm{s} / \mathrm{d}-$

105. -.... Bandeirantes e Sertanistas bahianos. Bahia, Imprensa Official do Estado, 1919.

106: -----. Novos Documentos para a História Colonial. Bahia, Imprensa Official do Estado 1931, 284 p.

107. BARROS, J . Teixeira. Os Correios na Bahia. Bahia, Lytho. TYE. e encardenação Reis, 1908.

108. BARROSO, Gustavo. Histōria secreta do Brasil - São Paulo, 1939. $2 \mathrm{v}$.

109. BASILIO MAGNO; São. As regras monästicas. Coll. Os padres da Igreja/.4. Trad. Ir. Hildegardis Pasch e Ir. Helena Nagem Assad. Petrópolis, Vozes, 1983. 297. p. 
110. BASTOS, Fernando. Panorama das Idéias estéticas no Ocidente I. Estética Antiga e medieval. Brasilia, Ed. Universidade Brasilia, 1981. 51 p.

111. BAST́OS, José Timóteo da Silva. História da Censura Intelectual em Portugal. Coimbra, 1926.

112. BEIRÃo, Caetano. D. Maria I. S/l, S/d.

113. BELLIDO, Remijo de. Catálogos dos jornais paraenses $1822 /$ 1908 Pará, Imprensa oficial, 1909.

114. BELLO, Oliveira. Imprensa Nacional. Rio de Janeiro, 1908.

115. BELLO, Josē Maria. Inteligência do Brasil. 3 ed. São Pau1o, Cia. Ed. Nacional, 1938.

116. BERLIN, Isaiah, Vico e Herder. Brasilia, Ed. Univ. Trad. Juan Antonio Gili Sobrinho. 1982. 215 p.

117. Bernardes, Pe. Manoel. Obras. Porto, Lello \& Irmão, 1974. $5 \mathrm{v}$.

118. BESSA, IUIS Agustina. Sebastião José. Lisboa, Imprensa Nacional - Casa da Moeda, 1981. 294 p.

119. BLAKE, Augusto Vitoriano Alves Sacramento. Dicionário bibliográfico brasileiro . Rio de Janeiro, 1883/1902, 7 vol.

120. BIANCARDI, Teodoro José. Cartas Americanas. s/l, s/d.

121. BIBLIOGRAFIA Vicentina. Lisboa, Bib. Nacional, 1942. 1002. P.

122. BIBLIOTECA brasiliensis. London, 1931.

123. BIBLIOTECA da Universidade de Utrecht. Portugal e Brasil. Catálogo de livros portugueses e publicações estrangeiras sobre portugal e 으 Brásil. Utrecht, Biblioteca Universidade, 1959. $3 \mathrm{v}$.

124. BIBLIOTECA Nacional. Indice do Correio Braziliense (1808-1822). Rio de Janeiro, 1976, 420 p.

125. BITTENCOURT, Raul J. "Perspectiva histórica dos ideais de educação nò Brasil": Revista Brasileira de Estudos Pedagógicos, n.20, fevereiro de 1946, São Paulo. 
126. Bó̇AGE. Sonetos. LIsboa - Livros de bolso EuropaAmérica. 224 p.

127. --.--. Apólogos, adivinhações e epigramas. Estudos prévios de Rebelo da Silva e Teófilo Braga. Lisboa . Livros de bolso Europa- América. 301 p.

128. BoCCACCIO, Giovanni. Decamerão. Trad. Torrieri Guima rães. São Paulo, Abril Cultural, 1971. 582 p.

129. BOCCANERA Jr, Silio. Bahia Cívica e religiosa, subsidios para a história. Bahia, A Nova Graphia, 1926.

130. -...-. Bahia histórica; reminiscências do passado, registro do presente. Bahia, Typ. Bahiana de cincinnato Melchiades, 1921.

131. --..-. Theatro Nacional. Bahia, Imprensa Official do Estado, 1923.

132. BOESH, Bruno, org. História da literatura alemã. São Pau10, Ed. Herder, EDUSP..1967. 503 p.

132. BOGGS, Ralph Steele, org. A nau Catarineta. Separata da Rev. Arq. Mun. CLXIX. São Paulo. Arq. Hist. 1962. $36 \mathrm{p}$.

133." BOSSETZ, Jean. História do protestantismo. São Paulo, Difel, 1971. 136 p.

134. BOLETIM Bibliográfico brasileiro, n.5, v.III. Rio de Janeiro, set-out. 1955.

135. Boletim da Academia Nacional de História. Buenos Aires, 1940. V. XIII, p. 115.

136. BOLETIM de Pesquisa da Cedeam. Universidade do Amazonas Comissão de Documentação e Estudos da Amazônia. Manaus, v. 3, n. 4. 145 p. Jan-Dez. 1984.

137. BOLETIM Geral das Colônias: Indices 1 a 200.

138. BORGMEISTER, Fr. Tomás. A história da Flora Fluminense de Frei Veloso. Rio de Janeiro, 1937. 
139. BORGMEISTER, Fr. Tomás. Fradés Naturalistas. Vozes, 1919.

140. BOUCHOT, Augusto. História de Portugal e suas Colônias. Bahia, Imprensa Econômica, 1884, 464 p.

141. BOURROUL, Estevam Leão. "A tipografia e a lytografia no Brasil, Revista do IHG de São Paulo, 13 (1): 28 (1909?)

142. BOUTERWẸ, História da literatura portuguesa. Lisboa, 1804.

143. BOXER, Charles Ralph: Some liberaty sources for the history of Brazil in the 18 th century, London, Oxford, U.P, 1967.

144. -----. The golden age 으 Brazil. 1695/1750. Berkeley, Los Angeles, 1962.

145. BOYER, A. A idade de ouro no Brazil, dores e crescimento de uma sociedade colonial. 2. ed. São Paulo, Cia Ed. Nacional, 1969. 380 p.

146: BRAGA, Té́filo. História da Universidade de Coimbra. S/l $\mathrm{s} / \mathrm{d}$.

147. -.-.-. Manual de história da literatura de Portugal. Porto, 1825.

148...---. Os árcades. Porto, 1918.

149. Brandão, Ambrósio Fernandes. Diálogos da grandeza do Brasil. Recife, Universidade Fereral de Pernambuco, 1966. 150. BRANDAO, Darvin e Silva, Motta e . Cidade do Salvador. São Paulo, Cia, Ed. Nacional, 1958.

151. BRANDÃo, Mário. A inquisição e os professores do Colégio das Artes. Coimbra, Universidade, 1969. 2 v.

152. BRANDENBERGER, Clemens. "Die altesten brasileschen Drucke", gutenbergfestschvift zur Feir des 25. Uechrigen Bestehens des gutenbergmuseums in Mainz 1925. Mainz, 1925. 58-61.

153- BRIGUIET, Raul. "Instrução pública na colônia e no Império". In: Revista Brasileira de estudos Pedagógicos, n. 4, 1944 . 
154. BRIONES, A. Valbuena. Literatura hispanoamericana.2.ed. Barcelona, Editorial Gustavo Gili, 1965. 556. p.

155. BRITO, Domingos d'Abreu de. Grandezas das capitanias do Brasil. s/l, 1952 .

156. BRITO, Francisco Tavares de. Itinerário geográfico com a verdadeira descripção dos caminhos, estradas, rossas, sitios, povoacões, lugares, villas, rios, montes, e serras, que há na cidade de s.Sebastião do Rio de Janeiro. Até as Minas de Ouro. Sevilha, of. Antonio da Sylva, 1732

157. BRUNETIERE, F. Evolução dos Gêneros. s/l, s/d.

158. BUENo, Silveira. Antologia arcaica. São Paulo, Edições Saraiva, 1968. 2. ed. $215 \mathrm{p}$.

159. BURKE, Edmund. Reflexões sobre a Revolução em França. Trad. Renato de Assumpção Faria, Denis Fontes de Souza Pinto e Carmem Lidia Richter Ribeiro Moura. BrasiIia, Ed. Univ., 1982. 239 p.

160. CABRAL, Alfredo do Vale. Anais da Imprensa Nacional do

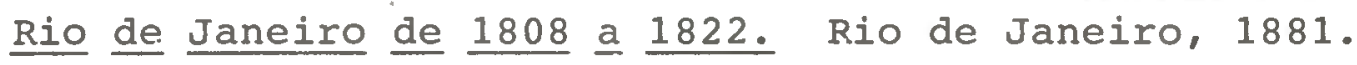

161. CABRAL, Luiz Gonzaga. Jesuitas no Brasil (sec 16). São Paulo, Melhoramentos, 1925. 276 p.

162. CAEIRo, José. Desterro dos Jesuitas. s/l, s/d.

163. -.... Jesuitas do Brasil e da India na preseguição de Pombal- Rio de Janeiro, ABL, 1936.

164. CAIOLA, Lourenço. A- característica da colonizacão portuguesa. Boletim Geral das Colônias. Lisboa, 9 (91), 1933. p.3 a 9.

165. CALlADO, Manuel. Valeroso Lucideno. Recife, Fundarpe, 1985. $2 \mathrm{v}$.

166. CALDCLEUCH, Alexander. Travels in South América during the years 1819-20-21, London, Murray, 1825. 
167. CALIXTO, Benedito. A vila de Itanhẻm. Itanhaém, 1895.

168. -.... A história do Brasil na poesia do povo. s/l, s/d.

169. CALMON, Pedro. Figuras de azulejo. s/1, s/d.

170. -----, História da Casa da Torre. Rio de Janeiro, José Olimpio, 1939.

171. ----, História da literatura baiana. Rio de Janeiro, .1949 .

172. -----, História do Brasil. Rio de Janeiro, J. Olimpio, 1963. 7v.

173. ----, História Social do Brasil. 2 ed. São Paulo, Cia. Ed. Nacional, 1937.

174. CALOGENAS. Os jesuitas e 으로으. Rio de Janeiro, 1911.

175. CAMARA, Manuel Arruda da - Obras reunidas. Recife, Fundação de Cultura da cidadē do Recife, 1982. 331 p.

176. CAMARGo, Mons. Paulo F. da Silveira. A igreja na história de São Paulo. São Paulo, '1952.

177. CAMELLO, Maurilio José de oliveira. Caraça, Centro mineiro de educacão e missão 1820/1830. Belo Horizonte, Imp. of., 1973. 208 p.

178. ----. Lirica Completa. Prefácio e notas de Maria de Lourdes Saraiva. Lisboa, Imp. Nac. casa da Moeda, 1980. $3 \mathrm{v}$.

179. CAMÕES, Luís de . Os Lusiadas. Lisboa, Imp. Nac, 1889. $391 \mathrm{p}$.

180. - - Sonetos de Camões. Porto, Editorial Domingos Barreira, 2 ed. s/d. 172 p.

181. CAMpos, Fernando Arruda. Tomismo e neo-tomismo no Brasil. São Paulo, Grijalbo, 1968. 241 p.

182. CAMPos, Francisco. Educação é cultura. Rio de Janeiro, J. Olympio, 1940.

183. CAMPOS, João dà Silva. Fortificações da Bahia. Rio de Janeiro, 1940: 
184. CAMPos, João da Silva. Tempo antigo. Bahia, Secretaria de Educação e Saúde, 1942.

185. -- - Tradicões Bahianas. Bahia, Seção graphica da Escola de Aprendizes, 1930.

186. CAMPOS, Sandoval \& LÖBO, Amynthas. Imprensa Mineira, memória histórica. Belo Horizonte, O. Costa, 1922. $169 \mathrm{p}$.

187. CAMPOS, Ernesto Souza. Instituicões culturais e de educação superior no Brasil. Rio de Janeiro, IMp. Nacional, 1941 .

188. CĀNIDO, Antônio. Formação da literatura brasileira. 5 ed. São Paulo, USP, Itatiaia, 1975, 2 v.

189. CANECA,Fr. Obras politicas e literárías. Col. Antônio Joaquim de Melo. Recife, 1875. 2 v.

200. CARDIFF, P. Guillermo Furlong. Las bibliotecas coloniais en el rio de la Plata. Bol. Ac. Nacional Hist, Buenos Aires, 1940. V. XIII, p. 115.

201. CARDIM, Fernão. Narrativa epistolar. s/1, 1583.

202. ----. Tratados da terra e gente do Brasil. São Paulo, EDUSP, Belo Horizonte, Ed. Itatiaia, 1980. 206 p.

203. CARIGE, Eduardo. Geographia physica e política da Província da Bahia. Bahia, Imprensa Econômica. 1882 .

204. CARNAXIDE, Visconde de. O Brasil na administração pombaIina. São Paulo, Cia. Ed. Nacional, 1940.

205. CARNEIRO, Diogo Gomes. Oracão apodíxica aos cismáticos da pátria. Iisboa, 1641.

206. CARNEIRO, Édison. A cidade do Salvador em 1549. s/l $s / d$.

207. CARRATO. As Minas Gerais e os primórdios do Caraca. São Paulo, Nacional, 1963."

208. CARRATO, José Ferreira. Igreja, iluminismo e escolas mineiras coloniais. Brasiliana v. 334. São Paulo, Cia. Ed. Nacional EDUSP, 1968. 
209. CARPEAUX, otto Maria. História da literatura ocidental. 2 ed. Rio de Janeiro, Alhambra, 1980. 7v.

210. CARVALHO, Alfredo F.de. Anais de imprensa periódica pernambucana de 1821-1908. Recife, 1908, Jornal do Recife.

211. CARvalHo, Joaquim de. A livraria dum letrado do séc.

XVI. Frei Diogo de Murça. In: Boletim bibliogrāfico da Biblioteca da Universidade de Coimbra, 1927, ano VIII, p. 1 .

212. CARvalHo, Joaquim de Montezuma de. "Frei Luís de Granada". In: "Kriterion", Belo Horizonte, v. 55-56, janeiro a junho de 1961 , p. 230-249.

213. CARVALHO, Joaquim de et allii. 을 nascimento da moderna pedagogia: Verney. Rio de Janeiro, PUC/RJ - Conselho Federal de Cultura - Ed. Documentário, 1979. 112 p.

214. CARVALHO, Laerte Ramos de: As reformas pombalinas da instrução pública. São Paulo, Saraiva, EDUSP, 1978. 241 p.

215. CARVALHO, M.E. Gomes de. Os deputados brasileiros nas cortes de 1821. Brasilia, Editora da Universidade de Brasilia, 1978. 2 ed. 274 p. (co. edição com o Senado Federal).

216. CARVALHO FILHO, José Eduardo Freire de. Datas e factos. Bahia, Imprensa official do Estado, 1916.

217. CAscudo, Luís Câmara. o doutor Barata. s/1, s/d.

218. CASTELO, J. Aderaldo. Manifestacões literárias da era Colonial. São Paulo, Cultrix, 1962.

219. -----, Movimento academista no Brasil. s/1, s/d.

220. CASTRO, Renato Berbert de. A primeira imprensa da Bahia e suas publicações. Tipografia de Manuel Antonio da Silva Sexva. 1811-1819. Salvador, 1968.

221. CATÁLOGO da exposição de História do Brasil realizada pela Biblioteca Nacional. Rio de Janeiro, 1885. 3. v . 
222. CATÁLOGO da exposição permanente dos cimelios da Biblioteca Nacional. Rio de Janeiro, 1885.

223. CATÁLOGo da Exposição provincial da Bahia. Bahia, Typographia de J.G. Tourinho, 1872.

224. CÁTALOGO de livros portugueses que se acham à venda na loja de Mongie. Rio de Janeiro, Typ. J. Villeuve, 1847. Idem, Imprensa Nacional, 1924.

225. CAYOLA, Jílio. Brasil, terra lusíada. Lisboa, Atica 1942. $293 \mathrm{p}$.

226. CAZAL, Manuel Aires. Corografia brasilica. Rio de Janeiro, Imp. Régia, 1817. $2 \mathrm{v}$.

227. CERVANTES, Miguel de. El ingenioso hidalgo D. Quijote de la Mancha. 25 ed. Madrid, Espasa - Calpe, 1973. $680 \mathrm{p}$.

228. CESARINY, Mário, org. Horta de literatura de cordel. Lisboa, cooperativa Editora e livreira, 1983, 256 p.

229. CHEVALIER, Jean- Jacques. As grandes obras políticas de Maquiavel a nosscs dias. Trad. Lydia Christina. 3.ed. Rio de Janeiro, Agir, Brasilia, Ed. 1982, 440 p.

230. CICLO de Conferências sobre o Sesquicentenário da Independência na Bahia em 1973 no Instituto de Música da UCSAL. Salvador, Universidade Católica de Salvador, 1'977. $227 \mathrm{p}$.

231. - - A expansão ultramarina e a 1 iteratura portuguesa. Boletim geral das colônias. Lisboa, 1943.

232. CIDADE, Hernani. Licões de Cultura. s/l, s/d.

233. - -..... Livros velhos. O Estado de são Paulo, 1936.

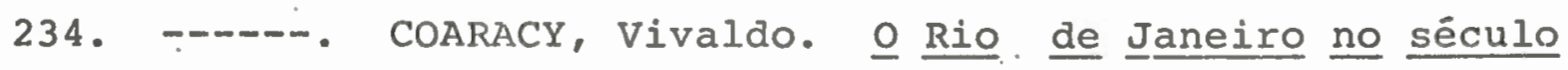
XVIII. Rio de Janeiro, J. Olumpio, 1944.

235. CODICES manuscritos da Academia dos esquecidos. Rio de Janeiro, Inst. Hist. Geog. Bras., s/d. 
236. COELHO, Duarte de Albuquerque: Memōrias diārias da guerra do Brasil. Recife. Fundarpe, 1981. 395 p.

237. COELHO, Jacinto do Prado (dir). Dicionário de Literatura. 3. ed. Porto, Figueirinhas, 1979. 3 v.

238. COELHO, Latino. Élogio histōrico de José Bonifácio. Lisboa, 1877 .

239. COLEGIO Inst. Est. Luso Brasileiro I. Washington, 1950.

240. CONFÍsșós do santo ofício. , s/d

241. I CONGRESSO de História da Bahia. 1949. Bahia - Indice abreviado dos documentos do século XVII do Arquivo Histórico Colonial de Lisboa, por Luiza da Fonseca.

242. Conselho Estadual de Cultura de Minas Gerais. Seminário sobre cultura mineira no periodo colonial. Belo Horizonte, 1978. Imprensa oficial, 1979.

243. CONStituiç̊̃o do Estado da Bahia. 20. de agosto de 1935. (s.n.t.) .

244. ConstrtuIÇס̋Es primeiras do Arcebispado da Bahia. s/l, s/d.

245. CONTIER, Arnaldo D. Imprensa e ideologia em São Paulo: 1822-1842. Petrópolis, Vozes, Campinas, Universidade Estadual de Campinas, 1949. 314 p.

246. CONVERGENCIA: Revista Cultural do Centro de Estudos do Real Gabinete Portuguēs de Leitura, Ano I - no 1. Rio de Janeiro, Imprinta, 1976. 255 p.

247. CORRIA, Natália. Antologia da poesia do período barroco. Lisboa, Círculo de Poesia/Moraes Editores, 1982. 341 p.

248. CORREIA, Viriato. A instrução colonial. " Correio da. Manhã". Rio de Janeiro, 17/12/1920.

249. CORREIA Filho. Alexandre Rodrigues Ferreira. Vida e Obra do grande naturalista brasileiro. São Paulo, Cia. Ed. Nacional, 1939. 
250. CoRTes, Jerônimo. Lunário perpétuo para todos os reinos e.provincias. porto, Lello \& irmão, 1980.

251. CORTIGA, Artur William. Cartas de portugal. s/1, s/d.

252. CosTA, Augusto da. Artes e Letras Coloniais. Boletim Geral das coloonias. Lisboa, 21 (239). 1954.

253. costa, Glaudio Manuel da. Memória histórica e geografica da deśc. das Minas, extraídados manuscritos de C.M.C. O patriota. Rio de Janeiro, Imp Régia, n.4, abr. 1813.

254. CosTA, F.A. Pereira da. Anais Pernambucanos. Recife, $1951 / 1966,10 \mathrm{v}$.

255. -...... Dicionärio biográfico Recife, 1882 .

de pernambucanos célebres.

--. Estudo histórico retrospectivo sobre as artes em Pernambuco: Rio de Janeiro, 1954.

257. --.-. Estabelecimento da Tipografia em Pernambuco. Recife, jornal do Recife, 1875.

258. : COSTA, Hipólito José da. Narrativa de perseguição. Porto Alegre, Associação Ric grandense de Imprensa, Universidade Federal do Rio Grande do Sul, 1974.

259. CostA, João Cruz. Contribuição à história das idéias no Brasil. Rio de Janeiro, J. Olympio, 1956.

260. --.--. Panorama da história da filosofia no Brasil. são Paulo, Cultrix, 1960:

261. CostA, Luiz Monteiro da. Na Bahia Colonial. Bahia, câmara de Vereadores, s/d. $168 \mathrm{p}$.

261. COSTER, Henry. Voyage dans la partie septentionale du. Brésil - depuis 1809 jusqui'en 1815. Paris, 1818 .

262. Coutrinho, Afrânio, org. Caminhos do pensamento crítico. Rio de Janeiro, Pallas - MEC, 1980. 2 v.

263. -..-.-. Introducão à literatura no Brasil. 7 ed. Rio de Janeiro, Distribuidora de Livros Escolares, 1975. 392 p. 
264. COUTINHO, Dr. José Lino. Cartas sobre a educação de Cora. Introd. Dinorah d'Araújo Berbert de Castro. Salvador, Universidade Católica, 1977.

265. CoUtinHo, Milson. A Revolta de Belquimão. São Luiz, Sec. Cult. Ést. Maranhão, 1984. 176 p.

266. COUTO, Domingos de Loreto. Desagravos do Brasil e Glörias de Pernambuco. Anais da Biblioteca Nacional. v. $24-25$. 1904 .

267. CoUto, João José Almeidà. Ofício que dirigiu 은 10 vice-Presidente da Província da Bahia, O Excelentissimo Senhor Dez. João José Almeida Couto ao 40 Vice-Presidente Dr. Eduardo Freire de Carvalho. Bahia, Tipographia do Correio da Bahia, 1878.

268. CoUTo, Soter. Vultos e fatos de Diamantina. Belo Horizonte, Imprensa Oficial, 1954. 286.p.

269. CRISTÓVÃo, Fernando. Marilia de Dirceu de Tomas Antônio Gonzaga ou a poesia. como imitação e pintura. Lisboa, Casa da Moeda, 1981.

270. CRULS, Gastão. Aparência do Rio de Janeiro. Rio de Janeiro, J. Olumpio, 1949. 2 v.

271. CUNHA, Iigia da Fonseca Fernandes da. A Coleção de estámpas le Grand Theatre de 1'univers. Rio de Janeiro, 1970 .

.272. -----. Noticia histörica da Oficina Tipográfica, Calco gráfica e Literăria do Arco do Cego. Rio de Janeiro, Biblioteca Nacional., 1979.

273. CUNHA, Ten. Cel. Joaquim Marques da. A evolução do ensino militar no Brasil. In : Anuărio da Escola Militar, n. 1, 1914. p. 9-58. 
274. DAMASCENO, Darcy. Vilancicos seiscentistas. Rio de Janeiro, Biblioteca Nacional 1970.

275. DEBIDOUR, A. Decouverte et Colonisation du Brèsil. $s / 1, s / d$.

276. DENIS, Ferninand. Brasil. Trad. João Etiane Filho e Malta Lima. Belo Horizonte, Ed. Itatiaia, São Paulo, EDUSP, 1980. 434 p.

277. DENIS, Ferdinand. Lettres familieres. Publicados e anotadas por León Bourdon. Brasília, v.IX. 1958.

278.

Resumo da histōria da literatura de Portugal. $\mathrm{s} / 1,1825$.

278. DESCARTES, René. Discurso do método. trà. Elza Moreira Marcelina. Brasilia, Ed. Univer. 1981.110 p.

279. DEUS, Fr. Gaspar da Madre de - Memórias para a da Capitania de são Vicente. ' São Paulo, comissão do IV centenário da Cidade de São Paulo, 1953. 250 P.

280. DIÁRIo de Pernambuco 2 a 4 de setembro de 1886.

281. DIÁrio ecclesiástico e civil no ano de 1830. Bahia, Typog. do Bahiano, 1829 .

282. DIAS. Antonio Caetano. Catälogo das obras raras ou valiosas da Biblioteca da Escola Nacional de Belas Artes Rio de Janeiro, Imp. Nacional, 1945, Mec/ INL.

283. DIAS, Eduardo. A terra da Vera crü na era de quinhentos. Lisboa, Seção de Intercâmbio Luso- Brasileiro do SNI, 1949. $163 \mathrm{p}$.

284. DIAS, José Sebastịão da silva. O primeiro rol de livros proibidos: Coimbra, Biblos, 1963.

285. DIAS, Malheiros. Introducão História da colonização portuguesa no Brasil. Porto, 1921. 3. v. 
286. DIAS, Manuel Nunes. Politica pombalina na Colonização da Amazônia. (1755/1778). In "studia", 23, 1968, p.7 -32 .

287. DIAS, Maria Odila da Silva. 으 fardo do homem branco. Southey, historiador do Brasil. São Paulo, s/d.

288. DIDEROT; Denis. Obras filosóficas. Buenos Aires, Editorial Tor. s d. 157 p.

289. DINIZ, Silvio Gabriel. Biblioteca setecentista nas Minas Gerais. In: Revista do Instituto Histörico de Minas Gerais, V II, 1959.

290. --.--., "Um livreiro em Vila Rica no meado do século XVIII" In KRITERION, 1959,.n. 47/48, jan/jun, p. 180 -198 .

291. Documentos interessantes. São Paulo, Irmão Ferraz, 1930. 292. DOCUMENTos interessantes para a.ristória e costumes de São Paulo, v. 92, São Paulo, Div. Arquivo Estadual, $1978,236 \mathrm{p}$.

293. IDEM. V.93, São Paulo, Divisão do Arquivo do Estado, 1980. $136 \mathrm{p}$.

294. DoIs autos de Gil Vicente (o de Mofina Mendes e o da Alma) Explicados por Sousa da Silveira. Rio de Janeiro, MEC/ Fundação Casa de Rui Barbosa, 1973. Col. Estudos filológicos.

295. DÓREA, Escragnolle. Memória histórica. Rio de Janeiro, MEC, 1937.

296. DORNAS FILHO, João. O que lia num letrado de $1818 \mathrm{em} \mathrm{Mi-}$ nas Gerais, Anuário brasileiro de literatura 4:393 (1939).

297. DOURADO, Mecenas. Hipólito da Costa e o Correio Braziliense. Rio de Janeiro, 1957. 2 v. 
298. DUAS páginas de nossa Históría. Salvador, Progresso, 1954. $160 \mathrm{p}$.

299. EDMUNDO, Luís. O Rio de Janeixo no tempo dos Vice-Reis. Rio de Janeiro, Conquista, 1957. 3 v.

300. ELLIS, Myriam. Documentos sobre a primeira biblioteca pública oficial de são Paulo. Rev. de História, n.30, $388-447,1957$

301. ESTADO de Minas, 25 de outubro de 1960. Artigo e notícia sobre exposição de livros do Coraça.

302. ESTATUTOS da Real Biblioteca mandados ordenar por sua Magestade. Rio de Janeiro, 1821.

303. ESTATUTOS do seminārio episcopal de Nossa Senhora da Graca ordenados por D. Josē Joaquim da cunha Azevedo Coutinho, XII bispo de Parnambuco (sic) do Conselho de S.Magestade Fidelissíma, fundador do seminārio. Iisboa, 1798 .

304. EStatutos para os Estudos da Próvíncia de N.S. da Conceição do Rio de Janeiro, ordenados segundo as disposições dos Estatutos da Nova Universidade... Lisboa, Régia of. Tip., 1766 .

305. ESTRABÃO. Descricão da peninsula ibérica. s/l, s/d 306. EUCLIDES. A margem da histōria. Porto, Chardum, 1922.

307. EVREUX, IVo d'. História da missão dos padres capuchinhos. (Viagem ao Norte do Brasil). Lisboa, 1514.

308. ----. Viagem ao Norte do Brasil feita nos Annos de 1613 e 1614 pelo Padre Ivo.d'Evreux. Trad.Dr. Cézar Augusto Marques Maranhão, Typ. de Frias. 1814.

309. FALCAั, Aníbal. Fórmula da civilização brasileira. Recife, Diārio de Pernambuco, 1883.

310. FALCAO, Edgaṛd de Cexqueira Reliquias da Bahia, Brasil. Trad. de S. Marie Leona, E. de Neuville, J. Orazes Fernandes e outros. São Paulo; Graphicars Romiti * Lanzara, 1940. 
311. FALCÃ, Edgard de Cerqueira. Religião da terra do ouro. São Paulo, 1946.

312. FARIA, Francisco Leite de - Os impressos quinhentistas portugueses referentes exclusivamente ao Brasil. Universidade de Lourenço Marques, 1972.

313. FARIA, Maria Isabel Ribeiro de. Diderot: Carta Histórica e politica sobre 으 comércio do livro. Coimbra, Coimbra Editora, 1978. 88 p.

314. FARRINGTON, Benjamin. A doutrina de Epicuro. Trad. Edmond Jorge. Rio de Janeiro, Zahar, 1968, 156 p.

315. Féval, Paul. Jesuitas. Paris, 1878.

316. FIGUEIREDO, Guilherme, trad. e org. Tartufo '81. 3 ed. revista do Tartufo de Molière, acrescida de um ensaio sobre a poética da.tradução do teatro em verso. Rio de Janeiro, Civilização, Brasilia, INL, 1980. 221 p.

317. FILHO, Moraes Melo. Curso de literatura nacional. Rio; Garnier, 1881.

318. ---.-. Parnaso brasileiro. Rio, Garnier, 1885.

319." -.... "Qual a influência dos jesuitas em nossas letras?" "Revista Inst. Hist. Geog." Rio de Janeiro, 1917.

320. FAzENDA, José Vieira: Antiqualhas e memörias do Rio, Revista do IHGB $88: 113-116$.

321. FEIJO, Abeilard. O leitor brasileiro. Rio de Janeiro, :Garnier, s/d. 330 p.

322. FERRÃO, Antonio. A censura literária durante o governo pombalino. Estudos pombalinos. I série, n.3 separata do Boletim da Acad. das Ciências de Lisboa, v. XVII. 1927.

323. FERREIRA, Delson Gonçalves. Cartas chilenas: retrato de uma época. Belo Horizonte. ED. Lemi, 1982. 
324. FERREIRA, Félix. Notas bibliogrä́ficas. Rio de Janeiro, 1882. $16 \mathrm{ed}$.

325. FERREIRA, Francisco Leitão. Alphabetos dos lentes da insigne Universidade de Coimbra desde $1537 \mathrm{em}$ diante. Coimbra, Imp. Àcad. 1937.

326. FERREIRA, João Palma, org. Novelistas e contistas portuqueses dos séculos XVII e XVIII. Lisboa, Imp. Nac. Casa da Moeda, 1981.

327. FERREIRA, Silvestre Pinheiro. Ensaios Filosóficos. Rio de Janeiro, Documentário PUC; CFC, 1978.

328. --.-. Idéias políticas. Rio de Janeiro, documentário: PUC:CFC, 1976 .

329. --.--. Preleções filosóficas. Introđução de Antônio Paim. 2 ed. São Paulo, Grijalbo, 1970.

330. FLEIUSS, Max. Dicionário Histórico Geográfico e etnografico do Brasil. Revista IHGB, v. 47, 1 a parte, p. 167 .

331. FONSECA, Mariano José Pereira da. Máximas, pensamentos e reflexões do marquês de Maricā. Ed. dir. e anotada por Souza da Silveira. Rio de Janeiro, 1958.

332. FORTES, Luís Roberto Salinas. Rosseau: da teoria à prática. São Paulo, Atica, 1976. 134 p.

333. FRAGOSO, Tasso: O ensino militar e a Escola militar. Revista "Nação Armada", n.5, abril 1940.

334. FRANÇA, Antônio d'Oliveira'Pinto, org. Cartas Bahianas: 1821-1824. São Paulo, cia. ED. Nacional; Rio de Janeiro, Núcleo Editorial da U.E.R.J, 1980. 184 p.

335. FRANÇA, Pe. Leonel. A filosofia no Brasil. 3 ed. Rio de Janeiro, Pimento de Mello \& Cia. 1928.

336. FRANCo, Afonso Arinos de Melo. Conceito de civilização brasileira. São Paulo, cía. ed. Nacional, 1936. 238.p. 
337. FRANCO, Afonso Arinos de Melo. 으 indio e a Revolução Francesa. 2 ed. Rio de Janeiro, J. Olympio/MEC, 1976.

338. FRANCO, Francisco de Melo. O reino da estupidez. Lisboa, Tipografia de Academia, 1823.

339. FRANCOVICHI, Guiliermo. Filósofos brasileiros. Rio de Janeiro, 1939.

340. FRECHES, Claude-Henri. Le Théâtre du p. Anchieta. Napolis, 1961.

341. FREITAS, José Antônio de - 을irismo brasileiro. s/l, 1877 .

342. FRIAS, José Maria Correa de. Memória sobre a tipografia maranhense. 'São Luĩs, 1866.

343. FRIEIRO, Eduardo. O diabo na Iivraria do cônego e outros temas mineiros. Rio de Janeixo, 1957.

344. -----. O mameluco Boaventurà. 3 ed. São Paulo, Saraiva 1962.

345. -----. OS Iivros, nossos amigos. Belo Horizonte,1941, 2.ed., aumentada, Belo Horizonte, Inconfidencia, 1945.

34.6. FURLAN, Oswaldo A. Das letras latinas às luso-brasileiras. Florianópolis, ed. do Autor, 1984.

346. FURLONG, Guillermo.. Bibliotecas argentinas durante la dominación hispánica. Buenos Aires, 1944.

345. FURTADO, Francisco Xavier de Mendonça. A Amazônia na era pompalina.' 1751/1759. 'Rio de Janeiro, IHGB, 1963. $3 \mathrm{v}$.

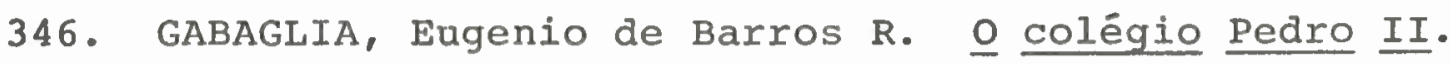
Rio de Janeiro, 1914. 
347. GALVAO, Ramiz. O pülpito no Brasil. Rio de Janeiro, Revista do Instituto histórico, CXVI, s/d.

348. GAMA, Basilio da. Uruguai, 3ed., Rio de Janeiro, Agir, 1976.

349. GANDAVO, Pero de Magalhães. Tratado da terra do Brasil, história da Província de Santa Cruz. Belo Horizonte, Ed. Itatiaia, SP, EDUSP. 1980. 150 p.

350. GARCIA, Manuel Correia. História da Independência da Bahia. Typ e Encardenação Empresa Editora, 1900.

351. GARCIA, Rodolfo. Denunciaçōes do Santo ofício em Pernambuco. Rio de Janeiro, 1929.

352. ----. Histöria Geral. s/l, s/d

353. --.--. Os judeus na histöria do Brasil. Rio de Janeiro, Uri zwerling, 1936.

354. GARRAUX, Anatole Louis. Bibliographie brësilienne: Catalogue des ouvrages frangais \& latina relatifs au Brésil. (1500 - 1898) 2 ed. Rio, J. Olympio, 1962. $519 \mathrm{p}$.

355. GARRET, Almeida. Bosquejo da história da poesia da lingua portuguesa. Lisboa, 1829 .

356. GENOVESI, Antonio. A instituição da lógica. RJ, PUC/RJ, Cons. F Cultura, Ed. Documentário, 1977. 127 p.

357. GOELDI, Emilio A. Alexandre Rodrigues Ferreira. Brasi1ia, Ed. Univ. /CNPQ, 1982. 80 p.

358. GOES, Eurico de. 으 culto e 으 amor ao livro - evolução $\frac{\text { do }}{\text { de }} \frac{\text { livro e }}{\text { editores, }} \frac{\text { da }}{1932 .}$ biblioteca. São Paulo, Cooperativa

359. GONÇALVES, Alvaro. Aspectos humanos, históricos e literários de Pernambuco oitocentista. Rio de Janeiro, Letras Brasileiras, 1944. 
360. GONZAGA, Tomas Antonio. Marilia de Dirceu. Biografia e Introdução de M. Cavalcanti Proença. Rio de Janeiro, Ediouro, s.d.

361. GRAHAM, Maria. Journal of a voyage to Brazil. London, 1824 .

362. GRAVATA, Hélio. Contribuições bibliográficas para a história de Minas Gerais. Belo Horizonte, 1969. Cópia datilografada ex. Col. Mineiriana.

363. GRIECO, A. Evolução da prosa brasileira. Rio de Janeiro, Arièl, 1933.

364. GROPP, Dorothy. Bibliotecas do Rio de Janeiro e de são Paulo. Trad. Francisco Azevedo. Separata da Rev. do Arquivo, LxvIII. Dep. de cultura, São Paulo, 1940 .

365. GUEDES, João Alfredo Libânio. História administrativa do Brasil, a união ibérica: administração do Brasil holandês. Ed. rev.e anotada por Vicente Tapajós. 2 ed. Brasilia, Ed. Univ. de Brasilia/Fundação Centro de Formação do Serviço público, 1983. V.3 Tomo I e II. $504 \mathrm{p}$.

367. GUERRA, F. Bibliografia médica brasileira. Yale Un, 1958.

368. GUERREIRO, Fernão. Relaçam das covsas que fizeram os padres da Companhia de Jesus. Lisboa, 1605.

369. GUIA do viajante na bahia. s/l, s/d.

370. GUIMARÃEs, Argeu. Histōria das artes plásticas no Brasil. Rio de Janeiro, Imp. Nac., 1930.

371. GUIMARÃES, Ruth. Dicionário da mitologia grega. São Paulo, Cultrix, s/l. 
372. HALLEWELL, L. Books in Brazil. A history of the publishing Trade, 1982, 537 p.

373. --..-. O livro no Brasil (sua história). Trad. Brasil da Penha. Villa Lobos e Lêliotiọurenço Oliveira. São Paulo, T.A. Quieroz, 1985.

374. HESIODO. Teogonia: a origem dos deuses. Estudo e trad. de J. Torrano. São Paulo, Massao Ohno - Roswitha Kempf/ Editores, 1981. 160 p.

375. HESSEL, Lothar Francisco. O teatro jesuístico no Brasil. Porto Alegre, UFRGS, 1972. 109 p.

376. -.... Antologia dos poetas brasileiros da $\frac{\text { dase }}{512} \frac{\text { folo- }}{\text { nial. }}$

377. HOLANDA, Sérgio Buarque de. História da civilização Brasileira. 3 ed. São Paulo, DIFEL, 1973.

378. HOMENS de São Paulo: reimpressão parcial da 1 ed. (1954). São Paulo, Abrii Cultural, 1978. 223 p.

379. HOMERo. Odisséia. Trad. Antonio Pinto de Carvalho. São Paulo, Abril cultural, 1978. 223 p.

380. HORCH, Rosemarie E. Catālogo dos incunábulos da Biblioteca nacional. Rio de Janeiro, 1956.

HUM AMIGO DA ORDEM.

382. A Amérịca Ingleza e o Brasil contrastados por um amigo ordem Bahia.

383. IGNOTUS. Sessenta anos de jornalismo. $\mathrm{s} / 1,1883$.

384. IBERT, E. Anderson. Histöria de la literatura hispanoamericana. 5 ed. Buenos Aires, Fondo de cultura econômica, 1965, 473. p.

385. IMPRENSA NACIONAL: ACtividade de uma casa impressora, Lisboa, Imprensa Nacional, 1975. 
389. INDICE Militar de todas as leis, alvarās, cartas Régias, decretos etc. Rio de Janeiro, Imp. Régia, 1812.

390. INFORMAÇÕES Jesuîtas. Lisboa, 1584.

391. INOCENCIO. Dicionário bibliográfico português. s/l, s/d

392. INVENTÅRIO dos documentos relativos ao Brasil, existentes no archivo da Marinha e Ultramar de Lisboa. Rio, Bib. Nacional, 1913/36. 8 v. (Do conselho Ultramarino extinto em 1833 ao Arq. Hist. Ultramarino).

393. INVENTÁRIOS e testamentos doc. sec. hist. São Paulo, Pub. Oficial, 1975. 229 p.

394. IPANEMA, Marcello de \& Cybelle de: História da comunicação: notas, Brasilia, EUB, 1967.

395.

A tipografia na Bahia: documentos sobre suas origens, Rio de Janeiro, Instituto de comunicação Iparema, 1977. $128 \mathrm{p}$.

396.

-----. Imprensa fluminense, ensaios e trajetos. Rio de Janeiro, instituto de comunicação Ipanema, 1984. 441 p.

397. JESUS, Rafael de - Castrioto Lusitano. s/l, s/d.

398. JORNAL do Brasil. Rio de Janeiro, 3 de outubro de 1937. 399. JOSE, Oiliam. Historiografia mineira. Belo Horizonte, $1959,216 \mathrm{p}$.

400. JUNTA de Investigação do Ultramar. Colóquios sobre o Brasil. Lisboa, 1967. $171 \mathrm{p}$.

401. KEITH, Herry Edward, S.F. Conflito e continuidade na sociedade brasileira. Rio de Janeiro, 1970.

402. KIDDES, Daniel. Reminiscências de viagem e permanência do Brasil. São Paulo, Martins, 1951. 
403. KOSTER, Henry. Travels in Brazil, London, Iongman, 1816, reimpr. Carbondale, Southern Illionis University Press, 1966.

404. LA BARBINAIS. Voyage autour du monde. $\mathrm{s} / \mathrm{l}, \mathrm{s} / \mathrm{d}$.

405. LA BARCA, Don Pedro Calderon de. Obras Completas. II Comédịas Madrid, Aguilar,. 1973. 2158 p.

406. LAMEGo, Alberto. Academia Brasillica dos Renascidos. Paris-Bruxelas, 1923.

407. LAMEgo, A. Mentiras históricas. Rio de Janeiro, s/d.

408. -----. Novas epanáforas. s/l, s/d.

409. LAPA, J. R, do. Amaral (org.). Livro da visitação do Santo ofício da Inguisição ao Estado do Grão Parā: $\underline{1763}-\underline{1769}$. Vozés, 1978.

410. LAPA, M. Rodrigues. Licões de Literatura portuguesa. 10 ed. Coimbra, coimbra Ed. 1981. 499 p.

411. LAvradio, Marquês do. Cartas do Rio de Janeiro: 1769 1776. Rio de Janeiro, Arquivo Nacional, 1975. v.1. $191 \mathrm{p}$.

412. -..-.. Idem. idem. Rio de Janeiro, Secr. Cultura, INELIVRO, $1978,171 \mathrm{p}$.

413. LEAL, Antonio Henriques. Panteon maranhense. Rio de Janeiro, 1873 .

414. -..... Apontamentos históricos dos jesuitas no Brasil. Lisboa, 1874 .

415. LECLERC, Max. Lettres du Brésil. Paris, Plon, 1890.

416. LEITE, Serafim da silva. "As primeiras bibliotecas do Brasil". Revista de cultura. Rio de Janeiro, 1937. v.21, p. 33 .

417. -.--. (org.) Cartas dos primeiros jesuitas do Brasil, são Paulo. Comissão do IV centenário da cidade de são Pau$10,1954$. 
418. LEITE, Serafim da silva. Histöria da Companhia de Jesus Brasil. Rio de janeiro, 1938/1950, $10 \mathrm{v}$.

419. --n. Novas cartas jesuítas

420. ----- Páginas da história do Brasil. São Paulo, Cia. Ed. Nacional, 1937. V.93.

421. - Revista de Cultura. Rio de Janeiro, 1938.V.24, p. 48 .

422. LEONARD, Irving A. The books of the conquests. Cambridge Mass, 1949 .

423. ----. Los libros del conquistador. México. Fondo de Cultura 1979 .

424. LESKY, Albin. A tragédia grega. São Paulo, Perspectiva, 1971. 266 p.

425. LESSA, Clado Ribeiro de. "As bibliotecas brasileiras dos empos Coloniais." In: Revista do Inst. Hist. Geog. v. 191,1946 .

426. LEWIN, Boleslao. La Inquisicion en Hispanoamérica.

Buenos Aires, Ed. Projeccion, 1962.

427. ----. Los judios bajo la Inquisicion en HispanoaméricaBuenos Aires, Dedalo, 1960.

428. IIMA, Abreu e. Bosquejo histōrico, político e literário do Brasil. Lisboa, 1835 .

429. LIMA, Arthur Cerqueira da Rocha. Lucas da Feira, 으 Saltéador. Cachoeira, Litro- Typographia "genesis", 1896.

430. LIMA, Manuel de Oliveira. D. João VI no Brasil. Rio de Janeiro, J. Olympio, 1946.

431. LIMA, Oliveira. Aspectos da literatura colonial brasileira. Leipzig, Bróckhaus, 1896. 301 p. 
432. LIMA, Oliveira. "Os primeiros livros de Direito Internacional no Brasil" 'Rev. Ac. Fac. Direito Recife,' 127, v.35, p.3.

433. --..-. Pernambuco e seu desenvolvimento literário. Leipzig, 1895.

434. LIMA JUNIOR, Augusto. A capitania das Minas Gerais. Lisboa, 1940.

435. LIMA JONIOR, Francisco Pinheiro \& ĖASTRO, Dinorah d'Araújo Berbert de. Padre mestre con. Antonio Joaguim das Mercês 1786 - 1854, Mestre dé Filosofia. Salvador, Universidade católica do Salvador, 1977.

436. IINDLEY, Thomas. Narrative of a voyage to Brazil. London, $1805^{\circ}$.

437. LINS, Ivan. Aspectos do padre Vieira. s/l, s/d.

438. LISANTI, Luís. Negócios colóniais, numa correspondência comercial do século XVIII. Rio de Janeiro, 1973. $5 \mathrm{v}$.

439. LISBOA, Baltasar da Silva. Anais do Rio de Janeiro, 1834. 440. ----.. Memōrias do Erasil Reino. s/l, s/d

441. IISBOA, J.C. Obras: Belo Horizonte. Revista do Arquivo púb1ico de Minas, s/d.

442. --1---. Uma peça desconhecida sobre 으 holandês na Bahia. Rio de Janeiro, INL, 1961. 150.p.

443. LISBOA, João Francisco. Obras. S\%1, 1865.

444. Lista das Bibl. no Brasil em 1930. Estatisticas Int. do Brasil. Rio de Janeiro; 1932. v.2.

445. LIVRo do tombo da Misericórdia da Bahia. S/1, s/d. 
446. LIVRO do primeiro governo do Brasil 1607/1633. Pref. J.C. Macedo Soares. Rio de Janeiro, Imprensa Nacional, 1958.

447. LOBO, Ovídio da Gama. Os jesuítas perante a história. Maranhão, 1860 .

448. LOPES, Antonio. História da Imprensa no Maranhão. Rio de Janeiro, 1959.

449. LUBIN, Harold. Heroes and anti-heroes. Chicago, Chandler - Publishing. 1968.

450. LUCCOCK, John. Notes of Rio de Janeiro and the southern parts of Brazil taken during a residence of ten years in that country from 1808 to 1818 . London, Leigh, 1820 .

451. LUDWING, Emil. Goethe. Porto Alegre, Globo. 2 ed. 1949. $391 \mathrm{p}$.

452. LuIs, Norton. A corte de Portugal no Brasil. s/l, s/d.

453. LUTTERBECK, Jorge Alfredo. Jesuitas no sul do Brasil. S.Leopoldo (RS), Instituto Anchietano de Pesquisa, 1977. $172 \mathrm{p}$.

454. MARCARTNEY, George, fist Earl Macartney: Journal 으 a voyage from Londom to cochin China, 11th July 1792 - 15th June 1793, Manuscrito 3352, Wellcome Historical Medical Library, London.

455. MACAU - Imprensa. Tipos móveis nos fins do século XVI, pela cia. de Jesus, padre Alexandre Valiganano.

456. MACEDO, Joaquim Manuel de. Ano Bibliográfico brasileiro $\mathrm{s} / 1,1876$.

457. MACEDO, Roberto. Bibliografia de Minas Gerais. "Correio da Manhã", Rio de Janeiro., 1953, novembro, 12,13, $18,19,21,26$. (Ao alto do título: Notas histōricas). 
458. MACEDO, Sérgio D.T. de. A literatura no Brasil Colonial. Rio de Janeiro, Brasilia Editora, s.d.

459. MACHADO, Alcântara Vida e morte do Bandeirante. São Pau10, 1929.

460. -----. Idem. 2 ed. São Paulo. Martins, s.d.

461. MACHADO, Cirilo Vokmar. Coleção de memórias relativas às vidas dos pintores, escultores, arquitetos e gravadores portugueses e estrangeiros que estiveram em Portugal. Lisboa, 1823.

462. MACHADO, Diogo Barbosa. Biblioteca lusitana. $s / 1$, s/d

463. MACHADO, Lourival Gomes. Barroco mineiro. São Paulo, Perspectiva, 1969.

464. MACHADO, Max Lopes - História da Provincia da Paraíba. 1912.

465. MACHADO FILHO, Aires da Mata. Arraial do Tijuco Cidade de Diamante. Rio de Janeiro, MEC, 1944.

466. MADUREIRA, J. A Companhia de Jesus e 으 Brasil. Rio de Janeiro, 1926.

467. MAGALHAES, Domingos. Discurso sobre a história da literatura do Brasil. s/l, 1836.

468. -.... . Opúsculo históricos e literários. s/l, s/d.

469. MAISTRE, Comte J. de. Pensẻes sur la Relation philosophique; politique, l'histoire et la litterature. 'Toulose, s/d, Ed. Privat. 2 v.

470. MANCINI, Augusto. História da literatura grega. Lisboa, Editorial Estủdios cor, 1973.

471. MANCHESTER, Alan Krebs: The transfer of the portuguese Court to Rio de Janeiro in. Cciflict and continuity in Brazilian Society, com. Henry H. Keith e S.F. Edwards, Columbia, University of South carolina Press, 1969. 
472. MANUEL, Francisco . Epariőforas. s/l, s/d

473. MAQUIAVEL. O príncipe. Brasilia, Ed. Univ. Trad. Sêrgio Bath, 1979, 97 p.

474. MARCONDES, Athayde. Pindamonhangaba através de dois e meio séculos. $(1672$ - 1922). São Paulo, Typ. Paulista, 1922.

475. MARIA, Pe. Júlio. A religião. Ordens religiosas. In: Livro do centenário. Rio de Janeiro, Imp. Nacional, 1900 .

476. MARRIANI, José. Exposição de acontecimentos do Pará. Rio de Janeiro, 1834.

477. MARQUES, Manuel Eưfrázio. Apóntamentos históricos da Província de São Paulo. Rio de Janeiro, 1879. 2 v.

478. MARQuES, Maria Adelaide Salvador. "A Real Mesa Censória e a cultura racinal (aspectos da geografia cultural portuguesa no século xVIII)". Separata do Boletim da Biblioteca da Universidade de Coimbra. v. XXVI.

47.9. MARROCOS, Luis Joaquim dos Santos. Cartas. Anais da Biblioteca Nacional, v.65, 1934.

480. MARTINS, Dionysio Gonçalves. Catálogo da exposição Bahiana no ano de 1875. Bahia, Imprensa Ecônomica, 1875.

481. MAR'TINS, Eduardo. Primeiro jornal paraibano: apontamentos Históricos, João Pessoa, Sec, 1978.

482. MARTINS, Heitor. Neo-çlassicismo una visão temática. Rio de Janeiro, ABL, 1982.

483. MARTINS, J. Carlos. Origem. da Escola Militar. In Revista da E cola Militar. Ano XVI, n. 27, agosto 1934, p. $60-62$.

484. MARTINS, Joaquim Dias. Os mártires pernambucanos víctimas da iiberdade nas duas revoluções em 1710 e 1810. Recife, 1853 : 
484. MARTINS, Mário, S.J. Teatro quinhentista nas naus da India. Lisboa, Edições "Brotéria", 1973, 71 p.

485. MARTINS, Oliveira. O Brasil è as colōnias portuguesas. Lisboa, 1887.

486. MARTINS, Wilson. A palavra escrita. São Paulo, 1957.

487. -..-. História da inteligência brasileira. São Paulo, Cultrix, $1976 / 1978,7 \mathrm{v}$.

488. MARTIUS, Karl Friedrich von. Como se deve escrever a história do Brasil. Lisboa, 1843.

489. MATTOS, Florisvaldo. A comunicação social na Revolução dos Alfaiates. Salvador UFBA, 1974.

490. MAtos, João Xavier de. Rimas. Iisboa, Imp. Régia, 1827. $2 \mathrm{v}$.

491. MAtTos, José Veríssimo de. A Imprensa em Associação do quarto centenārio do descobrimento do Brasil: Livro do Centenário, Rio de Janeiro, Imprensa Nacional, 1900: vl. (4): 32

492. MATTOS, Ricardo Pinto de. Manual bibliographico portuguez de livros raros, clássicos e curiosos. Porto, liv. Portuense, 1878. Rev. e pref. por Camilo Castelo Branco.

493. MATTOSO, Katia M. de Queiroz. Presença francesa no movimento democrático baiano de 1798. Salvador, Ed. Itapuã, 1969.

494. MAWE, John. Travels in the interior of Brazil, particulary in the gold and Diamond districts of that country. London, 1812 .

495. MAY, Luiz Aug. Protesto feito à face do Brasil Rio de Janeiro, 1824. 
496. MELLL, José Gonsalves de. Yempo dos flamengos. 2.ed. Recife, gov. Est-Sec Ed. e Cult., Dep. Cult, 1978.

497. MELLO, José Barbosa. Síntese histōrica do livro. 2 ed. corrig. São Paulo, IBRASA - INL, 1979, 334 p.

498. MELLO, Antonio Joaquim de. Biografias de alguns poetas e homens ilustres da provincia de Pernambuco. s/l, $\bar{s} / \bar{d}$.

499. --.-. Biografia de José Natividade Saldanha. Recife, 1895.

500. MELO, D. Francisco Manoel de. Hospital das letras. Rio de Janeiro, Bruguera, s/d. $142 \mathrm{p}$.

501. - - - O fidalgo aprendiz. Lisboa, livraria Clässica Ed. 4 ed. s/d. 105 p.

502. MELO, Francisco Freire de. Representação às cortes e Invectiva contra a Inquisicão. Lisboa, 1821.

503. MELO, José Marques de. Sociologia da imprensa: a implantação, Petrópolis, Vozes, 1973.

504. MELO, Teixeira de. Efemérides nacionais. s/l, s/d.

505. MEMÓRIAS do Marquez de Pombal. Lisboa, 1872.

506. MEMORIAS econômicas da Academia Real das Sciencias de Lisboa, para o adiantamento da agricultura, das artes e da industria em Portugal, e suas conquistas. Iisboa; Of. Acad. 1790. Fac- simile ed. da Fundação Brasileira para a conservação da natureza/Conselho Federal de Cultura. 1977, Ri. 187 p.

507. MENDES, Teixeira. A pätria Brasileira. Lisboa, 1882.

508. MENDES DE ALMEIDA, Cândido. Memōrias históricas do extinto estado do Maranhão. Rio de Janeiro, 1860. 2 v.

509. MENDONÇA, Carlos Sussekind de. Histöria do Teatro brasileiro. Rio de Janeiro, 1926. 
510. MENDONÇA, H. de - Primeira visitação do santo oficio às PARTES DO Brasil. São Paulo, Paulo Prado, 1929.

511. --.-. A A Amazônia na era pombalina. São Paulo, IHGB, 1962 .

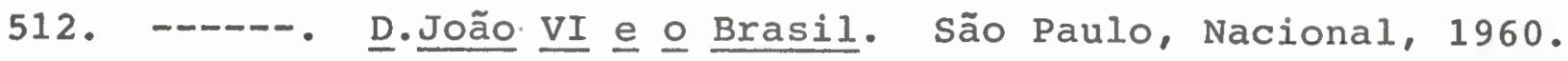

513. MENDONÇA, Marcos Carneiro de. O intendente Câmara. Rio de Janeiro, 1933.

514. MENESES, Manoel Joaquim. Exposição histórica da maçonaria no Brasil. Rio de Janeiro, 1857.

515. MENEZES, Djair. Evolução do pensamento literário no Brasil. s/l, s/d.

516. MENEzES, Joaquim Furtado de. Igrejas e irmandades de Ouro Preto. BH, IEPHA - MG, 1975. 155 p.

517. MENSÅRIo do Jornal do Commércio. Rio de Janeiro, 1940. T. 12, p. 53 e T. 11 - p. 65 ? a 747 .

518. MIRALLES, José de. História militar do Brasil. Rio de Janeiro, v. 22 dos Anais da Biblioteca Nacional, s/d.

519. MIRANDA, Francisco Gonçaives. Memória histórica da Imprensa Nacional, Rio de Janeiro, Imprensa Nacional, 1922 .

520. MOACIR, Primitivo. A instrução e as provincias. $\mathrm{s} / 1, \mathrm{~s} / \mathrm{d}$.

521. ------. A universidade de D.João VI. "Estado de São Pau10", dez 1939 - 10 de janeiro 1940:

522. MOBRAL. Mapa Cultural. Rio de Janeiro, 1980.

523. MOLIERE. O Tartufo; Escola de Mulheres; 0 Burguês fidalgo. Trad. Jacy Monteiro, Millor Fernandes, Octavio Mendes Cajado. São Paulo, Abril Cultural, 1980. 429 p.

524. MOISÉs, Massaud. Bibliografia da literatura portuguesa. São Paulo, Saraiva/EDUSP. 
525. MOLINA, Tirso de. El burlador de Sevilla, El condenado por disconfiado; la prudencia en la muyer. Edición e introductión de Pedro Henriquèz Urena. Buenos Aires, Editorịal Losadas S.A, 4 ed, 1976. 280 p.

526. MONCADA, I. Cabral de - Um iluminista português do século XVIII: 'Luis Antonio Vernez. s/l, s/d.

527. MONIz de Aragão. Antonio Ferrão. A bahia e os seus governadores na República. Banhia, Imprensa official do Estado, 1923.

528. MONTEIRO, Mário Ypiranga. Fases da literatura amazonense. Manaus, Universidade do Amazonas, Instituto de Ciências Humanas, 1977. 205 p.

529. MONTEIRo, Tobias. Histōria do Império. Rio de Janeiro, 1927.

530. MONTENOR, Jorge de. Diana. s/l; s/d

531. MONTENEGRO, João Alfredo de Souza. O liberalismo radical de Fr. Caneca. Rio de janeiro, Tempo Brasileiro, 1978 .

532. MONTES, José, - Góngora 'y la poesia portuguesa del siglo.XVII. Madria, 1956.

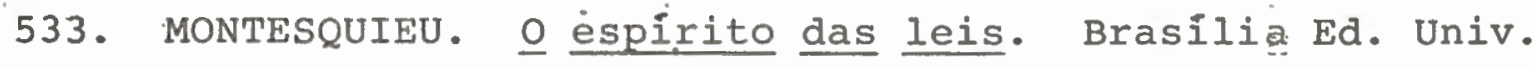
1982. Trad. Fernando Henrique Cardoso e Leôncio Martins Rodrigues. 720 p.

534. MORAES, A.J. de Melo. Fitografia ou botânica brasileira. Rio de Janeiro, 1881.

535. MORAES, Rubens Borba Alves de. Bibliografia brasileira do periodo colonial ...., São Paulo, IEB/USP, 1969.

536. -..-. Bibliographia brasiliana... published abroad before … 1822, Rio/Ansterdam, Colibris, 1958.

537. --.-. Livros e bibliotecas no Brasil Colonial, Rio de Janeiro; LTC, 1979. 
538. MORAES; Rubens Borba Alves de. O problema das bibliotecas brasileiras. Rio de Janeiro, 1943.

539. --... Relatório do diretor da Div. de Prep. dá Bibl. Nac. ao Min. Ed. e Saúde (março de 1945). Rev. de Biblioteconomia de Brasilia, v. 2, 1974.

540. MARAES, Rubens Borba e Berrien; Willim. Manual bibliogrāfico de estudos brasileiros. Rio de Janeiro, gráfica Souza, 1949.

541. MORAIS, Francisco. Catálogo dos manuscritos da Universidade de Coimbra Relativos ao Brasil. Coimbra, 1941.

542. MORAIS, Francisco. Estudantes da Universidade de Coimbra nascidos no Brasil. Brasilia, supl. do v. 5, 1949.

543. MORAIS, José Mariz de. 'Nóbrega. Rio de Janeiro, Imp. Nacional, 1940. Separata da Revista do IHGB.

544. MORAIS, Melo. A independência do Brasil. s/l, s/d.

545. -.... A independência e 을 império do Brasil. Rio de Janeiro, 1877.

545. --..-. Brasil histórico. s/l, s/d.

546. ----. Corografia histōrica e 으 império do Brasil. Rio de Janeiro, 1877.

547. -.---. História do Brasil Reino e Brasil Império. Rio de Janeịro, 1871. 2 v.

548. -.-... História dos jesuitas e suas missōes na América do Sul. Rio de Janeiro, 1872, 2 v.

549. MORALISTAS do século XVIII. Rio de Janeiro, Documentário: PUC - CFC, 1979.

550. MOREIRA, Juliano. O Progresso das ciências no Brasil. Anais da Biblioteca Nacional, 1913. v. XxxV, 1916. 
551. MOTA, Artur. Histöria da literatura brasileira. s/l, s/d.

552. MOURA, Carlos Francisco. O teatro em Mato Grosso no século XVIII. Cuiabá, Edições UFMT, 1976. 84 p.

553. MUIR, Christoffel. História dos jesuitas no ministério de Pombal. Pará, 1923.

554. MULER Daniel Pedro. Ensaio d'um quadro estatístico da Provincia de São Paulo. São Paulo, 1838.

555. MULLER, Christiano. Memória histórića sobre a religião na Bahia, 1823 - 1923. Bahia, Imprensa Official do Estado, 1923.

556. MUNIZ, Heitor. Vultos da literatura brasileira. s/1, $s / d$.

557. NABUCO, J. José de Anchieta. III centenário. Paris-Lisboa, 1900 .

558. NAEHER, Julius. Land und Lente in der brasilianischen Provinz Bahia. Leipzig, Verlag von Gustav Weigel, 1881 .

559. NASH, Roỳ. A conquista do Brasil. São Paulo, 1938.

560. NASSAU, Joahann Maurits von. Gregen, a humanist in Europe and Brasil. Haia, 1979.

561. NEIL, Paul A. Mc. "Livros raros na Biblioteca Oliveira Lima." "Bol. União Pan Americana U.S.A." 1935, setembro, p. 584 .

562. NEIVA; Artur. Esboço histórico sobre a botânica e a zoologia no Brasil. São Paulo, Soc. Imp. Paulista, $\overline{1929 .}$ 
563. NINTzoviCH, Oscar. 400 anos de teatro. São Paulo, Correio Paulistano, 1954 - 24/01/54, 6ạ seção.

564. NÓBREGA, Manuel da. Cartas do Brasil. Rio de Janeiro, ABI, 1931.

565. ----. Diálogo sobre a conversão do gentio. s/1,1554.

566: NORTON; Luís. A corte de Portugal no Brasil. São PauIo, Cia. Ed. Nacional, Brasilia, INL, 1979. 338 p.

567. NOVEAU Bibliothéque des bouages anciens et modernes. Paris, s/d, $12 \mathrm{v}$.

568. "O. ARQUEOLLOGO PORTUGUES" - revista. Ministério da Educação Nacional, secretaria de Estado de Instrução e Cultura - Direção Geral para Assuntos Culturais. Museu Nacional de Arquitetura e Etnologia.

569. O NASCIMENTO da moderná pedagogia: Verney. Iritrodução do prof. Antonio Paim. Rio de Janeiro: Documentārio: PUC:CFC, 1979.

570. O TUTOR Namorado ou as indústrias das mulheres. Ed. Org. por Carlos Francisco Moura, Cuibá, Coleção Memória Social da cuiabania, 1982. ed. fac-similar,

571. OS DESCOBRIMENTOS e a problemática cultural do século XVI. Coimbra, 1973.

572. OLIVEIRA, José. Teixeira de. História do Estado do Espírito Santo. 2, ed ampliada e atualizada. Vitória ES, Fundação Cultural do ES, 1975, 596 p.

573. OLIVEIRA, Manfredo Araújo de et allii. Kant. Brasilia, Ed. UnB, 1981, 83 p.

574. OLIVEIRA, Tarquínio J. B. de. As cartas chilenas fontes textuaìs. São Paulo, Referência. 1972.

575. OLIVEIRA NETO, Luis Camilo. "Histōria, Cultura e liberdade. Rio de Janeiro, 1975. 
576. OMEGAN, Nelso. A cidade cultural EBRASA/MEC, 1962. 2. ed.

577. ORTA, Teresa Margarida da Silva. Aventuras de Diófones. $s / 1, s / d$.

578. ORTEGA Y GASSET: Histōria como sistema. Mirabeau ou 으 politico. Brasilia, Ed. UnB, Trad. Juan A. Gili Sobrinho e Elisabeth Hanna Côrtes Costa. 1982. 86 p.

579. PACHECO, Félix. Duas Charadas bibliográficas. Rio de Janeiro, Revista do Instituto Histórica , v. 47, 1931.

580. PAGANO, Sebastião. O conde dos Arcos e a revolução de 1817. São Paulo 1938.

581. PAIM, Antonio, org. Pombal e a cultura brasileira. Rio de Janeiro, Edicões Tempo Brasileiro, Fundação Cultural Brasil-poṛtugal, 1982. $137 \mathrm{p}$.

582. PAIVA, Tancredo de Barros. Achegas e um dicionário de pseudônimos. Rio de Janeiro; Ed. J. Leite, 1929.

583. PAIXAO, Mucio da - 을 teatro no Brasil. Rio de Janeiro, Ed. Moderna, s/d.

584. PARA, João Francisco Madureira. o déspotismo desmascacarado. Lisboa, 1822 .

585. PARDINHAS, Albertina Alves. Teatro de Gil Vicente. Porto, Ed. Asa, 1983.

586: PASSOS, Alexandre. A imprensa no periodo colonial, Rio de Janeiro, MEC, 1952.

587. PASSOS, Filipe. A viagem de Patroni pelas provincias brasileiras. Lisboa, 1851. $2 \mathrm{v}$.

588. PEIXoTo, Afrânio. Breviário da Bahia . Rio de Janeiro, agir, 1945 .

589. --n-. História da literatura brasileira. s/l, s/d 
590. PEIXOTO, Afrânio. Livro de Horas. Rio de Janeiro, Agir, 1945.

591. ---.-. Noções de história da educação. São Paulo, Cia. ed. Nacional, 1933.

592. -.-.- Noções de história da literatura brasileira. Rio de Janeiro, F. Alves, 1931.

593. --.-. Panorama da Literatura Brasileira. São Paulo, $\mathrm{s} / \mathrm{l}, \mathrm{s} / \mathrm{d}$.

594. PEIXOTO, Rocha. A terra portuguesa. s 1, s/d.

595. PEQUENO Dicionário de Literatura Brasileira, Moiséis et elli. São Paulo, Cultrix, 1967. 278 p.

596. PEREIRA, Antonio Pacífico. Memória sobre à Medicina na Bahia. Salvađor, imp. Of., 1923.

597. PEREIRA, José Esteves. O pensamento político em Portugal no Século XVIII: Antonio Ribeiro. dos Santos. Lisboa Imprensa Nacional - Casa da Moeda, 1983. 430 p.

598. PEREIRA, Nuno Marques. O peregrino da América. Lisboa, 1765.

599. PERIE, Eduardo. A literatura brasileira nos tempós colo-

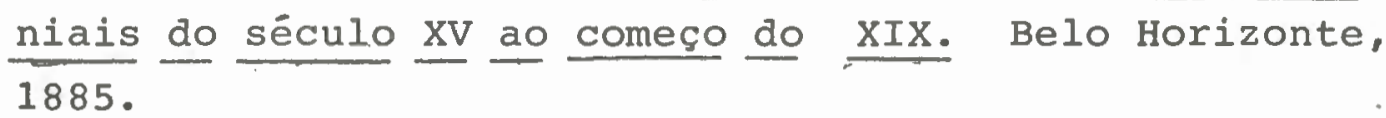

600. PIRASSUNUNGA; A. Sampaio. O ensino militar no Brasil. "Revista Militar", 1936.

601. PINHEIRO, Fernandes. Curso elementar de literatura nacional. Rio de Janeiro, Garnier, 1862.

602. -----. Discurso sobre a poesia em geral e em particular no Brasil. Rio de Janeiro, Garnier, 1852.

603. -----. Resumo de história literária. Rio de Janeiro, Garnier, 1872 . 
604. PINHO, wanderley de Araújo. História de um engenho do recôncavo. Rio de Janeiro, $\mathrm{Z}$. Valverde, $\overline{1946 .}$

605. -..... Idem. 2 ed., ilustrada e acrescida de um apêndice. São Paulo, Ed. Nacional, 1982.

606. PINTA Llorence, Miguel de la. La inquisición española $y$ los problemas de la cultura de la intolerancia. $\mathrm{s} / 1, \mathrm{~s} / \mathrm{d}$.

607. PINTo, Américo cortez. Da arte da imprimisão. Iisboa, 1948 .

608. PINTO, Roquete Ensaios brasileiros. $s / 1, s / d$.

609. PITA, Sebastião da Rocha. História da América portuguesa. Lisboa, Offcina de Joseph Antonio da Silva, 1878, 513 p.

610. PLAUTO \& TERENCIO. A comédia latina. Prefãcio, seleção, tradução e notas de Agostinho da Silva. Rio de Janeiro, Ediouro, s/d. 452 p.

611. PONTES, Joel. Teatro de Anchieta. Rio de Janeiro, MEC/ SNT, 1978. 86 p.

612. PRADO , J.F. de Almeida. A Bahia e as capitanias do Centro do Brasil, $(1530$ - 1626). São Paulo, Cia. Ed. Nacional, 1948. 21 (Brasiliana, série 5a, v. 247 - a).

613. --..-. A idade de ouro da Bahia. $(1530$ - 1626). "São Paulo, Cia. Ed. Nacional, 1930. 315 p.

614. PRATT, André. Notas históricas sobre as missões carmelitanas. Recife, 1941.

615. PRESAS, D. José. Memórias secretas de D. Carlota Joaquina. Rio de Janeiro, 1940.

616. PRIMO Congresso Mondiale delle Biblioteche e di Bibliografia Roma-Venezia, 1931. v.2, p. 321. La Bibliogra phie des jésuites. 
617. PRIOR, James. Voyages along the eastern coast of Africa to Moçambique--- to st Helena, Rio de Janeiro, Bahia and Pernambuco in Brazil. London, 1819.

618. QUERINo, Manuel Raymundo. A Bahia d'outrora, vultos e Eactos populares. 2 ed. aum. Bahia conōmica, 1922.

619. QUIRINO, Tarcizio do Rego. Os habitantes do Brasil no fim do século XVI. Recife, Univ. 1966, Imp. Universitảria, $91 \mathrm{p}$.

620. RAEZYNZKI, A. Diccionaire historique- artistique du Portugal. Paris, 1847.

621. RAIOL, Domingos Antônio: Motins políticos, ou histōria dos principais acontecimentos politicos da Província do Pará desde 으 ano de 1821 até 1835. Rio de Janeiro $1865-1890,5 \mathrm{v}$.

622. RAMALHO, Américo da Costa. Estudos sobre 으 século XVI. Lisboa, Imp. Nac. - Casa da Moeda, 1983, 416 p.

623. RAMOS, Arthur. As culturas européias. Introducão à antropologia brasileira. Rio de Janeiro, casa do Estudante do Brasil, s/d.

624. RAMOS, Domingos. Cursos. s/l, s/d

625. RAMOS, Vitor. A edicão de lingua portuguesa em França $1800-1850 \ldots$ Paris, Gulbenkian, 1972 .

626. RANGEL, Alberto. Rumos e perspetivas. São Paulo, Cia. Ed. Nacional, 1934 .

627. RANGEL, Carlos. Do bom selvagem ao bom revoluncinário. Trad. Berenice de Souza otero. Brasilia, ed. Universidade de Brasilia, 1982. $280 \mathrm{p}$.

628. RANGO, Ludwing von \& LEIHOL, Theodor von. O Rio de Janeiro visto por dois prussianos em 1819. São Paulo, Nacional, 1966. $166 \mathrm{p}$. 
630. RAU, Virginia \& SILVA, Maria Fernanda Gomes da. Livro das pessoas que foram sentenciadas pela Inquisição. In: Os manuscritos do Arquivo da casa de Cadaval respeitantes ao Brasil, s/d, v.1.

631. REBELO, Luiz Francisco. História do teatro português. Lisboa, Publ. Europa - América, 3 ed, s/d . 166 p.

632. RECKERT, Stephen. Espirito e letra de Gil Vicente. Lisboa, Imp. Nac. Casa da Moeda, 1983. 290 p.

633. REGIMENTO interno da Assembléia Legislativa da Província da Bahia. B̈hia, Typographia de A.O. da Franca Guerra, 1856. $82^{\circ} \mathrm{p}$.

634. REGISTRO de Estrangeiros. 1802 - 1822. Rio de Janeiro, Arquivo Nacional, 1960.

635. REGO, Antonio da Silva. O ultramar português no século 18 ( 1700 - 1823). Lisboa, Agência Geral de Ultramar, 1967. $404 \mathrm{p}$.

636. REGULAMENTO da Biblioteca Pública do Estado da Bahia. Bahia, Imprensa Official do Estado, 1931. 13 p.

637: REIS, Antonio Simões dos. Bibliografia das bibliografias brasileiras. hio de Janeiro, INL, 1942.

638. REIS, Arthur Cezar Ferreira. Aspectos da foramação brasileira. Rio de Janeiro, livraria José olympio Editbra, Brasilia, INL, 1982. 273 p.

639. --.-. A politica portuguesa no vale amazônico. Belém 1940 .

640. REIS, Sotero dos. Curso de literatura portuguesa e brasileira. Rio de Janeiro, Garnier, 1866.

641. REIS, T. Furtado. Os brasileiros na história da navegacão aérea. Rio de Janeiro, 1934.

642. REVAH, J.S. La censure inguisitonale portugaise au XVI siecle Paris, 1960. 
643. REVELLO, José Torre. "Biblioteca e imprentas en la Amērica colonial"' "Boletim da Academia Nacional de História. Buenos Aires, 1941. v. XVI

644. REVISTA Americana. Rio de Janeiro, 1910. T 3.:

645. Idem. Rio de janeiro, 1911. T.6.

646. REVISTA Brasileira de estudos politicos. Belo Horizonte, 1960 , n.9, pg. 68 a 100 .

647. REVISTA Brasilia. Fac. Letras Universidade le Coimbra Inst: Estudos Brasileiros. Suplemento ào v. IV

648. Idem. Coimbra, 1942, v.1.

649. REVISTA da Associação. Recreio Instrutivo. São Paulo, 1861 .

650. REVISTA da Faculdade de Direitos da USP, 1911, v. 7,

651. REVISTA da Cultura. Rio de Janeiro, 1940, v. 28,

652.: REVISTA do Arquivo Público Mineiro. BH, 1978, Ano XXIX, abr. 1978 .

653. Idem . IV. Ano XXIV - 1933. BH, Imp. Of. de MG, 1933.

654. Idem Ano XXXI - 1980. BH, 1980.

655. Idem Ano XXX - 1979. BH, 1979.

656. Idem. Ano VII - 1902 BH, 1902

657. Idem. Ano VIII - 1903 BH, 1903

658. Idem. Ano II - 1897 BH, 1897.

659. Idem. Ano XXVI - 1933, v. I

700. Idem. Ano IV - 1899.

701. REVISTA do Instituto Hiștórico de Recife, 1937 - 1938, $\mathrm{v}$. 
702. REVISTA DO INSTITUTO Arqueológico Histórico e Geogrāgráfico Pernambucano. V.L. Recife, 1978. 344 p.

703. Idem, v. XLIX. Recife, 1977. 327 p.

704. Idem, $1939-1940$, v. 36.

705. Idem, 1961, v. 35.

706. REVISTA do Instituto Histórico e Geogrāfico Brasileiro. Rio de Janeiro, v. 47 ,

707. Idem, v. 301, 1973.

708. Idem. Dep. Imp. Nacional. Rio de Janeiro, 1959. $15 \mathrm{v}$. -- Catálogo de Documentos sobre a história de são Paulo existentes no arquivo Histórico Ultramarino, de Lisboa .

709. Idem. T.15, 1852. 2 ed. 1888.

710. Idem. T. $6,1844.2$ ed. 1865.

711. REVISTA IHG - SP, V.2, 1896/1897.

712. REYNARD, Robert. Recher sur quelques brésiliens étudiants en medicine à Mont pellier à la fin du XVIII siécle. Languedoc Medical n.3, mai-juin 1951.

713. RIBEIRO, Bernardim.. Menina e moça. Lisboa, Livraria Clássica Editora, 1942. 101 p.

714.. RIBEIRO, Darcy. O Processo civilizatório. 3 ed. Rio de Janeiro, Civilização brasileira, 1964.

715. RIBEIRO, João. Introdução às obras de cláudio Manuel da Costa. Rio de Janeiro, 1903. 2 v.

716. RIBEIRO, José Silvestre. História dos estabelecimentos cientificos, literărios e artisticos de portugal nos sucessivos reinados da Monarquia. Lisboa, 1871 : 1893. 
717. RICARDO. História Universal da Companhia de Jesus. Rio de 'Janeiro, 1870.

718. RIO DE JANERIO. Anais da Biblioteca Nacional. V.95, t. $1-2,1975$.

719. RIZZINI, Carlos. o jornalismo antes da tipografia. São Paulo, Nacional, 1977.

720. RIZZINI, Carlos. 으 livro, 으 jornal e a ․ㅡㅁografia no Brasil. 1500 - 1822. Rio de Janeiro, Kosmos, 1946.

721. --.-- Hipólito da Costa e 으 Correio Braziliense. s/l. s/d.

722. ROCHA, Daniel. O teatro no Brasil Colonial. Rio de Janeiro, SBAT, 1955, Jul - Ago.

723. RODRIGUES, Francisco. . A formação intelectual do jesuita. Porto, 1917.

724. ----.. História dá companhia de Jesus na assistência de portugal. Porto, 1931.

725. RODRIGUES, Graça de Almeida. Literatura e sociedade na obra de Fr. Lucas de Santa Catarina. (1660-1740). Lisboa, Imp. Nac. Casa da Moeda, 1983. 282 p.

726. RODRIGUES, J. C. Catálogo annotado dos iivros sobre o Brasil. Rio de Janeiro, Jornal do Commercio, 1907.

727. RODRIGUES, José Honório. Indice anotado da Revista do Inst. Arg. Hist. e Geog. de Pernambuco. Recife, 1961.

728. -...-. História da História do Brasil. P.1 = 'Histografia colonial. São Paulo, Cia. Ed. Nacional.

729. --..- Histografia bibliografia do dominio holandês no Brasil. Rio de Janeiro, MEC., 1949.

730. RODRIGUES, José Honório e RIBEIRọ; Joaquim. Civilização Holandesa no Brasil. São Paulo, Cia. Ed.Nacional, 1940. 
731. ROJAS, Fernando de. La Celestina. Madrid, Ed. Nacional, 1977.

732. ROMERO, sílvio. A pátria portuguesa. s/l, s/d.

733. ----- História da literatura brasileira. 7 ed. Rio de Janeiro, J. Olympio/MEC, 1980. $5 \mathrm{v}$.

734. RÓNAI, Paulo. O teatro Moliére. Brasília, Ed. Un. Brasilia, 1981 .

735. ROSA, Carlos \& ROSA, Neuza. Do individuo ao grupo. (para ửa história do livro em Cuiabă). Cuiabā, Empresa Gráfica correio da Imprensa, 1975. 56 p.

736. ROUSSEAU, Jean - Jacques. Discurso sobre a origem 으 os fundamentos da desigualdade entre os homens. Trad. Iracema Gomes Soares e Maria Cristina Roveri Nagle. Brasilia, Ed. Univ. 1981. 190 p.

737. ROTERDAM, Erasmo de. Elogio da loucura. Rio de Janeiro, Tecnoprint, 1968.

738.: ROWER, Fr. Basílio. A província Franciscana de Imaculada Conceição do Brasill. Petrópolis, 1922.

7.39. --.-. Páginas de história franciscana no Brasil. Vozes, 1957. 543 p.

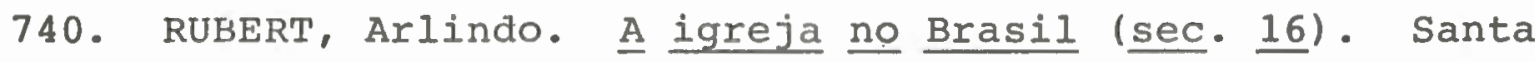
Maria (RS), 1981. 392 p.

742. RUGENDAS, Johan Moritz. Viagem pitoresca através do Brasil. Trad. Sērgio Milliet. São Paulo, Círculo do Livro, s/d, $271 \mathrm{p}$.

743. RUI, Afonso. A primeira revolucão social brasileira. São Paulo, 1942 .

744. S.J. Manual de literatura ou estudos sobre a literatura dós principais povos da América e Europa. s 1, 1878. 
745. SÁ, José de. 음ombardeio da Bahia e seus efeitos. Ba "Diário da Bahia", 1918.

746. SA, Arthur Moreira de. Indice dos livros proibidos em 'Portugal no século XVI. Lisboa, Instituto Nacional de Investigação Cientifica, $1983,849$.

747. SAINT - HILARE; Augusta. Viagem à provincia de são paulo. Trad. São Paulo, Martins, 1945.

748. -...-. Viagem para as provincias do Rio de Janeiro e Minas Gerais. Trad. São Paulo, cia. Ed. Nacional, 1938 .

749. SALAS, Mariano Picón. De la conquista a la independência. México, Fondo de cultura economica, 1944.

750. SALDANHA, Nélson. História das idéias políticas no Brasil. Recife,1968.

751. SALINAS, Pedro. Jorge Manrique 'o tradición y originalidad. 2 ed. Buenos Aires, Editorial Sud Americana, 1952.

752. SALVADOR, Fr. Vicente de. História do Brasil: 15c0 - 1627 7 ed. Belo Horizonte, Ed. Itatiaia, São Paulo, EDUSP, 1982. $437 \mathrm{p}$.

753. SAMPAIO, Theodoro Fernandes. As incrições lapidares da igreja de nossa Senhora da Victoria. São Paulo, Escolas Prof. Selesiana, 1910.

754. -----. História da fundação da cidade do Salvador. Obra póstuma. Bahia, Tipografia Beneditina, 1949.

756. SANTIAGO, Diogo Lopes. História da guerra de Pernambuco. Recife, Fundarpe, 1984. 1. ed. integral segundo apógrafo Biblioteca Municipal do Porto. 596 p.

757. SANToS, J. Lựcio Inconfidência Mineira. São Paulo, 1927. 
758: SANTOS, Leri dos. Panteon fluminense. Rio de Janeiro 1880.

759. SANTOS, Luís Gonçalves dos. Memórias para servir à História do Reino do Brasil. Rio de Janeiro, Valverde, 1943.

760. SANTOS FILHO, Licurgo de Castro. Histōria geral da medicina brasileira. São Paulo, Hucitec/EDUSP, 1977.

761. SARAIVA, Antonio José \& Lopes, Oscar. História da literatura portuguesa. 12 ed. Porto 1982.1218 p.

762. SCAIIgERo, Júlio César. Poética. s/l, s/d.

763. SEMINARIOS de Direito Romano na Universidade de Brasilia: realizados em 1981 e 1982. Brasilia, ed. da Universidade, $1984,186 \mathrm{p}$.

7.64. SENNA, Ernesto.' "A imprensa Régia", Revista do IHGS de São Paulo. 13:43 (1909).

765.: SEPP, Padre Antōnio, s.J. Viagem às missões jesuisticas e trabalhos apostólicos. São Paulo, EDUSP, Belo Horizonte, Ed. Itatiaia, 1980. 249. p.

766. SEQUIERA, Gustavo de Maros. 으 Carmo e a Trindade. $\mathrm{s} / \mathrm{l}, \mathrm{s} / \mathrm{d}$.

767. SÉrgio, António. Ensaios. Lisboa, Seara Nova, 1929.

768. 'SERRA, Joaquim. Sessenta anos de jornalismo, a imprensa no Maranhão. (1820 - 1880 . Rio de Janeiro, 1883.

769. SERRANO, Jonatas. Histōria do Brasil. Brigueite \& Cia, 1931.

770. -Anchieta educador. J. Commercio, 29/9/1940. 
771. SHEARMAN, John, o maneirismo. São Paulo, Cultrix, EDUSP 1978,220 p.

772. SERRÃo, Joaquim Veríssimo: 을arquês de pombal: 으 homem, 으밍omata e 으 estadista. Lisboa, Edição Câmaras Municipais de Lisboa, Oieras e Pombal, 1982. 204 p.

773. SHEARMAN, John. o maneirismo. São Paulo, cultrix, EDUSP, 1978,220 p.

774. SILVA, Antonio Diniz da Cruz e. Hissope. s/1, s/d.

7.75. --- Poesias. s/1, s/d.

776. SILVA, Antonio José da. Esopaida ou vida de Esopo. Coimbra, univ: 1979. 354 p.

777. --.... Labirinto de Creta. Lisboa, 1740.

778. SILVA, Domingos Carvalho da. As origens da poesia. In: COUTINHO, Afranio \& COUTINHO, Eduardo (org). A literatura no Brasil. V.1, t.1, Rio de Janeiro, 1985.

779. SILVA, Garcilenil do Lago. Educação na Amazônia Colonial: Contribuição à história brasileira. Manaus SUFRAMA, 1985.

780. SILVA, H. Pereira da Montaigne: Brasil, alma e obra. Rio de Janeiro, Museógráfica,1977. 172 p.

781. SILVA; Inácio Accioli de Cerqueira e.Memórias históricas e politicas da Provincia da Bahia. Salvador, $1835-1852,6 \mathrm{v}$.

782. SILVA, Inocêncio Francisco da. Dicionário bibliográfico português. Lisboa, $1858-1923.2 \mathrm{v}$.

783. SILVA, J. M. Pereira da. Quadros da história colonial do Brasil: Rio de Janeiro, Garmier, 1895. 252 p. 
784. SILVA, J. M. Velho. Crônica dos Tempos Coloniais. Rio de Janeiro, Imprensa Industrial, 1875.

785. SILVA, Joaquim Norberto de souza e. Bosquejo da História da literatura brasileira nas modulações poéticas. Rio de Janeiro, 1841.

785.

------. História da conjuração Mineira. Rio de Janeiro, INL, 1948, $2 \mathrm{v}$.

786. SILVA, Maria Beatriz Nizza da. "A transmissão, a conservação e a difusão da cultura no Rio de Janeiro (1808 - 1821) "Revista de História, n.37 e 102 $(1974-1975)$.

787. - "A livraria pública da Bahia em 1818". Revista de História. v. 43. (1971).

788. - - "- . Produção, diṣtrubuição e consumo de livros e folhetos no Brasil colonia". Revista do IHGB 314: 78 - $94(j a n / \operatorname{mar} 1977)$. .

789. -----. Cultura e Sociedade no Rio de Janeiro (1808 1821). 2 ed. Brasiliana, v. 363. Säo Palilo, cia. Ed. Nacinal, 1978.

790. ----. A primeira gazeta da Bahia: Idade d'ouro do Brasil. São Paulo, cultrix/MEC, 1978.

791. Cultura no Brasil Colônia. Petrópolis, Vozes, 1981. 792.. SILVA, Pereira da. Parnaso brasileiro. s/l, 1843. 793. -----. Plutarco brasileiro. s/1, 1847.

794. ------ História da fundação do Império brasileiro. Rio de Janeiro, 1864. $7 \mathrm{v}$.

795. SILVEIRA, Simão Estácio da: Relação sumārio das cousas do Maranhão. São Luiz, UFMA / słoge,1979 - 7 ed. $62 \mathrm{p}$. 
796. SIMONSEN, Roberto. História Econômica do Brasil. São Paulo, 1937. 2 v.

797. SISMONDI. Literaturas do meio-dia da Europa. S/1, 1819.

798. SOARES, José Carlós de Macedo. Fontes da história da Igreja Católica no Brasil. São Paulo, 1954. São Paulo, 1954 .

799. SOARES, Teixeira. O marques de Pombal. (a lição do passado e a lição do presentel. Rio de Janeiro, Ed. Alba Ltda., 1961. $270 \mathrm{p}$.

800. ----. A pequena imprensa na Regência e no Império. Separata da Revista do Arquivo CxxxIV. São Paulo, Départamento de Cultura. 1950. 69 - 86 .

801: -----. Orientações do pensamento brasileiro. Rio de Janeiro, Vecchi, 1942 .

802. SOFOCLES. Edipo rei. Versão e adaptação teatral moderna de Geir Çamp.s. São Paulo, Abril Cultural, 1976. $106 \mathrm{p}$.

803. SOUSA, Alberto de. Os Andradas. São Paulo, 1922. 3 v. 804. SOUZA, Gabriel Soares de. Noticias do Brasil. Introd. Comentário e notas do prof. Pirajá da silva. são Paulo, Martins, 1948. 2v.

805. - - Tratado Descritivo do Brasil, 1587.

806. SousA, J. Galante de. O teátro no Brasil. Rio de Janeiro, MEC, 1960, 2v.

807. SousA, Otávio Tarquínio de. História dos fundadores do Império do Brasil. $10 \mathrm{v}$. Rio de Janeiro, 1957 - 1958. V. VI e IX.

809. SOUTHEY, Robert. A história do Brasil. s/l, s/d. 810. SOUTO, Domingos, Mauríco Gomes de. Balanço cultural dos Jesuitas no Brasil. Coimbra, Revista Brasilia, IX, s/d 
811. SoỦzA, Joaquim de Almeida Novaes e. Índice geral das obras de Manoel de Almeida e Souza, de Lobão.

812. SOUZA, Pedro de. Diārio da navegação de 1530 a 1532. 'Rio de Janeiro, 1927. 2v.

813. SPANDING, Tassilo Orpheu. Dicionário da mitologia latina. São Paulo, Cultrix, 1982.

814. Spix, Joahann Baptist von e Martius, Karl Friedrich Philip von. Reis in Brasilien ... in dem Jahren 1817 bis 1820 gemacht, Mthchen, Lindauer, 1823 .

815. -.-.-. Através da Bahia. São Paulo, Brasiliana, 1938.

816. STADEN, Hans. Duas Viagens ao Brasil. Trad. Guiomar de Carvalho Franoc, transcrito em alemão moderno por Carlos Fouquet. Belo Horizonte, Ed. Itatiaia, São Paulo, EDUSP, 1974. 216 p.

817. STELLFELD, Carlos. Os dois Vellozo. Rio de Janeiro, 1952 .

818. STUDART, Guilherme. Datas e fatos para a histōria do Ceará. Fortaleza, 1896. 2 v.

819. SYPHER, Wylie. Do rococó ao cubismo. São Paulo, Perspectiva, $1980.243 \mathrm{p}$.

820. TAdues, Pedro. História da Capitania de são vicente. $s / 1, s / d$.

821. -...-. A missão artística de 1816. Brasilia, Editora da Universidade de Brailia, 1983, 322 p.

822. -...- A vida gloriosa e trágica de Bartolomeu Gusmão: São Paulo, Imp. Oficial, 1938.

823. …-. Bartolomeu de Gusmão e a sua prioridade aerostática. São Paulo, Imp. Of́icial, 1935. 
824. TAUNAY, Afonso de Escragnolle. "De Brasiliae rebus pluribus: o primeiro livro impressiono Brasil." Anais do Museu Paulista, 7: 421 - 474 (1936).

825. - História seiscentista da vila de são Paulo. 1926. $4 \mathrm{v}$.

826. TAUNAY, Alfredo d' Escragnolle. A expulsão dos jesuitas do Colégio são Paulo. s/l, s/d.

827. …… Anais do Museu Paulista. s/l, s/d.

828. -----. O Rio de Janeiro de Antanho - impressão de viajantes estrangeiros. São Paulo, Cia Ed. Nacional, 1942 .

828. ----. Os visitantes do Brasil Colonial. São Paulo, MEC, $1933,241 \mathrm{p}$.

829. TAVARES, Francisco Muniz. História da Revolução de Pernambuco em 1917, anotada por Manuel de Oliveira Lima.

830. TÁVARES, Muniz. Histōria da Revolução Pernambucana de 1817. Recife, 1917.

831. TEIXEIRA; Rento. Naufráfio é Prosopopéia. Recife, UFPE; 1969.

832. TELlEs, Baltazar. Cronica da Cia de Jesus na provin'cia de Portugal. Lisboa, 1665. $2 \mathrm{v}$.

833. TELLES, Augusto Carlos da.silva. Ȧtlas dos monumentos Históricos e artisticos do Brasil. Rio de Janeiro, MEC; $1980.342 \mathrm{p}$.

834. TENAUX, Henrique. Companhs: Bibliothèque americaine. Paris, 1837 .

835. TOLLENARE; L. F, de. Notes dominicales prise pendant un Voyage en Portugal et au Brésil en 1816, 1817 et 1818. Paris, 1973. 
836. TQRRES, Alberto. A organização nacional. São Paulo, cia. Ed. Nacional, 1933.

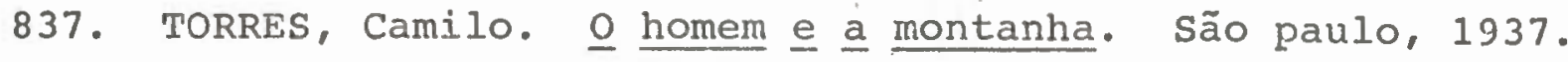

838. TORRES, João Nepomuceno, Comp. Annaes da imprensa da Bahia. Bahia, Typogr. Bahiana de cincinato Melchia.des, 1911.

839. TORRES, José Revello. El livro, la imprenta y el periodismo española. Buenos Aires, 1940.

840. TORRES, Maria Celestina Teixeira Mendes. Um Lavrador paulista do tempo de IMpério. Separata da Revista do Arquivo Municipal no CLXXII. São Paulo, Div. Arqu. 1966. $78 \mathrm{p}$.

.841. TORRI,J. La literatua espanōla. e ed. México, Buenos Aires, Fondo de eultura econômica, 1955, 394 p.

842. TOURINHo, Eduardo. Alma e corpo. da Bahià. Rio de JaneiRo, Irmãos Pongett, 1953.

843. TOURINHo, João Gonçalves. História dạ sedição na Bahia em 24 de novembro de 1891. Bahia, Lytho- typografia de João Gonçalves Tourinho, 1983.

844. TRANCOSO, Gonçalo Fernandes. Histórias de Trancoso. Rio Janeiro, Cátedra, Brasília, INL, 1983. 180 p.

845. ToCIDES. Histöria da Guerra do Peloponeso . Brasilia, Ed. UNB, trad, intr. e notas de Mário da Gama Kury. $1982,533 \mathrm{p}$.

846. VALENTE, Pe. Milton. A ética estóica em Cícero. Caxias do sul, EDUCS. 1984.

847. VARNHAGEN, Francisco Adolfo de. Florilégio da poesia brasileira.. Lisboa, Imprensa Nacional, 1850. 
845. VARNHAGEN, Francisco Adolfo da. Instrucões para os viajantes e empregados nas colônias. s/l s/a.

846. ---- Tópicos brasileiros. Lisboa, Imprensa NacioNAL, 1845 .

846. -- "Caramuru perante a História". T.X, p 129 da Revista Hist. Bra. 1885 .

847. -----. História Geral do Brasil. São Raulo, Melhoramentos. 3 ed.

848. -----. História das letras com holändeses no Brasil. Lisboa, 1872 .

849. VASCONCELOS, Carolina Michalis de. Notas vicentinas. $s / 1, s / d$.

850. --.-- Romances velhos de Portugal. Porto, Lello \& Irmão, $1980.416 \mathrm{p}$.

851. VASCONCELOS, Leitẹ de. Religiões da Lusitânia. s/1, s/d

852. VASCONCELOS, Simão de. Crônicas da Companhia de Jesus. Vozes/MECE, 1977. $2 \mathrm{v}$.

853. VASSALO, Lígia Pondé et alli. Teatro sempre. Rio de Janneiro, Tempo Brasileiro,1983.

854. VEIGA, Cláudia. Aproximacões: estudos de literatura comparada. Salvador, Centro Editorial e Didático, 1978.

855. 'VEIGA, J.P.Xavier. A imprensa em Minas Gerais. $1807 /$ 1894. Ouro Preto, 1894.

856. VEIGA, Luis Francisco. O primeiro reinado estudado à luz da Ciência. Rio de Janeiro, 1877.

857. VERGILIO, Eneida. Trad. Carlos Alberto Nunes no metro original. Id. São paulo, A montanha .ED. 1981. $278 \mathrm{p}$. 
859. VERISSIMO, José. Estudos de literatura brasileira. Belo Horizonte, Itatiaia - USP, 1979, $7 \mathrm{v}$.

860. --.-. História da literatura brasileira. Brasília, UNB 1981 .

861. ----. Teoria, crítica e história literária. São Paulo, EDUSP. 1977, $287 \mathrm{p}$.

862. -----. A educação nacional. 2 ed. Rio de Janeiro, Francisco Alves, 1906.

863. VERNEY, Luiz Antônio. Verdadeiro método de estudar. Lisboa, sá da costa, 1952, 5 v.

864. VERSIANI, Ivana. "Teresa Margariada e as Aventuras de Diófanes. In "Kriterion", v. 67, 1973/1974. Belo Horizonte. p. $293-310$.

865. VEsPÚCIO, Amērico. Cartas. s/l, s/d.

867. VIANA, F.J. Oliveira. O povo brasile.iro e sua evolução. São Paulo, 1934 .

867. VIANA, Hélio. Contribuição à História da imprensa brasileira. Rio de Janeiro, Imprensa Nacional, 1945.

868. --.--. "Educação no Brasil Colônia. In: Revista Brasileira de Estudos Pedagógicos , v. VI, n. 18, 1945.

869. ----. Formação brasileira . Rio de Janeiro, J. Olympio; 1935 .

870. VIANNA, Victor. Os Jesuitas e 으르으. São Paulo. 1934 .

871. VIANNA, Francisco Vicente Memória sobre o Estado da Bahia Bahia, Typografia e encadernação do "Diário da Bahia", 1893.

872. VICENTE, Gil.' O velho da Horta, Auto da Barca do inferno; A farsa de Inès Pereira. São Paulo, Brasiliense, 1969. 
873. VIEGA, Arthur. O poeta Santa Rita Durăo. Paris, 1914.

874. VILANCISos da Coleção Barbosa Machado. Rio de Janeiro, Biblioteca Nacional, 1969.

875. VILHENA, Luís dos Santos. A Bahia no século XVIII. Notas e comentários de Braz do Amaral. Apresentação Edison Carneiro. Bahia, Itapuâ, 1969, 3 v. (v. $1,292 \mathrm{p})$

876. ----. Cartas de Vilhena. Noticias soteropolitanas e brasileira. Bahia, Imprensa official do Estado, 1922. $3 \mathrm{v}$.

877. VIVEIROS, Jerônimo de. História do comércio do Maranhão 1612 - 1895. Publicação comemorativa da passagem do 10 centenário da Fundação da Comissão da Praça. São Luís, Associação Comercial do Maranhão, 1954, 3 v.

878. VolTAIRE. Contos. Trad. Mario Quintana. São Paulo, Abril Cultural, 1979. 413 p.

879. WALDWOGEL, Luís. A fascinante história do livro. são Paulo, União Cultural, 1952.

880. WATJEN, Hermann. O domínio colonial holandês no Brasil. Trad. P. C. Uchoa Cavalcante. São Paulo, cia Ed. Nacional 1938 .

881. WIED - NEUWIED. Viagem ao Brasil. São Paulo, Cia. Ed 1940.

882. WOLF, Ferdinand. História de la litterture brēsilense. $s / 1, s / d$.

883. -..-.. Le Brésil littéraire. Berlin, 1863.

884. ZURARA,- Gomes Eanes de. Prosas Históricas. Belo Horizonte, Ed. Itatiaia, 1960, 76 p. 


\section{NOTAS}

1 o titulo original, The book of the braves, resultou da tese do Prof. Irving A. Leonard apresentada à Universidade de Harvard e publicada pela primeira vez, em inglês, em 1949. A edição de que nos socorremos aqui é a segunda, mexicana, da editora Fondo de Cultura, 1979.

2 MORAES, R. B. de. (1979), p. 2

3 LEITE, Serafim, SJ. (org.) (1954), v. I, p. 131

4 Ibidem, p: 168

5 Ibidem, p. 467

6 Ibidem, p. 497

7 Ibidem, p. 517

8 LEITE, S. Op. cit., v. II, p. 25

9 Ibidem, p. 147

10 mORAES, R. B. de. Op. cit., p: 1

11 A propósito da introdução da imprensa em Portugal, veja-

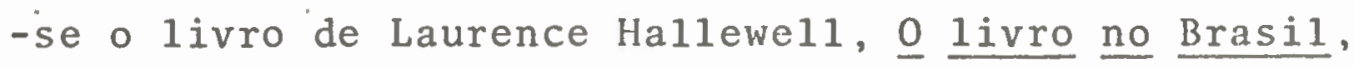
especialmente as päginas 2 e 9.

12 Fernão Cardim na "Informação da.Missão do P. Christóvão Gouvea às Partes do Brasi, Anno de 83 ou Narrativa epis- 
tolar de uma viagem e missão jesuítica". In: Tratado da terra e gente do Brasil, Belo Horizonte, Itatiaial /São Paulo, USP., 1980, p. 144-145.

13 CARDIM, F. Op. cit., p. 166

14 ROWER, B. (1957). p. 264

15 LEITE, S. (1950), t. II, Livro V.

16 MORAES, R. B. de. Op. cit., p. 52-54.

17 LEITE, S. História da Companhia de Jesus no Brasil, Ioc. cit. A propósito do ensino dos clássicos, Afrânio Péixoto, no 1ivro Breviário da Bahia, p. 281, 1embra, embora sem documentação convincente alêm do impressionismo, que na Bahia "o irmão jesuĩta Luís Carvalho, desde 1564, dá 1ỉção da Encida, $1{ }^{\circ}$ Livro, de Virgílio."

18 MARTINS, W. (1976), c. I, p. 16

19 Em värios trechos e sucessivos capítulos da obra citada de Irṿing Leonard ocorre farta demonstração de uma leitura subversiva na América espanhola.

20 LEITE, S. (1950), v. II, p. 550 e seg.

21 SARAIVA, A. J, (1967), v. I, p. 9

22 RIBEIRO, J. "Administração do Brasil holandês". In:

TAPAJÓS, Vicente (dir.). História administrativa do Brasil. 2. ed. Brasilia, Ed. UNB, 1983, p. 379 
23 MELO, J. A. G. de. (1978); p. 211-212

24 COARACY, V. (1944), p. 100-102

25 COUTINHO, M. (1984), p. 69

26. Braz do Amaral transcreve as duas cartas a propósito do Seminärio de Belém no final do volume I das Cartas soteropolitanos de Vilhena, publicadas sob o título A Bahia no século XVIII, Salvador, Ed. Itapuã, 1969.

27 Sobre Alexandre de Gusmão e sua presença na pedagogia jesuitica do Brasil vale recordar as referências de Serafim Leite, S.J., História da Companhia de Jesus no Brasil, t. 8, p. 289-298 e de Mário Martins, in: "História do Predestinado peregrino e seu irmão Precito" in: "Brotêria", t. 78,1964, p. 697-708.

28 Valemo-nos aqui da 4. ed. do Valeroso Lucideno, Recife, Fundarpe, 1985, v. I. Sobre a leitura de Camões na prätica de textos brasileiros, desde o Quinhentismo, passando pelo século XVII, ver Gilberto Mendonça Teles. In: Camões e a poesia brasileira.

29 Apud "Revista do Instituto Arqueológico, Histörico e Geogräfico Pernambucano", v. LI, 1979, p. 259.

30 MACHADO, A. Vida e morte do bandeirante. São Paulo, Martins, s.d., p. 94-95. Gilberto Mendonça Teles, op. cit., p. 102-103, também menciona à transcrição das estâncias camoneanas. 
31 CAMÓES, L. de. Os Lusiadas. In: -... Obra completa. Rio de Janeiro, Aguillar, 1963, p. 115-118

32 MACHADO, A. Op. cit., p. 95, com base nos Inventärios e Testamentos. São Paulo, Arquivo do Estado, 1921. v. 12, p. 401. As referências anteriores dos inventärios foram colhidas in: Inventários e Testamentos, São Paulo, Arquivo do Estado, 1920.

33 MACHADO, A. Op. cit., p. 95

34 Inventärios e Testamentos, 1920

35 ARQUEB, Seção Histórica, Livro 8, f1. 242 ou Livro 9, f1. 12

36 Ibidem, Doc. 989, Livro 9, f1. 18

37 Ibidem, v. 12 ou 17, nümero 23

38 Ibidem, Ordens Rëgias, 5, 12, $10^{\circ}$

39 Ibidem, Parte $5-5,11,10$

40 Anaes do ARQUEB, v. 17, p. 224

41 A fama de probo e dedicado servidor das coisas de Deus atribuída ao bispo D. Thomas de Encarnação Costa Lima permaneceu, ao menos, até fins do século XIX no Brasil, como se pode observar no farto dispêndio elegíaco feito por Franklin Távora no capítulo III de O Cabeleira, obra de 1876 , aliăs, defendida por seu autor e aqui apropriadamente considerada como romance histórico. A citação vem 
no romance de Távora, São Paulo, Ed. Três, 197̣, p. 53$-55$

42 CostA, P. da. (1954), v. VI, p. 356-357

43 OLIVEIRA, J. T. de. (1975), p. 236

44 MOURA, Carlos. "O ensino em Mato Grosso no século XVIII e início do XIX". In: Convergência, revista cultural do Centro de Estudos n. 3, ju1ho a dezembro de 1977, p. $145-157$

45 Apud AZEVEDO, J. de. (1930), p. 394

46 SILVA, G. L. $(1984)$, p. $88-89$

47 Idem, op. cit., p. 111-112

48 In: Revista do Arquivo Püb1ico Mineiro, Ano XXXI, Be1o Horizonte, 1980 , p. 95

49 Ibidem, Ano XXIV, I v., Belo Horizonte, Imprensa Oficial, 1933 , p. 347

50 Ibidem, Ano XXIV, Belo Horizonte, Imprensa Oficial, 1933, p. $\quad 355$

51 AHU, Bahia. Processos ordenados n. 4814-4828, publicados por Eduardo de Castro e Almeida. In: Inventário dos documentos relativos ao Brasil existente no Archivo de Marinha e U1tramar. Rio de Janeiro, 1913, v. 1, p. 375

52 Ibidem, op. cit., p. 380 
53 Documento anexo ao $\mathrm{n}^{8} 4898$ do Inventārio dos documentos relativos ao Brasil existentes no Archivo de Marinha e U1tramar, p. 385

54 VERNEY, L. A. (1940), v. I, p. 135

55 MORAES, R. B. de. (1969), p. 315

56 Docamento "Bahia, 12 de abril de 1788". In: Inventärio dos documentos relativos ao Brasil existentes no Archivo de Marinha e U1tramar, p. 389

57 MORAES, R. B. de: Livros e bibliotecas no Brasil Colonial, p. 6

58 SILVA, G. L. Educação na Amazônia Colonial, p. 90-91

59 ABAPp, 8, 1918, p. 283-284, cit.. In: SILVA, Garcilenil do Lago.' Op. cit., p. 90-91

60 Cit. In: SERRÃo, J.V. o marquês de pombal - $\underline{\text { o ho- }}$ mem, o diplomata e o estadista. Lisboa, Ed. Câmaras Municipais de Lisboa, Oeiras e Pombal, 1982, p. 39

61 As inúmeras fontes sobre Pombal e a reforma dos estudos devem, necessariamente, ser consultadas por quem melhor invista na compreensão do fenômeno extra os interesses imediatos desta tese. Assim, merecem destaque obras respeitáveis como "um iluminista português no século XVIII: Luis Antonio Verney". In: "Estudos de História do Direito", v. III, Coimbra, 1901; Contribuiçäo para a histōria da pedagogia em Portugal, v. I e II, Coimbra, 1981, 
de Antonio Alberto Banha de Andrade; "A Censura 1iterária durante o governo pombalino. Subsídios para a história do pensamento em Portugal". In: "Boletim de. Segunda Classe da Academia de Ciências", v. XVII, Coimbra, 1972, p. 285-39.5; A Rea1 Mesa Censória e a Cultura nacional, Coimbra, 1982, obra de Maria Adelaide Salvador Marques, entre outros. Também vale referência a comunicação apresentada por Duarte K1ut ao I Congresso Luso-Brasileiro de Filosofia, "O momento pedagógico pombalino". In: Pombal e a cultura brasileira, org. por Antonio Paim, Rio de Janeiro, Tempo Brasileiro, 1982, p. 32 et seg.

62 Apud CARVAlHo, J. de. "A crítica da Segunda Escolástica Portuguesa". In: O nascimento da moderna pedagogia: Verney, Rio de Janeiro, Conselho Federal de Cultura/Ed. Documentário, 1979, p. 45.

63 0: 1ivro de António Alberto Banha de Andrade, Contributos para a história da mentalidade pedagógica portuguesa, (Lisbioa, Imprensa Naciona1/Casa da Moeda, 1982, p. 456) traz interessante quadro das vārias ediçc̃es do Verdadeiro método de estudar. A primeira seria a de Nāpoles, 1746, seguida, no mesmo ano, por uma segunda de Valensa, e de uma terceira, tambëm de Valensa, em 1747.

64 VERNEY, L. A. (1940), v. II, p. 130

65 VERNEY, L. A. Op. cit., Carta terceira, v. I, p. 216 66 VERNEY, L. A. Op. cit., p. 217. 
67 VERNEY, L. A. Op. cit., loc. cit.; p. 218. E possive1 que Verney tenha aqui a intenção de mencionar Gil Vicente, autor inteiramente desconsiderado no Verdadeiro mëtodo, que não the faz uma única referência. Antonio Salgado Jr., na nota 6, p. 218 , do $v$. I do VM, porêm, admite a possibilidade de Verney desconhecer o teatro de Gil Vicente, atestando, para tanto, que Maria Parda tambẻm estaria na tradição do cordel português, cujo exemplo típico seria encontrado no Pranto de Maria Parda, título mais sugestivo para o exemplo utilizado por Verney.

68 VERNEY, L. A. Op. cit., Carta terceira, v. I, p. 232

69 Ibidem, Carta quarta, v. I, p. 260

70 Ibidem, Carta terceira, v. I, p. 228

71. Ibidem, 1oc.'cit., v. I, p. 226-227

72 Cit. em Apendice documental, 2a. parte do livro de An'tonio Alberto Banha de Andrade, Vernei e a cultura do seu tempo, Coimbra, Universidade, 1965, p. 642.

73 Estatuto do Seminärio Episcopal de Nosse Senhora da Graça etc. Lisboa, Tipografia da Academia Real das Sciencias, 1798, p. 59

74 Cit. In: ANDRADE, Antonio Alberto Banha de. A reforma dos estudos secundários no Brasil, São Paulo, EDUSP, 1978, Apêndice VI, p. 185-186. Alêm desse, outros documentos interessantes da reforma de Pombal, indispensäveis 
para nossa compreensão dos diplomas legais do regalismo português encontram-se no citado livro, extraídos do Arquivo Histórico Ultramarino, como a "Breve instrução para ensinar a Doutrina christãa, ler e escrever aos meninos e, ao mesmo tempo, os principics da Lingoa Portugueza e sua Orthografia e o Estatuto que hão de observar os mestres. das escollas dos meninos nesta capitania de São Paulo, Luiz Antonio de Sousa ao Conde de Oeiras, em 12 de maio de $1768:$

Alguns documentos de época também interessantes e referentes à província de São Paulo, no século XVIII, encontramos no Instituto Histórico e Geográfico de São Paulo e seria de boa lembrança recomendar sua 1 ura para os efeitos da história da educação naquele Estildo.

75 Cit. In: ANDRADE, Antonio Alberto Banha de. Contributos para a história da mentalidade pedagógica portuguesa, p. 513 .

76 ANDRADE, A. A. B. de. Op. cit., p. 550, apud Inocêncio, ao Dicionārio Bibiiográfico português.

77 ANDRADE, A. A. B. de. (1982), p. 514-515

78 Ibidem, p. 517

79 Ibidem, p. 537

80 o título completo é: Antídoto gramatical, bá1samo preservativo da corrupcão da língua latina ou curioso descobrimento dos principais erros, barbaridades e incocrências 
do Novo Método para aprender a dita 1íngua. Valença, Antonio Balle, 1750 .

81 ANDRADE, A. A. B. de. (1982), p. 547

82 Cit. In: MORAES, Rubens Borba de. Livros e bibliotecas no Brasil Colonial, p. 53-54

83 Anais do ARQUEB, v. 44

84. LEITE, S. (1949), v. ?, p. 326

85 Cit. por Banha de Andrade, in: A reforma dos estudos secundários no Brasil, p. 18 e Apêndice documental II no fim da mesma obra.

86 Ibidem, p. .175 et sèg. e no Apêndice documental III, "Alvará Régio de 28 de junho de 1759 , em que se extinguem todas as escolas reguladas pelo método dos jesuítas e: se estabelece um novo regime Diretor dos Estudos, Professores de Gramatica Latina, de Grego e Retórica".

87 Ibidem, p. 172

88 Ibidem, p. 175

89 "Auto de Inventário e Avaliação dos livros que se achão no Colégio desta Cidade do Rio de Janeiro sequestrados aos denominados Jesuitas... 1775. Revista IHGB, v. 301 (1973), p. 212-259. Sobre o assunto, ver também Serafim Leite, SJ., e Rubens Borba de Morais, nas obras citadas. 
90 Cit. por Basilio Rower, päginas da história franciscana no Brasil, 1957, p. 450 .

91 AVILA, Afonso. 을 teatro em Minas Gerais: sêculo XVIII e XIX. Ouro Preto, Prefeitura Municipal de Ouro Preto, 1978, p. 4. Sobre o assunto, ver também Joaquim Ferreira de. Menezes, "Igrejas e irmandades de Ouro Preto", na revis-. ta IEPHA, Belo Horizonte, 1975, p. 36 e 55

92 ÂVIla, A. Op. cit., p. 29, apud Joaquim Felicio dos Santos, Memörias do distrito diamantino, p. 162; e apud Josë Teixeira Neveș, "Teatro de Província", in: "Revista do Livro", n. 8, Rio de Janeiro, 1957, p. 133. para uma mais completa informação sobre o desenvolvimento do teatro no Brasil, ver o melhor historiador brasileiro, J. Galante de Sousa. In: O Teatro no Brasil, Rio de Janeiro, INL, 1967. Ver também Mücio Paixão, o teatro no Brasil; Afonso Rui, o Primeiro teatro no Brasil, Salvador, UFBA, 1955: e o irıdispensāvel Lafaiete Silva, Histöria do teatro brasileiro, Rio de Janeiro, MES, 1938.

93 MOURA, Carlos Francisco. O Teatro em Mato Grosso no século XVIII. Cuiabā, UFMT, 1976. Ver também José Barbosa de Sá, "Relação das povoações de Cuyabā e Mato Grosso de seos principios the os presentes tempos", in: Anais da Biblioteca Naciona1, 1901, v. XXIII, p. 25.

94 Ver Lafaiete Silva, História do teatro brasileiro, 1938 , p. 20. 
95 PEIXOTO, A. (1946), p. 155

96 Ibidem, (1946), p. 288

97 Cit. por Alberto Lamego, in: A Academia Brazíica dos

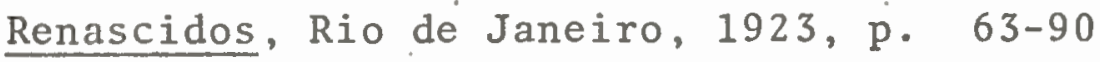

98 MADRE DE DEUS, Gaspar da. (1953), p. 227

99 TAUnAY, Afonso d'Escragnolle. In: "Folha da Manhã", São Paulo, 20 de abril de 1947.

100 Cit. por Rubens Borba de Moraes. In: Livros e Bibliotecas do Brasil Colonia1, (1979), p. 25

101 Ibidem, p. 26

102 SANTOS, João Felício dos. Memórias do distrito diamantino, Rio de Janeiro, 1868 , p. 221, nota e.482, nota. Em nossas investigações nos documentos de Diamantina, na Biblioteca Antonio Torres, não encontramos livros como esses de Rousseau e Montesquieu. Aliás, a grande maioria de livros ali encontrados pertencem ao século XIX.

103 MORAES, R. B. de. (1979), p. 27

104 Cit. por José Timóteo da Silva. In: História da censu-

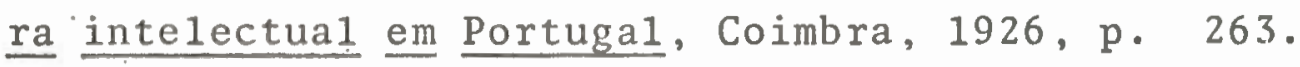

105 Cit. por Carlos Rizzini. In: 을ivro, o jornal e a tipografia no Brasil, (1946), p. 26.4-266:

106 ARQUEB', Seção Histórica, "Documentos para a História An- 
tiga (1705-1817, cópia manuscrita), do Archivo Publico e Museu do Estado, 19.20, Gov. J. J. Seabra". A linha pontilhada indica trecho ilegível no documento.

107 o mérito da informação sobre esse comércio de livros em Minas Gerais cabe a Silvio Gabriel Diniz, quem primeiro dispôs o assunto e pesquisou, mediante o artigo "um livreiro em Vila Rica no meado do século XVIII", in: "Revista Kriterion", Be1o Horizonte, UFMG, 19.59, n. 47-48, p. $180-198$.

108 A partir dessa nota, dispensamo-nos de estabelecer a expressa referência ao documento encontrado no Arquivo Público Mineiro, limitando-nos a remeter o curioso ao artigo em epígrafe, que melhor sintetiza e informa sobre o documento. Seguimos as transcrições do manuscrito.

10.9 Cit. por João Palma Ferreira, na seleção de Novelistas e contistas portugueses dos séculos XVII e XVIII, Lisboa, Casa da Moeda, 1981, p. 282, e 293.

110 Volume 89 dos Documentos interessantes para a história e costumes de São Paulo, São Paulo, Arquivo do Estado, p. 40 .

111 Ibidem, p. 131-132

112 Ibidem, p. 145

113 tbidem, p. 153

114 Documentos interessantes para a história e costumes de 
São Paulo, São Paulo, Typ: Andrade Mello \& Cia., 1898, v. 29, p. 40 .

115 Ibidem, p. 42

116 Ibidem, p. 55-56.

117 Ibidem, p. 125

118 Ibidem, p. 148

119. Ibidem, p. 156

120 Ibidem, p. 184

121. Documentos interessantes para a história e costumes de São Paulo, São Paulo, Arquivo do Estado, v. 32, p. 243 e 245 .

122. Ibidem, v. 19, p. 167

123 Ibidem, v. 92, p. 84

124 Ibidem, p. 95

125 Ibidem, p. 128

126. Ibidem, p. 146

127 Ibịdem, p. 148-149

128 VERNEY, L. A. (1940), v. II, p. 116

129 Cit. por Cônego Raimundo Trindade, no artigo "São Francisco de Assis de Ouro Preto". In: Revista do DPHAN n? 17. p. 189. 
130 Documentos interessantes para a história e costumes de São Paulo, v. 30, (1899), p. 37

131 Ibidem, p. $39-42$

132 Ibidem, p. 148-149

133 Ibidem, p. 228-229

134 Documentos interessantes para a história e costumes de São Pau1o, v. 89, (1967), p. 240-242

135 Documentos interessantes para a história e costumes de São Paulo, v. 55, (1937), p. 319

136 Ibidem, p. 255

137 AVILA, A. (1978), p. 31-32

1.38 Documentos interessantes para a história e costumes de São Paulo, v. 59 (1937), p. 62-63

139 ROWER, B. $(1957)=$ p. 355

140 MOURA, C. (1977), p. 150-152

141 SILVA, M. B. N. da. (1978), p. 158 et. seg.

142 Documentos interessantes para a história e costumes de Sāo Paulo, v. 29 (1899), p. 166

143 SILVA, M. B. N. da. (1978), p. 156 e Doc. int. v. 29, p. 166 .

144 Ibidem, p. 134 
145 Arquivo do Estado de São Paulo, ordem 337, lata 90

146 SILVA, M. B. N. da. (1981), p. 135

147 Ibidem, p. 141

148 "Revista do Arquivo Público Mineiro" (1933), p. 355-356

149 SILVA, M. B. N. da. (1981), p. 70

150 Ibidem, p. 73

151 Estatutos do Seminário Episcopal de Nossa Senhora das Graças da Cidade de Olinda de Pernambuco, (1798), v. I, p. 191s.

152. Ibidem, 1oc. cit.

153 "Revista do Instituto Arqueológico Histórico e Geográfico Pernambucano" (1977), v. 29 e 30, p. 84-85.

154 Divisão de Pesquisa Histörica da UFPE, AHU-PE, papëis avulsos, maço 24 e 32 , microfilme.

155 Arquivo Püblico do Estado, Recife, Instrução Püblica, 1

156 Ibidem.

157 VILHENA, L. (1968), p. 273-287

158 Ibidem, v. I, p. 62

159 LIMA JR., F. P. \& CASTRO, D. B. de. (1977), p. 13

160 Ibidem, p. $70-73$ 
161 Hallewel, L. (1985), p. 21

162 SILVA, M. B. N. da. (1978), p. 113

163 CONTIER, A. D. (1979), p. 35

164 HALLEWEL, L. (19.85), p. 38-40

165 Ibidem, p. 39

166 MORAES, R. B. (1979)

167 HaLlewel, L. (1988), p. 113-114 e p. 15

168 BRIGUIET, R. (1844), p. 10

169 HALLEWEL, L. (1985), p. 47

170 Ibidem, p. 48

171 Ibidem, p. $41-42$

172 MAgALHAES JR., R. (1972), p. 60

173 HALLEWEL, L. (1985), p. 43

174 SILVA, M. B. N. da. (1978), p. 185-191

175 In: contra-capa de $\underline{\text { Juramento }}$ dos Numes, Rio de Janeiro; Imprensa Nacional, 1825

176 Ibidem, 1oc. cit.

177 Ibidem, loc. cit.

178 HALLEWEL, L. (1985), p. 47 et seǵ. 
179 CosTA, P. da. (1951), p. 445

180 VIVEIROS, J. (1954), p. 340-341

181 Ibidèm, p. 368

182 Ibidem, 1oc. cit.

.183 Ibidem, p. 130 et. seg.

184 SILVA, I. F. da. (1852), IX, p. 130

185 CASTRO, R. B. de. (s.d.), p. 96

186 Ibidem, p. 103

187 Ibidem, p. 106

188 Ibidem, p. 113

189 Dicionário de Literatura (1979), p. 430

190 CASTRO, R. B. de. (s.d.), p. 160

191 'As variedades ou ensaios de 1iteratura" (1982), s. p.

192 Ibidem, p. 33-34

193 VEIGA, G. (1983), p. 51

194 CosTA, P. da. (1960), IX, p. 373

195 MELO, J. B. (1979), p. 212-213

196 SILVA, M. B. N. da. (1978), p. 182

197 DENIS, F. $(1980), \mathrm{p} .130^{\circ}$ 
198

DENIS, F. $\quad(1980)$, p. 400

199 MESQUITA, J. de. (1945), p. 45-57

200 ROSA, G. \& ROSA, N. (1975), p. 25

201 cosTA, H. J. da. $(1974)$, p. $24-25$

202

Ibidem, p. $60-62$

203 Ibidem, p. 106-107

204 Ibidem, p. 107

205 NORTON, L. (1979), p. 98

206 Os Deputados às Cortes Constitucicnais de 1821 (1980), p. 64 et. seg.

207 ANDRADE, M. F. (1945), p. 481

208 FRANÇA, A. O. P. da. (1980), p. 18-20

Eis a mote e o vilancete de Camōes:

CANTIGA ALHEIA

Pergigão perdeu a pena,

não hă mal que lhe não venha.

VOLTAS

Perdigão, que o pensamento

subiu em alto lugar,

perde a pena do voar

ganha a pena do tormento.

Não tem no ar nem no vento

asas com que se sustenha:

não hă mal que lhe não venha.

Quis voar a üa alta torre

mas achou-se desasado;

e, vendo-se depenado,

de puro penado morre.

Se a queixumes se socorre,

lança no fogo mais lenha:

não hà mall que lhe não venha. 
FRANÇA, A. O. P. da. (1980), p. 74-76

210

Ibidem, p. XXIII-XXIV

211

ANAES ARQUeb (1971), v. 40, p. 199-200

212

ANAES ARQUEB (1976), p. 176-177

213 AZEVEDO, F. de. (1964), p. 241

214 Ibidem, p. 529

215 Nota sobre arquivos pesquisados

$\mathrm{Da}$ investigação em documentos manuscritos, consultamos arquivos, museus, institutos, bibliotecas püblicas, universidades em Manaus, Belém, São Luiz (incluindo documentação de Alcântara), Teresina, Fortaleza (com inventārios de Fortaleza, Baturité, Acaraü; Ibiapina, Campo Grande, Solonôpolis, Iguatu, Jucäs, Boa Viagem, Barbalha, Crato, Jardim, Missão Velha, Pereiro, Aquiraz, Quixelau, Telha, Quixadá, Milagres, Sobral, Camocim, São Benedito, Saboeiro, e Tauâ), Natal, João Pessoa, Recife, Igarassu, Goiana, Ipojuca, Maceió (incluindo documentação de Rio Largo e Porto das Pedras) Aracaju (incluindo documentaçã̃o de Itabaiana e Estância ), São Cristóvão-SE, Salvador (incluindo Santo Amaro, Cachoeira, São Félix, Maragogipe; Jacobina, Catulë, Caiteté, Ilhẻus, Feira de Santana, São Francisco do Conde, Carinhanha, Ituberá, Camamu), Arquivo Regionail de Cachoeira-BA, Goiânia, Goiâs-GO, Campo Grande-MS, Cuiabá, Vitória, Anchieta-ES, Belo Horizonte, Sabarā, Diamantina, Caeté, Serro, Mariana, Ouro Preto, Congonhas, São João Del Rẹ-MG, Rio de Janeiro (Arquivo Nacional inclui documentação de todo o país, com predominância para a antiga Capital Federa1). Campos, Niteröi, Petrópolis, Teresópolis, Nova Friburgo-RJ, São Paulo (incluindo documentação. de Itu, São Paulo, Guara- 
tinguetā, Pindamonhangaba, Mogi das Cruzes, etc.), Jundiaí, Campinas, Santos, Curitiba, Paranaguá, Florianöpo1is, São Francisco do Sul, Laguna-SC, Porto Alegre (incluindo documentação de Porto Alegre, Pelotas, Rio Grande, Bagé, Santa Maria, Santo Antonio da Patrulha, Jaguarão, Triunfo, São Josē do Norte, Arroio Grande, Osório, Passo Fundo, Dom Pedrito, Encruzilhada, I taqui, Jülio de Castilhos, Montenegro, Piratini, Rio Pardo, Cachoeira do Su1, Cruz Alta, Palmeira das Missões, Alegrete, São Leopoldo, Santana do Livramento, Uruguaiana, Torres, São Borja, São Sepê, Rosärio do Sul, Taquari, Caçapava do Sul e Jaguarão). Relacionados com todos esses lugares foram vistos e investigados diretamente os documentos, embora nem todos, claro, contenham livros como bens. Não foram feitas investigações diretas ou localizadas apenas nos Estados do Acre e Rondônia e nos territórios de Fernando de Noronha e Roraima, Amapá e no Distrito Federal por constituírem localidades sabidamente de recente história extra-colonial ou cuja guarda de documentos do período colonial revelou-se inexistente. Nossas viagens, no entanto, compreenderam Brasilia para coleta de dados bibliográficos para uma Memória Bibliográfica no Brasil. Desde 1980, com coleta de informações sobre bibliotecas hoje existentes com livros anteriores a 1826. E desde 1982 para levantamento de documentação primária. No caso específico de documentos, ainda não fizemos uma estatística definitiva, mas estimamos um número nada falacioso de perto de 50 mil documentos consultados.

216 PAIVA, M. O. D. Guidinha do poço. São Paulo, Ed. Três, 1981 .

217 PINHO, V. (1982), p. 497

218 OLIMPIO, D. Luzia-Homem. Rio de Janeiro, 194

219 Livro dos espólios dos mónges do Mosteiro de São Bento, Rio de Janeiro, f1. 1 
220 AZEVEEDO, F. (1971), p. 537

221 WILEKE, V. "Convento de Santo Antonio do Ipojuca, Pernambuco". In: "Revista do Patrimônio Histórico e Artístico Naciona1"', XIII, Rio de Janeiro, 1956

222 PINHO, M. (1982), p. 497

223 PEREIRA, N. M. (1979), p. 21

224 TÁORA, F. O Cabeleira. São Paulo, Ed. Três, 1973, p. 53

225 PAIVA, M. O. Op. cit., p. 85

226 SANTOS FILHO, L. (1977); p. 282

227 Ibidem, p. 337

228 Ibidem, p. 351

229 LEONARD, I. (1975), p. 102

230 MatTos, J. X. de. (1827), v. III

231 "Revista do Instituto Histórico e Geogräfico Brasileiro" (1973), p. 259

232 op. cit. (1903), t. 66, P. I, p. 297

233 Op. cit. (1867), t. 30, P. II, p. 209

234 VERTSSIMO, J. (1981), p. 183

235 Autos da devassa da Inconfidência Mineira (1984), v. VI, p. $\quad 98-99$ 
236 Op. cit., (1984), v. 348-350

237 Op. cit., (1984), p. 439-440

238 FRIEIRO, E. (1981), p. 18

239 Apud FRIEIRO, E. (1981), p. 21

240 FRIEIRO, E. (1981), p. 48

241 Apud FrIEIRO, E. (1981), p. 99

242 "Revista do Instituto Histórico e Geogräfico Brasileiro" (1901), T. 63, P. I I

243 ARQuEB, Seção Histórica; Maço 575

244 Ibidem, 1oc. cit.

245 Ibidem, 1oc. cit.

246 Ánaes do ARQUEB, (1959), v. 36, p. 305

247. Ibidem, 1oc. cit.

248 Ibidem, 1oc. cit. 
ARAujo, Jorge de Souza. Perfil do leitor colonial. Tese de Doutorado em Literatura Brasileira, apresentada à Coordenação dos Cursos de Pós-Graduação da Faculdade de Letras da UFRJ. Rio de Janeiro, 1988. $732 \mathrm{fls}$.

\section{RESUMO}

0 perfil das tendências e caracteristicas de leitura no Brasil Colónia, particularizando o interesse provocado por determinadas obras em prosa e em verso nos hábitos leitores, era estudo imperioso na ārea de Letras, tendo em vista o resgate da memória nacional sob o āngulo da cultura bibliogräfica. Buscando fornecer elementos de anālise e descrição do leitor colonial mediante a anotação discriminada de livros como bens em inventārios de época, desde o século XVII ao XIX, este trabalno é o resultado de pesquisas realizadas em todo o pais, para estabelecer um marco seguro das opções e dos gostos estilisticos desenvolvidos pelo leitor brasileiro, em especial no que se refere a obras literārias. 


\begin{abstract}
ARAUJo, Jorge de Souza. Perfil do leitor colonial. Tese de Doutorado em Literatura Brasileira, apresentada à Coordenação dos Cursos de Pós-Graduação da Faculdade de Letras da UFRJ. Rio de Janeiro, 1988. 732 fls.
\end{abstract}

\title{
ABSTRACT
}

The profile of tendencies and characteristics of reading in colonial Brazil, emphasizing the interest provoked by works of prose and poetry in reading habits, constituted an imperative study in the area of Letters, with a view to preserving the national memory under the angle of literary culture.

In an attempt to supply analysis and description elements of the colonial reader by means of the itemized list of books, included as goods in period inventories, since the seventeenth through the nineteenth century, this work is the result of research conducted all over the country to establish a safe register of options and stylistic tastes developed by the Brazilian reader, especially in what refers to. 1 iterary works. 


\begin{abstract}
ARAUJo, Jorge de Souza. Perfil do leitor colonial. Tese de Doutorado em Literatura Brasileira, apresentada à Coor-denação dos Cursos de Pös-Graduação da Faculdade de Letras da UFRJ. Rio de Janeiro, 1988. $732 \mathrm{fls}$.
\end{abstract}

\title{
RESUME
}

Il s'ayit d'une ētude fondamentale dans le domaine des Lettres, surtout si l'on prend en considēration la récupēration de la mémoire naturale dans l'esprit de la culture bibliographique. On a établit un profil des tendences et des caractëristiques de la lecture au Brēsil à l'ēpoque coloniale, en particulier l'intērēt des lecteurs vis-ã-vis certaines oeuvres en prose et en vers.

On a fournit des l'ēiéments pour l'analyse et description du lecteur colonial, d'aprēs la notation discriminèe des livres inscrits comme des biens dans les inventaires de l'époque, dupuis le XVII ème siēcle jusqu'au XIX ēme. Ce travail est le résultat des recherches realisées dans tout le pays, pour établir un cadre bien dēfini des options de lecture et des goûts stylistiques developpēs par le lecteur brésilien, en particulier en ce qui concerne les oeuvres littēraires. 